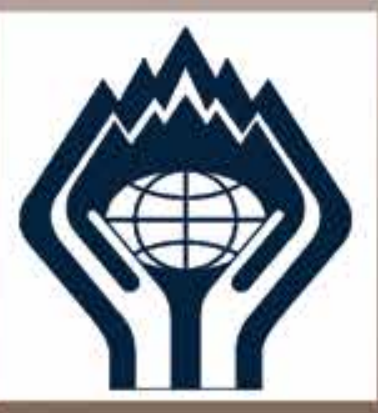

НАУЧНЫЙ ЖУРНАЛ

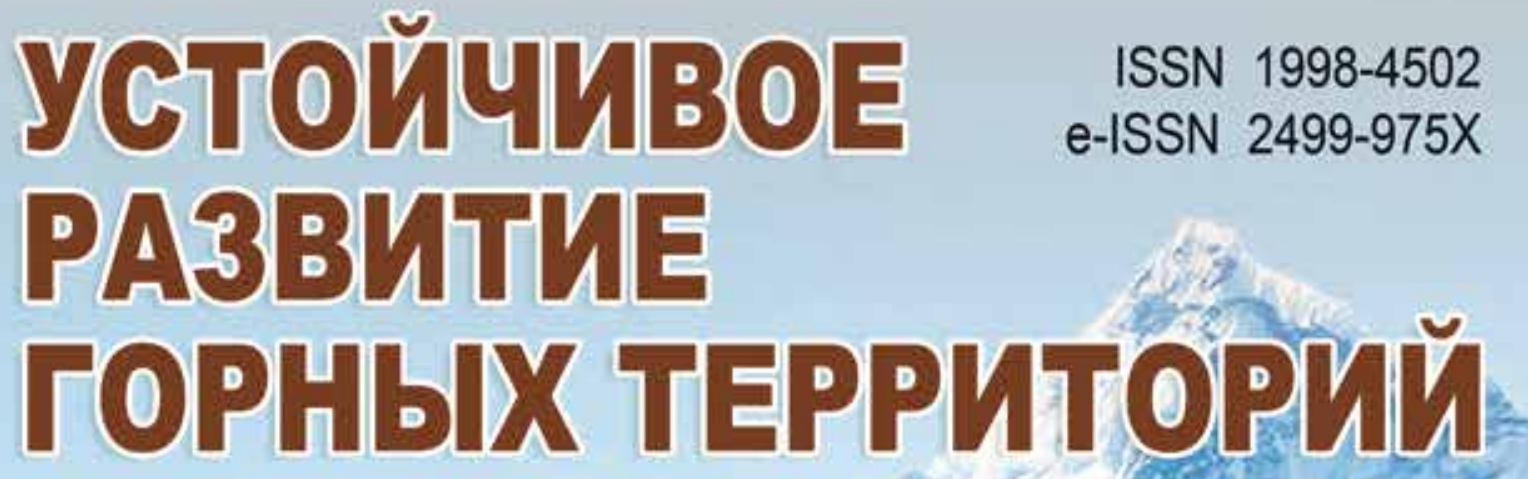

Sustainable Development of Mountain Territories
Земпя - планета не простая: A. де Сент-Экэюпери

\section{T.12}

№4(46)

2020

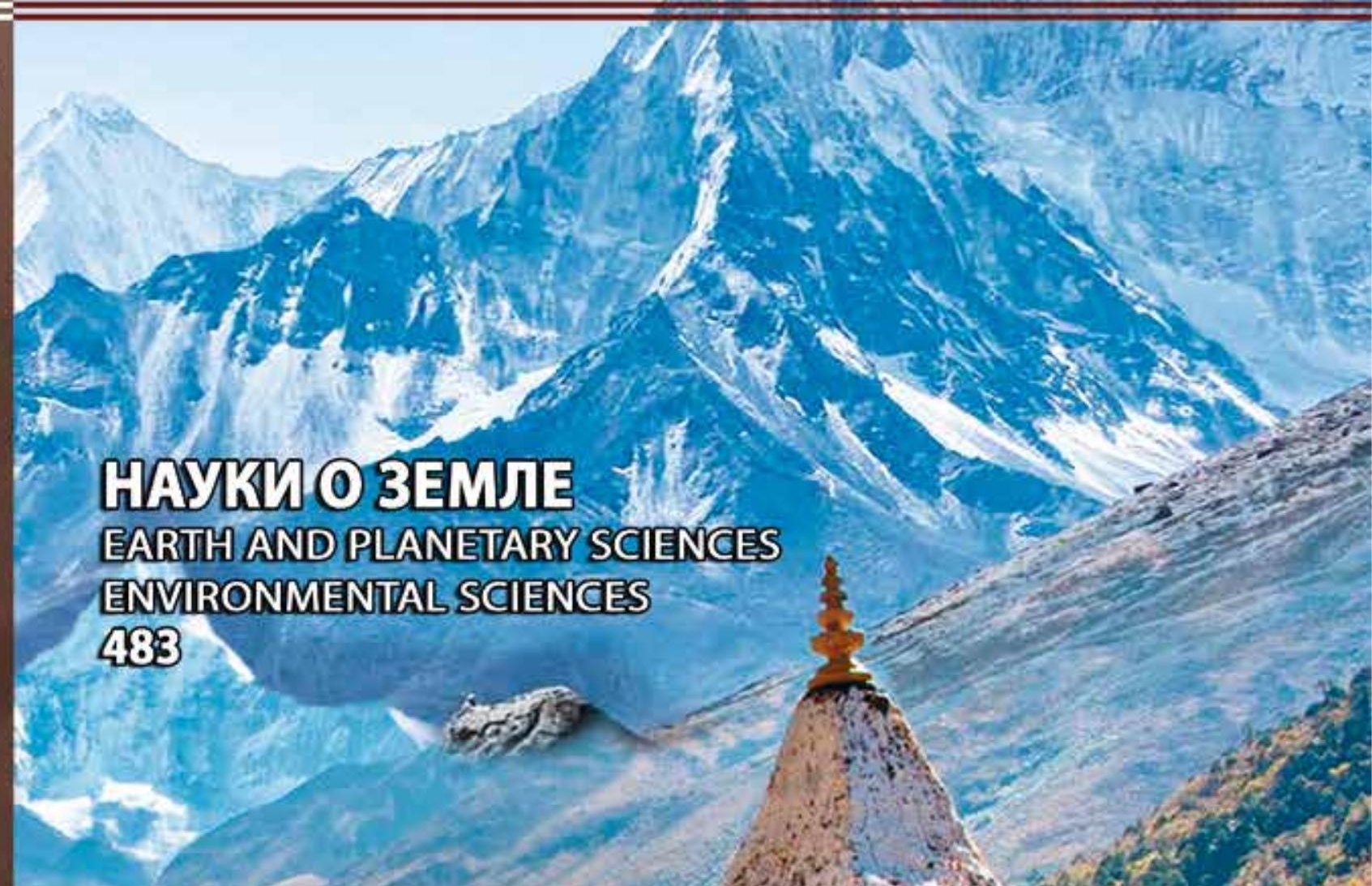
EARTH AND PLANETARY SCIENCES ENVIRONMENTAL SCIENCES 483
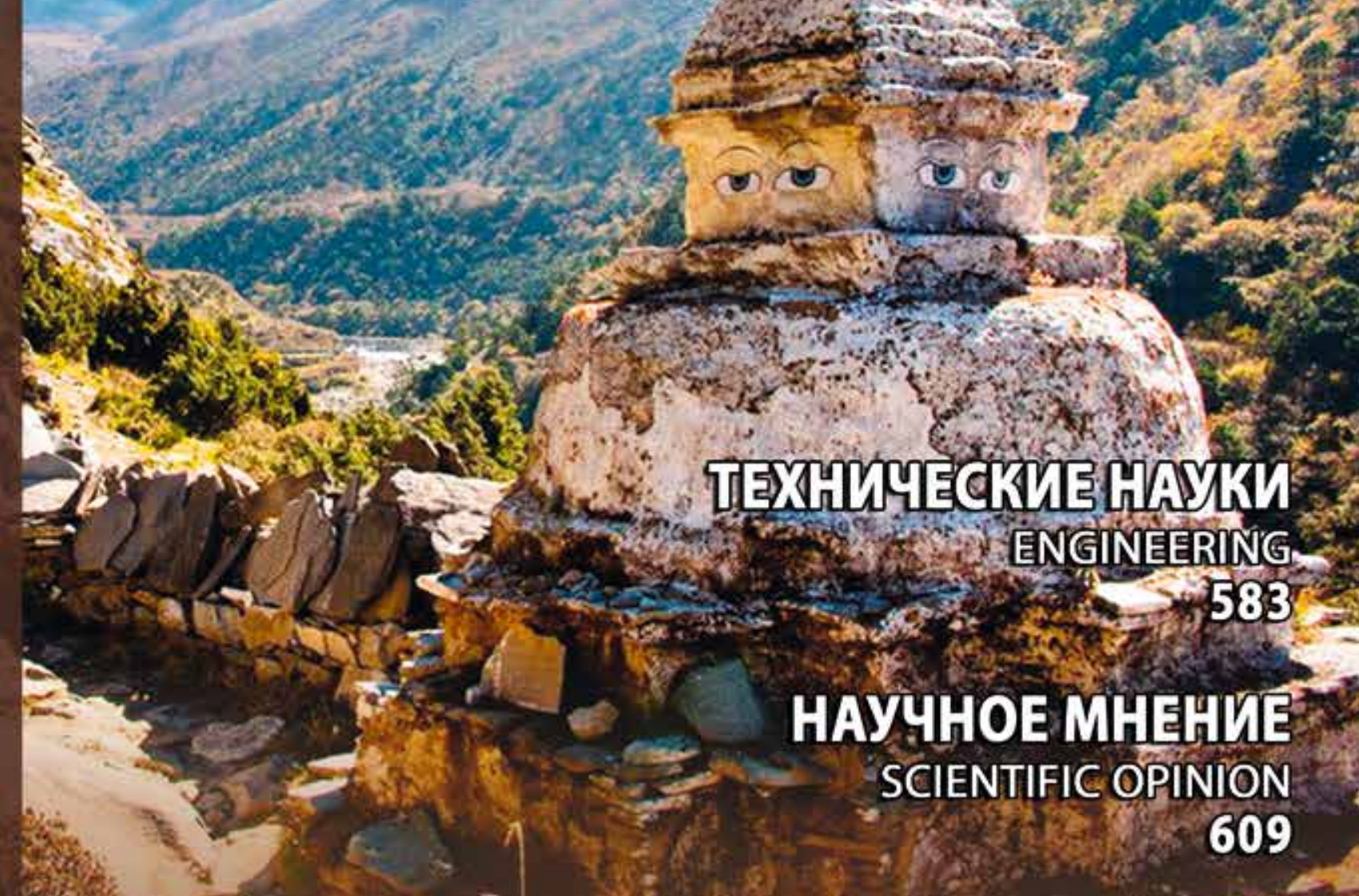

HAУपНOEMHЕНИЕ SCIENTIFIC OPINION 


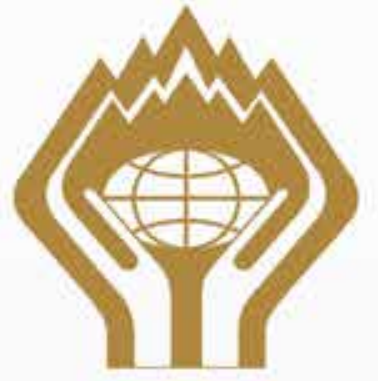

НАУЧНЫЙ ЖУРНАЛ "УСТОЙЧИВОЕ РАЗВИТИЕ ГОРНЫХ ТЕРРИТОРИЙ"

Журнал входит в Перечень изданий, рекомендованных Высшей аттестационной комиссией (ВАК)

Журнал включен в международную рефреративную базу данных и систему цитирования Scopus (3 квартиль)

\section{Адрес редакции, учредителя, издателя: \\ 362021, РСО-Алания,}

г. Владикавказ, ул. Николаева, 44,

Северо-Кавказский горно-

металлургический институт

(государственный технологический университет)

редакция журнала «Устойчивое развитие горных территорий».

Тел.: 8(918) 707-39-25, 8(8672) 40-73-60, 8(8672) 40-72-28.

Адрес в Интернете: http://www.naukagor.ru E-mail: editor@naukagor.ru

Ответственность за содержание статей несут авторы.

Редакция не имеет возможности возвращать присылаемые материалы. За сведения в рекламных материалах редакция ответственности не несет.

Перепечатка допускается только с разрешения редакции

и с обязательной ссылкой на журнал «Устойчивое развитие горных территорий».

Журнал зарегистрирован в Федеральной службе по надзору за соблюдением законодательства в сфрере массовых коммуникаций и охраны культурного наследия.

Свидетельство о регистрации ПИ №ФС77-27831 от 19.04.2007 г. Издается с 2009 г.

Редактор МИСИКОВА И.А.

Технический перевод ПЕЙКАРОВА Н.И. Компьютерный дизайн и верстка ПРОВОТОРОВА Н.М.

Тираж 50 экз. Заказ №

Подписано в печать: 27.12.2020 г. Дата фрактического выхода: 30.12 .2020 r.

Отпечатано в типографии ИП Федосеев В. А

344013 , г. Ростов-на-Дону, ул. Мечникова, 112 А.

(c) «Устойчивое развитие горных территорий», 2020
УЧРЕДИТЕЛЬ:

СЕВЕРО-КАВКАЗСКИЙ ГОРНО-МЕТАЛЛУРГИЧЕСКИЙ ИНСТИТУТ (ГОСУДАРСТВЕННЫЙ ТЕХНОЛОГИЧЕСКИЙ УНИВЕРСИТЕТ)

\section{РЕДАКЦИОННАЯ КОЛЛЕГИЯ:}

Главный редактор - Дмитрак Ю.В. - доктор технических наук, профессор, ректор Северо-Кавказского горно-металлургического института (государственного технологического университета), (Владикавказ, Россия).

\section{ПЕРВЫЙ ЗАМЕСТИТЕЛЬ ГЛАВНОГО РЕДАКТОРА:}

Хадзарагова Е.А. - доктор технических наук, профессор, проректор по научной работе и инновационной деятельности Северо-Кавказского горно-металлургического института (государственного технологического университета), (Владикавказ, Россия).

\section{ЗАМЕСТИТЕЛИ ГЛАВНОГО РЕДАКТОРА}

Клюев Р.В. - доктор технических наук, профессор, заведующий кафедрой «Электроснабжение промышленных предприятий» Северо-Кавказского горно-металлургического института (государственного технологического университета), ответственный за выпуск номеров журнала, (Владикавказ, Россия).

Хетагуров В.Н. - доктор технических наук, профессор, руководитель рабочей группы по подготовке журнала к изданию, профессор кафедры «Технологические машины и оборудование» Северо-Кавказского горно-металлургического института (государственного технологического университета), (Владикавказ, Россия).

Гуня А.Н. - доктор географических наук, профессор, руководитель горной группы МАВ-6 программы ЮНЕСКО «Человек и биосфера» в Институте географии Российской Академии наук, старший научный сотрудник ИГ РАН, (Москва, Россия).

ОТВЕТСТВЕННЫЕ СЕКРЕТАРИ (по направлениям):

Науки о Земле - Керимов И.А. - доктор физико-математических наук, профессор, вице-президент Академии наук Чеченской Республики (Грозный, Россия)

Технические науки - Кондратьев Ю.И. - доктор технических наук, профессор Северо-Кавказского горно-металлургического института (государственного технологического университета), (Владикавказ, Россия).

\section{РЕДАКЦИОННЫЙ СОВЕТ:}

\section{Председатель редакционного совета:}

Котляков В.М. - доктор географических наук, академик РАН, Почетный президент Русского географического общества, председатель экспертного совета Национальной премии «Хрустальный компас», член Межправительственной группь экспертов по проблеме изменения климата, (Москва, Россия).

\section{СОПРЕДСЕДАТЕЛИ РЕДАКЦИОННОГО СОВЕТА:}

Вейнгартнер Р. - доктор наук, профессор Университета г. Берн (Швейцария), заведующий кафедрой гидрологии Географического института Университета г. Берн. Руководитель Международной Исследовательской Инициативы (MRI) (г. Берн, Швейцария)

Дзасохов А.С. - доктор политических наук, заместитель председателя Комиссии Российской Федерации по делам ЮНЕСКО, (Москва, Россия)

Кавалла Р. - кандидат технических наук, профессор, директор Института обработки металлов давлением Фрайбергской Горной Академии, (Фрайберг, Германия).

Пучков Л.А. - доктор технических наук, профессор, член корр. РАН, профессор кафедры «Безопасность и экология горного производства» Горного института Национального исследовательского технологического университета «Московский институт стали и сплавов», (Москва, Россия)

\section{СОСТАВ РЕДАКЦИОННОГО СОВЕТА:}

Айдаралиев А.А. - доктор медицинских наук, академик Национальной Академии наук Республики Кыргызстан, Председатель попечительского Совета УНПК «Международный университет Кыргызстана», (Бишкек, Кыргызская Республика). Бабаян Г.А. - кандидат физико-математических наук, заведующий отделом мониторинга и инноваций Института геологических наук Национальной Академии наук Армении, (Ереван, Республика Армения).

Баденков Ю.П. - кандидат геолого-минералогических наук, ведущий научный сотрудник Института географии РАН, научный руководитель горной группы МАВ-6 программы ЮНЕСКО «Человек и биосфера» в Институте географии РАН, (Москва, Россия)

Большаков В.Н. - доктор биологических наук, профессор, академик Российской академии наук, Советник РАН, главный научный сотрудник, заведующий лабораторией эволюционной экологии Института экологии растений и животных УрО РАН, (Москва-Екатеринбург, Россия).

Вагин В.С. - доктор экономических наук, профессор, директор Института международного образования Южно-Российского государственного политехнического университета (Новочеркасского политехнического института), (Новочеркасск, Россия).

Викторов С.Д. - доктор технических наук, профессор, заместитель директора по научной работе Института проблем комплексного освоения недр РАН, (Москва, Россия).

Винчигуерра С. - доцент кафедры наук о Земле Университета Турина, (Турин, Италия)

Глазырина И.П. - доктор экономических наук, кандидат физико-математических наук, профессор, заведующая кафедрой «Прикладная информатика и математика» Забайкальского государственного университета, (Чита, Россия).

Голик В.И. - доктор технических наук, профессор; профессор кафедры «Технология разработки месторождений» Се веро-Кавказского горно-металлургического института (государственного технологического университета), (Владикавказ, Россия).

Гроппен В.О. - доктор технических наук, профессор, заведующий кафедрой «Автоматизированная обработка информации» Северо-Кавказского горно-металлургического института (государственного технологического университета), (Владикавказ, Россия).

Дребенштедт К. - профессор, декан Фрайбергской горной Академии, (Фрайберг, Германия)

Заксенхофер Р. - заведующий кафедрой нефтегазовой геологии, профессор Горного университета в Леобене, (Леобен, Австрия).

Залиханов М.Ч. - доктор географических наук, профессор, академик РАН, Главный научный сотрудник Высокогорного геофизического института Росгидромета, (Нальчик, Россия).

Лурье П.М. - доктор географических наук, профессор, ведущий метеоролог Северо-Кавказского управления по гидрометеорологии и мониторингу окружающей среды, (Ростов-на-Дону, Россия).

Матвеева Л.Г. - доктор экономических наук, профессор, заведующая кафедрой «Информационная экономика» экономического факультета Южного федерального университета, (Ростов-на-Дону, Россия).

Минцаев М.Ш. - доктор технических наук, профессор, ректор Грозненского государственного нефтяного технического университет им. акад. М.Д. Миллионщикова, (Грозный, Россия)

Прхалова М. - программный специалист отдела «Экология и науки о Земле» Секретариата ЮНЕСКО, (Париж, Франция).

Сысоев Н.И. - доктор технических наук, профессор кафедры «Нефтегазовая техника и технологии» Южно-Российского государственного политехнического университета (НПИ) имени М.И. Платова, (Новочеркасск, Россия).

Темираев Р.Б. - доктор сельско-хозяйственных наук, профессор, заведующий кафедрой «Технология продуктов общественного питания» Северо-Кавказского горно-металлургического института (государственного технологического уни верситета), (Владикавказ, Россия).

Хосаев Х.С. - доктор технических наук, профессор кафедры «Теоретическая и прикладная механика» Северо-Кавказского горно-металлургического института (государственного технологического университета), (Владикавказ, Россия). Штадельбауэр Й. - доктор философских наук, профессор Фрайбургского университета, (Фрайберг, Германия) 
FOUNDER

NORTH CAUCASIAN INSTITUTE OF MINING AND METALLURGY (STATE TECHNOLOGICAL UNIVERSITY)

\section{EDITORIAL TEAM}

Chief Editor - Yuri V. Dmitrak - DSc in Technical Sciences, Professor, Rector of the North Caucasian Institute of Mining and Metallurgy (State Technological University) (Vladikavkaz, Russia)

\section{FIRST DEPUTY OF EDITOR-IN-CHIEF}

Elena A. Khadzaragova - First Deputy Editor-in-Chief, DSc in Technical Sciences, Professor, Vice-Rector on Research and Innovation North-Caucasian Institute of Mining and Metallurgy (State Technological University) (Vladikavkaz, Russia)

\section{DEPUTY CHIEF EDITORS:}

Roman V. Klyuev - DSc in Technical Sciences, Professor, Head of Department "Power Supply of Industrial Enterprises", North Caucasian Institute of Mining and Metallurgy (State Technological University) (Vladikavkaz, Russia)

Valery N. Khetagurov - DSc in Technical Sciences, Professor of Department of Technological Science and Equipment, North Caucasian Institute of Mining and Metallurgy (State Technological University) (Vladikavkaz, Russia)

Alexey N. Gunya - DSc in Geographical Sciences, Professor (Institute of Geography, Russian Academy of Sciences, Moscow, Russia)

\section{EDITORIAL EXECUTIVE SECRETARY:}

Earth Sciences - Ibragim A. Kerimov - DSc in Physics and Mathematics, Professor, Vice President of the Academy of Sciences of the Chechen Republic (Grozny, Russia)

Engineering Sciences - Yuri I. Kondratyev - DSc in Technical Sciences, Professor, North Caucasian Institute of Mining and Metallurgy (State Technological University) (Vladikavkaz, Russia)

\section{EDITORIAL BOARD:}

\section{Chairman}

Vladimir M. Kotlyakov - DSc in Geographical Sciences, Academician of the Russian Academy of Sciences, Honorary President of the Russian Geographical Society, Chairman of "Crystal Compass" National Award Expert Board, Member of the Intergovernmental Panel on Climate Change (Moscow, Russia)

\section{Co-Chairmans:}

Rolf Weingartner - Professor of the University of Bern (Switzerland)

Alexander S. Dzasokhov - PhD in Historical Sciences, DSc in Political Sciences, Deputy Chairman of the Russian Commission for UNESCO (Moscow, Russia)

Rudolf Kawalla - PhD in Technical Sciences, Professor, Director of Institute of Metal Processing Pressure Freiberg University of Mining and Technology (Germany)

Lev A. Puchkov - DSc in Technical Sciences, Professor, Corresponding Member, Russian Academy of Sciences, Member of the Academy of Natural Sciences, Member of the International Academy of Higher Education (Moscow, Russia)

\section{EDITORIAL BOARD MEMBERS:}

Asylbek A. Aidaraliev - DSc in Medical Sciences, Academician, National Academy of Sciences of the Kyrgyz Republic, Head of the UNESCO Department "Sustainable Mountain Development» of EDUCATIONAL RESEARCH AND PRODUCTION COMPLEX "INTERNATIONAL UNIVERSITY OF KYRGYSTAN" (Bishkek, Kyrgyz Republic)

Hektor E. Babayan - PhD in Physico-Mathematical Sciences, Head of Department, Institute of Geological Sciences, National Academy of Sciences of Republic of Armenia (Yerevan, Republic of Armenia)

Yuri P. Badenkov - PhD in Geographical Sciences, Deputy Director of Science, Institute of Geography, Russian Academy of Sciences (Moscow, Russia)

Vladimir N. Bol'shakov - DSc in Biological Sciences, Professor, Academician, Russian Academy of Sciences (Moscow, Russia) Vladimir S. Vagin - DSc in Economic Sciences, Professor, Minister of Housing and Communal Services of the Rostov Region (Rostov-on-Don, Russia)

Sergey D. Viktorov - DSc in Technical Sciences, Professor, Deputy Director for Research Institute of Comprehensive Exploitation of Subsoil, RAS (Moscow, Russia)

Serjio Vinciguerra - Associate Professor of the Department "Earth Sciences" University of Turin (Turin, Italy)

Irina P. Glazyrina - DSc in Economic Sciences, PhD in Physical and Mathematical Sciences, Professor, Head of the Department of Applied Mathematics, Informatics" of Trans-Baikal State University (Chita, Russia)

Vladimir I. Golik - DSc in Technical Sciences, Professor, Professor of the Department "Development of mineral deposits", North-Caucasian Institute of Mining and Metallurgy (State Technological University) (Vladikavkaz, Russia)

Vitaly O. Groppen - DSc in Technical Sciences, Professor, Head of Automated Processing of Information, North Caucasian Institute of Mining and Metallurgy (State Technological University) (Vladikavkaz, Russia)

Carsten Drebenstedt - Dean of the Freiberg Mining Academy, Professor (Freiberg, Germany)

Rainhad Sachsenhofer - Head of the Department "Petroleum Geology", Professor of Leoben Mining University (Leoben, Austria)

Mihail Ch. Zalikhanov - DSc in Geographical Sciences, Academician, Russian Academy of Sciences (Nalchik, Russia)

Petr M. Lur'e - DSc in Geographical Sciences, Professor, Member of the Dissertation Council at the Southern Federal University (Rostov-on-Don, Russia)

Ljudmila G. Matveeva - DSc in Economics, Professor, Head of Department of the Information Economy of Economic Faculty of South Federal University (Rostov-on-Don, Russia)

Magomed Sh.Mintsaev - DSc in Technical Sciences, Professor, Rector of Acad. M.D. Millionshtchikov Grozny State Oil Technical University (Grozny, Russia)

Marie Prchalova - Programme Specialist, Division of Ecological and Earth Sciences, UNESCO Secretariat (Paris, France)

Nikolaj I. Sysoev - DSc in Technical Sciences, Professor of Petroleum Engineering and Technology of M.I. Platov SouthRussian State Technical University (Novocherkassk, Russia)

Rustem B. Temiraev - DSc in Agricultural Sciences, Professor, Head of the Department "Food technology" North-Caucasian Institute of Mining and Metallurgy (State Technological University) (Vladikavkaz, Russia)

Khazbi S. Khosaev - DSc in Technical Sciences, Professor, Deputy Director of Centre for International Cooperation, External Relations and Sustainable Development, North Caucasian Institute of Mining and Metallurgy (State Technological University) (Vladikavkaz, Russia)

Jorg Stadelbauer - DSc in Philosophy, Professor (Germany)
INTERNATIONAL

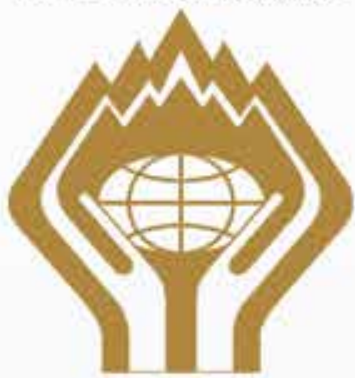

SCIENTIFIC JOURNAL

"SUSTAINABLE DEVELOPMENT OF MOUNTAIN TERRITORIES"

The journal is included in the List of publications recommended by Supreme

Attestation Commission (VAK)

The journal is included in the International Reference Database and Scopus citation System (quartile 3)

Address of the editorial office, founder, publisher:

44 Nikolaev Street, Vladikavkaz, RNO-Alania, 362021, NORTH CAUCASIAN INSTITUTE OF MINING AND METALLURGY (STATE TECHNOLOGICAL UNIVERSITY) Editorial Office of the journal "Sustainable

Development of Mountain Territories". Tel.: +7(918) 707-39-25, +7 (8672) 40-73-60, +7 (8672) 40-72-28.

Internet address: http://www.naukagor.ru E-mail: editor@naukagor.ru

Authors are responsible for the content of the articles.

Editorial staff is not in the position to return the submitted materials.

Editorial staff is not responsible for the information in promotional materials. Reprinting is allowed only with the permission of the editorial office and reference to the journal

«Sustainable Development of Mountain Territories» is required.

The journal is registered in the Federa Service for Media Law Compliance and Cultural Heritage Protection.

Registration Certificate PI No FS 77-27831 From April, 192007

Published since 2009 is free Editor MISIKOVA I.A.

Technical translation PEYKAROVA N.I.

Computer design and make-up PROVOTOROVA N.M.

Covering -50 copies Order No

Signed to print: 27.12 .2020

Date of actual release: 30.12.2020

Printed by IE Fedoseev V. A. 112 A Mechnikov st. 344013, Rostov-on-Don 


\section{СОДЕРЖКАНИЕ}

НАУКИ О ЗЕМЛЕ

.483

Горбунова Т. Л., Матова Н. И.

МЕТОДОЛОГИЯ МОНИТОРИНГА

И УПРАВЛЕНИЯ ЭКОЛОГИЧЕСКИМ

СОСТОЯНИЕМ РЕК С ИСПОЛЬЗОВАНИЕМ

ИНТЕГРАЛЬНЫХ БИОИНДИКАТОРОВИ

МЕТОДОВ УПРАВЛЕНИЯ КАЧЕСТВОМ.

Антонинова Н. Ю., Усманов А. И., Шубина Л. А., Собенин А. В.

ОЦЕНКА ВОЗМОЖНОСТИ ПРИМЕНЕНИЯ

ТОРФО-ДИАТОМИТОВОГО МЕЛИОРАНТА

ПРИ РАЗРАБОТКЕ МЕРОПРИЯТИЙ ПО

ЭКОЛОГИЧЕСКОЙ РЕАБИЛИТАЦИИ

НАРУШЕННЫХ ЭКОСИСТЕМ..

Nguyen Quoc Long, Le Thi Thu Ha, Si Son Tong,

Kim Thi Thu Huong

UAV PHOTOGRAMMETRY-BASED FOR OPEN

PIT COAL MINE LARGE SCALE MAPPING, CASE

STUDIES IN CAM PHA CITY, VIETNAM

Ефимов В. И., Абрамкин Н. И.,

Вернигор В. В., Хакимов Б. Х.

КОМПЛЕКТЫ ОБОРУДОВАНИЯ

ДЛЯ ПОДЗЕМНОЙ ДОБЫЧИ УГЛЯ

В ПОЛОГИХ ПЛАСТАХ

Lasman Parulian Purba, Yustinus Budi Hermanto

MANAGEMENT COMPETENCY

AND ENTREPRENEURIAL INTENTION

OF THE 60-YOUNG VILLAGERS IN A PART

OF SLOPE OF MT. ARJUNA EAST JAVA

INDONESIA.

Маргарян В. Г.

ИЗМЕНЧИВОСТЬ ЗИМНИХ ЭКСТРЕМАЛЬНЫХ

НИЗКИХ ТЕМПЕРАТУР ПРИЗЕМНОГО СЛОЯ

ВОЗДУХА В БАССЕЙНЕ

ОЗЕРА СЕВАН (Армения)

Тайсумов М.А., Магомадова Р.С.,

Астамирова М. А-М, Умаров М.У.

КСЕРОФИЛЬНЫЕ ЭНДЕМЫ ФЛОРЫ

РОССИЙСКОГО КАВКАЗА

И ИХ РОДСТВЕННЫЕ СВЯЗИ

Фоменко Н. Е., Гапонов Д. А.,

Боровик Н. Ю., Фоменко Л. Н.

ПРИМЕНЕНИЕ ЭЛЕКТРОРАЗВЕДОЧНЫХ

И АТМОГЕОХИМИЧЕСКИХ ТЕХНОЛОГИЙ ПРИ

СЕЙСМИЧЕСКОМ МИКРОРАЙОНИРОВАНИИ

ТОННЕЛЬНОГО ПЕРЕХОДА ЧЕРЕЗ

МАРКОТХСКИЙ ХРЕБЕТ
Музаев И. Д., Созанов В. Г.

МАТЕМАТИЧЕСКОЕ МОДЕЛИРОВАНИЕ

ВОЛНОВОГО ДВИЖЕНИЯ ВОДЫ

В ВОДОХРАНИЛИЩЕ, ВЫЗВАННОГО

ВТОРЖЕНИЕМ В НЕГО ОБВАЛЬНО-

ОПОЛЗНЕВОГО МАССИВА

Кортиев Л. И., Кортиев А. Л., Ванеев С. Д.,

Кулумбегов Р. П.

ФУНКЦИОНИРОВАНИЕ И ДИНАМИКА

ЛАНДШАФТОВ ПРИ ПРОЕКТИРОВАНИИ

АВТОМОБИЛЬНЫХ ДОРОГ В ГОРНЫХ

УслОвиях 565

Ganapathy G. P., Zaalishvili V. B.,

Chandrasekaran S. S, Melkov D. A.

INTEGRATED MONITORING OF SLOPE

PROCESS IN INDIA AND RUSSIA

ТЕХНИЧЕСКИЕ НАУКИ

Жуковский Ю. Л., Лаврик А. Ю.,

Семенюк А. В., Васильков О. С.

ПОТЕНЦИАЛ УПРАВЛЕНИЯ

ЭЛЕКТРОПОТРЕБЛЕНИЕМ

В УСЛОВИЯХ ИЗОЛИРОВАННОЙ

ЭНЕРГОСИСТЕМЫ УДАЛЕННОГО

НАСЕЛЕННОГО ПУНКТА

Кравцов А. А., Анищенко В. И.,

Атрушкевич В. А., Пыталев И. А.

ПЕРСПЕКТИВЫ ПРИМЕНЕНИЯ ТЕХНОЛОГИИ

WEВRTС ДЛЯ ДИСТАНЦИОННОГО

УПРАВЛЕНИЯ ГОРНЫМ ОБОРУДОВАНИЕМ

Костюк С. Г., Чичерин И. В.

Федосенков Б. А., Дубинкин Д. М.

МОНИТОРИНГ ДИНАМИЧЕСКОГО СОСТОЯНИЯ

АВТОНОМНЫХ ТЯЖЕЛЫХ ПЛАТФОРМ НА

КАРЬЕРНЫХ МАРШРУТАХ ГОРНОРУДНЫХ

ПРЕДПРИЯТИЙ .600

НАУЧНОЕ МНЕНИЕ

Гуня А. Н., Хадзарагова Е.А.,

Хетагуров В.Н., Караев Ю.И.

МЕЖДИСЦИПЛИНАРНЫЕ АСПЕКТЫ

УСТОЙЧИВОГО РАЗВИТИЯ ГОРНЫХ

ТЕРРИТОРИЙ: РОЛЬ СОЦИАЛЬНО-

КУЛЬТУРНЫХ ФАКТОРОВ 609

ИНФОРМАЦИЯ ДЛЯ АВТОРОВ 620

ПОДПИСКА 


\section{CONTENTS}

\section{EARTH AND PLANETARY SCIENCES}

ENVIRONMENTAL SCIENCES

Gorbunova T. L., Matova N. I.

MONITORING AND MANAGEMENT OF THE

RIVER'S ECOLOGICAL STATE METHODOLOGY

USING INTEGRAL BIOMARKERS AND QUALITY

MANAGEMENT METHODS.

N. Yu. Antoninova, A. I. Usmanov,

L. A. Shubina, A.V. Sobenin

ASSESSMENT OF THE POSSIBILITY OF USING

PEAT-DIATOMITE IMPROVER

IN THE DEVELOPMENT OF MEASURES

FOR THE ENVIRONMENTAL REHABILITATION

OF DISTURBED ECOSYSTEMS.

Nguyen Quoc Long, Le Thi Thu Ha,

Si Son Tong, Kim Thi Thu Huong

PHOTOGRAMMETRY-BASED FOR OPEN PIT

COAL MINE LARGE SCALE MAPPING,

CASE STUDIES IN CAM PHA CITY, VIETNAM ...... 501

V. I. Efimov, N.I. Abramkin,

V.V. Vernigor, B. Kh. Khakimov

UNDERGROUND MINING EQUIPMENT KITS

COAL IN SHALLOW BEDS.

Lasman Parulian Purba, Yustinus Budi Hermanto

MANAGEMENT COMPETENCY AND

ENTREPRENEURIAL INTENTION

OF THE 60-YOUNG VILLAGERS IN A PART

OF SLOPE OF MT. ARJUNA EAST

JAVA INDONESIA

V. G. Margaryan

VARIABILITY OF WINTER EXTREME LOW

TEMPERATURES

OF THE SURFACE AIR LAYER IN THE LAKE

SEVAN BASIN (ARMENIA).

M. A. Taisumov, R. S. Magomadova,

M. A.-M. Astamirova, M. U. Umarov

XEROPHILIC ENDEMES OF THE FLORA

OF THE RUSSIAN CAUCASUS

AND THEIR RELATED RELATIONS

N. E. Fomenko, D. A. Gaponov,

N. Yu. Borovik, L. N. Fomenko

APPLICATION OF ELECTRIC EXPLORATION

AND ATMOGEOCHEMICAL TECHNOLOGIES

IN SEISMIC MICROZONING OF A TUNNEL

JUNCTION THROUGH THE MARKOTKH RIDGE .. 542
I. D. Muzaev, V. G. Sozanov

MATHEMATICAL MODELING OF WATER WAVE

MOTION IN A RESERVOIR CAUSED BY THE

INTRUSION

OF A LANDSLIDE ARRAY

L. I. Kortiev, A. L. Kortiev,

S. D. Vaneyev, R. P. Kulumbegov

FUNCTIONING AND DYNAMICS

OF LANDSCAPES IN THE DESIGN

OF HIGHWAYS IN MOUNTAINOUS

CONDITIONS

Ganapathy G. P., Zaalishvili V. B.,

Chandrasekaran S. S, Melkov D. A.

INTEGRATED MONITORING OF SLOPE

PROCESS IN INDIA AND RUSSIA

ENGINEERING

Yu. L. Zhukovsky, A. Yu. Lavrik,

A. V. Semenyuk, O. S. Vasilkov

POTENTIAL FOR ELECTRIC CONSUMPTION

MANAGEMENT IN THE CONDITIONS OF AN

ISOLATED ENERGY SYSTEM IN A REMOTE

POPULATION

A. A. Kravtsov, V. I. Anischenko,

V. A. Atrushkevich

PERSPECTIVES OF APPLYING WEBRTC

FOR REMOTE-CONTROLLED MINING

EQUIPMENT

S. G. Kostyuk,I. V. Chicherin,

B. A. Fedosenkov, D. M. Dubinkin

MONITORING OF THE DYNAMIC STATE

OF AUTONOMOUS HEAVY PLATFORMS

ON THE QUARRY ROUTES

OF MINING ENTERPRISES

SCIENTIFIC OPINION

A. N. Gunya,E. A. Khadzaragova, V. N. Khetagurov,

Yu. I. Karaev

INTERDISCIPLINARY ASPECTS

OF SUSTAINABLE DEVELOPMENT

OF MOUNTAIN TERRITORIES:

THE ROLE OF SOCIO-CULTURAL

FACTORS

INFORMATION FOR AUTHORS 
УСТОЙЧИВОЕ $\quad$ No1, 2009

РАЗВИТИЕ

ГОРНЫХ ТЕРРИТОРИЙ

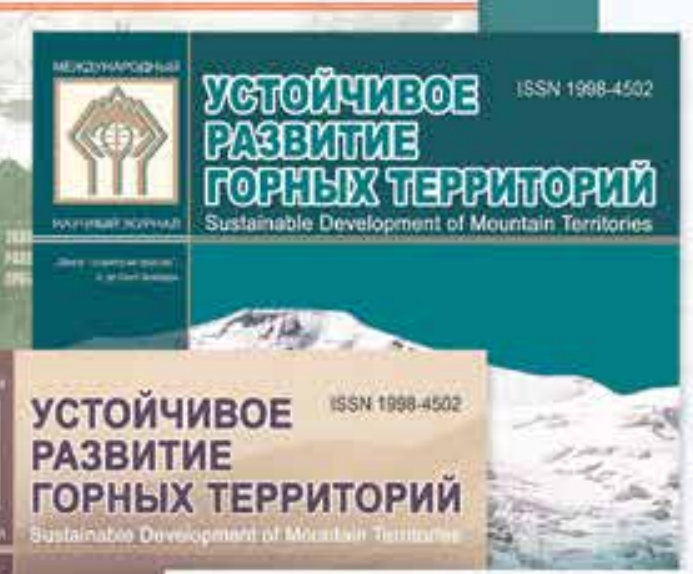

$-\rightarrow+2=$
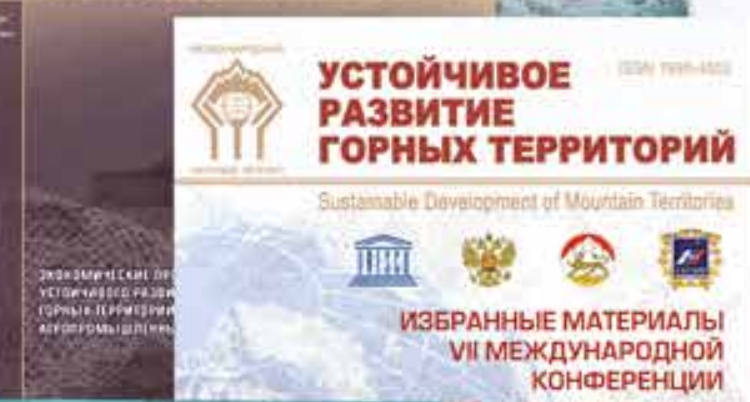

ИЗБРАННЫЕ МАТЕРИАЛЬ VIМЕЖДУНАРОДНОЙ КОНФЕРЕНЦИИ

УСTOЙИВOE

PA3BИTИE

ГОРНЬX TЕРРИTOРИЙ

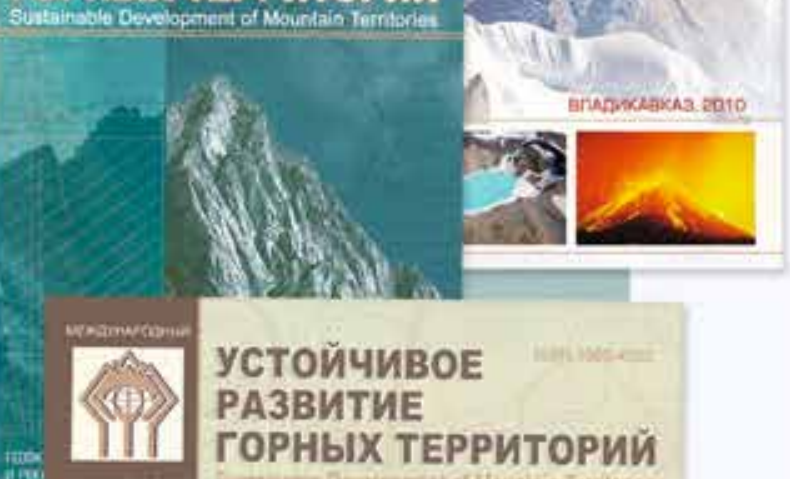

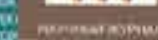

ГОРНЫХ ТЕРРИТОРИЙ

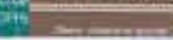

УСТОЙчИвоЕ

РАЗВИТИЕ

ГОРНЫХ ТЕРРИТОРИЙ

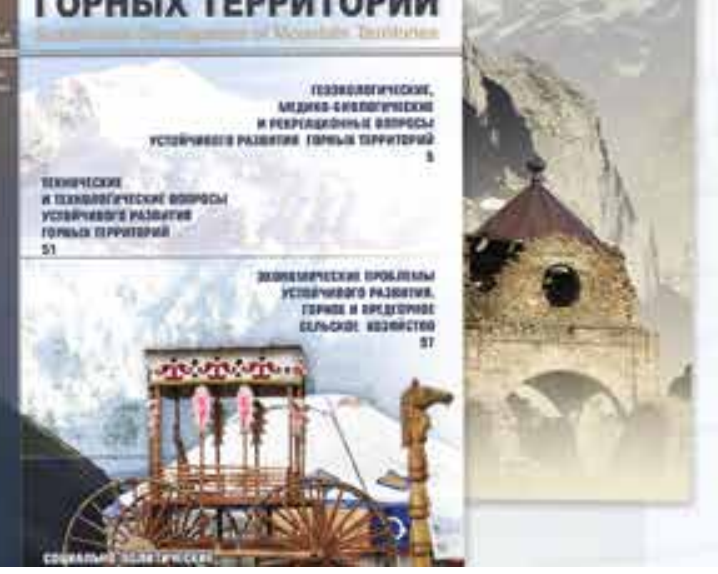

\section{Уважаемые коллеги!}

В соответствии с заключением Президиума ВАК Минобрнауки РФ от 26.03.2019 г. статьи для публикации в журнале «Устойчивое развитие горных территорий» принимаются по следующим отраслям и группам наук:

05.05.06 - Горные машины (технические науки);

25.00.13 - Обогащение полезных ископаемых (технические науки);

25.00.20 - Геомеханика, разрушение горных пород, рудничная аэрогазодинамика и горная теплофизика (технические науки);

25.00 .22 - Геотехнология (подземная, открытая и строительная) (технические науки);

25.00.23 - Физическая география и биогеография, география почв и геохимия ландшафтов (географические науки);

25.00.24 - Экономическая, социальная, политическая и рекреационная география (географические науки).

Помимо этого, в рамках международной базы цитирования Scopus тематика Журнала ориентирована на следующие отрасли и группы наук:

1. Технические науки (Engineering);

2. Науки о Земле и планетарные науки (Earth and Planetary Sciences);

3. Наука об окружающей среде (Environmental Science).

В связи с тем, что журнал «Устойчивое развитие горных территорий» входит в «Перечень российских рецензируемых научных журналов, в которых должны публиковаться основные научные результаты диссертаций на соискание ученых степеней доктора и кандидата наук» и включен в международную реферативную базу данных и систему цитирования Scopus, просьба к авторам:

- соблюдать требования к авторам публикации;

- текст статьи сопровождать необходимыми сопутствующими материалами;

- не выходить за рамки обозначенного допустимого объема статьи;

- выполнять все требования, предъявляемые к рисункам, диаграммам, фотографиям и пр. Напоминаем, что редакция не возвращает авторам присланные материалы равно как на бумажных, так и на электронных носителях.

Сообщаем также, что количество журналов, в рекламных целях рассылавшихся ранее бесплатно, значительно сокращено, в связи с чем информируем, что подписка на журнал продолжается. Те, кто не успел подписаться на 1 полугодие 2021 года в отделениях Роспечати, могут сделать это в самой редакции (подробности стоимости и условий подписки в разделе «Подписка. Реклама» журнала).

Редакция также осуществляет услуги по изготовлению и размещению рекламных материалов на страницах журнала (обложка, цветные вклейки, черно-белые вставки). Вы можете прорекламировать продукцию, разработанную в ваших лабораториях и научных центрах, предложить запатентованное вами оборудование, приборы, новые технологии, сделать предложение о сотрудничестве, предложить услуги научного либо прикладного характера, попытаться привлечь инвестиции под ваши проекты, проанонсировать монографию, т.е. на правах рекламы разместить любую необходимую для вас информацию.

Сделав заявку и прислав текст и примерный вид вашей предполагаемой рекламы, Вы, связавшись с нами по телефону редакции $+7(918) 707-39-25$, обговариваете все детали. Получив от нас счет за выполненную работу, оплачиваете его, а копию платежного получения присылаете на электронный адрес редакции.

Всегда рады сотрудничеству. 


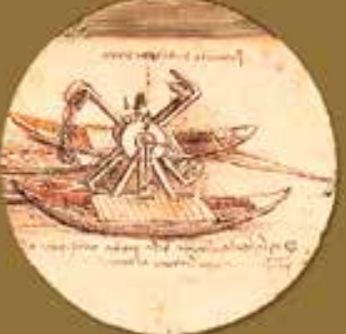

Крупные катастрофы, уюсе разоривиие и продолюсающие разорять современный мир, происходят от нежелания человека считаться с законами природы, от нежелания понять, что голод нельзя утолить, опустошая землю.

Жан ДОРСТ

\section{МЕТОДОЛОГИЯ МОНИТОРИНГА И УПРАВЛЕНИЯ ЭКОЛОГИЧЕСКИМ СОСТОЯНИЕМ РЕК С ИСПОЛЬЗОВАНИЕМ ИНТЕГРАЛЬНЫХ БИОИНДИКАТОРОВ И МЕТОДОВ УПРАВЛЕНИЯ КАЧЕСТВОМ}

Горбунова Т. Л. ${ }^{1}$ Матова Н. И. ${ }^{1 *}$,

${ }^{I}$ Филиал Института природно-технических систем, Сочи, Россия, http://iptssochi.ru

\section{Введение}

Характеристики и свойства воды рек оказывают определяющее влияние на состояние экосистем водного объекта и прибрежных экосистем, имеют большое значение для экономики территории водостока реки, потребляющей природную воду в хозяйственных целях, важны для населения, использующего природные водотоки в качестве источника питьевой воды, а также места отдыха и оздоровления. В соответствии с Водным кодексом РФ органы местного самоуправления и различных уровней власти обязаны осуществлять меры по охране водных объектов, находящихся в их собственности.

Однако в процессе осуществления природопользования вообще, и водопользования в частности, различными субъектами хозяйствования в ходе реализации обязанностей и полномочий властных органов возникают конфликты интересов различных уровней - как межсубъектные, так и конфликты экономических, экологических, социальных и личных интересов, что приводит в конечном счете к разрозненности, сегментарности и формальности предпринимаемых природоохранных мер [1-3].

Основные проблемы, снижающие эффективность проводимой водоохранной деятельности, мы видим в отсутствии оперативной объективной информации о «факторах влияния»: химических, физических и биологических аспектах, которые часто носят антропогенный характер и потенциально могут регулироваться природопользователями; характеристиках воды, сформировавшихся в результате первичного и вторичного загрязнения; состоянии экосистем водного объекта [4], а главное - в отсутствии методики, позволяющей специалистам природоохранных структур на основании этих данных провести оперативный анализ и выявить причины, в наибольшей степени влияющие на ухудшение качества воды в реке, предпринять необходимые административные меры и оценить их результативность.

Решить эти проблемы призвана предлагаемая методология мониторинга и управления экологическим состоянием рек с использованием интегральных
УДК: 502.175

DOI: $10.21177 / 1998-4502-2020-$

$12-4-483-492$

Для оптимизации процесса управления качеством воды природных водотоков, испытывающих антропогенную нагрузку, целесообразно и эфрфективно применять методы улучшения процессов, зарекомендовавшие себя в различных бизнес-процессах (производстве, оказании услуг, проектировании и m.д.), с целью достижения стабильного и гарантированного качества природной воды. Речь идет о применении статистических количественных методов управления качеством и улучшения процессов, объединенных методологией «Шесть сигм». Возможность применения этого подхода для систематического оздоровления экологической ситуации на природных водотоках была разработана и апробирована на реке Мзымта (2. Сочи, Краснодарский край).

\section{КЛЮЧЕВЫЕ СЛОВА:} мультиметрический индекс, территориальный экологический менеджмент, управление качеством, "шесть сигм», умный город.

Статья поступила в редакцию 16.07.2019. 
биоиндикаторов и методов управления качеством. Данная статья является первой в серии публикаций, посвященных описанию представленной методологии.

\section{Материал и методы исследования}

Первая группа обозначенных выше проблем может быть решена путем расчета значений мультиметрического индекса (ММИ) - показателя качества и стабильности процессов в водных гидробиоценозах, предложенного как интегрального биоиндикатора оценки состояния водной среды в ходе предыдущих исследований авторов [5]. Этот показатель был разработан для водных объектов территории Юга России с субтропическим климатом и динамичным развитием рекреационно-курортного сектора экономики. При дальнейшем изучении эффективности этой методологии в применении к практике экологического контроля и мониторинга, другие характеристики могут быть включены в систему расчета ММИ с учетом целей и условий работ. Исследования производились в течение 2016-2018 гг.

ММИ включает в себя показатели, отражающие биоразнообразие и стабильность биологических сообществ рек горного типа, степень толерантности составляющих их гидробионтов к внешнему воздействию и токсобность водной среды для гидробионтов. ММИ рассчитывается на основе показателей анализа качественного и количественного состава проб макрозообентоса и перифитона в соответствии с Руководством по методам гидробиологического анализа поверхностных вод и донных отложений [6].

Информационная ценность ММИ значительно увеличивается, когда он применяется как составляющая системного подхода к последовательному мониторингу качества водной среды и управлению ее восстановлением путем устранения и/или минимизации выявленных факторов влияния на природные водотоки, испытывающие антропогенную нагрузку, сформированного на основании методологии управления качеством DMAIC и статистических количественных методов улучшения процессов, объединенных методологией «Шесть сигм» [7; 8]. Возможность применения этого подхода для систематического оздоровления экологической ситуации на природных водотоках была разработана и апробирована на реке Мзымта (г. Сочи, Краснодарский край).

Для создания функциональной модели, отображающей структуру и функции предлагаемой системы мониторинга и управления экологическим состоянием рек, применен графический метод, реализуемый методологией моделирования IDEF0 [9].

\section{Результаты исследований}

Методология DMAIC включает пять этапов: определение, измерение, анализ, улучшение и контроль (английская аббревиатура DMAIC - define, measure, analyse, improve and control). В настоящей статье пред- ставлена методология выполнения первых двух этапов - «определение» и «измерение».

Первый шаг этапа «определение» предполагает выявление потребителей и заинтересованных сторон, анализ их потребностей и представление этих потребностей в виде измеримых требований, а также установление целей улучшения.

Основной ожидаемый результат процесса «мониторинг и управление экологическим состоянием реки»- это состояние воды водотока, оптимальное для заинтересованной стороны с наиболее жесткими требованиями.

Выявлены и принимаются во внимание следующие потребители: водные и прибрежные экосистемы реки; население, использующее реку как источник питьевой воды, для полива в подсобном хозяйстве, для отдыха и рекреации; сельскохозяйственные и промышленные предприятия, использующие воду реки в производственных целях.

Для удовлетворения нужд различных категорий потребителей пресной воды в соответствии с «Санитарными правилами и нормами охраны поверхностных вод от загрязнения» установлены две категории водоемов: питьевого и культурно-бытового назначения и рыбохозяйственного назначения. Для водоемов первого типа используют санитарно-токсикологический, общесанитарный и органолептический лимитирующие показатели, а для водоемов второго типа добавляются токсикологический и рыбохозяйственный (по воздействию на жизнедеятельность и воспроизводимость гидробионтов). В нашей работе принимались во внимание характеристики водного объекта по его соответствию рыбохозяйственному назначению, так как для сохранения водоема как единой экосистемы важно не только обеспечить безопасность водопотребления человеком, но и сохранить биологические ресурсы, их биоразнообразие и трофические цепи. Нормативы соответствующих показателей приведены в ГОСТ 17.1.04-77 «Охрана природы. Гидросфера. Показатели состояния и правила таксации рыбохозяйственных водных объектов», а также в «Нормативах качества воды водных объектов рыбохозяйственного значения...» (утверждены Приказом Приказ Минсельхоза России N 552 от 13.12.20160).

Под заинтересованной стороной, вслед за стандартом ИСО 37101 [10], будем понимать лицо или организацию, которые могут подвергать воздействию, подвергаться воздействию или считать, что подвергаются воздействию решения или мероприятия, сформированного в процессе мониторинга и управления экологическим состоянием реки.

Таким образом, к заинтересованным сторонам, помимо пользователей, относятся органы местного самоуправления поселений, расположенных на территории водостока реки, другие собственники водного объекта или его участков, контролирующие государ- 


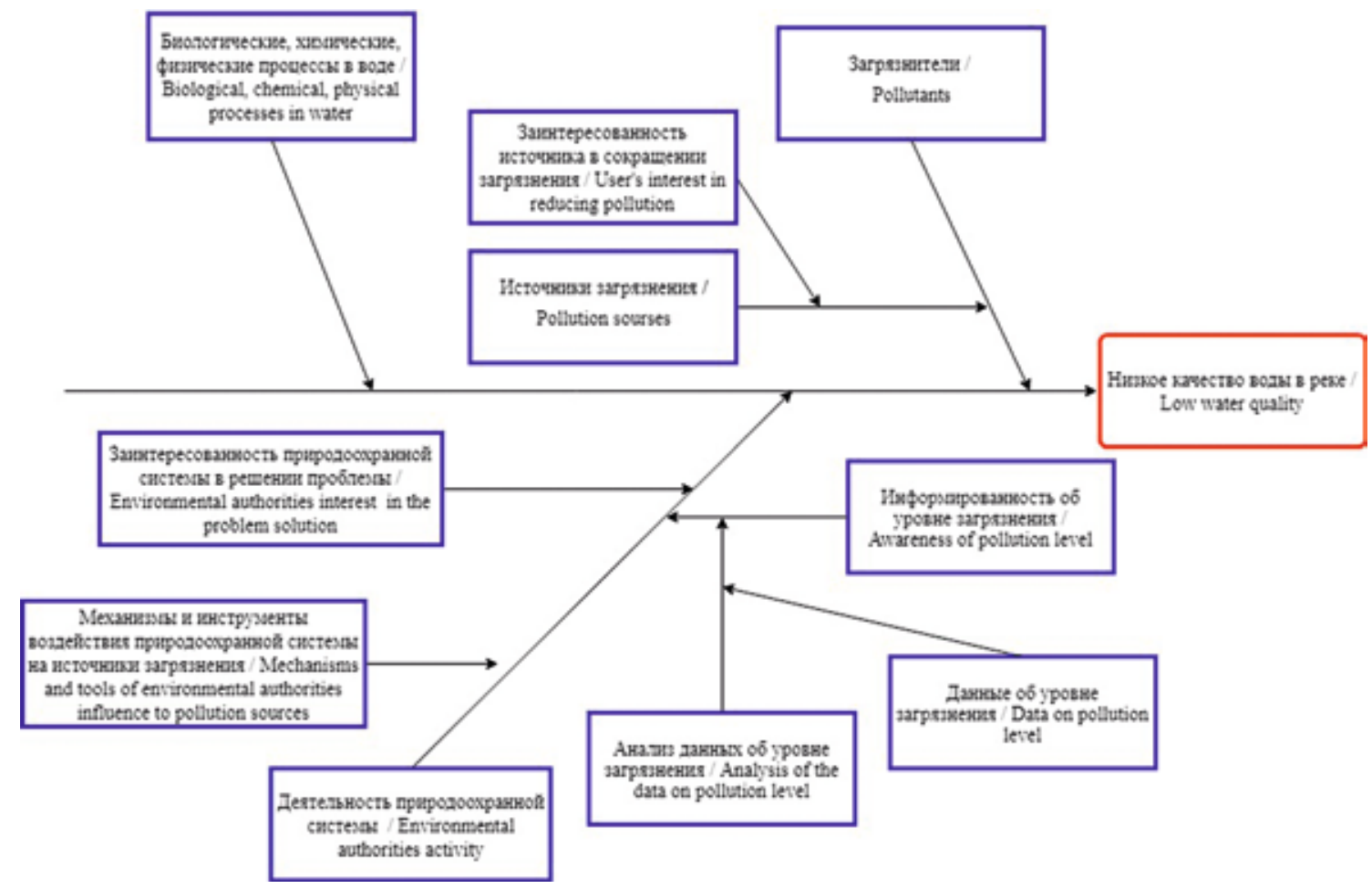

Puc. 1. Диаграмма Исикавы, отражающая причинно-следственные взаимосвязи между факторами и проблемой «низкое качество воды в реке»

Fig. 1. Ishikawa diagram reflecting the cause and effect relationship between factors and the "low water quality in the river» problem

ственные органы, в совокупности формирующие основу территориального экологического менеджмента муниципального уровня ${ }^{1}$, а также предприятия и лица, не использующие воду данного природного водотока, но оказывающие влияние на ее состояние (в первую очередь - источники загрязнения).

Сегодня у органов местного самоуправления поселений появился в распоряжении новый инструмент, позволяющий преобразовать различные сферы городского хозяйства, в том числе охрану и рациональное использование природных ресурсов, посредством внедрения цифровых технологий и инженерных решений. Речь идет о ведомственном проекте Минстроя РФ Цифровизации городского хозяйства «Умный город», реализация которого предполагается в течение шести лет (с 01.12.2018 по 31.12.2024) [11]. Считаем целесообразным и перспективным интегрировать предлагаемую методику мониторинга и управления экологическим состоянием реки с процессами «Умного города», что, с одной стороны, повысит результативность системы, с другой - обеспечит необходимые финансовые, административные и инфраструктурные ресурсы для ее внедрения и функционирования. Отметим, что в марте 2019 г. между Минстроем РФ и мэрией Сочи

\footnotetext{
${ }^{1}$ Территориальный экологический менеджмент муниципального уровня представляет собой систему управления отношениями, возникающими между различными субъектами по поводу использования, охраны и восстановления природных ресурсов и активов на территории муниципального образования, направленную на максимальную экономическую эффективность решения задач экологической безопасности для всей совокупности субъектов, действующих на территории.
}

подписано соглашение о реализации ведомственного пилотного проекта Минстроя «Умный город» в городе Сочи. Кроме того, в 2018 году Сочи, в числе восьми российских городов, стал членом Международного клуба устойчивых и умных городов (ISSCC).

Одним из ключевых факторов сохранения функциональных характеристик водного объекта является стабильность его гидробиоценозов и их биоразнообразие. Поэтому тактическая задача применения методологии DMAIC для исследуемого аспекта была определена как достижение стабильности процессов, протекающих в сообществах реки, за счет снижения воздействия регулируемых антропогенных факторов. Стратегическая задача - последовательное улучшение экологической ситуации водотока, связанное с тем, что свойства среды станут оптимальными для обеспечения условий, при которых поддерживается естественный баланс всего биоразнообразия биоценозов, их самовосстановление и рекреационный потенциал водного объекта.

Следующий шаг этапа «определение» заключается в описании деятельности или процесса. Для установления факторов наибольшего влияния на загрязнение водной среды была построена диаграмма «анализа корневых причин» Исикавы (рис. 1).

Предлагаемая методика охватывает цепочку из представленных на диаграмме (рис. 1) причинно-следственных связей факторов, оказывающих в конечном счете влияние на качество воды природного водотока: 


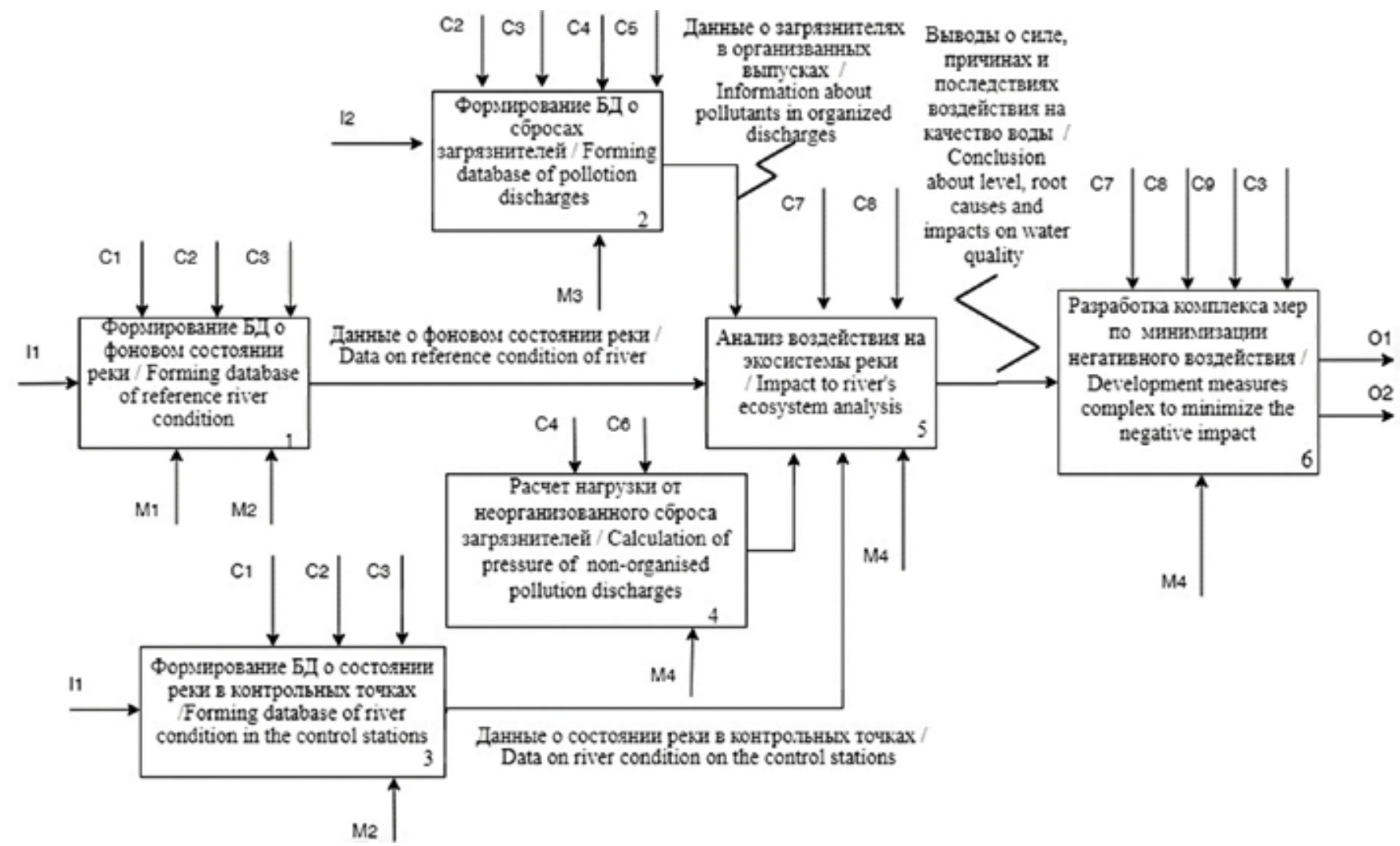

Puc. 2. Функциональная модель процесса «Мониторинг и управление экологическим состоянием реки» (второй уровень)

Fig. 2. Functional model of the process "Monitoring and management of the river ecological state" (second level)

Обозначения / Symbol:

I1 - Вода реки / River water

I2 - Организованные стоки источников загрязнения / Organized discharges from the sources of pollution

C1 - Методика по отбору и анализу проб / Methods of samples collection and analysis

C2 - График отбора проб / Sampling timetable

C3 - Процедуры внесения данных в БД “Умный город”/ Procedure of entering data into the «Smart City» database

$C 4$ - Физико-географические и социально-экономические карты; сборники государственной статистики об экономическом и социальном развитии МО, расположенных в бассейне водотока; экспертные наблюдения; открытые данные Росгидрометцентра и других контролирующих структур; информация СМИ / Physical-geographical and socio-economic maps; state statistics digests on economic and social development of the municipal formation, located within the water stream's catchment; experts observations; open data of Rosgidromet center and other regulatory agencies; media information;

C5 - Инструкция по установке и работе автоматического датчика / Instructions on automatic sensor establishment and operation

C6 - Методики расчета нагрузки от неорганизованного сброса в реку загрязнителей / Methods of pressure level calculation from non-organized pollutants discharges

$C 7$ - Устав МО, Регламент администрации, Положение о территориальном экологическом менеджменте МО (если есть) / Constitution of the Municipal formation, Regulations of the administration about the territorial environmental management (if applicable)

$C 8$ - Методология мониторинга и управления экологическим состоянием рек с использованием интегральных биоиндикаторов и методов управления качеством / Methodology of monitoring and management of rivers ecological state using integrated bioindicators and quality management methods

C9 - Природоохранное законодательство, правовые нормативные акты всех уровней / Environmental legislation, legal regulations at all levels

M1 - Лаборатория СЦГМС ЧАМ / Laboratory of the Specialised Center of Hydrometeorology and Monitoring of the Black and Azov Seas Environment

M2 - Специалист(ы) по биологическому мониторингу / Specialist(s) on biological monitoring

M3 - Автоматический датчик сбрасываемых в реку загрязнителей на организованных выпусках / Automatic sensor of incoming to the river pollutants on organized discharges

M4 - Уполномоченный орган системы территориального экологического менеджмента / Authorized body of territorial environmental management system

O1 - Меры по минимизации негативного воздействия на качество воды реки / Measures to minimize the negative impact on the river water quality

$O 2$ - Данные о разработанном комплексе мер по минимизации негативного воздействия на воды реки для процедур «Умного города» / Information about the developed complex of measures to minimize the negative impact on the river water for the procedures of «Smart City». 
получение данных об уровне загрязнения воды - анализ данных об уровне загрязнения воды - информированность управляющей природоохранной системы об уровне загрязнения воды - деятельность (разработка и осуществление мер по снижению загрязнения) управляющей природоохранной системы.

Графическое описание рассматриваемого процесса построено с использованием методологии функционального моделирования IDEF0. Это технология описания системы как множества иерархически вложенных действий или функций, представляемых графически блоком (прямоугольником, содержащим имя и номер) со входом (Input: материал или информация, которые используются и преобразуются работой для получения результата), выходом (ㅁotput: материал или информация, которые представляют результат выполнения работы), управлением (ontrol: управляющие, регламентирующие и нормативные данные, которыми руководствуется работа) и механизмами (ㅆechanism: ресурсы, которые выполняют работу). Любой блок может быть декомпозирован на составляющие его действия до необходимого уровня детализации.

В нашей статье мы пропускаем представление контекстной функции верхнего уровня (диаграммы А-0) и переходим сразу к ее декомпозиции второго уровня (рис. 2).

В ходе процедур, описываемых блоком 1 и 3 (рис. 2), происходит отбор проб, позволяющих оценить физико-химические свойства воды, и гидробиологических проб. Исходя из опыта природоохранных организаций г. Сочи, в условиях преобладания паводкового режима на реках региона и высокой вероятности смены их русел, установка автоматических датчиков непосредственно в природных водотоках нецелесообразна. На определенных в ходе последующих этапов исследования станциях анализ качества среды должен определяться лабораторно-приборным методом, а его результат своевременно вносится в соответствующую базу данных, формирующуюся по процедурам и на технологической платформе проекта «Умный город».

Блок 2 (рис. 2) предполагает формирование базы данных об организованных сбросах загрязнителей. На этапе «определение» должен быть сформирован список значимых источников загрязнения (в числе заинтересованных лиц), имеющих организованный сброс в реку. На каждом из таких выпусков должен быть размещен автоматический датчик, отслеживающий наиболее значимые загрязнители для данного объекта. Например, предприятие по автосервису (автомойка, заправка) устанавливает анализатор взвешенных веществ и нефтяных углеводородов, а коллективное средство размещения (гостиница, санаторий, турбаза и др.) - анализатор, позволяющий контролировать органическое загрязнение - биогены.

На территории водосбора исследуемого водного объекта также существует проблема неорганизованного сброса в реку сточных вод, когда невозможно определить их количество и состав, а, следовательно, и нагрузку на водоем, которую они оказывают. Это такие объекты, как неканализованные поселки, объекты стихийного (неорганизованного) туризма, ливневые стоки с дорог. Необходима инвентаризация таких участков и определение потенциальной нагрузки от них расчетным путем (например, в зависимости от количества жителей или площади водосбора ливневой канализации) [12].

Это обеспечит фундамент для принятия решений по дальнейшему развитию данной территории. Процедуры, необходимые для проведения расчетов нагрузки от неорганизованного сброса в реку сточных вод, содержатся в блоке 4 (рис. 2).

Декомпозиции и детализации вышеописанных блоков будут посвящены последующие статьи цикла.

Второй этап методологии улучшения процессов DMAIC - «измерение», целями которого являются: а) наглядное представление данных; б) определение базовой эффективности текущего процесса для конкретизации целей проекта.

Шаг первый - на основе измеримых показателей качества воды реки выбирают одну или несколько критичных переменных (загрязнителей) для улучшения. Далее происходит определение данных, которые должны быть собраны для характеристики процессов, происходящих в водотоке, и выявления факторов, влияющих на его изменчивость.

Выявление и анализ потенциальных источников загрязнения и факторов влияния, как антропогенных, так и природных, производилось на основании данных природоохранных организаций города, физико-географических и социально-экономических сведений, аналитических материалов государственной статистики об экономическом и социальном развитии муниципальных образований, расположенных в бассейне водотока, данных научных исследований и экспертных наблюдений, а также информации, предоставленной лабораторией СЦГМС ЧАМ. При этом были использованы собственные исследования водного объекта с отбором проб на всем протяжении водотока. На основе полученного материала было произведено зонирование реки выявление однородных по существенным критериям зон на основе первичного обследования [13-15].

В результате предпринятого исследования были выявлены на протяжении реки четыре основные зоны, различающиеся по своим физико-химическим и биологическим характеристикам. Важно отметить, что выделенные участки также отличаются по характеру землепользования в пределах их водостока. Многие авторы, работающие над развитием системы интегральных биоиндикаторов состояния водотоков, отмечают значительное влияние этого фактора на динамику речных экосистем [16-18].

Сводная характеристика зон реки Мзымта представлена в таблице. 
Зонирование водотока реки Мзымта

Zoning of the Mzymta river waterstream

\begin{tabular}{|c|c|c|c|c|}
\hline $\begin{array}{c}\text { Нижняя граница } \\
\text { зоны } \\
\text { (вниз по течению } \\
\text { р. Мзымта) } \\
\text { Lower boundary zone } \\
\text { (downstream of the river } \\
\text { Mzymta) }\end{array}$ & $\begin{array}{c}1 \text { км выше } \\
\text { п. Роза Хутор, верхнее } \\
\text { течение } \\
\text { (Фоновая станция) } \\
1 \text { km up from the village } \\
\text { Rosa Khutor, upper current } \\
\text { (Reference station) }\end{array}$ & $\begin{array}{c}1 \text { км ниже п. Роза Хутор } \\
1 \text { km down from the village } \\
\text { Rosa Khutor }\end{array}$ & $\begin{array}{l}100 \text { м ниже впаде- } \\
\text { ния р. Чвижепсе, } \\
\text { среднее течение } \\
100 \text { m down from the } \\
\text { point of confluence } \\
\text { with the Chvezhipse } \\
\text { river, middle current }\end{array}$ & $\begin{array}{c}\text { Устье } \\
\text { Mouth of the river }\end{array}$ \\
\hline $\begin{array}{c}\text { Тип биотопа } \\
\text { Type of biotope } \\
\text { Гидро-физикохими- } \\
\text { ческие показатели, } \\
\text { средние } \\
\text { Hydro-physic and } \\
\text { chemistry parameters: }\end{array}$ & $\begin{array}{c}\text { Эпиритраль } \\
\text { Epiritral }\end{array}$ & $\begin{array}{c}\text { Эпиритраль } \\
\text { Epiritral }\end{array}$ & $\begin{array}{c}\text { Эуритраль } \\
\text { Euritral }\end{array}$ & $\begin{array}{c}\text { Гипоритраль } \\
\text { Hyporitral }\end{array}$ \\
\hline $\begin{array}{c}\text { Степень заиления } \\
\text { субстрата } \\
\text { Substrate silting level }\end{array}$ & $\begin{array}{c}1.33-1.43 \\
\text { (минимальная } \\
\text { minimal) }\end{array}$ & $\begin{array}{c}1.43-2.00 \\
\text { (слабая } \\
\text { low) }\end{array}$ & $\begin{array}{c}1.5-3.29 \\
\text { (средняя - } \\
\text { значительная } \\
\text { medium - significant) }\end{array}$ & $\begin{array}{c}2.5-3.88 \\
\text { (значительная - } \\
\text { сильная } \\
\text { significant - high) }\end{array}$ \\
\hline $\begin{array}{c}\text { Взвешенные } \\
\text { вешества, мг/л } \\
\text { Suspended solids, } m g / l\end{array}$ & $2.4-4.54$ & $2.4-11.7$ & $4.7-22.33$ & $15.73-118.51$ \\
\hline $\begin{array}{l}\mathbf{Б П К ~}_{\mathbf{5}}, \mathbf{м г / л} \\
B O D_{s}, m g / l\end{array}$ & $0.81-1.24$ & $1.3-2.55$ & $1.48-1.75$ & $2.24-2.6$ \\
\hline $\begin{array}{c}\text { Сумма биогенов, мг/л } \\
\text { Nutrients total, } m g / l\end{array}$ & $0.02-0.03$ & $0.08-0.13$ & $0.23-0.34$ & $0.26-0.48$ \\
\hline $\begin{array}{c}\text { Значения ММИ, } \\
\text { средние } \\
\text { MMI values, averaged }\end{array}$ & 0.47 & 0.46 & 0.43 & 0.39 \\
\hline $\begin{array}{c}\text { Преобладающие } \\
\text { организмы } \\
\text { Dominating organisms }\end{array}$ & $\begin{array}{c}\text { Приспособление к } \\
\text { быстрому течению, } \\
\text { доминируют } \\
\text { соскребатели, хищники: } \\
\text { Adapted to rapid flow, } \\
\text { dominating scrapers and } \\
\text { predators: } \\
\text { Perlidae, Heptagenia, } \\
\text { Blephariceridae, Diamesa, } \\
\text { Simuliidae }\end{array}$ & $\begin{array}{c}\text { Приспособление к быстро- } \\
\text { му течению, доминируют } \\
\text { соскребатели, хищники: } \\
\text { Adapted to rapid flow, } \\
\text { dominating scrapers and } \\
\text { predators: } \\
\text { Perlidae, Heptagenia, } \\
\text { Blephariceridae, Diamesa, } \\
\text { Simuliidae, однако появл- } \\
\text { ются формы, устойчивые к } \\
\text { органическому загрязнению } \\
\text { - фильтраторы: } \\
\text { however, forms resistant to } \\
\text { organic pollution appeared- } \\
\text { filtrators: } \\
\text { Hydropsyche pellucidula, } \\
\text { Baetis. }\end{array}$ & $\begin{array}{c}\text { Приспособление к } \\
\text { быстрому течению, } \\
\text { доминируют } \\
\text { фильтраторы: } \\
\text { Adapted to } \\
\text { rapid flow, } \\
\text { dominatingfiltratos } \\
\text { Hydropsyche } \\
\text { pellucidula, } \\
\text { Rhyacophila, Baetis, } \\
\text { Ephemerella ignita. }\end{array}$ & $\begin{array}{c}\text { Мощные } \\
\text { обрастания } \\
\text { позволяют } \\
\text { развиваться } \\
\text { хирономидам, } \\
\text { ручейники } \\
\text { Massive } \\
\text { overgrowing } \\
\text { allow developing } \\
\text { chironomida, } \\
\text { the caddisflies } \\
\text { Hydroptila } \\
\text { femoralis }\end{array}$ \\
\hline
\end{tabular}

Первые две зоны верхнего течения реки принадлежат типу эпиритраль, характеризующегося холодной водой, быстрым течением и необильным обрастанием каменистого грунта, в основном выраженным тонкой пленкой диатомей. Дно не заилено. Поступление органики - листовой опад и грубый детрит. Антропогенное влияние в этой зоне минимально. Русло реки не зарегулировано. По берегам отмечается значительное облесение и большое количество мелких ручьев, источников, притоков, питающих реку.

Однако во второй зоне в эпиритрали присутствуют незначительные заиление дна и обрастания грунта зелеными и бурыми водорослями. Отмечается увеличение поступления органики. Антропогенное 
влияние здесь обусловлено в основном курортнорекреационными объектами, частным жилым сектором с приусадебными территориями, ливневыми стоками с дорог и строительных площадок. Река зарегулирована габионами, многие ручьи и источники, питающие реку, зарегулированы в бетон. Русло окружено твердым асфальтовым покрытием.

Следующая зона относится к эуритрали - быстрый поток с обильным органическим питанием, значительным заилением под камнями и у берегов, а также мощными обрастаниями каменистого субстрата. Антропогенное влияние на этом участке обусловлено курортно-рекреационными объектами и частным жилым сектором с приусадебными территориями, сбросами с очистных сооружений, выемкой гравия и карьерами, ливневыми стоками с дорог. Русло реки зарегулировано габионами и частично бетоном, окружено твердым асфальтовым покрытием.

Зона гипоритрали представляет собой водоток с интенсивными рыхлыми обрастаниями каменисто-галечного субстрата. Там имеются значительные иловые отложения. Участок характеризуется комплексным антропогенным влиянием различного происхождения: промышленность, густонаселенный район Адлер, обилие спортивных, курортно-рекреационных объектов, множество интенсивных автомагистралей и дорог. Русло реки зарегулировано в бетон и окружено твердым покрытием [19].

Далее на этапе «измерение» происходит, согласно стандарту, проверка применимости выбранных показателей, разработка плана сбора данных, их анализ и валидация, определение пригодности или воспроизводимости процесса сбора данных.

На этой стадии определялись и уточнялись точки отбора и анализа проб таким образом, чтобы данные, полученные при исследовании, могли предоставить необходимую аналитически-значимую информацию по соответствующей зоне и ее биотопу. Для каждой станции отбора необходимо определить период наблюдения в зависимости от особенностей жизненного цикла источника загрязнения: наличия сезонности, зависимости от погодных явлений, экономических циклов и процессов.

Так, в исследуемом регионе основная антропогенная нагрузка фиксируется в летний период. Это обусловлено как природными факторами - период летней межени, засухи, так и увеличивающимся антропогенным влиянием на прибрежных территориях, связанным с высоким туристическим сезоном, в течение которого возрастает водозабор из рек, в том числе Мзымты, и увеличиваются транспортные потоки. Поэтому, если в зимний период достаточно провести разовый отбор проб, то в летний период (июнь - октябрь) он должен осуществляться ежеме- сячно [20]. Кроме того, по мере накопления данных можно определить сезонные коэффициенты показателей качества гидробиоценозов.

\section{Заключение и выводы}

С целью создания системы, обеспечивающей последовательный мониторинг качества водной среды, формирование по результатам мониторинга актуальной и востребованной базы данных, используемой для формирования комплекса мер по восстановлению качества воды путем устранения и/или минимизации выявленных факторов негативного влияния на природные водотоки, испытывающих антропогенную нагрузку, были применены методологические принципы управления качеством и улучшения процессов «Шесть сигм». В статье представлено описание следующих шагов:

- выявление сторон, заинтересованных в сохранении/повышении качества (безопасности) воды, их требований к качеству (свойствам) воды, уровню ее безопасности,

- анализ и выявление потенциальных антропогенных и природных источников загрязнения на основе различных данных,

- зонирование природного водотока - выявление однородных по существенным критериям зон на основе первичного обследования (взятия проб по всему протяжению водотока),

- выбор точек отбора проб для определения мультиметрического индекса,

- выбор точек и установка датчиков для выявления загрязнителей в местах возможного загрязнения - на основании перечня потенциальных источников загрязнения. Для каждой точки необходимо определить период наблюдения в зависимости от особенностей жизненного цикла источника загрязнения (наличия сезонности, зависимости от погодных явлений, экономических циклов и процессов).

Разработанная система может применяться для процесса информационного обеспечения и принятия эффективных управленческих решений в сфере охраны водных объектов, а также экологического планирования развития территории водостока реки, в том числе в рамках проекта «Умный город». 


\section{ЛИТЕРАТУРА:}

1. Мишулина С. И., Бондаренко Т. И. Методическое обеспечение экологизации стратегического планирования // Региональная экономика. Юг России. 2018. N 3. С. 58-68. DOI: 10.15688/re.volsu.2018.3.7

2. Мишулина С. И. Механизмы согласования интересов природопользователей в ходе реализации инвестиционных проектов в регионах туристской специализации // Туризм: право и экономика. 2017. N 1. С. 12-16.

3. Матова Н. И. Анализ эколого-экономических интересов субъектов туриндустрии, формирующих организационно-экономические и институциональные предпосылки перехода рекреационных регионов к «зеленой» экономике // Туризм: право и экономика. 2017. N 3. С. $25-29$.

4. Галачиева С. В., Соколов А. А., Соколова О. А., Махошева С. А. Система оценки устойчивого развития региональных народнохозяйственных комплексов горных территорий // Устойчивое развитие горных территорий. 2018. N 3 (T. 10). C. 329-335. DOI: 10.21177/1998-4502-2018-104-329-335.

5. Горбунова Т. Л. Разработка и апробация мультиметрического биотического индекса для оценки экологического состояния рек на территории Большого Сочи // Системы контроля окружающей среды. Севастополь: ИПТС. 2019. Вып. 3 (37). С. 51-59.

6. Абакумов В. А. Руководство по методам гидробиологического анализа поверхностных вод и донных отложений / Государственный комитет СССР по гидрометеорологии и контролю природной среды. Л.: Гидрометеоиздат, 1983. $240 \mathrm{c}$.

7. ISO 13053-1:2011 «Quantitative methods in process improvement - Six Sigma - Part 1: DMAIC methodology». URL: https://www.iso.org/standard/52901.html (Дата обращения: 15.07.2019).

8. ISO 13053-2:2011 «Quantitative methods in process improvement - Six Sigma - Part 2: Tools and techniques». URL: https://www.iso.org/ru/standard/52902.html (Дата обращения: 15.07.2019).

9. Integration definition for function modeling (IDEF0). Draft Federal Information Processing Standards Publication 183, 1993 December 21. URL: http://www.iso.staratel.com/ IDEF/IDEF0/IDEF0.pdf (Дата обращения: 15.07.2019).

10. ISO 37101:2016 «Sustainable development in communities - Management system for sustainable development - Requirements with guidance for use». URL: https://www.iso. org/standard/61885.html (Дата обращения: 15.07.2019).

11. Технологии для умных городов. Доклад [Электронный ресурс]. Центр стратегических разработок «Северо-За- пад»( 2000-2016 ЦСР «Северо-Запад». - Санкт-Петербург. 2017. 107 c. URL: http://csr-nw.ru/files/publications/doklad tehnologii_dlya_umnyh_gorodov.pdf (Дата обращения: 02.02.2019)

12. Меншутин Ю. А., Верещагина Л. М., Керин А. С., Фомичёва Е. В., Логунова А. Ю. Рекомендации по расчету систем сбора, отведения и очистки поверхностного стока с селитебных территорий, площадок предприятий и определению условий выпуска его в водные объекты. Москва. ФГУ «НИИ ВОДГЕО». 2015. $143 \mathrm{c}$.

13. Ежегодник качества поверхностных вод Российской Федерации. Ростов-на-Дону: ФГБУ «Гидрохимический институт». 2018. URL: http://gidrohim.com/node/72 (Дата обращения 25.11.2018).

14. Подгорный К. А. Требования и подходы к разработке биологических индикаторов и проведению интегрированного анализа состояния водных экосистем: обзор [Requirements and approaches to the development of biological indicators and the conduct of integrated analysis of the state of aquatic ecosystems: review]. Works of AtlantNIRO. 2017. New Series, 4(1), 5-45.

15. Чертопруд М. В. Реофильные сообщества макробентоса Северо-Западного Закавказья // Материалы IV Всероссийского Симпозиума по амфибиотическим и водным насекомым и $\mathrm{X}$ Трихоптерологического Симпозиума. Владикавказ: СОГУ. 5-7 мая, 2010. С. 131-135

16. Deborde D. D., Hernandez M. B., Magbanua F. S. Benthic macroinvertebrate community as an indicator of stream health: the effects of land use on stream benthic macroinvertebrates // Science Diliman. July-December 2016. V.28:2. Pp. 5-26.

17. Kyriakeas S. A., Watzin M. C. Effects of adjacent agricultural activities and watershed characteristics on stream macroinvertebrate communities // Journal of the American Water Resources Association. 2006. V. 42(2). Pp. 425-441.

18. Walsh C. J., Sharpe A. K., Breen P. F., Sonneman J. A. Effects of urbanization on streams of the Melbourne region, Victoria, Australia. Benthic macroinvertebrate communities // Freshwater Biology. 2001. V. 46(4). Pp. 535-551.

19. Illies J. Attempt of generalization biozonotic structure of the flowing water // Int. Revue Ges. Hydrobiol. 1961. Vol. 46, N 2. Pp. 205-213 (in Germany).

20. Гудкова Н. К., Горбунова Т. Л., Любимцев А. Л. Идентификация экологических рисков, связанных с развитием рекреационно-туристических регионов Черноморского побережья Кавказа на примере комплексной оценки экосистемы горной реки Лаура // Устойчивое развитие горных территорий. 2018. Т. 10. N1(35). С. 23-34. DOI: 10.21177/19984502-2018-10-1-23-34. 


\section{СВЕДЕНИЯ ОБ АВТОРАХ / Information about authors:}

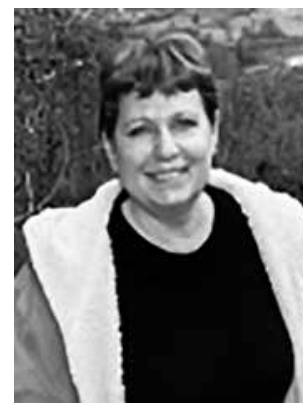

ГОРБУНОВА Татьяна Львовна - научный сотрудник лаборатории экономики природопользования и экологии, филиал Института природно-технических систем в г. Сочи; действительный член Сочинского городского отделения Русского географического общества (секция экологии).

$$
\text { г. Сочи, Россия. }
$$

Тел.: 8(988)284-15-70.

e-mail: tatianashaw@mail.ru

Tatiana L. GORBUNOVA - Laboratory of Economy of Natural Resources Management and Ecology Researcher in the Branch of the Institute of Natural and Technical Systems in Sochi; Active Member of the Sochi Branch of the Russian Geographic Society (Ecology Section).

Kurortny Av., 99/18, Sochi, Russia.

Ph.: +7(988)284-15-70.

e-mail: tatianashaw@mail.ru

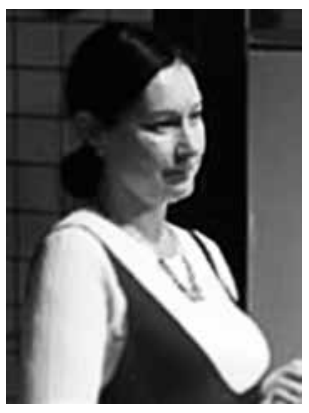

e-mail: lelj06@yandex.ru

МАТОВА Наталья Ивановна - кандидат экономических наук, старший научный сотрудник лаборатории экономики природопользования и экологии, филиал Института природно-технических систем в г. Сочи, Россия.

ORCID: https://orcid.org/00000001-6084-6233

Тел.: 8(918)303-13-70.

Natalia I. MATOVA - PhD of Economic, Laboratory of Economy of Natural Resources Management and Ecology Head Researcher in the Branch of the Institute of Natural and Technical Systems in Sochi. Kurortny Av., 99/18, Sochi, Russia.

ORCID: https://orcid.org/0000-0001-6084-6233

Ph.:+7(918)303-13-70

e-mail:lelj06@yandex.ru.

\section{MONITORING AND MANAGEMENT OF THE RIVER'S ECOLOGICAL STATE METHODOLOGY USING INTEGRAL BIOMARKERS AND QUALITY MANAGEMENT METHODS}

\section{Gorbunova T. L. ${ }^{\text {, }}$}

Matova N. I. ${ }^{*}$ *

${ }^{1}$ Branch of the Institute of Natural and Technical Systems, Sochi, Russian Federation, http://iptssochi.ru/

\section{DOI: $10.21177 / 1998-4502-2020-12-4-483-492$}

The water quality of most rivers near the settlements is below the optimal level, taking in account natural ecosystems condition and numerous needs of various users. Considering the environmental, economic and social importance of this factor, measures are required to improve natural reservoirs water quality management conducted by local civil autonomy and various levels of government. The goal of this work is to offer methodical recommendations on the system design of collecting, analyzing and forming the river's water and ecosystems conditions database for the information support of complex management decision-making directed to accomplishment and preservation of the water bodies specified functional characteristics.

Presently none of the existing methods of water environment assessment can take into account all possible biological communities' responses to the various stress factors and their combinations impacts. For every type of impact the corresponding to it approaches in sampling and analysis methods are used; values of such methods are often difficult to collate and, especially, provide statistical evaluation of the water streams processes. The presented methods are based on the multimetric index application, which include parameters, reflecting biological communities biodiversity and stability in mountain type rivers, tolerance degree of the constituted them water organisms to external impacts and water environment toxicity for its inhabitants.

Modern quality management, including quality of the processes, has a wide range of proven tools. The offered quality management process improvement method of the natural watersheds experiencing an anthropogenic pressure, is aiming to reach stability and guaranteed quality of the natural waters, based on the DMAIC quality management methodology and statistic quantitative methods united under the Six-Sigma approach. This article is the first in publications series devoted to the description of the methodology of the rivers ecological state monitoring and management using integrated biomarkers and quality management methods.

Formed during the study organizational and methodical approaches can be applied to digital transformation of effective administrative decisions making process in sphere of water objects protection and development of the river's catchment territory ecological planning within the project of the RF Construction Ministry "The Smart City".

Keywords: Multimetric index, territorial environmental management, quality management, Six Sigma, Smart City.

\section{References:}

1. Mishulina S. I., Bondarenko T. I. "Methodological provision for the ecologization of strategic planning", Regional Economy. South of Russia, 2018, no. 3, pp. 58-68. DOI: 10.15688/re.volsu.2018.3.7 (in Russian)

2. Mishulina S. I. "The mechanisms of stakeholders' interests coordination during the investment projects implementation in the tourism specialization regions", Tourism: Law and Economics, 2017, no. 1, pp. 12-16. (In Russian)

3. Matova N. I. "Analysis of ecological and economic interests of the tourism industry subjects, forming organizational, economic and institutional preconditions for transition of 
recreational regions to "green" economy", Tourism: Law and Economics, 2017, no. 3, pp. 25-29. (In Russian)

4. Gulachieva S. V., Sokolov A. A., Sokolova O. A., Makhosheva S. A. "System of assessment of regional mountain territories economic complexes sustainable development ", Sustainable Development of Mountain Territories, 2018, no. 3 (10), pp. 329-335. DOI: 10.21177/1998-4502-2018-10-4329-335. (In Russian)

5. Gorbunova T. L. "Development and testing multi-metrics biotic index for the rivers ecological assessment on the Larger Sochi territory", Environmental Monitoring Systems, Sevastopol, IPTS, v. 3 (37), pp. 51-59.

6. Abakumov V. A. Manual on hydrobiological analysis methods of surface waters and bottom sediments, State Committee of the USSR on Hydrometeorology and Environmental Control, Leningrad, Hydrometeoizdat Publ., 1983, 240 p. (In Russian).

7. ISO 13053-1:2011 «Quantitative methods in process improvement - Six Sigma - Part 1: DMAIC Methodology». URL: https://www.iso.org/standard/52901.html (accessed 15.07.2019)

8. ISO 13053-2:2011 «Quantitative methods in process improvement - Six Sigma - Part 2: Tools and Techniques» URL: https://www.iso.org/ru/standard/52902.html (accessed: 15.07.2019)

9. Integration definition for function modeling (IDEF0). Draft Federal Information Processing Standards Publication 183, 1993, December 21. URL: http:/www.iso.staratel.com/ IDEF/IDEF0/IDEF0.pdf (Accessed: 15.07.2019)

10. ISO 37101:2016 «Sustainable development in communities - Management system for sustainable development - Requirements with guidance for use» URL: https://www. iso.org/standard/61885.html (accessed 15.07.2019)

11. Technologies for smart cities. Report [Electronic resource], Center for strategic development "North-West》" (C) 2000-2016 CSR “North-West”, Saint Petersburg, 2017, 107p. URL: http://csrnw.ru/files/publications/doklad_tehnologii_ dlya_umnyh_gorodov.pdf, (Accessed: 02.02.2019)

12. Menshutin Y. A., Vereshchagina L. M., Fomicheva E. V., Logunova A. Y. Recommendations for the systems calculation of surface runoff from residential areas and enterprises sites collection, removal and treatment and the definition of conditions for its release it into water bodies, Moscow, FGU "NII VODGEO", 2015, 143p. (In Russian)

13. Annual report book of surface water quality of the Russian Federation, Rostov-on-Don, FGBU Hydrochemistry Institute. 2018. URL: http://gidrohim.com/node/72 (accessed 25.11.2018). (In Russian)

14. Podgorny K. A. Requirements and approaches to the development of biological indicators and the conduct of integrated analysis of the state of aquatic ecosystems: review, Works of AtlantNIRO, 2017, New series, 4(1), 5-45.

15. Chertoprud M. V. "Rheo-fill communities of macroinvertibrates of North-Western Transcaucasia", Materials of IV All-Russian Symposium on Amphibiotic and Aquatic Insects and X Trichopterological Symposium, Vladikavkaz, North Ossetian State University Publ., 5-7 May, 2010, pp. 131-135. (In Russian).

16. Deborde D. D., Hernandez M. B., Magbanua F. S. "Benthic macroinvertebrate community as an indicator of stream health: the effects of land use on stream benthic macroinvertebrates", Science Diliman, July-December 2016, v. 28, 2, pp. 5-26.

17. Kyriakeas S. A., Watzin M. C. "Effects of adjacent agricultural activities and watershed characteristics on stream macroinvertebrate communities", Journal of the American Water Resources Association, 2006, v. 42(2), pp. 425-441.

18. Walsh C. J., Sharpe A. K., Breen P. F., Sonneman J. A. "Effects of urbanization on streams of the Melbourne region, Victoria, Australia, Benthic macroinvertebrate communities", Freshwater Biology, 2001, v. 46(4), pp. 535-551.

19. Illies J. "Attempt of a general bio-zoning outline of the flowing water", Int. Revue Ges. Hydrobiology, 1961, vol. 46, no. 2, pp. 205-213. (In German).

20. Gudkova N. K., Gorbunova T. L., Lubimtsev A. L. "The identification of the ecological risks concerning the recreation - tourist's region development of the Caucasian Black Sea shore using the complex estimation of the mountain river Laura ecosystem", Sustainable Development of Mountain Territories, 2018, v. 10, no. 1 (35). pp. 23-34. DOI: 10.21177/1998-4502-2018-10-1-23-34. (In Russian).

Article received 16.07.2019 


\section{ОЦЕНКА ВОЗМОЖНОСТИ ПРИМЕНЕНИЯ ТОРФО- ДИАТОМИТОВОГО МЕЛИОРАНТА ПРИ РАЗРАБОТКЕ МЕРОПРИЯТИЙ ПО ЭКОЛОГИЧЕСКОЙ РЕАБИЛИТАЦИИ НАРУШЕННЫХ ЭКОСИСТЕМ}

\begin{abstract}
Антонинова Н. Ю.*1,2, Усманов А. И. ${ }^{1,3}$, Шубина Л. А. ${ }^{2}$, Собенин А. В. ${ }^{2}$ ${ }^{1}$ Федеральное государственное бюджетное образовательное учреждение высшего образования "Уральский государственный горный университет», 620144, Екатеринбург, Россия

${ }^{2}$ Федеральное государственное бюджетное учреждение науки «Институт горного дела Уральского отделения РАН», 620075, Екатеринбург, Россия, natal78@list.ru ${ }^{3}$ ООО «Экоинноватор», 620010, Екатеринбург, Россия
\end{abstract}

\section{Введение}

Урал - уникальная геохимическая провинция, характеризующаяся наличием разведанных и осваиваемых месторождений полезных ископаемых на территориях от Заполярья до южных границ Оренбургской области и Башкортостана. Долгие годы индустриального развития привели к значительному ухудшению геосферы, поэтому изучение процессов землепользования при освоении недр в аспекте влияния на окружающую среду актуально с различных позиций [1-4].

Во-первых, это процесс изъятия из биологического круговорота веществ и энергии при нарушении целостности земной поверхности и уничтожении биологически активных её компонентов - растительного и животного мира разных уровней организации - от низших до высших. То есть изъятие земель для развития промышленного производства - это нарушение биопродукционных систем, сопровождающееся экономическим ущербом.

Во-вторых, в результате достаточно активного освоения месторождений полезных ископаемых в течение нескольких столетий на территории Уральского региона образовалось большое количество отвалов, складов, хранилищ отходов обогащения. В 2019 году в Свердловской области насчитывалось 23 бесхозных объекта размещения отходов (данные Министерства экологии и природных ресурсов Свердловской области), занимающие площадь 380 га. На включение в реестр объектов накопленного вреда могли бы претендовать еще 39 выведенных из эксплуатации объектов общей площадью 1578 га и объемом размещенных отходов 0.85 млрд т, значительная часть которых, хотя и находится на балансе собственников, но не подвергается реабилитации либо безопасной консервации, несмотря на завершенный период эксплуатации. Как и бесхозные объекты, более 50 \% выведенных из эксплуатации хранилищ промышленных отходов являются результатом добычи и передела черных и цветных металлов - отвалами вмещающих пород, хвостами обогащения, шламами металлургических производств.

Возникшие на месте природного ландшафта техногенные образования (ТМО) изменяют эстетику местности, качественно изменяют водные ресурсы и атмосферу не только в центре их создания, но и далеко за пределами, так как размещение и длительное хранение данного вида отходов, являющихся практически неиспользуемой резервной материальной базой перерабатывающих предприятий, приводит к экспоненциальному росту загрязнения окружающей среды [5-8]. Последствия неблагоприятных изменений природных компонентов, вызванных деятельностью предприятий горнопромышленного сектора экономики, не могут быть устранены есте-
УДК: 622.85:504.062

DOI: $10.21177 / 1998-4502-2020-12-$ 4-493-500

Для реабилитации техногенно загрязненных объектов, рекультивации нарушенных земель необходимо проведение исследований по эфрфективности применения новых видов мелиорантов, в качестве материалов для формирования которых возможно использование природных и минеральных удобрений.

В статье приведены результаты полученных экспериментальных данных, позволяющие оценить эфффективность использования торфодиатомитового мелиоранта, так как в период проведения исследований отчетливо просматривается положительная динамика сорбционного процесса.

\section{КЛЮЧЕВЫЕ СЛОВА:}

экологическая реабилитация, промышленные отходы, экспериментальные модули, техногенный грунт, сорбция, диатомит, торфодиатомитовый мелиорант.

Статья поступила в редакцию 30.09.2020 
ственным путем. Восстановление экологического равновесия требует соответствующих природоохранных мероприятий, поэтому исследование процессов миграции и накопления тяжелых металлов является одной из важнейших задач при разработке вышеуказанных мероприятий [9].

Настоящая работа была нацелена на оценку эффективности применения торфо-диатомитового мелиоранта при разработке мероприятий по экологической реабилитации. Для реабилитации техногенно загрязненных объектов, рекультивации нарушенных земель необходимо проведение исследований по эффективности применения новых видов мелиорантов в качестве материалов, для формирования которых возможно использование природных и минеральных удобрений [10-16].

\section{Материалы и методы исследований}

В лаборатории экологии горного производства ИГД УрО РАН в рамках проведения исследований была рассмотрена возможность использования в качестве сорбента осадочной горной породы, на 85-90\% состоящей из кремния-диатомита. В качестве модельного раствора были использованы шахтные воды бывшего Дегтярского рудника с содержанием меди 4.61 мг/л и рН-2.8, отрабатывавшего до 1995 г. одноимённое месторождение медноколчеданных руд, расположенное в 34 км юго-западнее г. Екатеринбурга в долине реки Дегтярки. Навески с заданной массой были помещены в колбы с модельным раствором объёмом 100 мл. Техногенный грунт для микрополевых опытов был отобран в период летних полевых исследований. Торфо- диатомитовый мелиорант - собственная разработка ООО «Экоинноватор».

Содержание ионов меди определяли атомно-абсорбционным методом при помощи Spectr AA-240 FS (VarianOpticalSpectr. Instrum, Australia). Минерализацию проб для определения валового содержания меди производили в концентрированной $\mathrm{HNO}_{3}$ при помощи лабораторной микроволновой системы MARS 5 (CEM, USA). Подвижные формы меди определялись в вытяжках 0,5 $\mathrm{M} \mathrm{HNO}_{3}$ в соотношении 1:25 (почва : раствор).

\section{Результаты исследований и их обсуждение}

Результаты экспериментальных исследований приведены в табл. 1.

Так как общую загрязненность почвы характеризует валовое содержание тяжелых металлов, а доступность элементов для растений определяется их подвижными формами, для оценки непосредственно экологической опасности необходимо знать возможную массу геохимически активных форм, способных поглощаться растительностью и биотой, представляющей собой наиболее важную с точки зрения питания растений группу соединений [17-22].

В связи с вышеизложенным и с целью выявить влияние концентраций торфо-диатомитового мелиорантана на подвижность ионов меди был заложен микрополевой опыт продолжительностью 92 календарных дня. В экспериментальные модули были помещены субстраты, состоящие из техногенного грунта, торфо-диатомитового мелиоранта и сапропеля, а также высажены семена ржи посевной (Secalecereale L.) и клевера ползу-

таблица 1 / Table 1

Результаты экспериментальных исследований

Results of experimental studies

\begin{tabular}{|c|c|c|c|c|c|c|}
\hline № & $\begin{array}{c}\text { Наименование } \\
\text { Name }\end{array}$ & $\begin{array}{l}\text { Навеска, гр } \\
\text { Value, grams }\end{array}$ & $\begin{array}{l}\text { Время, мин } \\
\text { Time, } \min \end{array}$ & pH & $\begin{array}{c}\text { OBח, } \mathbf{m V} \\
(O R P)\end{array}$ & $\begin{array}{c}\text { Си, } \\
\text { мг/л } \\
(p p m)\end{array}$ \\
\hline 1 & $\begin{array}{l}\text { Диатомит } \\
\text { Diatomite }\end{array}$ & 10 & 5 & 2.86 & 425 & 2.743 \\
\hline 2 & $\begin{array}{l}\text { Диатомит } \\
\text { Diatomite }\end{array}$ & 10 & 10 & 2.88 & 419 & 2.593 \\
\hline 3 & $\begin{array}{l}\text { Диатомит } \\
\text { Diatomite }\end{array}$ & 10 & 15 & 2.86 & 416 & 2.683 \\
\hline 4 & $\begin{array}{l}\text { Диатомит } \\
\text { Diatomite }\end{array}$ & 15 & 5 & 2.93 & 415 & 2.241 \\
\hline 5 & $\begin{array}{l}\text { Диатомит } \\
\text { Diatomite }\end{array}$ & 15 & 10 & 2.92 & 417 & 2.189 \\
\hline 6 & $\begin{array}{l}\text { Диатомит } \\
\text { Diatomite }\end{array}$ & 15 & 15 & 2.93 & 415 & 2.175 \\
\hline 7 & $\begin{array}{l}\text { Диатомит } \\
\text { Diatomite }\end{array}$ & 20 & 5 & 2.94 & 416 & 2.109 \\
\hline 8 & $\begin{array}{l}\text { Диатомит } \\
\text { Diatomite }\end{array}$ & 20 & 10 & 2.96 & 417 & 2.134 \\
\hline 9 & $\begin{array}{l}\text { Диатомит } \\
\text { Diatomite }\end{array}$ & 20 & 15 & 3.28 & 415 & 1.754 \\
\hline
\end{tabular}




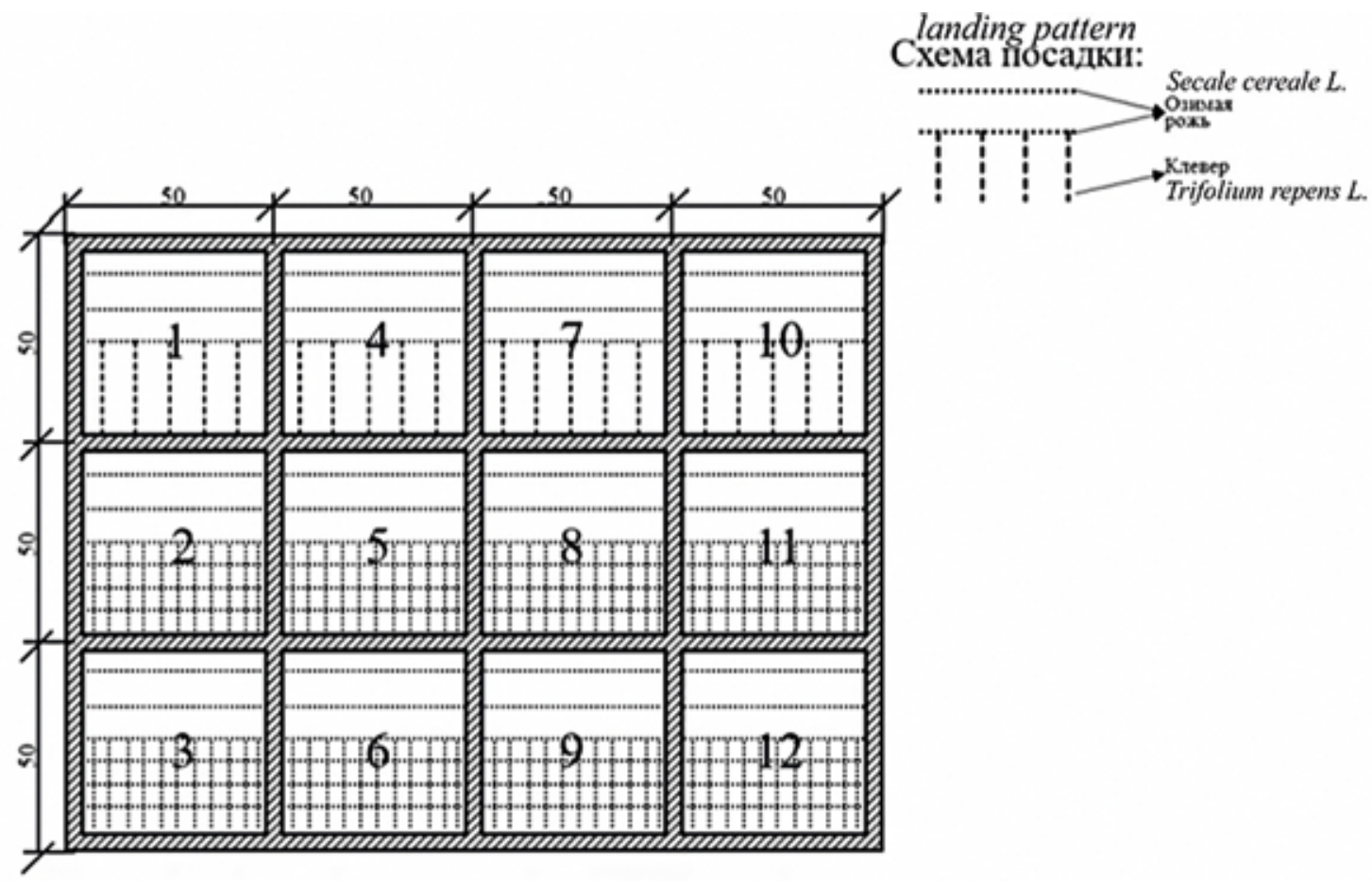

Рис. 1. Схема микрополевого опыта:

Обозначения: 1.Торф/диатомит/сапропель 40/30/30 - фон; 2. Торф/диатомит/сапропель 50/40/10 - 10 кг - фон; 3. Диатомит/сапропель 60/40 - 10 кг - фон; 4. Торф/диатомит/сапропель 40/30/30 - 6 кг + 5 кг техногенный грунт; 5. Торф/диатомит/сапропель 50/40/10 - 6 кг + 5 кг техногенный грунт; 6. Диатомит/сапропель 60/40 - 6 кг + 5 кг техногенный грунт; 7. Торф/диатомит/сапропель 40/30/30 - 14 кг +5 кг техногенный грунт; 8. Торф/диатомит/сапропель 50/40/10 - 14 кг + 5 кг техногенный грунт; 9. Диатомит/сапропель 60/40 - 14 кг + 5 кг техногенный грунт; 10. Торф/диатомит/сапропель 40/30/30 + техногенный грунт; 11. Торф/диатомит/сапропель 50/40/10 + техногенный грунт; 12. Диатомит/ сапропель 40/60 - 10 кг техногенный грунт

Fig. 1. Microfield experiment scheme:

Designations: 1. Peat / diatomite / sapropel 40/30/30 - background; 2. Peat / diatomite / sapropel 50/40/10 - $10 \mathrm{~kg}$ - background; 3. Diatomite / sapropel 60/40 - $10 \mathrm{~kg}$ - background; 4. Peat / diatomite / sapropel 40/30/30 - $6 \mathrm{~kg}+5 \mathrm{~kg}$ technogenic soil; 5. Peat / diatomite / sapropel 50/40/10 - 6 kg + $5 \mathrm{~kg}$ technogenic soil; 6. Diatomite / sapropel 60/40 - 6 kg + $5 \mathrm{~kg}$ technogenic soil; 7. Peat / diatomite / sapropel 40/30/30 - $14 \mathrm{~kg}+5 \mathrm{~kg}$ technogenic soil; 8. Peat / diatomite / sapropel 50/40/10 - $14 \mathrm{~kg}+5 \mathrm{~kg}$ technogenic soil; 9. Diatomite / sapropel $60 / 40-14 \mathrm{~kg}+5 \mathrm{~kg}$ technogenic soil; 10. Peat / diatomite / sapropel 40/30/30 + technogenic soil; 11. Peat / diatomite / sapropel 50/40/10 + technogenic soil; 12. Diatomite / sapropel 40/60 - $10 \mathrm{~kg}$ technogenic soil

чего (Trifoliumrepens L.) для определения возможности использования при проведении мероприятий по экологической реабилитации экосистем, сельскохозяйственных культур. В первый месяц зафиксирована гибель большей части ростков клевера (рис. 1).

Микрополевой опыт был заложен на территории опытно-промышленной базы лаборатории экологии горного производства ИГД УрО РАН (рис. 2).

Для определения степени трансформации, оценки перехода загрязняющих веществ в окружающую среду и выявления возможностей локализации потенциальных загрязнителей были определены валовое содержание и концентрации подвижных форм меди в грунте.

Содержание валовой формы меди во всех исследуемых пробах превышает содержание подвижной формы. К завершению эксперимента во всех пробах, кроме модуля №9, наблюдается снижение концентрации, как валовой формы меди, так и подвижной.

Снижение концентраций подвижных форм меди

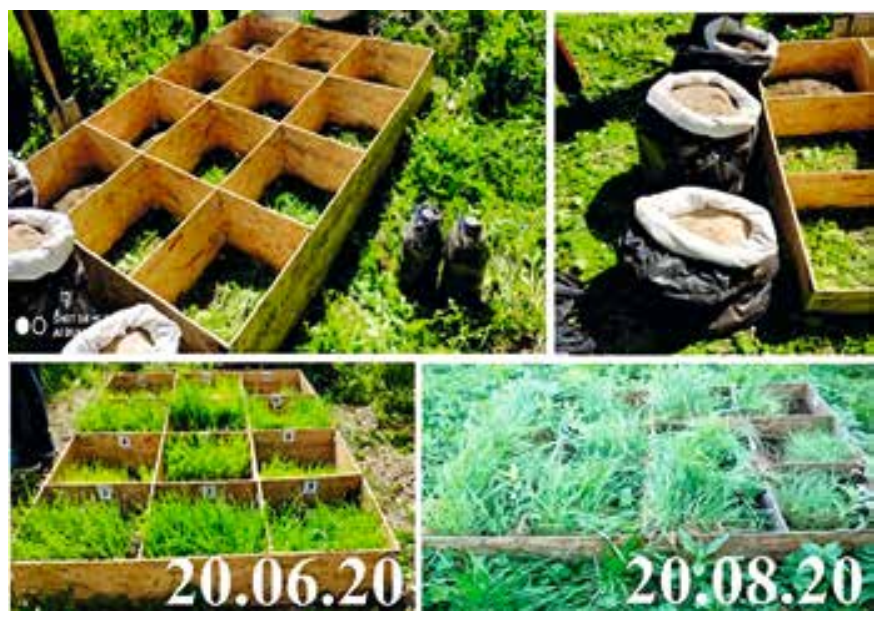

Pис. 2. Фрагмент экспериментальной площзадки

Fig. 2. Fragment of the experimental site

также подтверждается результатами анализа отобранных образцов ржи посевной (рис. 4). 


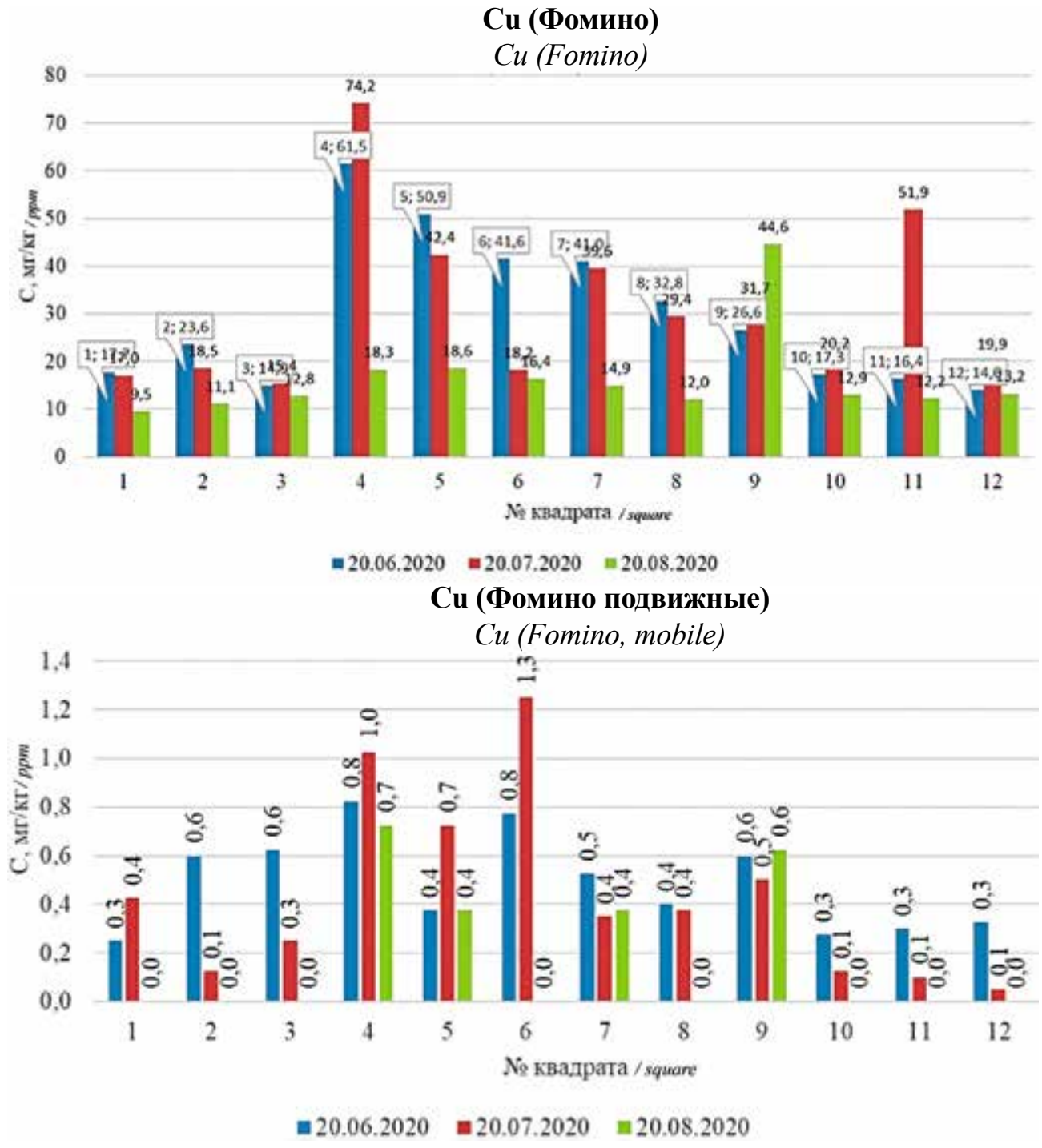

Puс. 3. Содержание валовой и подвижной форм меди в исследуемых пробах

Fig. 3. Content of gross and mobile forms of copper in the studied samples

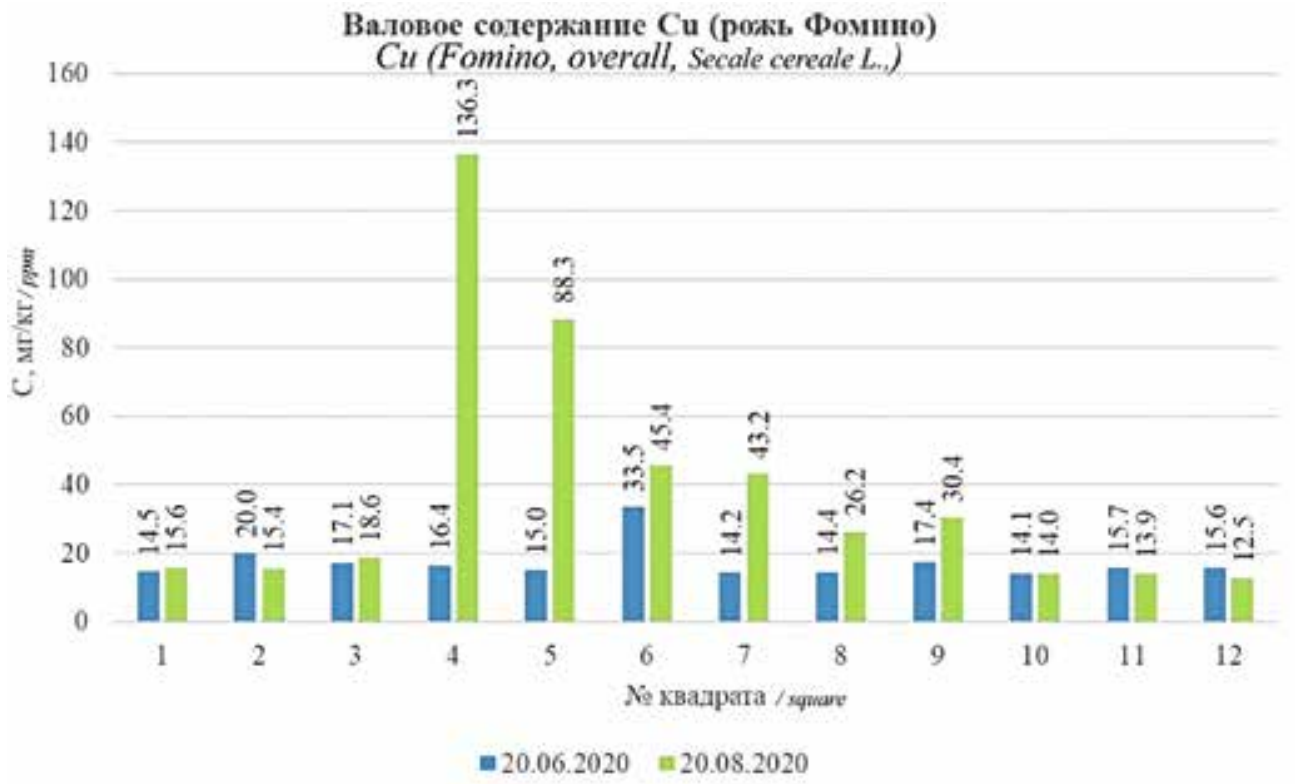

Pис. 4. Валовое содержание меди в особях ржи посевной (Secale cereale L.), выращенных на исследуемых субстратах

Fig. 4. The total contents of copper in specimens of rye seed (Secale cereale L.) grown on the investigated substrates

\section{Выводы}

Таким образом, по результатам анализа полученных экспериментальных данных отчетливо просматривается тенденция сорбционного процесса с одновременным увеличением $\mathrm{pH}$ при использовании в качестве сорбента «диатомита», а внесение торфо-диатомитового мелиоранта, в составе которого присутствует и сапропель, сказалось на уменьшении концентрации меди в исследуемом грунте.

Следовательно, используя мелиоративные приемы путем внесения минеральных и органических удобрений можно регулировать подвижность ионов меди, а выявленный характер изменений в количестве подвижных соединений меди следует учитывать в процессе разработки природоохранных мероприятий при экологической реабилитации нарушенных природных экосистем. 


\section{БЛАГОДАРНОСТЬ / Acknowledgement:}

Исследование подготовлено в соответствии с государственным заданием ФГБОУ ВО «Уральский государственный горный университет» № 0833-2020-0008 «Разработка и эколого-экономическое обоснование технологии рекультивации нарушенных горно-металлургическим комплексом земель на основе мелиорантов и удобрений нового типа» и выполнено совместно с сотрудниками Центра коллективного пользования (ЦКП) с использованием фондов Центра коллективного пользования научным оборудованием ФНЦ БСТ РАН (No Pocc RU.0001.21 ПФ59, Единый российский реестр центров коллективного пользования - http://www.ckp-rf.ru/ckp/77384).

The study was prepared in accordance with the state task of the URAL state mining University No. 0833-2020-0008 "Development and ecological and economic justification of the technology for reclamation of land disturbed by the mining and metallurgical complex based on meliorants and fertilizers of a new type" and was carried out jointly with Employees of the center for collective use (CCP) using the funds of the Center for collective use of scientific equipment of the Federal research center BST RAS (No Ross RU.0001.21 PF59, unified Russian register of collective use centers - http://www.ckp-rf.ru/ckp/77384).

\section{ЛИТЕРАТУРА:}

1. Старицына И. А., Старицына Н. А. Экологические проблемы уральских горнорудных городов на примере свердловской области // Экологический вестник России. 2018. N2. C. 51-55.

2. Яковлев В. Л., Корнилков С. В., Соколов И. В. Инновационный базис стратегии комплексного освоения ресурсов минерального сырья. Уральское отделение РАН, 2018. $360 \mathrm{c}$.

3. Динамика негативного воздействия на окружающую среду на разных стадиях горного производства / А. Ф. Фадеичев, А. В. Хохряков, Н. В. Гревцев, Е. М. Цейтлин // Известия вузов. Горный журнал. 2012. N1. С.39-46.

4. Антонинова Н. Ю., Шубина Л. А. Экологическая реабилитация экосистем в районах функционирования горно-металлургических комплексов // Известия высших учебных заведений. Горный журнал. 2013. N8. С. 64-68.

5. Антонинова Н. Ю., Шубина Л. А. К вопросу сохранения техногенных образований ГМК путем экологически безопасной консервации и восстановления ландшафтов / В сборнике: Фундаментальные исследования и прикладные разработки процессов переработки и утилизации техногенных образований "Техноген-2019". Труды конгресса с международным участием и конференции молодых ученых. Редакционная коллегия: Леонтьев Л. И., Смирнов Л. А., Селиванов Е. Н., Чесноков Ю. А. 2019. С. 173-178.

6. Техногенно-минеральные месторождения и их влияние на природную окружающую среду / А. Б. Макаров, О. М. Гуман, И. А. Антонова, А. В. Захаров // Известия Уральского государственного горного университета. 2012. N27-28. C. 38-45.

7. Цейтлин Е. М. О прогнозе загрязнения окружающей среды в районе объектов размещения отходов горных предприятий как инструмент повышения эффективности экологического менеджмента и снижении затрат предприятия / Е. М. Цейтлин, О. А. Москвина, И. В. Ларионова, Г. А. Студенок // Сборник статей пятой заочной всероссийской научно-практической конференции: Актуальные проблемы экономики и управления. 2017. С. 199-204.

8. Рыбникова Л. С., Рыбников П. А. Гидрогеологические исследования в горнопромышленных районах на постэксплуатационном этапе // В сборнике: Подземные воды востока России. Материалы Всероссийского совещания по подземным водам Востока России (XXII Совещание по подземным водам Сибири и Дальнего Востока с междуна- родным участием). Ответственные редакторы Д. А. Новиков, С. В. Алексеев, А. Ф. Сухорукова. 2018. С. 403-408.

9. Копцик Г. Н. Современные подходы к ремедиации почв, загрязненных тяжелыми металлами (обзор литературы) // Почвоведение. 2014. N7. С. 851-868.

10. Ремедиация почвы, загрязненной никелем, с помощью мелиоранта-стабилизатора в форме сорбционноактивного струвита / Е. А. Носенко, Ю. В. Кузнецова, Л. И. Исмагилова, А. В. Шутова, Г. В. Леонтьева // Химия. Экология. Урбанистика. 2017. Т.12. N2. С. 401-406.

11. Апакашев Р. А., Гуман О. М., Валиев Н. Г. Рекультивация нарушенных земель с использованием техногенных осадков водоподготовки // Устойчивое развитие горных территорий. 2020. Т.12, N2(44). С. 229-236.

12. Мосендз И. А., Кременецкая И. П., Дрогобужская С. В., Алексеева С. А. Сорбция тяжелых металлов фильтрующими модулями с вермикулит-сунгулитовыми продуктами // Вестник МГТУ. 2020. Т. 23, N 2. С. 182-189.

13. Материалы природоохранного назначения из отходов добычи флогопита / И. П. Кременецкая, С. А. Алексеева, Е. Д. Рухленко, В. В. Лащук (и др.) // Экология и промышленность России. 2015. Т.19, N2. С.18-23.

14. Шепелев И. И., Еськова Е.Н. Применение кальцийсодержащих отходов в качестве мелиоранта кислых почв // В сб.: Наука и образование: опыт, проблемы, перспективы развития. Материалы международной научно-технической конференции. Красноярский государственный аграрный университет. 2017. С. 162-164.

15. Виноградова А. В., Зоричева А. С. Исследования возможности применения соединения крмения в качестве мелиоранта-стабилизатора ионов тяжелых металлов в загрязненной почве // Вестник Пермского национального исследовательского политехнического университета. Химическая технология и биотехнология. 2017. ⒉ С. 20-31.

16. Биохимические и микробиологические аспекты применения биоугля в качестве мелиоранта почв / Н. Е. Орлова, Н. М. Лабутова, Е. Е. Орлова, Т. А. Банкина // В сб.: Проблемы рекультивации отходов быта, промышленного и сельскохозяйственного производства. Сборник научных трудов по материалам V Международной научной экологической конференции, посвященной 95-летию Кубанского ГАУ. 2017. С. 323-325.

17. Клюев Р. В., Босиков И. И., Майер А. В., Гаврина О. А. Комплексный анализ применения эффективных тех- 
нологий для повышения устойчивого развития природнотехнической системы // Устойчивое развитие горных территорий. 2020. N2. С. 283-290.

18. Клюев Р. В., Босиков И. И., Егорова Е. В., Гаврина О. А. Оценка горно-геологических и горнотехнических условий карьера "Северный" с помощью математических моделей // Устойчивое развитие горных территорий. 2020. N3. С. 418-427. DOI: 10.21177/1998-4502-2020-12-4-418-427.

19. Yazbek L. D. Hydrogeochemical Factors Influencing Metal Transport and Transformation in a Stream Impaired by
Acid Mine Drainage: Thesis, Kent State University, 2019.

20. Clemens S. Toxic metal accumulation, responses to exposure and mechanisms of tolerance in plants // Biochimie 2006. 88. P. 1707-1719.

21. Bradl H. B. Adsorption of heavy metal ions on soils and soils constituents // J. ColloidInterfaceSci. 2004. 277. P. 1-18.

22. Stafilov T. Determination of trace elements in minerals by electrothermal atomic absorption spectrometry // Spectrochimica Acta Part B: Atomic Spectroscopy. 2000. Vol. 55. N. 7. C. 893-906.

\section{КРИТЕРИИ АВТОРСТВА / Contribution:}

Авторы заявляют о равном вкладе каждого в работу над статьей / The authors declare the equal contribution of everyone to the work on the article.

\section{КОНФЛИКТ ИНТЕРЕСОВ / Conflict of interest:}

Авторы заявляют об отсутствии конфликта интересов / The authors declare that there is no conflict of interest.

\section{СВЕДЕНИЯ ОБ АВТОРАХ / Information about authors:}

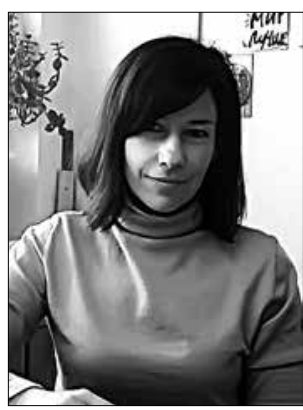

\section{АНТОНИНОВА Наталья}

Юрьевна - кандидат технических наук, доцент кафедры природообустройства и водопользования, зав. лабораторией экологии горного производства, Институт горного дела Уральского отделения РАН.

620075, Екатеринбург, Россия.

Тел.: +7(912)678-69-94.

e-mail: natal78@list.ru

Natalia Y. ANTONINOVA - Candidate of Technical Sciences, Head of the Laboratory of Mining Ecology of the Institute of Mining Engineering of the Ural Branch of the Russian Academy of Sciences, Associate Professor of the Department of Nature Management and Water Use.

Yekaterinburg, 620075 Russia.

Ph.: +7(912)678-69-94.

e-mail:natal78@list.ru

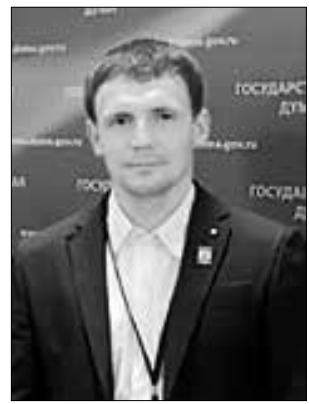

УСМАНОВ Альберт Исмагилович - младший научный сотрудник научно-исследовательской лаборатории рекультивации нарушенных земель и техногеных объектов, Уральский государственный горный университет; генеральный директор ООО «Экоинноватор».

620144, Екатеринбург, Россия.

Тел.: +7(963)271-95-18.

e-mail: albert3179@mail.ru

Albert I. USMANOV-Junior Researcher at the Research Laboratory for Reclamation of Disturbed Lands and Man-made Objects of the Ural State Mining University, General Director of Ecoinnovator LLC. Yekaterinburg, 620144 Russia.

Ph.: +7(963)271-95-18.

e-mail: albert3179@mail.ru

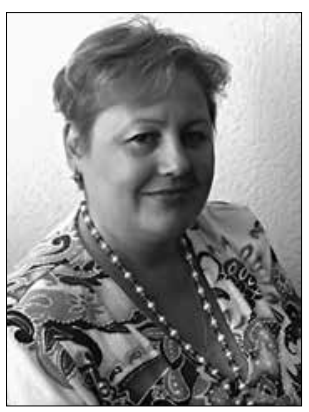

ШУБИНА Любовь Андреевна - научный сотрудник лаборатории экологии горного производства, Институт горного дела Уральского отделения РАН.

620075 , Екатеринбург, Россия.

Тел.: +7(996)189-22-48.

e-mail: las714@mail.ru

Lyubov A. SHUBINA - Researcher at the Laboratory of Mining Ecology of the Institute of Mining of the Ural Branch of the Russian Academy of Sciences. Yekaterinburg, 620075 Russia. Ph.: +7(996)189-22-48. e-mail:las714@mail.ru

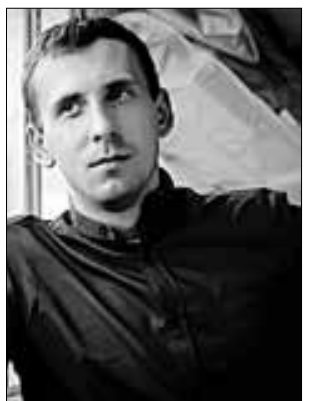

СОБЕНИН Артём Вячеславович - младший научный сотрудник лаборатории экологии горного производства, Институт горного дела Уральского отделения РАН.

620075 , Екатеринбург, Россия.

Тел.: +7(950)643-05-07.

e-mail: $\underline{\operatorname{arsob} @ \text { yandex.ru }}$

Artem V. SOBENIN - Junior Researcher at the Laboratory of Mining Ecology of the Institute of Mining of the Ural Branch of the Russian Academy of Sciences. Yekaterinburg, 620075 Russia.

Ph.: +7(950)643-05-07.

e-mail:arsob@yandex.ru 


\title{
ASSESSMENT OF THE POSSIBILITY OF USING PEAT-DIATOMITE IMPROVER IN THE DEVELOPMENT OF MEASURES FOR THE ENVIRONMENTAL REHABILITATION OF DISTURBED ECOSYSTEMS
}

\author{
N. Yu. Antoninova ${ }^{1,2 *}$, \\ A. I. Usmanov ${ }^{1,3}$, \\ L. A. Shubina ${ }^{2}$, \\ A.V. Sobenin ${ }^{2}$ \\ ${ }^{1}$ Federal State Budgetary Educational Institution of Higher Education Ural State Mining University, Yekaterinburg, 620144, \\ Russia \\ ${ }^{2}$ Federal State Budgetary Institution of Science Institute of Mining of the Ural Branch of the Russian Academy of Sciences, \\ Yekaterinburg,620075,Russia,natal78@list.ru \\ ${ }^{3}$ Ekoinnovator LLC, 620010, Yekaterinburg, Russia
}

\section{DOI: $10.21177 / 1998-4502-2020-12-4-493-500$}

One of the main factors determining the transformation of natural technogenic complexes is the storage of large masses of industrial waste on the day surface, and their further transformation leads to a change in geochemical processes in landscapes associated with dumps.

Objective. On the basis of the experimental studies performed, to evaluate the effectiveness of the use of peat-diatomite ameliorant in the development of measures for the ecological rehabilitation of disturbed ecosystems.

Research methods. The content of copper ions was determined by the atomic absorption method using a Spectr AA-240 FS (Varian Optical Spectr. Instrum, Australia). Mineralization of samples to determine the gross copper content was carried out in concentrated HNO3 using a MARS 5 laboratory microwave system (CEM, USA). The mobile forms of copper were determined in extracts of $0.5 \mathrm{M} \mathrm{HNO}_{3}$ in a ratio of 1:25 (soil: solution). Mine waters of the former Degtyarsky mine with a copper content of $4.61 \mathrm{mg} / \mathrm{L}$ were used as a model solution. Technogenic soil for microfield experiments was selected during the summer field research. Peat-diatomite ameliorant own development of "Ekoinnovator".

Research results. According to the results of the analysis of the obtained experimental data, the tendency of the sorption process from $4.61 \mathrm{mg} / 1$ to $1.754 \mathrm{mg} / \mathrm{l}$ is clearly visible when using "diatomite" as a sorbent, and the introduction of a peatdiatomite meliorant in the composition of which sapropel is also Therefore, using reclamation techniques by introducing mineral and organic fertilizers, it is possible to regulate the mobility of copper ions, and the revealed nature of changes in the amount of mobile copper compounds should be taken into account in the development of environmental protection measures for the ecological rehabilitation of disturbed natural ecosystems.

Keywords: environmental remediation, industrial waste, experimental modules, technogenic soil, sorption, diatomite, peat-diatomite ameliorant.

References:

1. Staritsyna I. A., Staritsyna N. A. "Environmental problems of the Ural mining towns on the example of the Sverdlovsk Region", Ecological Bulletin of Russia, 2018, no. 2, pp. 51-55.

2. Yakovlev V. L., Kornilkov S. V., Sokolov I. V. Innovative basis of the strategy for the integrated development of mineral resources, Ural Branch of the Russian Academy of Sciences Publisher, 2018, 360 p.

3. Fadeichev A. F., Khokhryakov A. V., Grevtsev N. V.,
Zeitlin E. M. "Dynamics of negative impact on the environment at different stages of mining", Izvestiya vuzov. Mining Journal, vol.12, no.1, pp. 39-46.

4. Antoninova N. Yu., Shubina L. A. "Ecological rehabilitation of ecosystems in the regions of functioning of mining and metallurgical complexes", News of higher educational institutions, Mining Journal, 2013, no.8, pp. 64-68.

5. Antoninova N. Yu., Shubina L. A. "On the issue of preserving the technogenic formations of the mining and metallurgical complex through environmentally safe conservation and restoration of Landscapes", In the collection: Fundamental research and applied development of the processes of processing and utilization of technogenic formations "Technogen-2019". Proceedings of the Congress with International Participation and the Conference of Young Scientists, 2019, pp. 173-178.

6. Makarov A. B., Guman O. M., Antonova I. A., Zakharov A.V. "Technogenic-mineral deposits and their impact on the natural environment", Bulletin of the Ural State Mining University, 2012, no.27-28, pp. 38-45.

7. Tseitlin E. M, Moskvina O. A., Larionova I. V., Studenok G. A. "On the forecast of environmental pollution in the area of waste disposal facilities of mining enterprises as a tool to increase the efficiency of environmental management and reduce the costs of the enterprise", Collection of articles of the fifth correspondence All-Russian Scientific and Practical Conference: Actual problems of economics and management, 2017, pp.199-204.

8. Rybnikova L. S., Rybnikov P. A. "Hydrogeological studies in mining areas at the post-exploitation stage. In the collection: Underground waters of the east of Russia", Materials of the All-Russian Meeting on Groundwater in the East of Russia (XXII Meeting on Groundwater in Siberia and the Far East with International Participation), 2018, pp. 403-408.

9. Koptsik G. N. "Modern approaches to the remediation of soils contaminated with heavy metals (literature review)", Pochvovedenie, 2014, no.7, pp. 851-868.

10. Nosenko E. A., Kuznetsova Yu.V., Ismagilova L. I., Shutova A.V., Leontiev G.V. "Remediation of soil contaminated with nickel with the help of an ameliorant-stabilizer in the form of sorption-active struvite", Chemistry. Ecology. Urbanism, 2017, vol.12, no.2, pp. 401-406.

11. Apakashev R. A., Guman O. M., Valiev N. G. "Reclamation of disturbed lands using technogenic precipitation of water treatment", Sustainable Development of Mountain Territories, 2020, vol.12, no.2(44), pp. 229-236.

12. Mosendz I. A., Kremenetskaya I. P., Drogobuzhskaya 
S. V., Alekseeva S. A. "Sorption of heavy metals by filter modules with vermiculite-sungulite products", Vestnik MGTU, 2020, vol.23, no.2, pp. 182-189.

13. Kremenetskaya I. P. Kremenetskaya I. P., Alekseeva S. A., Rukhlenko E. D., Laschuk V.V. et al. "Materials for environmental protection from phlogopite mining waste", Ecology and Industry of Russia, 2015, vol.19, no.2, pp.18-23.

14. Shepelev I. I. Shepelev I. I., Eskova E. N. “Application of calcium-containing waste as a meliorant of acidic soils", In Science and Education: Experience, Problems, Development Prospects. Materials of the International Scientific and Technical Conference, Krasnoyarsk State Agrarian University, 2017, pp. 162-164.

15. Vinogradova A.V., Zoricheva A. S. "Investigations of the possibility of using a silicon compound as an ameliorantstabilizer of heavy metal ions in contaminated soil", Bulletin of the Perm National Research Polytechnic University. Chemical Technology and Biotechnology, 2017, no.2, pp. 20-31.

16. Orlova N. E., Labutova N. M., Orlova E. E., Bankina T. A. "Biochemical and microbiological aspects of using biochar as a soil meliorant", In: Problems of Reclamation of Household Waste, Industrial and Agricultural Production. Collection of Scientific Papers Based on the Materials of the $V$ International Scientific Environmental Conference Dedicated to the 95th Anniversary of the Kuban State Agrarian University, 2017, pp. 323-325.
17. Klyuev R. V., Bosikov I. I., Mayer A. V., Gavrina O. A. "Comprehensive analysis of the effective technologies application to increase sustainable development of the naturaltechnical system", Sustainable Development of Mountain Territories, 2020, no.2, pp. 283-290.

18. Klyuev R. V., Bosikov I. I., Egorova E. V., Gavrina O. A. "Assessment of mining-geological and mining technical conditions of the Severny pit with the use of mathematical models", Sustainable Development of Mountain Territories, 2020, no.3, pp. 418-427. DOI: 10.21177/1998-4502-2020-124-418-427.

19. Yazbek L. D. Hydrogeochemical Factors Influencing Metal Transport and Transformation in a Stream Impaired by Acid Mine Drainage, Thesis, Kent State University, 2019.

20. Clemens S. "Toxic metal accumulation, responses to exposure and mechanisms of tolerance in plants", Biochimie 2006, 88, pp. 1707-1719.

21. Bradl H. B., "Adsorption of heavy metal ions on soils and soils constituents", J. Colloid Interface Sci., 2004, 277, $1-18$.

22. Stafilov T. "Determination of trace elements in minerals by electrothermal atomic absorption spectrometry", Spectrochimica Acta Part B: Atomic Spectroscopy, 2000, vol. 55, no.7, pp. 893-906.

Article received 30.09.2020 


\section{UAV PHOTOGRAMMETRY-BASED FOR OPEN PIT COAL MINE LARGE SCALE MAPPING, CASE STUDIES IN CAM PHA CITY, VIETNAM}

\begin{abstract}
Nguyen Quoc Long ${ }^{1}$,
Le Thi Thu Ha ${ }^{1 *}$,

Si Son Tong',

Kim Thi Thu Huong ${ }^{3}$

${ }^{1}$ Department of Mine Surveying, Hanoi University of Mining and Geology, Hanoi, Vietnam, lethithuha@humg.edu.vn

${ }^{2}$ University of Science and Technology of Hanoi, Vietnam Academy of Science and Technology, Hanoi, Vietnam.

${ }^{3}$ Department of Geodesy, Hanoi University of Mining and Geology,
\end{abstract}

Hanoi, Vietnam

\section{Introduction}

Unmanned Aerial Vehicle (UAV) or Unmanned Aerial System (UAS) indicates an aircraft without a human pilot on board. Specialized cameras with a high-resolution, stable construction are designed to appropriately assemble on the UAV to carry out the missions related to the surface investigation. Primitively, UAV technology has mainly been used for military purposes, but it has been widely used in various industrial and academic domains. UAVs are characterized by the ability to reach high-risk, dangerous, and inaccessible areas without endangering human operators to implement tasks as disaster management [1], safety inspection on construction sides [2]. UAV integrated cameras is also a new photogrammetric measurement and mapping tool to complete or enhance the accuracy of the previous surveying and mapping methods $[3 ; 4]$. UAV photogrammetry produces results with higher accuracy than the existing via-photogrammetry or satellite imaging [5]. Moreover, UAV also has numerous advantages in the field of mapping compared to the traditional technologies such as high-spatial-resolution imaging, low-cost operation, and management; lightweight, easy to use and analyze data, abundant products (orthogonal images, DSM, DEM, and 3D models) [5-15].

The rapid development of UAV technology has brought many benefits to the mining industry in terms of safety, accuracy, and productivities. The UAVs are extensively applied in the open-pit mine areas. The air quality in a coal mine has been monitored using UAV in Vietnam [15]. In this study, sensors mounted on a UAV measured the variation of environmental variables as temperature, dust, $\mathrm{CO}_{2}$, and NOx concentrated in the air of the mine. The multitemporal UAV images were used to measure the surface extent and volumetric excavation in the Sa Pigada Bianca mine [16]. One of the most popular applications of UAV techniques for open mines is the measurement and creating maps for managing and exploiting. UAV is the innovative monitoring techniques, which have been used to build DEM, DSM models $[6 ; 9 ; 10 ; 13 ; 17]$. These models are very important inputs for mining geodesy activities, such as monitoring mining subsidence and deformation surface [18-23], creation of terrain maps, 3D maps [5;11; 14; 15], extracting terrain parameters for geomorphology, etc. In the open-pit mines, monitoring of topographic and volumetric changes through time shows great importance to the excavation process and management [24;25]. It can be used to control the tripping ratio estimation and evaluate the costs of mining compared to the ore-derived profit. Furthermore, a local government also requires a highly accurate estimation of excavation volume to manage the environment and the tax regime [17].

Many other significant applications of UAVs in mining activities have been carried out: pit and dump management in mine using UAV technology [26]; stock-

\section{УДК: 528.7}

DOI: 10.21171/1998-4502-202012-4-501-509

The use of lightweight Unmanned Aerial Vehicle with the aerial photogrammetry approach to construct the Digital Surface Model (DSM) has been effectively applied for various types of topography. However, the ability to carry out this approach for huge active open coal mines is insufficiently investigated, furthermore, the influences of topographical factors on the accuracy of DSM are ambiguous.

This experiment attempts to apply the UAV method for the two active coal mines with the total area of $7.99 \mathrm{~km}^{2}$, exploited at a range from $-300 \mathrm{~m}$ to $300 \mathrm{~m}$ altitude to figure out the effect of topographic factors on the accuracy of DEM constructed from UAV images. A total of 972 UAV images and 17 ground control points have been coupled to construct DSM of the mines. Besides, 16 checking points located at different elevations are used to evaluate the accuracy of DEM and to define the influence. DEMs are generated with the maximum RMSE of $0.086 \mathrm{~m}, 0.099 \mathrm{~m}$, and $0.170 m$ corresponding to $X, Y$, and $\mathrm{Z}$ dimensional errors. The results show the unclear correlation between the vertical accuracy of DEM and the relative elevation $(R 2=0.064)$, the general slope of the mines, and the number of ground control points using in the coal mines as well.

\section{KEYWORDS:}

Unmanned Aerial Vehicle, Digital Surface Model, open-pit mine accuracy, Cam Pha city.

$\overline{\text { Article received } 28.09 .2020}$ 
pile management [27; 28]; mapping of inaccessible steep inclines and cliffs [29], monitoring and analyzing subsurface heating, geological modeling [30]. Most of these studies used lightweight UAV integrated simple cameras to generate DEM, DSM of mines with significant accuracy. However, the ability to carry out this approach for huge acitve open coal mines is insuficantly investigated, furthermore, the influences of topographical factors on the accuracy of DSM are ambiguous.

In Visetnam, there were several publications related to researches in open-pit mines using UAV drones, for example, quarries [14]. These mines are often small, easy to reach, and stable. In contracts, active open coal mines are characterized by located in rocky mountains, occupying a huge area, deep exploitation, steep slope, unstable ground, dense transportation, quick deformation, limited visibility due to the dust concentration in the air, etc. The difficulties of working in the field prevent surveyors from investigating the topography of the open coal mines even though the remote sensing or field measurement techniques are implemented. This study overcomes the challenges to construct DSMs of open coal mines using lightweight UAV images coupling ground control points (GCP). This approach is applied for three mines to evaluate the ability to use the UAV technique for such a special environment as an open coal mine. Besides, the effects of factors as slope, relative elevation, number of GCPs on the accuracy of DEM constructed by UAV imagery technique are assessed in the experiment.

\section{Study area and methodology}

\subsection{Study area}

This research utilized two study sites locates in Cam Pha city, Quang Ninh coal basin, North-East Vietnam,

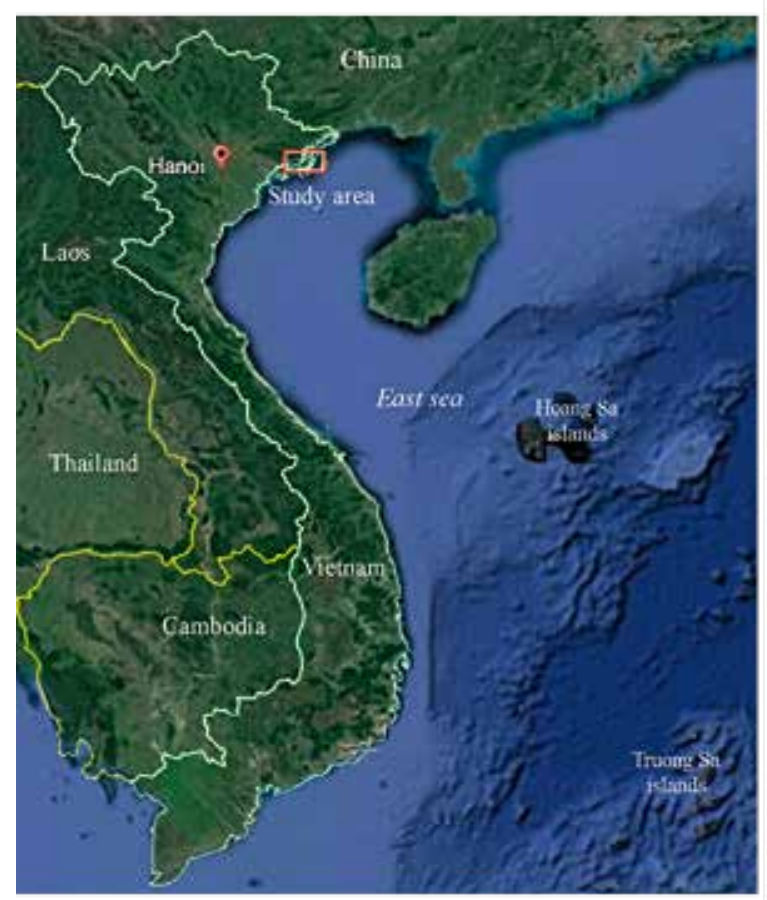

namely Cao Son, and Deo Nai (Fig 1). These sites are open coal mines that provide coal for the power plan and export. Each mine contains exploited layers characterized by various components bench height, bench face angle, catch bench, bench width, toe, crest bench, toe to crest slope. Generally, a catch bench is $5 \mathrm{~m}$ wide with a toe to crest slope of 55 degrees and a bench height of around $20 \mathrm{~m}$. Coal is exploited in a catch bed and the useless materials such as rocks or soil are transported to the surrounding area which forms the topography of open mines with huge holes. Three coal mines are close together at the location of $21^{\circ} 01^{\prime} 00^{\prime \prime} \mathrm{N}-21^{\circ} 20^{\prime} 00^{\prime \prime} \mathrm{N}$ latitudes and $107^{\circ} 18^{\prime} 15^{\prime \prime} \mathrm{E}-107^{\circ} 19^{\prime} 20^{\prime \prime} \mathrm{E}$ longitudes.

Cao Son mine occupies an area of about $3.3 \mathrm{~km}^{2}$ with the highest point of $150 \mathrm{~m}$ above sea level and the bottom at the elevation of $-150 \mathrm{~m}$. Deo Nai mine has an area of about $2.6 \mathrm{~km}^{2}$ with an exploitation reserve of 42.5 million tons, and a fertility of 2.5 million tons a year ( $\mathrm{Vi}$ nacomin, 2015). These mines are exploiting by cutting down from the top, forming a steep rocky slope from 8 to 20 degrees. The continuous exploitation of coal, the unstable ground, and the transportation of rocky material prevent the surveyors from directly measuring the topography of the mines. Besides, the dense concentration of dust caused by the activities in the mines makes the difficulties in using remote sensing techniques to investigate the surface of mines.

\section{Materials and research method}

\subsection{UAV system and Camera}

In this work, the Phantom 4 pro with integrated camera and Inspire 2 with Zenmus camera was used to capture images. Both are quadcopter drone with four powerful rotors [http://blog.geekbuying.com/2016/11/

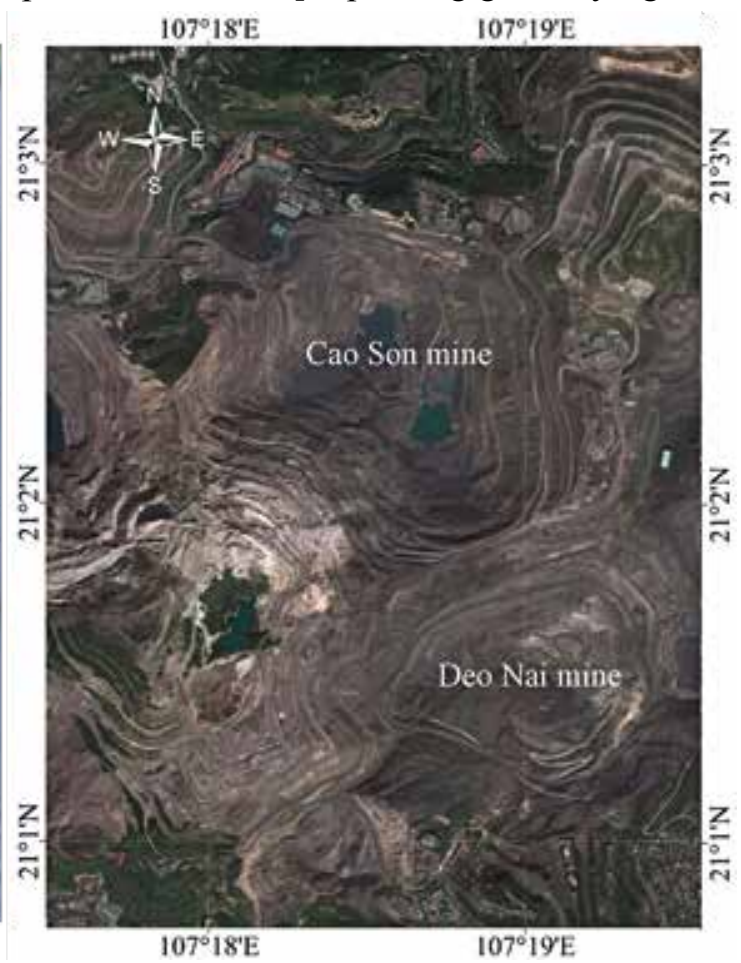

Fig. 1. Location of investigating open-cast mines 
Flying parameters

\begin{tabular}{|l|c|c|}
\hline \multicolumn{1}{|c|}{ Specs name } & Cao Son mine & Deo Nai mine \\
\hline Number of images & 544 & 428 \\
\hline Flying altitude & $349 \mathrm{~m}$ & $324 \mathrm{~m}$ \\
\hline Ground resolution & $9.55 \mathrm{~cm} / \mathrm{pix}$ & $8.92 \mathrm{~cm} / \mathrm{pix}$ \\
\hline Coverage area & $4.43 \mathrm{~km}^{2}$ & $3.56 \mathrm{~km}^{2}$ \\
\hline
\end{tabular}

dji-inspire-2-release-date-price-and-specifications]. The Inspire 2 and Phantom 4 Pro are capable of both automatic mode using the smart device applications and manual mode using the remote control. In the automatic flight mode, the parameters as the flight path, flight altitude, flight speed, overlapping of the photographs, etc., can be set before take-off. The two drones are attached to the GPS/IMU that enables it to take off and land with high stability automatically [31]. The Phantom 4 Pro is equipped with an integrated 20-megapixel RGB camera [32]. The ability flying time of Phantom 4 Pro up to 30 minutes, respectively, but it may reduce by some factors such as the wind, speed, and carried equipment.

\subsection{Ground control placement and Image acquisition}

Two main types of data are collected during the experiment compositing of measuring ground control points and flying UAVs to acquire images. The design of the GCP network and the plan for the flights must be primarily prepared before working in the field.

Ground control points were marked with highly reflective material for enhancing the contrast, the size of the marks was $60 \times 60 \mathrm{~cm}$, and it's large enough to easily detect GCPs in acquiring images. They were placed well distribution in the bottom, top, benches, and roads of mines. The number of GCPs was different in each mine, there are 15,11 , and 16 GCPs in Cao Son and Deo Nai, mine, respectively (Fig 2a, Fig 3a). Once $R M S E_{X}=$ all GCPs were placed the survey was performed. All GCPs are surveyed using GNSS/RTK technique and the GCP network is connected to the national coordinate stations with the VN2000 projection, WGS84 datum, Zone $48 \mathrm{~N}$.

UAV images are acquired using the Phantom 4 pro in Deo Nai mine and Cao Son mine. The automatic flight mode was established using the Pix4D Capture application installed in an IOS smartphone, parameters such as the size of mapping areas, flight height, as well as endlap and side-lap of images are uploaded to the drone before the start. Weather conditions for data collection are the same in two mines, on sunny days with wind speeds of below $8 \mathrm{~km} / \mathrm{h}$. The flights are implemented in parallel lines crossing the mines with the front lap of $80 \%$ and side lap of $70 \%$. The GCPs measurement and image acquisition are carried out in March 2020.

\subsection{Image Processing and accuracy assessment}

Image processing began with importing photos into Agisoft Photoscan. Photoscan is an advanced imagebased solution for creating three-dimensional content from still images, it is produced by the Russian company Agisoft and in this work, it operates on windows 10-64 bit installed in laptop Dell 5520 precision with chip Xeon E, $32 \mathrm{~Gb}$ ram for image processing. Firstly, all photos of each mine were imported into one chunk, the next step, image alignment was performed where photos are aligned resulting in a sparse point cloud, the camera locations, and calibration parameters [33]. Next, the majority of scene details are built by applying Multiview stereo reconstruction on the previously aligned photos resulting in a dense point cloud. Finally, the mesh is generated and textured using the photographs [33].

In this project, both the horizontal and vertical assessments were carried out by comparing DSM with the GCPs measured by a GNSS/RTK in the term of Root Mean Square Error (RMSE). More specifically, assessments in easting (RMSEX), northing (RMSEY), vertical (RMSEZ), and all components (RMSEXYZ) were used, using equations as follows:

$$
\begin{aligned}
& R M S E_{Y}=\sqrt{\left[\left(\frac{1}{n}\right) \sum_{i=1}^{n}\left(Y_{D S M}-Y_{G C P}\right)^{2}\right]}=\sqrt{\left[\left(\frac{1}{n}\right) \sum_{i=1}^{n}(\Delta Y)^{2}\right]} \\
& R M S E_{Z}=\sqrt{\left[\left(\frac{1}{n}\right) \sum_{i=1}^{n}\left(Z_{D S M}-Z_{G C P}\right)^{2}\right]}=\sqrt{\left[\left(\frac{1}{n}\right) \sum_{i=1}^{n}(\Delta Z)^{2}\right]} \\
& R M S E_{X Y Z}=\sqrt{\left.\left[\left(\frac{1}{n}\right) \sum_{i=1}^{n}\left((\Delta X)^{2}+(\Delta Y)^{2}+(\Delta Z)^{2}\right)\right)\right]}
\end{aligned}
$$

where and are the X-coordinate component of GCP and corresponding coordinate in DSM, respectively; and are the Y-coordinate component of GCP and corresponding coordinate in DSM, respectively; and are the Z-coordinate component of GCP and corresponding coordinate in DSM, respectively. 


\section{Research results}

\subsection{Cao Son mine case}

For the case of Cao Son mine, with an area of 4.43 $\mathrm{km}^{2}$, a total of 544 images were acquired through 6 missions. The point cloud of the mine with approximately 300 thousand points, was extracted according to the data processing method described above, and ground resolution (orthographic image) with resolutions of $9.55 \mathrm{~cm}$. Besides, topographic contours at $5 \mathrm{~m}$ intervals could be extracted from the DSM. The orthophoto and topographic contour map are shown in Figure 2. For the model calibration, the RMSE of the position coordinates was analyzed to be about $1.221 \mathrm{~cm}$ and $1.638 \mathrm{~cm}$ in the North (X) and East (X) direction, respectively. The RMSE of $1.278 \mathrm{~cm}$ in the vertical $(Z)$ direction. The detailed results are shown in Table 2.

Table 2 shows the coordinates and RSME of components at 7 checking points of the DSM in Cao Son mine. In general, the RMSE of the X component presents the highest accuracy with $0.063 \mathrm{~m}$, the biggest error is found at the point $\mathrm{CS} 12$ with $-0.165 \mathrm{~m}$. The $\mathrm{Z}$ component shows the lowest accuracy with the RMSE of $0.170 \mathrm{~m}$. Vertical error reaches to the maximum with $0.361 \mathrm{~m}$ at points CS5.

\subsection{Deo Nai mine case}

For the case of Deo Nai mine, with an area of 3.56 $\mathrm{km}^{2}$, a total of 428 images were acquired through 5 missions. The point cloud of the quarry with approximately 200 thousand points, was extracted according to the data processing method described above, and an orthographic image with resolutions of $8.92 \mathrm{~cm}$. Also, topographic contours at $5 \mathrm{~m}$ intervals could be extracted from the DEM. The accuracy assessment is shown in Table 4 . The orthoimage and contour map is shown in Figure 3.

RMSE of checking points of DSM in Deo Nai is listed in Table 3. The DSM constructed with similar errors of $\mathrm{X}$ and $\mathrm{Y}$ components with $0.086 \mathrm{~m}, 0.049 \mathrm{~m}$, respectively. However, the accuracy of the vertical component is almost double greater than the horizontal ones with the RMSE of $0.129 \mathrm{~m}$. The critical error is found at the checking point DN16 with $0.244 \mathrm{~m}$ vertical error, but the best accuracy is seen at the point DN8 with $-0.011 \mathrm{~m}$.
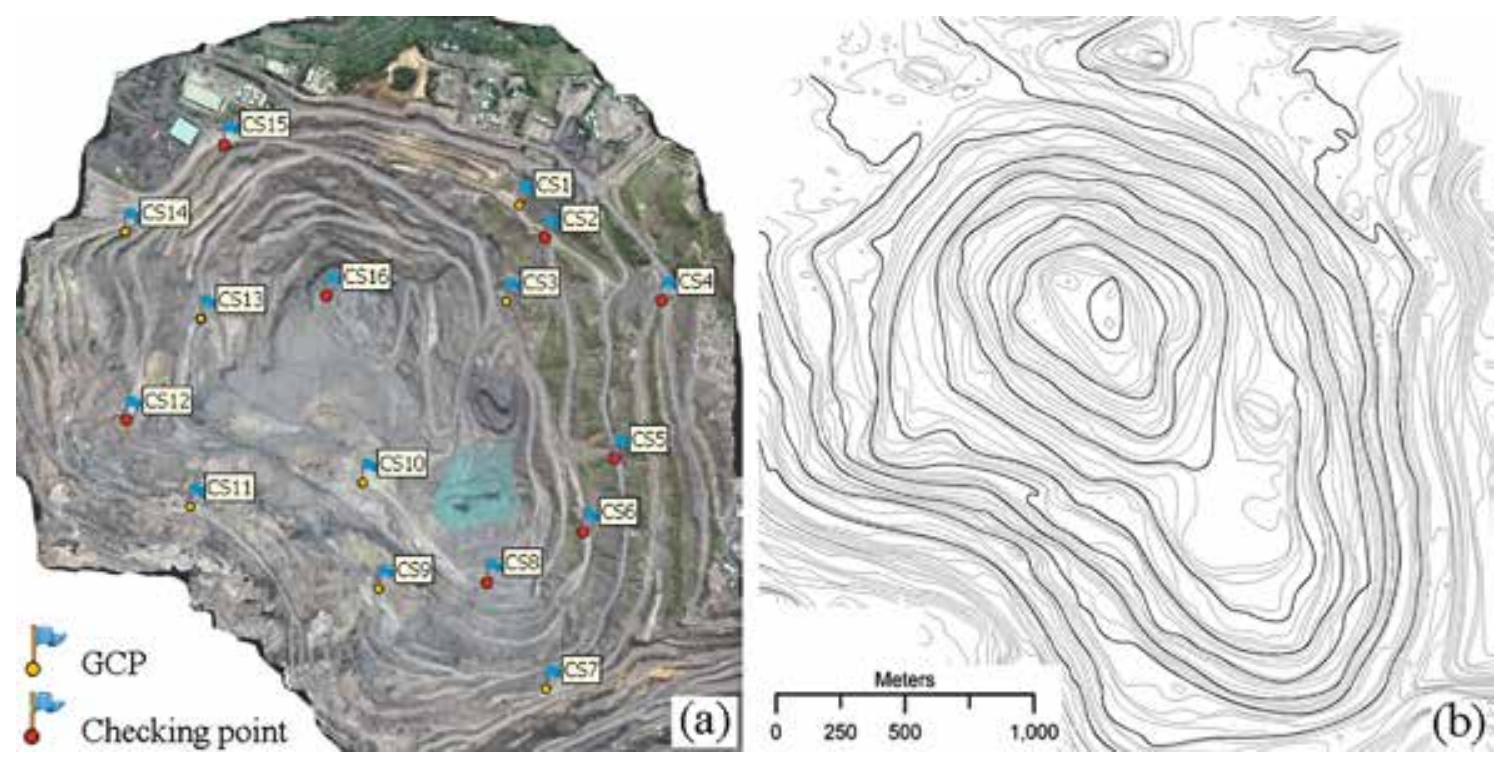

Fig. 2. (a) Distribution of GCPs and checking points; (b) $5 \mathrm{~m}$ contour interval of Cao Son mine

Coordinates and RMSE of checking points in Cao Son mine

\begin{tabular}{|c|c|c|c|c|c|c|c|}
\hline $\begin{array}{c}\text { Checking } \\
\text { points }\end{array}$ & $\boldsymbol{X}(\mathbf{m})$ & $\boldsymbol{Y}(\mathbf{m})$ & $\boldsymbol{Z}(\mathbf{m})$ & $\begin{array}{c}\boldsymbol{X} \text { error } \\
(\mathbf{m})\end{array}$ & $\boldsymbol{Y}$ error (m) & $\boldsymbol{Z}$ error (m) & $\begin{array}{c}\boldsymbol{X Y Z} \text { error } \\
(\mathbf{m})\end{array}$ \\
\hline CS2 & 454522.860 & 2327873.609 & 51.953 & 0.011 & 0.023 & 0.032 & 0.041 \\
\hline CS4 & 454870.650 & 2327673.533 & 135.808 & 0.008 & -0.010 & 0.136 & 0.136 \\
\hline CS5 & 454732.882 & 2327194.050 & 73.805 & 0.027 & 0.113 & 0.361 & 0.379 \\
\hline CS6 & 454644.165 & 2326966.584 & 18.311 & -0.039 & 0.127 & 0.042 & 0.140 \\
\hline CS8 & 454346.064 & 2326806.950 & -24.545 & 0.005 & 0.113 & -0.071 & 0.133 \\
\hline CS12 & 453231.072 & 2327312.298 & 49.723 & -0.165 & -0.068 & -0.200 & 0.267 \\
\hline CS15 & 453532.256 & 2328164.421 & 39.143 & 0.046 & -0.150 & 0.182 & 0.240 \\
\hline CS16 & 453836.675 & 2327710.044 & -137.072 & -0.010 & -0.091 & -0.046 & 0.103 \\
\hline RMSE & & & & 0.063 & 0.099 & 0.170 & 0.206 \\
\hline
\end{tabular}



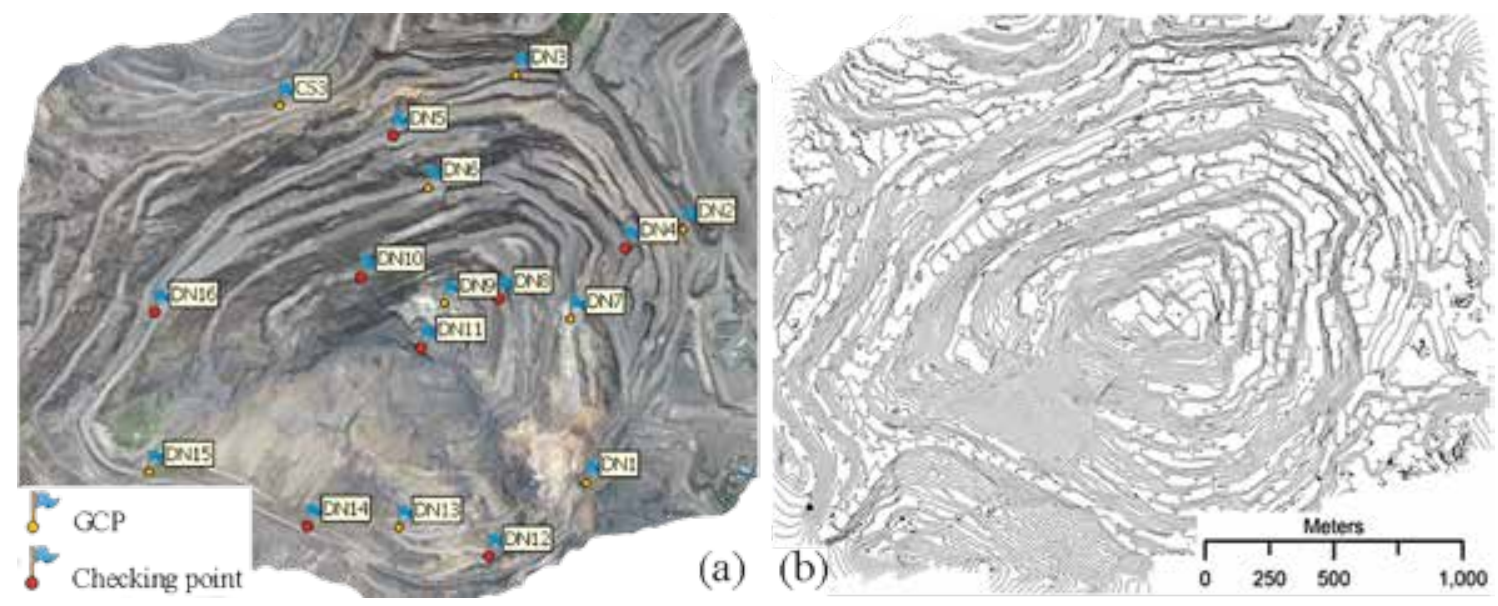

Fig. 3. (a) Distribution of GCPs and checking points; (b) $5 \mathrm{~m}$ contour interval of Deo Nai mine

Coordinates and RMSE of checking points in Deo Nai mine

\begin{tabular}{|c|c|c|c|c|c|c|c|}
\hline $\begin{array}{c}\text { Checking } \\
\text { points }\end{array}$ & $\boldsymbol{X}(\mathbf{m})$ & $\boldsymbol{Y}(\mathbf{m})$ & $\boldsymbol{Z}(\mathbf{m})$ & $\boldsymbol{X}$ error (m) & $\begin{array}{c}\boldsymbol{Y} \text { error } \\
(\mathbf{m})\end{array}$ & $\boldsymbol{Z}$ error (m) & $\boldsymbol{X Y Z}$ error (m) \\
\hline DN4 & 455482.845 & 2326106.010 & 4.822 & 0.023 & 0.062 & 0.156 & 0.170 \\
\hline DN5 & 454833.741 & 2326415.103 & 51.500 & -0.146 & -0.021 & 0.108 & 0.183 \\
\hline DN8 & 455137.570 & 2325963.144 & -103.023 & -0.120 & -0.001 & -0.011 & 0.120 \\
\hline DN10 & 454742.036 & 2326025.983 & -87.998 & -0.087 & 0.049 & -0.143 & 0.175 \\
\hline DN11 & 454915.419 & 2325820.997 & -181.268 & -0.021 & 0.080 & -0.119 & 0.145 \\
\hline DN12 & 455099.895 & 2325245.329 & 38.588 & 0.091 & -0.043 & -0.053 & 0.114 \\
\hline DN14 & 454595.253 & 2325335.053 & 66.356 & 0.076 & -0.049 & -0.022 & 0.094 \\
\hline DN16 & 454174.124 & 2325927.990 & 63.784 & 0.014 & -0.038 & 0.244 & 0.248 \\
\hline RMSE & & & & 0.086 & 0.049 & 0.129 & 0.162 \\
\hline
\end{tabular}

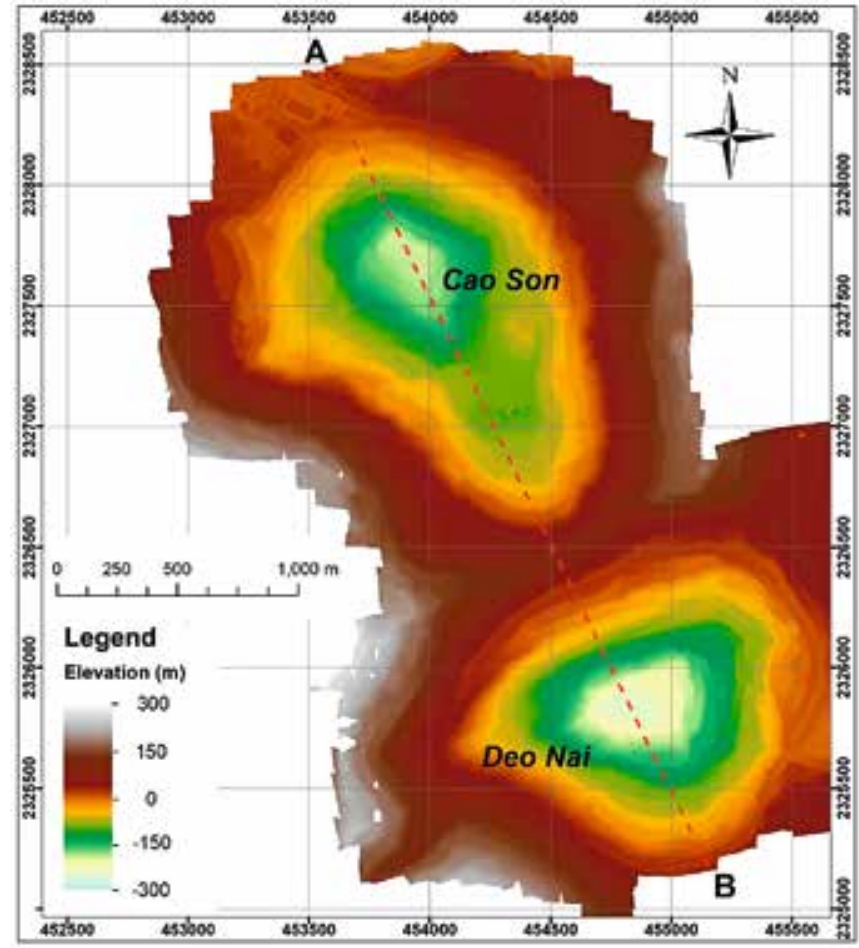

Fig 4. Constructed DSM using UAV photos of the open mines

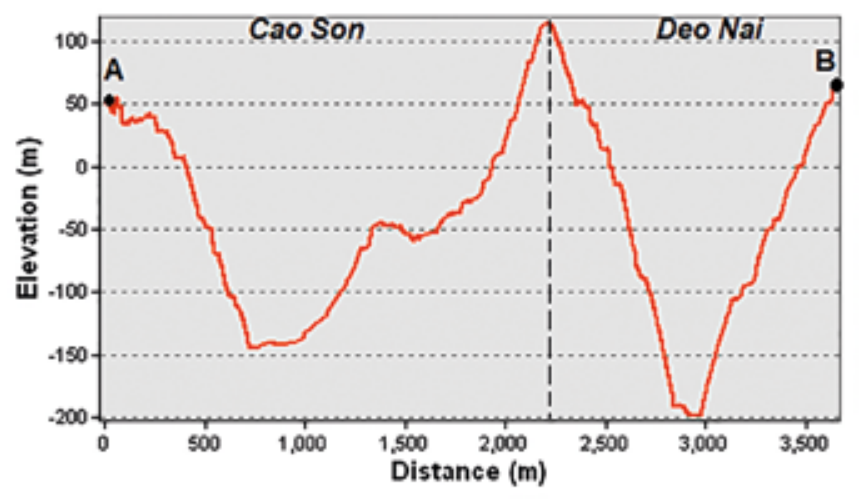

Fig. 5. Elevation of the cross-section in the study area

Figure 4 illustrates the continuous variation of the elevation of the coal mines. This model is the representation of the DSMs constructed by UAV images. The color histogram shows the elevation range from $-300 \mathrm{~m}$ to 300 $\mathrm{m}$ corresponding the bottom to the top of mines. The slopes of mines are investigated using a vertical profile extracted from the map of DSM (Figure 5). The difference of slopes between Cao Son and Deo Nai mines can be observed thought the $\mathrm{AB}$ elevation profile. 


\subsection{Discussions of results}

The implement of lightweight UAVs to investigate the topography has been popularly used in various studies. As an example, this work has completely constructed the DSM and orthophoto of three open coal mines. However, the quality of the constructed DSM needs to discuss more in such a particular environment as the open-pit coal mines. There are 33 GCPs have been surveyed in the study area, in which 16 GCPs are checking points. The discussion focuses on these checking points to evaluate the accuracy of DSM.

It is proved that the increase in the number and the even distribution of GCPs improves the accuracy of DSM constructed by UAV photos [34]. However, the trend is right for the horizontal dimensions but the vertical error seems to be a disagreement $[35 ; 36]$. This experiment is an example supporting the above assertion. The horizontal errors in this study are relatively similar in the mines, the vertical error is almost double compared to the others. Besides, the use of 8 GCP in Deo Nai, and 8 GCPs in Cao Son produces DSM with corresponding vertical errors of $0.129 \mathrm{~m}$, and $0.170 \mathrm{~m}$ (Figure 6). The great number of used GCPs does not improve the vertical accuracy of DSMs.

Thus, this section vestigates the vertical error of DSM in the correlation with the factors as the elevation of checking point, the topography, absolute flight height. The checking points in the study area are located at different layers of elevation from the bottom to the top of mines with an elevation range of $360 \mathrm{~m}$. It is seen that the elevation of checking points does not relate to the vertical accuracy of DSM due to the insignificant correlation with R2 of 0.064 (Figure 7). The lowest checking points located at $-181 \mathrm{~m}$ (DN11) and $-137 \mathrm{~m}$ (CS16) even represent the small vertical error with several 0.145 and 0.103 centimeters, respectively. In contrast, the checking points with the lowest vertical accuracy of $0.361 \mathrm{~m}$ at the point CS5 in Cao Son is seen at the top of mines with an elevation of $73.8 \mathrm{~m}$.

The flight height is a factor controlling the accuracy of DSM and orthophoto. Conventionally, the camera captures images with a higher resolution at shorter flight high than that of a higher flight height. UAV is set to fix flight high at around $300 \mathrm{~m}$ above the sea level. The maximum perpendicular distance between the camera and the bottom of the mine is $500 \mathrm{~m}$ and between the camera and the top of the mine is around $200 \mathrm{~m}$. In this case, the resolution of photos at the tops of mines is double better than that of the bottom. However, there are no significant variation of accuracy between checking points at the bottom and the top of mines. Even though the effect of flight high on the accuracy of DSM is not well exhibited in the frame of this experiment, the flights are recommended to design at different altitudes according to the variation of terrain.
Deo Nai has been exploited at the layer of $-230 \mathrm{~m}$ which formed topography with a steep slope of around 19 degrees (Figure 5). Inversely, the DSM with a lower slope of 9 degrees in Cao Son represents the significantly higher errors comparing to the others. The variation of the general slope shows the unclear correspondence of the accuracy of DSM in this investigation.

The coordinates and the accuracy of every point in DSM are influenced by the surrounding GCPs using in processing UAV photos. In other words, the even distribution of GCPs may minimize the error of DSM. Thus, this work investigates the effect of the distances between checking points and surrounding GCPs on the accuracy of checking points. The checking points DN11 and DN16 located at the bottom and the top of the Deo Nai mine with the elevation of $-181.268 \mathrm{~m}$ and $63.784 \mathrm{~m}$, have vertical errors $-0.119 \mathrm{~m}$ and $0.244 \mathrm{~m}$, respectively (Table 3).

The opposite variation between the vertical error and the elevation of DSM may relate to the decrease of vertical errors according to the increase of distances from the surveying point to the nearest GCPs. DN16 is surrounded by the thee closest GCPs CS3, DN15, and DN9 with the average distance of $649 \mathrm{~m}$ counted from them, which is double longer than that of the checking point DN11 (361 m) calculated from the closest GCPs DN6, DN7, and DN9. Similarly, in the cases of checking points CS12 and CS16 in Cao Son mine, the average distances from 3 closest GCPs to CS12 and CS16 is $536 \mathrm{~m}$ and 439 $\mathrm{m}$, respectively, may cause the lower accuracy of DSM at the top of the mine than the one at the bottom. The effect of surrounding GCPs on the accuracy of DSM is observed in this study; however, this relation should be investigated more in a future study [37-41].

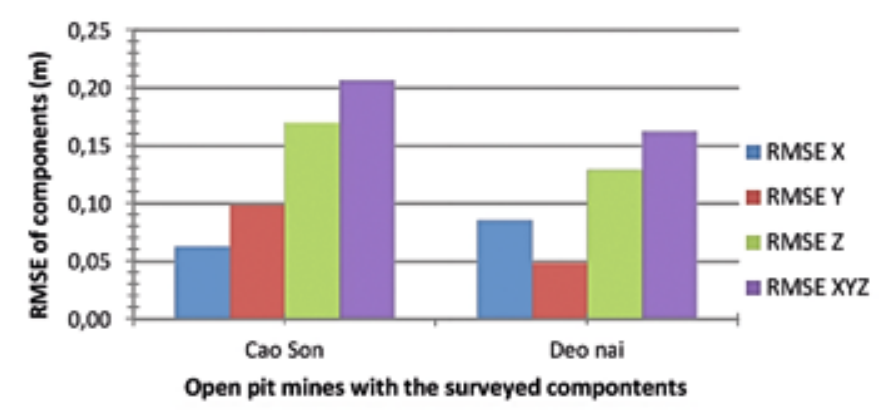

Fig. 6. RMSE of checking points in two open-pit mines

In sum, the accuracy of DSMs constructed from UAV photos may be affected by various factors. The comparison of thee DSMs constructed in two open coal mines indicates the insignificant correlation between the accuracy of DSMs and the flight altitude, the general slope, the relative elevation in this study. The ambiguous variation of error may be random due to the complicated topography and the weak reflectance of optical radiance at the black surface of a coal mine as well. 


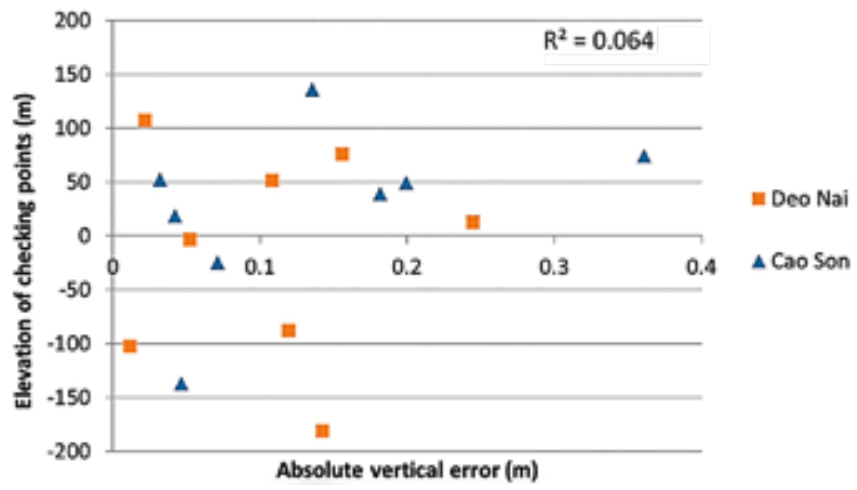

Fig. 7. The correlation between elevation and the absolute error of elevation of the DSM

\section{Conclusion}

The investigation of the topology of active open mine is always a challenge due to the unstable ground, rocky steep slope, high intensity of dust which affect the accuracy of ground measurement using optical instruments. UAV technique is an appropriate method, in this case, regarding the accuracy, safety, time, and money efficiency. The experiment of using the UAV aerial photogrammetry approach in this study in the open coal mines proved the above assertion. DSMs are generated at a very high horizontal accuracy with the $\mathrm{cm}$ level. The vertical error is, as usual, a bit higher than that of horizontal error with a $0.17 \mathrm{~m}$ RMSE in Cao Son mine. The effects of the slope of mines, the elevation, and the flight height on the accuracy of DSMs are insignificant in the frame of the study, the influence of the designed flight path on the quality of DSM should be evaluated in the future research. In general, the quality of the constructed DSMs adapts the requirement of the accuracy of topographical investigation of open coal mines that confirm the ability to use lightweight UAV for such a huge, complicated target as mines in this study.

The method of using UAV images combined GCPs to construct DSM may be applied for other open mines, however, a new technique that integrates the RTK receiver on board of UAV may be more effective and it should be tested in the future works.

\section{ACKNOWLEDGEMENT:}

This work was financially supported by the Ministry of Education and Training (MOET) in Vietnam under grant number B2020-MDA-14.

\section{CONFLICT OF INTEREST:}

The authors declare no conflict of interest.

\section{REFERENCES:}

1. Luo, C., Miao, W., Ullah, H., McClean, S., Parr, G., Min, G. Unmanned Aerial Vehicles for Disaster Management, 2019, pp. 83-107.

2. Melo, R.R.S.d., Costa, D.B., Álvares, J.S., Irizarry, J. "Applicability of unmanned aerial system (UAS) for safety inspection on construction sites", Safety Science, 2017, 98, 174-185.

3. Bi, H., Zheng, W., Ren, Z., Zeng, J., Yu, J., "Using an unmanned aerial vehicle for topography mapping of the fault zone based on structure from motion photogrammetry", International Journal of Remote Sensing, 2017, 38, 2495-2510.

4. Ahmad, M., Ahmad, A., Kanniah, K. "Large scale topographic mapping based on unmanned aerial vehicle and aerial photogrammetric technique", IOP Conference Series: Earth and Environmental Science, 2018, 169, 012077.

5. Siebert, S., Teizer, J., "Mobile 3D mapping for surveying earthwork projects using an Unmanned Aerial Vehicle (UAV) system", Automation in Construction, 2014, 41, 1-14.

6. Ruiz, J., Diaz-Mas, L., Perez, F., Viguria, A. "Evaluating the accuracy of DEM generation algorithms from UAV imagery", Int. Arch. Photogramm. Remote Sens. Spat. Inf. Sci., 2013,40, 333-337.

7. Colomina, I., Molina, P. "Unmanned aerial systems for photogrammetry and remote sensing: A review, ISPRS Journal of Photogrammetry and Remote Sensing, 2014, 92, 79-97.

8. Shahbazi, M., Sohn, G., Théau, J., Menard, P. "Develop-

ment and evaluation of a UAV-photogrammetry system for precise 3D environmental modeling", Sensors, 2015, 15, 27493-27524.

9. Uysal, M., Toprak, A., Polat, N. "DEM generation with UAV Photogrammetry and accuracy analysis in Sahitler hill", Measurement, 2015, 73, 539-543.

10. Sammartano, G., Spanò, A. DEM Generation based on UAV Photogrammetry Data in Critical Areas. In: GISTAM, pp. 92-98. (Year)

11. Bui, D.T., Long, N.Q., Bui, X.-N., Nguyen, V.-N., Van Pham, C., Van Le, C., Ngo, P.-T.T., Bui, D.T., Kristoffersen, B. "Lightweight unmanned aerial vehicle and structure-from-motion photogrammetry for generating digital surface model for open-pit coal mine area and its accuracy assessment", In: International Conference on Geo-Spatial Technologies and Earth Resources, pp. 17-33. Springer, (Year)

12. Coveney, S., Roberts, K. "Lightweight UAV digital elevation models and orthoimagery for environmental applications: data accuracy evaluation and potential for river flood risk modelling", International Journal of Remote Sensing, 2017, 38, 3159-3180.

13. Forlani, G., Dall'Asta, E., Diotri, F., Cella, U.M.d., Roncella, R., Santise, M. "Quality assessment of DSMs produced from UAV flights georeferenced with on-board RTK positioning", Remote Sensing, 2018, 10, 311.

14. Nguyen, Q.L., Bui, X.N., Cao, X.C., Le, V.C. "An ap- 
proach of mapping quarries in Vietnam using low-cost Unmmaned Aerial Vehicles", Sustainable Development of Mountain Territories, 2019, 2, 199-209.

15. Bui, X.N., Lee, C., Nguyen, Q.L., Adeel, A., Cao, X.C., Nguyen, V.N., Le, V.C., Nguyen, H., Le, Q.T., Duong, T.H. "Use of Unmanned Aerial Vehicles for 3D topographic Mapping and Monitoring the Air Quality of Open-pit Mines", Inżynieria Mineralna, 2019, 21.

16. Esposito, G., Mastrorocco, G., Salvini, R., Oliveti, M., Starita, P. "Application of UAV photogrammetry for the multitemporal estimation of surface extent and volumetric excavation in the Sa Pigada Bianca open-pit mine, Sardinia, Italy", Environmental Earth Sciences, 2017, 76, 103.

17. Karuppasamy, S., Kaliappan, S., Karthiga, R., Divya, C., "Surface area estimation, volume change detection in lime stone quarry, tirunelveli district using cartosat-1 generated digital elevation model (dem)", Circuits and Systems, 2016, 7, 849.

18. Shi, B., Liu, C. "UAV for landslide mapping and deformation analysis", In: International Conference on Intelligent Earth Observing and Applications, 2015, pp. 98080P. International Society for Optics and Photonics (Year).

19. Vrublová, D., Kapica, R., Jiránková, E., Struś, A., Documentation of landslides and inaccessible parts of a mine using an unmanned UAV system and methods of digital terrestrial photogrammetry, 2015.

20. Peppa, M., Mills, J., Moore, P., Miller, P., Chambers, J. "Accuracy assessment of a UAV-based landslide monitoring system", ISPRS-International Archives of the Photogrammetry, Remote Sensing and Spatial Information Sciences, 2016, 41, 895-902.

21. Peppa, M.V., Mills, J.P., Moore, P., Miller, P.E., Chambers, J. E., "Brief communication: Landslide motion from cross correlation of UAV-derived morphological attributes", Natural Hazards and Earth System Sciences, 2017, 17, 2143-2150.

22. Peternel, T., Kumelj, S., Oštir, K., Komac, M., "Monitoring the Potoska planina landslide (NW Slovenia) using UAV photogrammetry and tachymetric measurements", Landslides, 2017, 14, 395-406.

23. Suh, J., Choi, Y., "Mapping hazardous mining-induced sinkhole subsidence using unmanned aerial vehicle (drone) photogrammetry", Environmental Earth Sciences, 2017, 76, 144.

24. Nghia, N.V., "Building DEM for deep open-pit coal mines using DJI Inspire 2", Journal of Mining and Earth Sciences, 2020, 61, 1-10.

25. Van Le, C., Cao, C.X., Le, V.H., Dinh, T., "Volume computation of quarries in Vietnam based on Unmanned Aerial Vehicle (UAV) data", Journal of Mining and Earth Sciences, 2020, 61, 21-30.

26. Padró, J.-C., Carabassa, V., Balagué, J., Brotons, L., Alcañiz, J.M., Pons, X., "Monitoring opencast mine restorations using Unmanned Aerial System (UAS) imagery", Science of the Total Environment, 2019, 657, 1602-1614.

27. Raeva, P., Filipova, S., Filipov, D., "VOLUME COMPUTATION OF A STOCKPILE-A STUDY CASE COMPARING GPS AND UAV MEASUREMENTS IN AN OPEN PIT QUARRY", "International Archives of the Photogrammetry, Remote Sensing \& Spatial Information Sciences", 2016, 41.

28. Tucci, G., Gebbia, A., Conti, A., Fiorini, L., Lubello, C., "Monitoring and Computation of the Volumes of Stockpiles of Bulk Material by Means of UAV Photogrammetric Surveying", Remote Sensing, 2019, 11, 1471.
29. Fernandez-Lozano, J., Gonzalez-Díez, A., GutierrezAlonso, G., Carrasco, R.M., Pedraza, J., Garcia-Talegon, J., Alonso-Gavilan, G., Remondo, J., Bonachea, J., Morellon, M., "New perspectives for UAV-based modelling the Roman gold mining infrastructure in NW Spain", Minerals, 2018, 8, 518

30. Szentpeteri, K., Setiawan, T., Ismanto, A., "Drones (UAVs) in mining and Exploration. An application example: Pit Mapping and Geological Modelling", Unconventional Exploration Target \& new tools in mineral and coal exploration, 2016, 45-49.

31. Ajayi, O.G., Salubi, A.A., Angbas, A.F., Odigure, M. G., "Generation of accurate digital elevation models from UAV acquired low percentage overlapping images", International Journal of Remote Sensing, 2017, 38, 3113-3134.

32. DJI: Phantom 4 Pro Visionary intelligence and elevated imagination, https://www.dji.com/phantom-4-pro. (2017)

33. Verhoeven, G., "Taking computer vision aloft-archaeological three dimensional reconstructions from aerial photographs with photoscan", Archaeological Prospection, 2011, 18, 67-73.

34. Clapuyt, F., Vanacker, V., Van Oost, K., "Reproducibility of UAV-based earth topography reconstructions based on Structure-from-Motion algorithms", Geomorphology, 2016, 260, 4-15.

35. Carrivick, J.L., Smith, M.W., Quincey, D.J., Structure from Motion in the Geosciences, John Wiley \& Sons, 2016.

36. Tonkin, T., Midgley, N., "Ground-Control Networks for Image Based Surface Reconstruction: An Investigation of Optimum Survey Designs Using UAV Derived Imagery and Structure-from-Motion Photogrammetry", Remote Sensing, 2016, 8, 786.

37. Klyuev R., Bosikov I., Gavrina O., Madaeva M., Sokolov A., (2021) "Improving the energy efficiency of technological equipment at mining enterprises", In: Murgul V., Pukhkal V. (eds), International Scientific Conference Energy Management of Municipal Facilities and Sustainable Energy Technologies EMMFT 2019. EMMFT 2019. Advances in Intelligent Systems and Computing, vol 1258, pp. 262-271, Springer, Cham. https:// doi.org/10.1007/978-4-030-57450-5 24.

38. Klyuev R., Fomenko O., Gavrina O., Turluev R., Marzoev S. (2021), "Energy indicators of drilling machines and excavators in mountain territories", In: Murgul V., Pukhkal V. (eds), International Scientific Conference Energy Management of Municipal Facilities and Sustainable Energy Technologies EMMFT 2019. EMMFT 2019. Advances in Intelligent Systems and Computing, vol. 1258, pp. 272-281, Springer, Cham. https://doi.org/10.1007/978-4-030-57450-5_25.

39. Golik, V.I., Znaurovich, G.O., Alexandrovich, M.S., Muratovna, K.Z., Petrovich, S.L., "The provision of development conversion perspectives into undeground one for Russian Iron ore deposits development", Social Sciences (Pakistan), 2016, 11(18), pp. 4348-4351.

40. Golik V.I., Razorenov Yu.I., Efremenkov A.B., "Recycling of metal ore mill tailings", Applied Mechanics and Materials, 2014, v. 682, pp. 363-368.

41. Klyuev R. V., Bosikov I. I., Egorova E. V., Gavrina O. A., "Assessment of mining-geological and mining technical conditions of the Severny pit with the use of mathematical models", Sustainable Development of Mountain Territories, 2020, no.3, pp. 418-427. DOI: 10.21177/1998-4502-2020-12-4-418-427. 


\title{
СВЕДЕНИЯ ОБ АВТОРАХ / Information about authors:
}

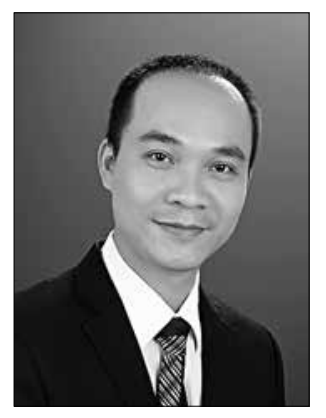

Dr. Nguyen Quoc Long - Head of Department, Department of Mine Surveying, Faculty of Geomatics and Land administration, Hanoi University of Mining and Geology. Duc Thang - Bac Tu Liem, Hanoi, Vietnam.

e-mail: nguyenquoclong@humg. edu. vn

Нгуен Куок Лонг - доктор наук, заведуюший кафедрой маркшейдерского дела факультета геоматики и землеустройства Ханойского университета горного дела и геологии, Вьетнам.

e-mail:nguyenquoclong@ @umg.edu.vn

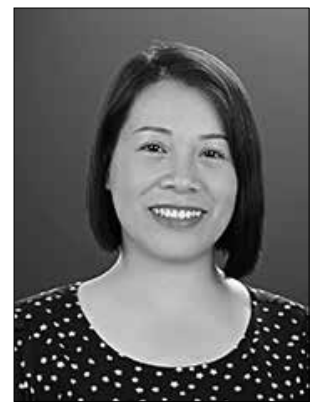

Dr. Le Thi Thu Ha - Deputy Head of Department, Department of Mine Surveying, Faculty of Geomatics and Land administration, Hanoi University of Mining and Geology. Duc Thang Bac Tu Liem, Hanoi, Vietnam.

e-mail: lethithuha@humg.edu.vn

Ле Тхи Ту Хa - доктор наук, заместитель заведующего кафедрой маркшейдерского дела факультета геоматики и землеустройства Ханойского университета горного дела и геологии, Вьетнам.

e-mail:lethithuha@humg.edu.vn

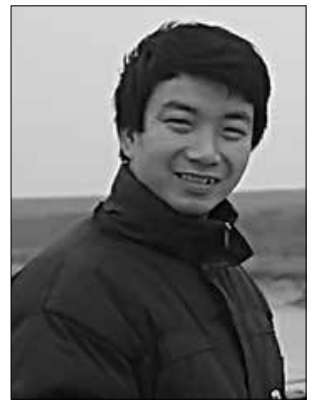

Dr. Tong Si Son - Department of Space and Applications, University of Science and Technology of Hanoi, Hoang Quoc Viet street, Hanoi, Vietnam.

e-mail: tongsison@gmail.com

Тонг Си Сон - доктор наук, Департамент космоса и приложений, Ханойский университет науки и технологий, Вьетнам.

e-mail:thinsison@gmail.com

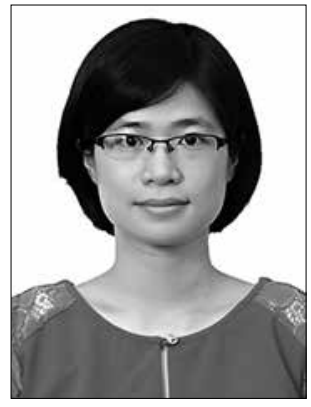

MSc. Kim Thi Thu Huong - Lecturer of Department of Geodesy, Faculty of Geomatics and Land administration, Hanoi University of Mining and Geology. Duc Thang - Bac Tu Liem, Hanoi, Vietnam.

e-mail: kimthithuhuong@humg. edu. vn

Ким Тхи Тху Хыонг - магистр, преподаватель кафедры геодезии факультета геоматики и землеустройства Ханойского университета горного дела и геологии, Вьетнам.

e-mail: kimthithuhuong@humg.edu.vn

\section{БЕСПИЛОТНАЯ ФОТОГРАММЕТРИЯ В КРУПНОМАСШТАБНОМ КАРТОГРАФИРОВАНИИ ОТКРЫТОЙ УГОЛЬНОЙ РАЗРАБОТКИ НА ПРИМЕРЕ Г. КАМФА (ВЬЕТНАМ)}

\author{
Нгуен Куок Лонг ${ }^{1}$, \\ Ле Тхи Ту Хa ${ }^{1^{*}}$ \\ Тонг Си Сон², \\ Ким Тхи Тху Хыонг ${ }^{1}$ \\ ${ }^{1}$ Ханойский университет горного дела и геологии, Вьетнам, lethithuna@humg.edu.vn \\ ${ }^{2}$ Ханойский университет науки и технологий, Вьетнам
}

DOI: $10.21177 / 1998-4502-2020-12-4-501-509$

Использование легкого беспилотного летательного аппарата (БПЛА) с подходом аэрофотограмметрии для построения цифровой модели поверхности (ЦМР) эффективно применяется для различных типов топографии. Однако возможность реализации этого подхода для огромных действующих угольных шахт недостаточно исследована, кроме того, влияние топографических факторов на точность ЦМР неоднозначно.

В этом эксперименте предпринимается метод БПЛА для двух действующих угольных шахт с общей площадью 7,99 км², эксплуатируемых на высоте от -300 м до 300 м, чтобы выяснить влияние топографических факторов на точность ЦМР, построенной с данным изображений беспилотного летательного аппарата.

В общей сложности 972 изображения с БПЛА и 17 наземных контрольных точек были связаны для построения
ЦМР в шахте. Кроме того, 16 контрольных точек, расположенных на разных отметках, используются для оценки точности матрицы высот и определения влияния. ЦМР генерируются с максимальным среднеквадратичным отклонением 0,086 м, 0,099 м и 0,170 м, соответствующими ошибкам размеров по осям $X, Y$ и $Z$.

Результаты показывают нечеткую корреляцию между вертикальной точностью DEM (цифровая модель высоты) и относительной высотой $\left(R^{2}=0,064\right)$, общим наклоном шахт, а также количество наземных контрольных точек, используемых на угольных шахтах.

Ключевые слова: беспилотный летательный аппарат, цифровая модель поверхности, точность карьера, город Камфа.

Статья поступила в редакциию 28.09.2020. 
УДК: 622.232.8

DOI: $10.21177 / 1998-4502-2020-$

12-4-510-515

Рассмотрены вопросы выбора оборудования при подземной отработке полезного ископаемого в пологих угольных пластах. Уточнено классическое определение «очистной механизированный комплекс» (ОМК).

Приведены результаты анализа работы очистных машин, применяемых на многих шахтах Акционерного общества холдинга компании "Сибирский деловой союзуголь».

Дана характеристика комплекта оборудования для механизированной отработки полезного ископаемого подземным способом или «лавакомплекс».

\section{КЛЮЧЕВЫЕ СЛОВА:}

подземная выемка угля, пологое падение пластов, лава- комплекс, комбайн, комплект оборудования.

Статья поступила в редакцию 15.10.2020.

\section{КОМПЛЕКТЫ ОБОРУДОВАНИЯ ДЛЯ ПОДЗЕМНОЙ ДОБЫЧИ УГЛЯ В ПОЛОГИХ ПЛАСТАХ}

Ефимов В. И. ${ }^{1^{*}}$,

Абрамкин Н. И. ${ }^{1}$,

Вернигор В. В. ${ }^{2}$,

Хакимов Б. X. ${ }^{1}$

${ }^{1}$ Национальный исследовательский технологический университет «Московский институт стали и сплавов», 119049, Москва, Россия, v.efimov@msk.sds-ugol.ru ${ }^{2}$ Северо-Кавказский горно-металлургический институт (государственный технологический университет), 362021 г. Владикавказ, Россия

\section{Введение}

В угольной отрасли период основного подъёма отработки углей подземным способом обеспечивался с применением комбайновых и струговых комплексов, которые оборудовались механизированной крепью. Опыт работы механизированных комплексов приходится на семидесятые, восьмидесятые годы двадцатого столетия, а также в настоящее время эти виды горно-шахтного подземного оборудования продолжают оставаться перспективно развивающимися [1-3].

Очистные механизированные комплексы сделали переворот в угольной добыче, что привело к резкому подъёму производительности труда. Новые технологии разработки подземного способа выемки полезного ископаемого дали гигантский подъём объёмов добычи угля, что имело исключительно важную задачу для технического обновления шахт на самом высоком техническом и технологическом уровне. Это способствовало увеличению нагрузки на очистной забой, а также повысило технический уровень каждого звена в технологии подземной отработки пластовых месторождений угля.

Радикальные изменения в экономическом механизме России заставляют искать новые резервы повышения эффективности добычи угля, в том числе в обеспечении производства высокопроизводительной техникой [4-7].

Цель исследований: актуализировать необходимость корректировки концепции классификации горно-шахтного оборудования для горного дела и таможенного законодательства.

\section{Методика исследований}

Были применены способы аналитического исследования: описание, ретроспективный причинно-следственный анализ применения горного оборудования и оценка его взаимозаменяемости, прогнозирование и концептуализация.

\section{Результаты исследований}

Сказанное поясняется из опыта работы очистного механизированного комплекса на подземных горных предприятиях Акционерного общества холдинговой компании «Сибирский деловой союз-уголь».

В восьмидесятых годах на шахте Инская (в настоящее время - ш. Листвяжная) производилась отработка мощного пологого пласта Сычёвский-2, на добычном участке №5.

Параметры очистного забоя составляли 140 метров, 126 секций, механизированная крепь 2 ОКП-70. В очистном механизированном комплексе использовались: вместе с мехкрепью типа ОКП-70 узкозахватный комбайн марки КНЛКГУ с конвейером СУ-ОКП70, мехкрепи с удлинёнными козырьками на сопряжении очистного забоя со штреком, маслостанции СНУ5, водоорошение и электросборка. 
Изготовителями оборудования являлись: секции механизированного и конвеерного комплекса, которые разрабатывались на Узловском, Горловском и Скопинском машиностроительных заводах.

С начала 2001 г. на добычном участке (1317) пологого пласта Грамотеинский 2 , который оснащался мехкомплексом 1 КМ 144 с лавой 130 метров, помимо мехкрепи 1 КМ 144 в ОМК использовали комбайн 1 КШЭ, линейный конвейер.

Установлено, что в очистных забоях применялась шахтная техника отечественного производства, но изза низкой конкурентоспособности обанкротившихся отечественных машиностроительных заводов шахты проводили закупки импортного оборудования, при этом таможенные пошлины были нулевыми.

На шахтах АО ХК «СДС-Уголь» (Южная и Листвяжная) с 2014 по 2020 год в добычных участках применяли комплект оборудования (лава-комплект) с механизированной крепью 2000/4300-2X4207-1750, Bucyrus DBT и ZMJ соответственно [19].

На угольном предприятии ООО «Шахта Южная» лава 9в с 09.2014 г. по 09.2015 г. работала механизированной крепью 2000/4300-2X4207-1750, Bucyrus DBT с очистным комбайном SL500 Eickhoff и со скребковым забойным конвейером PF 4/1032 Bucyrus DBT; использовался штрековый скребковый перегружатель PF 4/1132 Bucyrus DBT; дробилка SK 1111"Hazemag \&amp EPR $\mathrm{GmbH}$; самопередвигающаяся станция SMB 1200 3000 Bucyrus DBT, Europe озон GmbH; система управления Bucyrus, DBT, Europe GmbH; насосная станция HAUHINCO EHP-3K 200\53 FL - все европейское оборудование.

Лава 7л с 03.2015 по 02.2016 добывала уголь комплектом, включающим в себя китайские крепи ZY11000/15/36, ZMJ, применяя также очистной комбайн немецкой фирмы Eickhoff и скребковый конвейер PF 4/1032 Bucyrus DBT. Остальное оснащение очистного механизированного забоя тоже в основном европейского производства.

После на шахте лавы отрабатывались исключительно из-за экономии с помощью китайских крепей, китайское вспомогательное оборудование также постепенно вытесняло западное, хотя и тут видна взаимозаменяемость, например, на китайском очистном комбайне MG500/1170-AWD1, TIANDI используется немецкий шнековый орган [19].

Но особенно наглядно взаимозаменяемость частей очистного комплекса можно увидеть на примере шахты Листвяжная.

Так, с 03.2014 г. по 10.2014 г. 13 Лава 1315 по пл. Грамотеинский II работала механизированной крепью «ZMJ» ZY 6800/18/38 (Китай) с очистным комбайном 4LS20 «Joy Vining Macheri» (США) и со скребковым забойным конвейером «JoyViningMacheri» (США); использовался штрековый скребковый пе- регружатель «JoyViningMacheri» (США); дробилка «JoyViningMacheri» (США); насосная станция HDP-170 Tiefenbach (Германия); система управления Tibatron iSA 10/1 Tiefenbach (Германия) - мы видим, что комплект оборудования для очистного комплекса состоит из горного оборудования разных фирм и заводов-изготовителей.

Лава 1316 по этому же пласту с 11.2016 г. по 10.2018 г. добывала уголь комплектом, включающим те же китайские крепи ZY11000/15/36, ZMJ, и применяя также комбайн 4LS20 «Joy Vining Macheri» (США), но скребковый конвейер АНЖЕРА-38, штрековый скребковый перегружатель ПСП-308, дробилка ДУ-910, подвижная станция ПСП-1200 всё это сделано на заводе ОАО «Анжеромаш» - Россия; остальное: насосная станция HDP-170 Tiefenbach, Германия; система управления Tibatron iSA 10/1 Tiefenbach, Германия. Мы видим, что комплект оборудования для очистного комплекса состоит из ещё более разнообразного горного оборудования по фирмам и странам его изготовления.

Технические характеристики оборудования изготовителей разных стран и фирм примерно одинаковы. Например, сравнивая конвейеры АНЖЕРА-38 и JOY-AFG, мы увидим, что производительность у них одинаковая 2000 т/ч, длина рештаков тоже одинаковая - 1756 , по остальным параметрам они отличаются в пределах возможной взаимной замены. Также перегружатели Ажерского машиностроительного завода и фирмы JOY-AFG практически по всем основным параметрам - производительности, мощности электродвигателей, скорости скребковой цепи, длине рештаков - подходят друг к другу.

Из вышеприведенных примеров можно сделать вывод, что сегодня в основном на шахтах в лавах работает комплект взаимозаменяемого оборудования. Само понятие именного очистного комплекса, например, как раньше ОКП-70, или как 1 КМ 144 устарело, но эти понятия прочно сидят в таможенных правилах.

Методика таможенных органов при начислении сборов на импортное оборудование различается. Так, например, при поступлении на шахту секций крепи, при таможенном оформлении которых таможенная пошлина составила $2 \%$, а при поступлении комбайна $-5 \%$.

Таможенный режим назначается таможенным органом. Отдельно взятое оборудование расценивается проверяемыми лицами как комплекс, а получатель товара является нарушителем таможенного законодательства, поскольку при таможенном оформлении нужно было уплатить таможенный налог за секции в размере $5 \%$, исходя из принципа выполнения комбайном главной основной функции в процессе добычи угля, и поэтому на все оборудование, поступившее в совокупности с комбайном, таможенная пошлина составит $5 \%$, как на единый очистной комплекс. 
Однако технические характеристики очистного комбайна не связаны с количеством механизированных крепей. Количество крепей определяет возможность отработки очистной единицы (лавы) необходимой длины. В данный момент очистной комбайн может работать без секций крепи, находящихся на поверхности.

Поставленные в рамках контракта механизированные крепи могут использоваться с другими моделями комбайнов, как очистной комбайн типа SL-300 (производство компании Eickhoff).

Механизированные крепи, задекларированные в таможенных декларациях, не являются неотъемлемой частью какого-либо комплекса. В частности, очистной комбайн может использоваться и в настоящее время используется без значительной части приобретенных крепей, находящихся на поверхности. Скребковый конвейер, перегружатель и дробилка также могут использоваться по отдельности в различных транспортных цепочках и технологических циклах (например, в шахте «Листвяжная»).

Очистной комбайн является самоходным и имеет возможность передвигаться без наличия (или при отсутствии) механизированных крепей. Поэтому, исходя из принципа выполнения комбайном главной основной функции в процессе добычи угля, устанавливать

\section{ЛИТЕРАТУРА:}

1. Wang Gang, Xie Jun, Xue Sheng, Wang Haiyang. Mining a coal seam below a heating goaf with a force auxiliary ventilation system at Longhua underground coal mine // International Journal of Mining Science and Technology. China. 2015. Vol. 25. P. $67-72$.

2. Modern experience of low coal seams underground mining in Ukraine / M.V. Petlovanyi, V. H. Lozynskyi, P. B. Saik, K. S. Sai // International Journal of Mining Science and Technology. 2018. Vol. 28. Issue 6. P. 917-923.

3. Голик В. И., Комащенко В. И., Страданченко С. Г., Масленников С. А. Повышение полноты использования недр путем глубокой утилизации отходов обогащения угля // Горный журнал. 2012. N 9. С. 91-95.

4. Голик В. И., Цидаев Б. С., Логачев А. В. Повышение рентабельности добычи нефти путем диверсификации технологий // Устойчивое развитие горных территорий. 2019. T.11. N1(39). C. 98-104.

5. Nawrocki T. L., Jonek-Kowalska I. Assessing operational risk in coal mining enterprises - Internal, industrial and international perspectives // Resources Policy. 2016. Vol. 48. P. 50-67.

6. Drebenstedt C. et al. Living with the Earth: Faculty of Earth Sciences, Geotechnics and Mining. Acamonta: magazine for friends and sponsors of the TU Bergakademie Freiberg. Freiberg, 2014. P. 62-77.

7. Экспериментальные исследования параметров работы очистного комбайна угольной шахты при различных скоростях подачи / К. Н. Копылов, С. С. Кубрин, И. М. За- таможенную пошлину в размере $5 \%$ на все оборудование, поступившее в совокупности с комбайном, - не правильно.

В 90-е годы таможенный налог на оборудование, которое не производилось в России, не взимался. Шахтеры приобретали оборудование за границей, однако дополнительных сложностей при ввозе оборудования не возникало.

Понятие «комплекс» носит условный характер и отражает только кинематические связи, электрогидравлические и электронные системы управления взаимозаменяемых комплектов оборудования, предназначенных для добычи угля. Назрела необходимость скорректировать концепцию классификации оборудования для добычи угля [16-19].

Затронутые в статье вопросы рассмотрены в ряде работ российских и зарубежных специалистов [20-28].

\section{Выводы}

Техническая характеристика современного оборудования, мехкрепей, которые применяются для современного ОМК, у зарубежных производителей разных стран одинаковы, которые могут позволить в связи с возникшей технической необходимостью заменять друг друга.

Таможенное законодательство в части пошлин на горное оборудование нуждается в корректировке.

коршменный, С. Н. Решетняк // Горный информационноаналитический бюллетень. 2017. N 12. С. 48-55.

8. Zich A., Linnik Yu.N., Linnik V.Yu. Extension of the service life of chisel holder cutting coal extraction machines // Mining report. Gluckauf. 2017. No 153. P. $474-479$.

9. Dos Santos J. A. Sandwich Belt High Angle Conveyors Coal Mine to Prep Plant and Beyond-2016 // Proceedings of the XVIII International Coal Preparation Congress - Cham: Springer International Publishing, 2016. P. 111-117.

10. Лемешко М. А., Трифонов А. В. Исследование привода адаптивной машины «УБГ-1А» // Горный информационно-аналитический бюллетень (научно-технический журнал). 2013. N 6. С. 202-207.

11. Ордин А. А., Никольский А. М. Оптимизация ширины захвата производительности шнекового комбайна при отработке пологого угольного пласта длинным очистным забоем // Физико-технические проблемы разработки полезных ископаемых. 2018. N1. C. 79-86.

12. Kuidong Gao, Changlong Du, Jianghui Dong, Qingliang Zeng. Influence of the Drum Position Parameters and the Ranging Arm Thickness on the Coal Loading Performance // Minerals. 2015. Vol. 5. P. 723-736.

13. Лемешко М. А., Трифонов А. В. Математическая модель ограничений адаптивного управления машинами вращательного бурения // Горный информационно-аналитический бюллетень (научно-технический журнал). 2012. N 2. С. 207-210.

14. Абрамкин Н. И., Дородний А. В., Бухарбаев И. У. 
Анализ интегрированной технологии высокопроизводительной отработки запасов выемочных участков угольных шахт // Уголь. 2019. N 1 (1114). С. 40-45

15.Филатов П. Ю., Федин К. В., Дмитриев М. А., Андраханов С. В., Кузнецов С. А., Соснин Р. Г. Технология «опережающей отработки» угольных пластов с применением комплекса глубокой разработки пластов // Вестник НЦ ВостНИИ. 2017. N 2. С. 42-49.

16. Ефимов В. И., Абрамкин Н. И., Стась П. П. Отработка крутых угольных пластов // Горный информационно-аналитический бюллетень (научно-технический журнал). 2019. N 4. С. $20-29$

17. Фам Д. Х., До А. Ш., Нгуен В. К. Анализ технических факторов, влияющих на эффективность отработки механизированных очистных забоев // Горно-геологический и горнотехнический журнал. 2016. N 57. С. 34-39.

18. Жабин А. Б., Поляков А. В., Ковалева Т. В., Аверин Е. А. О расчетной схеме для определения устойчивости проходческого комбайна // Горное оборудование и электромеханика. 2018. N 2. С. 46-49.

19. Ефимов В. И., Хмелинский А. А., Мефодьев С. Н. Современные подходы к компоновке оборудования для добычи угля на пологих пластах // Уголь. 2019. N 6 (1119). C. $36-40$.

20. Хетагуров В. Н., Каменецкий Е. С., Минасян Д. Г., Гегелашвили М. В. Исследование движения измельчаемого материала в центробежной мельнице вертикального типа при установке в ее рабочем пространстве коаксиального кольца // Устойчивое развитие горных территорий. Владикавказ. 2017. Т.9, N 3. С. 286-291.

21. Klyuev R., Bosikov I., Gavrina O., Madaeva M., Sokolov A. (2021) Improving the energy efficiency of technological equipment at mining enterprises. In: Murgul V., Pukhkal V. (eds). International Scientific Conference Energy Management of Municipal Facilities and Sustainable Energy Technologies EMMFT 2019. EMMFT 2019. Advances in Intelligent Systems and Computing, vol 1258, pp. 262-271, Springer, Cham. https:// doi.org/10.1007/978-4-030-57450-5_24.

22. Klyuev R., Fomenko O., Gavrina O., Turluev R., Marzoev S. (2021) Energy indicators of drilling machines and excavators in mountain territories. In: Murgul V., Pukhkal V. (eds). International Scientific Conference Energy Management of Municipal Facilities and Sustainable Energy Technologies EMMFT 2019. EMMFT 2019. Advances in Intelligent Systems and Computing, vol 1258, pp. 272-281, Springer, Cham. https://doi. org/10.1007/978-4-030-57450-5_25.

23. Клюев Р. В., Босиков И. И., Егорова Е. В., Гаврина О. А. Оценка горно-геологических и горнотехнических условий карьера "Северный" с помощью математических моделей // Устойчивое развитие горных территорий. 2020. Т. 12, N3. C. 418-27. DOI: 10.21177/1998-4502-2020-12-4-418-427.

24. Белюшин Д. В., Лагунова Ю. А. Анализ экспериментальных данных ударного взаимодействия рабочих поверхностей вибромашин с горной породой // Горный журнал. Екатеринбург. 2017. N6. C 79-85.

25. Волкова Л. П., Костин В. Н., Панкрушин П. Ю. Концептуальная модель базы данных САПР струговых агрегатов и установок // Горный информационно-аналитический бюллетень. 2016. N7. C. 57-62.

26. Mendyka P., Kotwica K., Stopka G. Innovative Roadheader / Mining Head With Assymetrical Disc Tools. 2016. P. 489-496.

27. Кумар Ч., Мурти В. М. С. Р., Кумарасвамидхас Л. А., Пракаш А. Методология проектирования фрезерного барабана и выбор оптимальных эксплуатационных параметров карьерного комбайна в различных горно-геологических условиях // Физико-технические проблемы разработки полезных ископаемых. 2018. N4. C.60-69.

28. Нецветаев А. Г., Григорян А. А., Пружина Д. И. Алгоритм расчета геомеханических параметров, обеспечивающих безопасность технологии безлюдной добычи угля с применением КГРП // Уголь. 2015. N 1. С. 25-28.

\section{СВЕДЕНИЯ ОБ АВТОРАХ / Information about authors:}

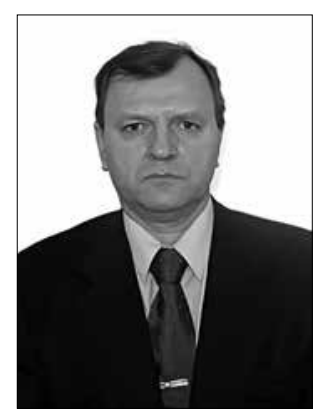

ЕФИМОВ Виктор Иванович доктор технических наук, профессор.

Национальный исследовательский технологический университет «Московский институт стали и сплавов», 119049, Москва, Россия. e-mail: v.efimov@msk.sds-ugol.ru

Viktor I. EFIMOV - Doctor of Technical Sciences, Professor.

National Research Technological University "Moscow Institute of Steel and Alloys", 119049, Moscow, Russia. e-mail:v.efimov@msk.sds-ugol.ru

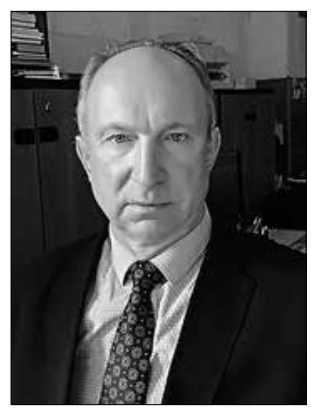

АБРАМКИН Николай Иванович - доктор технических наук, профессор. Национальный исследовательский технологический университет «Московский институт стали и сплавов», 119049, Москва, Россия.

e-mail: abramkin57@mail.ru

Nikolay I. ABRAMKIN - Doctor of Technical Sciences, Professor, National Research Technological University "Moscow

Institute of Steel and Alloys", 119049, Moscow, Russia. e-mail:abramkin57@mail.ru 


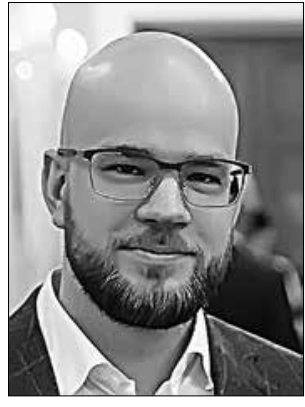

ВЕРНИГОР Владимир Владимирович - горный инженер, аспирант кафедры «Горное дело».

Северо-Кавказский горно-металлургический институт (государственный технологический университет), 361021, г. Владикавказ, Россия.

Vladimir V. VERNIGOR - Mining Engineer, Post-Graduate Student of the Department of Mining.

North Caucasian Institute of Mining and Metallurgy (State Technological University), 361021, Vladikavkaz, Russia.

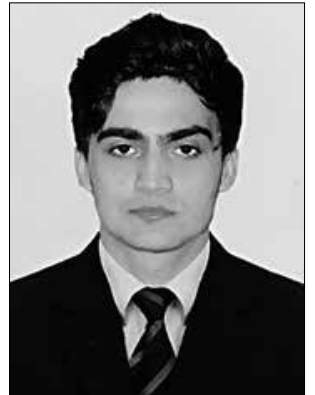

ХАКИМОВ Бехруз Хушвахтович - аспирант кафедры «Геотехнологии освоения недр». Национальный исследовательский технологический университет «Московский институт стали и сплавов», 119049 , Москва, Россия.

e-mail: Bisl7@bk.ru

Behruz Kh. KHAKIMOV - Postgraduate Student of the Department of Geotechnology of Subsoil Development. National Research Technological University "Moscow Institute of Steel and Alloys", 119049, Moscow, Russia.

e-mail:Bisl7@bk.ru

\title{
UNDERGROUND MINING EQUIPMENT KITS COAL IN SHALLOW BEDS
}

\author{
V. I. Efimov ${ }^{1^{*}}$ \\ N.I. Abramkin', \\ V.V. Vernigor', \\ B. Kh. Khakimov ${ }^{1}$

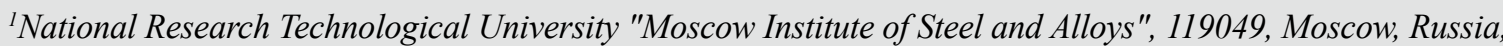 \\ v.efimov@msk.sds-ugol.ru \\ ${ }^{2}$ North Caucasian Institute of Mining and Metallurgy (State Technological University), Vladikavkaz, 361021 Russia.
}

\section{DOI: $10.21177 / 1998-4502-2020-12-4-510-515$}

In Russian practice, at the author of the mines of the revolution, equipment was used, which was well made at the pest of domestic factories. In view of the core bankruptcy of the domestic factories, the coat of arms of the miners were forced to carry the burden and had the choice to buy foreign equipment.. In 90-ies tax on trail equipment, which was not produced in Russian boards, was not collected at all. The miners bought the equipment abroad, without any additional problems for the equipment import did not arise. Powered roof support and shearers are not produced in Russia and the plants had to buy them abroad both the avalanche and the separate equipment.

The term fund "complex" pest has a conditional blue character, the conclusion reflecting taking only the stage of the kinematic announcement of the connection, the input of the electrohydraulic and if the electronic system suddenly controls interchangeable author sets of equipment address. temperament It is advisable to revise the concept of more classification of the kiln cleaning mechanized complexes and the lighthouse to adjust the core of the customs due to legislation to address some of the tinder customs duties on the author of the mining equipment.

Keywords: Underground mining, coal, flat seams, treatment complex, harvester, equipment set, lava-set.

\section{References:}

1. Wang Gang, Xie Jun, Xue Sheng, Wang Haiyang. "Mining a coal seam below a heating goaf with a force auxiliary ventilation system at Longhua underground coal mine", International Journal of Mining Science and Technology. China, 2015, Vol. 25, pp. 67-72.

2. Petlovanyi M.V., Lozynskyi V.H., Saik P.B., Sai K.S., "Modern experience of low coal seams underground mining in Ukraine", International Journal of Mining Science and Technology, 2018, vol. 28, issue 6, pp. 917-923.
3. Golik V. I., Komashchenko V. I., Stradanchenko S. G., Maslennikov S. A. "Increased the fullness of the use of the subsoil by deep waste disposal enriching coal", Mountain Journal, 2012, no 9, pp. 91-95.

4. Golik V. I., Tsidaev B. S., Logachev A. V. "Improving the profitability of oil production by diversifying technologies", Sustainable Development of Mountain Territories, 2019, v.11, no.1(39), p. 98-104.

5. Nawrocki T. L., Jonek-Kowalska I. "Assessing operational risk in coal mining enterprises - Internal, industrial and international perspectives", Resources Policy, 2016, vol. 48, pp. 50-67.

6. Drebenstedt C. et al. Living with the Earth: Faculty of Earth Sciences, Geotechnics and Mining. Acamonta: magazine for friends and sponsors of the TU Bergakademie Freiberg, Freiberg, 2014, p. 62-77.

7. Kopylov K. N., Kubrin S. S., Zakorshmenny I. M., Reshetnyak S. N., "Experimental studies of the parameters of the coal mine treatment plant at different feeder speeds", Mountain Newsletter, 2017, no 12, pp. 48-55.

8. Zich A., Linnik Yu. N., Linnik V. Yu. "Extension of the service life of chisel holder cutting coal extraction machines ", Mining report, 2017, no. 153, pp. 474-479.

9. Dos Santos J. A. "Sandwich Belt High Angle Conveyors Coal Mine to Prep Plant and Beyond-2016", Proceedings of the XVIII International Coal Preparation Congress, Cham: Springer International Publishing, 2016, pp.111-117.

10. Lemeshko M. A., Trifonov A. V. "Study of the drive of adaptive machine "UUG-1A", Mountain Information and Analysis Bulletin (Scientific and Technical Journal), 2013, no.6, pp. 202-207.

11. Ordin A. A., Nikolsky A. M. "Optimization of width 
capture of the performance of the combine when working out the sloth coal seam long treatment retardation", Physics and Technology Problems of Mineral Development, 2018, no.1, pp. 79-86.

12. Kuidong Gao, Changlong Du, Jianghui Dong, Qingliang Zeng, "Influence of the Drum Position Parameters and the Ranging Arm Thickness on the Coal Loading Performance", Minerals, 2015, vol. 5, pp. 723-736.

13. Lemeshko M. A., Trifonov A. V. "Mathematical model of limitations of adaptive control of rotary drilling machines", Mountain Information and Analysis Bulletin (Scientific and Technical Journal), 2012, no.2, pp.207-210.

14. Abramkin N. I., Dorodny A. V., Bukharbayev I. U. "Analysis of integrated technology of high-performance development of coal mine extraction sites", Ugol' Journal, 2019, No 1 (1114), pp.40-45.

15. Filatov P. Yu, Fedin K.V., Dmitriev M.A., Andrakhanov S.V., Kuznetsov S.A., Sosnin R. G. "Technology "advanced development" of coal seams using a complex of deep development of reservoirs", Bulletin of the Scientific Center of VostNII on Industrial and Environmental Safety, 2017, no.2, pp.42-49.

16. Efimov V. I., Abramkin N.I., Stas P. P. "Development of steep coal seams", Mountain Information and Analysis Bulletin (Science and Technology Journal), 2019, no. 4, pp. 20-29.

17. Pham D. H., Do A. S., Nguyen V. K. "Analysis of technical factors influencing the efficiency of the development of mechanized treatment retags", Mining and Geological Journal, 2016, no.57, pp.34-39.

18. Jabin A. B., Polyakov A. V., Kovaleva T. V., Averin E. A. "About the calculation scheme to determine the stability of the passing combine", Mining Equipment and Electrical Mechanics, 2018, no. 2, pp. 46-49.

19. Efimov V. I., Hmelinsky A. A., Mefodyev S. N. "Modern approaches to the layout of equipment for coal mining on flat seams", Ugol' Journal, 2019, no. 6 (1119), pp.36-40.

20. Khetagurov V. N., Kamenetsky E. S., Minasyan D. G., Hegelashvili M.V. "Study of the movement of shredded material in a vertical centrifugal mill when installed in its working space coaxial ring", Sustainable Development of Mountain Territories, 2017, vol. 9, no.3, pp.286-291.

21. Klyuev R., Bosikov I., Gavrina O., Madaeva M., Sokolov A. (2021) "Improving the energy efficiency of technologi- cal equipment at mining enterprises", In: Murgul V., Pukhkal $V$. (eds), International Scientific Conference Energy Management of Municipal Facilities and Sustainable Energy Technologies EMMFT 2019. EMMFT 2019. Advances in Intelligent Systems and Computing, vol 1258, pp. 262-271, Springer, Cham. https://doi.org/10.1007/978-4-030-57450-5_24.

22. Klyuev R., Fomenko O., Gavrina O., Turluev R., Marzoev S. (2021) "Energy indicators of drilling machines and excavators in mountain territories", In: Murgul V., Pukhkal $V$. (eds), International Scientific Conference Energy Management of Municipal Facilities and Sustainable Energy Technologies EMMFT 2019. EMMFT 2019. Advances in Intelligent Systems and Computing, vol 1258, pp. 272-281, Springer, Cham. https://doi.org/10.1007/978-4-030-57450-5 25.

23. Klyuev R. V., Bosikov I. I., Egorova E. V., Gavrina O. A. "Assessment of mining-geological and mining technical conditions of the Severny pit with the use of mathematical models", Sustainable Development of Mountain Territories, 2020 , v. 12 , no.3, pp. 418-427. DOI: $10.21177 / 1998-4502-$ 2020-12-4-418-427.

24. Belyushin D. V., Lagunova J. A. "Analysis of experimental data of shock interaction of working surfaces of vibrating machines with rock", Mountain Journal, Yekaterinburg, 2017, no.6, pp.79-85.

25. Volkova L. P., Kostin V. N., Pankrushin P.Yu. "Conceptual model of the database of SAPR strug aggregates and installations", Mountain Information and Analysis Bulletin, 2016, no.7, pp.57-62.

26. Mendyka P., Kotwitsa K., Stopka G. "Innovative Road header", Head of the mining industry with asymmetric disk instrument, 2016, pp. 489-496.

27. Kumar C, Murti W. M. S. R., Kumaraswamidhas L. A, Prakash A. "Methodology for designing a milling drum and the choice of optimal operating parameters of a surface miner in various mining and geological conditions", Physical and Technical Problems of the Development of Minerals, 2018, no.4, pp. 79-86.

28. Nezvetaev A. G., Grigoryan A. A., Spring D. I., “Algorithm for calculating geomechanical parameters that ensure the safety of the technology of deserted coal mining using KGRP”, Ugol' Journal, 2015, no. 1, pp. 25-28.

Article received 15.10.2020. 
УДК: 334.7

DOI: $10.21177 / 1998-4502-2020-$

12-4-516-522

Our interest is to explore such a characteristics of the young villagers who live in the slope of Mountain Arjuna, East Java Province of Indonesia prior to their existing management competency and existing entrepreneurial intention.

\section{KEYWORDS:}

system engineering; industrial management; modelling; sustainable development; decision making

$\overline{\text { Article received 30.09.2020. }}$

\section{MANAGEMENT COMPETENCY}

AND ENTREPRENEURIAL INTENTION

OF THE 60-YOUNG VILLAGERS IN A PART OF SLOPE OF MT. ARJUNA EAST JAVA INDONESIA

\section{Lasman Parulian Purba ${ }^{1^{*}}$}

Yustinus Budi Hermanto ${ }^{2}$

${ }^{1}$ Industrial Engineering Department, Darma Cendika Catholic University, Surabaya, Indonesia.

Jl. Dr. Ir. H. Soekarno No. 201, Surabaya, 60117, East Java, Indonesia, Iasman.parulian@ ukdc.ac.id

${ }^{2}$ Management Department, Darma Cendika Catholic University, Surabaya, Indonesia JI. Dr. Ir. H. Soekarno No. 201, Surabaya, 60117, East Java, Indonesia.

\section{Introduction}

This is a very beginning basic research that explore such a good potential of young villagers in a part of the slope of the Mountain Arjuna (sometimes called Arjuno) located administratively between Batu City (Malang Regency) and Pasuruan Regency in East Java Province of Indonesia since there is no publication until this report is written especially about the current characteristics of the 60-young villagers who leaved near the mountain Arjuno. Mountain Arjuno is a volcano cone with height 3.339 meters upper the sea level (Gunung_Arjuno, 316AD; Dan, 2016). Management of the mountain is called as the Taman Hutan Raya (Grand Forest Parks) R. Soeryo (sometimes called as R. Surjo or Raden Soerjo) which total area of the forest was 27.868,30 ha based-on Decree of the Ministry of Forestry Indonesia No. 80/ Kpts-II/2001, 19 Mei 2001 (Yudohartono, 2008; Siswanto, 2017). The Grand Forest Parks R. Soeryo administratively located in Tulungrejo Village, Batu City, Malang Regency, East Java Province, Indonesia at $112^{\circ} 32^{\prime} 00^{\prime \prime}$ East Longitude and $7^{\circ} 44^{\prime}$ 30" South Latitude (NGalamediaLABS, 2013; Dan, 2016). Areas of the Grand Forest Park were lies in the five different Regency area of East Java Province i.e.: Mojokerto Regency, Malang Regency, Jombang Regency, Pasuruan Regency and Batu City. There are seven mountains included in the Grand Forest Parks R. Soeryo i.e: Mt. Arjuno (3.339 m), Mt. Welirang (3.156 m), Mt. Anjasmoro (3.217 m), Mt. Kembar I (3.061 m), Mt. Biru (2.337 m), Mt. Kembar II (3.256 m) and Mt. Ringgit (2.474 m) (NGalamediaLABS, 2013). In Pasuruan Regency, there are only two districts lies in the slope of Mt. Arjuno i.e: Prigen District and Puwodadi District. There are fourteen villages in the Prigen district of the Pasuruan Regency, and thirteen villages in the Purwodadi District (BADAN PUSAT STATISTIK KABUPATEN PASURUAN BPS - Statistics of Pasuruan Regency, 2020). The villages near the Mt. Arjuno in Prigen District are Jatiarjo Village, Dayurejo Village, Lumbangrejo Village, Ledug and Pecalukan. The villages near the Mt. Arjuna in Purwodadi District are Tambaksari Village, Jatisari Village and Pucangsari village. Area of the forest on the mountain especially in Pasuruan Regency was about 12.000 ha. There are only 300 ha of 1.500 ha that conserved the forest which broke caused by fire in 2012 (Nugroho et al., 2019).

\section{Conceptual development}

Forest areas are an important land of agricultural production or farming (Guresci, 2015). According to the forest conservation as proposed and implemented by $(\mathrm{Nu}-$ groho, 2018; Nugroho et al., 2019), this research aims to gain an understanding what is the characteristics of the peoples near the Mountain Arjuno especially young villagers in their management competency and their entrepreneurial intention. We hope, in the next time, the people especially their young villagers will have better qualities 
in life as the strategic planned and processed by (Dinas pertanian jawa timur, 2014; PEMERINTAH PROVINSI JAWA TI, 2015; Dinas Pertanian Provinsi Jawa Timur, 2016; Bappeda, 2017) which is supported by our research concept shown in figure 1.

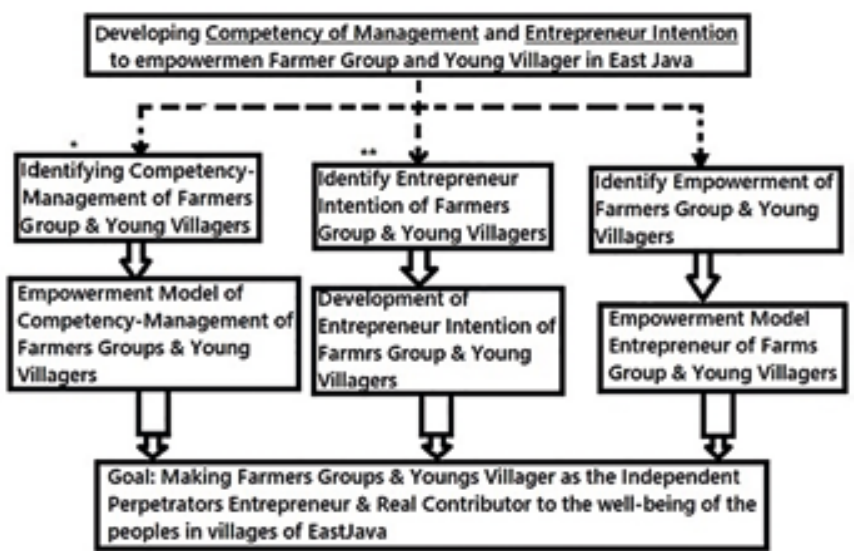

Fig. 1. Roadmap / Concept of our research (Direktorat Riset dan Pengabdian Masyarakat Direktorat Jenderal Riset dan Pengembangan Kementrian Riset, Teknologi, 2019), parts of* and $* *$ is reported in this paper works

There are three individual competencies-management that need to know-well in every body in order to success in their work as well (Spencer and Spencer, 1993; Hertanto, 2017). Here in this research work we put in the questionnaires with 9 indicators used to detect the intellectualcompetence of the young villagers (42 respondents from Dayurejo Village, 18 respondents from Jatiarjo Village), 5 indicators for the emotional-competence and 7 indicators for the social-competence. Total respondents were sixty as we don't know population but we have four variables that's why it is a must at least 40 respondents (Sugiyono, 2019). Our future research's goal is the young villagers become an entrepreneur; their family economic-development become sustainable as SDGs (SustainAbility, 2020; Yulaswati, 2020).

Model Core Entrepreneurial Intention of the young villagers was adopted from (Linan and Chen, 2011; Sari, 2013), shown in figure 2.

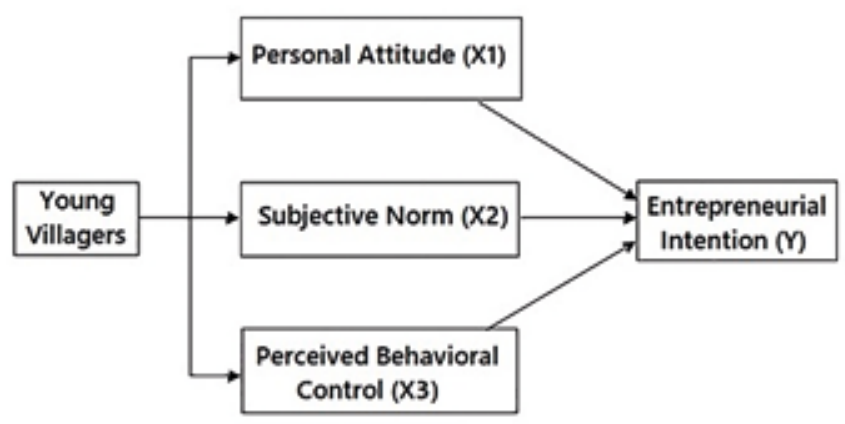

Fig 2. Concept development about entrepreneurial intention model

\section{Methodology of research}

It was developed a list of indicators to the concept as discussing above in a questionnaires (the EIQ, Entrepre- neurial Intention Questionnaire) follow (Linan and Chen, 2011; Sari, 2013). which is $X 1$ with 5 indicators, $X 2$ with 5 indicators (adopted from (Linan and Chen, 2011; Sari, 2013), $X 3$ use the same indicators as (Linan and Chen, 2011; Sari, 2013) and $Y$ use the same indicators as (Linan and Chen, 2011; Sari, 2013) for young villagers.

Table 1

Comparison of sum of the EIQ' indicators

\begin{tabular}{cccc}
\hline Variables & $\begin{array}{c}\text { (Linan and } \\
\text { Chen, 2011) }\end{array}$ & (Sari, 2013) & Proposed \\
\hline PA, X1 & 5 indicators & 5 indicators & 5 indicators \\
SN, X2 & 3 indicators & 7 indicators & 5 indicators \\
PBC, X3 & 6 indicators & 5 indicators & 6 indicators \\
EI, Y & 6 indicators & 5 indicators & 6 indicators \\
\hline
\end{tabular}

The questionnaires spread to the villages in a part of the slope of the mountain to sixty young villagers there. After collecting the data from the questionnaires then proceed and analyzed them through software Statistical Packages for Social Sciences (SPSS) version 21.0, respectively.

\section{Analysis}

About 60 of 100 respondents are the young villagers (Badan Pusat Statistik Provinsi Jawa Timur, 2016) which is the persons who have 16 to 30 years old prior to the survey conducted. It was found that there are $30 \%$ of the

Table 2

Kinds of farming of the young villagers

(Primary data, analyzed (2020))

\begin{tabular}{ccc}
\hline No. & Kind of Farming & Frequency \\
\hline 1 & Coffee & 24 \\
2 & Banana & 13 \\
3 & Cassava & 12 \\
4 & Clove & 11 \\
5 & Corn & 11 \\
6 & Avocado & 11 \\
7 & Durian & 9 \\
8 & Pineapple & 3 \\
9 & Jackfruit & 3 \\
10 & rambutan & 3 \\
11 & Soursop & 2 \\
12 & Rice & 1 \\
13 & Carrot & 1 \\
14 & Elephants' grass & 1 \\
15 & Strobery & 1 \\
16 & Eggplant & 1 \\
17 & Orange & 1 \\
18 & Guava & 1 \\
19 & Vegetable & 1 \\
20 & Sea-wood & 1 \\
21 & Tree & 1 \\
22 & Petai & 1 \\
23 & Grape & 1 \\
\hline
\end{tabular}




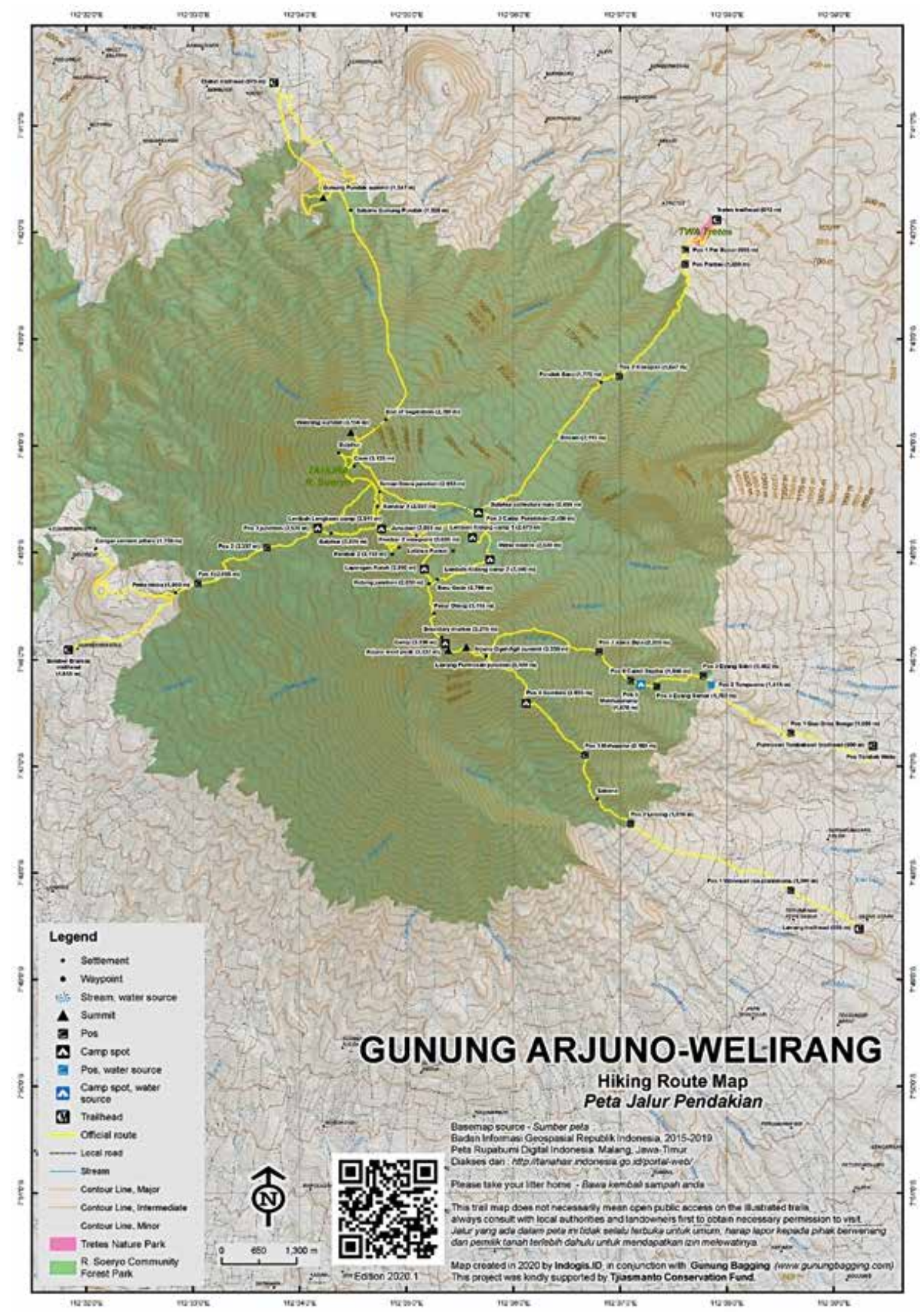

Fig. 3. Location of the research participants especially from Tretes Route ('peta-jalur-pendakian-gunung-arjuno-welirang.pdf', no date; Dan, 2016) 

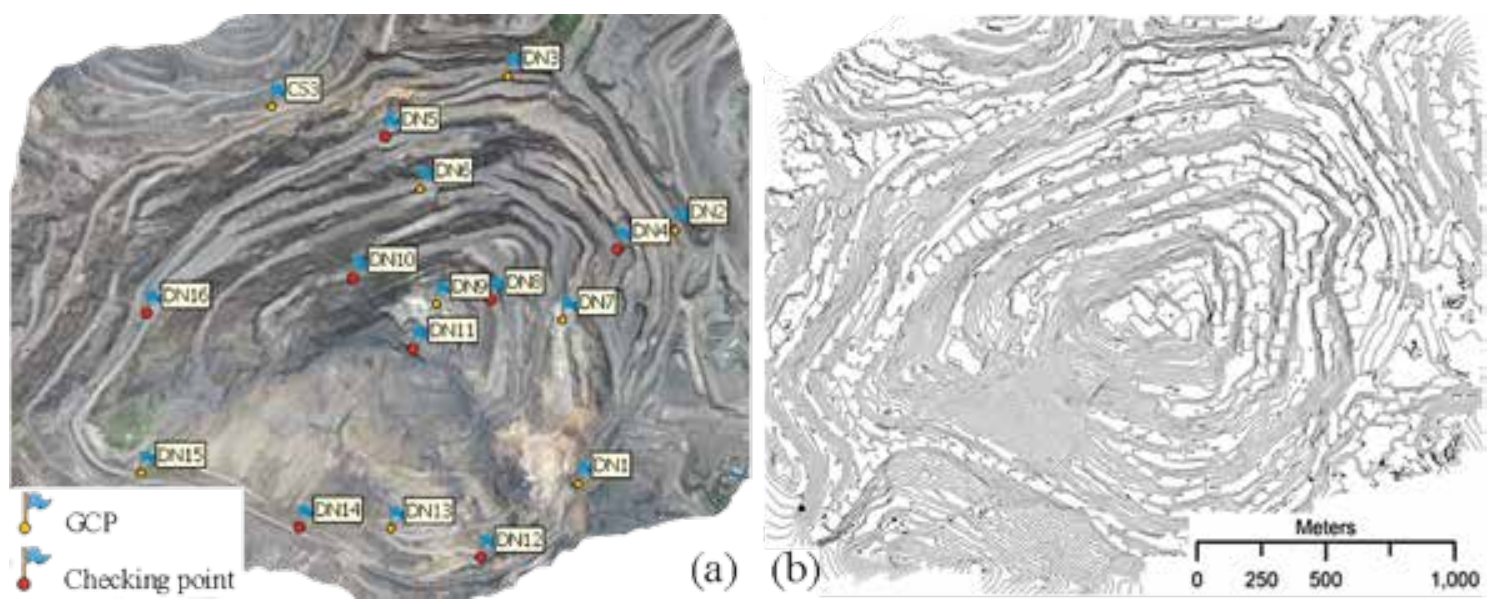

Fig. 4. Location of the Young Villagers in the Prigen Subdistrict, Pasuruan Regency, East Java Province, Indonesia (Kec. Prigen, no date)

young villagers comes from Senior High School and 70\% from others $(35 \%$ Junior High School, $27 \%$ graduated from Foundation School and 8 not graduate from any others school). There are 52\% man and $48 \%$ women. They came from Dayurejo Village, Jatiarjo Village of Prigen District (shown in Fig 3. and Fig 4.).

From all the young villagers surveyed, 38\% have their own land but $62 \%$ not (they borrow land from other people in the village). Most of the young villagers, $93 \%$ was become a farmer less than or equals to 5 years and the rest more than 5 years, respectively. There are six kinds of farming of the young villager diligence i.e.: coffee farming, banana farming, cassava farming, avocado farming, cloves farming and corn farming (shown in Table 1).

There are $57 \%$ of the young villagers stated that they receive benefit when they do their farming beside $43 \%$ do not receive benefit. The farming that they do still in less coordination. The farming is done $80 \%$ by inter cropping and $20 \%$ is not. For the $61 \%$ of the young villagers agreewell about bee cultivation but there are $20 \%$ was not agree.

Through this research it is a need to explore how the young villagers manage themselves and or other peoples in term of the farming that they have done before. We then use questionnaires based-on (Pengertian Kompetensi Manajemen SDM, no date) to understand their personalities, knowledges and skills. In this research work we do not take into accounts personalities of the young villagers according to the lack of information we have and our research background.

The young villagers informed that the knowledge about farming come from themselves $(42 \%)$, work in group $(11 \%)$. Their knowledge about management theory came from themselves reach $50 \%$ but from work in group about $8 \%$. There are only $25 \%$ of the young villagers has a group work and $75 \%$ are not. Every group work has a functional leader. Usually, they sell their crop of farming in the original form (66\%) directly by themselves (37\%) and by middleman (63\%). Their crop of farming can be found only in the next near after the crops time in the tour objects which is not so far from their village such as tradi- tional market, Taman Safari market, Taman Dayu, Cheng Ho, Pintu Langit, Jatiarjo Gifts Store and Makoya.

They obtained skills in farming from training (63\%), themselves (36\%) and Television program (2\%), but they do farm without a group leader $(64 \%)$ and with a group leader (36\%). Ability to find skill (self-learning) by themselves is pretty high (67\%) and without ability to find (selflearning) by themselves $33 \%$ although they have ability to teach other (34\%) and but there are $65 \%$ of the young villagers cannot teach other in farming skill. From the questionnaire also found that there are $45 \%$ can do farming stand alone and $55 \%$ cannot do farming stand alone. Their life is adequate, $44 \%$ and non-adequate, $56 \%$. The young villagers have a working group of farming $(24 \%)$ and have not a working group of farming ( $76 \%)$. Skill that they have in farming also the same as their knowledge about farming i.e.: coffee farming (1st), banana farming (2nd), cassava farming (3rd), avocado (4th), clove (5th) and corn (6th).

The average of intellectual competency (ten indicators) of the young villagers was 3.81 out of 5.00 (Likert's scale, $1=$ very not agree, $2=$ not agree, $3=$ neutral, $4=$ agree, $5=$ very agree) which is $76 \%$, range from 3.53 to 4.27 . The average of emotional competency (5 indicators) of the young villagers was $3.56 / 5.00$ which is $71 \%$, range between 3.50 and 3.68. The average of social competency ( 7 indicators) of them was $3.45(69 \%)$ in the range of 3.22 to 3.67 .

After analysis by using SPSS, all of the items in the questionnaires are valid with $r_{-}$calculated $>r_{-}$table (0.2542) as of Pearson correlation method (Product Moment) as $N=60, \mathrm{~d} f=60-2=58$ for two-tailed of significant at least at $95 \%$ level $(p<0.05)$ for all of indicators. (Junaidi, no date).

To test reliability of the proposed scales was using the usual threshold level of Cronbach's alpha 0.7 for newly developed measures as (Sugiyono, 2019). In this case, the values for four variables (PA, SN, PBC and EI) were $0.922,0.786,0.922$ and 0.946 . Thus, the theoretically developed scales may be considered as reliable. The results affirmed by (Linan \& Chen, 2011; Priyatno, 2010; Sari, 
2013; Sugiyono, 2007, 2019) which values of Cronbach's Alpha more than 0.6.

The independent (inputs) variables i.e.: $X 1, X 2$ and $X 3$ (together) effects the dependent (output) variable, $Y$ with regression equation as:

$$
Y=-2.158+0.701 X 1+0.350 X 2+0.248 X 3 \text {. (Eq. 1) }
$$

Coefficient correlation (simultaneously) of inputs to output, $R$ is 0.846 . According to the interpretation of the coefficient correlation, $R$ by (Sugiyono, 2007, 2019), the $R$ value 0.846 is fall in the range $0.80-1.000$ so that there is a very strong correlation among inputs to effect output.

The value of $R^{2}$ (coefficient determination) was 0.715 , it means that variation of input variables i.e. Personal Attitude $(X 1)$, Subjective Norm $(X 2)$ and Perceived Behavioral Control $(X 3)$ could explains only $71.5 \%$ the Entrepreneurial Intention $(Y)$ variation. Adjusted $R$ Square were 0.700, with Std. Error of Estimate 2.127.

$\mathrm{F}$-test results show that $\mathrm{F}$ _calculated was 46.854 which is more than F table (2.769) with the level of significant, $=0.05$, means that Personal Attitude $(X 1)$, Subjective Norm $(X 2)$ and Perceived Behavioral Control $(X 3)$ together affect Entrepreneurial Intention $(Y)$.

Because T_calculated through SPSS for every independent variable were more than $T_{-}$table (2.003), means that every input variable partially gives positive effect for output variable.

\section{Discussion and adoption}

The 60-young villagers, in general : graduate from Senior High School, came from Dayurejo Village and Jatiarjo Village, do farming already less than 5 years, have knowledge in farming by themselves but they do farming

\section{REFERENCES:}

1. BADAN PUSAT STATISTIK KABUPATEN PASURUAN BPS - Statistics of Pasuruan Regency (2020) 'Kabupaten Pasuruan Dalam Angka Pasuruan Regency in Figures 2020', (1102001.3514), p. 304. Available at: https://pasuruankab.bps.go.id.

2. Badan Pusat Statistik Provinsi Jawa Timur (2016) STATISTIK PEMUDA PROVINSI JAWA TIMUR 2016.

3. Bappeda (2017) 'Data Dinamis Provinsi Jawa Timur', pp. 1-144.

4. Dan (2016) Arjuno, July 3, 2016. Available at: http://www. gunungbagging.com/arjuno/ (Accessed: 24 May 2020).

5. Dinas pertanian jawa timur (2014) 'Rencana Strategis Satuan Kerja Perangkat Daerah (RENSTRA SKPD)'.

6. Dinas Pertanian Provinsi Jawa Timur (2016) 'PEMERINTAH PROVINSI JAWA TIMUR HORTIKULTURA JAWA TIMUR ISSN - 1412-1352'.

7. Direktorat Riset dan Pengabdian Masyarakat Direktorat Jenderal Riset dan Pengembangan Kementrian Riset, Teknologi, dan P. T. (2019) 'Pengembangan Kompetensi Manajemen dan Orientasi Kewirausahaan dalam Rangka Pemberdayaan (coffee, banana, cassava, avocado, clove and corn) not in their own land. They do not have group work on farming although in the same time they do farm. Their ability to self-learning on farming quite high and they cannot teach other do the same as they do. They have skill on farming from training, but the trainer probably was their parents and or their family member.

The characteristics of the peoples near the Mountain Arjuno especially for the 60 -young villagers in their management competency could be stated as follows: they have average $76 \%$ intellectual competency, emotional competency $71 \%$ and social competency $69 \%$.

The characteristics of the peoples near the Mountain Arjuno especially for the 60 -young villagers in their entrepreneurial intention could be stated as the linear regression model (Eq. 1). The equation can be stated as an Entrepreneurial Intention Model for the young villagers based-on data analyzed.

The Eq 1 only based-on the 60 data, and this is as a starting point to generate innovation management for a better future goals that is a must following Sustainable Development Goals in the area (Yulaswati, 2020).

\section{Conclusions}

It was found what is the characteristics of the peoples near the Mountain Arjuno especially for the 60-young villagers in their management competency and their entrepreneurial intention. They have averaged $76 \%$ of intellectual competency, $71 \%$ of emotional competency and $69 \%$ of social competency. The Personal Attitude $(X 1)$, Subjective Norm $(X 2)$ and Perceived Behavioral Control $(X 3)$ together effects the Entrepreneurial Intention $(Y)$ with model regression equation as: $Y=-2.158+0.701 X 1+$ $+0.350 \times 2+0.248 \times 3$.

Kelompok Petani dan Pemuda Pedesaan Di Jawa Timur'. doi: 1a633551-34df-4b0e-9528-2b4d251bf984.

8. Gunung_Arjuno (316AD). Available at: https:// id.wikipedia.org/wiki/Gunung_Arjuno.

9. Guresci, E. (2015) 'Farming in the Forests of Black Sea Coastal; Case Study of Black Sea Region in Turkey', Procedia Economics and Finance. Elsevier B.V., 23(October 2014), pp. 628-629. doi: 10.1016/s2212-5671(15)00360-3.

10. Hertanto, E. (2017) 'Teori Kompetensi Manajemen Sumber Daya Manusia', Manajemen Sumber Daya Manusia, (November), pp. 1-7.

11. Junaidi (no date) Tabel $r$ (Koefisien Korelasi Sederhana), Art \&Photos. Available at: https://www.slideshare.net/ hendrayudha9028/19-tabelnilaikritisrpearson.

12. Kec. Prigen (no date). Available at: https://www. google.com/maps/place/Kec.+Prigen,+Pasuruan, + Jawa+Ti mur/@-7.6906302,112.5678194,12z/data=!3m1!4b1!4m5!3 $\mathrm{m} 4$ ! 1s0x2dd7d7ec1e43e171:0xb5cb192d43f3ae3d!8m2!3d$7.6965985 ! 4 \mathrm{~d} 112.6437026$. 
13. Linan, F. and Chen, Y.-W. (2011) 'Development and Cross-Cultural Application of a Specific Instrument to Measure Entrepreneurial Intentions', Development Dialogue, (56), pp. 35-39.

14. NGalamediaLABS (2013) Taman Hutan Raya Raden Soeryo, 12th October 2013. Available at: http://ngalam.id/ read/1362/taman-hutan-raya-raden-soeryo/ (Accessed: 24 May 2020).

15. Nugroho, M. (2018) 'Bab 2. Kajian Pustaka', in $P R O-$ POSAL DISERTASI. Malang: PROGRAM DOKTOR KAJIAN LINGKUNGAN DAN PEMBANGUNAN PROGRAM PASCASARJANA UNIVERSITAS BRAWIJAYA MALANG 2018.

16. Nugroho, M. et al. (2019) 'Forest Vegetation Profile for Springs Preservation in Arjuna Mount, East Java-Indonesia', American Journal of Agriculture and Forestry, 7(6), pp. 290296. doi: 10.11648/j.ajaf.20190706.17.

17. PEMERINTAH PROVINSI JAWA TI (2015) 'RENCANA KINERJA TAHUNAN (RKT) DINAS PERTANIAN PROVINSI JAWA TIMUR TAHUN 2015'.

18. Pengertian Kompetensi Manajemen SDM (no date). Available at: https://ilmumanajemenindustri.com/pengertiankompetensi-competency-dalam- $\% 09$ manajemen-sdm/ diakses 2019. date).

19. 'peta-jalur-pendakian-gunung-arjuno-welirang.pdf' (no
20. Priyatno, D. (2010) Paham Analisa Statistik Data dengan SPSS. MediaKom, Yogyakarta, Indonesia.

21. Purba, L. and Hermanto, Y. (2020) KOMPETENSI MANAJEMEN DAN ORIENTASI KEWIRAUSAHAAN PEMUDA DI PEDESAAN LERENG GUNUNG ARJUNA JAWA TIMUR. Surabaya.

22. Sari, E. T. (2013) 'Entrepreneurial Intention among Employees', Jurnal Entrepreneur dan Entrepreneurship, 3, pp. 39-48.

23. Siswanto, W. (2017) 'Conservation Area Management in Indonesia', p. 24. Available at: http://www.forclime.org.

24. Spencer, J. L. M. and Spencer, S. M. (1993) Competence at Work: Models for Superior Performance. 1st edn. New Jersey: John Wiley \& Sons, Inc.

25. Sugiyono (2007) Metode Penelitian Bisnis. Bandung: CV. Alfabeta.

26. Sugiyono (2019) Metode Penelitian \& Pengembangan (Research and Development/ $R \& D$ ). Edited by S. Suryandari. Bandung: ALFABETA, CV.

27. SustainAbility (2020) 'What' s next for sustainable business? Trends 2020'.

28. Yudohartono, T. P. (2008) 'Peranan Taman Hutan Raya Dalam Konservasi Sumberdaya Genetik : Peluang Dan Tantangannya', Informasi Teknis, 6(2), pp. 1-6.

29. Yulaswati, V. (2020) 'SDGs IMPLEMENTATION IN INDONESIA'.

\section{СВЕДЕНИЯ ОБ АВТОРАХ / Information about authors:}

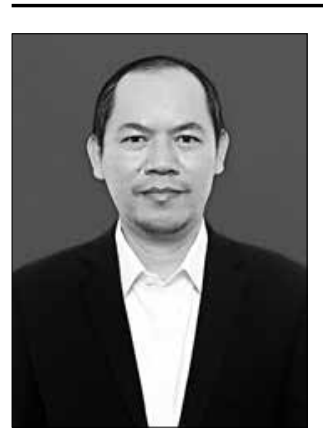

Lasman Parulian PURBA is a permanent Lecturer of Engineering Faculty of Darma Cendika Catholic University. He also served as Head of the Center for Sustainable Development Studies besides Head of the Business Incubator University of Catholic Darma Cendika. He was awarded a full scholarship to take a Master of Engineering Degree from Thai Government namely The NRCT-JSPS (National Research Council of Thailand - Japan Society for the Promotion of Science) Joint Research Program from Prince of Songkla University Thailand (PSU Hat Yai Campus) in 2006. His bachelor of engineer (graduated: 2000) was from Sepuluh Nopember Institute of Technology Surabaya (ITS Surabaya). He is an Asst. Professor since 1st April 2006. He also awarded as Senior Professional Engineer (Certification Number: 2-07-00-000814-00) from The Instution of Engineers, Indonesia (BKTI-PII).

Industrial Engineering Department, Darma Cendika Catholic University, Surabaya, Indonesia

J1. Dr. Ir. H. Soekarno No. 201, Surabaya, 60117, East Java, Indonesia.

E-mail: lasman.parulian@ukdc.ac.id

ORCiD ID: 0000-0002-2318-6181

SCOPUS ID: 55217749800

Ласман Парулиан ПУРБА - профессор Католического университета Дарма Чендика. Он занимал должность руководителя Центра исследований устойчивого развития, а также руководителя бизнес-инкубатора Католического университета Дарма Чендика. Был награжден полной стипендией для получения степени магистра инженерных наук от правительства Тайланда, а именно совместной исследовательской программой NRCT-JSPS (Национальный исследовательский Совет Тайланда - Японское общество по продвижению науки) от Университета принца Сонгкла Таиланда (PSU Hat Yai Campus) в 2006 году.

Католический Университет Дарма Чендика, Сурабая, Индонезия.

e-mail: lasman.parulian@ukdc.ac.id

ORCID: 0000-0002-2318-6181

SCOPUS ID: 55217749800 


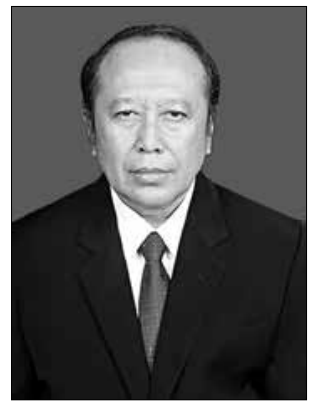

Yustinus Budi HERMANTO is a permanent Lecturer of Economic Faculty of Darma Cendika Catholic University. He also served as Rector of the Darma Cendika Catholic University and a Pastor. He is an Asst. Professor.

Management Department, Darma Cendika Catholic University, Surabaya, Indonesia

J1. Dr. Ir. H. Soekarno No. 201, Surabaya, 60117, East Java, Indonesia.

ORCID: 0000-0002-4117-5750

Юстинус Буди ХЕРМАНТО - профессор Католического университета Дарма Чендика. Он занимал пост ректора университета Дарма Чендика (Darma Cendika Catholic University) и пастора. Является доцентом кафедры менеджмента Католического университета Дарма Чендика, Сурабая, Индонезия.

ORCID: 0000-0002-4117-5750

\author{
Ласман Парулиан Пурба $\mathbf{1}^{*}$, \\ Юстинус Буди Херманто ${ }^{1}$ \\ ${ }^{1}$ Католический университет Дарма Чендика, Сурабая, Индонезия, \\ lasman.parulian@ukdc.ac.id

\section{DOI: $10.21177 / 1998-4502-2020-12-4-516-522$} \\ Наш интерес заключается в том, чтобы изучить ха- \\ рактеристики молодых сельских жителей, которые жи- \\ вут на склоне горы Арджуна, провинция Восточная Ява \\ в Индонезии, в рамках существующей управленческой \\ компетентности и существующих предпринимательских \\ намерений.
}

УПРАВЛЕНЧЕСКАЯ КОМПЕТЕНТНОСТЬ

И ПРЕДПРИНИМАТЕЛЬСКИЕ НАМЕРЕНИЯ МОЛОДЫХ СЕЛЬЧАН, ПРОЖИВАЮЩИХ НА СКЛОНЕ г. АРДЖУН (ВОСТОЧНАЯ ЯВА, ИНДОНЕЗИЯ)
Ключевые слова: системный инжиниринг; промышленный менеджмент; моделирование; устойчивое развитие; принятие решений.

Статья поступила в редакијию 30.09.2020. 


\section{ИЗМЕНЧИВОСТЬ ЗИМНИХ ЭКСТРЕМАЛЬНЫХ НИЗКИХ ТЕМПЕРАТУР ПРИЗЕМНОГО СЛОЯ ВОЗДУХА В БАССЕЙНЕ ОЗЕРА СЕВАН (АрМеНИЯ)}

\author{
Маргарян В. Г.', \\ Ереванский государственный университет, Ереван, Армения, \\ vmargaryan@ysu.am
}

\section{Введение}

Чрезмерно важна роль термического режима, так как он является залогом здоровья человека и стабильного развития экономики [1]. Температура воздуха является одной из важнейших характеристик состояния атмосферы, одной из звеньев глобальной климатической системы [2]. Экстремальные значения метеорологических величин показывают границы их естественной изменчивости и в значительной мере определяют степень воздействия погоды и климата на жизнедеятельность людей, их социальное и экономическое состояния. Суровый климат определяет высокую стоимость многих инвестиционных проектов, которая обусловлена внушительными финансовыми затратами на строительство в условиях значительных перепадов температур, промерзания грунта, более высокого прожиточного минимума людей, издержек на отопление, эксплуатационных расходов на поддержание объектов инфраструктуры и производства. Воздействие низких температур ведет и к негативным последствиям для организма человека [3].

Возрастающий интерес к изучению изменений экстремальности климата и развитию подходов прослеживается в оценочных докладах МГЭИК [4], в многочисленных научных публикациях [5-7].

Бассейн озера Севан - один из богатейших и уникальных районов Республики Армения по рекреационным ресурсам. Озеро Севан - стратегическое хранилище пресных вод Республики Армения. В результате длительного и интенсивного использования вековых запасов воды озера значительно снизился его уровень воды, что привело к резким изменениям природных условий озера и всего его бассейна, к нарушению экологического баланса. Выявилась проблема Севана, крупнейшая проблема Армении, основной смысл которой заключается в рациональном использовании водных ресурсов озера и бассейна, сохранении состояния озера по возможности близкому к естественному, в комплексном решении проблем экологического нарушенного баланса и восстановлении качества воды.

Начиная с 1934 г. по 2002 г. уровень озера значительно снизился (18.5 м): с 1915.56 м на 1896 м. За 2002-2018 гг. уровень озера поднялся на 3 м: на 18.09.2019 г. уровень озера составлял $1900.61 \mathrm{м.}$

Таким образом, в результате векового использования водных ресурсов (объем воды сократился на 44 \% от первоначальных запасов, а площадь акватории - на 180 кв. км), что полностью изменило гидрологический, термодинамический, ледовый, химический и биологический режимы водоема, нарушило равновесие прибрежных экосистем и гидрологический режим устьевых участков притоков, произошли значительные негативные изменения в климате.

Цель работы - проанализировать и оценить закономерности изменчивости пространственного распределения зимних экстремальных низких температур (абсолютных минимальных температур) приземного слоя воздуха бассейна, самого важного водного объекта для Армении (озера Севан), выявить и оценить их временные изменения в ряде многолетних данных.

\section{УДК: 911.2:551.58 DOI: 10.21171/1998-4502-2020- 12-4-523-531}

В результате анализа величин экстремальных низких температур приземного слоя атмосферного воздуха горных mерриторий Армении (на примере бассейна озера Севан) можно отметить, что на рассматриваемых территориях генезис зимних экстремальных низких температур различен. Зимние экстремальные низкие температуры выделяются своим неравномерным распределением колеблются в пределах om $-26,3{ }^{\circ} \mathrm{C}$ do $-38,1^{\circ} \mathrm{C}$. Для расчета зимних экстремальных низких температур воздуха не изученных или мало изученных территорий получены корреляционные зависимости между величиной экстремальных низких температур и высотой местности над уровнем моря. На изучаемой территории преимущественно наблюдается тенденция повышения зимних экстремальных низких mемператур.

\section{КЛЮЧЕВЫЕ СЛОВА:}

бассейн озера Севан, зимние экстремальные низкие температуры воздуха, абсолютные минимумы, пространственновременная изменчивость распределения, тренд, статистические характеристики.

Статья поступила в редакцию 15.07.2020. 


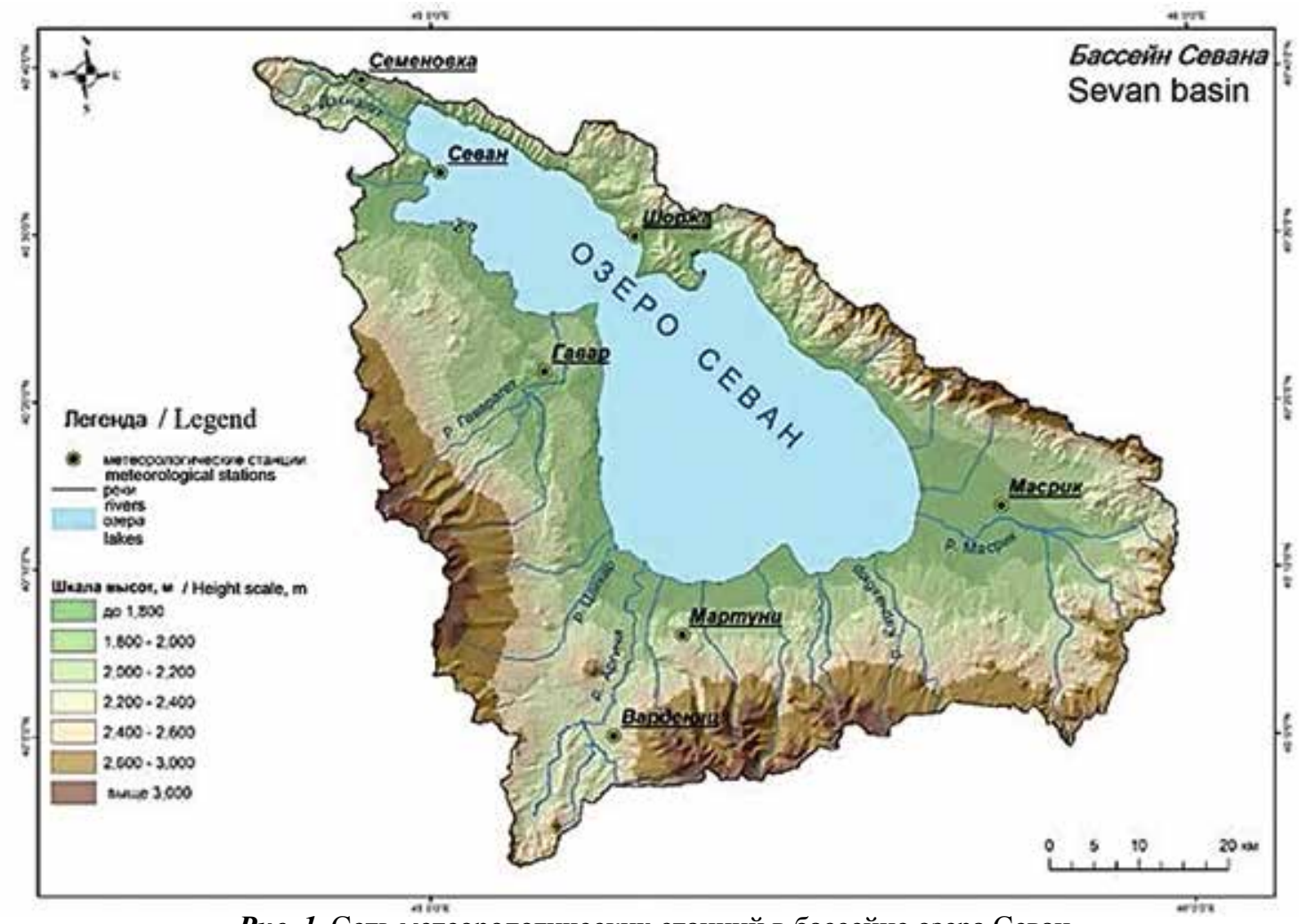

Puc. 1. Сеть метеорологических станций в бассейне озера Севан

Fig. 1. Network of meteorological stations in the basin Sevan Lake

\section{Материалы и методы исследования}

В качестве исходного материала использованы фактические наблюдения за абсолютной минимальной температурой воздуха на метеорологических станциях изучаемой территории (табл. 1, рис. 1), имеющих длинный ряд наблюдений (данные «Центра гидрометеорологии и мониторинга» ГНКО Министерства окружающей среды Республики Армения). На территории бассейна озера Севан в разные годы действовали более 41 метеорологической станции и поста. По состоянию на 1 января 2019 года здесь действуют 7 метеорологических станций, данные которых стали основой для выполнения исследований. Метеостанция Варденяц с 1995 года работает только в теплое время года. Однако учтено, что он является высокогорной станцией. В качестве определителя использованы также данные высокогорных метеорологических станций республики Амберд и Арагац, в/г, а также метеостанция Ератумбер, несмотря на то, что последний закрыт с середины 1988 года.

В качестве методологической основы применены математическо-статистический, экстраполяционный, аналитичесий, корреляционный, картографический методы.

\section{Характеристики метеорологических станций бассейна озера Севан} Characteristics of meteorological stations in the Sevan lake basin

\begin{tabular}{|l|c|c|c|c|}
\hline $\begin{array}{c}\text { Метеостанция } \\
\text { Meteorological station }\end{array}$ & $\begin{array}{c}\boldsymbol{\varphi}^{\circ} \text { (геогр. широта) } \\
\text { Geographic latitude }\end{array}$ & $\begin{array}{c}\lambda^{\circ} \text { (геогр. долгота) } \\
\text { Geographic longitude }\end{array}$ & $\begin{array}{c}\text { Высота, м } \\
\text { Height, } m\end{array}$ & $\begin{array}{c}\text { Годы наблюдений } \\
\text { Observation period }\end{array}$ \\
\hline $\begin{array}{l}\text { Семеновка } \\
\text { Semуопоvka }\end{array}$ & $40^{\circ} 39^{\prime}$ & $44^{\circ} 54^{\prime}$ & 2104 & $1927-2018$ \\
\hline $\begin{array}{l}\text { Севан } \\
\text { Sevan }\end{array}$ & $40^{\circ} 34^{\prime}$ & $45^{\circ} 00^{\prime}$ & 1917 & $1927-2018$ \\
\hline $\begin{array}{l}\text { Шоржа } \\
\text { Shorzha }\end{array}$ & $40^{\circ} 30^{\prime}$ & $45^{\circ} 16^{\prime}$ & 1917 & $1927-2018$ \\
\hline $\begin{array}{l}\text { Гавар } \\
\text { Gavar }\end{array}$ & $40^{\circ} 21^{\prime}$ & $45^{\circ} 08^{\prime}$ & 1961 & $1891-2018$ \\
\hline $\begin{array}{l}\text { Масрик } \\
\text { Masrik }\end{array}$ & $40^{\circ} 14^{\prime}$ & $45^{\circ} 45^{\prime}$ & 1940 & $1927-2018$ \\
\hline $\begin{array}{l}\text { Мартуни } \\
\text { Martuni }\end{array}$ & $40^{\circ} 08^{\prime}$ & $45^{\circ} 18^{\prime}$ & 1943 & $1927-2018$ \\
\hline $\begin{array}{l}\text { Варденяц } \\
\text { Vardenуаts }\end{array}$ & $40^{\circ} 00^{\prime}$ & $45^{\circ} 14^{\prime}$ & 2334 & $1929-2018$ \\
\hline
\end{tabular}




\section{Обсуждение результатов исследований}

На режим минимальной температуры воздуха в большей степени, чем на среднюю месячную температуру оказывают влияние особенности местоположения метеорологической станции: форма рельефа, ширина и направление долин, условия стока холодного воздуха, площадь воздухосбора, инверсии, близость больших водоемов, микроклиматические особенности подстилающей поверхности и т.д. [1]. В результате их влияния на небольшом расстоянии изучаемой территории формируются резко отличающиеся друг от друга микроклиматы, формируется сложное термическое поле, изучение которого становится более сложным и в то же время требует более подробных наблюдений и анализов. Многолетние значения зимних экстремально низких температур воздуха за период 1935-2019 гг. колеблются в пределах от $-26.3^{\circ} \mathrm{C}$ до $-38.1^{\circ} \mathrm{C}$ (табл. 2). Низкие температуры преимущественно наблюдаются в котловинных долинах (например, в Гаваре $\left.--33.0^{\circ} \mathrm{C}\right)$, а также на равнинах, окруженных горами, имеющих крутые склоны (например, в Масрике $\left.--38.1^{\circ} \mathrm{C}\right)$. Сравнительно более высокие значения температур наблюдаются в северо-западных частях бассейна (Семеновка - $\left.-26.3^{\circ} \mathrm{C}\right)$. В целом зимние минимальные температуры воздуха на рассмотренной территории могут опуститься от $-32.0^{\circ} \mathrm{C}$ один раз в 10 лет, от $-35.3^{\circ} \mathrm{C}$ - один раз в 100 лет (табл. 3).

В бассейне озера Севан экстремальные низкие температуры воздуха, обусловленные водной поверхностью озера, в отличие от других районов республики, в основном наблюдаются в феврале. Озеро, расходуя скрытые запасы тепла, уже не оказывает ощутимого смягчающего влияния на окружающую среду. Вдобавок к этому и понижение уровня озера на 18.5 м. Экстремальные низкие температуры воздуха наблюдаются также в январе, а в суровые зимы в отдельных районах бассейна - редко и в марте.

На изучаемой территории, в том числе и в Армении, под воздействием барических полей Скандинавского антициклона, антициклона Кара, Сибирского антициклона и местного антициклона, формируются сильные морозы. Зимой 1972 г. на территории Арме- нии наблюдались три случая воздействия Скандинавского антициклона. В январе и феврале на территории Армении наблюдался очень низкий термический режим [8]. В том году 1 февраля температура в Масрике понизилась до $-38.1^{\circ} \mathrm{C}$, в Гаваре и Мартуни - до $-31.0^{\circ} \mathrm{C}$. Именно в это время было зарегистрировано абсолютное минимальное значение приземного слоя воздуха изучаемой территории (Масрик, $-38.1^{\circ} \mathrm{C}$ ).

Отметим, что в связи с физико-географическими условиями (рельеф, расчлененность местности, экспозиция склонов и крутизна, высота над уровнем моря), терморадиационным режимом, локальной циркуляцией атмосферы критерии суровости морозов в разных местах республики разные: $-20.0^{\circ} \mathrm{C}$ и ниже - в долинных районах, $-32.0^{\circ} \mathrm{C}$ и ниже - в предгорных районах, $-35.0{ }^{\circ} \mathrm{C}$ и ниже - в горных районах.

Анализ наблюдений Армгидромета показал, что на изучаемой территории за последние 8-9 десятилетий экстремально холодные зимы наблюдались в 1947 , 1950, 1954, 1967, 1971-1973, 1982, 1985, 1990 годах. В большинстве метеорологических станций (за исключением Гавара, Варденяца) в ряде многолетних наблюдений в 1972 г. зарегистрирована абсолютная минимальная температура.

Как закономерность, с высотой температура воздуха понижается. Однако в бассейне озера Севан зимой на дне котловин температура более низкая, чем в более высоких местах (рис. 2). Так, на метеорологической станции Масрик (1940 м), которая находится на 160 м ниже, чем метеостанция Семеновка (2104 м) и на 400 м ниже станции Варденяц (2334 м), зарегистрированы более низкие величины экстремальных минимальных температур воздуха, чем в соседних районах, вследствие инверсии. Согласно корреляционной связи между зимней экстремальной низкой температурой воздуха приземного слоя и высотой местности выделены два района - высоты до 2000-2100 м и выше. Метеостанция Масрик не подчиняется этой закономерности. Причина в том, что метеостанция Масрик находится на низменной части одноименной местности, и с горных склонов в сторону котловины дует холодный воздух и скапливается, что все более и

Таблица 2 / Table 2

Значения экстремальных низких температур воздуха $\left({ }^{\circ} \mathrm{C}\right)$ в бассейне озера Севан

Values of extreme low air temperatures in the Sevan lake basin $\left({ }^{\circ} \mathrm{C}\right)$

\begin{tabular}{|c|c|c|c|c|c|c|c|}
\hline \multirow[b]{2}{*}{$\begin{array}{c}\text { Месяцы } \\
\text { Months }\end{array}$} & \multicolumn{7}{|c|}{ Метеорологические станции / Meteorological station } \\
\hline & $\begin{array}{l}\text { Семеновка } \\
\text { Semyonovka }\end{array}$ & $\begin{array}{c}\text { Севан } \\
\text { Sevan }\end{array}$ & $\begin{array}{l}\text { Шоржа } \\
\text { Shorzha }\end{array}$ & $\begin{array}{l}\text { Гавар } \\
\text { Gavar }\end{array}$ & $\begin{array}{c}\text { Масрик } \\
\text { Masrik }\end{array}$ & $\begin{array}{c}\text { Мартуни } \\
\text { Martuni }\end{array}$ & $\begin{array}{l}\text { Варденяц } \\
\text { Vardenyats }\end{array}$ \\
\hline I & -24.8 & -24.8 & -27.0 & -33.0 & -35.1 & -28.4 & -30.0 \\
\hline II & -26.3 & -32.5 & -31.8 & -32.7 & -38.1 & -31.7 & -29.2 \\
\hline III & -24.1 & -27.6 & -26.5 & -30.9 & -34.8 & -27.4 & -26.8 \\
\hline $\mathrm{XI}$ & -20.3 & -15.0 & -13.4 & -27.2 & -25.6 & -16.6 & -22.7 \\
\hline XII & -21.7 & -16.6 & -24.0 & -29.6 & -29.2 & -21.0 & -26.2 \\
\hline Год/Year & -26.3 & -32.5 & -31.8 & -33.0 & -38.1 & -31.7 & -30.0 \\
\hline
\end{tabular}


более усиливает морозы. Здесь в холодное время года очень часто наблюдается температурная инверсия, что нередко повторяется также в других котловинных местах бассейна Севан. Вертикальный градиент зимней экстремальной минимальной температуры воздуха

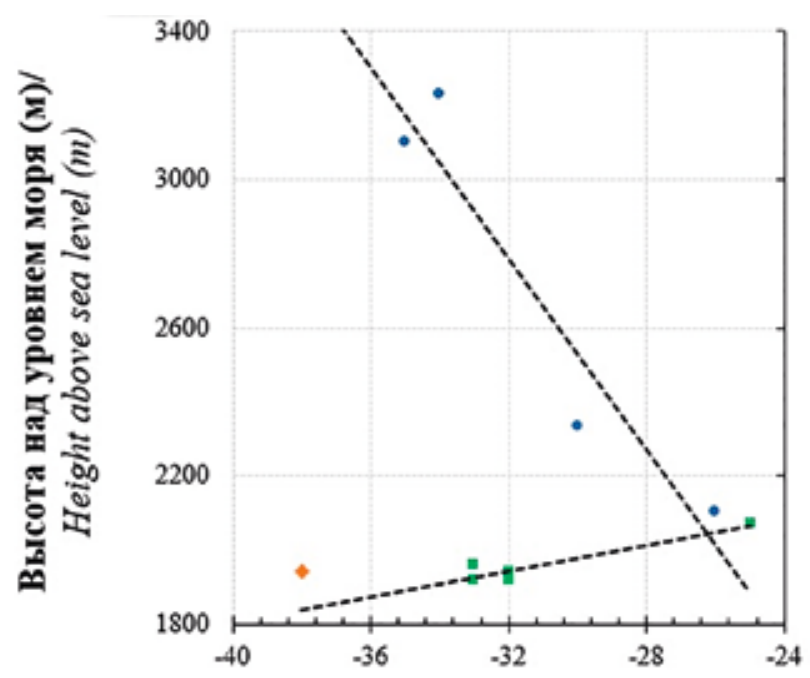

Экстремальная низкая температура

$\left({ }^{\circ} \mathrm{C}\right) /$ Extreme low temperatures $\left({ }^{\circ} \mathrm{C}\right)$

$\boldsymbol{P u c .}$ 2. Зависимость между зимней экстремальной низкой температурой воздуха и высотой местности $\left({ }^{\circ} \mathrm{C}\right)$ на территории бассейна озера Севан

Fig. 2. The relationship between the extreme low winter temperatures and the altitude of the area in the lake Sevan basin

Обозначения на рисунке / The symbols in the figure are:

- Метеорологические станции Севан озерная, Шоржа, Гавар, Мартуни, Семеновка и Амберд. Корреляционную связь можно выразить следующим равенством: $t_{\min }=$ $(h-2616) / 20.9$, где $t_{\min }-$ значения зимних экстремальных низких температур воздуха этих станций, а $h$ - абсолютная высота местности. Коэффициент корреляции составил 0,94.

Sevan lacustrine, Shorja, Gavar, Martuni, Semenovka, Amberd meteorological stations. The correlation can be expressed by the following equality: $t_{\min }=(h-2616) / 20.9$, wheret $t_{\text {min }}$ are the values of the winter extreme low air temperatures of these stations, and $h$ is the absolute height of the area. The correlation coefficient was 0.94 .

- Метеорологические станции Семеновка, Варденяц, Ератумбер, Амберд и Арагац в/г. Корреляционную связь можно выразить следующим равенством: $t_{\min }=$ $(h+964.7) / 118$. Коэффициент корреляции равен 0.96 .

Semenovka, Vardenyats, Eratumber, Amberd and Aragats $h / m$ meteorological stations. The correlation can be expressed by the following equality: $t_{\text {min }}=(h+964.7) / 118$. The correlation coefficient is 0.96 .

- Метеорологическая станция Масрик. Не установлена корреляционная связь. По нашему мнению это объясняется тем, что в Масрике наблюдалось самое низкое значение зимних экстремальных минимальных температур воздуха $\left(-38.1^{\circ} \mathrm{C}\right)$. С другой стороны, выделение метеорологической станции Масрик обусловлено также локальными факторами и особенностями рельефа.

Masrik meteorological station. No correlation has been established. In our opinion, this is explained by the fact that the lowest values of winter extreme minimum air temperatures $(-38.1 \mathrm{C})$ were observed in Masrik. On the other hand, the allocation of Masrik meteorological station is also due to local factors and features of the relief. в нижней зоне составляет $-0,5{ }^{\circ} \mathrm{C} / 100$ м, а в верхней зоне составляет $-0,8^{\circ} \mathrm{C} / 100 \mathrm{M}$.

На основе полученных связей составлена карта пространственного распределения абсолютных минимальных температур бассейна озера Севан (рис. 3). Эту карту можно использовать для изучения режима экстремальных низких температур воздуха неизученных и мало изученных районов обсуждаемой территории.

В работе рассмотрены временной ход и тренды зимних экстремальных низких температур воздуха для бассейна озера за период 1935-2019 гг. с оценкой их значимости (табл. 4, рис. 4), т.е. получены выводы об основной тенденции наблюдаемых изменений зимних экстремальных низких температур.

Для наглядности на рис. 4 показаны графики временного хода зимних экстремальных низких температур воздуха, на которые нанесены линии трендов. В бассейне озера Севан согласно данным фактических наблюдений метеостанций зимние экстремальные низкие температуры преимущественно проявляют тенденцию роста. Такие закономерности характерны как для республики Армения [1-2; 9-10], так и для других территорий планеты [11-16]. В большинстве регионов России отмечается уменьшение числа повторяемости экстремально морозных дней [15]. Уменьшение количества экстремально холодных дней отмечается также в Латвии [17-18]. Тренды числа зимних дней с экстремальными температурами незначимы в причерноморском регионе [5]. Безморозный период существенно уменьшился на востоке, северной и центральной части европейской части России [19]. А анализ межгодового хода количества экстремальных событий по данным наблюдений показал, что за период 1979-2016 гг. наблюдается рост количества дней с низкими зимними температурами $\left(T<-30^{\circ} \mathrm{C}\right)$ для всей территории Западной Сибири в целом. Наиболее часто понижение температуры воздуха до $-30^{\circ} \mathrm{C}$ и ниже отмечается на севере западной Сибири (до 50 дней в 2010 году), а наименее часто - в Томской области (до 12 дней в 2010 году) [20; 21].

Изменения тренда температуры воздуха представлены тремя линиями: за период 1935-1966 гг., 19671992 гг. и 1993-2019 гг. (рис. 4). Видно, что на всех метеорологических станциях бассейна озера Севан тренд зимних экстремальных низких температур за период 1967-1992 гг. и 1993-2019 гг. положителен, а отрицательный - за период 1935-1966 гг. на метеостанциях Севан, Масрик и Мартуни. Скорость изменения зимних экстремальных низких температур за период 1935-1966 гг. составляет от $-0,572{ }^{\circ} \mathrm{C} / 10$ лет до $+1,465$ ${ }^{\circ} \mathrm{C} / 10$ лет; за период $1967-1992$ гг. - от $+0,018^{\circ} \mathrm{C} / 10$ лет до $+1,629^{\circ} \mathrm{C} / 10$ лет; за период 1993-2019 гг. - от +0,601 ${ }^{\circ} \mathrm{C} / 10$ лет до $+0,965^{\circ} \mathrm{C} / 10$ лет. На изучаемой территории с 1967 г. по 1992 г. зимние экстремальные низкие температуы повысились на 0,05-4,24 ${ }^{\circ} \mathrm{C}$, а с 1993 по 2019 г. - на $1,62-2,61{ }^{\circ} \mathrm{C}$ (табл. 4). Значительный рост температур $\left(4,69^{\circ} \mathrm{C}\right)$ наблюдается в Гаваре. 
Экстремальные низкие температуры воздуха $\left({ }^{\circ} \mathrm{C}\right)$ различной вероятности Extreme low air temperatures $\left({ }^{\circ} \mathrm{C}\right)$ of various probabilities

\begin{tabular}{|c|c|c|c|c|c|c|c|c|c|}
\hline \multirow[t]{2}{*}{$\begin{array}{c}\text { Станция } \\
\text { Station }\end{array}$} & \multirow{2}{*}{$\begin{array}{l}\text { Средний } \\
\text { из абсолютных } \\
\text { минимумов } \\
\text { Average of absolute } \\
\text { minimums }\end{array}$} & \multicolumn{6}{|c|}{$\begin{array}{c}\text { Вероятность экстремальной низкой температуры } \\
\text { ниже указанных пределов (\%) } \\
\text { The probability of extreme low temperatures below the } \\
\text { specified limits (\%) }\end{array}$} & \multicolumn{2}{|c|}{$\begin{array}{c}\text { Абсолютный } \\
\text { минимум } \\
\text { Absolute minimum }\end{array}$} \\
\hline & & 1 & 10 & 50 & 90 & 95 & 99 & ${ }^{\circ} \mathrm{C}$ & год / year \\
\hline $\begin{array}{l}\text { Севан } \\
\text { Sevan } \\
\end{array}$ & -16.8 & -7.70 & -11.8 & -16.9 & -21.9 & -23.3 & -26.0 & -32.5 & 1972 \\
\hline $\begin{array}{l}\text { Гавар } \\
\text { Gavar }\end{array}$ & -25.3 & - & -20.9 & -25.5 & -29.0 & -30.9 & - & -33.0 & 1950 \\
\hline $\begin{array}{c}\text { Масрик } \\
\text { Masrik }\end{array}$ & -27.8 & -20.3 & -23.7 & -27.8 & -32.0 & -33.1 & -35.3 & -38.1 & 1972 \\
\hline $\begin{array}{c}\text { Мартуни } \\
\text { Martuni }\end{array}$ & -19.3 & -10.0 & -14.2 & -19.3 & -24.3 & -25.8 & -28.5 & -31.7 & 1972 \\
\hline
\end{tabular}

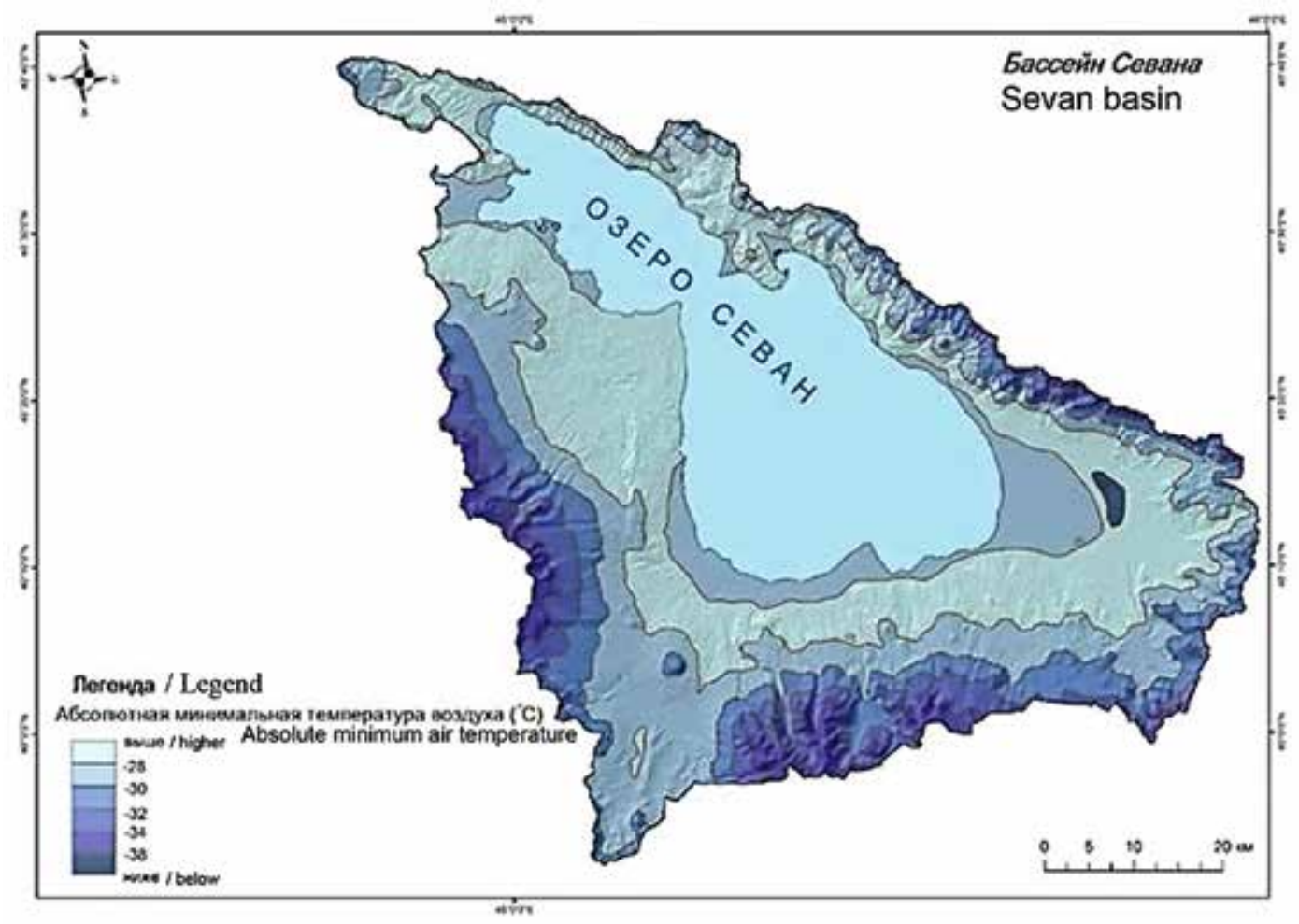

Puc. 3. Пространственное распределение абсолютных минимальных температур воздуха в бассейне озера Севан

Fig. 3. Spatial distribution of absolute minimum air temperatures in the lake Sevan basin

Анализируя полученные зависимости, можно отметить, что для рассматриваемых территорий наблюдается закономерное повышение зимних экстремальных низких температур. Эта закономерная динамика свидетельствует о том, что на изучаемой территории зимние условия становятся термически более мягкими. Учитывая, что рассматриваются горные регионы, построены зависимости исследуемой величины от абсолютной высоты местности. С характером подстилающей поверхности и особенностями рельефа выделены две зависимости, которые носят линейный характер и подтверждаются значимыми коэффициентами корреляции. До высот 2000-2100 м с увели- чением высоты повышаются зимние экстремальные низкие температуры, а на высотах выше 2000-2100 м - наоборот. Наличие подобных зависимостей открывает перспективы дальнейших исследований по разработке региональных методик определения зимних экстремальных низких температур в не изученных районах.

Научная новизна полученных результатов заключается в том, что в современных материалах наблюдений впервые оценены закономерности изменчивости пространственно-временного распределения зимних экстремальных низких температур приземного слоя воздуха бассейна озера Севан. 
Статистические характеристики зимний экстремальный низкий температур

Statistical characteristics of winter extreme low temperatures

\begin{tabular}{|c|c|c|c|c|}
\hline \multirow[b]{2}{*}{$\begin{array}{l}\text { Периоды } \\
\text { Periods }\end{array}$} & \multicolumn{4}{|c|}{ Статистические характеристики / Statistical characteristics } \\
\hline & $\begin{array}{c}\text { скорость изменения } \\
\text { температуры }\left({ }^{\circ} \mathbf{C} / \mathbf{1 0} \text { лет }\right) \\
\text { rate of change of temperature } \\
\left({ }^{\circ} \mathrm{C} / 10 \text { years }\right)\end{array}$ & $\begin{array}{l}\text { изменения } \\
\text { температуры, }{ }^{\circ} \mathbf{C} \\
\text { temperature } \\
\text { changes, }{ }^{\circ} \mathrm{C}\end{array}$ & $\begin{array}{c}\text { среднеквад } \\
\text { ратическая } \\
\text { погрешность } \\
\text { root mean square error }\end{array}$ & $\begin{array}{c}\text { коэффициент } \\
\text { вариации } \\
\text { coefficient } \\
\text { variations }\end{array}$ \\
\hline \multicolumn{5}{|c|}{ Севан / Sevan } \\
\hline 1935-1966 & -0.497 & -1.6 & 3.6 & 0.22 \\
\hline 1967-1992 & +0.690 & +1.8 & 4.6 & 0.26 \\
\hline 1993-2019 & +0.965 & +2.6 & 2.3 & 0.16 \\
\hline \multicolumn{5}{|c|}{ Гавар / Gavar } \\
\hline 1935-1966 & +1.465 & +4.7 & 3.5 & 0.13 \\
\hline $1967-1992$ & +1.629 & +4.2 & 3.3 & 0.13 \\
\hline 1993-2019 & +0.601 & +1.6 & 2.6 & 0.12 \\
\hline \multicolumn{5}{|c|}{ Масрик / Masrik } \\
\hline 1935-1966 & -0.362 & -1.2 & 2.4 & 0.08 \\
\hline 1967-1992 & +0.832 & +2.2 & 3.3 & 0.11 \\
\hline 1993-2019 & +0.789 & +2.1 & 2.7 & 0.11 \\
\hline \multicolumn{5}{|c|}{ Мартуни / Martuni } \\
\hline 1935-1966 & -0.572 & -1.8 & 4.0 & 0.21 \\
\hline $1967-1992$ & +0.018 & +0.0 & 4.4 & 0.22 \\
\hline 1993-2019 & +0.915 & +2.5 & 2.2 & 0.13 \\
\hline
\end{tabular}
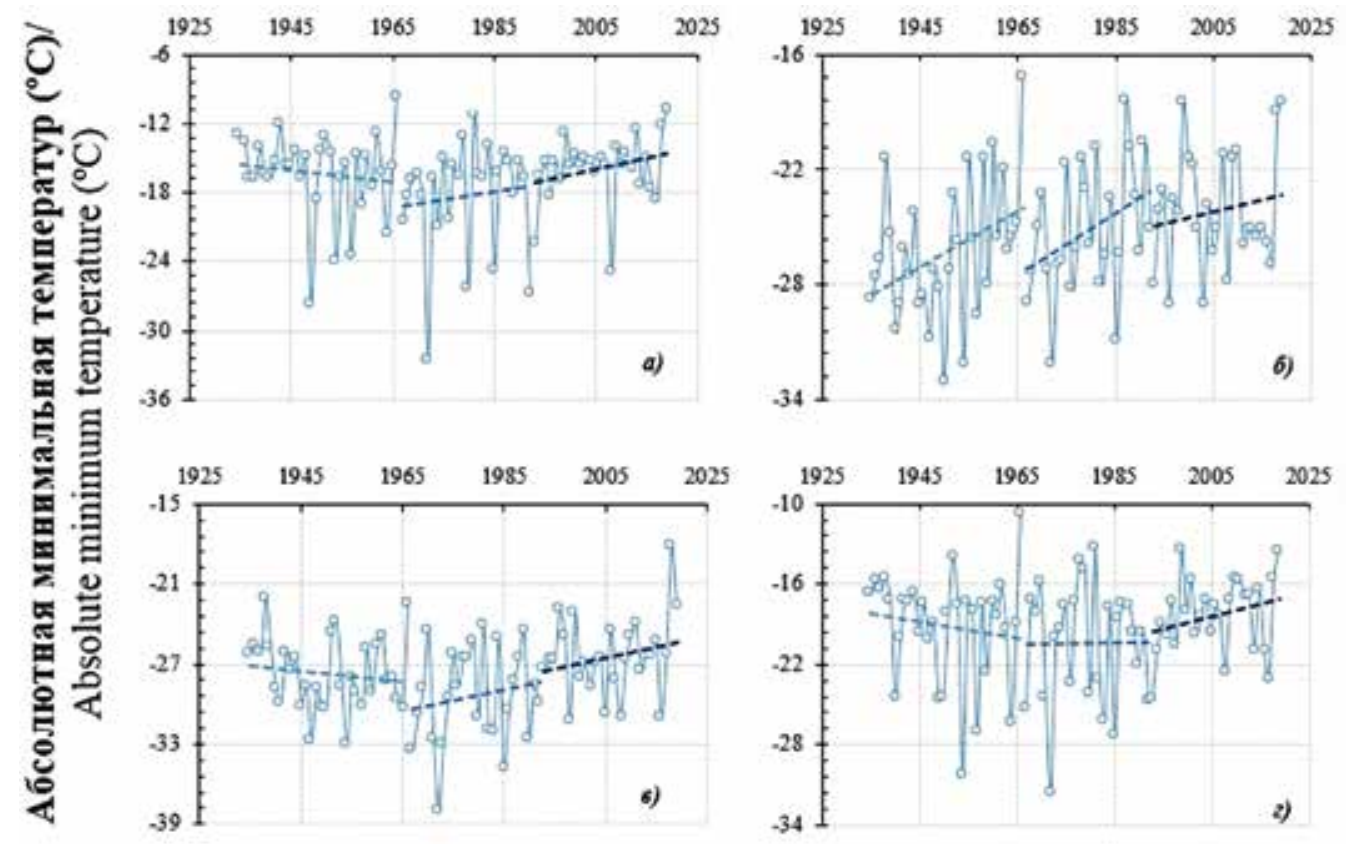

\section{Годы/ Years}

Puc. 4. Временной ход абсолютной минимальной температуры воздуха: $a$ - Севан; $\sigma$ - Гавар; в- Масрик; 2 -Мартуни

Fig. 4. Time course of the absolute minimum air temperature: $a$-Sevan; 6 - Gavar; 6 -Masrik; 2 -Martuni

Заключение

Изучение закономерностей изменчивости пространственно-временного распределения зимних экстремальных низких температур приземного слоя воздуха в условиях региональных и глобальных изменений климата является актуальной задачей современной географической науки.

Зимние экстремальные низкие температуры воз- 
духа преимущественно обусловлены характером подстилающей поверхности и особенностями рельефа. Наименьшие значения наблюдаются не в высокогорных зонах, а в тех местах, где происходит скопление холодного воздуха (то есть, в котловинах). Зимой в котловинных долинах в основном наблюдается инверсия - параллельно с высотой повышается температура воздуха. В долинах в результате накопления холодного воздуха довольно-таки длительное время могут наблюдаться низкие температурные условия.

Изучаемая территория выделяется характерным режимом и неравномерным пространственным распределением зимних экстремальных низких температур. Последние меняются в пределах от $-26,3{ }^{\circ} \mathrm{C}(\mathrm{Ce}-$ меновка) до -38,1 ${ }^{\circ} \mathrm{C}$ (Масрик);

До 2000-2100 м с высотой повышаются зимние экстремальные низкие температуры, а на высотах выше 2000-2100 м - наоборот, понижаются. Вертикальный градиент температур соответственно составляет $-0,5^{\circ} \mathrm{C} / 100$ м и $0,8^{\circ} \mathrm{C} / 100$ м.

На основе полученной корреляционной связи между зимними экстремальными низкими температурами и высотами местности выделены два района: 1) высоты до 2000-2100 м и 2) 2000-2100 м и выше.

Временные тенденции в ходе многолетних зимних

\section{ЛИТЕРАТУРА:}

1. Маргарян В. Г. Тренды изменения экстремальных температур приземного слоя воздуха в пределах Араратской равнины и ее предгорной зоны // Вестник Московского университета, Серия 5. География. 2019. N 2. С. 103-107.

2. Маргарян В. Г., Самвелян Н. И. Закономерности пространственно-временного изменения экстремальных температур приземного слоя атмосферы и их воздействие на ландшафтную структуру Араратской котловины // Вестник ВГУ. Серия: География. Геоэкология. 2019. N4. С. 15-22.

3. Кочугова Е. А. Изменчивость зимних минимальных температур воздуха в Предбайкалье // Известия Иркутского государственного университета. Серия «Науки о Земле». 2015. T. 13. C. $98-110$.

4. IPCC 2013. Climate Change. The Physical Science Basis. Contribution of Working Group I to the Fifth Assessment Report of the Intergovernmental Panel on Climate Change / Stocker, T. F., D. Qin, G.-K. Plattner, M. Tignor, S. K. Allen, J. Boschung, A. Nauels, Y. Xia, V. Bex and P.M. Midgley (eds.). Cambridge University Press, Cambridge, United Kingdom and New York, NY, USA. 2013. 1535 p.

5. Коваленко О. Ю., Бардин М. Ю., Воскресенская Е. Н. Изменения характеристик экстремальности температуры воздуха в Причерноморском регионе и их изменчивость в связи с крупномасштабными климатическими процессами межгодового масштаба // Фундаментальная и прикладная климатология. 2017. Т. 2. С. 42-62.

6. Domonkos P., Kysely J., Riotrowicz K., Petrovic P., Likso T. Variability of extreme temperature events in south-central Europe during the 20th century and its relationship with large scale circulation // International Journal of Climatology. 2003. No. 23. Pp. 987 - 1010. экстремальных низких температур носят неоднозначный характер. На изучаемой территории наблюдается преобладание положительных трендов. Отрицательные тренды характерны за период 1935-1966 гг. метеостанциям Севан, Масрик и Мартуни.

На изучаемой территории зимние условия становятся термически более мягкими, что должно быть учтено при разработке стратегических программ перспективного развития данной территории.

\section{Выводы}

В результате анализа величин экстремальных низких температур приземного слоя атмосферного воздуха горных территорий Армении (на примере бассейна озера Севан) можно отметить, что на рассматриваемых территориях генезис зимних экстремальных низких температур различен. Зимние экстремальные низкие температуры выделяются своим неравномерным распределением - колеблются в пределах от $-26.3^{\circ} \mathrm{C}$ до $-38.1^{\circ} \mathrm{C}$.

Для расчета зимних экстремальных низких температур воздуха не изученных или мало изученных территорий получены корреляционные зависимости между величиной экстремальных низких температур и высотой местности над уровнем моря. На изучаемой территории преимущественно наблюдается тенденция повышения зимних экстремальных низких температур.

7. Easterling D.R., Meehl G.A., Parmesan C., Changnon S.A., Karl T.R., Mearns L.O. Climate Extremes: Observations, Modeling, and Impacts. // Science. 2000. Vol. 289. Issue 5487. Pp. 2068-2074. DOI: 10.1126/science.289.5487.2068

8. Суренян Г. Г. Синоптический анализ барических полей, формирующих погодно-климатические условия Республики Армения: Диссертация на соискание ученой степени канд. географических наук. Ереван, 2010. С. 145. (На армянском яз.).

9. Margaryan V. G. Assessment of climatic trend of air temperature at the earth surface in the context of stable development (case of Gyumri city) // Visnyk of V. N. Karazin Kharkiv National University. Series: Geology. Geography. Ecology. 2019. No. 50. Pp. 125-135.

10. Margaryan V. G., Simonyan L. M. Estimation of dynamics change of average and extreme annual values of atmospheric air temperature of ground layer of Gyumri // ICUC9 - 9th International Conference on Urban Climate jointly with 12th Symposium on the Urban Environment. Toulouse, July 20-24, 2015.

11. Андрейчик М. Ф., Монгуш Л. Д.-Н. Динамика экстремумов температуры воздуха на фоне потепления в УлугХемской котловине Республики Тыва // Вестник КрасГАУ. 2013. N 8. C. 94-96.

12. Ашабоков Б. А., Ташилова А. А., Кешева Л. А., Теунова Н. В., Таубекова 3. А. Климатические изменения средних значений и экстремумов приповерхностной температуры воздуха на юге европейской территории России // Фундаментальная и прикладная климатология. 2017. Т. 1. С. 5-19. 
13. Перова М. В., Подрезов О. А. Режим температуры воздуха в холодное полугодие и климатические параметры отопительного периода на территории Северного, Северозападного Кыргызстана. Бишкек: Изд-во КРСУ. 2013. 181 с.

14. Подрезов О. А., Подрезов А. О. Современное потепление климата Северного и Северо-западного Кыргызстана в поле абсолютных минимальных температур // Вестник КРСУ. 2018. Т. 18. N 4. C. 180-187.

15. Титкова Т. Б., Черенкова Е. А., Семенов В. А. Региональные особенности изменения зимних экстремальных температур и осадков на территории России в 1970-2015 гг. // Лёд и Снег. 2018. Т. 58. N 4. С. 486-497.

16. Мешик О. П., Рыжковская И. А Экстремальные температуры воздуха на территории Беларуси // Вестник Брестского государственного технического университета. 2015. N2. C. 84-91.

17. Avotniece Z., Klavins M., Rodinovs V. Changes of Extreme Climate Events in Latvia // Environmental and Climate
Technologies. 2012. No. 9. Pp. 4-11.

18. Avotniece Z., Rodinov V., Lizuma L., Briede A., Kḷavin̦š $\mathrm{M}$. Trends in the frequency of extreme climate events in Latvia // Baltica. 2010. Vol. 23. No. 2. Pp. 135-148.

19. Shmakin A.B. and Popova V.V. Dynamics of climate extremes in northern Eurasia in the late 20th century // Izvestiya, Atmospheric and Oceanic Physics. 2006. Vol. 42, No. 2. Pp. $138-147$.

20. Харюткина Е.В., Логинов С.В., Усова Е.И., Мартынова Ю.В., Пустовалов К.Н. Тенденции изменения экстремальности климата Западной Сибири в конце XX - начале XXI веков // Фундаментальная и прикладная климатология. 2019. T. 2. C. $45-65$.

21. Клюев Р. В., Босиков И. И., Майер А. В., Гаврина О. А. Комплексный анализ применения эффективных технологий для повышения устойчивого развития природно-технической системы // Устойчивое развитие горных территорий. 2020. N2. C. 283-290.

\section{СВЕДЕНИЯ ОБ АВТОРЕ / Information about author:}

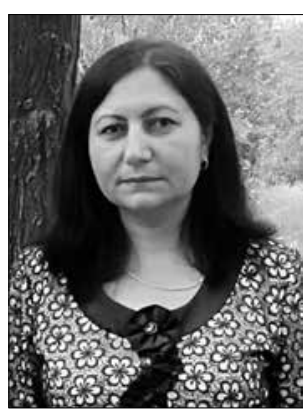

МАРГАРЯН Вардуи Гургеновна - кандидат географических наук, доцент. Факультет географии и геологии, кафедра физической географии. Ереванский государственный университет.

0025, Ереван, Республика Армения.

e-mail: vmargaryan@ysu.am

Vardui G. MARGARYAN - Candidate of Geographical Sciences, Associate Professor. Faculty of Geography and Geology. Chair of Physical Geography. Yerevan State University. Yerevan, 0025, Republic of Armenia.

e-mail:vmargaryan@ysu.am

\section{VARIABILITY OF WINTER EXTREME LOW TEMPERATURES OF THE SURFACE AIR LAYER IN THE LAKE SEVAN BASIN (ARMENIA) \\ V. G. Margaryan \\ Yerevan State University, Yerevan, Armenia,}

DOI: $10.21177 / 1998-4502-2020-12-4-523-531$

The purpose of this work to study, analyze and evaluate the patterns of spatial variability of long-term fluctuations in winter extreme low temperatures of the surface layer of atmospheric air in mountainous territories of Armenia (for example, the lake Sevan basin). To achieve this goal, the results of actual observations by Armhydromet and the available literary sources have been collected, processed and analyzed.

As a result of the analysis of the values of extreme low temperatures, it can be noted that the genesis of winter extreme low temperatures is different in the territories under consideration. Winter extreme low temperatures stand out for their uneven distribution - they range from -26.3 to -38.1 . For the calculation of winter extreme low air temperatures of unexplored or poorly studied territories, correlations were obtained between the value of extreme low temperatures and the altitude of the area above sea level. In the study area, a tendency towards an increase in winter extreme low temperatures is mainly observed.

The scientific novelty of the obtained results lies in the fact that in modern observational materials, for the first time, the regularities of the variability of the spatio-temporal distri- bution of winter extreme low temperatures of the surface air layer in the lake Sevan basin are estimated.

\section{Findings}

- The study of the patterns of variability of the spatial-temporal distribution of winter extreme low temperatures of the surface air layer under conditions of regional and global climate change is an urgent task of modern geographical science;

- Winter extreme low air temperatures are mainly due to the nature of the underlying surface and the features of the relief. The smallest values are observed not in high-altitude zones, but in those places where cold air accumulates (that is, in depressions). In winter, in the hollow valleys, an inversion is mainly observed- in parallel with the height, the air temperature rises. In valleys, as a result of the accumulation of cold air, low temperature conditions can be observed for quite a long time;

- The study area is distinguished by a characteristic regime and an uneven spatial distribution of winter extreme low temperatures. They range from -26.3 (Semenovka) to -38.1(Masrik).

-Winter extreme low temperatures rise up to $2000-2100 \mathrm{~m}$ 
with altitude, and on the contrary, they decrease at altitudes above $2000-2100 \mathrm{~m}$. The vertical temperature gradient is $-0.5 \mathrm{C} / 100 \mathrm{~m}$ and $0.8 \mathrm{C} / 100 \mathrm{~m}$, respectively;

- On the basis of the obtained correlation between winter extreme low temperatures and terrain heights, two regions were identified: 1) heights up to $2000-2100 \mathrm{~m}$ and 2) 2000$2100 \mathrm{~m}$ and higher;

- Temporal trends during perennial winter extreme low temperatures are mixed. In the study area, these is a predominance of positive trends. Negative trends are characteristic for the period 1935-1966 at the Sevan, Masrik and Martuni meteorological stations;

- In the study area, winter conditions become thermally milder, which should be taken into account when developing strategic programs for the future development of this area.

Keywords: Lake Sevan basin, winter extreme low air temperatures, absolute minimum, spatio-temporal variability of distribution, trend, statistical characteristics.

\section{References:}

1. Margaryan V. G. "Trends of extreme temperatures of the surface air layer within the Ararat plain and its foothill zone", Moscow University Bulletin. Series 5. Geography, 2019, no. 2, pp. 103-107. (In Russian).

2. Margaryan V. G., Samvelyan N. I. "The regularities of spatial and temporal change of extremal temperatures of earth layer of atmosphere and its influence on the environment Ararat valley hollow", Vestnik Voronezskogo Gosudarstvennogo Universiteta. Seria Geografia. Geoekologia, 2019, no. 4, pp. 15-22. (In Russian).

3. Kochugova E. A. "Variability of winter minimum temperatures at Predbaikalie", Bulletin of Irkutsk State University, series “Earth Sciences”, 2015, vol. 13, pp. 98-110. (In Russian).

4. IPCC 2013. Climate Change. The Physical Science Basis. Contribution of Working Group I to the Fifth Assessment Report of the Intergovernmental Panel on Climate Change / Stocker, T.F., D. Qin, G.-K. Plattner, M. Tignor, S.K. Allen, J. Boschung, A. Nauels, Y. Xia, V. Bex and P.M. Midgley (eds.). Cambridge University Press, Cambridge, United Kingdom and New York, NY, USA. 2013, 1535 p.

5. Kovalenko O.Yu., Bardin M.Yu., Voskresenskaya E. $\mathrm{N}$. "C hanges in characteristics of air temperature extremes over the black sea region and their variability assosiated with interannual large-scale climatic processes", Fundamental and Applied Climatology, 2017, vol. 2, pp. 42-62. (In Russian).

6. Domonkos P., Kysely J., Riotrowicz K., Petrovic P., Likso T. "Variability of extreme temperature events in south-central Europe during the 20th century and its relationship with large scale circulation", International Journal of Climatology, 2003, no. 23, pp. 987-1010.

7. Easterling D. R., Meehl G. A., Parmesan C., Changnon S. A., Karl T. R., Mearns L. O. "Climate Extremes: Observations, Modeling, and Impacts”, Science, 2000, vol. 289, issue 5487, pp. 2068-2074. doi: 10.1126/science.289.5487.2068

8. Surenyan G. G. Synoptic analysis of baric fields forming the climatic conditions of the Republic of Armenia. Ph.D. Thesis, Erevan, 2010, p. 145. (In Armenian).

9. Margaryan V. G. "Assessment of climatic trend of air temperature at the earth surface in the context of stable devel- opment (case of Gyumri city)", Visnyk of V.N. Karazin Kharkiv National University, series "Geology. Geography. Ecology", 2019, no. 50, pp. 125-135.

10. Margaryan V. G., Simonyan L. M. Estimation of dynamics change of average and extreme annual values of atmospheric air temperature of ground layer of Gyumri. ICUC9 - 9th International Conference on Urban Climate jointly with 12th Symposium on the Urban Environment. Toulouse, July 20-24, 2015.

11. Andreychik M. F., Mongush L. D.-N. "Air temperature extrema dynamics on the background of climate warming in Ulug-Khem basin of the Tyva Republic", Bulletin of Kras$G A U, 2013$, no 8, pp. 94-96. (In Russian).

12. Ashabokov B. A., Tashilova A. A., Kesheva L. A., Teunova N. V., Taubekova Z. A. "Climatic changes of mean and extreme values of surface air temperature in the south of European Russia", Fundamental and Applied Climatology, 2017, vol. 1, pp. 5-19. (In Russian).

13. Perova M. V., Podrezov O. A. The air temperature mode in the cold half-year and climatic parameters of the heating period in the territory of northern and north-western Kyrgyzstan, Bishkek, Publishing House of KRSU, 2013, 181 p. (In Russian).

14. Podrezov O. A., Podrezov A. O. "Modern climate warming of the Northern and North-western Kyrgyzstan in the field of the absolute minimum temperatures", Bulletin of KRSU, vol. 18, no. 4, pp. 180-187. (In Russian).

15. Titkova T. B., Cherenkova E. A., Semenov V. A. "Regional features of changes in winter extreme temperatures and precipitation in Russia in 1970-2015", Ice and Snow, 2018, vol. 58 no. 4, pp. 486-497. (In Russian).

16. Meshik O. P., Ryzhkovskaya I. A. "Extremal temperatures of air on the territory of Belarus", Bulletin of the Brest State Technical University, 2015, no. 2, pp. 84-91. (In Russian).

17. Avotniece Z., Klavins M., Rodinovs V. "Changes of Extreme Climate Events in Latvia", Environmental and Climate Technologies, 2012, no. 9, pp. 4-11.

18. Avotniece Z., Rodinov V., Lizuma L., Briede A., Kḷavinš M. "Trends in the frequency of extreme climate events in Latvia", Baltica, 2010, vol. 23, no. 2, pp. 135-148.

19. Shmakin A.B. and Popova V.V. "Dynamics of climate extremes in northern Eurasia in the late 20th century", Izvestiya, Atmospheric and Oceanic Physics, 2006, vol. 42, no. 2, pp. 138-147.

20. Kharyutkina E.V., Loginov S.V., Usova E.I., Martynova Yu.V., Pustovalov K. N. "Tendencies in changes of climate extremality in Western Siberia at the end of the XX century and the beginning of the XXI century", Fundamental and Applied Climatology, 2019, vol. 2, pp. 45-65. (In Russian).

21. Klyuev R. V., Bosikov I. I., Mayer A. V., Gavrina O. A. Comprehensive analysis of the effective technologies application to increase sustainable development of the natural-technical system, Sustainable Development of Mountain Territories, 2020, no.2, pp. 283-290.

Article received 15.07.2020 
УДК: 581.9(470.67)

DOI: 10.21177/1998-4502-202012-4-532-541

Изучены эндемики ксерофильной фолоры различных районов Российского Кавказа, смежных и отдаленных территорий (Западное Средиземноморье, Кавказ, Большой Кавказ, Закавказье, Малая и Передняя Азия, Восточное Средиземноморье, Понтическая область, Палеарктика), с целью выявления их видового состава, генетических связей между ними, необходимых для решения вопросов флорогенеза. Проанализированы результаты многолетних флористических исследований в разных территориях Кавказа, публикации по фолоре этих, примыкающих к ним и отчужденных территорий. Использованы методы исторической реконструкции, морфологоэколого-географического анализа, включая метод эволюционных рядов, а также метод флорогенетического анализа и синтеза. Информация о генетических и географических связях обсуждаемых таксонов получена путем анализа положения вида в системе рода (в случае монотипных родов - положения в системе семейства), что позволило выявить ближайших родственников, определить их географическую локализацию, предположить время и направления миграционных потоков анцестральных видов.

\section{КЛЮЧЕВЫЕ СЛОВА:}

Северный Кавказ, эндемик, неоэндемик, палеоэндемик, флора, ксерофиты.

Статья поступила в редакцию 08.05.2020.

\section{КСЕРОФИЛЬНЫЕ ЭНДЕМЫ ФЛОРЫ РОССИЙСКОГО КАВКАЗА И ИХ РОДСТВЕННЫЕ СВЯЗИ}

Тайсумов М.А. ${ }^{*}$,

Магомадова Р.C. ${ }^{2}$,

Астамирова М. А-М.' ${ }^{2}$,

Умаров М.У. ${ }^{3}$

'Институт природных ресурсов Академии наук Чеченской Республики. 364024,

г. Грозный, Чеченская Республика, Россия, musa_taisumov@mail.ru

гЧеченский государственный педагогический университет,

364031 , г. Грозный, Чеченская Республика, Россия

${ }^{3}$ Академия наук Чеченской Республики. 364024, г. Грозный, Чеченская Республика, Россия

\section{Введение}

В основе решения проблемы исторического развития флоры, её флорогенеза лежит всесторонний флористический анализ [1], который даёт основу для теоретических построений, выражающихся в постановке вопросов о времени и путях миграции анцестральных видов. Изучаемая флора имеет свою особую историю, связанную с особенностями экологии. Её становление проходило в условиях дефицита влаги во внешней среде, и действие этого фактора вызвало целый веер направлений адаптивной эволюции, по которым формировались различные группы ксерофитов, что отражается в их современной классификации. Эти процессы связаны с изменениями физико-географической среды, в первую очередь климата и рельефа, проходившими не только в пределах изучаемой территории, но и в целом в Палеарктике, что становилось движущей силой видообразования и пространственного перемещения как отдельных видов, так и целых флористических комплексов в составе палеофитоценозов.

Эндемичные виды обладают уникальным генофондом, и его сохранение имеет в связи с этим особо значение. Кроме того, полезные свойства большинства эндемиков практически не изучены и перспективы использования их в утилитарных целях не исследованы. Эта категория видов, наравне с реликтами, информативна в плане получения данных об исторических изменениях флоры не только региональной, но и сопредельных и отдалённых флор, и с этой точки зрения сохранение эндемичных видов имеет ещё и теоретическое значение.

История биоты свидетельствует о том, что виды существуют во времени определённый промежуток, затем вымирают, что является естественным процессом. Такие виды есть в составе любой флоры, обычно это реликты и палеоэндемики, имеющие ограниченный ареал. Исчезновение таких видов значительно ускоряется антропогенным воздействием через разрушение естественных местообитаний при строительстве или освоении новых земель для сельскохозяйственных нужд, а также путём массового изъятия растений в виде лекарственного сырья или поедания домашними животными при выпасе, в ряде случаев - при обрыве на букеты населением. Среди ксерофитов флоры Российского Кавказа, насчитывающей 1018 видов, к категории охраняемых относятся 368 видов $(36,1 \%)$, но ещё немалое их число также нуждается в охране.

Ксерофильная флора Российского Кавказа относится к разряду «оригинальных» как носитель неповторимого генофонда, насыщенного эндемичными видами. В составе этой флоры выделяются высокогорные комплексы, характеризующиеся приуроченностью к каменистым субстратам, отличающиеся уникальным флористическим составом. 
Богатая по систематическому составу и оригинальная ксерофильная флора Кавказа издавна привлекала внимание многих исследователей ботанического профиля, большей частью флористов и систематиков.

История её изучения, насчитывающая более 300 лет, связана с именами известных зарубежных [3-17] и отечественных [1; 18-22] исследователей, занимавшихся разносторонним её анализом, в том числе в различных природно-промышленных системах.

Во флоре ксерофитов Российского Кавказа насчитывается 162 эндемичных вида, большинство из которых относятся к категории локальных эндемиков, распространение которых ограничено иногда одним ущельем или горным массивом, или ареал находится в пределах одного флористического района. Остальные виды - эвриэндемики с более широкими ареалами в пределах изучаемой территории. Для установления их родственных связей нами исследована категория эуксерофитов наиболее ярко выраженной группы изучаемой флоры. Таких видов насчитывается 83, ниже обозначены их наиболее вероятные родственные связи.

\section{Объект и методы исследования}

Ксерофиты - это часть биологического разнообразия, особая группа растений, сформировавшаяся в результате адаптивной эволюции под действием одного из важнейших экологических факторов внешней среды - дефицита влаги. Этот фактор вызвал целый веер адаптаций, следствием которых явилось появление большого разнообразия приспособительных анатомо-морфологических структур и физиологических особенностей среди систематически разных групп видов, которые позволили переносить неблагоприятные условия дефицита влаги во внешней среде от почти полного пересыхания и впадения в анабиоз до крайне короткого сокращения вегетационного периода в онтогенезе. Эти виды в настоящее время составляют около четверти флоры Российского Кавказа. Одной из нерешенных до конца проблем является история формирования флоры ксерофитов на этой территории.

При решении этой проблемы нами обращено внимание на состав и пространственное распределение эндемичных ксерофильных видов флоры Российского Кавказа, относящихся к категории систематических реликтов, а также установление их родственных связей.

Основные методы исследования - метод исторической реконструкции, метод морфолого-эколого-географического анализа, включая метод эволюционных рядов, а также метод флорогенетического анализа и синтеза [18]. Информация о генетических и географических связях обсуждаемых таксонов получена путем анализа положения вида в системе рода (в случае монотипных родов - положения в системе семейства), что позволило выявить ближайших родственников и определить их географическую локализацию, предположить время и направления миграци- онных потоков анцестральных видов. Подобная методика была использована при анализе флоры западной части Центрального Кавказа [19], анализе флоры Предкавказья [20].

\section{Результаты исследований и их обсуждение}

Анализ распространения эндемичных видов позволил различать автохтонные (аборигенные) элементы, видообразование которых происходило в определенных локусах северного макросклона Большого Кавказа, и аллохтонные (миграционные) элементы, анцестральные типы которых формировались вне пределов северного макросклона.

Становление последних сочетало миграционные процессы, с одной стороны, и процессы вымирания и сокращения ареалов видов, с другой. По времени происхождения эндемики подразделяются на две группы:

- палеоэндемики, имеющие регрессивные (сокращающиеся), локальные или сильно дизъюнктивные ареалы, далеко отстоящие от распространения близкородственных видов, также, в свою очередь, обитающих на ограниченных территориях;

- неоэндемики, обладающие прогрессивными (расширяющимися) ареалами, во многих случаях относимые к географическим расам.

Эти аналитические данные позволяют проводить флорогенетические построения, в том числе и корректировать имеющиеся модели флорогенеза.

Для выяснения начальных этапов флорогенеза целесообразно рассмотреть филогенетические связи особой категории эндемиков, относящейся к систематическим реликтам, стоящим обособленно в системе родов определенного семейства и не имеющих ближайших родственников на видовом уровне. Сам факт наличия в составе флоры подобного типа эндемиков является следствием длительных эволюционных процессов ее формирования, связанных, в первую очередь, с древними миграциями анцестральных форм, вызванных изменениями климата и палеогеографии в пределах Древнего Средиземья и прилегающих территорий.

1. Agropyron pinifolium Nevski - эндемик южных каменистых склонов Черноморского побережья от Новороссийска до Геленджика, входящий в состав сборного вида A. cristatum (L.) Beauv. s.1., где близок к крымскому A. karadaghense Kotov.

2. Allium gunibicum Miscz. ex Grossh. - эндемик нижнего течения Аварского Койсу; Allium samurense Tscholok., эндемик Южного Дагестана (верховья р.p. Самур и Курах); Allium mirzajevii Tscholokaschvili эндемик Внутригорного Дагестана, низовий рек Андийского и Аварского Койсу. Три близкородственных вида входят в состав секции Oreiprason F. Herm., насчитывающей на Кавказе 7 видов, большинство из которых - кавказские эндемики. Близки к закавказскому эндемику A. albovianum Vved. и дагестанскому эндемику A. daghestanicum Grossh. 
3. Alyssum andinum Rupr. - эндемик Андийского хребта и хр. Салатау; Alyssum daghestanicum Rupr.эндемик Центрального Дагестана. Два близкородственных вида обширной секции Eualyssum Griseb, где их родственниками являются крымский эндемик A. calycocarpum Rupr. и эндемик Восточного Закавказья A. schemachense N. Busch

4. Anthemis markhotensis Fed. - эндемик Маркотхского хребта секции Cota (J.Gay ex Guss.) Rupr. Он близок к восточно-закавказскому эндемику A. saguramica Sosn. и крымскому эндемику A. monantha Willd.

5. Artemisia daghestanica Krasch. et A. Poretzky эндемик Центрального Дагестана. Ряд Dracunculi Pojark., все виды которого отличаются цельными листьями и (за исключением обсуждаемого) обширными ареалами в пределах Евразии, некоторые заходят в Северную Америку. Близок к восточно-азиатскому A. pamirica Winkl. и палеарктическому A. glauca Pall.

6. Asperula dasyantha Klok. - эндемик высокогорий Восточного Кавказа (верховья бассейна р. Ассы); Asperula intersita Klok. - эндемик Западного Кавказа. Представители ряда Cristatae Klok. секции Cynanchica DC., насчитывающего 5 видов кавказских эндемиков. Близки к A. accrescens Klok., эндемику верховий p. Уруп и эукавказскому A. cristata (Somm. et Levier) V. Krecz.

7. Asperula lipskyana V. Krecz. - эвриэндемик, ареал которого состоит из двух частей: Северо-Западное Закавказье, от Новороссийска до Геленджика и ущелье p. Уруп в области Скалистого хребта; A. markothensis Klok. - эндемик хребта Маркотх. Ряд Vestitae Klok. Два близкородственных вида той же секции. Близки к крымским эндемикам $A$. aemulans V. Krecz. и $A$. praevestita Klok.

8. Asphodeline tenuior (Bieb.) Ledeb. - эвриэндемик Пастбищного хребта и лакколитов Кавминвод. Входит в состав секции Asphodeline, насчитывающей на Кавказе 5 видов, где близок к армяно-иранскому эндемику A. tenuiflora (C. Koch) Miscz.

9. Astracantha arnacanthoides (Boriss.) Podlech - эндемик Северо-Западного Закавказья, ареал которого простирается от Новороссийска до Геленджика. Входит в состав тритипного ряда Arnacanthi Boriss. секции Oliganthos Boriss. Близок к армяно-иранскому эндемику A. insigiois (Boriss.) Podlech и крымскому эндемику A. arnacantha (Bieb.) Podlech

10. Astragalus fissularis Alexeenko - эндемик Внутригорного Дагестана. Вместе с двумя близкородственными видами образует тритипный ряд Badamensis Vass. секции Xiphidium Bunge, где родственен тянь-шаньским эндемикам A. badamensis M. Pop. и A. baranovii M. Pop.

11. Campanula ardonensis Fomin - локальный эндемик верховий р. Ардон. Вместе с C. kryophila Rupr. входит в состав дитипного ряда Ardonenses Fed. Родство с представителями кавказских рядов, дитипного Anomalae Fed. (C. anomala Fomin, C. circassica Fomin) и монотипного Besenginacae Fed. (C. besenginica Fomin).

12. Campanula dolomitica E. Busch. - эндемик Скалистого хребта (Балкария, Дигория). Представитель подсекции Cordifoliae (Fomin) Fed., насчитывающей 8 видов, 5 из которых - эукавказские эндемики, остальные - кавказско-малоазиатские виды. Близок к кавказско-малоазиатскому C. alliariifilia Willd. и эукавказскомy C. leskovii Fed.

13. Campanula komarovii Maleev - эндемик СевероЗападного Закавказья (окрестности Новороссийска); Campanula daghestanica Fomin - эндемик Центрального Дагестана - два близкородственных вида дитипного ряда Komarovianae Fed. подсекции Triloculares Boiss., насчитывающей на Кавказе 11 видов, большей частью эндемичных. Близки, с одной стороны, к видам дитипного ряда Caucasicae Charadzae (C. caucasica Bieb., $C$. fedorovii Charadzae), дагестанским эндемикам, с другой - к видам тритипного ряда Longistylosae Fed. (C. schischkinii Kolak. et Sachok., C. longistyla Fomin), западно-закавказским эндемикам.

14. Campanula sommieri Charadzae - эндемик высокогорий центральной части Северного Кавказа (от верховий Б. и М. Зеленчука до верховий Кубани). Относится к ряду Sarmaticae Charadzae подсекции Latilimbus Fed., насчитывающему 6 видов, являющихся эукавказскими эндемиками. Близок к абхазскому эндемику C. calcarea (Albov) Charadzae и эукавказскомy C. sarmatica Ker Gawl.

15. Centaurea pseudotanaitica Galushko - эвриэндемик, ареал которого охватывает Ставропольские высоты, лакколиты Кавминвод (г. Лысая), Терский и Сунженский хребты. От близкого понтического вида C. tanaitica Klok. отличается обёрткой 15-18 мм длиной (а не 16-23) и 10 мм в диаметре (а не 15-18), чёрно-бурыми придатками листочков обёртки (а не бурокоричневыми), ареалом. Входит в ряд Alatae Dobrocz. подсекции Scticticaules Czer., где близок к западно-закавказскому эндемику C. czercessica Dobrocz.

16. Centaurea scripczinskyi A.D. Mikheev - ареал вида охватывает останцовые горы Ставропольской возвышенности и передовые меловые хребты центральной части Северного Кавказа. Его родственниками являются виды ряда Arenariae (Hayek) Dumb., преимущественно понтические;

17. Centaurea vicina Lipsky - локальный эндемик окрестностей Новороссийска. Ряд Ovina Dumb., близок к крымскому эндемику C. koktebelica Klok. и восточно-кавказскому эндемику C. ovina Pall.

18. Cicer balcaricum Galushko - локальный эндемик Приэльбрусья (ущелье р. Баксан). В секции Polycicer M. Рор. Входит в состав пентатипного ряда Flexuosa Lincz., большинство из которых (4 вида) - среднеазиатские эндемики. Родственные связи проявляет с памиро-тянь-шаньским видом C. flexuosum Lipsky и переднеазиатским C. anatolicum Alef.

19. Convolvulus ruprechtii Boiss. - эндемик Центрального Дагестана (бассейна нижнего течения Аварское Косу и Каракойсу). Входит в состав секции Inermia Boiss., насчитывавющей 7 видов, 2 из которых являются крымскими эндемиками, 2 - кавказскими, 1 - евро-сибирский, 1 - сибирско-азиатский и 1 - северо-иранский. Близок к южно-закавказскому C. commutatus Boiss. и северо-иранскому C. calvertii Boiss. 
20. Convolvulus tshegemensis Galushko - локальный эндемик Чегемского ущелья в области Скалистого хребта. Близок к палеарктическому $C$. lineatus $\mathrm{L}$.

21. Dianthus acantholimonoides Schischk. - эндемик Северо-Западного Закавказья (Новороссийск-Геленджик). Представитель дитипного ряда Transcaucasici Schischk. секции Barbulatum Williams, где близок к южно-закавказскому эндемику D. grossheimii Schischk.

22. Draba longisiliqua Schmalh. - эндемик Северного Кавказа с ареалом в пределах Скалистого хребта от ущелья р. Б.Лаба до ущелья р. Аварское Койсу. Тритипный ряд Mollissimae Tolm., где близок к эукавказским субэндемикам D. ossetica (Rupr.) Somm. et Levier и D. molissima Stev.

23. Genista compacta Schischk. - эвриэндемик, pacпространённый в западной части Скалистого хребта и на меловых хребтах окрестностей г. Кисловодска; Genista angustifolia Schischk. - локальный эндемик Скалистого хребта в междуречье рек Белая и Малая Лаба. Два близкородственных вида ряда Albidae Schischk. (секция Voglera (Gaertn.) Reichenb.), насчитывающего 4 вида. Близки к причерноморскому эндемику G. albida Willd. и армяно-курдскому G. armeniaca Spach.

24. Genista lipskyi Novopokr. et Schischk. - локальный эндемик окрестностей городов Новороссийска и Геленждика. Ряд Depressae Schischk. той же секции, близок к восточно-закавказскому эндемику $G$. flagellaris Somm. et Levier и закавказско-малоазиатскоMy G. humifusa L.

25. Genista glaberrima Novopokr. - узколокальный эндемик мыса Мысхако (Новороссийск). Ряд Tetragonae Schischk. той же секции, близок к понтическомy G. tetragona Bess. и западно-закавказскому G. mingrelica Albov.

26. Gypsophila imbricata Rupr. - эндемик Скалистого хребта в ущельях рек Ардон, Фиагдон, Асса, указывается также для Центрального Дагестана. Входит в состав дитипной секции Pulvinares Boiss., где близок к южнозакавказско-ирано-туркменскому G. aretioides Boiss.

27. Gypsophula globulosa Stev. ex Boiss. - предкавказский эвриэндемик, распространённый на Ставропольской возвышенности, лакколитах Кавминвод, окрестностях Краснодара. Секция Capitatae Bieb., близок к юговосточноевропейско-крымскому G. glomerata Pall. и армяно-малолазиатскому G. cappadocica Boiss. et Bal.

28. Haplophyllum ciscaucasicum (Rupr.) Grossh.et Vved. - эвриэндемик, распространённый в основном в области Скалистого хребта от его начала до ущелья p. Малки, заходит также в Северо-Западное Закавказье до г. Новороссийска. Принадлежит к обширной, в основном среднеазиатской секции Oligoon Vved., где близок к южно-закавказскому $H$. tenue Boiss. и дагестано-восточнозакавказско-ирано-малоазиатскому $H$. villosum (Bieb.) G. Don.

29. Hedysarum biebersteinii Zertova - эвариэндемик, распространённый в центральной части Северного Кавказа, включая Ставропольскую возвышенность и лакколиты Кавминвод; H. daghestanicum Rupr. ex Boiss. - эндемик Центрального Дагестана. Представители обширной, в основной среднеазиатской секции Subacaulia Boiss., где близки к армяно-курдскомy $H$. elegans Boiss. et Huet, южно-закавказскому $H$. bordzilovskyi Grossh. и среднеазиатскому H. ferganense Korsh.

30. Jurinea Cass. - группа близкородственных видов секции Neobellae Nemirova, систематически разделённые на три подсекции, в каждой из которых группируются в несколько рядов (монотипные ряды). Подсекция Mamillosa Nemirova: тетратипный ряд близкородственных видов - J. pseudoiljinii Galushko et Nemirova. - эндемик верховий Большой Лабы (река Кислинка); J. iljinii Grossh. - эндемик верховий реки Малый Уруп, г. Ацгара, J. sosnovskyi Grossh. - эндемик ущелья Большой Лабы, прорезающего Скалистый хребет, J. venusta Iljin - эндемик системы Бокового хребта, где берут начало притоки рек Малая Лаба и Теберда. Подсекция Coronopifoliae Nemirova: тритипный ряд Levierana Nemirova - J. prokhanovii Nemirova - эндемик Скалистого хребта, ущелье р. Генальдон; $J$. dolomitica Galushko - эндемик Центрального Кавказа, верховий р. Чегем (окр. с. Верхний Чегем), J. levieri Albov - эндемик Западного Кавказа (города Фишт, Оштен); тритипный ряд Humilae Iljin ex Nemirova -J. akinfievii Nemirova - эндемик Скалистого хребта, ущелье р. Садон, J. coronopifolia Somm. et Levier - эндемик Центрального Кавказа, верховий рек Б. Зеленчук, Кубань, Малка, Баксан, J. filicifolia Boiss. - эндемик высокогорий восточной части Северного Кавказа (от верховий р. Ардон до верховий р. Аварское Койсу); Всего в этой секции насчитывается 16 узколокальных эндемиков Северного Кавказа, и секция в целом является эндемичной северо-кавказской, лишь один вид этой секции имеет ареал, выходящий за пределы этой территории - J. pumila Albov (Центральный Кавказ). Ещё два вида, относящиеся к подсекции Praetermissae (Galushko et Nemirova) Tscherneva, являются закавказскими эндемиками - J. cartaliniana Boiss. (Малый Кавказ), J. praetermissa Galushko et Nemirova (Юго-Восточное Закавказье).

31. Jurinea ruprechtii Boiss. - эндемик Внутригорного Дагестана, входит в состав тритипного ряда Apterae Iljin секции Jurinea Iljin, где близок к восточно-закавказскому J. grossheimii Sosn. и закавказско-иранскому $J$ spectabilis Fisch. et C.A. Mey.

32. Nepeta kubanica Pojark. - эвриэндемик центральной части Северного Кавказа, верховий рек Кубань, Теберда, Кума, Подкумок; Nepeta czegemensis Pojark. стеноэндемик, распространённый в верховьях рек Малка, Баксан, Чегем. Два близкородственных вида эндемичного северо-кавказского ряда Heterodontae Pojark. подсекции Tuberculatae Pojark., где близки к субкавказскому N. cyanea Stev., ареал которого заходит по северному склону в Азербайджан, и дагестанскому эндемику N. biebersteiniana (Trautv.) Pojark.

33. Onobrychis daghestanica Grossh. - эндемик северо-западной части Дагестана (хребты Андийский и Салатау). Входит в группу Macrocarpae Hand.-Mazz. подсекции Vulgatae Hand.-Mazz., насчитывающей 5 
видов, в основном кавказских эндемиков. Близок к общекавказскому O. biebersteinii и центрально-кавказскому $O$. hamata Vass.

34. Onobrychis novopokrovskii Vass. - эндемик восточной части Терско-Сунженской возвышенности и низкогорий в междуречье Терека и Сулака. Ряд Comosae Gross. группы Microcarpae Hand.-Mazz. той же подсекции. Близок к предкавказскому эндемику $O$. dielsii (Sirjaev) Vass. и эндемику горной Туркмении $O$. transcaspica V. Nikit. Остальные виды ряда в основном закавказско-иранские.

35. Polygala sosnowskyi Kem.-Nath. - эвриэндемик, ареал которого охватывает отроги Пастбищного хребта в окрестностях Кисловодска, Скалистый хребет от p. Урух до р. Фортанга, Внутригорный Дагестан. Ряд Sibiricae Kem.-Nath. секции Migratoria Tamamsch. Близок к восточно-европейскому P. rossica Kem.-Nath. и сибирско-дальневосточному P. sibirica L.

36. Psephellus maleevii Sosn. - локальный эндемик Западного Кавказа (верховья р. Курджипс); $P$. czerepanovii Alieva - эндемик Внутригорного Дагестана (ущелье р. Каракойсу); P. salviifolius Boiss. эндемик центральной и восточной частей Северного Кавказа: представители подсекции Hypoleuci Sosn., насчитывающей на Кавказе 7 видов, все они - кавказские эндемики, большей частью эукавказские. Близки к западно-кавказскому эндемику P. circassicus (Albov) Galushko и аджарскому эндемику P. hypoleucus (DC.) Boiss.

37. Psephellus prokhanovii Galushko - эндемик Скалистого хребта, ареал которого простирается от ущелья р. Урух до ущелья р. Ассы. Представитель эндемичной восточно-кавказской секции Schistosi Alieva., где близок к дагестанскому эндемику $P$. alexeenko Alieva и эндемику верховий рек Асса и Фортанга $P$. pseudoandinus Galushko et Alieva.

38. Psephellus ciscaucasicus (Sosn.) Galushko - локальный эндемик Пастбищного хребта с ареалом, расположенным от ущелья р. М. Зеленчук до ущелья p. Малка; P. leucophyllus (Bieb.) С.А. Меу. - эндемик Пастбищного хребта и лакколитов Кавминвод. Подсекция Leucophylli (Sosn.) Mikheev, где близки к крымско-новороссийскому P. declinatus (Bieb.) C. Koch.

39. Rhamnus tortuosa Somm. et Levier - эвриэндемик, ареал которого тянется вдоль Скалистого хребта и Юрской депрессии от ущелья р. Теберды до Внутригорного Дагестана. Ряд Pallasiana Grub. подсекции Principales Grub. близок к малоазиатско-ирано-кавказскому $R$. pallasii Fisch. et C.A. Mey.

40. Saxifraga desoulavy Oetting. - эндемик центральной части Северного Кавказа, S. kuznezowiana Oetting. - эндемик междуречья рек Терек и Ардон, S. columnaris Schmalh. - эндемик Скалистого хребта, ареал которого простирается от ущелья р. Малки до ущелья р. Фортанги, S. dinnikii Schmalh. - эндемик того же хребта, но с меньшим простиранием ареала на восток до ущелья р. Хызны-су, S. carinata Oetting. эндемик ущелья р. Штулу, S. oettingenii Galushko et. G. Kudrjaschova - локальный эндемик ущелья р. Сукан-су в области Скалистого хребта: шесть близкородственных видов преимущественно эукавказской секции
Kabschia Engl., насчитывающей 14 видов, 12 из которых (за исключением переднеазиатского S. kotschyi Boiss. и общекавказского S. juniperifolia Adams) являются эукавказскими эндемиками.

41. Scorzonera filifolia Boiss. - эвриэндемик, pacпространённый на Восточном Кавказе от ущелья р. Терек до верховий р. Самур, а также во Внутригорном Дагестане. Представитель дитипного ряда Filifolia Lipsch. секции Pulvinares (Boiss.) Lipsch., близок к закавказско-малоазиатскому S. seidlitzii Boiss.

42. Scutellaria karatschaica Charadzae - эндемик верховий Кубани и Баксана; $S$. paradoxa Galushko эндемик Южного Приэльбрусья (Баксан, Гижгит); $S$. andina Charadze - эндемик верховий р. Андийское Койсу и S. leptostegia Juz. - эндемик Главного хребта в области Казбека и прилегающих горных массивов: четыре близкородственных вида подсекции Orientales Juz., ряда Tauricae Grossh., насчитывающего 7 видов, 2 из которых - крымские эндемики, остальные - кавказские. Близки к крымско-кавказскому S. tatianae Juz. и эукавказскому эндемику $S$. raddeana Juz.

43. Scutellaria glanulosa Juz. - эндемик Внутригорного Дагестана, низовий рек четырёх Койсу; $S$. novorossica Juz. - эндемик хребтов Навагир и Маркотх; S. polyodon - эндемик Пастбищного и Скалистого хребтов в области Центрального Кавказа: три близкородственных вида, входящие в состав обширного ряда (28 видов) Euplatistegiae Juz. подсекции Orientales Juz., большинство из которых (16 видов) - кавказские эндемики и 3 эндемика Крыма, остальные 6 видов среднеазиатские. Наиболее близкие родственные связи проявляют с эукавказскими S. oreophylla Grossh. и $S$. daghestanica Grossh.

44. Scutellaria raddeana Juz. - эндемик депрессии между Боковым и Скалистым хребтами от ущелья р. Баксан до ущелья р. Аргун. Та же подсекция, но другой ряд - Tauricae Grossh., большинство видов которого - крымские эндемики. Близок к эндемику xp. Маркотх S. tatianae Juz. и эндемику S. leptostegia Juz., ареал которого занимают высокогорья от верховий Терека до верховий Аргуна.

45. Seselialexeenkoi Lipsky-эндемик Внутригорного Дагестана. Входит в состав секции Hippomarathroides DC., насчитывающей 5 видов, два из которых распространены в Европе и Сибири, один - тянь-шаньский эндемик, остальные - кавказские. Близок к евро-сибирскому $S$. ledebourii G. Don и крымско-кавказскому $S$. dichotomum Pall.

46. Sideritis euxina Juz. - эндемик Северо-Западного Закавказья (Анапа-Новороссийск). Входит в состав секции Empedoclea Benth., насчитывающей 7 видов, 6 из которых являются крымскими эндемиками. Близок к крымскому $S$. conifera Juz.

47. Sosnovskya ruprechtii (Boiss.) Takht. - эндемик Внутригорного Дагестана. Схизоэндемик, один их четырёх представителей эндемичного кавказского рода, внутри которого ближе всего к эндемику Закавказья S. amblyolepis (Ledeb.) Takht. и дагестанско-азербайджанскому эндемику $S$. daghestanica (Lipsky) Czer. Четвёртый вид этого рода - S. arpensis Czre., также эндемичный, распространён в Южном Закавказье. Родство 
Таблица 1 / Table 1

Соотношение родственных связей эндемичных эуксерофитов флоры Российского Кавказа

Correlation of family ties of endemic euxerophytes of the flora of the Russian Caucasus

\begin{tabular}{|c|c|c|c|}
\hline $\begin{array}{c}\text { Географическая область } \\
\text { Geographic area }\end{array}$ & $\begin{array}{c}\text { Количество установлен- } \\
\text { ных связей } \\
\text { Number of links established }\end{array}$ & $\begin{array}{c}\text { \% от количества } \\
\text { видов } \\
\% \text { of the number of } \\
\text { species }\end{array}$ & $\begin{array}{c}\text { \% от количества связей } \\
\% \text { of the number of con- } \\
\text { nections }\end{array}$ \\
\hline $\begin{array}{l}\text { Зап. Средиземье (вкл. Крым) } \\
\text { West Middle-earth (incl. Crimea) }\end{array}$ & 15 & 18.1 & 9.6 \\
\hline $\begin{array}{l}\text { Кавказ, в том числе: } \\
\text { Caucasus, including: }\end{array}$ & 57 & 68.7 & 36.5 \\
\hline $\begin{array}{l}\text { Большой Кавказ } \\
\text { Greater Caucasus }\end{array}$ & 41 & 49.4 & 26.3 \\
\hline $\begin{array}{l}\text { Закавказье } \\
\text { Transcaucasia }\end{array}$ & 16 & 19.3 & 10.3 \\
\hline $\begin{array}{l}\text { Малая и Передняя Азия } \\
\text { Asia Minor and Forward }\end{array}$ & 15 & 18.1 & 9.6 \\
\hline $\begin{array}{l}\text { Вост. Средиземье } \\
\text { East Middle-earth }\end{array}$ & 8 & 9.6 & 5.1 \\
\hline $\begin{array}{l}\text { Понтическая область } \\
\text { Pontic area }\end{array}$ & 2 & 2.4 & 1.3 \\
\hline $\begin{array}{l}\text { Палеарктика } \\
\text { Palearctic }\end{array}$ & 2 & 2.4 & 1.3 \\
\hline $\begin{array}{l}\text { Итого } \\
\text { Total }\end{array}$ & 156 & 188 & 100 \\
\hline
\end{tabular}

прослеживается с видами подрода Xanthopsis (DC.) Tzvel. (внутриродовой таксон Centaurea L.), обитающими в Передней Азии и Закавказье.

48. Thymus markhotensis Maleev - эндемик СевероЗападного Закавказья, ареал которого занимает хребты Черноморского побережья от пос. Сукко до Геленджика. Ряд Calleriani Klok. et Schost. секции Verticillati Klok., насчитывающий 16 видов, большей частью крымско-кавказских. Близок к эндемику Восточного Закавказья Th. tiflisiensis Klok. et Shost. и эндемику Крыма Th. littoralis Klok. et Schost.

49. Thymus helendzhikus Klok. et Shost. - эндемик Западного Закавказья (хр. Маркотх от Новороссийска до Геленджика); Th. majkopensis Klok. et Shost. - эндемик высокогорий северной части Западного и Центрального Кавказа. Входят в состав ряда Humilimi Klok. et Schost. секции Subbracteati Klok., насчитывающего 4 вида, два из которых - крымские эндемики. Близки к крымскому Th. tauricus Klok. et Shost.

50. Thymus pseudopulegioides Klok. et Shost. - эвриэндемик, распространённый по Скалистому хребту от ущелья р. Уруп до ущелья р. Андийское Койсу. Представитель ряда Pulegioides Klok. et Shost. (подсекция Goniotrichi Borb.), и является единственным представителем ряда на Кавказе, остальные три вида распространены в Европе. Близок к европейскому $T h$. pulegioides $\mathrm{L}$.

51. Veronica filifolia Lipsky - эндемик Северо-Западного Закавказья (хребты Утриш, Маркотх) - представитель ряда Orientales Wulff, насчитывающего 7 видов, ареалы подавляющего большинства которых (кроме крымского эндемика $V$. taurica Willd.) связаны с территорией Кавказа. Близок к субтуранскому $V$. multifida L. и эндемику Западного Закавказья $V$. denudata Albov.

52. Xanthobrychis majorovii (Grossh.) Galushko эндемичный вид Терско-Сунженской возвышенности и Предгорного Дагестана в бассейне нижнего течения р. Сулак; X. vassilczenkoi (Grossh.) Galushko - центрально-кавказский эндемик, обитающий в среденгорьях от Кубани до Терека, а также в Центральном Предкавказье: два близкородственных вида ряда Vaginales Grossh. рода Xanthobrychis Galushko, pacпространённого в восточной части Древнего Средиземноморья с центром происхождения в Ирано-Анатолии. Близки к восточно-закавказским эндемикам $X$. vaginalis (C.A. Mey.) Galushko и X. kachetica (Boiss. et Buhse) Galushko.

Соотношение родственных связей эуксерофитов флоры Российского Кавказа наглядно представлено в табл. 1 и на диаграммах (рисунок).

Наиболее тесные связи эндемичных эуксерофитов выражены в пределах территории Кавказа, большей частью Большого Кавказа (26,3\%), также значительная часть родственников распространены в Западном Средиземноморье и Передней и Малой Азии (по 9,1\%). Более отдалённые связи выражены слабее $-5,1 \%$ с Восточным Средиземноморьем и незначительный процент (по 1,3\%) с Понтической областью и Палеарктикой. Количество связей и их процент от количества видов (соостветственно 156 и 188) намного больше 
Таблица 2 / Table 2

Локализация ареалов эндемичных эуксерофитов на территории Российского Кавказа

Localization of areas of endemic euxerophytes in the territory of the Russian Caucasus

\begin{tabular}{|c|c|c|}
\hline Локус / Locus & $\begin{array}{l}\text { Количество видов } \\
\text { Number of species }\end{array}$ & $\begin{array}{l}\text { \% от количества видов } \\
\% \text { of the number of species }\end{array}$ \\
\hline $\begin{array}{l}\text { Маркотхский хребет } \\
\text { Markotkh Range }\end{array}$ & 14 & 16.9 \\
\hline $\begin{array}{l}\text { Западный Кавказ, в т.ч.: } \\
\text { Western Caucasus, including: }\end{array}$ & 8 & 9.6 \\
\hline $\begin{array}{l}\text { Скалистый хребет, зап. часть } \\
\text { Rocky ridge, west. part }\end{array}$ & 4 & 4.8 \\
\hline $\begin{array}{l}\text { Высокогорья Западного Кавказа } \\
\text { Highlands of the Western Caucasus }\end{array}$ & 4 & 4.8 \\
\hline $\begin{array}{l}\text { Центральный Кавказ, в т.ч.: } \\
\text { Central Caucasus, including }\end{array}$ & 34 & 41 \\
\hline $\begin{array}{l}\text { Пастбищный хребет и лакколиты КМВ } \\
\text { Pasture Range and laccoliths of Caucasian } \quad \text { Mineral Waters Region }\end{array}$ & 8 & 9.6 \\
\hline $\begin{array}{l}\text { Скалистый хребет, центр. часть } \\
\text { Rocky Range, Center. part }\end{array}$ & 13 & 15.7 \\
\hline $\begin{array}{l}\text { Высокогорья Центрального Кавказа } \\
\text { Highlands of the Central Caucasus }\end{array}$ & 13 & 15.7 \\
\hline $\begin{array}{l}\text { Восточный Кавказ, в т.ч. } \\
\text { East Caucasus, including }\end{array}$ & 27 & 32.5 \\
\hline $\begin{array}{l}\text { Внутригорный Дагестан } \\
\text { Inland Dagestan }\end{array}$ & 15 & 18.1 \\
\hline $\begin{array}{l}\text { Южный Дагестан } \\
\text { South Dagestan }\end{array}$ & 2 & 2.4 \\
\hline $\begin{array}{l}\text { Андийский хр. и хр. Салатау } \\
\text { Andean Range and Salatau Range }\end{array}$ & 2 & 2.4 \\
\hline $\begin{array}{l}\text { Скалистый хр., вост. часть } \\
\text { Rocky Range, East part }\end{array}$ & 8 & 9.6 \\
\hline $\begin{array}{l}\text { Предкавказье } \\
\text { Ciscaucasia }\end{array}$ & 7 & 8.4 \\
\hline Итого / Total & $90(83)$ & 108.4 \\
\hline
\end{tabular}

100, так как почти для каждого вида устанавливались связи с двумя родственниками.

Данные о пространственной локализации эуксерофитов на территории Российского Кавказа приведены в табл. 2. Из неё следует, что наибольшее количество видов сосредоточено в Центральном Кавказе (41\%), Восточном Кавказе $(32,5 \%)$ и в Северо-Западном Закавказье (Маркотхский хребет) $(16,9 \%)$, относительно небольшое число видов на Западном Кавказе и в Предкавказье (по 9,6\%). Что же касается отдельных регионов, то здесь на первое место выходит Внутригорный Дагестан $(18,1 \%)$, Маркотхский хребет $(16,9)$, центральная часть Скалистого хребта и высокогорья Центрального Кавказа (по 13\%).

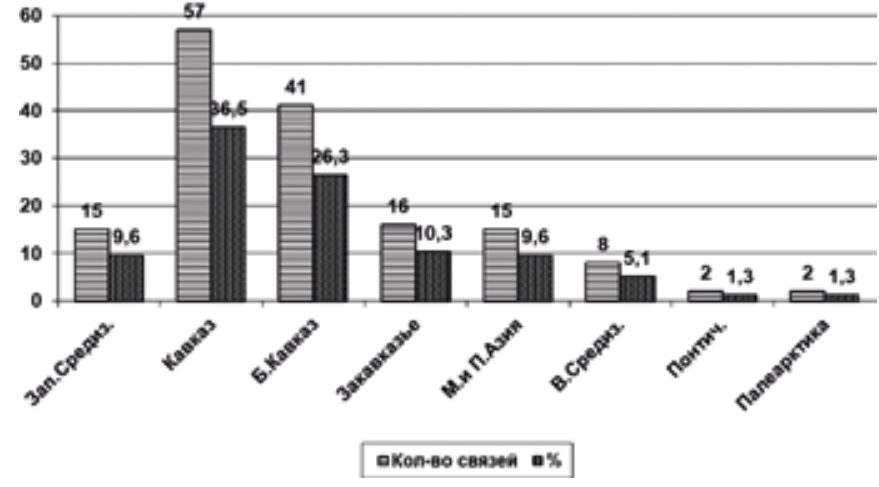

Соотношение родственных связей эндемичных эуксерофитов флоры Российского Кавказа

The relationship of family ties of endemic euxerophytes of the flora of the Russian Caucasus 


\section{Заключение}

Полученные данные о пространственном распространении эндемичных видов коррелируют с имеющимися сведениями о видообразовательных центрах ксерофильной флоры. Исходя из анализа родственных связей палео- и неоэндемиков можно заключить, что процесс становления эндемичного ядра флоры эуксерофитов проходил как минимум в три этапа, за счёт гетерохронных волн миграций из отдалённых западных и восточных центров образования ксерофильной фло-

\section{ЛИТЕРАТУРА:}

1. Тайсумов М. А., Магомадова Р. С. Ксерофиты флоры Российского Кавказа: общая характеристика, классифмкация, поликомпонентный анализ. Махачкала: Алеф, 2017. $226 \mathrm{c}$.

2. Тахтаджян А.Л. Отчет о подготовке и проведении XII Международного ботанического конгресса. Ленинград, 3-10 июля 1975 г. / Ботан. ин-т им. В. Л. Комарова АН СССР. XII Colloquia botanicorum. Leningrad 1975. Ленинград. 1975. $-64 \mathrm{c}$.

3. Gmelin S.G. Reise durch Russland zur Untersuchung der drei Natur-Reiche. Theil IV. St. Petersbourg, 1784. 304 p.

4. Braun-Blanquet J., Furrer E. Remarques sur l'etude des groupements de plantes // Bull. Soc. Languedos. Georg. 1913. N36. P. 20-41.

5. Braun-Blanquet J. Essaisur les notions «d'element» et de «territore» phytogeographiques // Archives des sciences physiques et naturalles. Geneve. 1919. Ser. 5. Vol. 1. P. 479-512.

6. Braun-Blanquet J. L'origineet le developpement des floresdans massif central de France. Paris; Zurich. 1923. 282 p.

7. Koch W. Die Vegetationseinheiten der Linthebere unter Berucksichtigung der Verhaltnisse in der N.O. Schweiz // Jb. St. Gall. Naturw. Ges. 1925. N 61(2). P. 1-146.

8. Davis P.H. Introduction // Flora of Turkey and the East Aegean Islands. Edinburg. 1965. Vol. 1. P. 1-26.

9. Клюев Р.В., Босиков И.И., Майер А. В., Гаврина О.А. Комплексный анализ применения эффективных технологий для повышения устойчивого развития природно-технической системы // Устойчивое развитие горных территорий. 2020. T. 12. N2. C. 283-290.

10. R. Klyuev, M. Madaeva, M. Umarova. Mathematical modeling of specific power consumption of electrolyzers. 2020 International Ural Conference on Electrical Power Engineering (UralCon). Date of Conference: 22-24 Sept. 2020. Date Added to IEEE Xplore: 07 October 2020. Conference Location: Chelyabinsk, Russia, Russia. Publisher: IEEE. DOI: 10.1109/UralCon49858.2020.9216247. pp. 356-361.

11. Favarger C. Endemism in the montane floras of Europe // Taxonomy, phytogeography and evolution, London-New-York, 1972. P. 191-204. ры Древнего Средиземноморья, через формирование вторичных центров в Малой и Передней Азии, а затем и в Западном Средиземноморье.

Новейшее наиболее интенсивное видообразование связано с территориями Внутригорного Дагестана, Центральным Кавказом и Северо-Западным Закавказьем, которое проходило уже на кавказской генетической основе в третичных кавказских видообразовательных центрах и привело к утрате многими видами отдалённых родственных связей.

12. Bosikov I.I., Klyuev R.V., Tavasiev V.Kh., Gobeev M.A. Influence of transport and road complex on the naturaltechnical system. IOP Conference Series: Materials Science and Engineering. Volume 918, Issue 1, 6 October 2020. Article 012124. 8th International Scientific Conference Transport of Siberia 2020; Siberian Transport University Novosibirsk; Russian Federation; 22 Мау 2020 до 27 May 2020; code 163906. doi: 10.1088/1757-899X/918/1/012123.

13. Дребенштедт К., Голик В.И., Дмитрак Ю.В. Перспективы диверсификации технологии добычи металлов в РСО-Алания // Устойчивое развитие горных территорий. 2018. T. 10, N 1. C. 125-131.

14. Boissier E. Flora Orientalis sive Enumeratio plantarum in Oriente, a Graecia et Aegypto ad India fines hucusque observatum. V. 1-5. Basileae et Genevae, 1867-1884. V. I, 1867. 1017 p.; V. II, 1872. 1150 p.; V. III, 1873. 1033 p.; V. IV. 1879.1276 p.; V. V, 1884. 808 p.

15. Favarger C. Endemism in the montane floras of Europe // Taxonomy, Phytogeography and Evolution, London-New-York. 1972. P. 191-204.

16. Ledyard G., Maior J. Endemism end speciation in the California flora // Ecol. Monographs, 1965. Vol. 35. N 1. P. 1-35.

17. Камелин Р. В. Лекции по систематике растений. Главы теоретической систематики растений. Барнаул, 2004. 226 с.

18. Галушко А. И. Анализ флоры западной части Центрального Кавказа / В кн.: Флора Северного Кавказа и вопросы ее истории. Вып. 1. Ставрополь, 1976. С. 5-130.

19. Иванов А. Л. Флора Предкавказья и ее генезис. Ставрополь, $1998.204 \mathrm{c}$.

20. Галушко А. И. Флора Северного Кавказа. Ростов: РГУ, 1980. Т. 2. 350 с.

21. Муртазалиев Р. А. Конспект флоры Дагестана. Махачкала: Изд-во ИД «Эпоха», 2009. T. I-IV. T. I, с. 320; T. II, c. 248; T. III, c. 304; T. IV, c. 232.

22. Галушко А. И. Новые таксоны и номенклатурные комбинации // Флора Северного Кавказа и вопросы её истории. Выпуск 3. Ставрополь, 1979. С. 53-57. 


\section{СВЕДЕНИЯ ОБ АВТОРАХ / Information about authors:}

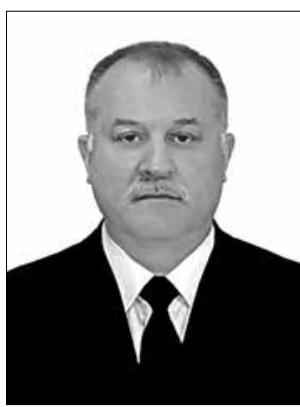

ТАЙСУМОВ Муса Анасович доктор биологических наук; директор института природных ресурсов Академии наук Чеченской Республики. 364024, г. Грозный, Чеченская Республика, Россия.

Тел.: +7(929)890-32-13 (моб.).

e-mail: musa_taisumov@mail.ru

Musa A. TAISUMOV - Doctor of Biological Sciences; Director of the Institute of Natural Resources of the Chechen Academy of Sciences.

Grozny, 364051, Chechen Republic, Russia.

Ph.: +7(929)890-32-13 (mob.);

e-mail:musa_taisumov@mail.ru

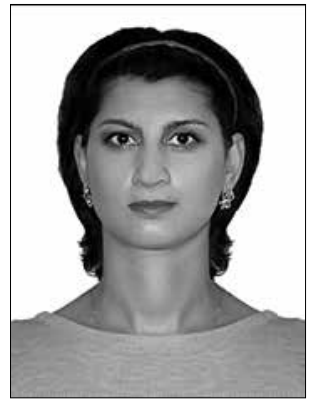

АСТАМИРОВА Маржан Абдул-Межидовна - кандидат биологических наук; доцент кафедры биологии и методики её преподавания Чеченского государственного педагогического университета. 364031, г. Грозный, Чеченская Республика, Россия.

Тел.: +7(928)000-85-87.

e-mail: astamirova@bk.ru

Marjan A.-M. ASTAMIROVA-Candidate of Biological Sciences; Associate Professor of the Department of Biology and Teaching Methodology of the Chechen State Pedagogical University.

Grozny, 364031, Chechen Republic, Russia.

Ph.: +7(928)000-85-87 (mob.).

e-mail: astamirova@bk.ru

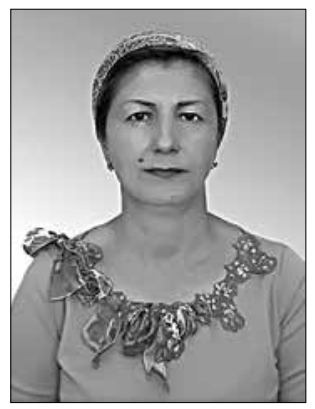

МАГОМАДОВА Раиса Сайпудиновна - кандидат биологических наук; доцент кафедры биологии и методики её преподавания Чеченского государственного педагогического университета.

364031, Грозный, Чеченская Республика, Россия.

Тел.: +7(928)740-73-62 (моб.).

e-mail: r.s.magomadova@mail.ru

Raisa C. MAGOMADOVA - Candidate of Biological Sciences, Associate Professor of the Department of Biology and Teaching Methodology of the

Chechen State Pedagogical University.

Grozny, 364031, Chechen Republic, Russia.

Ph.:+7(928)740-73-62 (mob.).e-mail:r.s.magomadova@mail.ru

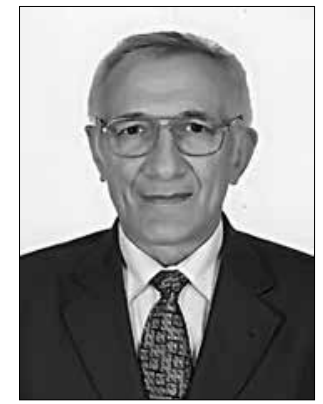

УМАРОВ Мухади Умарович доктор биологических наук; заведующий отделом биологических ресурсов, Академия наук Чеченской Республики. 364024, г. Грозный, Чеченская Республика, Россия.

Тел.: +7(928) 737-43-91 (моб.);

e-mail: umarovbiolog@mail.ru

Mukhadi U. UMAROV - Doctor of Biological Sciences; Head of the Department of Biological Resources, Academy of Sciences of Chechen Republic.

Grozny, 364051, Chechen Republic, Russia.

Ph.: +7(928)737-43-91 (mob.);

e-mail:umarovbiolog@mail.ru

\section{XEROPHILIC ENDEMES OF THE FLORA OF THE RUSSIAN CAUCASUS AND THEIR RELATED RELATIONS}

M. A. Taisumov ${ }^{*}$,

R. S. Magomadova ${ }^{2}$,

M. A.-M. Astamirova ${ }^{2}$,

M. U. Umarov ${ }^{3}$

${ }^{1}$ Institute of Natural Resources of Academy of Sciences of Chechen Republic, Grozny, 364024, Chechen Republic, Russia, musataisumov@mail.ru

${ }^{2}$ Chechen State Pedagogical University. Grozny, 364031, Chechen Republic, Russia

${ }^{3}$ Academy of Sciences of Chechen Republic, Grozny, 364024, Chechen Republic, Russia

DOI: $10.21177 / 1998-4502-2020-12-4-532-541$

The article is devoted to the study of endemics of xerophilous flora of various regions of the Russian Caucasus, adjacent and remote territories (Western Mediterranean, Caucasus, Greater Caucasus, Transcaucasia. Asia Minor and Western Asia, Eastern Mediterranean, Pontic region, Palaearctic).

The purpose of the study is to identify their species composition, genetic links between them, which are necessary for solving the problems of florogenesis. The article analyzes the results of many years of floristic research in different territories of the Caucasus, publications on the flora of these, adjacent and alienated territories. The study used methods of his- torical reconstruction, morphological-ecological-geographical analysis, including the method of evolutionary series, as well as the method of phlorogenetic analysis and synthesis. Information on the genetic and geographical relationships of the taxa under discussion was obtained by analyzing the position of the species in the genus system (in the case of monotypic genera, the position in the family system), which made it possible to identify the closest relatives, determine their geographic localization, and suggest the time and directions of migration flows of ancestral species.

As a result of the analysis of the distribution of 52 species 
of endemics of the xerophilic flora of the studied regions of the Russian Caucasus, as well as the flora of adjacent and remote areas, possible genetic links between them were revealed. The closest relationships of endemic euxerophytes were noted within the territory of the Greater Caucasus (26.3\%), they are significant with endemic species of the Western Mediterranean, Anterior and Asia Minor (9.6\% each) and weaker - with species of the Eastern Mediterranean $(5.1 \%)$, The Pontic region and the Palaearctic $(1.3 \%$ each). Based on the analysis of the relationship of paleoand neoendemics, it was concluded that the process of formation of the endemic nucleus of the flora of euxerophytes took place at least in three stages: due to heterochronous waves of migration from distant western and eastern centers of formation of xerophilic flora of the Ancient Mediterranean, through the formation of secondary centers in Asia Minor and Western Asia, and then in the Western Mediterranean; the most recent most intensive speciation, which took place in the territories of Inland Dagestan, the Central Caucasus and Northwestern Transcaucasia, on a Caucasian genetic basis in Tertiary speciation centers, led to the loss of many types of distant family ties.

The results obtained expand our understanding of migration processes and the history of the formation of the flora of the Caucasus.

Keywords: North Caucasus, endemic, neo-endemic, paleo-endemic, flora, xerophytes.

\section{References:}

1. Taysumov M. A., Magomadova R. S. Xerophytes of the flora of the Russian Caucasus: general characteristics, classification, multicomponent analysis, Alef, Makhachkala, 2017, 226 p.

2. Takhtadzhyan A. L. Report on the preparation and holding of the XII International Botanical Congress. Leningrad, July 3-10, 1975, V. L. Komarov Botan. Institute of the USSR Academy of Sciences, XII Colloquia Botanicorum, Leningrad 1975, $64 \mathrm{p}$.

3. Gmelin S. G. Travel through Russia to investigate the three natural realms. Theil IV, St. Petersbourg, 1784, 304 p.

4. Braun-Blanquet J., Furrer E. "Remarks on the study of plant groups", Bull. Soc. Languedos. Georg., 1913, N36, pp. $20-41$.

5. Braun-Blanquet J. "Essay on the concepts of "spontaneous" and "phytogeographic" territory", Archives of Physical and Natural Monument, Geneva,1919, Ser. 5, vol. 1, pp. 479-512.

6. Braun-Blanquet J. The origin and development of flora in the central massif of France. Paris; Zurich, 1923, $282 \mathrm{p}$.

7. Koch W. "The vegetation units of the Linthebere, taking into account the conditions in the N.O. Switzerland", St. Gall. Naturw. Ges., 1925, no. 61 (2), pp. 1-146.

8. Davis P. H. "Introduction", Flora of Turkey and the East Aegean Islands, Edinburg, 1965, Vol. 1, pp. 1-26.

9. Klyuev R. V., Bosikov I. I., Mayer A. V., Gavrina O. A. "Comprehensive analysis of the effective technologies application to increase sustainable development of the natural-technical system", Sustainable Development of Mountain Territories, 2020, vol. 12, no.2, pp. 283-290.
10. R. Klyuev, M. Madaeva, M. Umarova. Mathematical modeling of specific power consumption of electrolyzers. 2020 International Ural Conference on Electrical Power Engineering (UralCon). Date of Conference: 22-24 Sept. 2020. Date Added to IEEE Xplore: 07 October 2020. Conference Location: Chelyabinsk, Russia, Russia. Publisher: IEEE. DOI: 10.1109/UralCon49858.2020.9216247. pp. 356-361.

11. Favarger C. "Endemism in the montane floras of Europe", Taxonomy, Phytogeography and Evolution, LondonNew-Jork, 1972, pp. 191-204.

12. Bosikov I.I., Klyuev R.V., Tavasiev V.Kh., Gobeev M.A. Influence of transport and road complex on the naturaltechnical system. IOP Conference Series: Materials Science and Engineering. Volume 918, Issue 1, 6 October 2020. Article 012124. 8th International Scientific Conference Transport of Siberia 2020; Siberian Transport University Novosibirsk; Russian Federation; 22 Мау 2020 до 27 May 2020; code 163906. doi: 10.1088/1757-899X/918/1/012123.

13. Golik V.I., Dmitrak Yu.V., Drebenshtedt K. The prospects of diversification of technology of extraction of metals in RSO-Alaniya, Sustainable Development of Mountain Territories, 2018, vol. 10, no. 1, pp. 125-131 [In Russ].14. Boissier E. Flora Orientalis sive Enumeratio plantarum in Oriente, a Graecia et Aegypto ad India fines hucusque observatum. V. 1-5. Basileae et Genevae, 1867-1884. V. I, 1867.1017 p.; V. II, $1872.1,150$ p.; V. III, 1873.1033 p.; V. IV. 1879.1276 p.; V. V, 1884. 808 p.

15. Favarger C. "Endemism in the montane floras of Europe", Taxonomy, Phytogeography and Evolution, LondonNew-Jork, 1972, pp. 191-204.

16. Ledyard G., Maior J. "Endemism end speciation in the California flora", Ecol. Monographs, 1965, vol. 35, no. 1, pp. 1-35.

17. Kamelin R.V. Lectures on plant taxonomy. Chapters of theoretical plant taxonomy, Barnaul, 2004, $226 \mathrm{p}$.

18. Galushko A. I. "Analysis of the flora of the western part of the Central Caucasus", Flora of the North Caucasus and Questions of its History, issue 1, Stavropol, 1976, pp. 5-130.

19. Ivanov A. L. Flora of Ciscaucasia and its genesis, Stavropol, 1998, $204 \mathrm{p}$.

20. Galushko A. I. Flora of the North Caucasus, Rostov, Russian State University, 1980, v. 2, 350 p.

21. Murtazaliev R. A. Abstract of the flora of Dagestan, Epocha Publishing House, Makhachkala, vol. I-IV, 2009, vol. I, p. 320; v. II, p. 248; v. III, p. 304; v. IV, p. 232.

22. Galushko A. I. "New taxa and nomenclature combinations", Flora of the North Caucasus and Questions of its History, vol. 3, Stavropol, 1979, pp. 53-57.

Article received 08.05.2020. 


\section{УДК: 550.837}

DOI: $10.21171 / 1998-4502-2020$ -

12-4-542-554

Поднимаются вопросы применения при сейсмическом микрорайонировании территории проектируемого строительства тоннеля через Маркотхский хребет экспрессных электроразведочных и атмогеохимических технологий. Выполнен анализ современных подходов к решению задач микрорайонирования на участке проектирования.

Показана целесообразность параллельно с производством сейсморазведочных работ, по результатам которых оцениваются скоростные характеристики флишевой толщи с последующим определением в них показателей приращения балльности, применения электроразведочных технологий пространственной электрической фильтрации (МПЭФ) и электропотенциального томографического зондирования (ЭПТЗ), а также атмогеохимических измерений (АИ). Этим достигается оценка степени тектонической нарушенности пород вдоль трассы тоннеля и, тем самым, получение фактических данных для разработки мер по безаварийной эксплуатации будущего тоннеля.

\section{КЛЮЧЕВЫЕ СЛОВА:} тоннельный переход, сейсмическое микрорайонирование, электроразведочные и атмогеохимические измерения, тектонические разрывные нарушения, пространственная электрическая фильтрация.

Статья поступила в редакцию 20.02.2018.

\section{ПРИМЕНЕНИЕ ЭЛЕКТРОРАЗВЕДОЧНЫХ И АТМОГЕОХИМИЧЕСКИХ ТЕХНОЛОГИЙ ПРИ СЕЙСМИЧЕСКОМ МИКРОРАЙОНИРОВАНИИ ТОННЕЛЬНОГО ПЕРЕХОДА ЧЕРЕЗ МАРКОТХСКИЙ ХРЕБЕТ}

\author{
Фоменко Н. Е.1*, \\ Гапонов Д. А. ${ }^{2}$, \\ Боровик Н. Ю. ${ }^{3}$, \\ Фоменко Л. Н. ${ }^{4}$ \\ ${ }^{1}$ Южный фредеральный университет, 344090, Ростов-на-Дону, Россия, \\ fnegeophyskohle@yandex.ru \\ 20AО «Геострой-Ф», 344064, Ростов-на-Дону, Россия, protobull@yandex.ru \\ ${ }^{3}$ Веллард, 6170, Западная Австралия, borovik_7una@gmail.com \\ ${ }^{4}$ Донской государственный технический университет, 344022, Ростов-на-Дону, \\ Россия, detush@yandex.ru
}

\section{Введение}

Исследования по сейсмическому микрорайонированию (СМР) в настоящее время широко проводятся на территории РФ и в зарубежных странах [1-10]. Как правило, СМР проводится в следующем порядке: инженерно-геологические изыскания $\rightarrow$ сейсморазведочные исследования $\rightarrow$ сейсмологические наблюдения $\rightarrow$ расчетные методы $\rightarrow$ составление схемы или карты СМР. Особую значимость имеют исследования сейсмической опасности на площадках строительства и эксплуатации особо ответственных объектов (ОО), включая трассы магистральных трубопроводов [11-13]. Для таких объектов при СМР рекомендуется применять расширенный набор методов, включающий наряду с сейсмическими методы другой физической природы, в частности, электроразведки. Это необходимо в связи с тем, что помимо сейсмической опасности на площадках и вдоль трасс $\mathrm{OO}$ учитывается и опасность явлений, генетически связанных с проявлением землетрясений. К этим явлениям относятся: 1) тектонические разрывы, способные вызвать смещения; 2) карстовые явления; 3) неустойчивость склонов; 4) разжижение и просадки грунта при сильных колебаниях и др. [11;12;14].

Из теории и практики разведочной геофизики известно, что электроразведочные методы наиболее эффективны при решении задачи определения мощности рыхлого чехла и глубины скального массива. Эту задачу можно решать с помощью методов вертикальных электрических зондирований (ВЭЗ), становления электромагнитного поля в ближней зоне (ЗСБ) и др. Определённым образом этими методами решается и задача выявления разрывных тектонических нарушений, чему способствуют разработанные в последние годы томографические системы электроразведки [15-18]. В них вписываются и разработанные авторами технологии пространственной электрической фильтрации (МПЭФ) и электропотенциального томографического зондирования (ЭПТЗ) [19-21].

Отличительные особенности МПЭФ и ЭПТЗ в согласовании-рассогласовании электрического поля с геологической средой, при котором одни объекты целевого назначения «высвечиваются» в этом поле, а другие «нивелируются». Выполняется электрическая фильтрация, осуществляемая разнонаправленным возбуждением поля по отношению к анализируемому объекту. При этом исследуется многовариантная система представления полевых данных не только в виде томограмм, но и в форме электропрофилирования и зондирования. Результатом является выделение деструктивных зон, относящихся к тектонически нарушенным породам. Дополнительным методом, подтверждающим наличие последних, служит технология профильных и площадных атмогеохимических наблюдений (АН). 
Актуальность проведенных авторами исследований заключается в новом варианте постановки и решения задачи по применению в процессе СМР современных мобильных и малозатратных электроразведочных и атмогеохимических технологий с целью повышения полноты и достоверности данных о составе и степени тектонической нарушенности пород по оси тоннеля.

Цель работы: оценка результативности технологий МПЭФ, ЭПТЗ и АН на ОО прокладки магистральных нефтепродуктопроводов и сопутствующих коммуникаций «Технологический тоннель через Маркотхский хребет»; получение дополнительных характеристик к геологическим данным маршрутного обследования и бурения на участке проектирования тоннеля; совершенствование комплекса геофизических методов при проведении инженерных изысканий на ОО.

Задачи исследований: изучить состояние вопроса по применению современных электроразведочных и атмогеохимических методов при инженерных изысканиях на объектах OO; выполнить полевые экспериментальные исследования методами МПЭФ, ЭПТЗ и АН на продольном профиле по оси хребта; определить место геофизических исследований в комплексе инженерно-геологических изысканий.

\section{Краткая характеристика объекта}

\section{Основные сведения о геологическом строении}

Территория инженерно-геофизических работ находится в горной зоне Черноморского побережья в Краснодарском крае РФ (рис. 1). На объекте проектируется прокладка магистральных нефтепродуктопроводов и сопутствующих коммуникаций через Маркотхский хребет в специально построенном тоннеле с южным и северным порталами. Максимальная глубина заложения тоннеля 360 м, внутренний диаметр 3.5 м, длина 4.3 км.

Стратиграфический разрез Маркотхского хребта представлен толщей флишевых пород мелового возраста, смятых в изоклинальные складки. Залегание пластов наклонное и круто-наклонное, осложненное системой тектонических разрывных нарушений разных порядков; проектируемый тоннель ориентирован вкрест простирания пород.

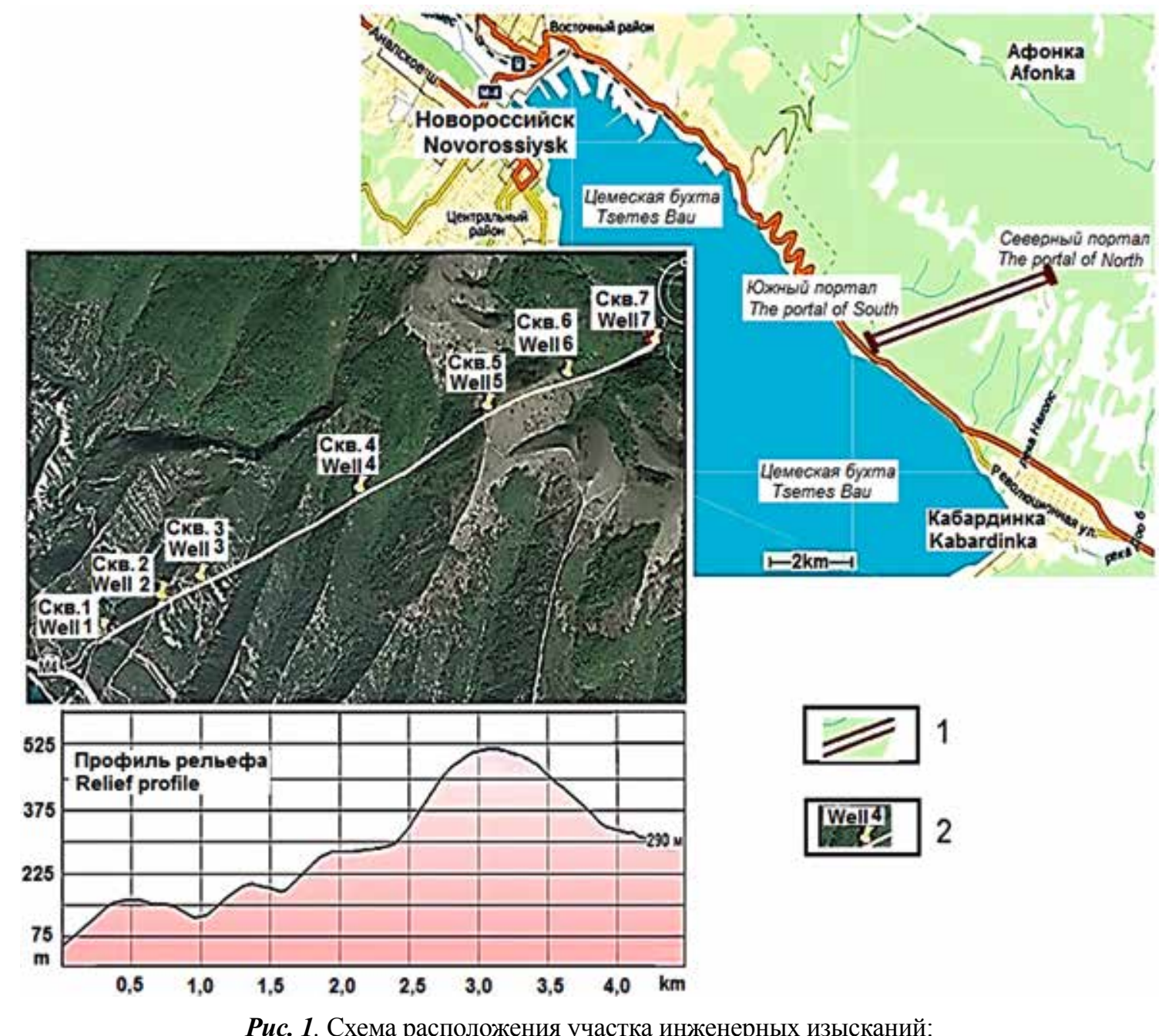

1 - полоса инженерно-геологических и геофизических исследований вдоль оси проектируемого тоннеля; 2 - расположение горных выработок (скважин) на участке

Fig. 1. Scheme of the location of engineering surveys site:

1 - Strip of engineer-geological and geophysical surveys along of projected tunnel axis; 2 - location of the mining excavations (wells) on the site 


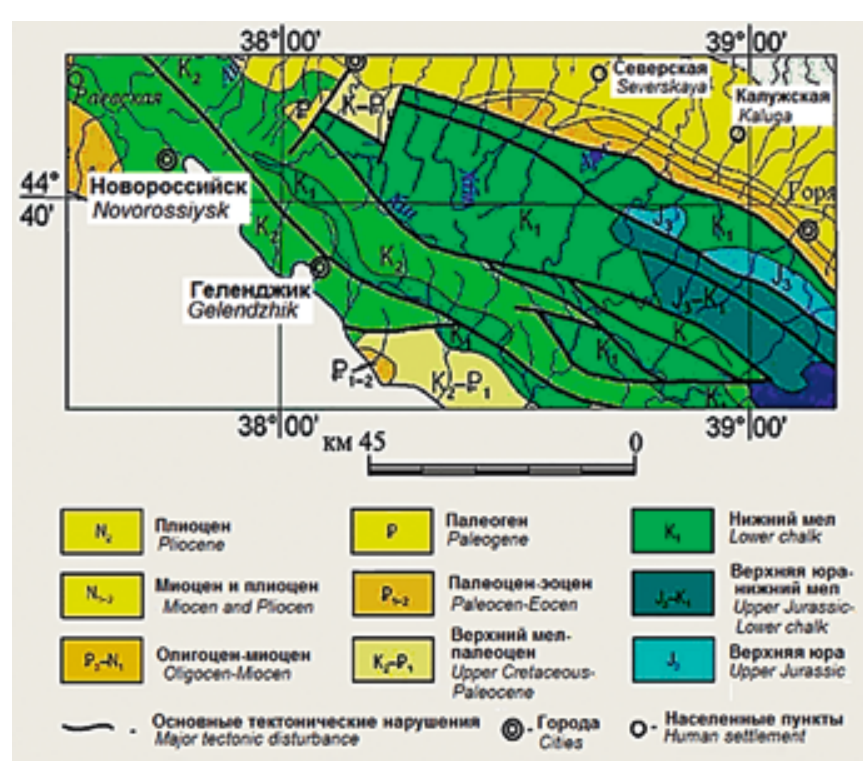

Puc. 2. Фрагмент геологической карты Краснодарского края

Fig. 2. Fragment of the Krasnodar district geological card

Тектоника участка инженерно-геологических изысканий достаточно четко контролируется геоморфологическим строением Новороссийской синклинальной зоны Северо-Западного Кавказа, а также сочетанием структур общекавказского и субмеридианального направлений (рис. 2). Ближайшая к участку изысканий тектоническая структура - $\mathrm{Ce}$ мигорская антиклиналь. Она имеет на площади проектируемого тоннеля квазисимметричное строение за счет синхронного надвига, зона которого состоит из более мелких надвигов, выраженных чешуйчатой структурой. Местами надвиг становится очень крутым, превращаясь в взброс.

Гидрогеологические условия определяются подземными водами приуроченных к трещинным коллекторам в зонах экзогенной и тектонической трещиноватости. Питание вод происходит за счёт инфильтрации атмосферных осадков и перетекания из нижележащих водоносных горизонтов.

\section{Результаты сейсмического микрорайонирования}

На рис. 3 для территории Краснодарского края приведен фрагмент карты расположения зон возможных очагов землетрясений (BО3), с указанием их названия и максимальной магнитуды $\left(M_{\max }\right)$ [3].

Участок проектируемого тоннеля (оконтурен кругом фиолетового цвета) находится в Михайловской зоне ВОЗ с магнитудой $M_{\max }=6.0$ и непосредственно примыкает со стороны Южного портала к Геленджикской зоне ВОЗ с $M_{\max }=6.5$.

Поскольку участок проходки тоннеля отнесен к повышенному уровню ответственности, то согласно требованиям нормативных документов в таких случаях рекомендуется уточнять сейсмическую интенсивность (I) района строительства.

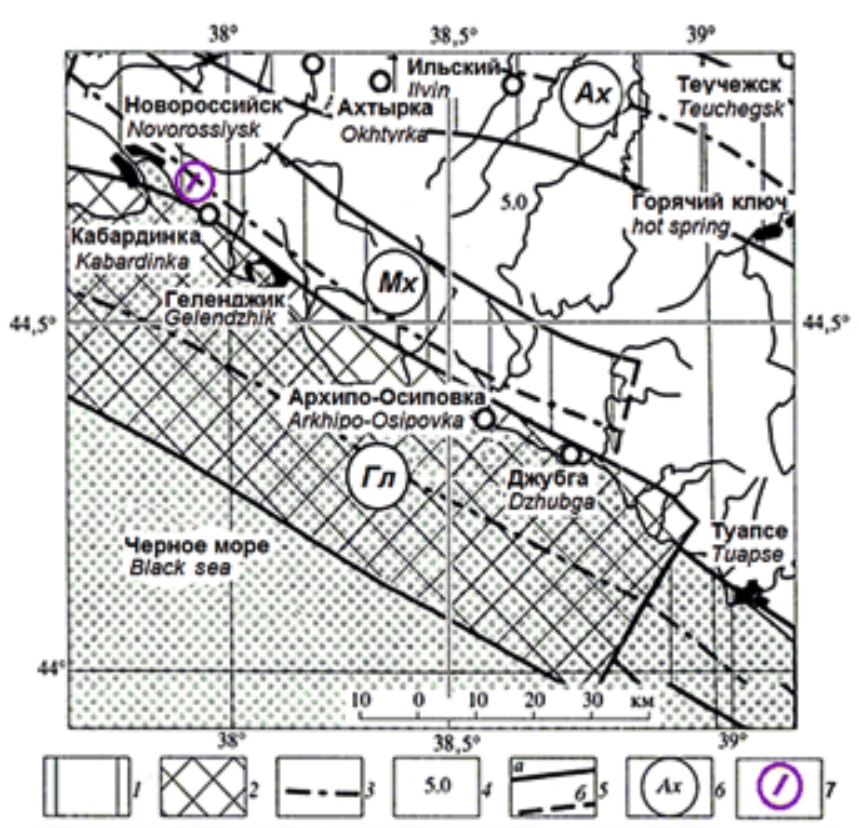

Puc. 3. Фрагмент зон ВОЗ Северо-Западного Кавказа. $1-2$ - зоны ВО3 с $\mathrm{M}_{\text {max }}: 1-6.0 ; 2-6.5 ; 3$-оси зон ВОЗ; 4 - фоновая сейсмичность; 5 - границы зон ВО3

( $a$-достоверные, $\sigma$ - предполагаемые); 6 - индексы зон ВО3 (Ах - Ахтырская, Мx - Михайловская, Гл - Геленджикская); 7 - тоннель

Fig. 3. Fragment of the North-Western Caucasus VOZ zones. 1-2-VOZ zones with $M_{\max }: 1-6.0 ; 2-6.5 ; 3$-axises of $V O Z$ zones; 4 - background seismicity; 5 - borders of VOZ zones ( $a$ real, $b$-supposed); 6 -indexes of VOZ zones (Ax-Achtyrskaya, Mx-Michaylovskaya, Gx-Gelendghikskaya); 7 - tunnel

Приращения сейсмической интенсивности, полученные в результате проведенных расчетов, составили от $\Delta \mathrm{I}=(-1,1)$ балла до $\Delta \mathrm{I}=(-1.5)$ балла. В этом случае суммарная интенсивность сейсмических колебаний $(\mathrm{I}+\Delta \mathrm{I})$ составит не менее 7,5 баллов, что в целочисленных единицах равно I = 8 баллам. Внутри же тоннеля сейсмическая интенсивность уменьшается (рис. 4).

В результате приращение сейсмической интенсивности по сравнению с исходной для центральной части тоннеля составляет (-2) балла, а для периферийной части тоннеля (-1) балл [12]. Следовательно, наиболее «уязвимыми» при возникновении землетрясений участками для проектируемого тоннеля будут места его выходов на дневную поверхность, т. е. площадки южного и северного порталов.

\section{Методика геофизических исследований}

Технология ЭПТЗ разработана авторами [20; 21].

Работы ЭПТЗ проведены на профиле, ориентированном вдоль оси проектируемого тоннеля. Применена схема осевой установки с последовательным удалением измерительной линии $\mathrm{MN}$ от питающей линии $\mathrm{AB}$. Точка зондирования привязывалась к питающему электроду, ближнему к $\mathrm{MN}$. Все измерения выполнялись комплектом электроразведочной аппаратуры Skat+Medusa на частоте 4.88 Гц. Необходимая точность измерений 


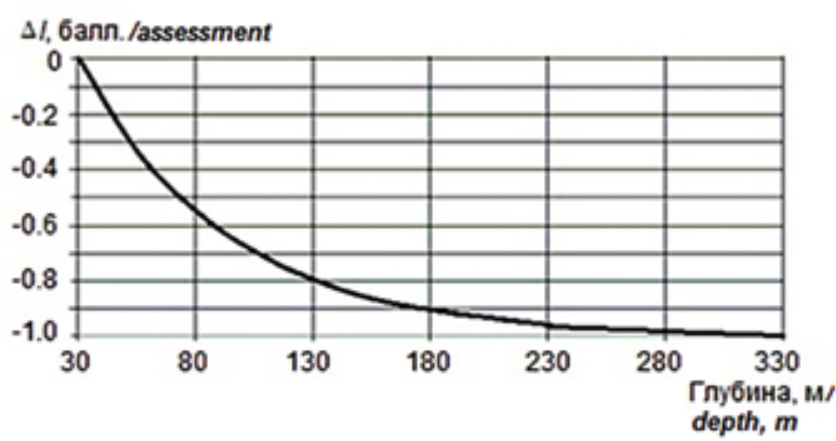

Puc. 4. График зависимости показателя приращения сейсмической интенсивности от глубины

Fig. 4. Dependency graph of the seismic intensity increment index from depth

составляла менее 0.1 мВ. Наблюдения производились в направлении от Южного портала к Северному. Расстояние между точками зондирования, размещаемых вдоль профиля, составляло 50 м. Размер питающей линии $\mathrm{AB}$ принимался равным 100 м при длине измерительной линии $\mathrm{MN}=10$ м. Максимальное удаление (разнос) между внутренними питающим и измерительным электродами (расстояние r) составляло 300 м при арифметическом шаге перемещения линии $\mathrm{MN}$, равным ее длине, т.е. 10 м. В результате при каждом смещении питающей линии $\mathrm{AB}$, в новом зондировании, линия $\mathrm{MN}$ проходила через те же точки, что позволяет производить накапливание сигналов и тем самым однозначно идентифицировать наклонные и круто-наклонные пласты флишевой толщи, выделять места проявления тектонических нарушений.

Технология МПЭФ состояла в проведении электроразведочных работ посредством двукратного перемещения по одному и тому же отрезку профиля измерительной линии $\mathrm{MN}=10$ м. Измеряются составляющие электрического поля первоначально при размещении питающей линии $\mathrm{AB}$ вдоль профиля, а затем вкрест его. Длина питающих линий составляла $\mathrm{AB}=300$ м, следовательно, отрезки измерений и шаг перемещений $\mathrm{AB}$ равнялись одной трети $\mathrm{AB}$, т.е. 100 м.

Следует указать, что способ, в котором питающая линия АВ ориентируется не менее чем в двух направлениях по отношению к элементам залегания геологических структур, а приемная линия $\mathrm{MN}$ каждый раз перемещается по одним и тем же точкам измерительного профиля, носит название фильтра направленного возбуждения (ФНВ) [19; 20].

При проведении электроразведочных работ принималось во внимание наличие по маршруту профиля уступов, ручьев, мочажин, склонов крутизной более $45^{\circ}$, мест наличия растений из редких и исчезающих видов. В этих местах электроразведочные работы не выполнялись.

Эманачионная съёмка производилась с шагом 25 м с отбором проб почвенного воздуха при помощи автономной воздуходувки АВ-07. Общее количество точек измерения плотности потока радона (ППР) составило 179, из которых в 16 точках, где были выявлены наи- большие значения, выполнено от одного до трёх повторных измерений. Отбор пробы начинался не ранее, чем через 20 минут после подготовки почвенного слоя в точке измерения. Время отбора каждой пробы -5 минут. При завершении отбора система воздуходувки прокачивалась атмосферным воздухом в течение 2 минут.

Сейсморазведка МПВ проведена на площадках Южного и Северного порталов в местах размещения горных выработок (скважин). Использовалась цифровая сейсмостанция «Лакколит 24-М2». Пункты возбуждения размечались на расстоянии -23, 0, 23, 46, 69 м. На одно физическое наблюдение производилось 10 синфазных накоплений. Длина приёмной линии составляла 46 м при расположении геофонов через 2 м. Обработка полученных сейсморазведочных материалов выполнялась в программах «RadExPro» и «ZONDST2D» с дальнейшим использованием программ Microsoft Office (Excel, Word) и Surfer. Для графического представления применялся AutoCAD.

На рис. 5 представлен геосейсмический разрез, на котором показана осреднённая сейсмическая граница и скорости Р- и S-волн, а также разрезы скважин. До глубины 20 м по скоростным характеристикам выделяется два слоя.

Первый слой соответствует зоне техногенных, осадочных и выветрелых отложений.

Максимальная мощность этой толщи достигает 2.5 м и характеризуется относительно низкими значениями скоростей $\left(V_{\mathrm{p}}-\right.$ от 0.51 до 0.62 км/с и $V_{\mathrm{s}}$ - от 0.30 до $0.42 \mathrm{\kappa м} / \mathrm{c}$ ).

Второй слой соответствует зоне коренных пород, представленных флишевым переслаиванием мергелей, глинистых мергелей, аргиллитов, алевролитов и песчаников. Мощность слоя составляет более 18 м. Значения скорости $V_{\text {p }}$ колеблются в пределах $2.50-$ $3.10 \mathrm{\kappa м} / \mathrm{c}$, a $V_{\mathrm{s}}-1.30-2.00 \mathrm{\kappa м} / \mathrm{c}$.

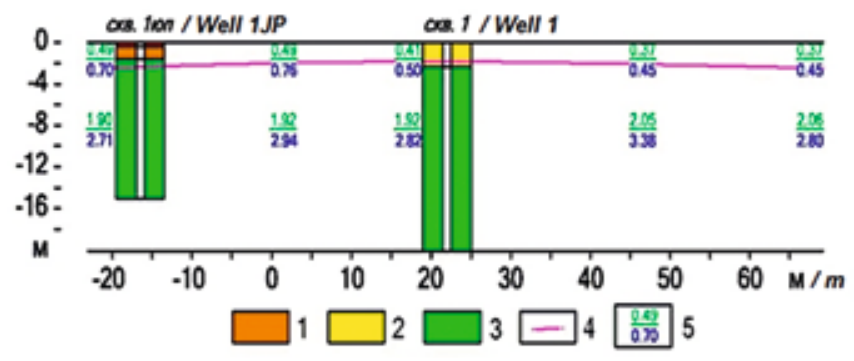

Puc. 5. Геосейсмический разрез на участке строительства Южного портала:

1, 2 - техногенные (1) и суглинистые выветрелые (2)

грунты; 3 - флишевая толща коренных пород;

4 - скоростная граница; 5 - значения скорости поперечных (в числителе) и продольных (в знаменателе) волн (км/с)

Fig. 5. Geoseismic section at the site of the South portal construction:

1, 2 - technogenetic (1) and loamy weathered (2) ground; 3 flysch stratum of the bedrocks; 4 -velocity border; 5 -velocity values of the transverse (in the numerator) and longitudinal (in the denominator) waves $(\mathrm{km} / \mathrm{s})$ 

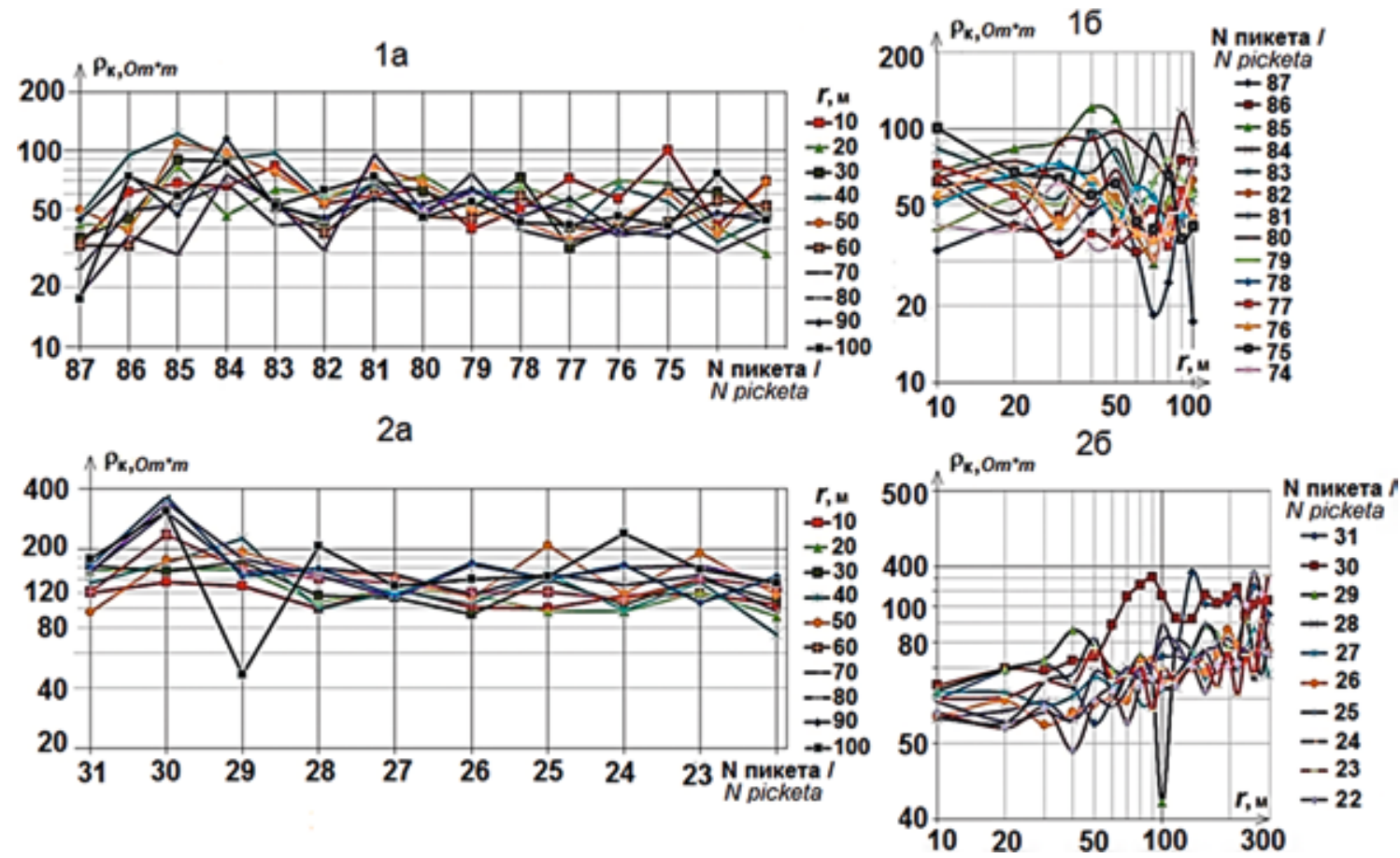

Puc. 6. Картограммы кажущегося удельного электрического сопротивления в форме электропрофилирования ( $1 a$ и $2 a$ ) и кривых электрозондирования (1б и 2 б)

Fig. 6. Cartograms of apparent electrical resistivity in the form of electrical profiling (1a and $2 a$ ) and electric sensing curves (16 and 26)

\section{Результаты исследований и их обсуждение}

На рис. 6 приведены картограммы значений кажущегося удельного электрического сопротивления (рк) в форме: 1) графиков электропрофилирования (фрагменты $1 a$ и $2 a) ; 2$ ) кривых электрозондирования (фрагмены 16 и 26 ).

При пошаговом анализе графиков, прежде всего, видим отсутствие коррелируемости кривых электрозондирования в соседних точках, что свидетельствует о невыдержанности исследуемого разреза по линии геофизического профиля. Далее не наблюдается превышение роста правых ветвей кривых зондирования выше $45^{\circ}$, что обычно характерно при направлении зондирования вкрест простирания крутопадающих толщ. Таким образом, наклонно-залегающая флишевая толща в данном случае «пробивается» электрическим током и поэтому ее можно рассматривать в качестве гетерогенной по латерали и квазиоднородной по электрическим свойствам на глубину. Это представление соответствует результатам инженерно-геологических исследований, согласно которым геологический разрез сложен терригенно-мергелистыми квазиоднородными по литологическому составу породами.

Анализ полученных данных показывает и то, что удельное электрическое сопротивление (УЭС) возрастает по мере роста высотных отметок. Это объясняется понижением природной влажности пород с высотой. Так, в интервале пикетов 87-73 (Южный портал), где высотные отметки не превышают 170 м, средние значения $\rho_{\text {к }}$ составляют 60 Ом·м, а в интервале пикетов 31-22 (собственно Маркотхский перевал), где высотные отметки 450-500 м, средние значения $\rho_{\mathrm{k}}$ составляют 170 Ом'м.

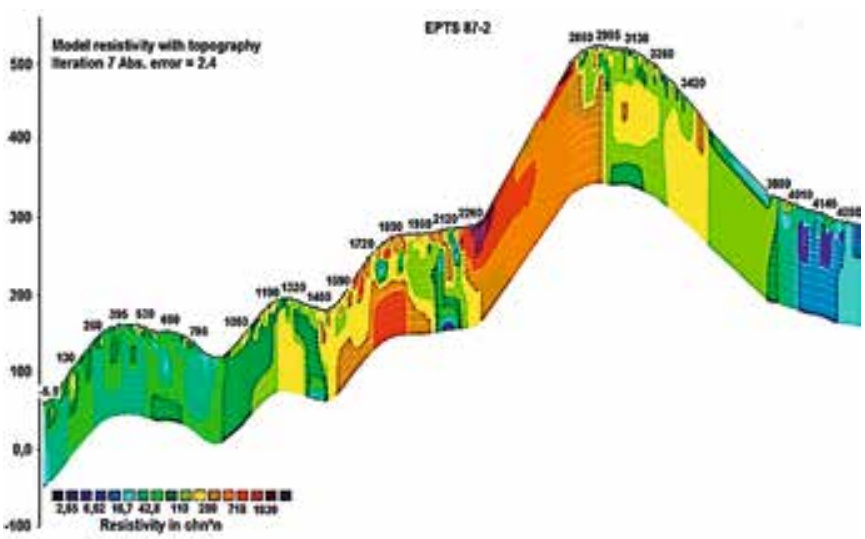

Puc. 7. Псевдогеоэлектрический разрез геофизического профиля по линии трассы проектируемого тоннеля

Fig. 7. Pseudogeoelectric section of geological profile along the line of the projected tunnel track

Псевдоразрез построен в программе Res2Dinv и отражает степень дифференцированности флишевой толщи. Анализ этих значений УЭС показывает, что наиболее увлажненными породами являются слои терригенно-мергелистой толщи на участке Северного портала. По направлению к Южному порталу значения УЭС уменьшаются, причем синхронно протяженности склоновой части.

На рис. 8 приведены примеры комплексного анализа результатов ЭПТЗ и МПЭФ.

Графики на фрагменте $8 a$ представлены для двух отрезков геофизического профиля: 1) в интервалах 

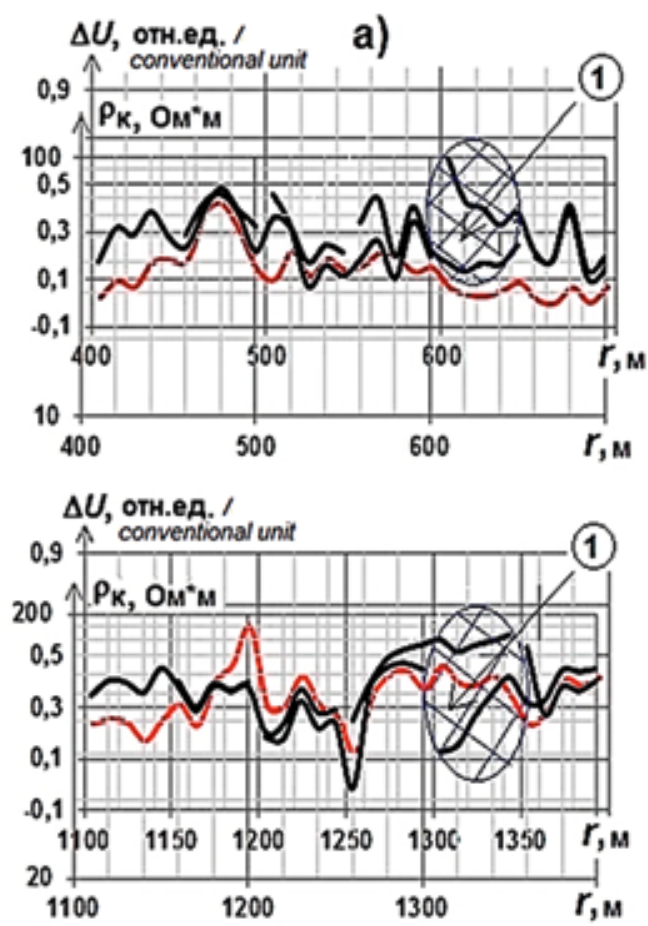

б)
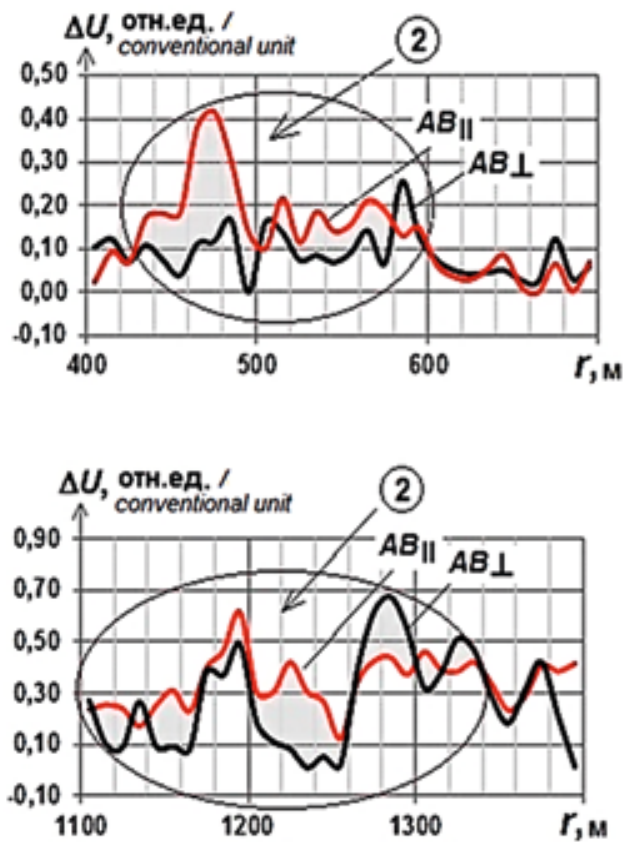

Puc. 8. Результаты электропрофилирования на геофизическом профиле вдоль оси тоннеля в интервалах пикетов 79-73 и 66-59: $a$ - сопоставление кривых ЭПТЗ, построенных в форме электропрофилирования (черный цвет) с графиком продольного СГ (красный цвет); б - совокупные графики МПЭФ (красный цвет - график продольного СГ, т.е. при размещении питающей линии АВ вдоль профиля, черный цвет - график электропрофилирования, полученный при размещении питающей линии АВ вкрест профиля).

1 - область несовпадения кривых ЭПТЗ по форме как признак мест проявления тектонических нарушений; 2 - интервалы несовпадения кривых МПЭФ по форме, связанные со структурными изменениями моноклинального залегания флишевой толщи

Fig. 8. Outcomes of electrical profiling at the geophysical profile along the tunnel axis in the picket intervals 79-73 and 66-59: a-matching of EPTZ curves constructed at the shape of electrical profiling (black colour) with the graph of longitudinal SG (red colour); $b$ - aggregated MPEF graphs (red colour - graph of longitudinal $S G$, i.e. by placing supply line AB along profile, black colour - electrical profiling graph gained by placing supply line $A B$ transversely to profile).

1 - area of the discrepancy of the EPTZ curves in shape, as a attribute of the places where tectonic disturbances appear; 2 -intervals of the discrepancy of the EPTZ curves in shape related to structural changing of the monoclinic lieing of the flysch stratum

пикетов 73-79 (400-700 м); 2) в интервалах пикетов 59-65 (1100-1400 м). На отрезке 520-580 м констатируется четкое совпадение по форме кривых ЭПТЗ с графиком продольного электропрофилирования. Те же признаки отмечаются на отрезке 1200-1300 м. На других отрезках форма кривых или не существенно, или существенно (интервалы помечены цифрой 1) отличается - признак деструктивной зоны. При этом следует подчеркнуть, что смещения одинаковых по форме аномалий на соседних кривых ЭПТЗ на расстояние, равное перемещению питающей линии $A B$, от пикета к пикету не наблюдается - признак горизонтально простирающегося и контрастного по УЭС слоя. Следовательно, разрез не является строго горизонтально слоистым толщи и характеризуется наличием деструктивных зон. Поэтому нетрудно заключить с учетом данных маршрутных наблюдений и бурения, что этими зонами являются многочисленные складчатые (пликативные) и разрывные (дизъюнктивные) нарушения как крупные, так и более мелкие. Последние на рис. $8 a$ отмечены цифрой 1 , а на рис. $87 б$ цифрой 2. Сравнение фрагментов $(a)$ и (б) показывает, что на кривых МПЭФ области рассогласования распространяются на значительно более протяженные интервалы, поскольку сканирование охватывает $360^{\circ}$ изучаемого пространства.

На рис. 9 приведены исходные (a) и осредненные скользящим окном по пяти значениям (б) показатели плотности потока радона (ППР) по линии геофизического профиля. На всем протяжении отмечается достаточно низкий фоновый уровень газонасыщенности радоном верхней части грунтовой толщи при некотором ее увеличении в направлении Северного портала.

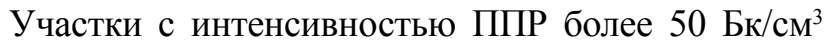
выявлены в шести точках профиля. Контрольные измерения также показали в этих местах повышеную аномальность. Погрешность составила $10.5 \%$. Это допустимо, поскольку газовые выделения по разломам зависят не только от температурных, но и других факторов, в частности солнечно-суточных вариаций.

Комплексная интерпретация результатов электроразведочнх и газометрических наблюдений иллюстрируется рис. 10. Результатом интерпретации явилось 


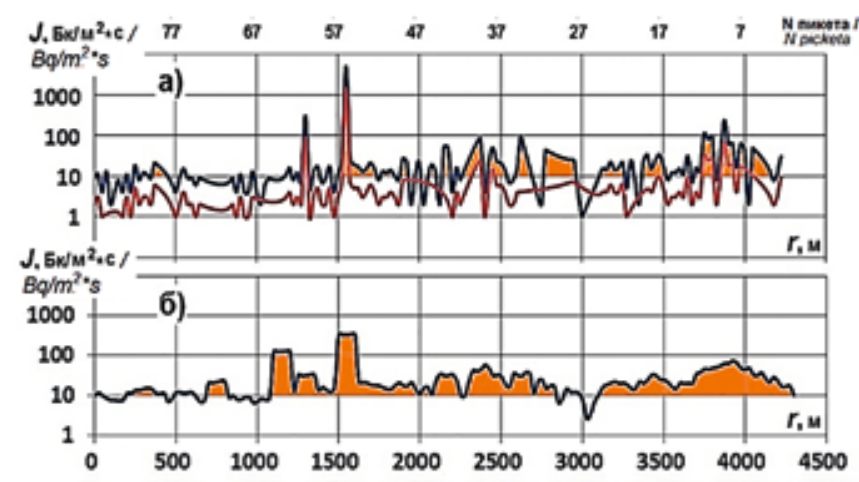

Puc. 9. Исходные (a) и осредненные скользящим окном по пяти значениям (б) показатели ППР по линии геофизического профиля

Fig. 9. Initial (a) and averaged by sliding window by five values (b) indexes PPR along geophysical profile line

построение схематического геологического разреза, структурно отражающего строение пересекаемой тоннелем флишевой мергелисто-терригенной толщи.

Фрагмент $10 a$ представлен совокупными кривыми электрического зондирования, по которым качественно оценивается, с одной стороны, степень дифференцированности пород по значениям УЭС, а с другой проявление в разрезе водоносных горизонтов.

Диагностическим признаком водообильности являются аномалии пониженных значений $\rho_{\text {к }}$, которые оконтурены овалами на фрагменте $10 a$ и также отслеживаются на кривых ЭПТЗ, построенных в форме профилирования на фрагменте 10б. Наиболее водообильными следует считать интервалы гео-

физического профиля 1780-1820 м, 2170-2280 м и 4000-4300 м. Эти интервалы, как правило, приурочены к зонам тектонических разрывных нарушений сбросового типа.

Разрывные и складчатые тектонические нарушения, выявленные на геофизическом профиле по результатам ЭПТЗ (кривые в форме эектропрофилирования на фрагменте $10 б$ и по результатам МПЭФ (фрагмент 108), транспонированы на проекцию тоннеля. По его трассе главной тектонической структурой является сводовая часть Маркотхского перевала, что соответствует и ранее известным данным по тектонике Северного Кавказа. Не в меньшей степени тектонически нарушены и породы южных горных склонов. При этом именно эта часть разреза характеризуется высокими значениями удельных электрических сопротивлений (см. рис. 7) и имеет повышенный фон ППР (рис. 9).

Прогнозная модель геологического строения тоннеля приведена на фрагменте 10д. Интервалы тектонически нарушенных зон, включая водообильные, сведены в табл. 1. В этих интервалах следует ожидать понижение значений физико-механических свойств пород.

На рис. 11 приведены результаты акустического видеокаротажа, выполненного в скважине 7. Скважина пробурена на площадке северного портала.

Исследования выполнены с использованием прибора видеокаротажа «ВЗЛЯД» [22]. Видеоизображения тектонически нарушенных пород в скважине и места установления уровня грунтовых вод во флише-

Таблица 1 / Table 1

Прогнозные интервалы по трассе тоннеля тектонически нарушенных зон и зон обводнения Forecast intervals along the tunnel route of tectonically disturbed zones and flood zones

\begin{tabular}{|c|c|c|c|c|}
\hline \multicolumn{3}{|c|}{$\begin{array}{c}\text { Тип разрывного нарушения } \\
\text { The type of discontinuous tectonic disturbance }\end{array}$} & \multirow[t]{2}{*}{$\begin{array}{l}\text { Зона обводнения } \\
\text { Flooded area }\end{array}$} & \multirow{2}{*}{$\begin{array}{c}\text { Прогнозный } \\
\text { интервал, м } \\
\text { Predictable interval, } m \\
180-210\end{array}$} \\
\hline $\begin{array}{l}\text { взбросо-надвиг } \\
\text { upthrust-overthrust }\end{array}$ & & & & \\
\hline $\mid /-/ /-/ /$ & & & & $500-580$ \\
\hline $\mid /-/ /-/ /$ & & & & $700-720$ \\
\hline$|/-/ /-/|$ & & $\begin{array}{c}\text { активный разлом } \\
\text { active fault }\end{array}$ & & $1360-1400$ \\
\hline \multirow[t]{3}{*}{$\mid /-/ /-/ /$} & & ||$-||-||$ & & $1590-1670$ \\
\hline & $\begin{array}{l}\text { cброс } \\
\text { reset }\end{array}$ & ||$-||-||$ & ||$-||-||$ & 1920-2050 \\
\hline & $/ /-/ /-/ /$ & $|/-||-| \mid$ & $|/-||-| \mid$ & $2300-2400$ \\
\hline $\begin{array}{l}\text { взвбросо-надвиг } \\
\text { upthrust-overthrust }\end{array}$ & & $\|-||-||$ & & $2550-2600$ \\
\hline \multirow[t]{2}{*}{$/ /-/ /-/ /$} & & ||$-||-||$ & & $2990-3020$ \\
\hline & $\begin{array}{l}\text { сброс } \\
\text { reset }\end{array}$ & $\|-\|-\|$ & $\|-||-||$ & $3800-3910$ \\
\hline \multirow[t]{2}{*}{$\begin{array}{l}\text { взвбросо-надвиг } \\
\text { upthrust-overthrust }\end{array}$} & & $\|-\|-\|$ & & $3950-3990$ \\
\hline & $\begin{array}{l}\text { cброс } \\
\text { reset }\end{array}$ & $\|-||-||$ & $\|-\|-\|$ & $4050-4120$ \\
\hline
\end{tabular}




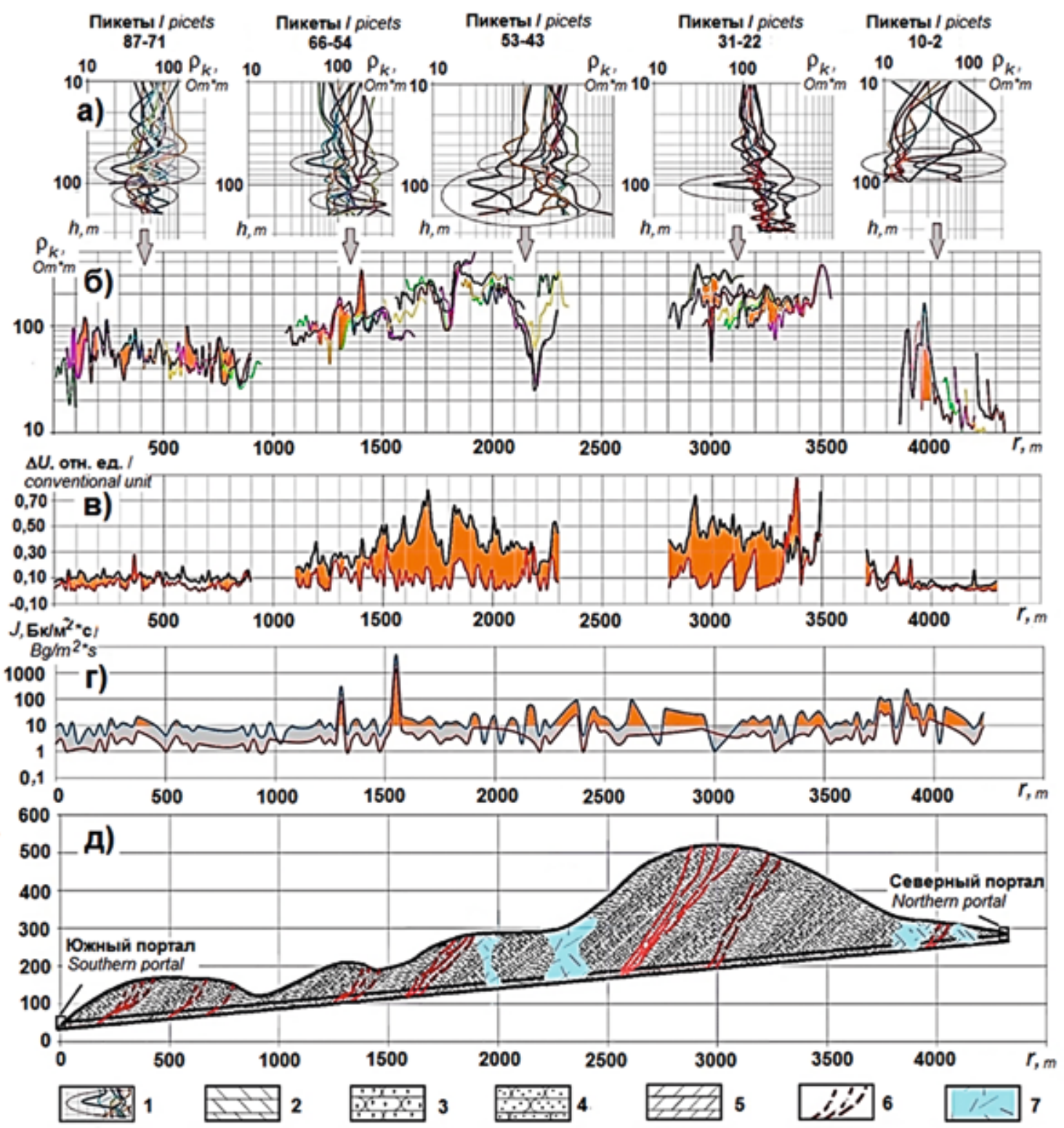

Puc. 10. Сопоставление графиков ЭПТЗ, МПЭФ и эманационной съемки по геофизическому профилю вдоль оси проектируемого тоннеля:

$a$ - совокупные кривые ЭПТЗ в форме электрозондирования; $\sigma$ - графики ЭПТЗ в форме электропрофилирования; в - графики МПЭФ; 2 - графики эманационной съемки (верхний - плотность потока радона, нижний - максимальная допустимая погрешность); $\partial$ - схематический инженерно-геологический разрез до глубины заложения тоннеля.

1 - места проявления водоносных горизонтов; 2 - аргиллиты; 3 - алевролиты ; 4 - песчаники; 5 - мергели; 6 - продольные взбросо-надвиги; 7 - поперечные обводненные сбросы

Fig. 10. Collating of the EPTZ, MPEF graphs and emanational survey by geophysical profile along projected tunnel axis: $a$-aggregated EPTZ curves in the shape of electrical sounding; $6-E P T Z$ graphs in the shape of electrical profiling; в-MPEF graphs; 2 - graphs of emanational survey (upper - density of radon flow, lower - maximum permissible error); $\partial$-schematic engineering-geological section to the depth of the tunnel laying.

1 -the places of the water stratums manifestations; 2 -argillites; 3 -siltstones; 4 -sandstones; 5 -marls; 6 - longitudinal upthrow-thrusts 7 -transverse flooded droppings

вой толще, подчеркивают достоверность прогнозных оценок методами ЭПТЗ и МПЭФ.

\section{Заключение}

Основным итогом выполненных авторами исследований следует считать положительное решение научно-технической задачи сопровождения работ CMP на особо ответственных, линейно протяженных объектах горных территорий электроразведочными технологиями ЭПТЗ, МПЭФ и АИ. Полученные на Маркотхском хребте с помощью этих методов геофизические характеристики позволяют существенно повысить полноту и достоверность данных о внутреннем строении массива.

Обзор отечественной и зарубежной литературы показывает, что технологии ЭПТЗ и МПЭФ уникальны в плане мобильности и простоты полевых измерений, 


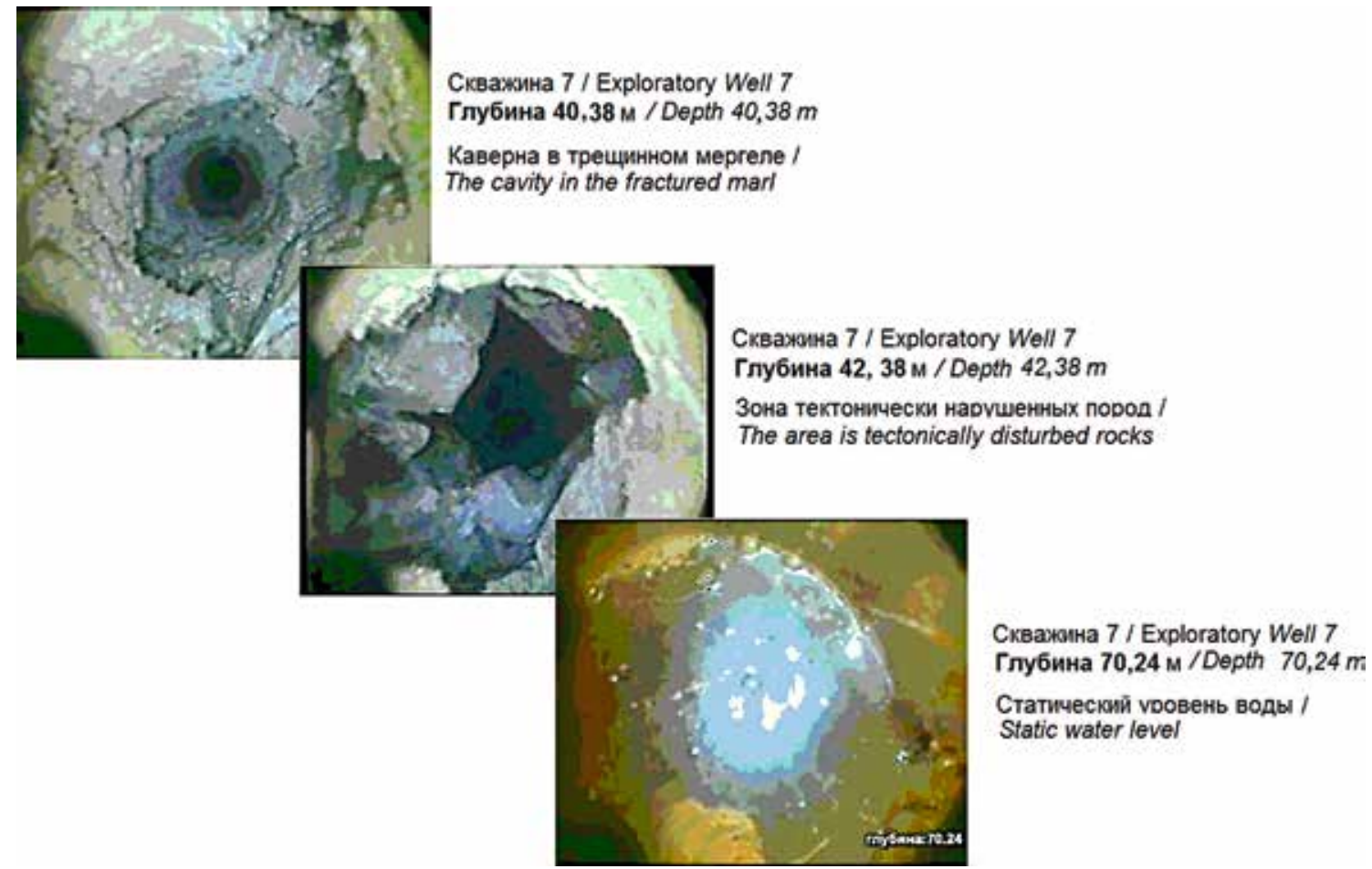

Puc. 11. Результаты акустического видеокаротажа, выполненного в скважине 7

Fig. 11. Outcomes of the acoustic well-logging conducted into the well 7

геолого-геофизического истолкования аномальных значений электрического поля на основе его перераспределения на целевых объектах при разнонаправленном возбуждении по отношению к этим объектам. Результатом является выявление мест развития тектонических разрывных нарушений и обводненных зон, сведения о которых дают возможность при проектировании, строительстве и последующей эксплуатации тоннельных переходов прогнозировать наряду с сейсмоустойчивостью внутреннего массива пород возможные места их потенциального обрушения и подтопления.

\section{Выводы}

Применена методика селективной электроразведки технологиями ЭПТЗ, МПЭФ и АИ, органично вписывающаяся в комплекс инженерно-геологических

\section{ЛИТЕРАТУРА:}

1. Керимов И. А., Гайсумов М. Я., Бадаев С. В. Сейсмическое районирование Северного Кавказа: история и современное состояние // Вестник АН Чеченской республики. 2017. N2(35). С. 39-52.

2. Уломов В. И. К вопросу о стандартизации норм и правил сейсмического районирования для сейсмостойкого строительства в Российской Федерации. // Инженерные Изыскания. 2015. N10-11. С. 6-17.

3. Рогожин Е. А., Лутиков А. И., Овсюченко А. Н. и др. Опыт детального сейсмического районирования Северного Кавказа // Природные и техногенные риски. Безопасность сооружений. 2013. N4. C. 38-42.

4. Келоев Т. А., Гудиева И. Н. Геофизическая информация - ключ к расшифровке тайн геологического строения изысканий при сейсмическом микрорайонировании горных территорий.

Предложена многовариантная система представления полевых данных в форме томограмм и совокупных кривых электропрофилирования и зондирования, что позволяет производить детализацию деструктивных зон, относящихся к тектонически нарушенным породам.

Выполнена оценка разрешающей способностикомплекса сеймо- и электроразведки при выявлении и прогнозирования на глубину тектонической нарушенности и обводненности горного массива на примере Маркотхского хребта.

Произведена заверка прогнозных оценок тектонической нарушенности массива по данным ЭПТЗ и МПЭФ и АИ посредством видео акустического каротажа.

Земли // Устойчивое развитие горных территорий. 2013. N1(15). C. 58-64.

5. Заалишвили В. Б., Джгамадзе А. К., Колесникова А. М., Гогичев Р. Р. Инженерно-геологическое районирование территории г. Моздок в РСО-Алания // Устойчивое развитие горных территорий 2015. N2(24). С. 44-48.

6. Artikov T. U., Ibragimov R. S., Ibragimova T. L., Mirzaev M. A. Study of modern seismic zoning maps' accuracy (case for Eastern Uzbekistan) // Geodesy and Geodynamics. November 2016. Vol.7, Issue 6. Pp. 416-424.

7. Artikov T. U., Ibragimov R. S., Ibragimova T. L., Mirzaev M. A. "Identification of expected seismic activity areas by forecasting complex seismic-mode parameters in 
Uzbekistan", Geodesy and Geodynamics, in press, corrected proof, Available online 8 December 2017.

8. Zamani A., Khalili M., Gerami A. Computer-based selforganized tectonic zoning revisited: Scientific criterion for determining the optimum number of zones // Tectonophysics. September 2011. Vol. 510, Issues 1-2, 15. Pp. 207-216.

9. Chang-Guk Sun, Han-Saem Kim, Choong-Ki Chung, Heon-Cheol Chi. Spatial zonations for regional assessment of seismic site effects in the Seoul metropolitan area // Soil Dynamics and Earthquake Engineering. January 2014. Vol. 56. Pp. 44-56.

10. Kuchai O. A., Kozina M. E. Regional features of seismotectonic deformations in East Asia based on earthquake focal mechanisms and their use for geodynamic zoning // Russian Geology and Geophysics. October 2015. Vol. 56, Issue 10. Pp. 1491-1499.

11. Алешин А. С. Континуальная теория сейсмического микрорайонирования // Инженерные изыскания. 2015. N9. C. 10-18. DOI:10.25296/1997-8650-2015-9-10-18.

12. Алешин А. С. Сейсмическое микрорайонирование особо ответственных объектов. М.: Светоч Плюс, 2010. 304 с.

13. Аптикаев Ф. Ф. Инструментальная шкала сейсмической интенсивности. М.: ООО «Наука и образование», 2012. $176 \mathrm{c}$.

14. Zhihui W., Xiangmin C., Jiayong Y., Jiming W., Lei Z. Using the integrated geophysical methods detecti ng active faults: A case study in Beijing, China. Journal of Applied Geophysics, In press, corrected proof, Available online 7 February 2017.

15. Villani F., Sapia V. The shallow structure of a surfacerupturing fault in unconsolidated deposits from multi-scale electricalresistivity data: The 30 October $2016 \mathrm{Mw} 6.5$ central Italy earthquake case study //Tectonophysics. October 2017. Vol. 717. N16. Pp. 628-644.
16. Wang Z., Cai X., Yan J., Wang J., Liu Y. Using the integrated geophysical methods detecting active faults: A case study in Beijing. China // Journal of Applied geophysics. vol. 150. March 2018. Pp. 1-10.

17. Barron A. J. M., Uhlemann S., Pook G. G., Oxby L. Investigation of suspected gulls in the Jurassic limestone strata of the Cotswold Hills, Gloucestershire, England using electrical resistivity tomography // Geomorphology. September 2016. Vol. 268. N1. Pp. 1-13.

18. Lesparre N., Boyle A., Grychtol B., Cabrera J., Adle A. Electrical resistivity imaging in transmission between surface and underground tunnel for fault characterization // Journal of Applied Geophysics. May 2016. Vol.128. Pp. 163-178.

19. Фоменко Н. Е., Порфилкин Э. Г., Боровик Н. Ю. Электроразведочные методы пространственной фильтрации при изучении сложнопостроенных структур // Геофизика. 2007. N 2. С. 56-63.

20. Fomenko N. E. Electroprospecting technologies of studying of flishevy thickness by tectonic disturbances in the mountain zone of the Black Sea coast when carrying out seismic microdivision into districts // International scientific journal Ecological bulletin of research centers of the black sea economic cooperatotion (BSEC). 2016. N1. Vol. 2. Pp. 23-24.

21. Фоменко Н. Е., Порфилкин Э. Г, Гапонов Д. А. Исследование геологической среды методом электропотенциального томографического зондирования с целью выбора мест безопасного размещения промышленных и бытовых отходов // Геофизика. 2017. N1. С. 63-71.

22. Зинченко В. С., Кобыш С. А. Определение физико-механических свойств карбонатных горных пород по результатам акустического каротажа в инженерно-геологических скважинах // Материалы Международной научно-практической конференции и выставки ЕАГО «Инженерная, угольная и рудная геофизика - 2015. Современное состояние и перспективы развития». Сочи, 28 сентября-2 октября, 2015. С. 51-54.

\section{БЛАГОДАРНОСТЬ / Acknowledgement:}

Авторы выражают искреннюю признательность ведущему научному сотруднику ИФЗ РАН, доктору физико-математических наук Алешину Александру Степановичу за консультации при проведении работ СМР и доценту кафедры туризма высшей школы бизнеса ЮФУ Рубану Дмитрию Александровичу за консультации по методике подбора англоязычной литературы.

The authors express the sincere appreciation to leading researcher IFZ RAN, doctor physics mathematical sciences Alexandr S. Aleshin for consultation during conducting SMR works and associate professor of Tourism Department of Business School YuFU Dmitry A. Ruban for consultation by the method of selection of English-language literature.

\section{КРИТЕРИИ АВТОРСТВА / Contribution:}

Фоменко Н. Е. составил структуру и написание рукописи, выполнил итоговый анализ и интерпретацию исходных материалов, несёт ответственность за плагиат; Гапонов Д. А. руководил и выполнил полевые экспериментальные геофизические наблюдения, составил сейсмические разрезы, произвел расчеты приращения балльности на территории размещения тоннеля; Боровик Н. Ю. произвела литературный обзор и выполнила анализ материалов МПЭФ применительно к осевым и орто-азимутальным установкам; Фоменко Л. Н. произвела комплексный анализ и обработку экспериментальных материалов МПЭФ, ЭПТЗ и АН, выполнила корректирование рукописи для подачи в редакцию.

N. E. Fomenko made up the structure and manuscript writing, performed final analysis and interpretation original data, carried up responsible for plagiarism; Gaponov D. A. guided and conducted the field experimented geophysical observation, made up seismic sections, produced calculation the increment of scores at the territory of the tunnel placement; $\boldsymbol{N}$. Yu. Borovik produced literature review and conducted analysis of MPEF data applied to axial ortho-azimuthal installations; L. N. Fomenko produced complex analysis and processing of experimented MPEF, EPTS and AI materials, conducted correction of the manuscript for submission to editorial office. 


\section{КОНФЛИКТ ИНТЕРЕСОВ / Conflict of interest:}

Авторы заявляют об отсутствии конфликта интересов / The authors declare no conflicts of interest.

\section{СВЕДЕНИЯ ОБ АВТОРАХ / Information about authors:}

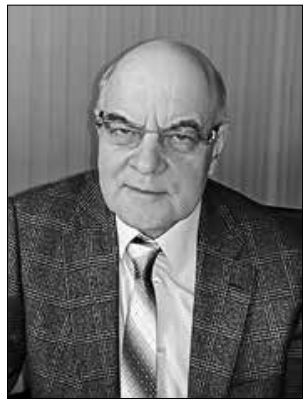

ФОМЕНКО Николай Евгенье-

вич - доктор геолого-минералогических наук, профессор кафедры геоэкологии и прикладной геохимии Института наук о Земле Южного федерального университета.

Отличник разведки недр, изобретатель СССР.

Автор и соавтор более 130 научных трудов и учебно-методических пособий. Научные интересы - угольная, инженерная и экологическая геофизика.

344090, г. Ростов-на-Дону, Россия.

Тел. +7(928)954-92-80.

E-mail: fnegeophyskohle@yandex.ru

Nikolay E. FOMENKO - Doctor of Geological and Mineralogical Sciences, Professor of Department of Geo-Ecology and Applied Geochemistry of Institution of Sciences about Earth of Southern Federal Institute. Excellence in mineral exploration, inventor of USSR. The author and co-author more than 130 scientific papers and teaching aids. Scientific interests - coal, engineering and ecological geophysics.

Rostov-on-Don, 344090, Russia.

Ph.: +7(928)954-92-80.

E-mail: fnegeophyskohle@yandex.ru

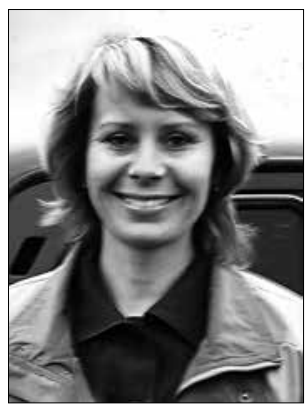

БОРОВИК Наталья Юрьевна - горный инженер-геофизик, гражданка Австралии.

Автор и соавтор более 20 научных трудов и учебно-методических пособий.

Научные интересы - разработка и совершенствование селективных электроразведочных методов решения инженерно-геологических и инженерно-экологических задач.

32 Даксбори Луп, Веллард, 6170, Западная Австралия.

Тел.: +(61)421373033.

E-mail: borovik_7una@gmail.com

Natalia Y. BOROVIK - Mining Engineer-Geophysicist, the author and co-author more than 20 scientific and study-methodical works.

Scientific interests - development and improving of selective electrical methods for solution of engineer-geological and engineerecological tasks.

32 Duxbury Loop, Wellard, 6170, Western Australia.

Ph.: +(61)421373033.

E-mail: borovik_7una@gmail.com

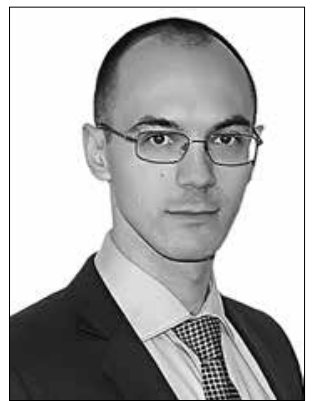

ГАПОНОВ Дмитрий Александрович - канд. геолого-минералогических наук, инженер-геофизик ОАО «Геострой-Ф».

Автор и соавтор более 30 научных трудов и учебно-методических пособий. Научные интересы - инженерная и экологическая геофизика.

344064, г. Ростов-на-Дону, Рос-

Тел.: +7(918)522-00-00.

E-mail: protobull@yandex.ru

Dmitriy A. GAPONOV - Candidate of Geological and Mineralogical Sciences, Engineer-Geophysicist OAO (Open Joint-Stock Company) "Geostroy-F".

The author and co-author more than 30 scientific papers and teaching aids.

Scientific interests - engineering and ecological geophysics.

Rostov-on-Don, 344064, Russia.

Ph.: +7(918)522-00-00.

E-mail: geophysics@land.ru

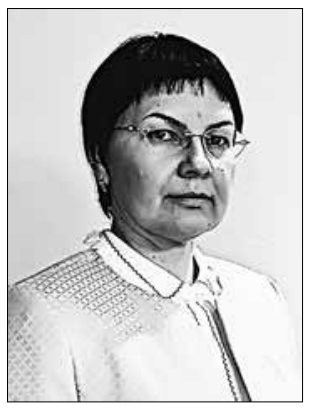

ФОМЕНКО Людмила Николаевна - кандидат технических наук, доцент кафедры математики и информатики Донского государственного технического университета.

Автор и соавтор более 30 научных трудов и учебно-методических пособий. Научные интересы - прикладная математика, программные продукты в инженерной и экологической геофизике.

344022, г. Ростов-на-Дону, ул. Социалистическая, 162, Россия.

Тел.: +7(928)198-39-65.

E-mail: detush@yandex.ru

Ludmila N. FOMENKO - Candidate of Technical Sciences, Docent of Department of Applied Computer Science and Computer Engineering of Academy of Building and Architecture of Don State Technical University.

The author and co-author more than 30 scientific papers and teaching aids.

Scientific interests - applied mathematics, program products in engineering and ecological geophysics.

Rostov-on-Don, 344022, Russia.

Ph.: +7(928)198-39-65.

E-mail:detush@yandex.ru 


\title{
APPLICATION OF ELECTRIC EXPLORATION AND ATMOGEOCHEMICAL TECHNOLOGIES IN SEISMIC MICROZONING OF A TUNNEL JUNCTION THROUGH THE MARKOTKH RIDGE
}

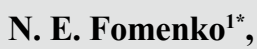 \\ D. A. Gaponov ${ }^{2}$, \\ N. Yu. Borovik ${ }^{3}$, \\ L. N. Fomenko ${ }^{4}$ \\ ${ }^{1}$ South Federal University, Rostov-on-Don, 344090, Russia, fnegeophyskohle@yandex.ru \\ ${ }^{2}$ Geostroy-F JSC, Rostov-on-Don, 344064, Russia, protobull@yandex.ru \\ ${ }^{3}$ Wellard, 6170, Western Australia, borovik_7una@gmail.com \\ ${ }^{4}$ Don State Technical University, Rostov-on-Don, 344022,Russia, detush@yandex.ru
}

DOI: $10.21177 / 1998-4502-2020-12-4-542-554$

Aim. Investigation of the electrical exploration effectiveness and atmogeochemical technologies for detecting discontinuous and folded tectonic disturbances during seismic microzoning of the tunnel crossing over the "Markotkhsky ridge"

Task. Study of the tectonic disturbance degree and flooding of the flysch strata using spatial electrical filtration, electropotential tomographic sensing, and atmogeochemical measurements along the tunnel route using data from route surveys and drilling at the tunnel design site.

Research methods. 1) Field electrical survey measurements of spatial electrical filtration and electropotential tomographic sensing and with installations of multidirectional electric field excitation for" highlighting " target objects. 2) Using a multi-variant system for presenting field data in the form of tomograms and in the form of electro-profiling and sounding to identify destructive zones related to tectonically disturbed rocks and flood zones.

Research results. The analysis of domestic and foreign publications on the use of electrical exploration methods in seismic microdistricting of design, construction and operation of critical facilities is performed. On the example of a tunnel crossing over the Markotkhski ridge: 1) geological, geo-ecological, and seismological characteristics of the area of engineering and geophysical research are considered; 2) the field studies of spatial technologies electric filtrazione, electropotentials tomographic probing and atmogeochemical of observations are produced; 3 ) the heterogeneity of fliteway thickness laterally and quasioperational this thickness on the electrical properties at depth is shown; 4) as a result poperechnogo analysis curves electropotentials tomographic probing, as well as charts of the spatial electric filtrational and atmogeochemical measurements of an tectonically disturbed and watery areas are identified; 5) the degree of differentiation of the flysch thickness by the values of the specific electrical resistance was estimated using a pseudo-section constructed in the Res2Dinv program.

Conclusions. The technologies of electropotential tomographic sounding and spatial electric filtration are unique in terms of mobility and simplicity of field measurements, subsequent geological and geophysical interpretation of anomalous values of the electric field based on its redistribution in tectonically and technogenically disturbed geological structures.

The result is the identification of places of development of tectonic discontinuities and watered zones, information about which makes it possible to predict, along with the seismicity of the rock mass inside the tunnel, possible places of potential collapse and flooding during the design, construction and subsequent operation of tunnel crossings.

A significant achievement of the experiments can be attributed to the identification of the possibility of electroprobing the flysch strata with steeply-and obliquely-lying layers by dipole electric exploration installations. The proof is that the growth of the right branches of the probing curves does not exceed $45^{\circ}$. Consequently, the steeply-and obliquely-lying flysch strata can be considered heterogeneous laterally and quasihomogeneous in depth in terms of electrical properties.

Keyword: tunnel crossing, seismic micro-zoning, electrical and atmogeochemical measurements, tectonic discontinuities, spatial electrical filtration.

\section{References:}

1. Kerimov I. A., Gajsumov M. A., Badaev S. V. "Seismic zoning of the North Caucasus: history and current status", Journal Bulletin of the Academy of Sciences of the Chechen Republic, 2017, no.2(35), pp. 39-52.

2. Ulomov V. I. "On the issue of standardization of norms and rules of seismic zoning for earthquake-proof construction in the Russian Federation", Inzenernye Izyskania, 2015, no.1011, pp. 6-17.

3. Rogozin E. A., Lutikov A. I., Ovsucenko A. N. et al. "The experience of detailed seismic zoning of the North Caucasus", Prirodnye i Tehnogennye Riski. Bezopasnost' Sooruzenij, 2013, no.4, pp. 38-42.

4. Keloev T. A., Gudieva I. N. "Geophysical information is the key to transcript the secrets of the geological structure of the Earth", Sustainable Development of Mountain Territories, 2013, no.1(15), pp. 58-64.

5. Zaalishvili V. B., Dzhgamadze A. K., Kolesnikova A.M., Gogichev R. R. "Engineering-geological zoning of the territory of Mozdok in RSO-Alania", Sustainable Development of Mountain Territories, 2015, no.2(24), pp. 44- 48.

6. Artikov T. U., Ibragimov R. S., Ibragimova T. L., Mirzaev M. A. "Study of modern seismic zoning maps' accuracy (case for Eastern Uzbekistan)", Geodesy and Geodynamics, November 2016, vol.7, issue 6, pp. 416-424.

7. Artikov T. U., Ibragimov R. S., Ibragimova T. L., Mirzaev M. A. "Identification of expected seismic activity areas by forecasting complex seismic-mode parameters in Uzbekistan", Geodesy and Geodynamics, In press, corrected proof, Available online 8 December 2017.

8. Zamani A., Khalili M., Gerami A. "Computer-based self-organized tectonic zoning revisited: Scientific criterion for determining the optimum number of zones", Tectonophysics, vol. 510, Issues 1-2, 15 September 2011, pp. 207-216.

9. Chang-Guk Sun, Han-Saem Kim, Choong-Ki Chung, Heon-Cheol Chi. "Spatial zonations for regional assessment 
of seismic site effects in the Seoul metropolitan area", Soil Dynamics and Earthquake Engineering, January 2014, vol. 56 , pp. 44-56.

10. Kuchai O. A., Kozina M. E. "Regional features of seism tectonic deformations in East Asia based on earthquake focal mechanisms and their use for geodynamic zoning", Russian Geology and Geophysics, October 2015, vol. 56, issue 10, pp. 1491-1499.

11. Aleshin A. S. "Continuum theory of seismic micro zoning", Inzhenernye Izyskaniya, 2015, no.9, pp. 10-18. DOI: 10.25296/1997-8650-2015-9-10-18.

12. Aleshin A. S. Seismic micro zoning of especially important objects, Moscow, Svetoch Plus, 2010, 304 p.

13. Aptikaev F. F. Instrumental scale of seismic intensity, Moscow, Nauka i obrazovanie, 2012, 176 p.

14. Zhihui W., Xiangmin C., Jiayong Y., Jiming W., Lei Z. "Using the integrated geophysical methods detecting active faults: A case study in Beijing, China", Journal of Applied Geophysics, in press, corrected proof, Available online 7 February 2017.

15. Villani F., Sapia V. "The shallow structure of a surface-rupturing fault in unconsolidated deposits from multiscale electrical resistivity data: The 30 October $2016 \mathrm{Mw} 6.5$ central Italy earthquake case study", Tectonophysics, October 2017, vol. 717, no.16, pp. 628-644.

16. Wang Z., Cai X., Yan J., Wang J., Liu Y. "Using the integrated geophysical methods detecting active faults: A case study in Beijing. China”, Journal of Applied Geophysics, March 2018, vol. 150, pp. 1-10.

17. Barron A.J.M., Uhlemann S., Pook G. G., Oxby L. "Investigation of suspected gulls in the Jurassic limestone strata of the Cotswold Hills, Gloucestershire, England using electrical resistivity tomography", Geomorphology, September 2016, vol. 268, no.1, pp. 1-13.

18. Lesparre N., Boyle A., Grychtol B., Cabrera J., Adle A. "Electrical resistivity imaging in transmission between surface and underground tunnel for fault characterization", Journal of Applied Geophysics, May 2016, vol. 128, pp. 163-178.

19. Fomenko N. E., Porfilkin E. G., Borovik N.U. "Electro prospecting methods of spatial filtration in the study of complex structures", Geofizika, 2007, no.2, pp. 56-63.

20. Fomenko N. E. "Electro prospecting technologies of studying of flishevy thickness by tectonic disturbances in the mountain zone of the Black Sea coast when carrying out seismic micro division into districts", International Scientific Journal Egological Bulletin of Research Centers of the Black Sea Economic Cooperatotion (BSEC), 2016, no.1, vol. 2, pp. 23-24.

21. Fomenko N. E., Porfilkin E. G, Gaponov D. A. "Investigation of the geological environment by the method of electro-potential tomographic sensing with the aim of the selecting locations for safe placement of industrial and domestic waste", Geofizika, 2017, no.1, pp. 63-71.

22. Zinchenko V. S., Kobysh S. A. "Determination of physic-mechanical properties of carbonate rocks from the results of the acoustic logging in engineering-geological wells", Materials of the International Scientific and Practical Conference and Exhibition of the EAGO "Engineering, Coal and Ore Geophysics - 2015. The Current State and Prospects for Development." Sochi, September 28-October 2, 2015, pp. 51-54.

Article received 20.12.2018. 


\section{МАТЕМАТИЧЕСКОЕ МОДЕЛИРОВАНИЕ ВОЛНОВОГО ДВИЖЕНИЯ ВОДЫ В ВОДОХРАНИЛИЩЕ, ВЫЗВАННОГО ВТОРЖЕНИЕМ В НЕГО ОБВАЛЬНО- ОПОЛЗНЕВОГО МАССИВА}

\begin{abstract}
Музаев И. Д. ${ }^{1,2^{*}}$,
Созанов В. Г. ${ }^{3}$

${ }^{1}$ Геофизический институт - фрилиал Федерального государственного бюджетного учреждения науки Федерального научного центра «Владикавказский научный центр Российской академии наук», 362002, PCO-A, г. Владикавказ, Россия, illarion.muzaev@yandex.ru ²Владикавказский филиал Финансового университета при Правительстве Российской Федерации, 362002, РСО-А, г. Владикавказ, Россия ${ }^{3}$ Северо-Осетинский государственный университет им. К.Л. Хетагурова, 362025, PCO-A, г. Владикавказ, Россия, v.sozanov@mail.ru
\end{abstract}

\section{Введение}

Искусственные водохранилища на горных реках строятся, как правило, в узких ущельях, имеющих параболическую форму поперечного профиля, часто с крутыми скальными откосами и высокими прирусловыми террасами. В таких условиях для создания водохранилища требуемой регулирующей призмы приходится возводить плотину значительной высоты. При проектировании таких плотин тщательно исследуются геотехнические характеристики откосов ущелья, в частности, возможность схода оползне-обвальных массивов в чашу строящегося водохранилища.

Наиболее опасные горные процессы для проектируемых и действующих объектов (Мизурская обогатительная фабрика, несколько действующих шахт в ущельях с селевыми склонами, Транскам, Зарамагская ГЭС, первая очередь туристического кластера Мамисон) изучались в предыдущие годы в процессе их строительства. При этом специально исследовались проектные решения и промышленная эксплуатация объектов, в том числе, их влияние на окружающую среду [1-3]. В результате было установлено, что причины и механизмы оползневых движений весьма разнообразны и связаны как с гравитационноклиматическими, так и с сейсмотектоническими процессами, происходящими в общем цикле неотектонических восходящих движений Большого Кавказа.

В последние годы широкое распространение получили методы, позволяющие непосредственно оценивать состояние территорий с помощью космических снимков. Одним из важных применений данных наблюдений Земли - это создание цифровых моделей рельефа (ЦМР), которые являются базовой информацией для определения характеристик уклона и изучения с помощью численных моделей [4]. Модели больших площадей при этом могут быть получены из спутниковых данных, таких как GTOPO30 с разрешением 1 км. Для локальных участков сканирование может выполняться в исключительных случаях с разрешением до долей метра.

Исследованию условий активации оползней и смягчению их проявлений в горных районах посвящено большое число современных исследований [5-7]. Для прогнозирования изменений состояния оползневого тела важно также знать его физические свойства и процессы, происходящие на различных уровнях, включая явления акустической эмиссии и высокочастотные явления, приводящие к изменениям структуры геологической среды [8].

В то же время построение математических моделей того или иного явления нередко позволяет создать условия, максимально приближенные к реально воз-
УДК: 532 (075.8)

DOI: 10.21177/1998-4502-2020-

12-4-555-564

Разработана

математическая модель

волнового движения

воды в водохранилище,

когда движение вызвано

вторжением в его чашу

обвально-оползневого

массива горной породы,

либо высокоскоростного

селелавинообразного

потока.

Модель представляет

начально краевую

задачу гидродинамики

гравитационных волн.

Поставленная начально-

краевая задача решена в трех

вариантах в зависимости

от конфигурации

водохранилища. Решения

получены строгими

аналитическими методами

математической фризики.

Получены совокупности

расчетных формул,

которые позволяют

вычислить на компьютере

амплитуду образованной

волны вытеснения у

створа плотины, расход

и объем воды, которая

может быть перелита

через гребень плотины,

а также зону и степень

затопления местности

в бьефах плотины. При

наличии этих данных

можно прогнозировать,

предотвратить либо

смягчить те последствия

и ущерб, которые может

вызвать образование

разрушительных волн

вытеснения.

\section{КЛЮЧЕВЫЕ СЛОВА:}

волна вытеснения, начальнокраевая задача, метод Фурье, бьеф плотины, запас устойчивости откоса, геотехнические характеристики откосов, обвально-оползневый массив.

Статья поступила в редакцию 29.06.2020. 
можным, что позволяет изучать те или иные явления с самых различных сторон.

При реальной возможности схода оползне-обвальных массивов в чашу строящегося водохранилища возникает необходимость оценки воздействия волны вытеснения, образованной вторжением возможного оползня-обвала в водохранилище на плотину и приплотинные сооружения. При этом наиболее опасной является возможность возникновения волны, могущей перехлестнуть через гребень земляной плотины, что может привести к размыву и образованию прорана в створе плотины.

Обычно при реальности подобных последствий оползня-обвала приходится отказываться даже от весьма привлекательного для строительства плотины створа. Причем при выборе створа главную роль играет правильная оценка опасности возникновения высокой волны при оползне-обвале откоса. Опасность потери регулирующей емкости менее существенна, ибо оползне-обвальная масса горной породы, как правило, умещается в емкость мертвого объема водохранилища.

Пристальный интерес, который проявляется специалистами горной гидротехники к задаче определения наибольшей высоты волны вытеснения, образуемой при обрушении откосов горных водохранилищ, становится понятным, если вспомнить о двух известных катастрофах, связанных с оползне-обвальными процессами.

Одно из этих больших бедствий, вызванное обрушением масс грунта в водохранилище, имело место в Италии, в ущелье реки Вайонт в 1963 году. Массив горной породы объемом около 300 млн. м³ обрушился в водохранилище с борта, что вызвало образование волны вытеснения высотой около 250 м и катастрофического паводка в бьефах водоема и дальше по ущелью реки Вайонт. В результате были снесены крупные населенные пункты и имели место более 3000 человеческих жертв [9].

Вторая примерная катастрофа произошла в горах Памира в 1911 году на границе республик Таджикистан и Афганистан $[10 ; 11]$. В верховьях реки Мургаб оползень-обвал, названный Усойским завалом, перегородил ущелье реки Мургаб на отметке 3000 м, в результате чего образовалось высокогорное водохранилище-озеро Сарез с емкостью 19 км³. Глубина озера у завальной плотины более 500 м. В настоящее время завальное озеро-водохранилище создает потенциальную угрозу населению на территории Средней Азии с точки зрения повторного обрушения в озере какоголибо обвально-оползневого массива, нависающего на крутых бортовых склонах, и образования высокой волны вытеснения и мощного паводкового потока, как это имело место в ущелье реки Вайонт [9-11].

Упомянутые случаи Вайонта и Усойского завала - это явления исключительной повторяемости. В подавляющем большинстве случаев оползне-обвальные процессы, приводящие к образованию волн в горных водохранилищах, происходят по причине потери устойчивости крутых откосов водохранилища из-за частых сработок уровней воды. Объемы таких оползней-обвалов значительно скромнее, чем в случае Вайонта или Усойского завала, но большей частью значительно скромнее по объемам и сами водохранилища. Поэтому, если в случае Вайонта оползень-обвал генерировал волну вытеснения высотой 200-300 м, то для обычных, часто встречающихся горных водохранилищ высота реально образуемых или прогнозируемых волн вытеснения редко превышает 10-15 м.

Однако и эти высоты могут быть крайне опасными при переливе (перехлесте) через гребни грунтовых и даже каменно-набросных плотин. Следовательно, прогнозирование возможных высот волн вытеснения, даже в случае, когда откосы бортов водохранилища имеют достаточный запас устойчивости, представляется весьма желательным, а в случаях, когда ниже по руслу реки находятся объекты жизнеобеспечения, даже обязательным.

Волны вытеснения могут быть вызваны также вторжением в водохранилище высокоскоростных селелавинообразных потоков. После возведения плотины и создания водохранилища надпойменная терраса заполняется, что приводит к воздействию лавинообразных потоков селевой природы непосредственно на водную массу, генерируя в ней волну вытеснения. Если при этом приток-лог направлен по касательной к основному руслу, то генерируемая вторжением селя волна вытеснения распространяется почти прямо к плотине, создавая при достаточной высоте угрозу перелива (перехлеста) через гребень плотины.

Количество научных публикаций по обсужденным выше проблемам невелико. В статьях [11-16] поставлены и решены начально-краевые задачи, моделирующие волновое движение воды в водохранилище, когда движение вызвано вторжением в нее обвальнооползневого массива горной породы. При этом геометрическая конфигурация водохранилища в указанных статьях схематизирована в виде прямоугольного параллелепипеда. Тем самым в них плановая непризматическая конфигурация и переменность глубины водохранилища не учтены.

В нашей статье проведено механико-математическое моделирование волнового движения воды с учетом как плановой непризматической конфигурации приплотинной области, так и с учетом наклона дна водохранилища.

\section{1. Составление и решение начально-краевой задачи}

Предположим, что в прямоугольной системе координат охуz часть пространства, ограниченная условиями 


$$
0 \leq x \leq L,-H(x) \leq z \leq 0,-\frac{B(x)}{2} \leq y \leq \frac{B(x)}{2},
$$

представляет схематизированное горное водохранилище, где $L$ - длина, $B(x)$ - ширина, $H(x)$ - глубина водохранилища (рис. 1).
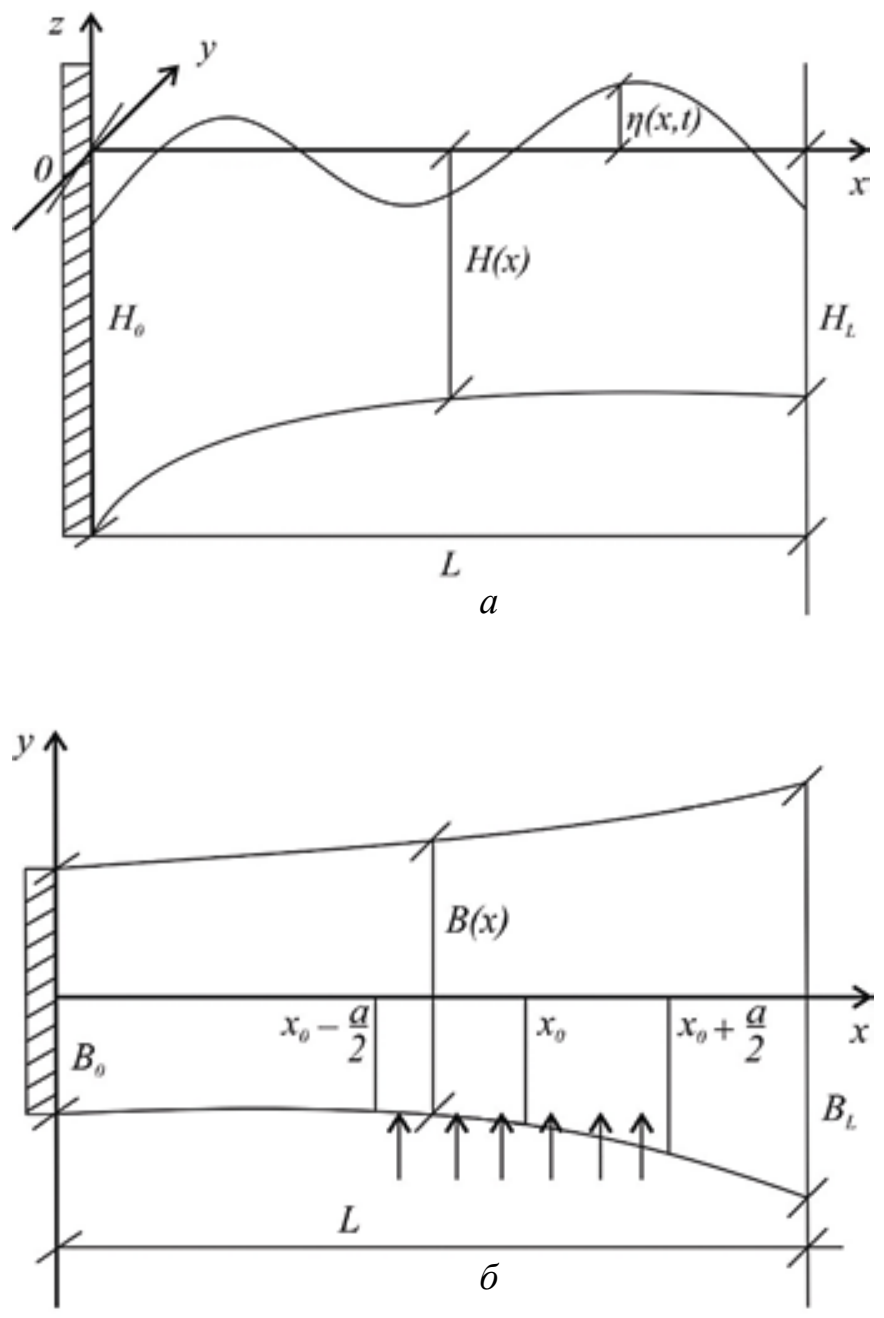

Puc. 1. Схематический рисунок водохранилища и расчетная схема поставленной задачи: $a$ - вертикальный профиль; $\sigma$ - плановый профиль.

$L$ - длина водохранилища; $B_{0}, B_{L}, B(x)$ - ширина водохранилища; $H_{0}, H_{L}, H(x)$ - глубина водохранилища; $\eta(x, t)$ - возвышение волновой поверхности воды над уровнем свободной поверхности водохранилища; $a, x_{0}-$ длина и координата центра участка боковой грани, через который вторгается массив

Fig. 1. Schematic drawing of the reservoir and design scheme of the task: $a$-vertical profile; $\sigma$-planned profile.

$L$ - length of the reservoir; $B_{0}, B_{L}, B(x)$-width of the reservoir; $H_{0}, H_{L}, H(x)$ - depth of the reservoir; $\eta(x, t)$ - elevation of the wave surface of the water above the level of the free surface of the reservoir; $a, x_{0}$-length and coordinate of the center of the side face section through which the array intrudes

Непризматическая конфигурация водохранилища учитывается через ширину $B(x)$ и глубину $H(x)$, зависящие от продольной координаты $x$.

Предположим, что через участок боковой грани, ограниченного условиями

$$
y=0, \quad x_{0}-\frac{a}{2}<x<x_{0}+\frac{a}{2},
$$

оторванный от крутого склона массив горной породы либо селелавинообразный поток вторгается в чашу водохранилища со скоростью $U_{0}$. Волновое движение воды в водохранилище, вызванное вторжением, математически можно смоделировать следующими дифференциальными уравнениями гидродинамики гравитационных волн [16-29]:

$$
\begin{gathered}
\frac{\partial V(x, t)}{\partial t}+g \frac{\partial \eta(x, t)}{\partial x}=0, \\
B(x) \frac{\partial \eta(x, t)}{\partial t}+\frac{\partial}{\partial x}[B(x) H(x) V(x, t)]=H(x) U(x, t),
\end{gathered}
$$

где $\eta(x, t)$ - амплитуда образованных волн, $V(x, t)$ - скорость движения воды в водоеме, $g$ - ускорение силы тяжести, $t$ - время, $x$ - продольная координата. В этих уравнениях искомыми функциями являются амплитуда $\eta(x, t)$ и скорость движения воды $V(x, t)$.

Функции $B(x)$ и $H(x)$ представляют среднюю ширину и глубину водохранилища и считаются заданными функциями от продольной координаты $x ; x_{0}$ - продольная координата центра участка боковой грани, через который вторгается обвально-оползневый массив либо селелавинообразный поток; $U(x, t)$ - скорость вторжения, которая в общем случае зависит от координаты $x$ и времени $t$. В дальнейшем функцию $U(x, t)$ будем задавать в следующем виде:

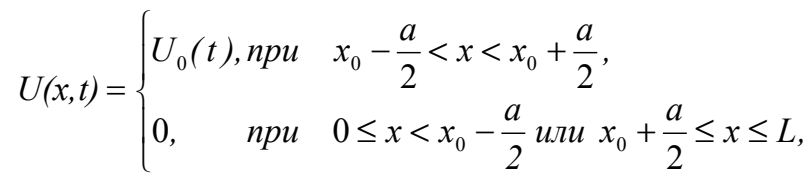

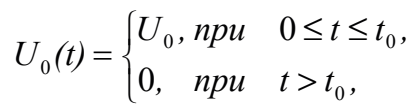

где $t_{0}$ - промежуток времени, в течение которого происходит вторжение обвально-оползневого массива в водохранилище, $U_{0}$ - средняя скорость вторжения.

Начальные и граничные условия для рассматриваемой задачи ставятся в следующем виде [7-21]:

$$
\begin{array}{cc}
\left.\eta(x, t)\right|_{t=0}=0, & \left.V(x, t)\right|_{t=0}=0, \\
\left.V(x, t)\right|_{x=0}=0, & \left.V(x, t)\right|_{x=L}=0 .
\end{array}
$$

Система дифференциальных уравнений (1) и (2) совместно с начальными условиями (3) и граничными условиями (4) в совокупности представляют механико-математическую модель волнового движения воды в водохранилище в случае вторжения в нем обвально-оползневого массива либо селе-лавинообразного потока. Составленная модель представляет линейную начально-краевую задачу математической физики. В результате решения поставленной задачи определятся неизвестные функции $\eta(x, t)$ и $V(x, t)$, представляющие амплитуду и скорость образованных волн. 
При известных функциях $\eta(x, t)$ и $V(x, t)$ легко можно определить волновое повышение воды в створе плотины, а также объем и расход воды, которая может перехлестнуть через гребень плотины. В свою очередь этими данными возможно прогнозировать, а затем предотвратить либо смягчить разрушительные последствия и ущерб, которые может вызвать образование разрушительных волн.

Систему (1)-(2), состоящую из двух дифференциальных уравнений первого порядка, можно привести к одному дифференциальному уравнению второго порядка. Для этого надо ввести вспомогательную функцию $\Phi(x, t)$, дважды дифференцируемую относительно переменных $x$ и $t$ [18-29]:

$$
V(x, t)=\frac{\partial \Phi(x, t)}{\partial x}, \quad \eta(x, t)=-\frac{1}{g} \frac{\partial \Phi(x, t)}{\partial t} .
$$

Непосредственной проверкой можно убедиться, что дифференциальное уравнение (1), записанное через функцию $\Phi(x, t)$, превращается в тождество, а уравнение (2) приводится к следующему виду:

$$
\begin{aligned}
\frac{\partial^{2} \Phi}{\partial t^{2}}-g H(x) \frac{\partial^{2} \Phi}{\partial x^{2}} & -g\left[H^{\prime}(x)+H(x) \frac{B^{\prime}(x)}{B(x)}\right] \frac{\partial \Phi}{\partial x}= \\
& =-\frac{g H(x)}{B(x)} U(x, t) .
\end{aligned}
$$

Начальные и граничные условия (3) и (4) через функцию $\Phi(x, t)$ запишутся в следующем виде:

$$
\begin{aligned}
& \left.\Phi(x, t)\right|_{t=0}=0,\left.\frac{\partial \Phi(x, t)}{\partial t}\right|_{t=0}=0, \\
& \left.\frac{\partial \Phi}{\partial x}\right|_{x=0}=0,\left.\quad \frac{\partial \Phi}{\partial x}\right|_{x=L}=0 .
\end{aligned}
$$

Дифференциальное уравнение (5) с начальными условиями (6) и граничными условиями (7) в совокупности представляют начально-краевую задачу математической физики [7]. Коэффициенты дифференциального уравнения (5) являются переменными, зависящими от продольной координаты $x$. В общем случае это создает большие математические трудности при попытке решить задачу аналитически.

В представленной статье удалось решить начально-краевую задачу (5)-(7) в трех частных случаях. В первом случае ширина $B(x)$ и глубина $H(x)$ заменяются своими среднеинтегральными значениями в пределах длины водоема:

$$
H_{0}=\frac{1}{L} \int_{0}^{L} H(x) d x, B_{0}=\frac{1}{L} \int_{0}^{L} B(x) d x .
$$

Во втором случае глубина заменяется своим среднеинтегральным значением, а зависимость ширины $B(x)$ от продольной координаты аппроксимируется экспоненциальной функцией следующего вида:

$$
B(x)=B(0) e^{S x}, \quad S=\frac{1}{L} \ln \frac{B(L)}{B(0)},
$$

где $B(0)$ и $B(L)$ - значения ширины в начале и в конце водохранилища соответственно.

В третьем случае ширина водохранилища заменяется своим среднеинтегральным значением, а глубина аппроксимируется следующей квадратной параболой:

$$
\begin{gathered}
B_{0}=\frac{1}{L} \int_{0}^{L} B(x) d x, H(x)=H(0)(1-S x)^{2}, \\
S=\frac{\sqrt{H(0)}-\sqrt{H(L)}}{\sqrt{H(0)} L},
\end{gathered}
$$

где $H(0)$ и $H(L)$ - глубина водохранилища в створе плотины и в конце соответственно.

Вычислительными экспериментами на компьютере доказано утверждение о том, что для полного учета влияния непризматической конфигурации водоема на амплитуду образованной волны у плотины достаточно получить решение общей начально-краевой задачи (5)-(7) при вышеперечисленных трех упрощающих предположениях и допущениях.

В первом частном случае $B(x)=B_{0}=$ const, $H(x)=H_{0}=$ const. При таких упрощающих предположениях начально-краевая задача (5)-(7) существенно упрощается и принимает следующий вид:

$$
\begin{gathered}
\frac{\partial^{2} \Phi}{\partial t^{2}}-g H_{0} \frac{\partial^{2} \Phi}{\partial x^{2}}=-\frac{g H_{0}}{B_{0}} U(x, t), \\
\left.\Phi(x, t)\right|_{t=0}=0,\left.\quad \frac{\partial \Phi(x, t)}{\partial t}\right|_{t=0}=0, \\
\left.\frac{\partial \Phi}{\partial x}\right|_{x=0}=0,\left.\quad \frac{\partial \Phi}{\partial x}\right|_{x=L}=0 .
\end{gathered}
$$

Коэффициент $g H_{0}$ в дифференциальном уравнении (10) - постоянная величина. В связи с этим поставленная задача (10)-(12) непосредственно легко решается методом Фурье [14-20]. Для уравнения волновой поверхности получается следующая совокупность расчетных формул:

$$
\begin{aligned}
& \eta(x, t)=\frac{H_{0} a U_{0}}{B_{0} L} f_{0}(t)+ \\
& +\frac{H_{0} U_{0}}{B_{0} \sqrt{g H_{0}}} \sum_{n=1}^{\infty} \frac{\alpha_{n}}{a_{n}} f_{n}(t) \cos a_{n} x, \\
& f_{0}(t)=\left\{\begin{array}{ll}
t, \text { при } & 0 \leq t \leq t_{0}, \\
t_{0}, \text { nрu } & t \geq t_{0},
\end{array} \quad a_{n}=\frac{n \pi}{L},\right. \\
& f_{n}(t)= \begin{cases}\sin \left(\sqrt{g H_{0}} a_{n} t\right), & \text { nри } 0 \leq t \leq t_{0}, \\
2 \cos \left(\sqrt{g H_{0}} a_{n}\left(t-\frac{t_{0}}{2}\right)\right) \sin \left(\sqrt{g H_{0}} a_{n} \frac{t_{0}}{2}\right), \text { nри } t \geq t_{0},\end{cases} \\
& a_{n}=\frac{n \pi}{L}, \\
& \alpha_{n}=\frac{4}{L a_{n}} \cos a_{n} x_{0} \sin a_{n} \frac{a}{2}
\end{aligned}
$$

Во втором частном случае, когда глубина водохранилища осредняется в пределах длины водохранилища, а ширина аппроксимируется экспоненциальной функцией вида (8), коэффициенты дифференциально- 
го уравнения становятся постоянными величинами, а само уравнение принимает следующий вид:

$$
\begin{aligned}
\frac{\partial^{2} \Phi}{\partial t^{2}} & -g H_{0} \frac{\partial^{2} \Phi}{\partial x^{2}}-g H_{0} S \frac{\partial \Phi}{\partial x}= \\
& =-\frac{g H_{0}}{B_{0}} e^{-S x} U(x, t) .
\end{aligned}
$$

В результате применения подстановки

$$
\Phi(x, t)=\varphi(x, t) e^{-\frac{S}{2} x}
$$

начально-краевая задача (17), (11) и (12) через введенную функцию $\varphi(x, t)$ перепишется в таком виде:

$$
\begin{gathered}
\frac{\partial^{2} \varphi}{\partial t^{2}}-g H_{0} \frac{\partial^{2} \varphi}{\partial x^{2}}-g H_{0} \frac{S^{2}}{4} \varphi=-\frac{g H_{0}}{B_{0}} e^{-\frac{S}{2} x} U(x, t), \\
\left.\varphi(x, t)\right|_{t=0}=0,\left.\quad \frac{\partial \varphi(x, t)}{\partial t}\right|_{t=0}=0 \\
\left.\left(\frac{\partial \varphi}{\partial x}-\frac{S}{2} \varphi\right)\right|_{x=0}=0,\left.\quad\left(\frac{\partial \varphi}{\partial x}-\frac{S}{2} \varphi\right)\right|_{x=L}=0 .
\end{gathered}
$$

Далее вводится еще одна вспомогательная функция $\psi(x, t)$ и применяется следующая подстановка:

$$
\frac{\partial \varphi}{\partial x}-\frac{S}{2} \varphi=\psi(x, t) .
$$

Начально-краевая задача (18)-(20) через функцию $\psi(x, t)$ перепишется в следующем виде:

$$
\begin{gathered}
\frac{\partial^{2} \psi}{\partial t^{2}}-g H_{0} \frac{\partial^{2} \psi}{\partial x^{2}}-g H_{0} \frac{S^{2}}{4} \psi=\left(-\frac{g H_{0}}{B_{0}} e^{-\frac{S}{2} x} U(x, t)\right)_{x}^{\prime}+ \\
+\frac{S}{2} \frac{g H_{0}}{B_{0}} e^{-\frac{S}{2} x} U(x, t), \\
\left.\psi(x, t)\right|_{t=0}=0,\left.\frac{\partial \psi(x, t)}{\partial t}\right|_{t=0}=0, \\
\left.\psi(x, t)\right|_{x=0}=0,\left.\psi(x, t)\right|_{x=L}=0 .
\end{gathered}
$$

Полученная начально-краевая задача (21)-(23) как и в первом случае решена методом Фурье [14-20].

Для уравнения волновой поверхности получена следующая совокупность расчетных формул:

где

$$
\begin{gathered}
\eta(x, t)=\frac{H_{0} a U_{0} S}{B_{0}\left(e^{S L}-1\right)} f_{0}(t)+\frac{U_{0} H_{0} e^{-\frac{S}{2} x}}{B_{0} \sqrt{g H_{0}}} \sum_{n=1}^{\infty} \mathrm{x} \\
\mathrm{x} \sum_{n=1}^{\infty} \frac{\alpha_{n}\left(\frac{S}{2} \sin a_{n} x+a_{n} \cos a_{n} x\right) f_{n}(t)}{a_{n}^{2}+\frac{S^{2}}{4}}, \\
\alpha_{n}=\frac{2}{L} \int_{x_{0}-\frac{a}{2}}^{x_{0}+\frac{a}{2}} e^{-\frac{S}{2} x}\left(\frac{S}{2} \sin a_{n} x+a_{n} \cos a_{n} x\right) d x, \\
a_{n}=\frac{n \pi}{L} .
\end{gathered}
$$

Функции $f_{0}(t)$ и $f_{n}(t)$ в этом случае не изменились и имеют вид (14) и (15) соответственно.

В пределе, когда $S \rightarrow 0$, совокупность расчетных формул (24)-(25) переходит в совокупность (13)-(16).

В третьем случае, когда ширина водоема $B(x)$ заме- няется своим среднеинтегральным значением, а глубина $H(x)$ воды в водохранилище аппроксимирована квадратной параболой (9), общая начально-краевая задача приводится к следующему виду:

$$
\begin{aligned}
\frac{\partial^{2} \Phi}{\partial t^{2}}-g H_{0}(1-S x)^{2} & \frac{\partial^{2} \Phi}{\partial x^{2}}+2 g H_{0} S(1-S x) \frac{\partial \Phi}{\partial x}= \\
& =-\frac{g H\left(x_{0}\right)}{B_{0}} U(x, t), \\
\left.\Phi(x, t)\right|_{t=0} & =0,\left.\frac{\partial \Phi(x, t)}{\partial t}\right|_{t=0}=0, \\
\left.\frac{\partial \Phi}{\partial x}\right|_{x=0} & =0,\left.\quad \frac{\partial \Phi}{\partial x}\right|_{x=L}=0 .
\end{aligned}
$$

В результате, применяя подстановки (то есть замена переменной)

$$
x=\frac{1-e^{-S z}}{S}, \quad z=-\frac{\ln |1-S x|}{S},
$$

начально-краевая задача (26)-(28) через новую независимую переменную $z$ существенно упрощается и принимает следующий вид:

$$
\begin{gathered}
\frac{\partial^{2} \Phi}{\partial t^{2}}-g H_{0} \frac{\partial^{2} \Phi}{\partial z^{2}}+g H_{0} S \frac{\partial \Phi}{\partial z}=-\frac{g H\left(x_{0}\right)}{B_{0}} U(z, t) \\
\left.\Phi(x, t)\right|_{t=0}=0,\left.\quad \frac{\partial \Phi(x, t)}{\partial t}\right|_{t=0}=0 \\
\left.\frac{\partial \Phi}{\partial z}\right|_{z=0}=0,\left.\quad \frac{\partial \Phi}{\partial z}\right|_{z=L_{1}}=0
\end{gathered}
$$

Коэффициенты дифференциального уравнения (29) стали постоянными величинами и начально-краевая задача (29)-(31) вновь решается легко методом Фурье.

Для волновой поверхности получается следующая совокупность расчетных формул:

$$
\begin{gathered}
\eta(x, t)=\frac{H_{0} a U_{0} S}{B_{0}\left(e^{S L}-1\right)} f_{0}(t)+ \\
+\frac{U_{0} H e^{-\frac{S}{2} z}}{B_{0} \sqrt{g H_{0}}} \sum_{n=1}^{\infty} \frac{\alpha_{n}\left(\frac{S}{2} \sin a_{n} z+a_{n} \cos a_{n} z\right) f_{n}(t)}{a_{n}^{2}+\frac{S^{2}}{4}}, \\
\alpha_{n}=\frac{2}{L_{1}} \int_{z_{0}^{1}}^{z_{0}^{2}} e^{-\frac{S}{2} z}\left(\frac{S}{2} \sin a_{n} z+a_{n} \cos a_{n} z\right) d z, \\
\left.z_{0}^{1}=-\frac{\ln |1-S| x_{n}=\frac{\ln |1-S L|}{L_{1}},}{S}, z_{0}^{2}=-\frac{a}{2}\right)\left|1-S\left(x_{0}+\frac{a}{2}\right)\right| \\
S=\frac{\sqrt{H(0)}-\sqrt{H(L)}}{\sqrt{H(0)} L} \cdot
\end{gathered}
$$


В пределе, когда $S \rightarrow 0$, совокупность расчетных формул (32)-(36) переходит в совокупность (13)-(16).

\section{2. Анализ результатов вычислительных экспериментов на компьютере}

Полученные в разделе 1 совокупности расчетных формул для всех трех способов схематизации конфигурации водохранилища реализованы на компьютере и выполнены вычислительные эксперименты по определению амплитуды образованной волны вытеснения у створа плотины. До начала экспериментов вручную определяются скорость $U_{0}$ и промежуток $t_{0}$ времени вторжения обвально-оползневого массива в чашу водохранилища.

Последовательность выполнения предварительных вычислений величин $U_{0}$ и $t_{0}$ и проведение вычислительных экспериментов на компьютере покажем на конкретном примере с условными числовыми значениями входных параметров. В качестве такого примера на рис. 2 представлена схематическая картина процесса движения обвально-оползневого массива по откосу боковой грани водохранилища, вторжения и погружения в чашу водохранилища.

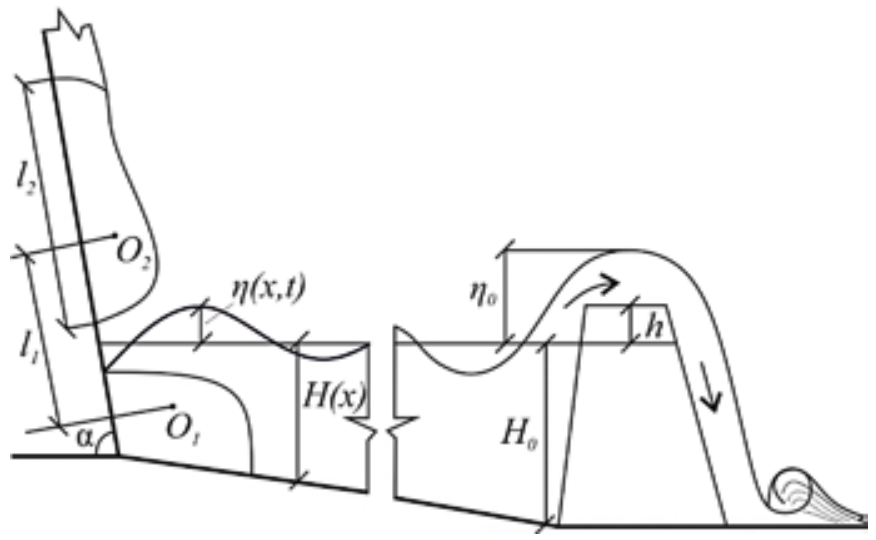

Puc. 2. Схематический рисунок процесса вторжения обвально-оползневого массива в водохранилище. $l_{1}$ - длина пути пробега массива; $l_{2}$ - длина массива;

$H_{0}, H(x)$ - глубина водохранилища; $\eta_{0}, \eta(x)$ - возвышения волновой поверхности воды над уровнем свободной поверхности водохранилища; $h$ - разность между отметками гребня плотины и свободной поверхности водохранилища; $\alpha$ - угол наклона склона к горизонту

Fig. 2. Schematic drawing of the process of landslide intrusion into the reservoir.

$l_{1}$ - length of the path of the path of the array; $l_{2}$ - the length of the array; $H_{0}, H(x)$ - depth of reservoir; $\eta_{0^{\prime}} \eta(x)$ is the wave elevation of the water surface above the level of the free surface of the reservoir; $h$-difference between the elevations of the crest of the dam and the free surface of the reservoir; $\alpha$-the angle of slope to the horizon

Для вычисления скорости вторжения массива проще всего использовать упрощенную формулу из теоретической механики для скорости движения по склону фрикционного тела, имеющую следующий вид:

$$
U_{0}=\frac{2}{3} \sqrt{2 g(\sin \alpha-f \cos \alpha) l_{1}},
$$

где $l_{1}$ - длина пути движения обвально-оползневого массива вдоль склона, $\alpha$ - угол наклона склона к горизонту, $f$ - коэффициент сухого трения на поверхности склона.

При условных значениях длины пути движения $l_{1}=50 \mathrm{м}$, коэффициента трения $f=0.25$, длины массива $l_{2}=200$ м, угла наклона склона $\alpha=27^{\circ}$, для скорости $U_{0}$ и промежутка времени вторжения получаются следующие числовые значения: $U_{0}=10.04 \mathrm{~m} / \mathrm{c}, t_{0}=20 \mathrm{c}$. Остальным входным параметрам присвоили следующие значения: длина водохранилища $L=3000 \mathrm{м}$; ширина водохранилища $B_{0}=300 \mathrm{~m}$; длина участка боковой грани, через которую происходит вторжение $a=100 \mathrm{M}$.

На рис. 3 представлены графики зависимости величины

$$
\frac{\eta(0, t)}{U_{0}}
$$

от времени $t$, где $\eta(0, t)$ - возвышение волновой поверхности над уровнем воды у плотины. Эксперименты выполнены и представлены на рис. 3 для следующих трех значений глубины водохранилища: $H_{0}=50$ м, 75 м и 100 м. При этом считается, что вторжение обвально-оползневого массива в чашу водохранилища происходит по всей глубине водохранилища. Максимальные значения величины (37) равны 0.904, 1.08 и 1.22 секунд соответственно. Эти результаты вычислительных экспериментов позволяют вычислить амплитуду $\eta_{0}$ образованной волны вытеснения у плотины, а также расход и скорость перелива (перехлеста) воды через гребень плотины. Результаты этих вычислений приведены в таблице.

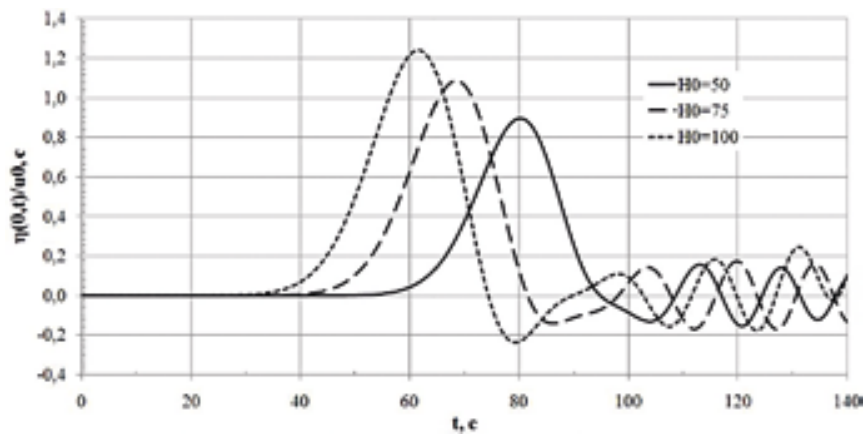

Puc. 3. Результаты выполненных вычислительных экспериментов на компьютере. Графики зависимости величины $\eta(0, t) / U_{0}$ от времени при следующих трех значениях глубины воды в водохранилище: $H_{0}=50,75$ и 100 м

Fig. 3. Results of computational experiments performed on a computer. Graphs of the dependence of the value of $\eta(0, t) / U_{0}$ on time for the following three values of water depth in the reservoir: $H_{0}=50 \mathrm{~m}, 75 \mathrm{~m}, 100 \mathrm{~m}$

\begin{tabular}{|c|c|c|c|}
\hline $\begin{array}{c}\text { Глубина, м } \\
\text { Depth, } m \\
\boldsymbol{H}_{\mathbf{0}}\end{array}$ & $\begin{array}{c}\text { Амплитуда, } \\
\mathbf{M} \\
\text { Amplitude, } m \\
\boldsymbol{\eta}_{\mathbf{0}}\end{array}$ & $\begin{array}{c}\text { Расход, } \\
\mathbf{M}^{3} / \mathbf{c} \\
\text { Consumption, } \\
\mathrm{m}^{3} / \mathrm{s} \\
\boldsymbol{Q}\end{array}$ & $\begin{array}{c}\text { Скорость, } \\
\mathbf{\mathbf { m }} / \mathbf{c} \\
\text { Speed, } \mathrm{m} / \mathrm{s} \\
\boldsymbol{V}\end{array}$ \\
\hline 50 & 9.04 & 3780 & 3.12 \\
\hline 75 & 10.7 & 6370 & 3.7 \\
\hline 100 & 12.4 & 9364 & 4.2 \\
\hline
\end{tabular}


При известных значениях амплитуды образованной волны у плотины расход и скорость перелива (перехлеста) воды через гребень плотины вычислены известными формулами гидравлики водослива с широким порогом [18]:

$$
\begin{gathered}
Q=0.35 B_{0} \sqrt{2 g}\left(\eta_{0}-h_{0}\right)^{1.5}, \\
V=0.35 \sqrt{2 g\left(\eta_{0}-h_{0}\right)},
\end{gathered}
$$

где $h_{0}$ - разность между отметкой гребня плотины и отметкой уровня воды в водохранилище. Его условное числовое значение в расчетах принято $h_{0}=5 \mathrm{M}$.

Полученные значения расходов и скоростей перелива воды через гребень плотины значительно превосходят размывающие (критические) значения для земляной и даже для каменно-набросной плотины. Это может привести к интенсивному размыву грунта и образованию прорана в теле плотины. В результате этого по ущелью реки потечет мощный паводковый поток в виде прорывной волны с опасными последствиями.

Результаты вычислительных экспериментов, представленных на рис. 3, относятся к первому способу схематизации конфигурации водохранилища, когда ширина и глубина - постоянные величины: $B_{0}=$ const и $H_{0}=$ const.

Обработка и анализ остальных результатов вычислительных экспериментов позволили сформулировать и вычислительными экспериментами доказать следующее утверждение.

Для того чтобы определить амплитуду волны вытеснения у плотины, надо выполнить следующие операции:

1. Вначале переменную ширину $B(x)$ и переменную глубину $H(x)$ заменить на их средние интегральнье значения в пределах иприны по фронту обвально-оползневого массива:

$$
\begin{gathered}
B_{0}=\frac{1}{a} \int_{x_{0}-\frac{a}{2}}^{x_{0}+\frac{a}{2}} B(x) d x, \\
H_{0}=\frac{1}{a} \int_{x_{0}-\frac{a}{2}}^{x_{0}+\frac{a}{2}} H(x) d x .
\end{gathered}
$$

\section{ЛИТЕРАТУРА:}

1. Klyuev R. V., Bosikov I. I., Mayer A. V., Gavrina O. A. Comprehensive analysis of the effective technologies application to increase sustainable development of the naturaltechnical system // Sustainable Development of Mountain Territories. 2020. N2. P. 283-290.

2. Klyuev R., Bosikov I., Gavrina O., Madaeva M., Sokolov A. (2021) Improving the energy efficiency of technological equipment at mining enterprises. In: Murgul V., Pukhkal V. (eds) International Scientific Conference Energy Management of Municipal Facilities and Sustainable Energy Technologies EMMFT 2019. EMMFT 2019. Advances in Intelligent Systems and Computing, vol. 1258, pp. 262-271, Springer, Cham. https://doi.org/10.1007/978-4-030-57450-5_24.

3. Klyuev R., Fomenko O., Gavrina O., Turluev R., Marzoev S. (2021) Energy indicators of drilling machines and
2. По значениям $B_{0}$ и $H_{0}$ выполнить вычислительный эксперимент и вычислить амплитуду $\eta_{0}$ образованной волны вытеснения у плотины.

3. Для вычисления значения амплитуды $\eta$ у плотины с учетом истинных значений ширины $B(0)=B u$ глубины $H(0)=H$ водохранилища у плотины надо воспользоваться следующей формулой Грина [9]:

$$
\eta=\sqrt{\frac{B_{0}}{B}} \sqrt[4]{\frac{H}{H_{0}}} \eta_{0} .
$$

\section{Заключение}

1. Доказано утверждение о том, что волна вытеснения, которая может образовываться в случае вторжения в чашу водохранилища обвально-оползневого массива горной породы либо селелавинообразного потока, может быть крайне опасной из-за возможного перехлеста воды через гребень грунтовой и даже каменно-набросной плотины. Следовательно, прогнозирование возможных высот волн вытеснения, даже в случае, когда откосы бортов водохранилища имеют достаточный запас устойчивости, представляется весьма желательным, а в случаях, когда ниже плотины по руслу реки находятся объекты жизнеобеспечения, даже обязательным.

2. В приложении к вышеописанной проблеме в статье разработана механико-математическая модель волнового движения воды в водохранилище, когда движение воды вызвано вторжением в чашу обвально-оплзневого массива горной породы либо высокоскоростного селелавинообразного потока. Модель представляет начально-краевую задачу гидродинамики. Поставленная задача решена аналитически методами математической физики. Получены совокупности расчетных формул, которые позволяют вычислить амплитуду образованной волны вытеснения у плотины, объем и расход воды, которая может быть перелита через гребень плотины, а также зону и степени затопления местности в бьефах плотины. Этими данными можно прогнозировать, предотвратить либо смягчить те последствия и ущерб, которые может вызвать образование разрушительных волн вытеснения.

excavators in mountain territories. In: Murgul V., Pukhkal V. (eds). International Scientific Conference Energy Management of Municipal Facilities and Sustainable Energy Technologies EMMFT 2019. EMMFT 2019. Advances in Intelligent Systems and Computing, vol. 1258, pp. 272-281, Springer, Cham. https://doi.org/10.1007/978-4-030-57450-5_25.

4. Klyuev R. V., Bosikov I. I., Egorova E. V., Gavrina O. A. Assessment of mining-geological and mining technical conditions of the Severny pit with the use of mathematical models // Sustainable Development of Mountain Territories. 2020. N3. Pp. 418427. DOI: 10.21177/1998-4502-2020-12-4-418-427.

5. Svalova V. B., Zaalishvili V. B., Ganapathy G. P., Nikolaev A. V. Natural hazards and disasters in mountain areas // Geology and Geophysics of Russian South. 2018. 8(2): 87101. (In Russ.) DOI: 10.23671/VNC.2018.2.14360. 
6. Svalova V. B., Zaalishvili V. B., Ganapathy G. P., Nikolaev A. V., Melkov D. A. Landslide risk in mountain areas // Geology and Geophysics of Russian South (in Russ.). 2019. 9 (2). Pp. 109-127. DOI: 10.23671/ VNC.2019.2.31981.

7. Svalova V. B., Zaalishvili V. B., Ganapathy G. P., Nikolaev A. V., Ginzburg A. A. Complex Environmental Monitoring in Russia and India // Geology and Geophysics of Russian South. 2019. 9(4): 87-101. (In Russ.) DOI: 10.23671/ VNC.2019.4.44491.

8. Zaalishvili V. B. Spectral characteristics of seismic waves at strong ground motions // International Journal of GEOMATE. 2016. T. 10. N2. Pp. 1706-1717.

9. Мюллер Л. Оползень в долине реки Вайонт. Проблемы инженерной геологии. Вып. 4. М.: Мир, 1967. 358 с.

10. Федоренко В. И. Основные инженерно-геологические аспекты проблемы Сарезского озера // Инженерная геология. 1981. N 3. С. 21-28.

11. Григорян С. С., Остроумов А. В., Нилов Н. Н., Федоренко В. С. Математическое моделиование горных обвалов и оползней больших объемов // Инженерная геология. 1983. N 6. C. 61-71.

12. Noda E.K. Water waves generated by landslides // Journal of the Waterways, Harbours and Coastal Engineering Division. 1970. Vol. 96. N ww4. Pp. 835-855.

13. Wiegel R. L. Water waves generated by landslides in reservoirs // Journal of the Waterways and Harbours Division. ASLL. 1970. Vol. 96. N ww2. Pp. 13-23.

14. Мамрадзе Г. П., Музаев И. Д. Возникновение волн в водохранилище вследствие оползневых явлений // Сообщения АН ГССР. Тбилиси, 1971. Т. 64. N 4. С. 115-120.

15. Тихонов А. Н., Самарский А. А. Уравнения математической физики. М.: Наука, 1972. 735 с.

16. Шокин Ю. И., Бейзель С. А. и др. Численное исследование дисперсионных волн, возникающих при движении подводного оползня // Вестник Южно-Уральского государственного университета. Сер. Математическое моделирование и программирование. 2014. Т. 7. N 1. С. 121-133.

17. Ламб Г. Гидродинамика. Т. 2. Москва-Ижевск: НИЦ, 2003. 482 с.

18. Штеренлихт Д. В. Гидравлика. М.: Колос, 2004. $655 \mathrm{c}$.

19. Muzaev I. D., Gvazava G. N., Kereselidze N. B. The Large-scale three-dimensional modelling application to hydraulic investigations of the breaking-wave // XIX Congress IAHR. New Delhi, India, 1981. Pp. 351-360.

20. Музаев И. Д., Музаев Н. И. Математическое моделирование сейсмических колебаний системы, состоящей из водохранилища, плотины, фундаментного блока и подфундаментных слоев грунта // Вычислительные технологии. 2015. Т. 20. N 4. С. 45-55.

21. Михайлов И.Е. Новый подход к исследованию потенциальных течений, которые не имеют аналитического выражения функции потенциала скорости // Гидротехническое строительство. 2015. N 2. С. 32-44.

22. Натишвили О.Г., Круашвили И.Г., Инашвили И.Д. Ударное воздействие структурного селевого потока на поперечные сооружения // Гидротехническое строительство. 2018. N 2. C. $46-48$.

23. Прокофьев В.А. Решение волновых задач с помощью многослойной модели открытого потока // Гидротехническое строительство. 2016. N 7. С. 18-25.

24. Шокин Ю. И., Хакимзянов Г. С. и др. О численных методах решения задач о накате волн на берег // Вычислительные технологии. 2015. Т. 20. N 5. С. 214-232.

25. Шокин Ю. И., Чубаров Л. Б. Численное моделирование наката волн цунами на побережье с использованием метода крупных частиц // Математическое моделирование. 2015. T. 27. N 1. C. 99-112.

26. Мацкевич Н.А., Чубаров Л.Б. Точные решения уравнения мелкой воды для задачи о колебании жидкости в модельной акватории и их применение в верификации численных алгоритмов // Сибирский журнал вычислительной математики. 2019. N 3. С. 281-299.

27. Зайцев А. И., Пелиновский Е. Н. и др. Вычислительный комплекс НАМИ-ДАНС в проблеме цунами // Вычислительная механика сплошных сред. 2019. N 2. C. $161-174$.

28. Талипова Т. Г., Пелиновский Е. Н. и др. Аналитическая теория и численное моделирование нелинейных волновых пакетов (бризеров) в океане, стратифицированном по плотности и течению // Вычислительные технологии. 2019. N 2. С. 99-110.

29. Зайцев А. И., Пелиновский Е. Н. и др. Деформация дна под действием длинных волн в рамках двухслойной модели Имамуры // Экологические системы и приборы. 2020. N 6. C. $40-48$.

\section{СВЕДЕНИЯ ОБ АВТОРАХ / Information about authors:}

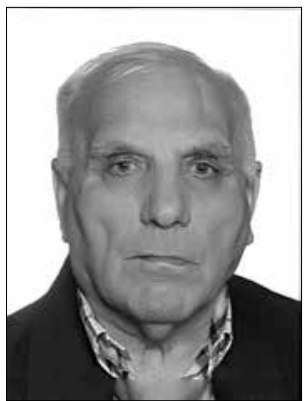

МУЗАЕВ Илларион Давидович - доктор технических наук, профессор.

Геофизический институт - филиал Федерального государственного бюджетного учреждения науки Федерального научного центра «Владикавказский научный центр Российской академии наук».

Владикавказский филиал Финансового университета при Правительстве Российской Федерации. 362002, РСО-А, Владикавказ, Россия.

Тел.: +7(8672)76-40-31.

e-mail: idmuzaev@,fa.ru

Illarion D. MUZAEV - Doctor of Technical Sciences, Professor.

Geophysical Institute - Branch of the Federal State Budgetary Institution of Science of the Federal Scientific Center "Vladikavkaz Scientific Center of the Russian Academy of Sciences".

Vladikavkaz Branch of the Financial University under the Government of the Russian Federation.

Vladikavkaz, 362002, Russia

Ph.: +7(8672)76-40-31.

e-mail:idmuzaev@fa.ru 


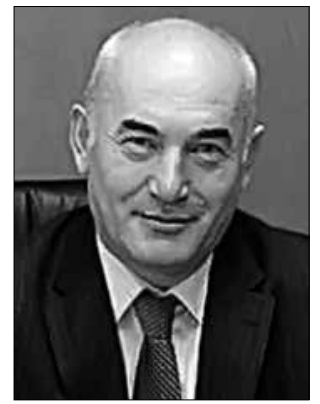

СОЗАНОВ Валерий Гаврилович - доктор технических наук, профессор.

Северо-Осетинский государственный университет им. К.Л. Хетагурова.

362025, РСО-А, Владикавказ, Россия.

Тел.: +7(918)822-38-66.

e-mail: v.sozanov@mail.ru

Valery G. SOZANOV - Doctor of Technical Sciences, Professor.

North Ossetian State University after K.L. Khetagurov.

Vladikavkaz, 362025, Russia.

Ph.: +7(918)822-38-66.

e-mail:v.sozanov@mail.ru

\title{
MATHEMATICAL MODELING OF WATER WAVE MOTION IN A RESERVOIR CAUSED BY THE INTRUSION OF A LANDSLIDE ARRAY
}

\author{
I. D. Muzaev ${ }^{1,2^{*} \text {, }}$ \\ V. G. Sozanov ${ }^{3}$ \\ ${ }^{1}$ Geophysical Institute - Branch of the Federal State Budgetary Institution of Science of the Federal Scientific Center \\ "Vladikavkaz Scientific Center of the Russian Academy of Sciences”, 93a, Markov St., Vladikavkaz, 362002, Russia, Illarion. \\ muzaev@yandex.ru \\ ${ }^{2}$ Vladikavkaz Branch of the Financial University Under the Government of the Russian Federation, 7 Moldezhnaya St., \\ 362002, Vladikavkaz, RSO-A, Russia \\ ${ }^{3}$ North Ossetian State University after K. L. Khetagurov, 46 Vatutina St., Vladikavkaz, 362025, Russia
}

\section{DOI: $10.21177 / 1998-4502-2020-12-4-555-564$}

The construction of dams and reservoirs in mountainous and foothill areas poses a number of urgent tasks for designers and researchers related to the wave movement of water in a reservoir with a complex geometric configuration. The collapse of significant masses of rock into the reservoir basin as a result of a landslide phenomenon provokes high surface waves, leading to catastrophic natural disasters in the form of victims and destruction. Designers, construction organizations and maintenance services are required to assess the expected wave increase in water level through the dam crest, as well as the zone and degree of flooding of the area in the reservoir bays and along the river gorge, depending on the geometric, kinematic and dynamic characteristics of potentially possible landslide massifs, mudslides and avalanche flows. In this way, you can predict and then prevent or mitigate the consequences and damage that can cause the formation of destructive waves.

In addition to the above problem, this article develops a mathematical model of the wave movement of water in a reservoir, when the movement is caused by the intrusion of a landslide rock mass or a high-speed mudflow into its bowl. The model is the initial boundary value problem of hydrodynamics and hydraulics of gravitational waves.

In contrast to previous works, the developed mathematical model takes into account the planned non-prismatic configuration of the reservoir and changes in the water depth in the longitudinal direction of the reservoir. Taking these factors into account significantly clarifies the numerical values of the amplitude of the wave formed, as well as the values of the flow rate, speed and volume of water poured over the dam crest.

In the General initial-boundary value problem, the coefficients of the main differential equation are variables that depend on the spatial coordinate. In the General formulation, this creates great difficulties in the analytical solution of the problem and has not been solved by anyone in the whole world to date.

In this article was found and applied original and effective substitution, i.e. replacing a variable that in two special cases based on the coefficients from the spatial coordinates that led basic differential equation initial-boundary value problem to the equation with constant coefficients, and thus substantially easier way of solving the initial-boundary value problem.

In the above-mentioned special cases, the initial-boundary value problem is solved by strict analytical methods of mathematical physics. For each case, a set of calculation formulas is obtained for calculating the amplitude of the waves formed, as well as for the flow rate and volume of water poured over the dam crest.

Keywords: Displacement wave, initial boundary value problem, Fourier method, dam relief, slope safety margin, geotechnical characteristics of slopes, landslide array.

\section{References:}

1. Klyuev R. V., Bosikov I. I., Mayer A. V., Gavrina O. A. "Comprehensive analysis of the effective technologies application to increase sustainable development of the naturaltechnical system", Sustainable Development of Mountain Territories, 2020, no.2, pp. 283-290.

2. Klyuev R., Bosikov I., Gavrina O., Madaeva M., Sokolov A. (2021), "Improving the energy efficiency of technological equipment at mining enterprises", In: Murgul V., Pukhkal V. (eds), International Scientific Conference Energy Management of Municipal Facilities and Sustainable Energy Technologies EMMFT 2019. EMMFT 2019. Advances in Intelligent Systems and Computing, vol.1258, pp. 262-271, Springer, Cham. https://doi.org/10.1007/978-4-030-574505_24. 
3. Klyuev R., Fomenko O., Gavrina O., Turluev R., Marzoev S. (2021), "Energy indicators of drilling machines and excavators in mountain territories", In: Murgul V., Pukhkal V. (eds), International Scientific Conference Energy Management of Municipal Facilities and Sustainable Energy Technologies EMMFT 2019. EMMFT 2019. Advances in Intelligent Systems and Computing, vol 1258, pp. 272-281, Springer, Cham. https://doi.org/10.1007/978-4-030-57450$5 \_25$.

4. Klyuev R. V., Bosikov I. I., Egorova E. V., Gavrina O. A. "Assessment of mining-geological and mining technical conditions of the Severny pit with the use of mathematical models", Sustainable Development of Mountain Territories, 2020, no.3, pp. 418-427. DOI: 10.21177/1998-4502-202012-4-418-427.

5. Svalova V.B., Zaalishvili V.B., Ganapathy G.P., Nikolaev A.V. Natural hazards and disasters in mountain areas. Geology and Geophysics of Russian South. 2018. 8(2): 87101. (In Russ.) DOI: $10.23671 /$ VNC.2018.2.14360.

6. Svalova V. B., Zaalishvili V. B., Ganapathy G. P., Nikolaev A. V., Melkov D. A. "Landslide risk in mountain areas", Geology and Geophysics of Russian South (in Russ.), 2019; 9 (2): 109-127. DOI: 10.23671/ VNC.2019.2.31981.

7. Svalova V. B., Zaalishvili V. B., Ganapathy G. P., Nikolaev A.V., Ginzburg A. A. "Complex Environmental Monitoring in Russia and India", Geology and Geophysics of Russian South, 2019. 9(4): 87-101. (In Russ.) DOI: 10.23671/VNC.2019.4.44491.

8. Zaalishvili V. B. "Spectral characteristics of seismic waves at strong ground motions", International Journal of GEOMATE, 2016, v.10, no. 2, pp. 1706-1717.

9. Muller L. "The Landslide in the Valley of Vajont", Problems of Engineering Geology, Issue 4, Moscow, Mir, 1967,358 p. (in Russian)

10. Fedorenko V. I. "Main engineering and geological problems of lake Sarez", Engineering Geology, 1981, no. 3, pp. 21-28. (in Russian)

11. Grigoryan S. S., Ostroumov A. V., Nilov N. N., Fedorenko V. S. "Mathematical modeling of mountain collapses and landslides of large volumes", Engineering Geology, 1983, no. 6, pp. 61-71. (in Russian)

12. Noda E. K. "Water waves generated by landslides", Journal of the Waterways, Harbours and Coastal Engineering Division, 1970, vol. 96, no. ww4, pp. 835-855.

13. Wiegel R. L. "Water waves generated by landslides in reservoirs", Journal of the Waterways and Harbours Division, ASLL, 1970, vol. 96, no. ww2, pp. 13-23.

14. Mamradze G. P., Muzaev I. D. "Occurrence of waves in the reservoir due to landslide phenomena", Messages of the GSSR Academy of Sciences, Tbilisi, 1971, vol. 64, no. 4, pp. 115-120. (in Russian)

15. Tikhonov A. N., Samarsky A. A. Equations of Mathematical Physics, Moscow, Nauka, 1972, 735 p. (in Russian)

16. Shokin Yu. I., Beizel S. A. at al. "Numerical study of dispersion waves that occur during the movement of an underwater landslide", Bulletin of the South Ural State University, Series Mathematical Modeling and Programming, 2014, vol. 7, no.1, pp. 121-133. (in Russian)

17. Lamb G. Hydrodynamics, vol. 2, Moscow-Izhevsk, SIC, 2003, 483 p. (in Russian)

18. Shterenlicht D. V. Hydraulics, Moscow, Kolos, 2004, 655 p. (in Russian)

19. Muzaev I. D., Gvazava G. N., Kereselidze N. B. “The Large-scale three-dimensional modelling application to hydraulic investigations of the breaking-wave", XIX Congress IAHR, New Delhi, India, 1981, pp. 351-360.

20. Muzaev I. D., Muzaev N. I. "Mathematical modeling of seismic vibrations of a system consisting of a reservoir, dam, Foundation block and subfundament layers of soil", Computing Technology, 2015, vol. 20, no. 4, pp. 45-55. (in Russian)

21. Mikhailov I. E. "New approach to the study of potential flows that do not have an analytical expression of the velocity potential function", Hydrotechnical Construction, 2015, no. 2, pp. 32-44. (in Russian)

22. Natishvili O. G., Kruashvili I. G., Inashvili I. D. "Impact of structural mudflow on cross structures", Hydrotechnical Construction, 2018, no. 2, pp. 46-48. (in Russian)

23. Prokofiev V. A. "Solving wave problems using a multi-layer open flow model", Hydrotechnical Construction, 2016, no. 7, pp. 18-25. (in Russian)

24. Shokin Yu. I., Khakimzianov G. S. at al. "On numerical methods for solving problems of waves roll-up on the shore", Computational Technologies, 2015, vol.20, no.5, pp. 214-232. (in Russian)

25. Shokin Yu. I., Chubarov L. B. "Numerical simulation of tsunami wave roll-up on the coast using the large particle method", Mathematical Simulation, 2015, vol. 27, no.1, pp. 99-112. (in Russian)

26. Matskevich N. A., Chubarov L. B. "Exact solutions of the shallow water equation for the problem of fluid oscillation in a model water area and their application in the verification of numerical algorithms", Siberian Journal of $\mathrm{Nu}$ merical Mathematics, 2019, no. 3, pp. 281-299. (in Russian)

27. Zaitsev A. I., Pelinovski E. N. at al. "NAMI-DANS computing complex in the tsunami problem", Computational Continuum Mechanics, 2019, no.2, pp. 161-174. (in Russian)

28. Talipova T. G., Pelinovski E. N. and others. "Analytical theory and numerical modeling of nonlinear wave packets (breezers) in the ocean stratified by density and current", Computational Technologies, 2019, no. 2, pp. 99-110. (in Russian)

29. Zaitsev A. I., Pelinovski E. N. and others. "Bottom deformation under the action of long waves in the framework of the two-layer Imamura model", Environmental Systems and Devices, 2020, no. 6, pp. 40-48. (in Russian).

Article received 29.06.2020. 


\section{ФУНКЦИОНИРОВАНИЕ И ДИНАМИКА ЛАНДШАФТОВ ПРИ ПРОЕКТИРОВАНИИ АВТОМОБИЛЬНЫХ ДОРОГ В ГОРНЫХ Условиях}

\author{
Кортиев Л. И. ${ }^{1}$, \\ Кортиев А. Л. ${ }^{*}$, \\ Ванеев С. Д. ${ }^{1}$, \\ Кулумбегов Р. П. ${ }^{2}$ \\ ${ }^{1}$ Северо-Кавказский горно-металлургический институт (государственный \\ технологический университет), 362021, Владикавказ, Россия, kortiev73@mail.ru \\ ${ }^{2}$ Юго-Осетинский государственный университет, 100001, Цхинвал, \\ Республика Южная Осетия
}

\section{Введение}

Дороги, как линейные инженерные сооружения в горных условиях, в целях безопасности движения должны обеспечивать плавное сопряжение и их гармоничное сочетание с окружающим ландшафтом с применением продольных уклонов и радиусов на кривых, обеспечивающих снижение аварийности и травматизма. При строительстве горных дорог и их эксплуатации происходит значительное воздействие на ландшафт и в целом на окружающую среду. Горный ландшафт - это охраняемый государством объект и функционирование и динамика ландшафта и проложенной на ней дороги не должны вызывать отрицательное взаимовлияние друг на друга. Антропогенное вмешательство на горный природный ландшафт, в целях устройства дороги, не всегда является безопасным, т.к. слабые грунты приходят в динамику и функционирование дороги осложняется. Решение динамических характеристик участков дороги, т.е. их смещения, повысит устойчивое функционирование дороги в горных условиях с повышением проблем безопасности движения [1-3].

Суть вопроса. Проектирование автомобильных дорог в горной местности без соблюдения ландшафтных принципов безопасного функционирования и с меньшими динамическими сдвигами земляного полотна приводят к нарушению форм рельефа, с выполнением больших объемов земляных работ, необходимых для обеспечения проектируемого уклона [4] (рис. 1).

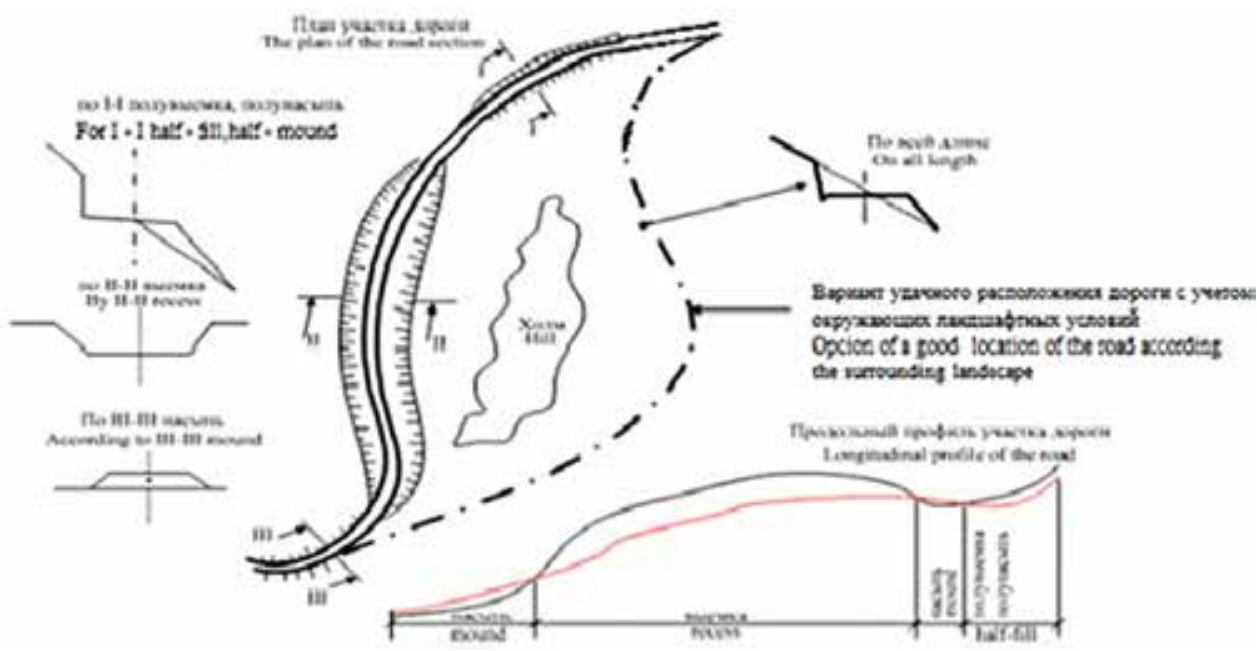

Puc. 1. Схема неудачного развития дороги на подъем без использования элементов ландшафтного проектирования и варианта удовлетворительного решения вопроса

безопасности движения

Fig. 1. The scheme of unsuccessful development of the road to rise without the use of landscape design elements and a satisfactory solution to the issue of traffic safety
УДК: $625.7 / .8$

DOI: 10.21177/1998-4502-2020$12-4-565-571$

Дороги должны максимально гармонично сочетаться с окружающей средой и с ландшафтом, что может быть достигнуто путем плавного сопряжения дороги с окружающей местностью. Это в свою очередь повышает удобство и комфорт движения, позволяет сохранить красоту природы, устраняя вызванные строительством дороги нарушения природного ландшафта.

С этой целью необходимо проводить пространственный анализ и комплексный подход к вопросу, охватывая все стороны ландшафтного проектирования дороги для ликвидации негативных последствий, как на самой дороге, так и на окружающем ее ландшафте в период их функционирования в условиях динамических воздействий от склоновых явлений. Такой комплексный подход и метод ландшафртного проектирования 6 горных условиях позволит снизить риски активизации склоновых явлений, совершения ДТП, расходы на содержание дороги, и самое главное, способствует повышению безопасности и жизнедеятельности населения горных территорий.

\section{КЛЮЧЕВЫЕ СЛОВА:}

динамика рельефа, ландшафрт, функционирование ландшафта и дороги, дизайн, эстетика, горный рельеф, подпорная стена, откосы, динамика ландшафта, обвалы, оползни.

Статья поступила в редакцию 22.07.2020. 


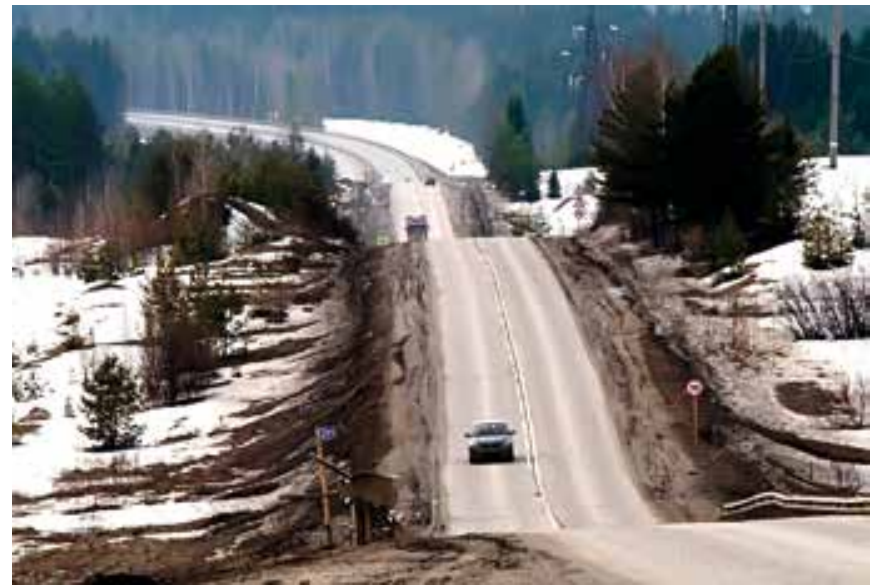

Puc. 2. Волнообразная дорога, проложенная параллельно поверхности земли без наличия причин динамических воздействий горных масс на проезжую часть

Fig. 2. Undulating road, laid parallel to the earth's surface without the presence of reasons for the dynamic impact of mountain masses on the carriageway

Из рис. 1 видно, что в целях спрямления дороги она проложена в глубоких выемках, вызывающих динамику не прочных грунтовых масс, обрушающихся на проезжую часть и создающих сложные условия функционирования дороги. Тем самым излишнее спрямление дороги приводит к нерациональному и неудобному для эксплуатации продольному профилю. Подобный нежелательный продольный профиль может быть создан из-за чередующихся подъемов и спусков поверхности земли, сопряженных с устройством вертикальных кривых, малых радиусов, что в свою очередь создают не достаточную видимость по вертикальной плоскости (рис. 2). Так, положительное решение одного вопроса или элемента дороги может вызвать негативное влияние другого элемента на безопасность дорожного движения. В таком случае взаимовлияние дороги и рельефа следует выбрать методом сравнения вариантов и предпочтение отдать варианту, обеспечивающему безопасность движения, как в продольном

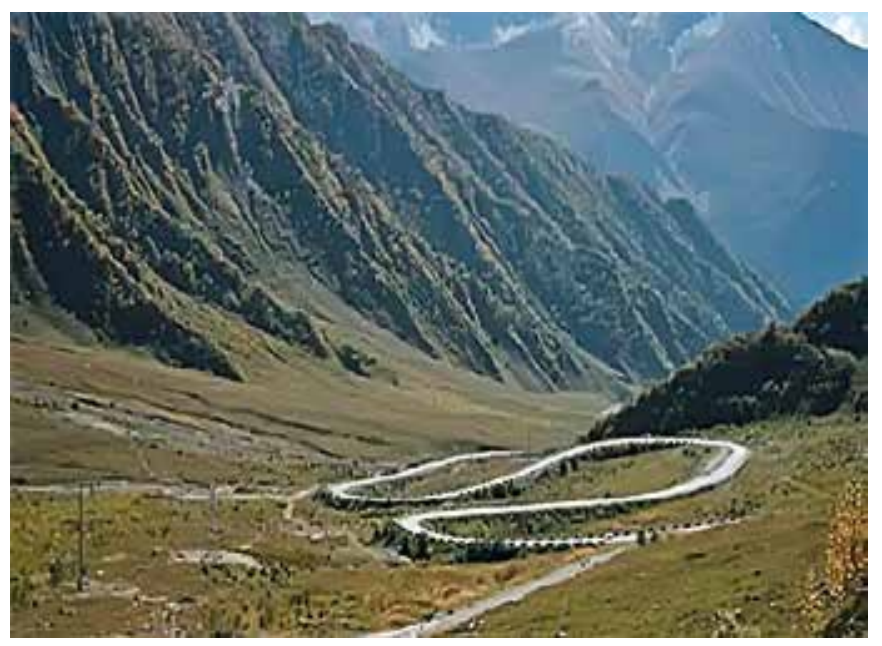

профиле, так и в плане трассы. На нашем примере участок дороги проложен без устройства выемок, с минимальным воздействием на ландшафт и, соответственно, на окружающую среду, отвечает требованиям нормального функционирования дороги [5-8] и архитектурно-дизайнерского оформления [9; 10].

При развитии дорог на склонах с применением радиусов на кривых наиболее целесообразным является прокладка трассы в насыпях в виде плавной линии, а в полувыемках и полунасыпях - по методу серпантинного развития - трассы, вписывающейся в элементы рельефа местности, что обеспечивает видимость на достаточно большое и необходимое расстояние (рис. 3).

В современных условиях с учетом необходимости развития транспортной связи в горных условиях и защиты горных территорий создаются определенные сложности в уширении дороги в сторону внутреннего (верхнего) откоса, могущего вызвать динамику и сползание рыхлых грунтов на откосы. Пример решения вопроса показан на рис. 4 , где возведена наружная подпорная стена, придающая прочность откосу и эстетичный вид. Подобный способ решения вопроса при оползневых грунтах оправдан не только в научном и практическом планах, но и в плане удобства функционирования участка дороги.

Следует обратить внимание на важный момент закрепления откосов выемок и полувыемок, применяемых для закрепления земляного полотна и защиты проезжей части от обвалов на внутренних откосах и оползней - при наружных. Иллюстрацией сказанному служит рис. 4, где показан пример устройства подпорной стены. В первом примере (рис. 4 a) при оползневых и рыхлых грунтах в целях нормального функционирования земляного полотна в статике находящаяся масса обеспечена за счет наружной стены. Если бы ширина дороги сохранилась за счет внутреннего откоса, то это вызвало бы процесс развития оползневого явления и нарушения нормального функционирования дороги при динамических неустойчивых грунтах. Так

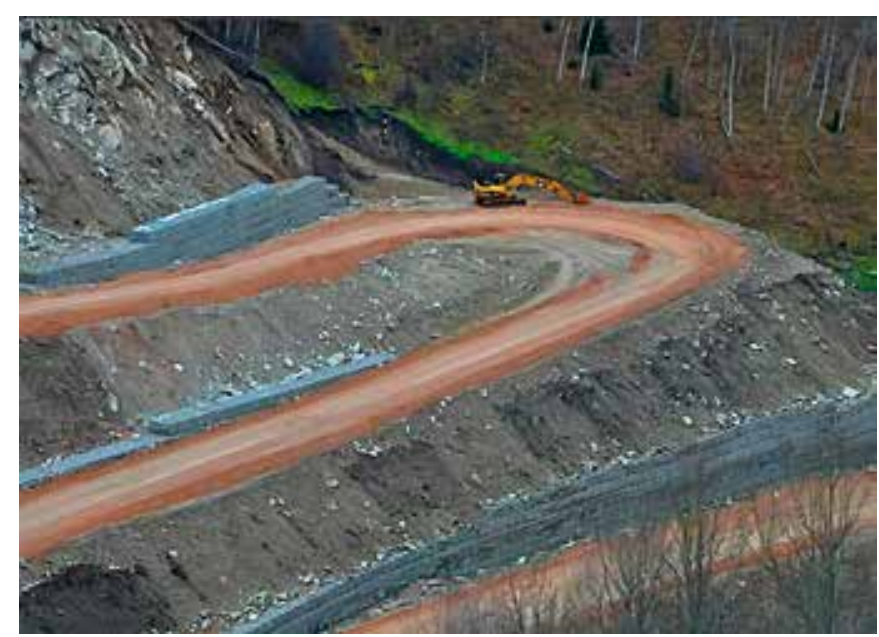

Puc. 3. Примеры строительства дороги в насыпях и в полунасыпях

Fig. 3. Examples of road construction in embankments and in semi-embankments 

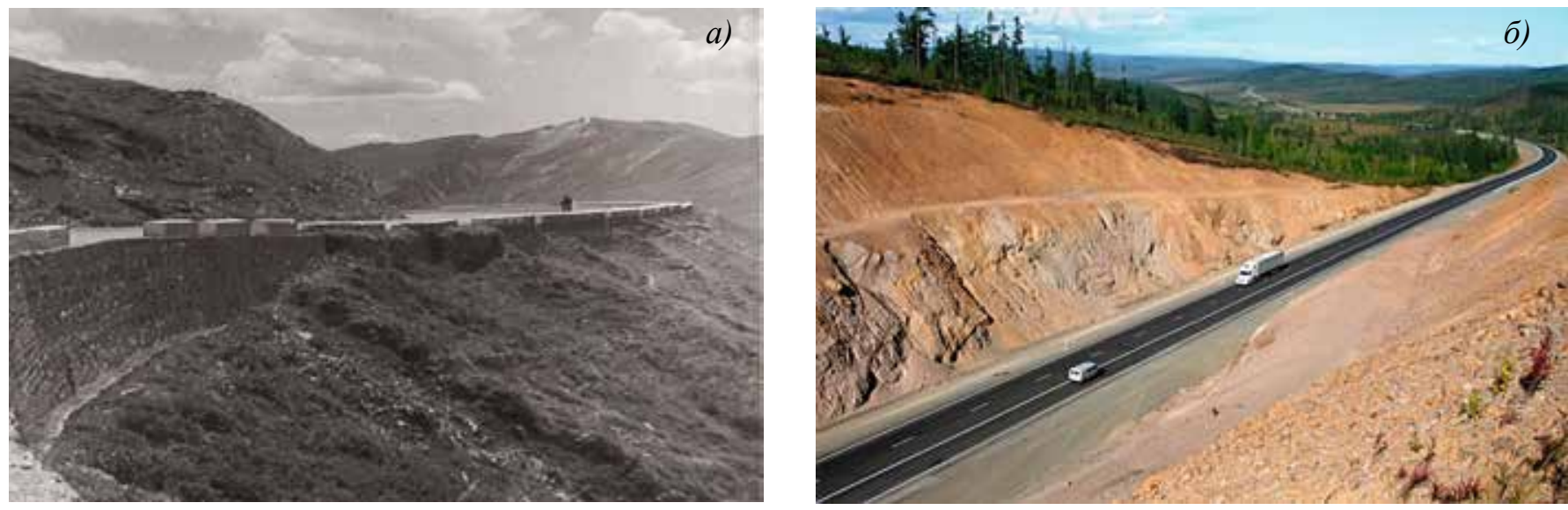

Puc. 4. Совмещение дороги со сложным рельефом местности:

$a$ - в условиях динамических воздействий грунтов (оползневых) на проезжую часть и подпорную стену;

$\sigma$ - без динамических воздействий на прочных скальных породах

Fig. 4. Combination of the road with difficult terrain:

$a$-under conditions of dynamic impacts of soils (landslide) on the roadway and retaining wall; $b$-without dynamic effects on solid rocks
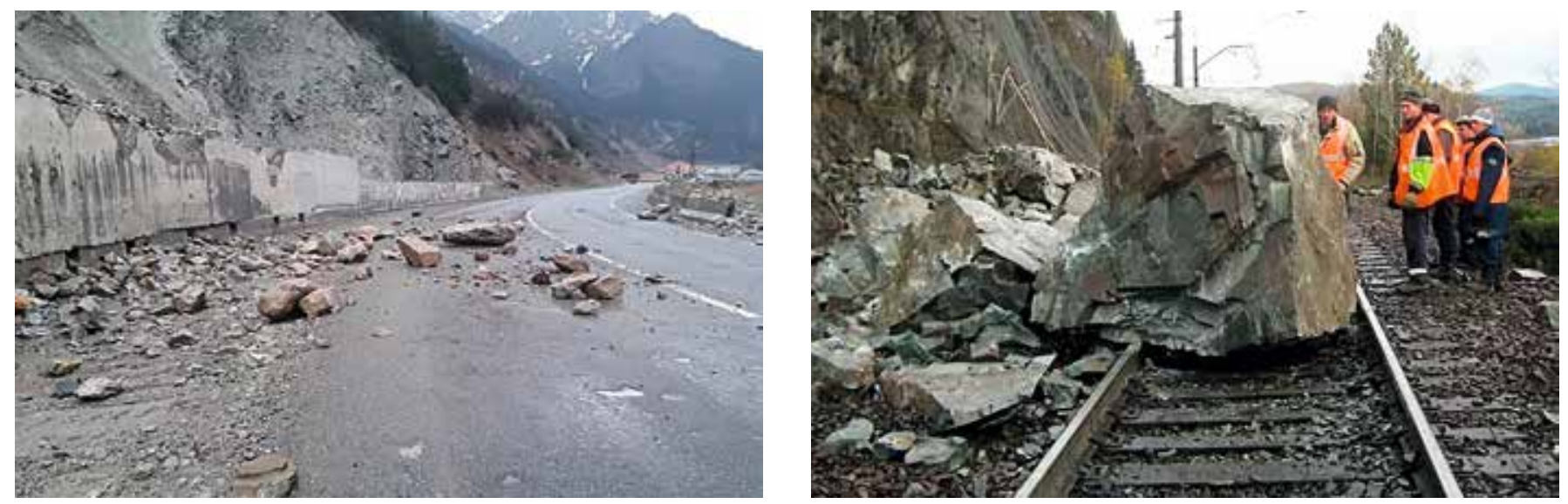

Puc. 5. Динамическое состояние горных пород, разрушающих защитные стены и нарушающих нормальное функционирование транспортных автомобильных и железных дорог

Fig. 5. Dynamic state of rocks destroying protective walls and disrupting the normal functioning of transport roads and railways

что при устройстве защитной и подпорной стены следует исследовать вопросы функционирования участка дороги в период ее эксплуатации [11-15].

Методы исследования. Проведены поиск и анализ литературы по тематике; наблюдение и сравнение при исследовании и выборе оптимального варианта строительства дороги.

Заключение. Длительный мониторинг показывает, что с удовлетворительным решением вписывания в рельефно-ландшафтные условия элементов дороги и искусственных сооружений снижаются стоимость строительства, а в последующем - при нормальном функционировании - и эксплуатационные затраты. С целью принятия научно-обоснованных решений при проектировании подпорной стены в сложных горных условиях приведем пример неудачного ее вписывания в ландшафт. На подпорные стены по защите проезжей части дороги, обрушаются скальные породы, которые отрываются от коренных пород, разрушая саму подпорную стену, а также проезжую часть. Это процесс характеризует переход элементов дороги и ландшафта из статического в динамическое. Обвалы, падая по склону, разрушают даже противообвальные подпорные стены (рис. 5) и нарушают нормальное функционирование дороги, т.е. эксплуатационные условия [16-24].

\section{Выводы:}

1. При проектировании автомобильных дорог в условиях горных ландшафтов следует находить гармоничное сочетание функционирования дороги и самого ландшафта с учетом безопасного их функционирования и динамики склоновых явлений в целях обеспечения безопасности дорожного движения.

2. Научно-обоснованный анализ и правильный выбор элементов ландшафтного проектирования при функционировании дороги позволит снизить динамику склоновых явлений, количество ДТП, расходы на содержание дороги, способствующие повышению безопасности на горных дорогах и в целом жизнеобеспечения населения горных территорий. 


\section{ЛИТЕРАТУРА:}

1. Трескинский С.А. Горные дороги. М.: Транспорт, 1974. $367 \mathrm{c}$.

2. Бабков В. Ф. Ландшафтное проектирование автомобильных дорог. М.: Транспорт, 1969. 168 с.

3. Поспелов П. И., Кортиев А. Л. Нормы проектирования дорог в горных условиях с учетом обеспечения безопасности движения // Устойчивое развитие горных территорий. 2018. T. 10. N 4 (38). C. 624-630.

4. Кортиев А. Л., Ванеев С. Д., Дряев М. М. Ландшафтный дизайн и эстетика автомобильных дорог в горных условиях // Устойчивое развитие горных территорий. 2020. Т. 12. N 1 (43). C. 55-60.

5. Дубелир Г. Д. Возведение земляного полотна в районах оползней и осыпей. М.: Дориздат, 1948.

6. Евгеньев И. Е., Миронов А. А. Вариантное проектирование автомобильных дорог с учетом их воздействия на окружающую среду // Автомобильные дороги. 1984. N 7. C.19.

7. Цыганов Р. Я. О характеристиках рельефа для ландшафтного проектирования дорог // Известия высших учебных заведений. Строительство и архитектура. 1966. N 8.

8. Кортиев Л. И. Строительство автомобильных дорог в горных условиях и их воздействие на ландшафт // Научная мысль Кавказа. Прил. N4. 2004. C. 114-116.

9. Залесская Л. С. Курс ландшафтной архитектуры. М.: Стройиздат, 1964

10. Бабков В. Ф. Сочетание автомобильных дорог с ландшафтом. М.: Высшая школа, 1964.

11. Добров Э. М. Механика грунтов. М.: Издательский центр "Академия", 2008. 272 с.

12. Золотарь И. А. и др. Повышение надежности автомобильных дорог. М.: Транспорт, 1977. 182 с.

13. Арешидзе Г. М. Оползни Грузинской ССР. Тбилиси: Мецниереба, 1980. 153 с.

14. Браславский В. Д. Определение устойчивости оползневых склонов // Автомобильные дороги. N 4. 1975. С. 34-36.

15. Руководство по инженерно-геологическим изысканиям в оползневых работах. М.: Стройиздат, 1966.78 с.

16. Zaalishvili V. B., Kulumbegov R. P., Kortiev L. I., Kortiev A. L., Margiev E. A. Avalanche-proof constructions dynamics and their scientific-technical support // Cite as: AIP Conference Proceedings 2188, 060001 (2019); https://doi. org/10.1063/1.5138470 Published Online: 17 December 2019.

17. Klyuev R., Bosikov I., Gavrina O., Madaeva M., Sokolov A. (2021) Improving the energy efficiency of technological equipment at mining enterprises. In: Murgul V., Pukhkal V. (eds) International Scientific Conference Energy Management of Municipal Facilities and Sustainable Energy Technologies EMMFT 2019. EMMFT 2019. Advances in Intelligent Systems and Computing, vol 1258, pp. 262-271, Springer, Cham. https:// doi.org/10.1007/978-4-030-57450-5_24.

18. Klyuev R., Fomenko O., Gavrina O., Turluev R., Marzoev S. (2021) Energy indicators of drilling machines and excavators in mountain territories. In: Murgul V., Pukhkal V. (eds) International Scientific Conference Energy Management of Municipal Facilities and Sustainable Energy Technologies EMMFT 2019. EMMFT 2019. Advances in Intelligent Systems and Computing, vol 1258, pp. 272-281, Springer, Cham. https:// doi.org/10.1007/978-4-030-57450-5_25.

19. Клюев Р.В., Босиков И.И., Егорова Е. В., Гаврина О.А. Оценка горно-геологических и горнотехнических условий карьера "Северный" с помощью математических моделей // Устойчивое развитие горных территорий. 2020. N3 C. 418-427. DOI: 10.21177/1998-4502-2020-12-4-418-427.

20. Клюев Р.В., Босиков И.И., Майер А. В., Гаврина О.А. Комплексный анализ применения эффективных технологий для повышения устойчивого развития природно-технической системы // Устойчивое развитие горных территорий. 2020. N2. C. 283-290.

21. Кортиев А. Л., Ванеев С.Д., Санакоев С. И. Конструкционные особенности подпорных стен и эффективность их применения для обеспечения безопасности дорожного движения / Сборник научных трудов: Транспортные системы Сибири. Развитие транспортной системы как катализатор роста экономики государства. Красноярск: СФУ, 2016. C. $187-192$.

22. Кортиев Л. И., Ванеев С.Д. Исследование параллелей склоновых явлений и защитных мероприятий в горных условиях Болгарии и Осетии / Тезисы докладов 9-й Международной научно-практической конференции. Издательский дом «АКЦЕНТ». София, Болгария. 2020. С. 448-457.

23. Иванов Р. А., Ванеев С. Д. Материалы обзорного обследования склоновых явлений на горных дорогах Болгарии и Осетии (Россия) / Современные достижения молодёжной науки 2020: сборник статей III Международного научно-исследовательского конкурса (22 мая 2020 г.). Петрозаводск: МЦНП «Новая наука», 2020. С. 155-163.

24. Кортиев А. Л. и др. Особенности взаимодействия дорожно-транспортного комплекса и природной среды в горных условиях с учетом научно-технического сопровождения / В кн.: Теоретические и методологические аспекты развития современной науки Выпуск N 7. М.: НИЦ МИСИ, 2019. 190 с. С. 175-184.

\section{БЛАГОДАРНОСТЬ / Acknowledgement:}

Исследование выполнено при финансовой поддержке РФФИ и Министерства образования и науки Республики Южная Осетия в рамках научного проекта № 19-511-07001.

The reported study was funded by RFBR and the Ministry of Education and Science of the Republic of South Ossetia according to the Research Project № 19-511-07001.

Авторы благодарны руководству РФФИ и Министерству образования и науки Республики Южная Осетия, а также редакции журнала «Устойчивое развитие горных территорий за предоставление возможности опубликовать статью.

We are grateful to the leadership of the Russian Foundation for Basic Research and the Ministry of Education and Science of the Republic of South Ossetia, as well as the editorial board of the journal Sustainable Development of Mountain Territories for providing the opportunity to write an article and publish. 
КОНФЛИКТ ИНТЕРЕСОВ / Conflict of interest:

Авторы заявляют об отсутствии конфликта интересов / The authors declare no conflict of interest.

\section{ДОЛЕВОЕ УЧАСТИЕ / Contribution:}

Авторы в написании статьи участвовали в равных долях / The authors participated in writing the article in equal parts.

\section{СВЕДЕНИЯ ОБ АВТОРАХ / Information about authors:}

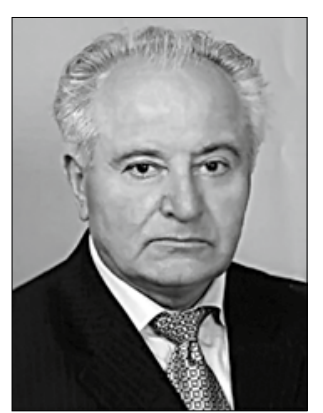

КОРТИЕВ Леван Исмаилович - кандидат технических наук, академик Российской академии транспорта, доцент кафедры «Организация и безопасность дорожного движения» Северо-Кавказского горно-металлургического института (государственного технологического университета).

362021, г. Владикавказ, Россия.

Тел.: +7(928) 486-11-30.

e-mail: lbtranskama@mail.ru

Levan I. KORTIEV - Candidate of Technical Sciences, Academician of the Russian Academy of Transport, Associate Professor of the Department "Organization and Road Safety" of the North Caucaian Institute of Mining and Metallurgy (State Technological University).

362021, Vladikavkaz, Russia.

Ph.: +7 (928) 486-11-30.

e-mail:lbtranskama@mail.ru

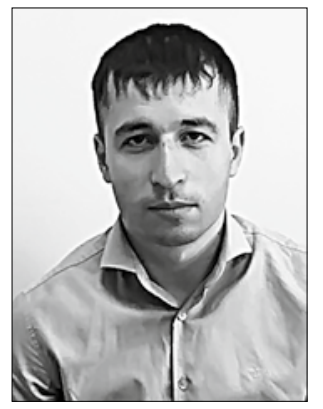

ВАНЕЕВ Сармат ДжемалиеВич - инженер.

Исполнитель международного проекта РФФИ и МОН РЮО № 15 MK/19 (19-511-07001).

362021, г. Владикавказ, Россия.

Тел.: +7(928) 686-56-69.

e-mail: vaneev.sarmat@yandex.ru

Sarmat D. VANEEV - Engineer.

Performer of the International Project of the Russian Foundation for Basic Research and the Ministry of Education and Science of the Republic of South Ossetia No. 15-MK / 19 (19-511-07001).

362021, Vladikavkaz, Russia.

Ph.: +7 (928) 686-56-69.

e-mail:vaneev.sarmat@yandex.ru

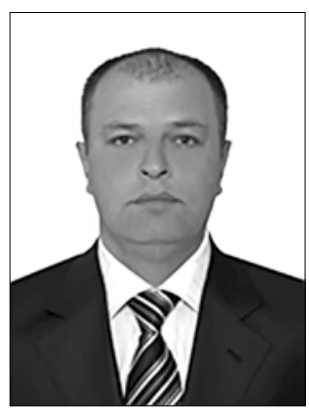

КОРТИЕВ Алан Леванович кандидат технических наук, доцент, и. о. зав. кафедрой «Организация и безопасность дорожного движения» Северо-Кавказского горно-металлургического института (государственного технологического университета).

362021, г. Владикавказ, Россия.

Тел.: +7(962)748-40-00.

e-mail:kortiev73@mail.ru

Alan L. KORTIEV - Candidate of Technical Sciences, Associate Professor, Acting Head of Department of Organization and Road Safety, North Caucasian Institute of Mining and Metallurgy (State Technological University).

362021, Vladikavkaz, Russia.

Ph.:+7(962)748-40-00.e-mail: kortiev73@mail.ru

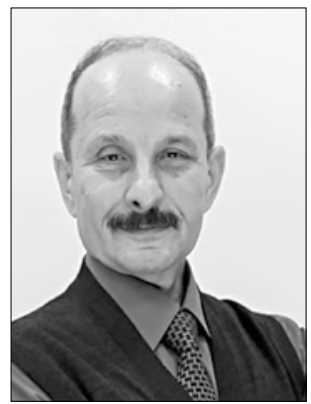

КУЛУМБЕГОВ Роберт Петрович - кандидат исторических наук, доцент кафедры «История Осетии и Кавказоведения». Юго-Осетинский государственный университет.

100001, г. Цхинвал, Республика Южная Осетия.

Тел.: +7(929)804-35-60.

e-mail: kulumbegov_2@mail.ru

Robert P. KULUMBEGOV-Candidate of Historical Sciences, Associate Professor of the Department of History of Ossetia and Caucasus Studies. South Ossetian State University. 100001, Tskhinvali, Republic of South Ossetia.

Ph.: +7 (929) 804-35-60.

e-mail:kulumbegov_2@mail.ru 


\title{
FUNCTIONING AND DYNAMICS OF LANDSCAPES IN THE DESIGN OF HIGHWAYS IN MOUNTAINOUS CONDITIONS
}

\author{
L. I. Kortiev', \\ A. L. Kortiev ${ }^{*}$, \\ S. D. Vaneyev', \\ R. P. Kulumbegov ${ }^{2}$ \\ ${ }^{1}$ North Caucasian Institute of Mining and Metallurgy (State Technological University), Vladikavkaz, Russia, \\ kortiev73@mail.ru \\ ${ }^{2}$ South-Ossetian State University, Tskhinvali, Republic of South Ossetia
}

\section{DOI: $10.21177 / 1998-4502-2020-12-4-565-571$}

Introduction. Roads, as linear engineering structures in mountainous conditions for the sake of traffic safety, should provide a smooth interface and their harmonious combination with the surrounding landscape with the use of longitudinal slopes and radii on curves that reduce accidents and injuries. Anthropogenic intervention on the mountain natural landscape, for the purpose of road construction, is not always safe, because weak soils come into dynamics and the functioning of the road is complicated.

For this, it is necessary to conduct a spatial analysis and an integrated approach to the issue, covering all aspects of landscape design of the road to eliminate negative consequences.

The essence of the question. The design of highways in mountainous areas without observing the landscape principles of safe operation and with less dynamic shifts of the roadbed leads to a violation of the relief forms, with the implementation of large volumes of earthworks necessary to ensure the projected slope.

Research methods. In the process of writing the article, the following methods were used: analysis - in the search and analysis of literature on the subject; observation and comparison in the study and selection of the optimal option.

\section{Conclusions:}

1. When designing highways in mountain landscapes, it is necessary to find a harmonious combination of the functioning of the road and the landscape itself.

2. A scientifically based analysis and correct choice of landscape design elements in the operation of the road will reduce the dynamics of slope phenomena, the number of accidents, the cost of road maintenance, which contribute to improving safety on mountain roads.

Keywords: terrain dynamics, landscape, landscape and road functioning, design, aesthetics, mountain terrain, retaining wall, slopes, landscape dynamics, landslides, landslides.

\section{References:}

1. Treskinsky S. A. Mountain roads, Moscow, Transport, 1974, 367 p.

2. Babkov V. F. Landscape design of highways, Moscow, Transport, 1969, $168 \mathrm{p}$.

3. Pospelov P.I., Kortiev A .L. "Norms of road design in mountain conditions taking into account traffic safety", Sustainable Development of Mountain Territories, 2018, v. 10, no 4 (38), pp. 624-630.

4. Kortiev A. L., Vaneev S. D., Dryaev M. M., "Landscape design and aesthetics of highways in mountain conditions", Sustainable Development of Mountain Territories, 2020, vol. 12., no 1 (43), pp. 55-60.
5. Dubelir G. D. Construction of a roadbed in landslides and talus areas, Dorizdat Publ., Moscow, 1948.

6. Evgeniev I.E., Mironov A.A. "Variant design of highways taking into account their impact on the environment", Automobile Roads, 1984, no. 7, p.19.

7. Tsyganov R.Ya. "On the characteristics of the relief for landscape design of roads", News of Higher Educational Institutions. Construction and Architecture, 1966, no. 8.

8. Kortiev L. I. "Construction of highways in mountainous conditions and their impact on the landscape", Scientific Thought of the Caucasus, Adj. no. 4, 2004, pp. 114-116.

9. Zalesskaya L.S. Landscape architecture course, Stroyizdat Publ., Moscow, 1964.

10. Babkov V. F. Combination of highways with the landscape, Vysshaya shkola, Moscow, 1964.

11. Dobrov E. M. Soil mechanics, Publishing Center "Academy", Moscow, 2008, 272 p.

12. Zolotar I. A. et al. Improving the reliability of highways, Transport Publ., Moscow, 1977, 182 p.

13. Areshidze G. M. Landslides of the Georgian SSR, Metsniereba, Tbilisi, 1980, $153 \mathrm{p}$.

14. Braslavsky V. D. "Determination of the stability of landslide slopes", Automobile Roads, 1975, no. 4, pp. 34-36.

15. Guidelines for engineering and geological surveys in landslide works, Stroyizdat Publ., Moscow, 1966, 78 p.

16. Zaalishvili V. B., Kulumbegov R. P., Kortiev L. I., Kortiev A. L., Margiev E. A. "Avalanche-proof constructions dynamics and their scientific-technical support", Cite as: AIP Conference Proceedings 2188, 060001 (2019); https://doi. org/10.1063/1.5138470 Published on line: 17 December 2019.

17. Klyuev R., Bosikov I., Gavrina O., Madaeva M., Sokolov A. (2021) "Improving the energy efficiency of technological equipment at mining enterprises”, In: Murgul V., Pukhkal V. (eds), International Scientific Conference Energy Management of Municipal Facilities and Sustainable Energy Technologies EMMFT 2019. EMMFT 2019. Advances in Intelligent Systems and Computing, vol. 1258, pp. 262-271, Springer, Cham. https://doi.org/10.1007/978-4-030-57450-5_24.

18. Klyuev R., Fomenko O., Gavrina O., Turluev R., Marzoev S. (2021) "Energy indicators of drilling machines and excavators in mountain territories", In: Murgul V., Pukhkal V. (eds), International Scientific Conference Energy Management of Municipal Facilities and Sustainable Energy Technologies EMMFT 2019. EMMFT 2019. Advances in Intelligent Systems and Computing, vol 1258, pp. 272-281, Springer, Cham. https://doi.org/10.1007/978-4-030-57450-5_25. 
19. Klyuev R. V., Bosikov I. I., Egorova E. V., Gavrina O. A. "Assessment of mining-geological and mining technical conditions of the Severny pit with the use of mathematical models", Sustainable Development of Mountain Territories, 2020, no 3, pp. 418-427. DOI: 10.21177/1998-4502-2020-124-418-427.

20. Klyuev R. V., Bosikov I. I., Mayer A. V., Gavrina O. A. "Comprehensive analysis of the effective technologies application to increase sustainable development of the naturaltechnical system", Sustainable Development of Mountain Territories, 2020, no. 2, pp. 283-290.

21. Kortiev A. L, Vaneev S. D, Sanakoev S. I. "Structural features of retaining walls and the effectiveness of their application to ensure road safety", Collection of scientific papers, Transport Systems of Siberia, Development of the Transport System as a Catalyst for the Growth of the State Economy, Krasnoyarsk, Siberian Federal University, 2016, pp. 187-192.

22. Kortiev L. I., Vaneev S. D. "Study of parallels of slope phenomena and protective measures in mountainous conditions in Bulgaria and Ossetia", Abstracts of the 9th International Scientific and Practical Conference, Publishing house "ACCENT", Sofia, Bulgaria, 2020, pp. 448-457.

23. Ivanov R. A., Vaneev S. D. "Materials of a survey of slope phenomena on mountain roads in Bulgaria and Ossetia (Russia)", Modern Achievements of Youth Science 2020: Collection of articles of the III International Research Competition (May 22, 2020), International Center for Scientific Partnership "New Science", Petrozavodsk, 2020, pp. 155-163.

24. Kortiev A. L. et al. Features of the interaction of the road - transport complex and the natural environment in mountain conditions, taking into account scientific and technical support. Rubric "Ecology" $M 7$ Theoretical and methodological aspects of the development of modern science, Issue 7, NITs MISI, Moscow, 2019, pp. 175-184.

Article received 22.07.2020. 


\section{УДК: 551.435 .627}

\section{DOI: 10.21177/1998-4502-2020-}

12-4-572-581

The common approach to landslide prediction is the integration of the observed landslide displacements, soil properties, and rainfall estimation into predictive models. In general, monitoring the evolution of an unstable slope may provide valuable information to gain a better understanding of the active prediction and early warning processes for potential geodisasters. With this background an initiation has taken between India and Russia to develop cost effective methodology to monitor landslides under the Indo Russian Bilateral Collaborative Projects by DSTRFBR. Based on the hazard assessment The Nilgiris District in Tamil Nadu and Wayanad and Idukki Districts in Kerela area identified for further detailed study on monitoring Vulnerable slopes. On the territory of North Ossetia three sites of different mass volume and differenent activity rates were selected. Landslides that have not moved for years (for example Luarskiy landslide) commonly reactivate if ground water levels change dramatically, particularly when water penetrates old ground cracks, or construction activity creates slope modification that reduces stability.

\section{KEYWORDS:}

landslide, monitoring, risk analysis, risk assessment, mapping.

\section{INTEGRATED MONITORING OF SLOPE PROCESS IN INDIA AND RUSSIA}

Ganapathy G. P. ${ }^{1}$,

Zaalishvili V. B..$^{*}$

Chandrasekaran S. $\mathrm{S}^{3}$,

Melkov D. A. ${ }^{2}$

${ }^{1}$ Centre for Disaster Mitigation and Management, Vellore Institute of Technology, Vellore 632014, Tamil Nadu, India, seismogans@yahoo.com

${ }^{2}$ Geophysical Institute of Vladikavkaz Scientific Centre of the Russian Academy of

Sciences, Vladikavkaz, 362002, Russia,cgi_ras@mail.ru

${ }^{3}$ School of Civil Engineering, Vellore Institute of Technology, Vellore 632014, Tamil Nadu,

India, sschandrasekaran@vit.ac.in

\section{Introduction}

According to one estimate, nature takes nearly 1000 years to produce a few centimetre of top soil, but destabilizing forces of nature in the mountainous areas wipes millions of cubic metres in just a second [1]. Scientists are globally working on landslide studies and particularly on Landslide monitoring and early warning studies. In recent years, various technologies have primarily supported landslide research with the goal of gaining a deeper understanding of earth phenomena, reducing the probability of landslides, and enhancing disaster prevention and preparedness capabilities. There are three closely related components in the main roles in landslide risk reduction and sustainable disaster management: monitoring, prediction and management. Monitoring of existing landslides as well as locations vulnerable to future landslides, will be the useful for prediction of landslides. In general, monitoring the evolution of an unstable slope may provide valuable information to gain a better understanding of the active prediction and early warning processes for potential geo-disasters. The common approach to landslide prediction is the integration of the observed landslide displacements, soil properties, and rainfall estimation into predictive models [2]. With this background an initiation has taken between India and Russia to develop cost effective methodology to monitor landslides under the Indo Russian Bilateral Collaborative Projects by DST- RFBR. Part of India and Russia are prone to landslide Hazards. In India, about 0.42 million sq. km or $12.6 \%$ of land area, excluding snow covered area, is prone to landslide hazard. Out of this, 0.18 million sq. km falls in North East Himalaya, including Darjeeling and Sikkim Himalaya; 0.14 million sq. km falls in North West Himalaya (Uttarakhand, Himachal Pradesh and Jammu \& Kashmir); 0.09 million sq. km in Western Ghats and Konkan hills (Tamil Nadu, Kerala, Karnataka, Goa and Maharashtra) and 0.01 million sq. km in Eastern Ghats of Aruku area in Andhra Pradesh. The landslide-prone Himalayan terrains are also prone to earthquake-triggered landslides [3]. In Russia the South East part of Russia is Prone to landslides and Landslide Hazards. The locations of landslide occurrences (rainfall induced) collected from Global Landslide Catalog (GLC) for the years 2007 to 2019 for India and Russia are presented in Figure 1.

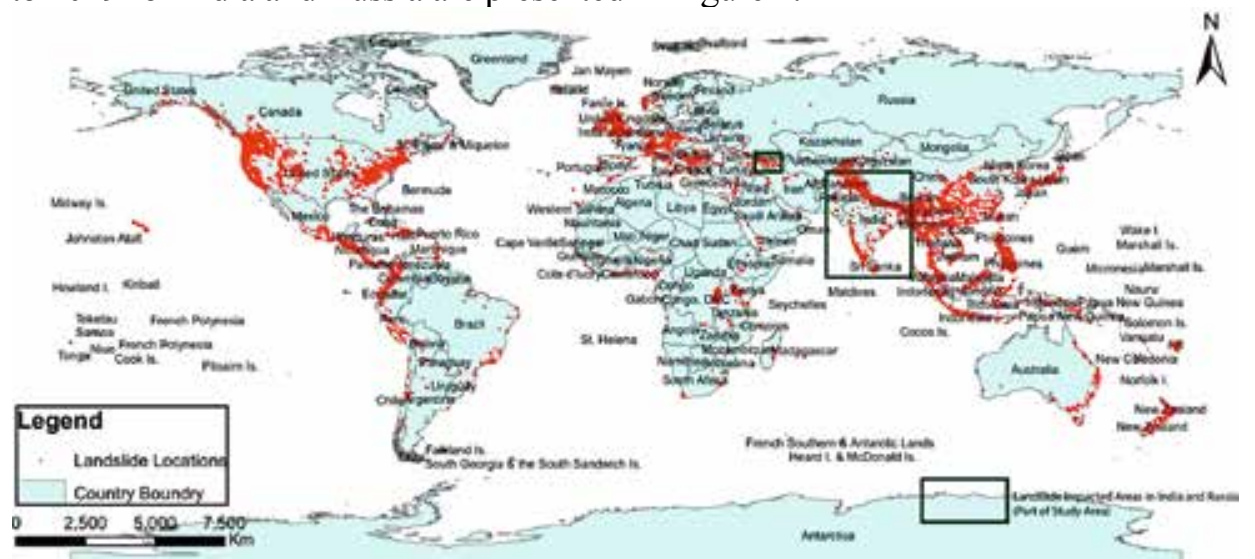

Fig. 1. Locations of landslides in India and Russia 


\section{Landslide Hazard in India}

The landslide hazard zonation atlas of India (Figure 2) shows that many part of India is prone for very high to severe landslide hazard [4]. Some of the densely populated areas fall under these hazardous zones. India contains different geo climatic conditions. The northern part of India will be different from Southern part and the Western Part will be different from Eastern part. The favourable geological units trigger landslides also different from North to South. The locations of past landslides are presented in Figure 3.

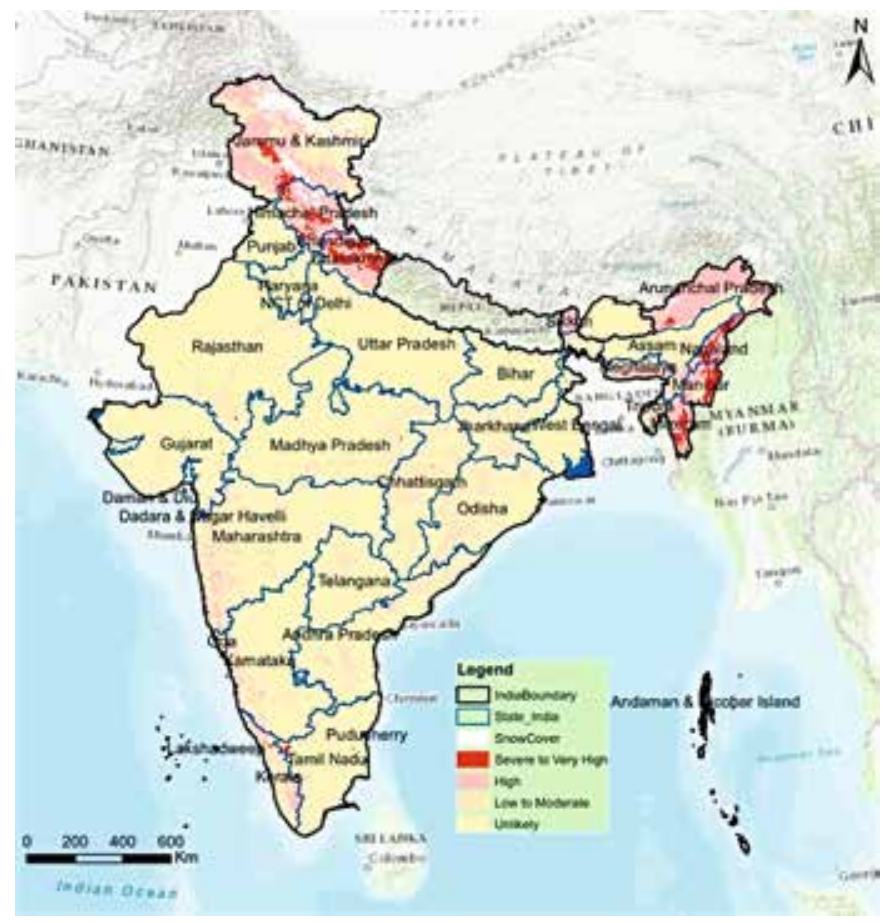

Fig. 2. Landslide Hazard Zonation Atlas of India

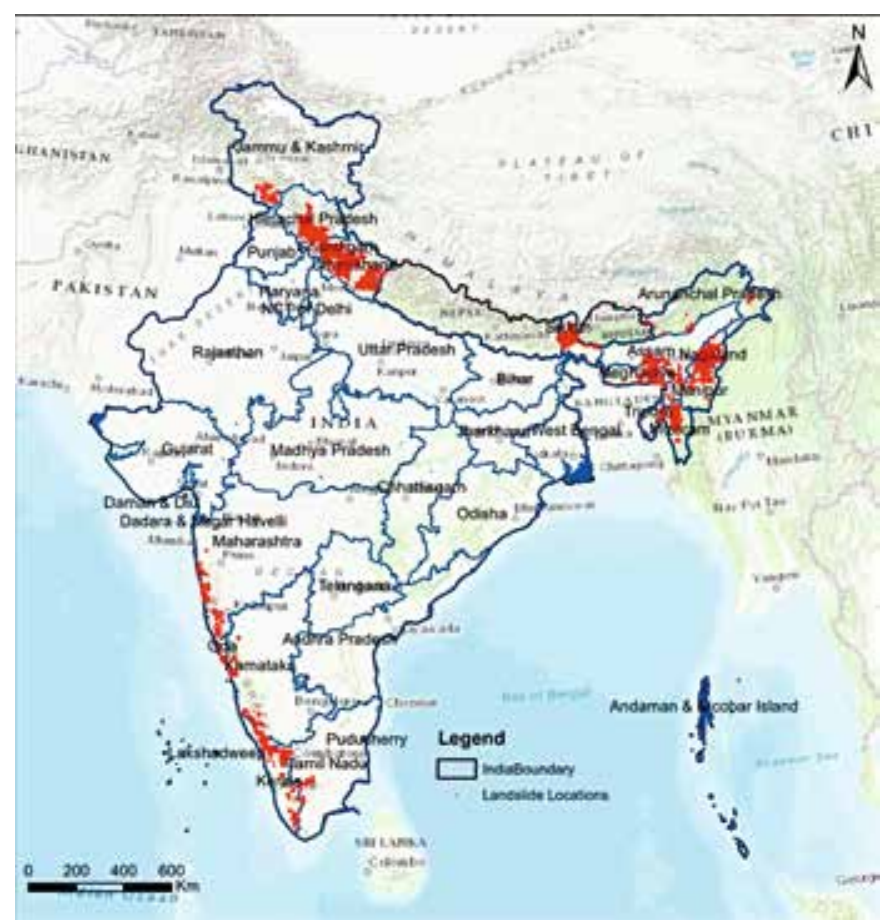

Fig. 3. Landslide Inventory Map of India
The Southern part of India Tamil Nadu and Kerela is prone to landslides particularly rainfall induced landslides. For the part of our Landslide monitoring Process the Nigiris District of Tamil Nadu and the Idukkiand Wayanad District of Kerela is considered.

To assess the landslide hazard at regional level to identify the vulnerable areas, Building Materials Technology Promotion Council of the Government of India method published for small scale landslide hazard map of India were used in a GIS platform [5]. To understand the district level severity of landslide hazard, a study has been carried out using various thematic maps viz. Geology (3) $-12 \%$, Slope (10) - $40 \%$, Landuse (9) - $36 \%$, Rainfall (3) $-12 \%$ using Analytical Hierarchy process. However the maps produced in this method limitations. This will be used for a quick analysis of landslide hazard at regional level to locate the very severe landslide prone areas. The landslide hazard zonation map for Tamil Nadu and Kerela prepared based on Building Materials Technology Promotion Council Methodology is presented Figure 4.

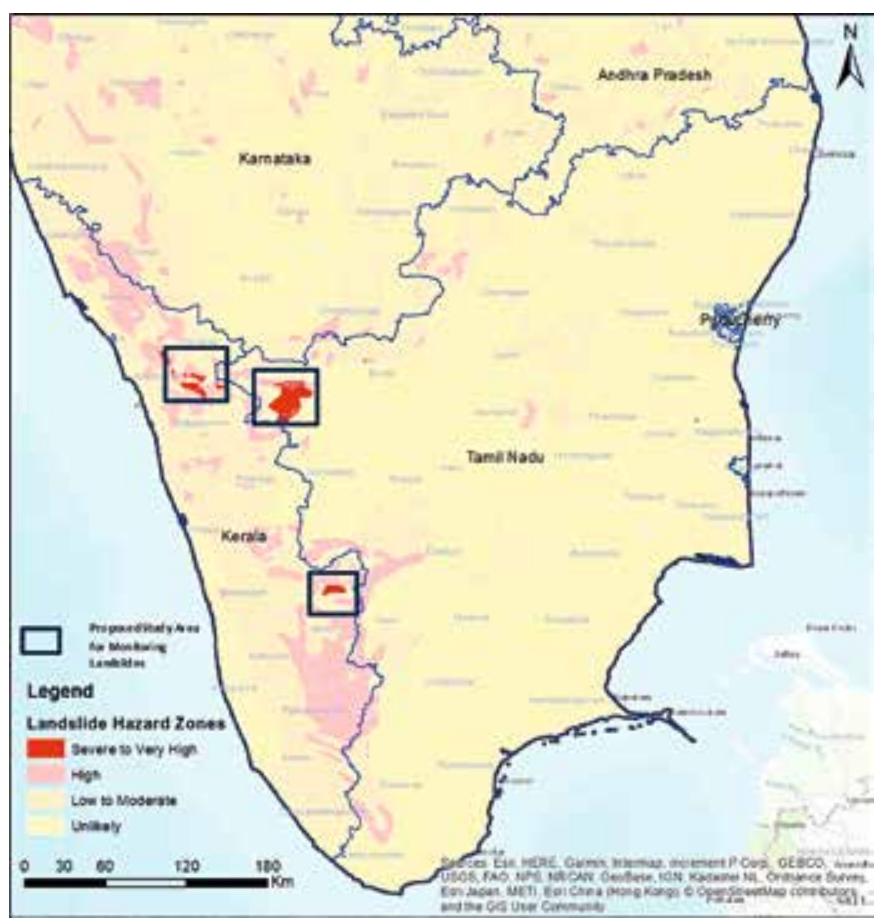

Fig. 4. Proposed study area for Monitoring landslides in Tamil Nadu and Kerela States of India

Landslide Hazard Zonation Atlas of India classified the Nilgiris district as high to severe landslide prone areas [4]. The Study area also falls under severe landslide prone areas. The landslide activity in the district is almost seasonal during every year [6]. The months of October \& November are prone to landslides. The years 1902, 1978, 1979, 1993, 2001, 2006 and 2009 are notable years for landslides in the history of The Nilgiris district. In November 1891 heavy rain caused many landslips on the Coonoor Ghat, and created more damage to the Kotagiri - Metuppalayam road [7-9]. Recently, in the Nilgiri Hills, casualties and damage caused by landslides have increased [10-11]. In 2009, heavy rains triggered a series of landslides in The 
Nilgiris regions of Ooty, Coonoor and Kotagiri. On 10th November 2009, 42 people died within 48 hours [9]. The details of landslide/landslip occurrences in different corridors during the year 2009 are listed in Table 1. The district receives rainfall both during southwest and northeast monsoons. The southwest monsoon is more active contributing nearly 50 percent in the west and 40 percent in the east. The northeast monsoon is moderate, contributing nearly 40 percent. The intensity of rainfall gradually decreases from west to east. The rains during the winter and summer periods are significant. The minimum and maximum annual rainfall varies from $750 \mathrm{~mm}$ to more than $3000 \mathrm{~mm}$ and the number of rainy days varies depending on the season and the area [12]. Approximately 2000 Housholds 6000 people exposed to landslides in the district. The Nilgiris district has lengthy history of landslides and it has generated more damage to property and infrastructure however the loss of life is less when compare to the number of landslides. In the recent times causalities and damage due to landslides have increased in the Nilgiri Hills. Increasing demands from different sections of society as well as the need to bring into the main stream the isolated communities in the remote hill areas, have resulted in an increase of all types of construction activities in these areas.

The state of Kerela also prone to landslides. Over 270 precious lives were lost in 67 major landslide events and hundreds of minor events between 1961 and 2013. According to data provided by GSI (https://www.gsi.gov. in/), the coastal state in the Western Ghats has experienced 67 major landslide events and hundreds of minor ones, in half a century. As per the report 145 people died in Kerela within for the past 2 years. It is a narrow strip of land, 47 percent of which is occupied by the Western Ghats mountain chain, the most prominent orographic feature of peninsular India. Kerala's highlands experience many kinds of landslides, the most common of which are debris flows [14]. All 13 of the 14 districts of Kerala except the coastal district of Alappuzha are prone to landslides. About 8\% $(1,400 \mathrm{~km} 2)$ of area in The Western Ghats of Kerala is classified as critical zone for mass movements [15]. Shallow landslides and debris flows are more common than deep seated ones in Kerela. The districts of Wayanad and Kozhikode are located north of Palakkad Gap is more vulnerable to landslides that are deep-seated. That can be explained by the greater amount of monsoon rainfall that this part of the state receives [13]. Quarrying, razing hills for homes, large road houses, and expansions in the mountains and mono-crop cultivations are contributing factors in the landslides caused by high magnitude incessant rains induced by climate change. The updated landslide inventory data collected from various resources are collected and entered in GIS plat form and presented in Figure 5.

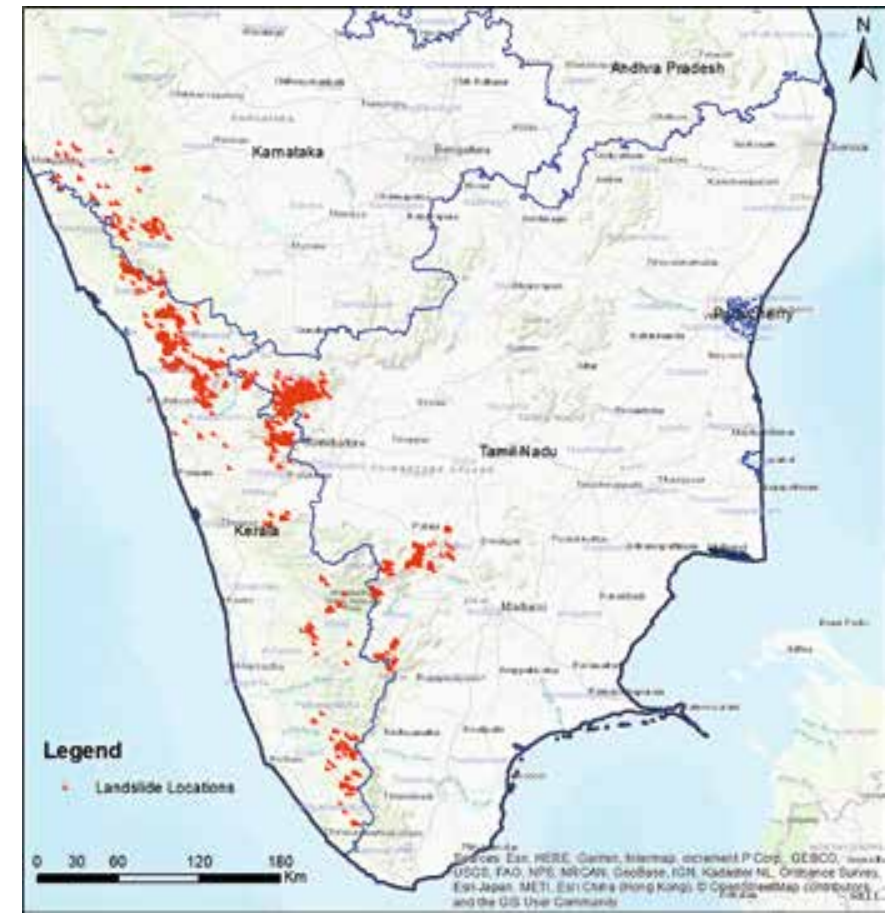

Fig. 5. Landslide inventories in the proposed study area in India

\section{Landslide Hazard in Russia, North Caucasus and the North Ossetia}

The territory of Russia, in general, is characterized by a fairly moderate and low level of landslide hazard. At the same time, some very large areas (territories) are characterized by a very hazardous and hazardous level of landslide formation [15-18]. At the same time, in the given regions (the Urals and the North Caucasus) some cities are significant in terms of their economic potential: Yekaterinburg, Nizhny Tagil (Fig. 6), Vladikavkaz, Grozny, Makhachkala, Nalchik, Maikop, Stavropol (Fig. 7). Moreover, in certain, rather extended coastal areas of the Krasnodar Territory (Sochi, Tuapse, etc.), the landslide hazard reaches an extremely high level (Fig. 7).

The most widespread landslide processes are observed in the mountainous part of the republic, especially in the zone of the Northern Jurassic intermountain depression, the subescarp zone of the Scalisty Range, in the areas of the Southern intermountain depression and the Glavny Vodorazdelny Range.

According to the scale, hazard and nature of their manifestation, they are divided into landslides, mudslides and sluffs. The former are large, have a significant depth of incorporation (up to tens of meters) and a volume of more than $100 \mathrm{~m} 3$. The reason for their formation is a steep slope, seismic shocks, conditions of bedding of the slope rocks. Mudslides and sluffs are smaller (up to 100 cubic meters) and can be caused by human activity, i.e. cutting of slopes during road laying, mining, etc.

Among 350 landslides studied in the mountains of North Ossetia-Alania, the following are distinguished by size: small (up to 1 thousand cubic meters), medium (up to 100 thousand cubic meters), large (up to 1 million cubic 
meters) and very large (with a volume of more than 1 million cubic meters). Examples of very large landslides are the Luarskiy, Donifarskiy, N. Narskiy, etc. (Figure 8).

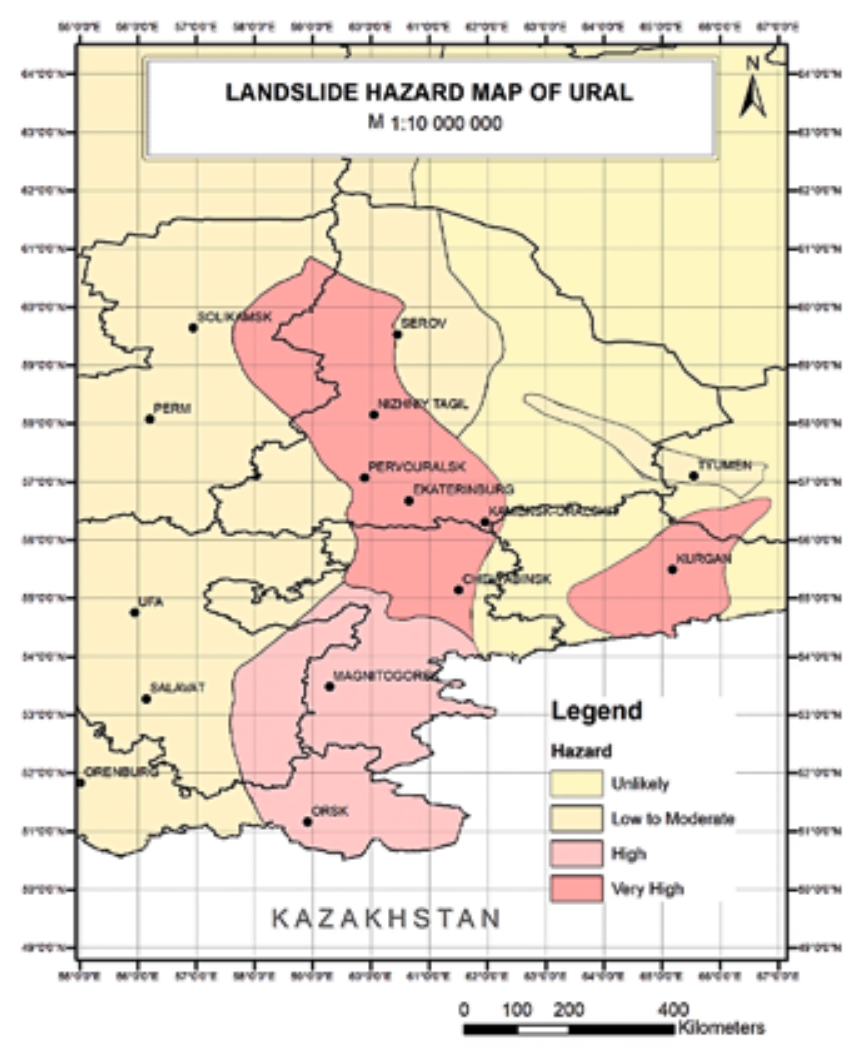

Fig. 6. Landslide hazard in the Ural

The processes of large-scale development of landslides cover an area of $2300 \mathrm{sq}$. $\mathrm{km}$. The causes of landslides have both natural and technogenic nature.
There is a growing threat of activation of landslide processes along the mountainous part of the river Ardon. Along with natural formations (Luarskiy, Zintsarskiy on the right and left sides of the valley of the Ardon river, Ursdonskiy, Dalagkauskiy, Tseyskiy landslides, etc.), new formations are added due to uncontrolled intense anthropogenic pressure on the territory (cutting and watering of landslide hazard slopes during the construction of economy facilities: Zaramag HPP, Fiagdon-Tskhinval power transmission line $35 \mathrm{kV}$, the network of intraregional roads.

Within the limits of the Southern intermountain depression and the Glavny Vodorazdelny Range, landslides are mainly small in size and volume; the largest of them are Zaramag landslides, situated on the left and right slopes of the Ardon river-valley (below the village of Zaramag) and Dallagkom landslides on the right side of the river Mamisondon. All of them are confined to the zones of the Nar faults.

Most commonly, the Transcaucasian Highway is exposed to the landslides. In general, in Mountain Ossetia, they were observed in modern times in 1960, 1975, 1984, 1985, 1987 and 1990, 1997, 1999.

In June 2002 after active mudflow activity, large landslide blocks began to move in the area of the villages of Sredny Zgid, V.Mizur of Alagirsky District, Fazikau Prigorodny district.

The main factor of landslide processes activation is the excessive watering of the slopes, which occurs during snowmelt and heavy rains. A sharp increase in river runoff contributes significantly to the activity of landslides; as a result, the erosion and destruction of the frontal parts of landslides occur, which often leads to displacements of the overlying masses, as was observed on the Luarskiy landslide in 1984 and on the Matsutinskiy landslide in 1991.

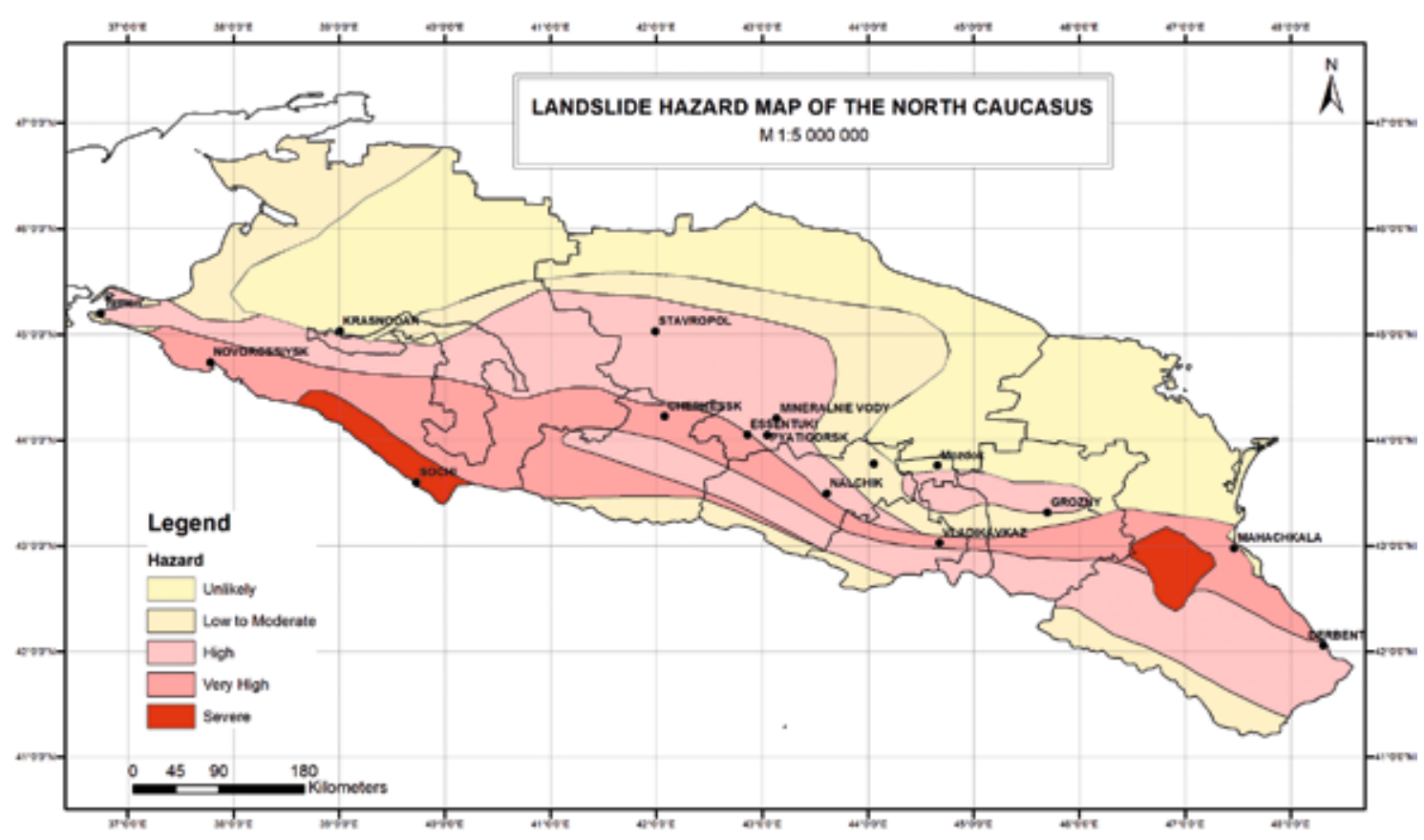

Fig. 7. Landslide hazard in the North Caucasus 
A noticeable increase in landslide activity is caused by seismic shocks associated with modern tectonic movements. In particular, they are associated with the movements of the Matsutinskiy and Donifarskiy landslides in 1990 and the Ursdonskiy landslides in 1993.

A retrospective analysis of the formation and large activation of landslides in the 20th century indicates that some of them are directly related to earthquakes (Dallagkauskiy, 1905; Korinskiy, 1915; Turmonskiy, 1981, etc.).

In total, 355 landslides were registered on the territory of the Republic. Landslide inventories are presented in Figure 6 . There are three categories of sites.

The most hazardous for the designed and operating national economic facilities (Mizur concentration plant, several operating mines in gorges with mudflow-prone slopes, Transkam, Zaramag HPP, the first stage of the Mamison tourism cluster) were studied in previous years during the process of the mentioned design solutions and the industrial operation of facilities and their impact on the environment [19-21]. As a result, it was found that the reasons and mechanisms of the landslide movements are quite diverse and are associated both with gravitational and climatic and seismotectonic processes occurring in the general cycle of neotectonic upward movements of the Greater Caucasus.

The reference object in this regard is the Luarskiy landslide (Figure 8,9), which combined all the extreme features of landslide structures known in the Central Caucasus, but never revealed the secrets of its static state, the definition of which is the most important task of research under the grant.

As a result of the analysis, we have selected the following areas as test sites: Luarskiy (Figure 9, 10), Zintsarskiy landslides (Figure 11), landslide in the Fiagdon tailing dump area (Figure 12), which is currently undergoing a noticeable technogenic impact as a result of tailing dump liquidation.

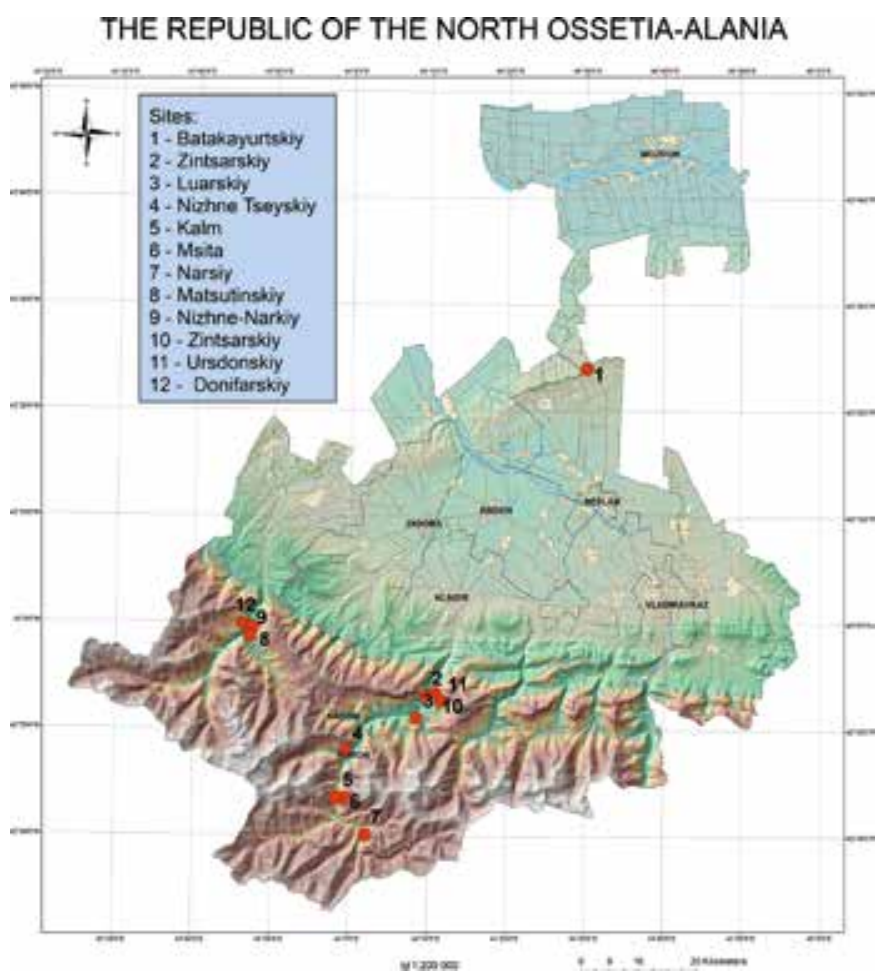

Fig. 8. Landslide inventories in the Proposed Study area in North Ossetia

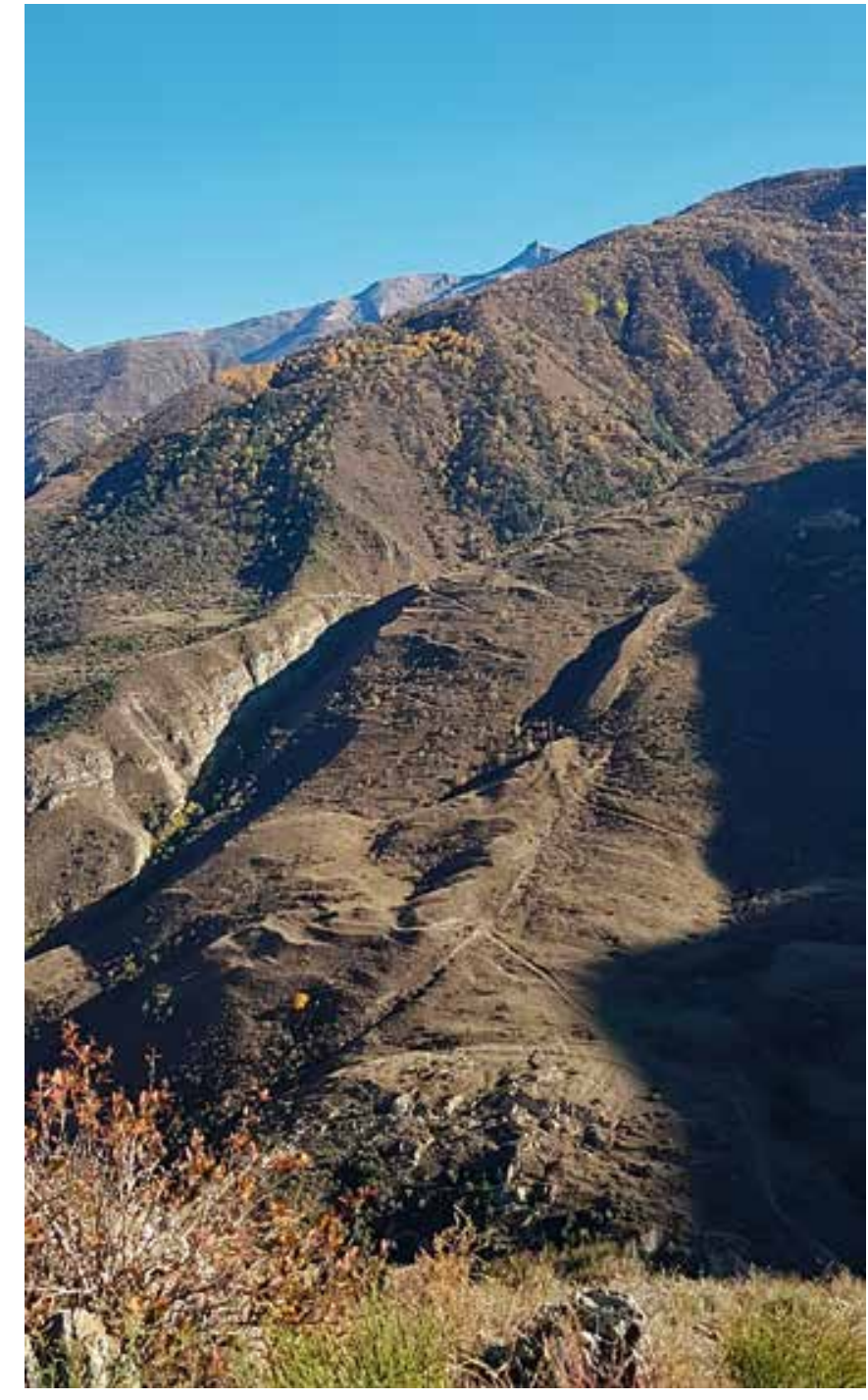

Fig. 9. Luarskiy landslide

\section{Instrumental monitoring}

Structural deformation and ground displacement during landslides can be monitored using various types of systems and methods. These methods and tools can be classified as remote sensing or satellite, photogrammetric and geodetic methods. The choice of instruments and measurement methods or the creation of a special monitoring system depends on the different types of deformation that will affect the method of stability analysis and therefore the entire monitoring system of deformation.

Satellite images in the optical region with the high spatial resolution are used to compile landslide inventory maps. Satellite data is used in addition to aerial photography or as a replacement if no aerial imagery is available recently. Also, satellite imagery is a more cost-effective database for regional and national hazard zoning. Another advantage of satellite remote sensing is the ability to repeated observations, which results in more frequent updates on landslide characteristics than in traditional data sources. With small-scale satellite imagery, only very large landslides can be directly identified.

Another important application of Earth observation 


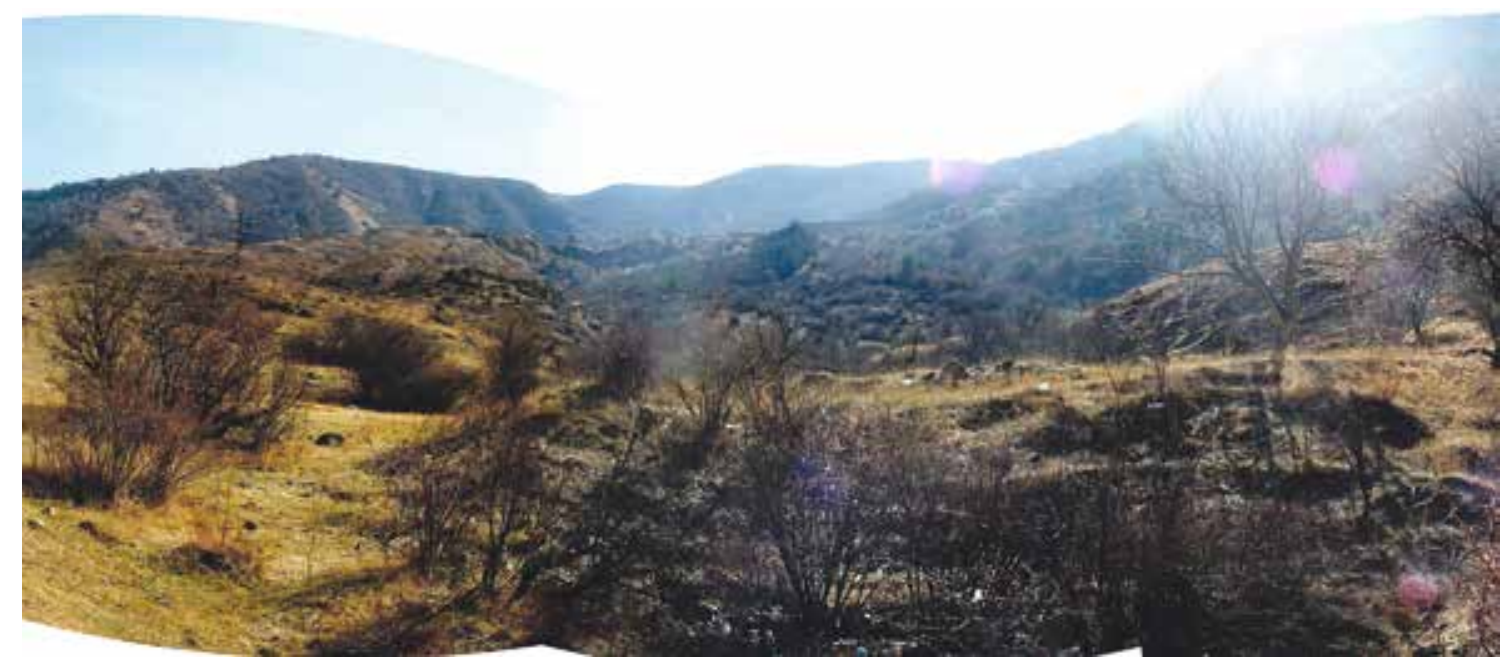

Fig. 10. Site of Luarskiy landslide (Photo by A.Yu. Marchenkov, MSU)

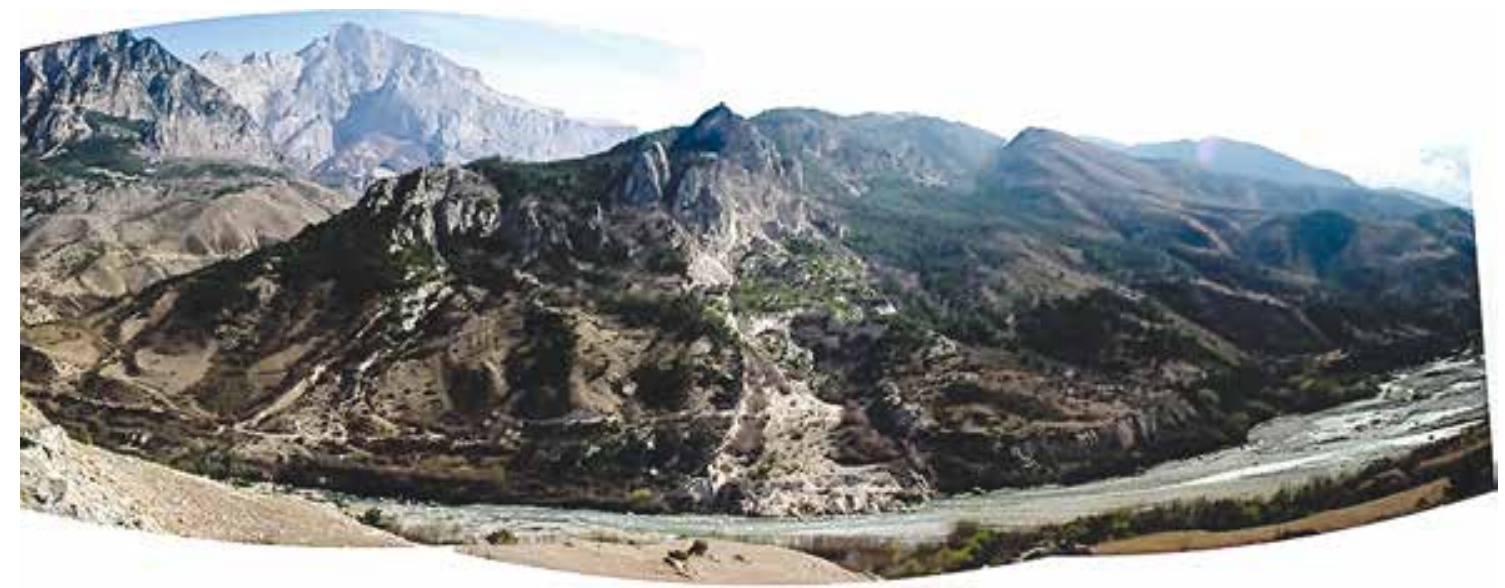

Fig. 11. Zintsarskiy landslide and view on river Ardon (Photo by A.Yu. Marchenkov, MSU)

data is the creation of digital elevation models (DEMs), which are basic information for slope characterization and numerical model study [22]. Large-area models can be derived from satellite data such as GTOPO30 with a resolution of $1 \mathrm{~km}$. For local areas, scanning can be performed with a resolution of up to fractions of a meter; it all depends on the speed of the equipment used and the feasibility of the problem being solved.

The use of robotic tacheometer opens up the possibility of collecting 3D position information for automatic monitoring of deformation. They can automatically measure angles and distances. Modern technology provides total stations capable of measuring angles with an accuracy of 1 second and distances with an accuracy of $\pm 1 \mathrm{~mm}$. At distances up to $3500 \mathrm{~m}$ (accuracy decreases with distance). Tacheometer allows measuring multiple points with prismatic targets on a controlled surface in a short period of time. Using Automatic Target Recognition (ATR) technology, each prism can be found and centered to ensure accurate targeting. Such technologies are ideal for precision applications where removal of sources of error is desired. However, using a sufficient number of prisms for permanent installation on a slope is not economically feasible; prisms are also precision optical devices that can be easily damaged not only by vandalism but also by natural factors. When moving and installing the prism manually, the advantage of using a tacheometer, which can measure at a distance, is lost. We investigated various reflective surfaces to provide a stable measurement over long distances for the Luarskiy landslide. The use of a robotic tacheometer allows aiming at the reflectors automatically, based on the results of the previous measurements. The created system requires the participation of the operator to aim accurately at the crosshair of the reflector, however, it still significantly reduces the work on regular geodetic monitoring. The disadvantage of using a tacheometric survey is the need for a line of sight to take measurements. However, in all cases, for all objects, we managed to select survey points covering the most important areas for monitoring. In extreme cases, GPS technology can be used. Modern robotic tacheometers have a scanning function. An example of scanning the area of a small landslide slope (Fiagdon tailing dump) is shown in Fig. 12. As a result, a digital surface model was built using the point cloud, which also shows the displacements of the reference points (Fig. $13 \mathrm{~b}$ ).

To predict changes in the state of the soil-forming land- 

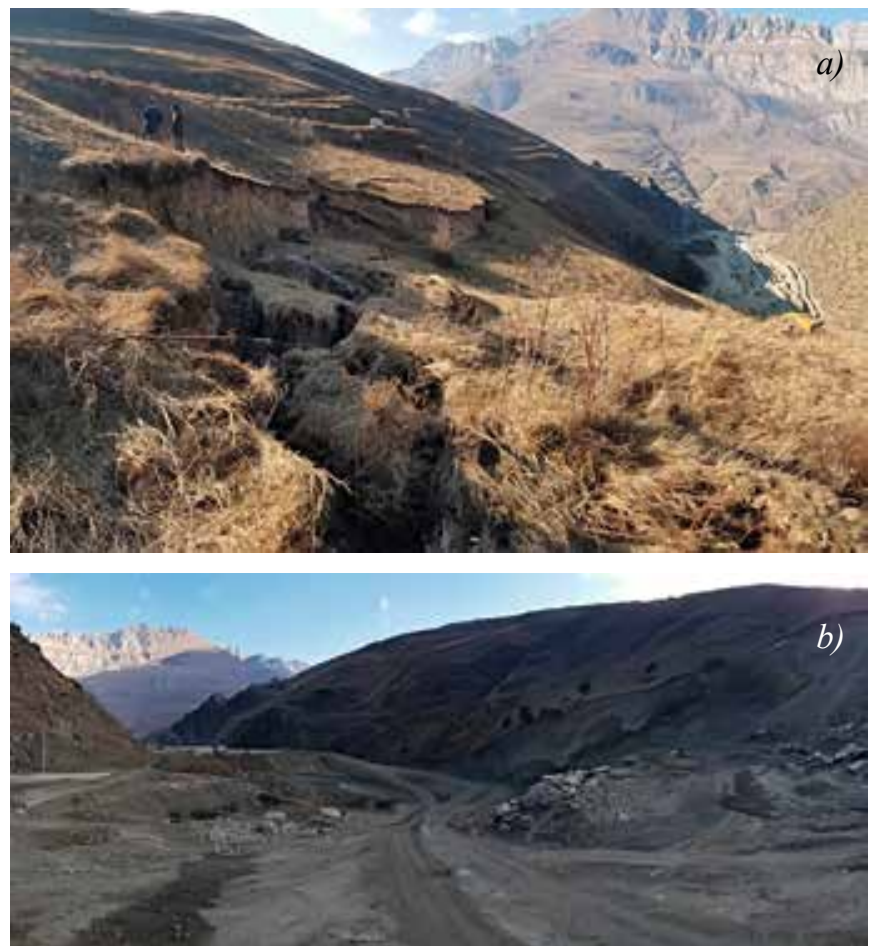

Fig. 12. Fiagdonskiy landslide: wall of separation (a) of landslide caused by cutting

of the lower part of the slope (b) during the liquidation of Fiagdon tailing dump, December 2019

slide body, it is important to know its physical properties [23-24] and processes occurring at various levels, including acoustic emission phenomena, and higher-frequency phenomena leading to changes in the structure of the geological environment. The method of infrared Fourier spectroscopy has recently found wide application in geology and geophysics [25]. Two instruments were used in the work: an FSM-1202 Fourier spectrometer (Infraspec) and a Bruker Alpha2 IR Fourier spectrometer.

\section{Conclusions}

Based on the hazard assessment the Nilgiris District in Tamil Nadu and Wayanad and Idukki Districts in Kerela area identified for further detailed study on monitoring Vulnerable slopes. On the territory of North Ossetia three sites of different mass volume and differenent activity rates were selected. Landslides that have not moved for years (for example Luarskiy landslide) commonly reactivate if ground water levels change dramatically, particularly when water penetrates old ground cracks, or construction activity creates slope modification that reduces stability. Steepening of a slope or removal of support at the toe by stream erosion or excavation also decreases slope stability. Beyond a critical point the slope fails due to lack of toe support. Cultural activities of man, such as road or rail cutting, terracing for agricultural or constructional work all inevitably involve toe removal land promote slope failures. Construction of a housing colony or other modes of load accumulation at the head of a slope strain the slope
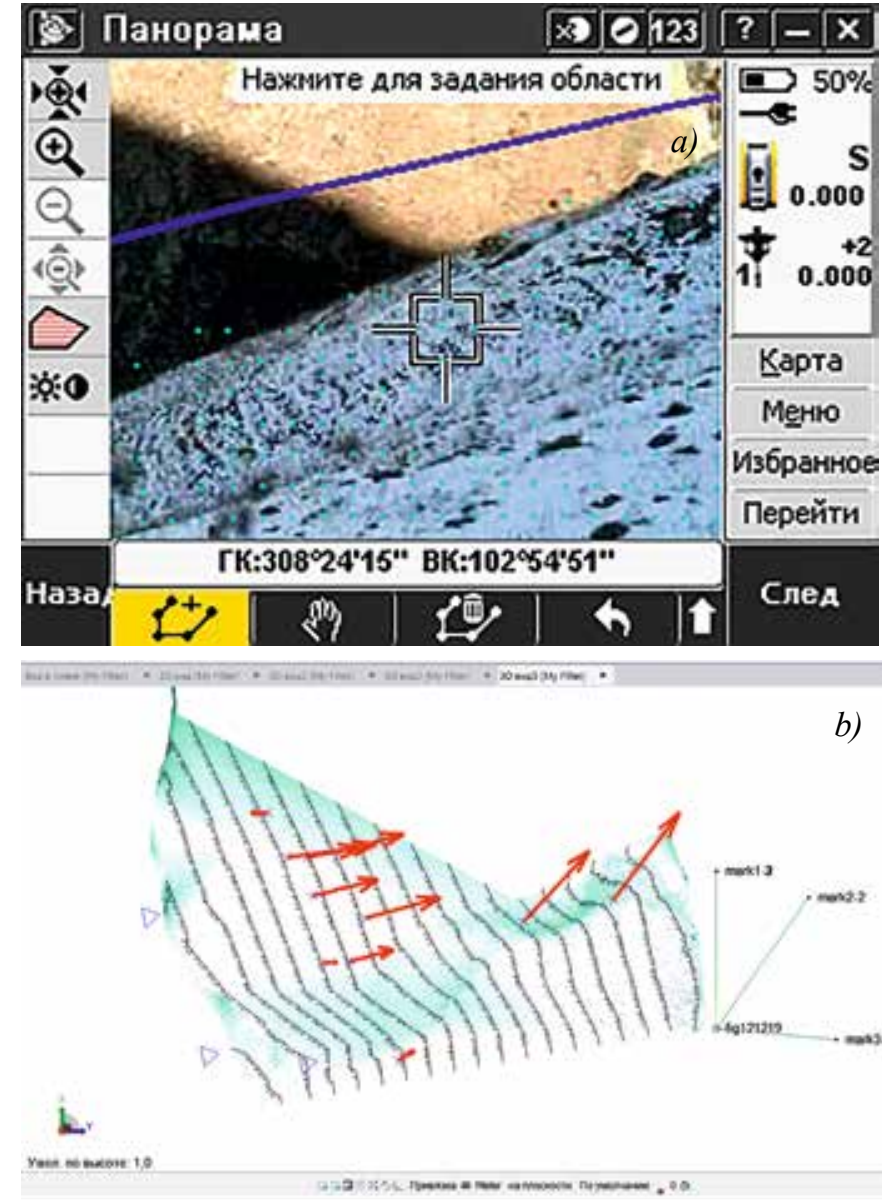

Fig. 13. Fragment of the Fiagdonskiy landslide in the process of scanning (a) and a digital surface model calculated from the point cloud (b). The arrows show the displacements

of the reference points

and it is relieved by landslides. It has been clearly reveals that landslides in Nilgiris, Wayanad, Idukki Districts are triggered by the intense rainfall, human and cultural activities, the toe of the slope was removed for laying road without any engineering measures, and unauthorized buildings gave additional weight on top of the slope. The government time to time giving awareness training to the local community, however there is no proper early warning system in the district. This is a big challenge for local authorities to communicate on the landslide to the local communities in the study area. The present project aims to develop a simple cost effective Community based early warning system for shallow landslides in the Nilgiris District. This will help mainly the local community which the people may not afford any high level technology. Many researchers carried out landslide hazard studies in these districts, however there is no much work carried out on monitoring of landslides in the of Western Ghats of India. Since the landslide occurrence in The Nilgiris, Wayanad, and Idukki Districts are quite a common phenomenon and frequently occurring one, it is necessary to safeguard the life and property. As well as to alert people a simple mechanism is required. 


\section{ACKNOWLEDGEMENT:}

The research was supported by Russian Science Foundation (Project No. 19-47-02010 RSF -DST (2018): "Natural hazards and monitoring for mountain territories in Russia and India".

\section{ЛИТЕРАТУРА:}

1. Bhandari RK, "The Indian Landslide Scenario, Strategic Issues and Action Points, (A Key Note address - Technical Session on Landslides)", First India Disaster Management Congress, 2006, New Delhi, pp. 29-30.

2. Arbanas Z., Fathani, T. F., Shoaei Z., Chae B. G., \& Tommasi P. Introduction: Monitoring, prediction and warning of landslides. In K. Sassa et al. (Eds.), Landslide Science for a Safer Geoenvironment, 2014, vol. 2, pp. 539-544, Berlin, Heidelberg, Springer.

3. GLC 2019, The Global Landslide Catalog, https://catalog. data.gov/dataset/global-landslide-catalog-export (Accessed on 03rd April 2020).

4. BMTPC, Landslide Hazard Zonation Atlas of India, Published by Building Materials and Technology Promotion Council, Government of India and Anna University, Chennai, 2003, p. 125.

5. Rajarathnam S, Ganapathy GP, "Landslide Hazard Zonation of India, a GIS Approach", Proceedings of the First India Disaster Management Congress, New Delhi, 2006, pp. 29-30.

6. Seshagiri DN, Badrinarayanan S, Upendran R et al., "The Nilgiris landslide - Miscellaneous publication", Geological Survey of India, 1982, no. 57.

7. Ganapathy GP, Hada CL, "Landslide Hazard Mitigation in the Nilgiris District, India - Environmental and Societal Issues", International Journal of Environmental Science and Development, 2012, 3: 5 .

8. Ganapathy GP, Rajawat AS, "Use of hazard and vulnerability maps for landslide planning scenarios: a case study of the Nilgiris, India", Journal of the International Society for the Prevention and Mitigation, 2015, vol. 77, no.1, pp. 305-316. https://doi.org/10.1007/s11069-015-1587-z

9. Thennavan E., Pattukandan Ganapathy G. Evaluation of landslide hazard and its impacts on hilly environment of the Nilgiris District - a geospatial approach. Geoenviron Disasters, 2020, 7, 3. https://doi.org/10.1186/s40677-019-0139-3

10. Thanavelu C, Chandrasekaran, "Geotechnical Assessment of November 2006 landslides in the Nilgiris Tamil Nadu", Abstract Volume: Proceedings of the National Seminar on Challenges in Engineering Geology, 03rd to 05th December 2008, Hyderabad.

11. Chandrasekaran SS, Sayed OR, Ashwin S et al., "Investigation on infrastructural damages by rainfall-induced landslides during November 2009 in Nilgiris, India", Natural Hazards, 2013, 65, pp.1535-1557. https://doi.org/10.1007/s11069-0120432-x

12. CGWB, District Groundwater Brochure Nilgiri District , TAMIL NADU, Technical Report Series, Government of India published by Ministry of Water Resources, Central Ground Water Board, South Eastern Coastal Region, Chennai, 2008, p. 21.

13. Kuriakose S. L., Sankar G. \& Muraleedharan C. History of landslide susceptibility and a chorology of landslide-prone areas in the Western Ghats of Kerala, India. Environ Geol, 2009, 57, 1553-1568. https://doi.org/10.1007/s00254-008-1431-9
14. Thampi PK, Mathai J, Sankar G, "A regional evaluation of landslide prone areas in the Western Ghats of Kerala", $A b$ stracts of the National Seminar on Landslides in Western Ghats, 29-30 Aug 1995, Centre for Earth Science Studies, Government of Kerala, Thiruvananthapuram, India, 1995.

15. Atlas of natural and man-made hazards and risks of emergency situations in the Russian Federation EMERCOM of Russia, Moscow, 2005. (In Russian)

16. Svalova V. B., Zaalishvili V. B., Ganapathy G. P., Nikolaev A. V. "Natural hazards and disasters in mountain areas", Geology and Geophysics of Russian South, 2018, 8(2): 87-101. (In Russ.). DOI: 10.23671/VNC.2018.2.14360.

17. Svalova V. B., Zaalishvili V. B., Ganapathy G. P., Nikolaev A. V., Melkov D. A. "Landslide risk in mountain areas", Geology and Geophysics of Russian South (in Russ.), 2019, 9 (2), 109-127. DOI: 10.23671/ VNC.2019.2.31981.

18. Svalova V. B., Zaalishvili V. B., Ganapathy G. P., Nikolaev A. V., Ginzburg A. A. "Complex Environmental Monitoring in Russia and India", Geology and Geophysics of Russian South, 2019, 9(4), 87-101. (In Russ.) DOI: 10.23671/ VNC.2019.4.44491.

19. Klyuev R. V., Bosikov I. I., Mayer A. V., Gavrina O. A. "Comprehensive analysis of the effective technologies application to increase sustainable development of the natural-technical system", Sustainable Development of Mountain Territories, 2020, no.2, pp. 283-290.

20. Klyuev R., Bosikov I., Gavrina O., Madaeva M., Sokolov A. (2021) "Improving the Energy Efficiency of Technological Equipment at Mining Enterprises". In: Murgul V., Pukhkal V. (eds), International Scientific Conference Energy Management of Municipal Facilities and Sustainable Energy Technologies EMMFT 2019. EMMFT 2019. Advances in Intelligent Systems and Computing, vol 1258. Springer, Cham. https://doi. org/10.1007/978-4-030-57450-5_24

21. Klyuev R., Fomenko O., Gavrina O., Turluev R., Marzoev S. (2021) "Energy Indicators of Drilling Machines and Excavators in Mountain Territories". In: Murgul V., Pukhkal V. (eds) International Scientific Conference Energy Management of Municipal Facilities and Sustainable Energy Technologies EMMFT 2019. EMMFT 2019. Advances in Intelligent Systems and Computing, vol 1258. Springer, Cham. https://doi.org/10.1007/9784-030-57450-5_25

22. Klyuev R. V., Bosikov I. I., Egorova E. V., Gavrina O. A. "Assessment of mining-geological and mining technical conditions of the Severny pit with the use of mathematical models", Sustainable Development of Mountain Territories, 2020, no.3, pp. 418-427. DOI: 10.21177/1998-4502-2020-12-4-418427.

23. Zaalishvili V. B., Melkov D., Kanukov A. S., Dzeranov B. V. "Spectral-temporal features of seismic loadings on the basis of strong motion wavelet database", International Journal of GEOMATE, 2016, vol. 10, no. 1, pp. 1656-1661

24. Zaalishvili V. B., Rogozhin E. A. "Assessment of seismic 
hazard of territory on basis of modern methods of detailed zoning and seismic microzonation", Open Construction and Building Technology Journal, 2011, vol. 5, pp. 30-40.

25. Grigorkina G. S., Ramonova A. G., Kibizov D. D.,
Kozyrev E. N., Zaalishvili V. B., Magkoev T. T., Fukutani K. "Probing specific oxides as potential supports for metal/oxide model catalysts: $\mathrm{MgO}(111)$ polar film", Solid State Communications, 2017, vol. 257, pp. 16-19.

\section{CONTRIBUTION:}

V. B. Zaalishvili - management of research, statement of tasks, analysis of results;

G. P. Ganapathy - management of research, statement of tasks, analysis of results;

S. S Chandrasekaran - data processing, calculations, preparation of illustrations;

D. A. Melkov - data processing, calculations, preparation of illustrations.

\section{CONFLICT OF INTEREST:}

The authors declare no conflict of interest.

\section{INFORMATION ABOUT AUTHORS / Сведения об авторах:}

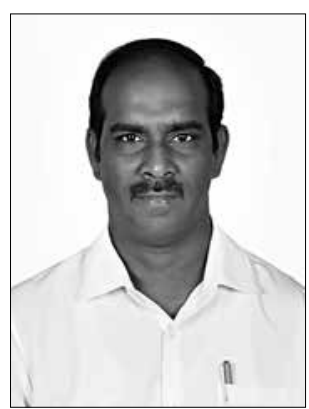

ститута технологий.

Веллор 663201, Тамил Наду, Индия.

Тел.: +914164207035.

E-mail: seismogans@yahoo.com

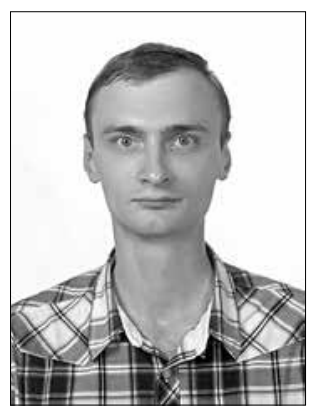

Dmitry A. MELKOV - Candidate of Technical Sciences, Leading Researcher of Department of Geophysics, Engineering Seismology and Geoinformatics.

Geophysical Institute - A Branch of the Federal State Budgetary Institution of Science of the Federal Scientific Center "Vladikavkaz Scientific Center of the Russian Academy of Sciences".

Ph.: +7(8672)76-19-28.

e-mail:melkovd@mail.ru

МЕЛЬКОВ Д. А. - кандидат технических наук, ведущиий научный сотрудник отдела геофизики, инженерной сейсмологии и геоинформатики.

Геофизический институт - филиал Федерального государственного бюджетного учреждения науки Федерального научного иентра "Владикавказский научный центр Российской академии наук", 362002, Владикавказ, Россия.

Тел.: +7(8672)76-19-28.

e-mail:melkovd@mail.ru

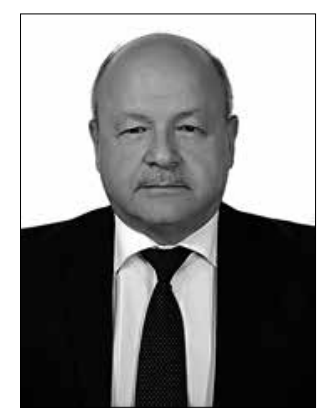

Vladislav B. ZAALISHVILI Doctor of Physical-Mathematical Sciences, Director, Head of Department of Geophysics, Engineering Seismology and Geoinformatics.

Geophysical Institute - A Branch of the Federal State Budgetary Institution of Science of the Federal Scientific Center "Vladikavkaz Scientific Center of the Russian Academy of Sciences".

Ph.: +7(8672)76-40-84

e-mail: vzaal@mail.ru

ЗААЛИШВИЛИ В. Б. - доктор физико-математических наук, профессор, директор, заведующий отделом геофизики, инженерной сейсмологии и геоинформатики.

Геофизический институт - филиал Федерального государственного бюджетного учреждения науки Федерального научного иентра "Владикавказский научныий иентр Российской академии наук", 362002, Владикавказ, Россия.

Тел.: +7(8672)76-40-84.

e-mail:vzaal@mail.ru

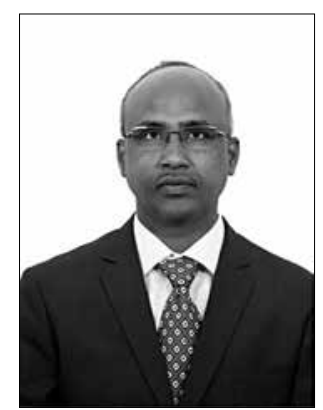

S. S. CHANDRASEKARAN Professor, School of Civil Engineering, Vellore Institute of Technology (VIT). Vellore 632014, Tamil Nadu, India.

ЧАНДРАСЕКАРАН С. С. - профессор, Школа гражданского строительства, Веллорийский Институт технологий.

Веллор 663201, Тамил Наду, Индия. 


\section{КОМПЛЕКСНЫЙ МОНИТОРИНГ СКЛОНОВЫХ ПРОЦЕССОВ \\ в индии и России}

Ганапати П. Г.,

Заалишвили В. Б. ${ }^{2 *}$,

Чандрасекаран C. C. ${ }^{3}$,

Мельков Д. А. ${ }^{2}$

${ }^{1}$ Центр смягчения и управления опасными процессами Веллорийского Института технологий. Веллор 663201, Тамил Наду, Индия, seismogans@yahoo.com

${ }^{2}$ Геофизический институт - филиал Федерального государственного бюджетного учреждения науки Федерального научного чентра "Владикавказский научный центр Российской академии наук", 362002, Владикавказ, Россия, cgi_ras@mail.ru

${ }^{3}$ Школа гражданского строительства, Веллорийский Институт технологий. Веллор 663201, Тамил Наду, Индия, sschandrasekaran@vit.ac.in

\section{DOI: $10.21177 / 1998-4502-2020-12-4-572-581$}

Общий подход к прогнозированию оползней - это интеграция наблюдаемых смещений оползней, свойств почвы и оценки количества осадков в прогностических моделях. В целом, мониторинг развития неустойчивого склона может предоставить ценную информацию для лучшего понимания процессов активного прогнозирования и раннего предупреждения о потенциальных геологических бедствиях. На этом фоне Индия и Россия инициировали разработку рентабельной методологии мониторинга оползней в рамках Российско-индийских двусторонних совместных проектов DST-RFBR.

На основании оценки опасности Район Нилгирис в Тамил Наду, а также районы Ваянад и Идукки в районе Керела определены для дальнейшего детального изучения по мониторингу уязвимых склонов.

На территории Северной Осетии выбраны три участка с разной массой и разной интенсивной активностью. Оползни, которые не двигались в течение многих лет (например, Луарский оползень), обычно возобновляются, если уровни грунтовых вод резко меняются, особенно когда вода проникает в старые трещины в грунте, или когда строительные работы приводят к изменению склона, которое снижает устойчивость.

Ключевые слова: оползень, мониторинг, анализ рисков, оценка рисков, картографирование.

Статья поступила в редакиию 18.07.2020. 


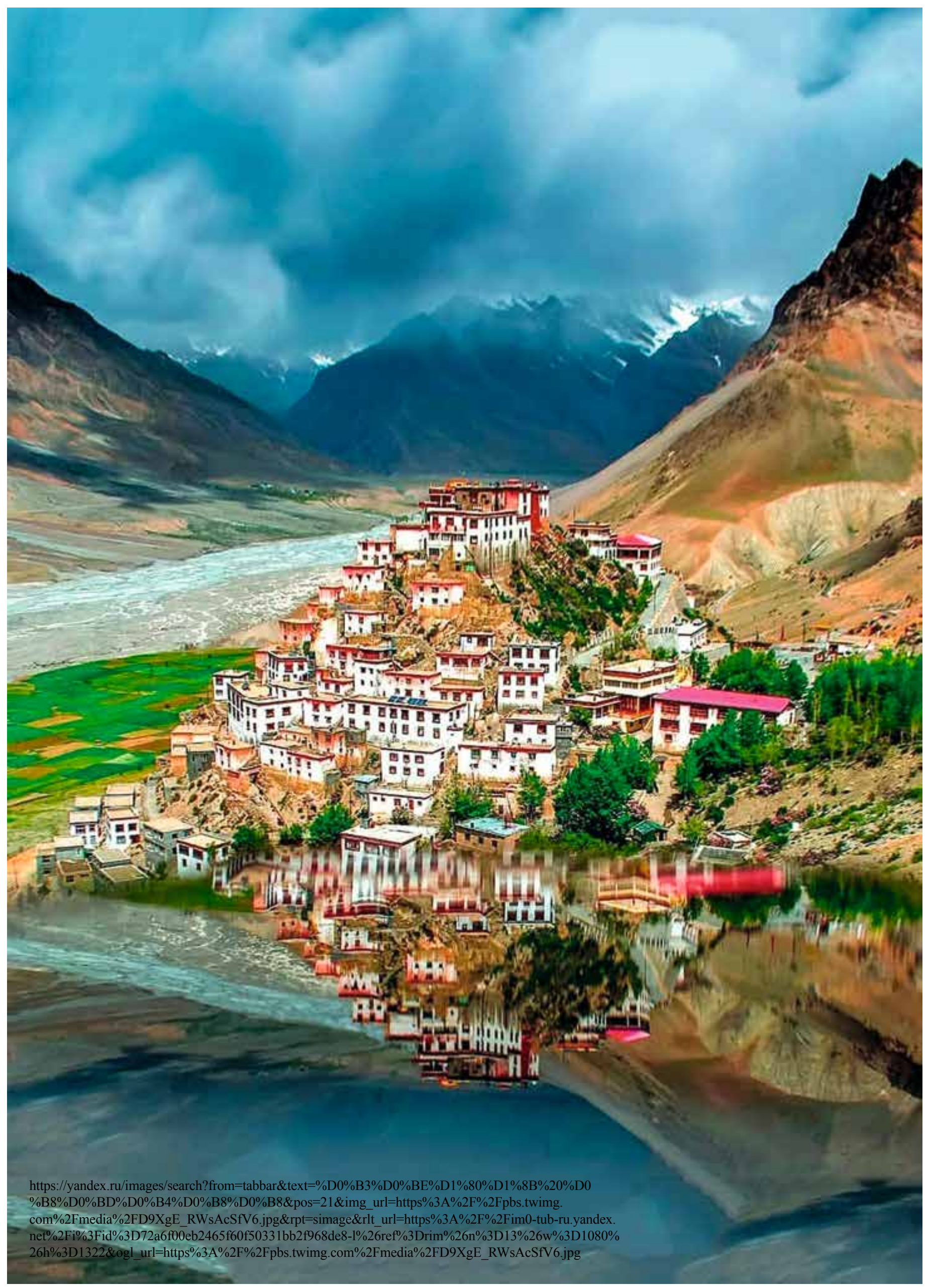




\section{ТЕХНИЧЕСКИЕ НАУКИ}

\section{ENGINEERING}

Если бы я захотел читать, ещце не зная букв, это было бы бессмыслицей.

Точно так же, если бы я захотел судить о явлениях природы, не имея никакого представления о началах вещей, это было бы такой жсе бессмыслицей.

Михаил ЛОМОНОСОВ

\section{ПОТЕНЦИАЛ УПРАВЛЕНИЯ ЭЛЕКТРОПОТРЕБЛЕНИЕМ В УСЛОВИЯХ ИЗОЛИРОВАННОЙ ЭНЕРГОСИСТЕМЫ УДАЛЕННОГО НАСЕЛЕННОГО ПУНКТА}

\author{
Жуковский Ю. Л. ${ }^{*}$, \\ Лаврик А. Ю.', \\ Семенюк А. В. ${ }^{1}$ \\ Васильков О. С. ${ }^{1}$ \\ ${ }^{1}$ Санкт-Петербургский горный университет, 199106, Санкт-Петербург, Россия, \\ spmi_energo@mail.ru
}

\section{Введение}

Энергоснабжение населенных пунктов и промышленных объектов, расположенных в горной местности, является серьезной проблемой, требующей решения в целях устойчивого развития не только этих территорий, но и всей страны. Зачастую строительство линий электропередач экономически не оправдано, а выработка электроэнергии возможна только с помощью локальных источников генерации. Децентрализованное электроснабжение охватывает значительную часть Сибири, Дальнего Востока и Арктики, занимая от 60 до 70\% территории страны, однако изолированные энергетические системы малой мощности (до 1 МВт) существуют и в других субъектах России, в том числе на Кавказе [1]. Как правило, такие системы включают в себя электростанции на ископаемом топливе. Наибольшее распространение получили ДЭС [2-4].

Высокая себестоимость электроэнергии, доходящая до 150-200 руб./кВт·ч [5] как за счет высоких отпускных цен на дизельное топливо (ДТ), так и за счет транспортной составляющей [6; 7], делает актуальным поиск альтернативных способов выработки электроэнергии. В связи с этим большое число исследований посвящено возобновляемым источникам энергии (ВИЭ), позволяющим снизить затраты на ДТ, повысить надежность электроснабжения и уменьшить негативное воздействие на окружающую среду [8-11].

Вместе с тем интеграция большинства видов ВИЭ (кроме стабильных по выработке, например - геотермальных станций) не позволяет отказаться полностью от ДЭС. Таким образом, оптимизация режима работы ДЭС как в системах с ВИЭ, так и без них, является актуальной задачей.

Одной из технологий, активно внедряемых в интеллектуальные энергети-
УДК: 620.93

DOI: $10.21177 / 1998-4502-2020-$

$12-4-583-591$

Рассмотрен способ повышения техникоэкономической эфрфективности распространенных в горной местности изолированных энергосистем малой мощности, основанный на реализации управления электропотреблением. Предложена методика предварительной оценки потенциала управления спросом на электроэнергию хозяйственно-бытовой нагрузки в автономной энергосистеме с дизельной электростанцией. Техникоэкономический эфрфект предлагается определять исходя из приближения режима работы дизельгенераторных установок к оптимальному. Применение методики показано на примере Амдермы Архангельской области.

\section{КЛЮЧЕВЫЕ СЛОВА:} энергоэфффективность, управление спросом, дизель, дизельная электростанция, электрическая нагрузка, график.

Статья поступила в редакцию 14.07.2020. 
ческие системы развитых стран, является управление спросом на электроэнергию [12]. Управление спросом может применяться и в автономных энергетических системах относительно небольшой мощности, что позволит осуществлять оптимальное распределение мощности по ДГУ и эффективное планирование пусков и остановов ДГУ, а также снижать негативное воздействие на окружающую среду [13].

\section{Управление спросом на электроэнергию}

Концепция управления спросом на электроэнергию предполагает активное участие потребителей электроэнергии в формировании графика нагрузки, заключающееся в изменении ими своего обычного профиля электропотребления в ответ на предоставляемые оператором экономические или какие-либо другие стимулы [14]. К основным задачам управления спросом на электроэнергию относится уменьшение пиковой нагрузки энергосистемы с целью понижения цен на рынке электроэнергии и предотвращения строительства новых электрических сетей и генерации; оптимизация управления энергосистемой и интеграция ВИЭ [15; 16].

В части мирового опыта управления спросом в больших энергосистемах показателен пример пилотного проекта EcoGrid EU, в котором приняло участие около 2000 чел. из 28 тысяч жителей о. Бронхольм (Дания). Потребители изменяли свой уровень энергопотребления в ответ на ценовые сигналы, получаемые в режиме реального времени. Энергосистема острова (пиковая нагрузка 55 МВт) характеризуется использованием разнообразных энергоресурсов, включая энергию ветра (35 МВт), теплоэлектростанции (16 $\mathrm{MBT})$, энергию солнца (2 МВт) и электромобили. Так, использование гибкого потребления снизило пиковую нагрузку приблизительно на 670 кВт, или на 1,2\% объема пиковой нагрузки острова [17].

Внедрение механизма управления спросом во многих странах позволило организовать централизованное управление ресурсами потребителей в объеме 2-6\% от пикового спроса или 0.5-14 ГВт мощности: США (РЈМ) - 13.9 ГВт, Южная Корея (КЕРСО) - 3.2 ГВт, Канада (IESO) - 0,7 ГВт.

Технология управления спросом на электроэнергию в адаптации к изолированным энергетическим системам относительно небольшой мощности будет иметь свои особенности. С одной стороны, в таких системах проще консолидировать население и промышленность для достижения технико-экономического эффекта. С другой стороны, прогнозирование спроса в системе небольшой мощности осуществлять сложнее, а ошибки могут привести к выходу системы электроснабжения из устойчивого состояния.

Не менее важным вопросом является разработка подходящей архитектуры и программ системы управления электропотреблением [18; 19]. Так, в сложных системах домашний контроллер потребления поддерживает двустороннюю связь с центральным контроллером, который отслеживает текущее электропотребление, осуществляет по определенному алгоритму планирование электропотребления и отправку управляющих сигналов или уведомлений на домашние контроллеры потребления пользователей. В более простых системах управления спросом домашний контроллер может осуществлять только прием сигналов от центрального контроллера.

\section{Методика оценки потенциала управления спросом на электроэнергию}

Для предварительной оценки потенциала управления спросом на электроэнергию предлагается использовать следующую методику.

В качестве исходных данных необходимо иметь суточные графики (ведомости) мощности нагрузки исследуемого объекта. Могут анализироваться данные за каждый день года, а при отсутствии таких данных усредненные за месяц графики. Рассмотрение большего числа лет предпочтительно.

Кроме того, необходимо использовать результаты проведенных исследований по управлению спросом для аналогичной нагрузки. Эти результаты могут быть представлены в виде графиков (ведомостей) несмещаемой или смещаемой части нагрузки.

Например, в работе [20] на основе информации с интеллектуальных счетчиков учета электроэнергии 60 домохозяйств в швейцарском Сьоне был составлен усредненный график несмещаемых нагрузок для жилого дома с семьей из трех человек, представленный на рис. 1. В исследовании отмечается, что пик несмещаемой по времени электрической нагрузки приходится на период времени с 17 до 18 часов, что обусловлено возвращением людей домой и производством работ, имеющих высокий приоритет без возможности смещения - например, приготовление пищи.

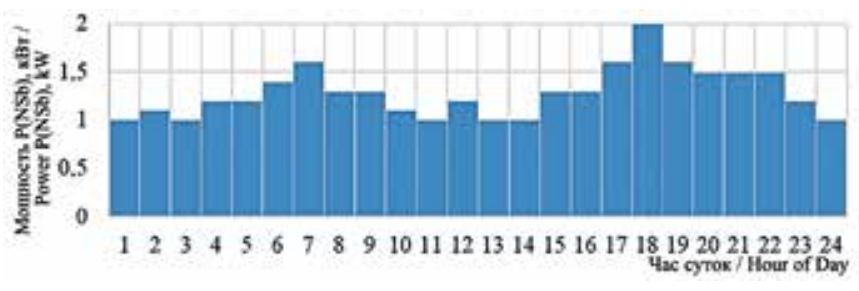

Puc. 1. Базовый график несмещаемой нагрузки домовладения в летние месяцы

Fig. 1. Base Non-shiftable Load Schedule of Household in Summer Months

Конечно, уровень электропотребления для двух аналогичных объектов зависит от государства, климата, качества жизни и так далее, и может иметь существенные отличия. Поэтому для оценки доли несмещаемой нагрузки в каждом исследуемом случае можно использовать форму графика без привязки к количественной оценке потребления электроэнергии. 
Обозначим мощность нагрузки исследуемого объекта $P(L) t$, а мощность несмещаемой нагрузки согласно базовому исследованию $P(N S b) t$, где $t=1-24$ ч. Получать график несмещаемой нагрузки $P(N S)$ предлагается изменением значений ряда $P(N S b)$ путем их умножения на коэффициент $\mathrm{k}$ следующим образом:

$$
P(N S)_{t}=k \cdot P(N S b)_{t},
$$

при этом величина $k$, в зависимости от выбора первого или второго способа, однозначно определяется исходя из следующих условий.

Согласно способу 1, должны быть выполнены два условия - неравенство (2) и равенство (3):

$$
\begin{array}{ll}
P(N S)_{t} \leq P(L)_{t} & \text { for } t=1 . .24, \\
P(L)_{t}=P(N S)_{t} & \text { for } t=i,
\end{array}
$$

где $k$ - коэффициент совмещения графиков; $i-$ час(ы) совмещения графиков нагрузки.

Согласно способу 2, должно быть выполнено только равенство (3). Отметим, что при выполнении условия (2) условие (3) всегда выполняется, однако обратное утверждение не верно.

В качестве проверки адекватности полученного результата необходимо определить получившуюся суммарную долю смещаемой нагрузки и сравнить ее с известной для данного типа нагрузки величиной. Так, для жилой нагрузки доля смещаемой нагрузки может оцениваться в $30 \%$ [21].

Затем экономически оптимальная с точки зрения расхода топлива загрузка ДЭС определяется исходя из спецификаций используемого оборудования.

\section{Применение методики на примере \\ п. Амдерма}

Поселок Амдерма располагается на Югорском полуострове на побережье Карского моря. Население составляет около 550 человек. Жилой фонд, административные и социальные постройки, морской порт и аэропорт являются основными потребителями электроэнергии. Мощность электрической нагрузки для четырех месяцев представлены в табл. 1.

На рис. 2 показана среднесуточная динамика мощности нагрузки Амдермы в июле.

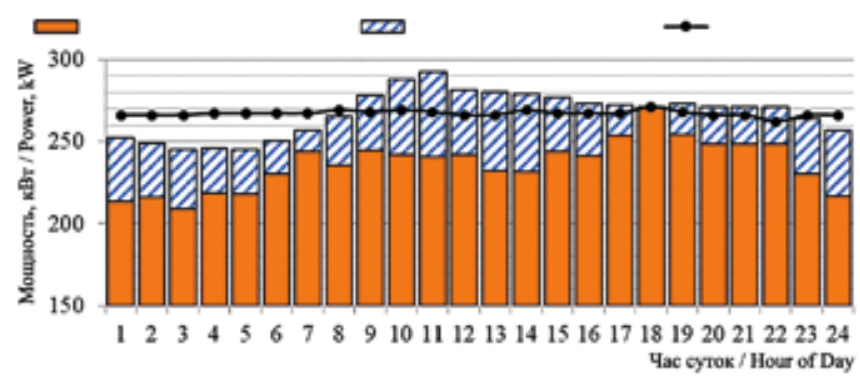

Puc. 2. Среднесуточная динамика мощности нагрузки Амдермы в июле (столбцы) с указанием смещаемой и несмещаемой части и итоговый график нагрузки ДЭС

Fig. 2. Average Daily Dynamics of Amderma's Load Power in July (Columns) with Indication of Shiftable and Non-shiftable Parts and Final Load Curve of Diesel Power Plant

В настоящее время основными источниками генерации электроэнергии в Амдерме являются три ДГУ Gesan, ранжированные по мощности, ДГУ ПСM ADV400 и 4 ветрогенератора установленной мощностью 50 кВт каждый. Кроме того, в составе ДЭС имеется 2 резервных ДГУ ТСС. Состав основного оборудования ДЭС Амдермы и расходные характеристики ДГУ представлены в табл. 2.

Таблица 1 / Table 1

Мощность электрической нагрузки некоторых месяцев Load Power of Some Months

\begin{tabular}{|l|c|c|c|c|}
\hline \multicolumn{1}{|c|}{ Мощность / Power } & $\begin{array}{c}\text { Апрель } \\
\text { April }\end{array}$ & $\begin{array}{c}\text { Июль } \\
\text { July }\end{array}$ & $\begin{array}{c}\text { Декабрь } \\
\text { December }\end{array}$ & $\begin{array}{c}\text { Январь } \\
\text { January }\end{array}$ \\
\hline $\begin{array}{l}\text { Средняя мощность, кВт } \\
\text { Average Power, } \mathrm{kW}\end{array}$ & 327 & 192 & 349 & 338 \\
\hline $\begin{array}{l}\text { Минимальная маощность, кВт } \\
\text { Мinimum Рower, } \mathrm{kW}\end{array}$ & 88 & 139 & 255 & 249 \\
\hline $\begin{array}{l}\text { Максимальная мощность, кВт } \\
\text { Махітит Роwеr, } \mathrm{kW}\end{array}$ & 414 & 343 & 478 & 442 \\
\hline
\end{tabular}

Таблица 2 / Table 2

Характеристики расхода топлива ДГУ / Fuel Consumption Characteristics of Diesel Generators

\begin{tabular}{|c|c|c|c|c|c|c|c|}
\hline \multirow{2}{*}{ № } & \multirow{2}{*}{$\begin{array}{c}\text { ДГУ } \\
\text { Diesel Power Plant Unit }\end{array}$} & \multicolumn{2}{|c|}{$\begin{array}{c}\text { Мощность, кВт } \\
\text { Power, } k W\end{array}$} & \multicolumn{4}{|c|}{$\begin{array}{c}\text { Расход топлива при загрузке, л/ч } \\
\text { Fuel Consumption when Load Factor, } l / h\end{array}$} \\
\cline { 3 - 8 } & & ном. / rat. & макс. / max & $\mathbf{2 5 \%}$ & $\mathbf{5 0 \%}$ & $\mathbf{7 5 \%}$ & $\mathbf{1 0 0 \%}$ \\
\hline 1 & Gesan DVA410ME & 300 & 330 & 21.9 & 39.4 & 58.4 & 78.7 \\
\hline 2 & Gesan DVA220ME & 160 & 176 & 11.3 & 23.1 & 34.6 & 46.1 \\
\hline 3 & Gesan DVA140ME & 103 & 114 & 8.2 & 14.5 & 21.8 & 29.1 \\
\hline 4 & ПCM ADV-400 & 400 & 440 & - & 51.5 & 74.5 & 102.1 \\
\hline 5 & ТСС АД-60C-T-400-1PM17 & 60 & 66 & - & - & 15.9 & 20.6 \\
\hline 6 & ТСС АД-280-T400-23HM & 280 & 308 & - & - & 52 & - \\
\hline
\end{tabular}


Система функционирует по принципу частичного замещения дизельного топлива, т.е. электроэнергия ветрогенераторов снижает загрузку находящихся в работе ДГУ, тем самым снижая расход ДТ. При этом система не переходит в минимальный режим, т.е. выработка электроэнергии ВИЭ не приводит к изменению числа работающих ДГУ.

В будущем планируется внедрение системы активного регулирования баланса мощностей, включающей двунаправленный преобразователь тока и аккумуляторные батареи. Это позволит переводить ДЭС в минимальный режим и, когда возможно, отключать ДГУ.

Для исследуемого объекта отсутствуют суточные графики (ведомости) электрической нагрузки жилого сектора. Вместе с тем есть информация о балансе годового потребления электроэнергии, представленная в табл. 3.

Согласно табл. 3 треть суммарного электропотребления Амдермы приходится на хозяйственно-бытовой и административный сектор. В соответствии с этим примем, что значения ряда суточного графика жилой нагрузки в 3 раза меньше значений суммарного графика электрической нагрузки поселка. Полученный график полной мощности жилой нагрузки Амдермы для характерного дня июля, обозначаемый $P(L)$, показан на рис. 3 .

Для получения графика несмещаемой нагрузки $P(N S)$ воспользуемся профилем графика несмещаемой нагрузки для частного домовладения $P(N S b)$, представленным на рис. 1 . Все значения ряда $P(N S b)$ меньше значений ряда $P(L)$ на рис. 3. Тогда, согласно выражению (1), необходимо увеличить значения ряда $P(N S b)$ в $k$ раз так, чтобы при выполнении неравенства (2) одно или несколько значений $P(N S)$ совместилось с одним или несколькими значениями $P(L)$ согласно выражению (3).

В рассматриваемом случае одновременное вы- полнение условий (2) и (3) достигается при $i=18$ (час совмещения графиков), на который согласно исследованию [20] приходится максимум несмещаемой нагрузки жилых домов. Коэффициент находится из выражения (3):

$$
k=\frac{P(L)_{18}}{P(N S b)_{18}}=\frac{89.4}{2}=44.7 .
$$

Тогда остальные значения графика несмещаемой нагрузки жилого сектора Амдермы P(NS) будут найдены по формуле (1).

Полученный график несмещаемой жилой нагрузки P(NS) показан на рис. 3. Видно, что в 18-й час отсутствует нагрузка, которая может быть смещена.

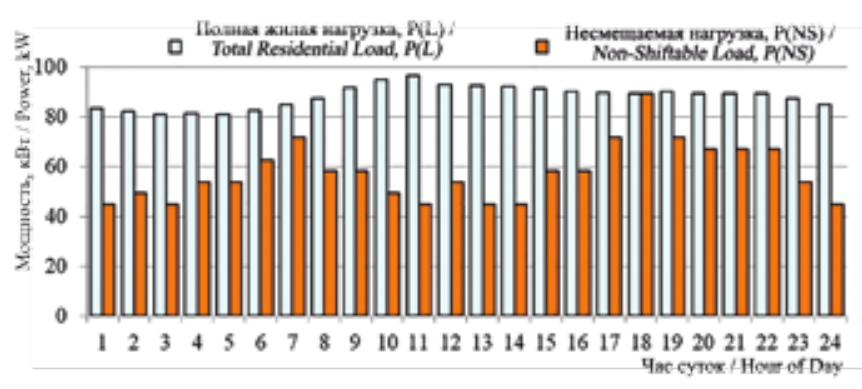

Pис. 3. График полной электрической мощности жилой нагрузки и график несмещаемой части жилой нагрузки (типовой день июля)

Fig. 3. Total Residential Electric Load Schedule and Residential Nonshiftable Load (Typical Day of July)

Тогда на суммарном графике электрической нагрузки поселка можно выделить часть смещаемой электрической нагрузки, результаты представлены на рис. 2. Стоит отметить, что в данном примере не рассматривалась возможность смещения части нагрузки промышленных потребителей.

Аналогичная методика была применена для некоторых других месяцев. Доля смещаемой части от

Баланс годового потребления электроэнергии в п. Амдерма

таблица 3 / Table 3 Annual Electricity Consumption Balance in Amderma village

\begin{tabular}{|c|c|c|c|c|}
\hline $\begin{array}{c}\text { Годовое потребление электроэнергии } \\
\text { в п. Амдерма }\end{array}$ & $\begin{array}{c}\text { Промышленность } \\
\text { Innual electricity consumption in } \\
\text { Amderma village }\end{array}$ & $\begin{array}{c}\text { Собственные } \\
\text { нужды } \\
\text { Self Needs }\end{array}$ & $\begin{array}{c}\text { Сторонние } \\
\text { потребители } \\
\text { Third Party } \\
\text { Consumers }\end{array}$ & $\begin{array}{c}\text { Потери } \\
\text { Losses }\end{array}$ \\
\hline $\begin{array}{c}\text { Доля в потреблении, \% } \\
\text { Part in Consumption,\% }\end{array}$ & 45 & 18 & 33 & 4 \\
\hline
\end{tabular}

таблица 4 / Table 4

Доля смещаемой части от суммарного потребления электроэнергии жилых домов Shiftable Part of Total Residential Electricity Consumption

\begin{tabular}{|c|c|c|c|c|}
\hline & Январь / January & Апрель / April & Июль /July & Декабрь / December \\
\hline $\begin{array}{c}\text { Доля смещаемой нагрузки, \% } \\
\text { Shiftable Load Part, \% }\end{array}$ & 37 & 28 & 35 & 29 \\
\hline
\end{tabular}


суммарного потребления электроэнергии жилым сектором Амдермы представлена в табл. 4.

Определим оптимальную загрузку дизель-генераторов при управлении спросом на электроэнергию. Рассмотрим ситуацию, когда ВЭС выключена, что может возникнуть при недостаточной скорости ветра, выходе из строя ВЭУ или штормовом ветре.

Наиболее предпочтительной является эксплуатация ДГУ при загрузке 40-80\% [22], т.к. именно в этом диапазоне мощностей обеспечивается оптимальный с точки зрения расхода топлива и износа режим работы ДГУ. При этом с наименьшим удельным расходом топлива ДГУ функционирует при загрузке около 75\%. Зависимость расхода топлива ДГУ №1 и ДГУ №4 представлены на рис. 4.

Анализ графика нагрузки, представленного на рис. 2, позволяет сделать вывод о том, что при отсутствии управления спросом на электроэнергию генерацию целесообразно осуществлять с помощью ДГУ №4, при этом ДГУ №4 будет функционировать с загрузкой $61-73 \%$.

Равномерное распределение электрической нагрузки, достигаемое путем переноса смещаемой части нагрузки, позволяет получить итоговый график электрической нагрузки, показанный на рис. 2 черной линией. При этом ДГУ №4 будет функционировать с загрузкой $66-67 \%$. Стоит отметить, что в данном случае осуществляется дозагрузка генераторов в ночные часы, а максимальное время переноса смещаемой части нагрузки не превышает 6 часов. Экономия топлива составляет 0,65 л/сут. и достигается за счет приближения режима работы ДГУ к оптимальному в соответствии с расходными характеристиками, представленными на рис. 4. Кроме того, это позволит предотвратить выброс в атмосферу около 1,8 кг диоксида углерода [23].

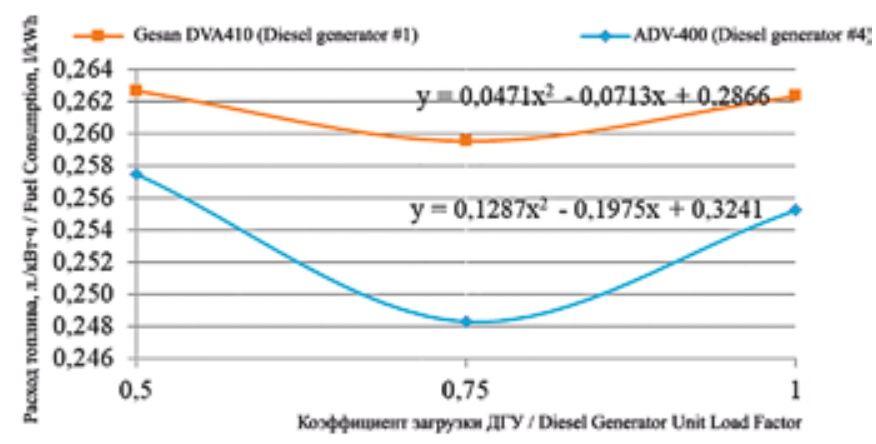

Puc. 4. Зависимость расхода ДТ (л/кВт·ч) ДГУ №1 и ДГУ №4 от коэффициента загрузки

Fig. 4. Diesel Fuel Consumption Dependence (l/kWh) of Diesel Generator No. 1 and Diesel Generator No. 4 on Load Factor
Вместе с тем неравномерность графика электрической нагрузки в произвольный день месяца существенным образом влияет на результат. Рассмотрим график электрической нагрузки не характерного, а произвольного дня июля, минимальная нагрузка которого составила 178 кВт, а максимальная -295 кВт.

По способу 2 , т.е. совмещением в 18 -й час графиков $P(N S)$ и $P(L)$, был получен график несмещаемой нагрузки $P(N S)$, а затем построен график электрической нагрузки с выделенной частью смещаемой нагрузки. При этом доля смещаемого электропотребления от суммарного суточного электропотребления жилым сектором составила 22,6\%. Загрузка ДГУ распределена максимально равномерно с учетом того, что не вся нагрузка может быть перенесена. Результаты представлены на рис. 5.

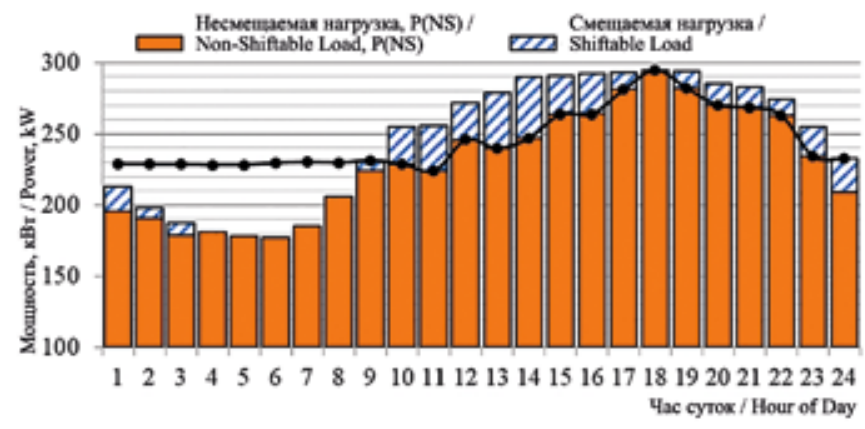

Puc. 5. Суточная динамика мощности нагрузки произвольного дня июля (столбцы) с указанием доли смещаемой и несмещаемой нагрузки (по способу 2). Итоговый график нагрузки ДЭС

Fig. 5. Daily Dynamics of Load Power in Arbitrary Day of July (Columns) with Indication of Shiftable and Non-Shiftable Parts (method \#2). Final Load Curve of Diesel Power Plant

Нужно отметить, что получение графика $P(N S)$ способом 1, т.е. учет условия (2), приводит к другому результату доли смещаемого электропотребления от суммарного суточного электропотребления жилой нагрузки - 39,4\%. График электрической нагрузки с выделенной частью смещаемой нагрузки, полученный способом 1, показан на рис. 6. Час совмещения графиков $i=6$.

Рассмотрим график, полученный способом 2 (рис. 5), т.к. потенциал смещаемой нагрузки по данному способу меньше, и следует избегать завышенных оценок потенциала управления спросом на электроэнергию. Обеспечение заданной нагрузки без управления спросом возможно двумя способами: работа ДГУ №1 в ночные часы с 0:00 по 6:00 и работа ДГУ №4 с 6:00 до 24:00; работа ДГУ №4 24 часа. Минимальный расход топлива в соответствии с данными табл. 2 и рис. 4 обеспечивается поочередной работой ДГУ №1 и ДГУ №4. Загрузка ДГУ №1 в течение дня составляет 59-66\%, загрузка ДГУ №4-51-74\%. 


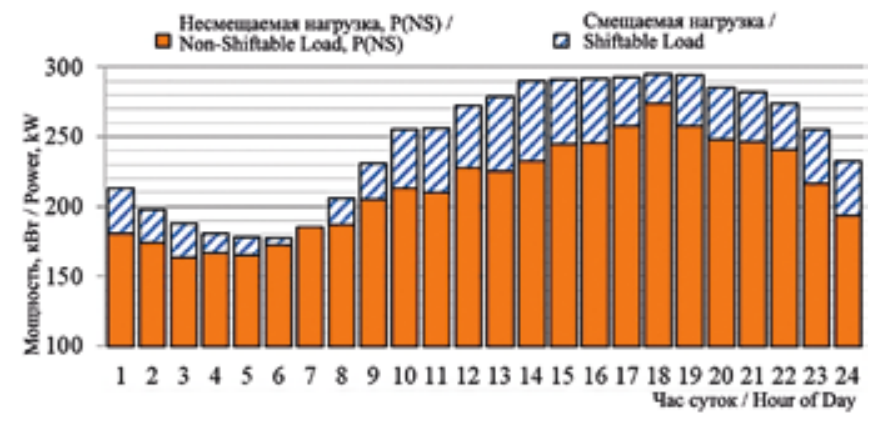

Puc. 6. Суточная динамика мощности нагрузки произвольного дня июля (столбцы) с указанием доли смещаемой и несмещаемой нагрузки в июле (по способу 1)

Fig. 6. Daily Dynamics of Load Power in Arbitrary Day of July (Columns) with Indication of Shiftable and Non-Shiftable Parts (method \#1)

Перенос смещаемой части нагрузки позволяет перейти на постоянную работу ДГУ №4 и повысить минимальный уровень загрузки ДГУ №4: теперь загрузка составляет 57-74\%. Итоговый график нагрузки ДГУ №4 показан черной линией на рис. 5. Экономия топлива за счет изменения режима работы составила 2,90 л/сут., а экологический эффект заключается в предотвращении выбросов в атмосферу около 7,8 кг/сут. диоксида углерода [23].

\section{Выводы}

Таким образом, по полученным значениям доли смещаемой части нагрузки в общем энергобалансе населенного пункта, составившим в примере от 28 до $37 \%$, можно сделать вывод о возможности применения предложенной методики, т.к. в целом для хозяй-

\section{ЛИТЕРАТУРА:}

1. Елистратов В.В. Энергетическое снабжение изолированных территорий России // Академия энергетики, 2015. N4. C. 26-33.

2. Kuznetsov P. A., Abramovich B. N., Sychev Y. A., Mukminova D. Z. Assessment and data analysis of beneficial implementation of cogeneration modules at mining enterprises to minimize negative influence on the environment // Journal of Physics: Conference Series. 2019. no. 1333. pp. 032048.

3. Лукутин Б. В., Суржикова О.А., Шандарова Е.Б. Возобновляемая энергетика в децентрализованном электроснабжении: монография. Москва: Энергоатомиздат, 2008. $231 \mathrm{c}$.

4. Koptev V. Y., Kopteva A. V. Structure of energy consumption and improving open-pit dump truck efficiency / IOPConference Series: Earth and Environmental Science. 2017. no. 87. pp. 022010. DOI: 10.1088/1755-1315/87/2/022010.

5. Lukutin B. V., Shandarova E.B., Fuks I.L. Energy efficiency of photovoltaic power plants in stand-alone power supply systems / 2nd International Conference on Industrial Engineering, Applications and Manufacturing (ICIEAM), Chelyabinsk, 2016. P. 1-5.

6. Смоленцев Д. О. Развитие энергетики Арктики: проблемы и возможности малой генерации // Арктика: экология и экономика, 2012. N3. С. 22-29. ственно-бытовых потребителей характерна доля смещаемой электрической нагрузки порядка $30 \%$.

Нужно отметить, что потенциал управления электропотреблением существенно зависит от графиков нагрузки исследуемого объекта и может значительно варьироваться от месяца к месяцу.

Потенциальный эффект от внедрения технологии в изолированные энергосистемы горных территорий, включающие не только ДЭС, но и ВИЭ, может быть существенно выше. При этом наибольший эффект при использовании в таких системах будет достигаться при значительной установленной мощности установки на базе ВИЭ - смещение мощности нагрузки во времени позволит повысить коэффициент использования установленной мощности ВИЭ.

Оцениваемый в нашей работе технико-экономический эффект без учета ВИЭ заключается в экономии топлива, что достигается за счет изменения режимов работы ДГУ, а именно приближения их коэффициентов загрузки к оптимальным значениям. Немаловажен и экологический эффект, заключающийся в снижении количества выбросов в атмосферу загрязняющих веществ. Кроме того, следует помнить также о продлении срока службы ДГУ за счет работы в оптимальных с точки зрения загрузки режимов.

Для уточненного анализа потенциала технологии требуется более детальное энергетическое обследование исследуемого объекта. Также особое внимание необходимо уделить разработке подходящей для конкретного объекта архитектуры и программы управления спросом на электроэнергию.

7. Дубровин Е. А., Дубровин И. А. Как снизить затраты на углеводородное топливо в Арктике // Энергетика и промышленность России. URL: https:/www.eprussia.ru/ epr/333-334/7102917.htm (Дата обращения 28.11.2020).

8. Lavrik A.Y., Zhukovskiy Y.L., Buldysko A.D. Features of the Optimal Composition Determination of Energy Sources During Multi-Criterial Search in the Russian Arctic Conditions // Proceedings of the 2nd 2020 International Youth Conference on Radio Electronics, Electrical and Power Engineering, REEPE 2020. P. 9059215. DOI: 10.1109/ REEPE49198.2020.9059215.

9. Керимов И.А., Дебиев М.В. Зелёная энергетика как фактор устойчивого развития Чеченской республики // Устойчивое развитие горных территорий. 2018. N2. С. 235-245.

10. Klyuev R., Bosikov I., Gavrina O., Madaeva M., Sokolov A. (2021) Improving the energy efficiency of technological equipment at mining enterprises. In: Murgul V., Pukhkal V. (eds) International Scientific Conference Energy Management of Municipal Facilities and Sustainable Energy Technologies EMMFT 2019. EMMFT 2019. Advances in Intelligent Systems and Computing, vol. 1258, pp. 262-271, Springer, Cham. https://doi.org/10.1007/978-4-030-574505-24. 
11. Епишев К.М., Красноярова Б.А., Крупочкин Е.П. Расселение на селения и проблемы энергоснабжения республики Алтай // Устойчивое развитие горных территорий, 2012. N3. С. 153-157.

12. Zhukovskiy Y.L., Batueva D.E., Buldysko A.D., Shabalov M.Y. Motivation towards energy saving by means of IoT personal energy manager platform. Journal of Physics: Conference Series. 2019. No. 1333. P. 062033.

13. Klyuev R., Fomenko O., Gavrina O., Turluev R., Marzoev S. (2021) Energy indicators of drilling machines and excavators in mountain territories. In: Murgul V., Pukhkal V. (eds) International Scientific Conference Energy Management of Municipal Facilities and Sustainable Energy Technologies EMMFT 2019. EMMFT 2019. Advances in Intelligent Systems and Computing. Vol. 1258. P. 272-281. Springer, Cham. https://doi.org/10.1007/978-4-030-57450-5_25.

14. Клюев Р. В., Босиков И. И., Егорова Е. В., Гаврина О.А. Оценка горно-геологических и горнотехнических условий карьера "Северный"с помощью математических моделей // Устойчивое развитие горных территорий. 2020. N3. C. 418-427.DOI: 10.21177/1998-4502-2020-12-4-418427.

15. Волкова И.О., Шувалова Д.Г., Сальникова Е.В. Активный потребитель в интеллектуальной энергетике // Академия энергетики, 2011. N2. C. 50-57.

16. Belsky A.A., Dobush V.S. Operation of a single-phase autonomous inverter as a part of a low-power wind complex. Journal of Mining Institute. 2019. No. 239. P. 564-569. DOI: 10.31897/pmi.2019.5.564.

17. Pallesen T., Jenle R.P. Organizing consumers for a decarbonized electricity system: Calculative agencies and user scripts in a Danish demonstration project. Energy Research \& Social Science. 2018. No. 38. P. 102-109. DOI: 10.1016/j. erss.2018.02.003.

18. Strasser T.I., Andren F.P., Kathan J., Cecati C. A review of architectures and concepts for intelligence in future electric energy systems. IEEE Transactions on Industrial Electronics. 2015. No. 62. P. 2424-2438. DOI: 10.1109/TIE.2014.2361486.

19. Abramovich B.N., Babanova I.S. Development of neural network models to predict and control power consumption in mineral mining industry. Mining Informational and Analytical Bulletin. 2018. P. 206-213. DOI: 10.25018/0236-1493-20185-0-206-213.

20. Azar A.G., Olivero E., Hiller J., Lesch K., Jiao L. et al. Algorithms for Demand Response and Load Control. SEMIAH-WP5-D5.1, European Comission FP7 Program (FP7-ICT-2013-11-619560). 2015. 91 p.

21. Siano P., Sarno D. Assessing the benefits of residential demand response in a real time distribution energy market. Applied Energy. 2016. No. 161. Pp. 533-551. DOI: 10.1016/j. apenergy.2015.10.017.

22. Rao K.S., Chauhan P.J., Gupta A. Optimal scheduling of diesel generators in offshore support vessels to minimize fuel consumption IECON 2015 - 41st Annual Conference of the IEEE Industrial Electronics Society, 2015.

23. Ogunjuyigbe A.S.O., Ayodele T.R., Akinola O.A. Optimal allocation and sizing of PV/Wind/Split-diesel/Battery hybrid energy system for minimizing life cycle cost, carbon emission and dump energy of remote residential building. Applied Energy. 2016. No. 171. P. 153-171. DOI: 10.1016/j. apenergy.2016.03.051.

\section{СВЕДЕНИЯ ОБ АВТОРАХ / Information about authors:}

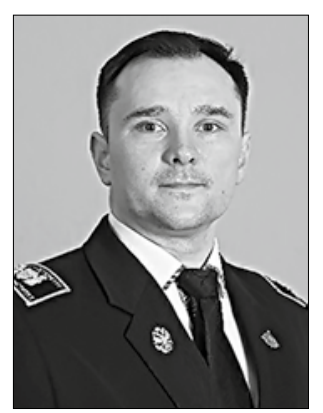

ЖУкОВСКИЙ Юрий Леонидович - кандидат технических наук, доцент кафедры электроэнергетики и электромеханики, директор Учебно-научного центра цифровых технологий Санкт-Петербургского горного университета. 199106, СанктПетербург, Россия.

Тел.: +7(911)168-92-41.

Yuri L. ZHUKOVSKY - Candidate of Technical Sciences, Associate Professor of the Department of Electric Power Engineering and Electromechanics, Director of the Educational and Scientific Center for Digital Technologies of the St. Petersburg Mining University. St. Petersburg, 199106 Russia. Ph.: +7(911)168-92-41.

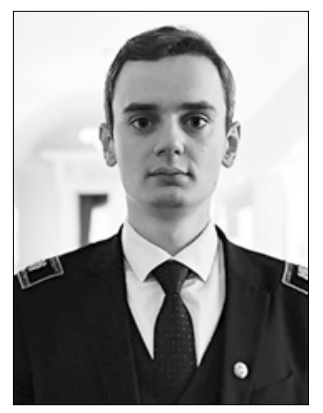

ЛАВРИК Александр Юрьевич - аспирант кафедры электроэнергетики и электромеханики СанктПетербургского горного университета. 199106, Санкт-Петербург, Россия. Тел.: +7(965)752-30-75

Alexander Yu. LAVRIK - Postgraduate Student. Department of Electric Power Engineering and Electromechanics of the St. Petersburg Min-

ing University.

St. Petersburg, 199106 Russia. Ph.: +7 (965)752-30-75.

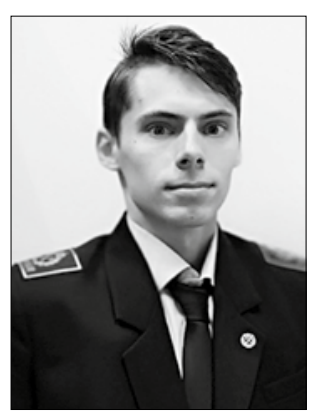

ВАСИЛЬКОВ Олег Сергеевич - аспирант кафедры общей электротехники Санкт-Петербургского горного университета. 199106, Санкт-Петербург, Россия.

Тел.: +7(911)150-78-82.

Oleg S. VASILKOV - Postgraduate Student of the Department of General Electrical Engineering of the St. Petersburg Mining University. St. Petersburg, 199106 Russia. Ph.: + 7 (911)150-78-82.

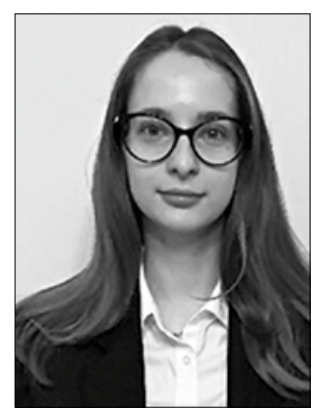

СЕМЕНЮК Александра Вадимовна - аспирант кафедры электроэнергетики и электромеханики Санкт-Петербургского горного университета. 199106, Санкт-Петербург, Россия.

Тел.: +7(981)150-27-30

Alexandra V.SEMENYUK - Postgraduate Student of the Department of Electric Power Engineering and Electromechanics of the St. Petersburg Mining University. St. Petersburg, 199106 Russia.

Ph.: +7 (981)150-27-30. 


\section{POTENTIAL FOR ELECTRIC CONSUMPTION MANAGEMENT IN THE CONDITIONS OF AN ISOLATED ENERGY SYSTEM IN A REMOTE POPULATION}

Yu. L. Zhukovsky ${ }^{1 *}$,

A. Yu. Lavrik',

A. V. Semenyuk ${ }^{1}$,

O. S. Vasilkov

${ }^{1}$ Saint Petersburg Mining University, 119019, Saint Petersburg, Russia, spmi_energo@mail.ru

\section{DOI: $10.21177 / 1998-4502-2020-12-4-583-591$}

The aim of this work is to develop approaches for a methodology creation that allows estimate preliminary assessment of the power consumption management potential in the absence of experimental data on the object under actual load study.

Analysis of diesel power plants operating modes in such systems showed that diesel generators often operate in suboptimal load ranges, which leads to increased diesel fuel consumption, reduction in diesel generators service life andas a result of poor diesel fuelcombustion in the cylinders or increased mechanical parts wear, etc. At the same time, electricity demand management technology used in large centralized power supply systems in some countries of the world can be adapted for use in isolated low power systems. Considering that diesel power plants are the sources of distributed generation in the power systems of hard-to-reach facilities in mountainous areas, demand management will allow to align the daily load schedule, plan the loading, start-ups and stops of diesel generators to improve the technical, economic and environmental performance of the entire complex.

This paper proposes a technique that allows estimate preliminary assessment of the object shiftable electrical load share on the basis of "base" data about a typical similar object. The initial data isthe average electrical load daily schedules for each month of the studied object, for example, a settlement. The schedule of non-shiftable partof the studied object load is constructed by scaling the base non-shiftable load schedule depending on the selected method: the series values of base schedule can be multiplied by a coefficient so that one of the base schedule values becomes equal to the corresponding series value of the studied object load schedule, and other base schedule values were less than or equal to the corresponding values. According to the second method the base schedule values can be multiplied by a coefficient so that the series values at the selected hour (for example, evening maximum) were equal to the corresponding series value of the studied object load schedule. An example of methodology application is shown to estimate the demand response potential for electricity in the Amderma settlementresidential sector in Arkhangelsk region. It also shows the calculation results of technical, economic and environmental effect of the demand side management technology, due to electric load schedule alignment and, as a result, diesel generators operationin modes close to optimal.

Keywords: energy efficiency, demand side management, diesel, diesel power plant, electrical load, schedule.

\section{References:}

1. Elistratov V.V. "Power supply of isolated territories of Russia”, Energy Academy, 2015, no.4, pp. 26-33.

2. Kuznetsov P. A., Abramovich B. N., Sychev Y. A., Mukminova D. Z. "Assessment and data analysis of beneficial implementation of cogeneration modules at mining enterprises to minimize negative influence on the environment", Journal of Physics: Conference Series, 2019, no.1333, pp. 032048.

3. Lukutin B. V., Surzhikova O. A., Shandarova E. B. Renewable energy in decentralized power supply, Energoatomizdat, Moscow, 2008, 231 p.

4. Koptev V. Y., Kopteva A. V. "Structure of energy consumption and improving open-pit dump truck efficiency", IOP Conference Series: Earth and Environmental Science, 2017, no.87, pp. 022010. DOI: 10.1088/1755-1315/87/2/022010.

5. Lukutin B. V., Shandarova E.B., Fuks I.L. "Energy efficiency of photovoltaic power plants in stand-alone power supply systems", 2nd International Conference on Industrial Engineering, Applications and Manufacturing (ICIEAM), Chelyabinsk, 2016, pp. 1-5.

6. Smolentsev D. O. "Development of the Arctic power industry: problems and opportunities of small generation", Arctic: Ecology and Economics, 2012, no.3, pp. 22-29.

7. Dubrovin E. A., Dubrovin I. A. How to reduce the cost of hydrocarbon fuel in the Arctic. Energy and Industry of Russia. URL: https://www.eprussia.ru/epr/333-334/7102917.htm [Date of treatment 11/28/2020].

8. Lavrik A. Y., Zhukovskiy Y. L., Buldysko A. D. "Features of the Optimal Composition Determination of Energy Sources During Multi-Criterial Search in the Russian Arctic Conditions", Proceedings of the 2nd 2020 International Youth Conference on Radio Electronics, Electrical and Power Engineering, REEPE, 2020, pp. 9059215. DOI: 10.1109/ REEPE49198.2020.9059215.

9. Kerimov I. A., Debiev M. V. "Green energy as a factor of sustainable development of the Chechen Republic", Sustainable Development of Mountainous Territories, 2018. no.2. pp. 235-245.

10. Klyuev R., Bosikov I., Gavrina O., Madaeva M., Sokolov A. (2021) "Improving the energy efficiency of technological equipment at mining enterprises", In: V.Murgul, V. Pukhkal (eds), International Scientific Conference Energy Management of Municipal Facilities and Sustainable Energy Technologies EMMFT 2019. EMMFT 2019. Advances in Intelligent Systems and Computing, vol 1258, pp. 262-271, Springer, Cham. https://doi.org/10.1007/978-4-030-57450-5_24.

11. Epishev K. M., Krasnoyarova B. A., Krupochkin E. P. "Settlement of the population and energy supply problems in the Altai Republic", Sustainable Development of Mountain Territories, 2012, no.3, pp. 153-157.

12. Zhukovskiy Y. L., Batueva D.E., Buldysko A.D., Shabalov M.Y. "Motivation towards energy saving by means of IoT personal energy manager platform", Journal of Physics: Conference Series, 2019, no.1333. pp. 062033.

13. Klyuev R., Fomenko O., Gavrina O., Turluev R., Marzoev S. (2021) "Energy indicators of drilling machines and 
excavators in mountain territories", In: V. Murgul, V. Pukhkal (eds), International Scientific Conference Energy Management of Municipal Facilities and Sustainable Energy Technologies EMMFT 2019. EMMFT 2019. Advances in Intelligent Systems and Computing, vol 1258, pp. 272-281, Springer, Cham. https://doi.org/10.1007/978-4-030-57450-5_25.

14. Klyuev R.V., Bosikov I. I., Egorova E.V., Gavrina O. A. "Assessment of mining-geological and mining-technical conditions of the open pit "Severny" using mathematical models", Sustainable Development of Mountain Territories, 2020, no. 3, pp. 418-427.DOI: 10.21177 / 1998-4502-2020-12-4-418-427.

15. Volkova I. O., Shuvalova D. G., Salnikova E.V. “Active consumer in intellectual energy", Energy Academy, 2011, no.2, pp. $50-57$.

16. Belsky A.A., Dobush V.S. "Operation of a single-phase autonomous inverter as a part of a low-power wind complex", Journal of Mining Institute, 2019, no. 239, pp. 564-569. DOI: 10.31897/pmi.2019.5.564.

17. Pallesen T., Jenle R. P. "Organizing consumers for a decarbonized electricity system: Calculative agencies and user scripts in a Danish demonstration project", Energy Research \& Social Science, 2018, no.38, pp. 102-109. DOI: 10.1016/j. erss.2018.02.003.

18. Strasser T. I., Andren F. P., Kathan J., Cecati C. "A review of architectures and concepts for intelligence in future electric energy systems", IEEE Transactions on Indus- trial Electronics, 2015, no.62, pp. 2424-2438. DOI: 10.1109/ TIE.2014.2361486.

19. Abramovich B. N., Babanova I. S. "Development of neural network models to predict and control power consumption in mineral mining industry", Mining Informational and Analytical Bulletin, 2018, pp. 206-213. DOI: 10.25018/02361493-2018-5-0-206-213.

20. Azar A. G., Olivero E., Hiller J., Lesch K., Jiao L. et al. Algorithms for Demand Response and Load Control. SEMIAH-WP5-D5.1, European Comission FP7 Program (FP7ICT-2013-11-619560), 2015, $91 \mathrm{p}$.

21. Siano P., Sarno D. "Assessing the benefits of residential demand response in a real time distribution energy market", Applied Energy, 2016, no.161, pp. 533-551. DOI: 10.1016/j. apenergy.2015.10.017.

22. Rao K. S., Chauhan P. J., Gupta A. "Optimal scheduling of diesel generators in offshore support vessels to minimize fuel consumption", IECON 2015 - 41st Annual Conference of the IEEE Industrial Electronics Society, 2015.

23. Ogunjuyigbe A.S.O., Ayodele T. R., Akinola O. A. "Optimal allocation and sizing of PV/Wind/Split-diesel/Battery hybrid energy system for minimizing life cycle cost, carbon emission and dump energy of remote residential building", Applied Energy, 2016, no. 171, pp. 153-171. DOI: 10.1016/j. apenergy.2016.03.051. 


\section{УДК: 622.23.05 \\ DOI: 10.21171/1998-4502-2020- \\ 12-4-592-599}

Рассмотрены существующие решения для дистанционного управления горным оборудованием. Описан принцип работы технологии WebRTC и используемые ө ней методы шифрования данных. Разработана модель дистанционно управляемой горной машины на базе гусеничного шасси, компьютера Raspberry Pi и контроллера Arduino, с ее помощью выполнена серия тестов по дистанционному управлению. Исходя из полученных данных сделано заключение о перспективности WebRTC как технологии для дистанционного управления горным оборудованием.

\section{КЛЮЧЕВЫЕ СЛОВА:}

автоматизация рудников, дистанционное управление, технология WebRTC, телеуправление, программное обеспечение.

Статья поступила в редакцию 13.07.2020

\section{ПЕРСПЕКТИВЫ ПРИМЕНЕНИЯ TЕХНОЛОГИИ WЕВRTC ДЛЯ ДИСТАНЦИОННОГО УПРАВЛЕНИЯ ГОРНЫМ ОБОРУДОВАНИЕМ}

Кравцов А. А. ${ }^{1^{*}}$,

Анищенко В. И.2,

Атрушкевич В. А. ${ }^{3}$

Пыталев И. А. ${ }^{4}$

${ }^{1}$ ООО «Инфообип», 198036, г. Санкт-Петербуре, Россия, havok.08@mail.ru 2000 «Спецмодульпроект», 143007, г. Москва, Россия, anischenko-vas@yandex.ru

${ }^{3}$ Северо-Кавказский горно-металлургический институт (государственный технологический университет), 362021, г. Владикавказ, Россия, iugi@mail.ru ${ }^{4}$ Институт горного дела и транспорта, Магнитогорский государственный технический университет им. Г.И. Носова, 455000, г. Магнитогорск, Россия

\section{Введение}

В настоящее время многие компании, производящие оборудование для горных работ, разрабатывают решения для дистанционного управления горными машинами и автоматизации производственных операций [1]. Среди них Caterpillar [2], Sandvik, Atlas Copco [3] и Komatsu. Задача этих технологий повышение эффективности труда и снижение рисков для работников горных предприятий [4-6]. Чтобы эффективно решать указанные задачи, аппаратные и программные комплексы для дистанционного управления должны обеспечивать передачу данных с минимальной задержкой, а также передавать данные в зашифрованном виде и предотвращать несанкционированный доступ третьих лиц в систему телеуправления.

B работе рассмотрена программная технология WebRTC, отвечающая указанным требованиям. Наибольшее распространение она получила как средство для телеконференций, но в настоящее время ведутся работы по применению ее в роботах телеприсутствия, медицине и других областях [7-10]. К тому же она поддерживается многими устройствами, что позволяет рассматривать ее как перспективную технологию при разработке новых и модификации уже существующих систем дистанционного управления.

\section{Цели и задачи исследования}

Целью исследования является определение возможности использования технологии WebRTC для дистанционного управления горным оборудованием. Задачи исследования - обзор существующих решений для телеуправления, изучение архитектуры и принципов работы WebRTC, анализ технологии на предмет безопасности передачи данных, разработка модели дистанционно-управляемой горной машины с применением WebRTC.

\section{Дистанционное управление на горных предприятиях}

Доступные на рынке программные комплексы дистанционного управления горными машинами являются проприетарным программным обеспечением, что усложняет их детальный анализ. Обзор и описание принципов их работы будут сделаны исходя из открытых данных нескольких компаний, разрабатывающих подобные решения, таких, как Cisco, Sandvik [11], Moxa [12] и Acksys [13]. Исходя из описаний их продуктов можно сделать вывод, что видеопоток передается оператору напрямую с IP-камер, установленных на машинах. Таким же образом передаются команды от оператора к машине - об этом свидетельствует требование об обязательном наличии статичных IP-адресов. Такой подход связан с рядом сложностей:

- каждая камера должна иметь аппаратную поддержку видеокодека, функ- 
цию шифрования видеопотока и модуль беспроводной передачи данных, что увеличивает их стоимость;

- каждая камера и бортовой компьютер на машине являются участниками беспроводной сети - это увеличивает количество одновременно подключенных устройств, что ведет к более сложной организации сетевой инфраструктуры;

- необходима дополнительная конфигурация сети для возможности подключения к оборудованию извне (другая подсеть, Интернет);

- более сложное обеспечение информационной безопасности ввиду большого количества подключенных к сети камер и другого оборудования различных производителей и конфигураций.

Указанные проблемы осложняют разработку, развертывание, эксплуатацию и поддержку инфраструктуры дистанционного управления.

Также отсутствие единого открытого формата для подобных систем приводит к следующим сложностям:

- делает невозможным интеграцию нескольких решений разных разработчиков;

- приводят к издержкам при обучении инженеров по эксплуатации специфике каждого отдельного продукта.

Применение WebRTC поможет решить обозначенные проблемы. Эта технология имеет единую открытую спецификацию и множество реализаций, поддерживающих шифрование данных и поиск сетевого маршрута как в локальной подсети, так и при передаче данных через Интернет.

\section{Принцип работы WebRTC}

Разработкой спецификации занимается рабочая группа Web Real-Time Communications Working Group - последняя версия доступна на их веб-сайте [14]. На рис. 1 представлен принцип работы WebRTC на примере дистанционного управления погрузочнодоставочной машиной.

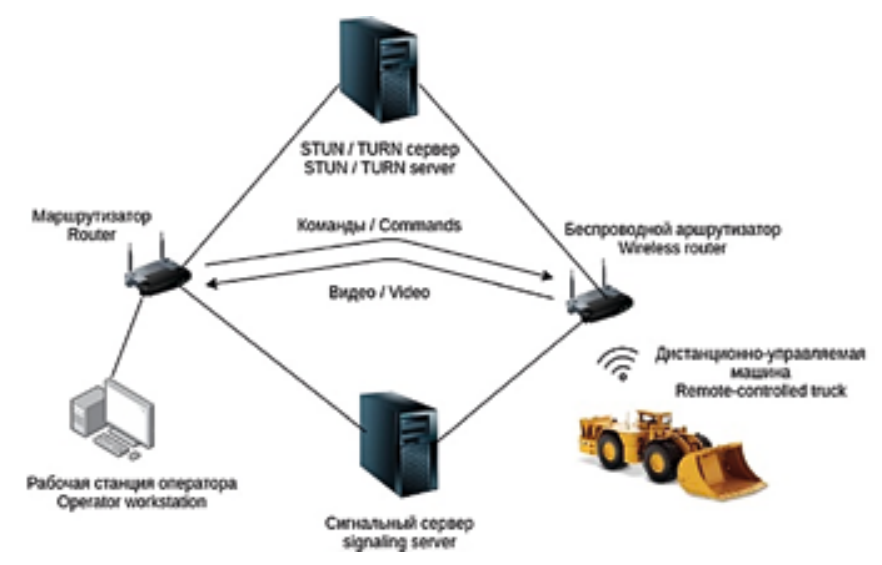

Puc. 1. Принцип работы WebRTC

Fig. 1. WebRTC operation principle

При установке соединения оператор и бортовой компьютер на машине генерируют пакеты SDP (Session Description Protocol), подключаются к сиг- нальному серверу, и с его помощью обмениваются пакетами [15]. B SDP-пакетах содержится информация о поддерживаемых аудио- и видеокодеках, отпечатки открытых ключей шифрования и другие данные, необходимые для установки соединения. Далее осуществляется попытка установить соединение с помощью протокола ICE. Первой производится попытка установки peer-to-peer - соединения с использованием STUNсервера (Session Traversal Utilities for NAT). Оператор и машина производят трассировку сетевого пути до STUN-сервера и через сигнальный сервер обмениваются найденными маршрутами, после чего через пары точек маршрутов пытаются создать NAT-туннель. B случае успеха соединение считается установленным. Если NAT-туннель создать не удалось, производится попытка соединения через TURN-сервер (Traversal Using Relay NAT) - в этом случае видеопоток и команды будут передаваться через сервер, доступный одновременно оператору и машине [16]. Впрочем, peer-topeer-соединение через NAT-туннель предпочтительнее, так как снижает задержки передачи данных ввиду отсутствия единого сервера (TURN), пропускающего через себя большой поток информации.

Таким образом, при использовании WebRTC нет необходимости обеспечивать каждое сетевое устройство внешним IP-адресом и проводить дополнительную конфигурацию сети в руднике для подключения к машинам через Интернет, что является преимуществом по сравнению с существующими решениями. Также отсутствует необходимость в дорогостоящих IP-камерах, которые могут быть заменены на более дешевые USB-камеры, подключенные к бортовому компьютеру машины. Бортовой компьютер может самостоятельно кодировать изображения с камер в видеопоток и отправлять его оператору через WebRTC (рис. 2).

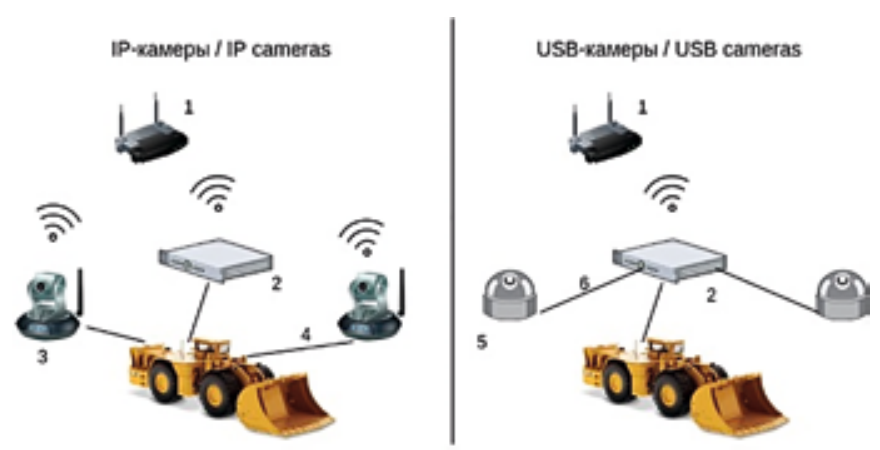

Puc. 2. Схема подключения камер: 1 - беспроводной маршрутизатор; 2 - бортовой компьютер; 3 - IP-камера; 4 - провод питания IP-камеры; 5 - USB-камера; 6 - USB-провод

Fig. 2. Cameras wiring diagram: 1 - wireless router; 2 - onboard computer; 3 -IP camera; 4-IP camera power cable; 5 - USB camera; 6-USB cable

\section{Информационная безопасность}

Важную роль в системе дистанционного управле- 
ния играет обеспечение информационной безопасности - предотвращение несанкционированного доступа третьих лиц к видеопотокам с камер, чтения и модификации команд оператора, управления техникой. Спецификация WebRTC предусматривает шифрование передаваемых данных, что защищает от чтения или изменения данных в сетевых узлах между оператором и машиной (атак типа man-in-the-middle) [17]. Шифрование происходит следующим образом:

- $\quad$ оператор и бортовой компьютер машины генерируют ключи шифрования, затем передают отпечатки открытых ключей через сигнальный сервер в SDPпакетах;

- когда соединение установлено, оператор и бортовой компьютер обмениваются ключами шифрования;

- $\quad$ каждая сторона производит вычисление отпечатка полученного ключа и проверяет, соответствует ли он отпечатку, полученному через сигнальный сервер.

Если отпечатки совпадают, то стороны используют ключи для шифрования передаваемых данных с помощью алгоритмов DTLS и SRTP. В противном случае соединение не устанавливается.

Следует отметить, что спецификация WebRTC не описывает реализацию сигнального сервера и каналов связи с ним, а лишь устанавливает формат сообщений, передаваемых через него. Следовательно, при незащищенном канале связи с сигнальным сервером становится возможным провести атаку man-in-the-middle, несмотря на защиту WebRTC [18]. Механизм атаки показан на рис. 3.

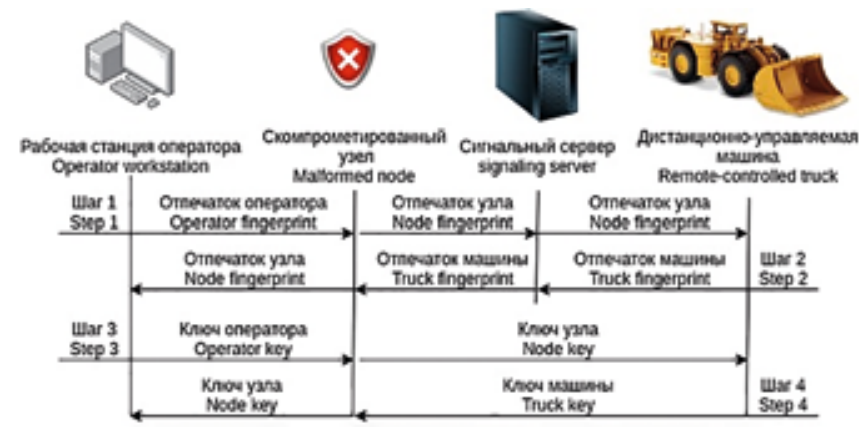

Puc. 3. Атака man-in-the-middle при незащищенном соединении с сигнальным сервером

Fig. 3. Man-in-the-middle attack on insecure signaling server connection

При передаче SDP-пакетов на шаге 1 скомпрометированный узел подменяет отпечаток ключа оператора на собственный и отправляет пакет дальше на сигнальный сервер. На шаге 2 происходит такая же подмена, но для отпечатка ключа машины. Далее на шаге 3 узел подменяет ключ шифрования оператора на собственный и передает его машине. Машина, сравнивая ключ и полученный на шаге 1 его отпечаток, не находит различий и считает, что ключ получен от оператора. То же самое происходит на шаге 4 при отправке ключа шифрования от машины к оператору. Таким образом, скомпрометированный узел, подменив ключи шифрования, может читать и модифицировать передаваемые данные. Для предотвращения описанной атаки достаточно использовать защищенное соединение с сигнальным сервером - например, протокол TLS.

\section{Описание модели и тестирование}

Для изучения параметров дистанционного управления по WebRTC была разработана модель горной машины, представленная на рис. 4.

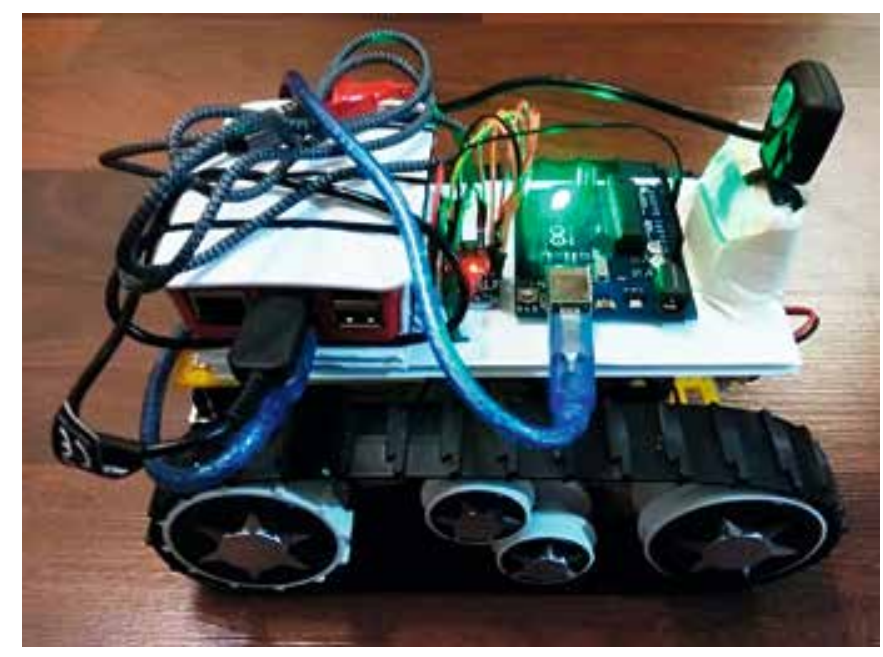

Puc. 4. Модель горной машины

Fig. 4. Mining truck model

Модель собрана на гусеничном шасси. Два электрических двигателя постоянного тока, приводящих в движение ведущие колеса гусениц, расположены сзади. За скорость и направление вращения электродвигателей отвечает драйвер DRV8833, получающий команды от контроллера Arduino. В качестве бортового компьютера используется Raspberry Pi 3 - он отвечает за подключение к беспроводной сети, передает команды движения на Arduino, а также кодирует и отправляет оператору видео с USB-камеры. В качестве источника питания двигателей и электроники служит литий-полимерный аккумулятор.

Программное обеспечение для бортового компьютера написано на языке Go, подключение по WebRTC реализовано с помощью библиотеки Pion, получение видео с камеры и его кодирование - с помощью инструментов GStreamer [19]. Сигнальный сервер написан на языке Java, веб-интерфейс оператора - на языке JavaScript. Сигнальный сервер развернут на сервисе Heroku, подключение к нему происходит по протоколу TLS, что исключает возможность описанной выше атаки man-in-the-middle. Исходный код доступен на github.com $[20 ; 21]$.

При проведении тестов на модели были опробованы три сценария дистанционного управления. Первый - управление в непосредственной видимости на небольшом расстоянии. Второй - также на небольшом расстоянии, но вне поля видимости. Оператор видел 
только изображение с камеры модели на своем компьютере. Третий - управление на большом расстоянии (около 1600 км) через Интернет. Модель находилась в Санкт-Петербурге, оператор - в г. Каменск-Шахтинском. Оператор, как и во втором случае, получал только изображение с камеры модели. В результате тестов было выявлено, что средняя задержка передачи данных на небольшое расстояние не превышает 200 миллисекунд, на большое - 300 миллисекунд. Задержка может быть вычислена по следующей формуле:

$$
D=C_{\text {enc }}+C_{\text {trans }}+C_{\text {dec }}+V_{\text {enc }}+V_{\text {trans }}+V_{\text {dec }}, \mathrm{Mc},
$$

где $C_{\text {enc }}-$ время кодирования команды, $C_{\text {trans }}-$ время передачи команды от оператора к машине, $C_{d e c}-$ время декодирования команды, $V_{\text {enc }}$ - время кодирования видеокадра, $V_{\text {trans }}$ - время передачи видеокадра от машины к оператору, $V_{d e c}$ - время декодирования видеокадра.

Время передачи данных является суммой времени передачи на каждом узле сети:

$$
C_{\text {trans }}=\sum_{i=1}^{n} C_{i}, \mathrm{Mc}
$$

где $C_{\mathrm{i}}$ - задержка команды на одном узле сетевого маршрута, $n$ - количество узлов между оператором и машиной.

$$
V_{\text {trans }}=\sum_{j=1}^{k} V_{j, \mathrm{Mc}}
$$

где $V_{\mathrm{j}}$ - задержка видеокадра на одном узле сетевого маршрута, $k$ - количество узлов между машиной и оператором. Результаты замеров каждой из величин представлены на рис. 5, 6 и 7.

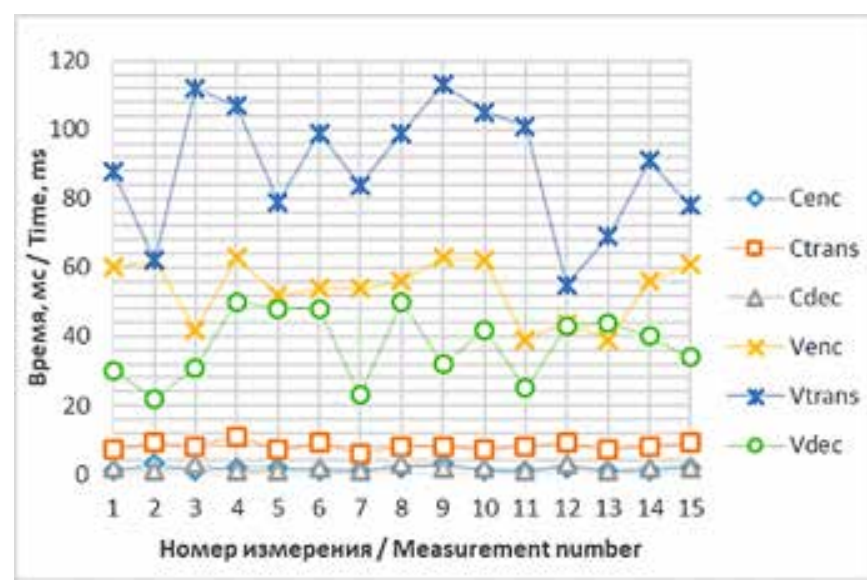

Puc. 5. Задержки в тесте управления в непосредственной видимости

Fig. 5. Delays in direct line of sight control test

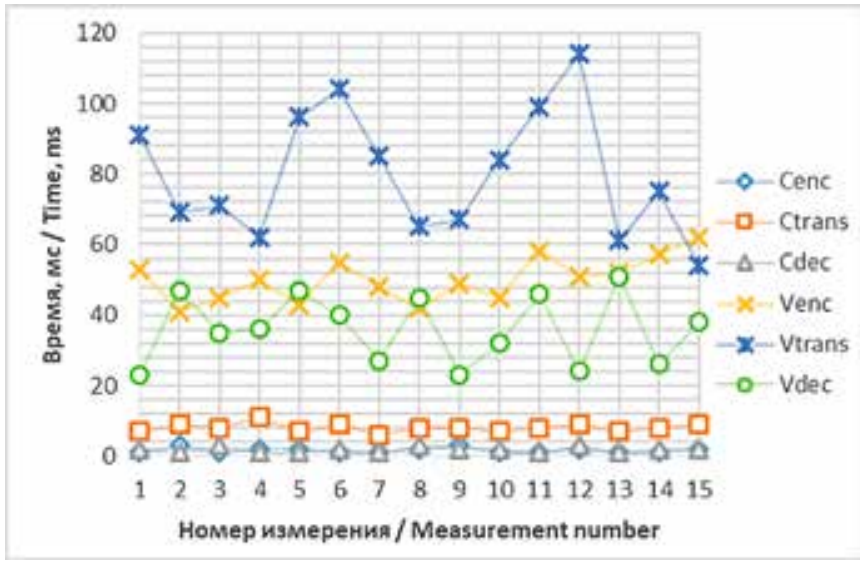

Puc. 6. Задержки в тесте управления на небольшом расстоянии

Fig. 6. Delays in short distance control test

\begin{tabular}{|c|c|c|}
\hline $\begin{array}{l}\text { Параметр } \\
\text { Parameter }\end{array}$ & $\begin{array}{c}\text { Решение на основе } \\
\text { WebRTC / WebRTC-based } \\
\text { solution }\end{array}$ & $\begin{array}{c}\text { Решения с прямой передачей данных (Sandvik и др.) } \\
\text { Direct data transmission solutions (Sandvik and others) }\end{array}$ \\
\hline $\begin{array}{c}\text { Обязательный внешний IP- } \\
\text { адрес / Mandatory external } \\
\text { IP-address }\end{array}$ & Нет / No & Да / Yes \\
\hline $\begin{array}{c}\text { Поиск маршрута через NAT / } \\
\text { NAT traversal }\end{array}$ & Да / Yes & Нет / No \\
\hline Шифрование / Encryption & DTLS, SRTP & $\begin{array}{c}\text { Зависит от IP-камеры и канала передачи команд / Depends } \\
\text { on IP-camera and command transmission channel }\end{array}$ \\
\hline Спецификация / Specification & Открытая / Open & Закрытая / Closed \\
\hline Лицензия / License & BSD, MIT & Проприетарная / Proprietary \\
\hline $\begin{array}{l}\text { Кроссплатформенность } \\
\text { Cross-platform }\end{array}$ & Да / Yes & Да / Yes \\
\hline $\begin{array}{l}\text { Стадия внедрения } \\
\text { Implementation stage }\end{array}$ & Исследование / Research & Промышленное использование / Production use \\
\hline
\end{tabular}

\section{Сравнение решений на основе WebRTC и прямой передаче данных} Comparison of WebRTC-based and direct data transmission solutions 


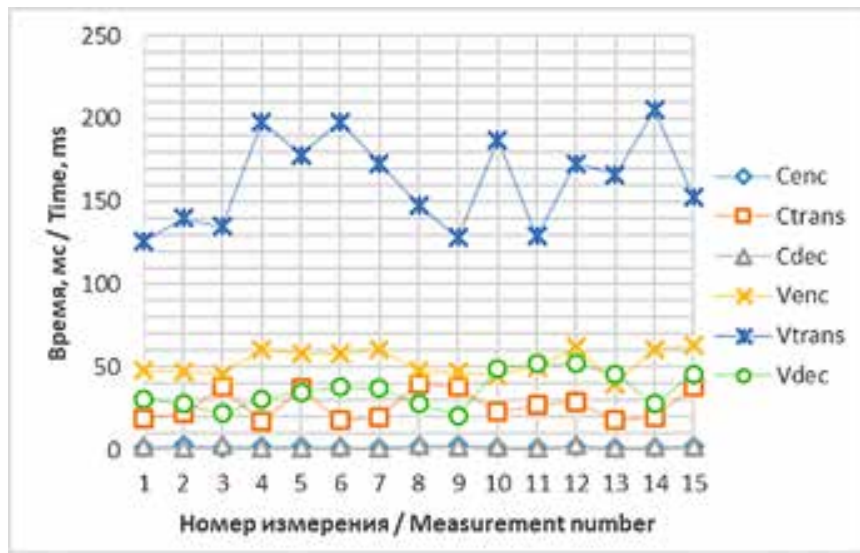

Puc. 7. Задержки в тесте управления на большом расстоянии

Fig. 7. Delays in long distance control test

Также операторы, участвовавшие в испытаниях, отметили, что управлять моделью легче, если она находится в прямой видимости. Это согласуется с другими исследованиями, где отмечено снижение производительности рабочих при управлении горной машиной дистанционно по сравнению с управлением из кабины [22-25].

В таблице приведено сравнение разработанного решения, основанного на WebRTC, и существующих решений, использующих прямую передачу видео с IPкамер и команд от оператора (например, решение от Cisco и Sandvik).

\section{ЛИТЕРАТУРА:}

1. Johansson I., Dadhich S., Bodin U., Jonsson T. Adaptive Video with SCReAM over LTE for Remote-Operated Working Machines // Wireless Communications and Mobile Computing. 2018. Vol. 2018, N1:3142496. Pp. 1-10. DOI: 10.1155/2018/3142496

2. Glover M. Caterpillar's Autonomous Journey - The Argument for Autonomy // SAE 2016 Commercial Vehicle Engineering Congress, Иллинойс, США, 4-6 октября, 2016. DOI: 10.4271/2016-01-8005

3. Опарин В. Н., Русин Е. П., Таисиев А. П., Фрейдин А. М. и др. Мировой опыт автоматизации горных работ на подземных рудниках. Новосибирск: СО РАН, 2007. 99 с.

4. J.-G. Li, K. Zhan. Intelligent Mining Technology for an Underground Metal Mine Based on Unmanned Equipment // Engineering. 2018. Vol. 4, N3. Pp. 381-391. DOI: 10.1016/j. eng.2018.05.013

5. Paraszczak J., Gustafson A., Schunnesson H. Technical and operational aspects of autonomous LHD application in metal mines // International Journal of Mining, Reclamation and Environment. 2015. Vol.29, N5. Pp. 391-403. DOI: 10.1080/17480930.2015.1086553

6. Марквардт Р. В. Актуальность применения дистанционного программного управления для проходческих комбайнов // Сборник статей XI международной научно-практической конференции «EurasiaScience», Москва, 31 октября, 2017. С. 107-108.

7. Ha V. K. L., R. Chai, H. T. Nguyen. A Telepresence
Решения по дистанционному управлению горным оборудованием могут найти применение, как элемент практически всех систем разработки, для выдачи руды из блоков при обеспечении компенсационного пространства во время взрывной отбойки и дробления минералов, а также при выпуске руды из магазина или из-под налегающих пород. Дистанционное управление горным оборудованием при осуществлении этих процессов является реальной мерой снижения травматизма работающих и повышения показателей выпуска руд [26-29].

\section{Выводы}

1. Технология WebRTC является перспективной при разработке систем дистанционного управления горным оборудованием. Единая и открытая спецификация позволяет проводить интеграцию различных программных систем разных производителей, а также может сократить издержки при разработке и сопровождении программного обеспечения.

2. Поддержка шифрования данных позволяет передавать видео и команды по незащищенным каналам связи, а технология ICE облегчает конфигурацию сети.

3. Впрочем, следует уделить внимание защищенности соединения с сигнальным сервером во избежание атаки man-in-the-middle.

Полученные в результате тестов задержки передачи данных не препятствуют управлению горным оборудованием в реальном времени.

Wheelchair with 360-Degree Vision Using WebRTC // Applied Sciences. 2020. Vol. 10, N1:369. Pp. 1-18. DOI: 10.3390/ app10010369

8. Melendez-Fernandez F., Galindo C., Gonzalez-Jimenez J. A web-based solution for robotic telepresence // International Journal of Advanced Robotic Systems. 2017. Vol. 14, N6. Pp. 1-19. DOI: 10.1177/1729881417743738

9. P. Pierleoni et al. An innovative WebRTC solution for e-Health services // 2016 IEEE 18th International Conference on e-Health Networking, Applications and Services (Healthcom). Munich, Germany, September 14-16, 2016. Pp. 1-6. DOI: 10.1109/HealthCom.2016.7749444

10. Jang-Jaccard J., Nepal S., Celler B., Yan B. WebRTCbased video conferencing service for telehealth // Computing. 2014. Vol. 98. Pp. 169-193. DOI: 10.1007/s00607-014-0429-2

11. Wireless Networks enabling Autonomous Vehicles for Underground Mines // Cisco. URL: https://www.cisco.com/c/ en/us/td/docs/solutions/Verticals/Industrial_Automation/IA Verticals/Mining/Mining1_5/IA-Mining-DḠ/IA-Mining-DG. html (Дата обращения: 27.09.2020).

12. Reliable Wireless for Monitoring Autonomous Mining Equipment // Moxa. URL: https://www.moxa.com/en/ articles/reliable-wireless-for-monitoring-autonomous-miningequipment (Дата обращения: 27.09.2020).

13. Mining solutions // Acksys. URL: https://www.acksys.fr/ en/markets/mining (Дата обращения: 27.09.2020).

14. Web Real-Time Communications Working Group // 
W3.org. URL: https://www.w3.org/groups/wg/webrtc (Дата обращения: 29.09.2020).

15. El Hamzaoui A., Bensaid H., En-Nouaary A. A Formal Model for WebRTC Signaling Using SDL // Lecture Notes in Computer Science. 2016. Vol. 9944. Pp. 202-208. DOI: 10.1007/978-4-319-46140-3_16

16. Sredojev B., Samardzija D., Posarac D. WebRTC technology overview and signaling solution design and implementation // 38th International Convention on Information and Communication Technology, Electronics and Microelectronics (MIPRO), Opatija, Croatia, May 25-29, 2015. Pp. 1006-1009. DOI: 10.1007/978-4-319-46140-3_16

17. Conti M., Dragoni N., Lesyk V. A Survey of Man In The Middle Attacks // IEEE Communications Surveys and Tutorials. 2016. Vol. 18, N3. Pp. 2027-2051. DOI: 10.1109/ COMST.2016.2548426

18. Levent-Levi T. WebRTC and Man in the Middle Attacks // Webrtchacks.com. URL: https://webrtchacks.com/webrtcand-man-in-the-middle-attacks (Дата обращения: 01.10.2020).

19. Taymans W., Baker S., Wingo A., Bultje R. и др. GStreamer 1.10 Application Development Manual. Samurai Media Limited, 2017. 160 c.

20. https://github.com/alexey-kravtsov/robot-webrtc-pion (Дата обращения: 02.10.2020).

21. https://github.com/alexey-kravtsov/robot-signalingserver (Дата обращения: 02.10.2020).

22. Dadhich S., Bodin U., Sandin F., Andersson U. From Tele-Remote Operation to Semi-Automated Wheel-Loader // International Journal of Electrical and Electronic Engineering and Telecommunications. 2018. Vol. 7, N4. Pp. 178-182. DOI: 10.18178/ijeetc.7.4.178-182

23. Dadhich S., Bodin U., Andersson U. Key challenges in automation of earth-moving machines // Automation in Con- struction. 2016. Vol. 68. Pp. 212-222. DOI: 10.1016/j.autcon.2016.05.009

24. Fernando C. L., Saraiji Y. S., Seishu Y., Kuriu N. Effectiveness of Spatial Coherent Remote Drive Experience with a Telexistence Backhoe for Construction Sites // ICAT-EGVE 2015 - International Conference on Artificial Reality and Telexistence and Eurographics Symposium on Virtual Environments, Kyoto, Japan, October 28-30, 2015. Pp. 1-7. DOI: 10.2312/ egve. 20151312

25. Larsson J., Broxvall M., Saffiotti A. An evaluation of local autonomy applied to teleoperated vehicles in underground mines // IEEE International Conference on Robotics and Automation, Anchorage, USA, May 4-8, 2010. Pp. 1745-1752. DOI: 10.1109/ROBOT.2010.5509276

26. Golik V. I., Gabaraev O. Z., Maslennikov S. A., Khasheva Z. M., Shulgaty L. P. The provision of development conversion perspectives into undeground one for Russian iron ore deposits development // The Social Sciences (Pakistan). 2016. Vol. 11. N18. Pp. 4348-4351.

27. Дмитрак Ю. В., Голик В. И., Вернигор В. В. Геомеханические предпосылки сохранения устойчивости выработок при разработке водообильных месторождений // Известия Тульского государственного университета. Науки о Земле. 2018. N 1. С. 218-229.

28. Клюев Р. В., Босиков И. И., Майер А. В., Гаврина О. А. Комплексный анализ применения эффективных технологий для повышения устойчивого развития природно-технической системы // Устойчивое развитие горных территорий. 2020. N2. C. 283-290. DOI: 10/21177/1998-4502-2020-12-2-283-290.

29. Клюев Р. В., Босиков И. И., Егорова Е. В., Гаврина О. А. Оценка горно-геологических и горнотехнических условий карьера "Северный" с помощью математических моделей // Устойчивое развитие горных территорий. 2020. N3. C. 418-427. DOI: 10.21177/1998-4502-2020-12-4-418-427.

\section{КРИТЕРИИ АВТОРСТВА / Contribution:}

Кравцов А. А. провел анализ технологии WebRTC, собрал модель и провел тесты. Анищенко В. И. и Атрушкевич В. А. и Пыталев И. А. собрали и проанализировали информацию о существующих технологиях дистанционного управления горным оборудованием.

Kravtsov A. A. has analyzed WebRTC technology, built a model and performed tests. Anischenko V. I. and Atrushkevich V. A. and Pytalev I. A. have collected and analyzed information on existing remote control solutions for mining equipment.

\section{КОНФЛИКТ ИНТЕРЕСОВ / Conflict of interest:}

Авторы заявляют об отсутствии конфликта интересов / The authors declare no conflict in interests.

\section{СВЕДЕНИЯ ОБ АВТОРАХ / Information about authors:}

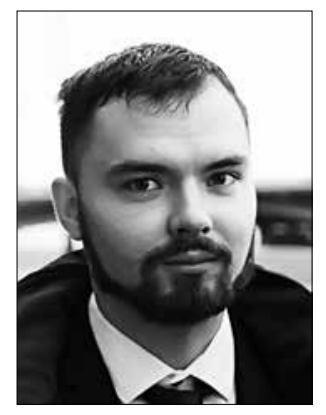

КРАВЦОВ Алексей Александрович - магистр, инженер-программист ООО “Инфобип”, 191036, г. Санкт-Петербург, Россия.

e-mail: havok.08@mail.ru

Alexey A. KRAVTSOV - M. Eng., Software Developer in "Infobip" Ltd, Saint-Petersburg, 191036, Russia.

Email:havok.08@mail.ru

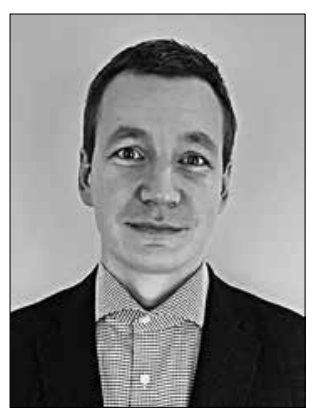

АНИЩЕНКО Василий Иванович - магистр горного дела, исполнительный директор ООО «Спецмодульпроект», 143007, г. Москва, Россия.

e-mail: anischenko-vas@yandex.ru

Vasily I. ANISCHENKO - Master of Mining, Executive Director of «Spetsmodulproekt» Ltd, Moscow, 143007, Russia. e-mail: anischenko-vas@yandex.ru 


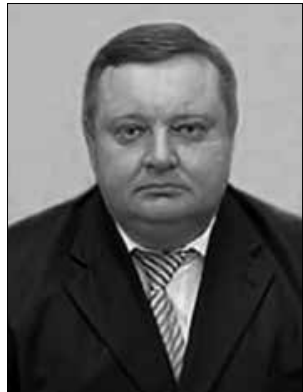

АТРУШКЕВИЧ Виктор Аркадьевич - профессор, доктор технических наук, профессор кафедры "Горное дело" Северо-Кавказского горно-металлургического института (государственного технологического университета), 362021 , г. Владикавказ, Россия. e-mail: iugi@mail.ru

Victor A. ATRUSHKEVICH - Professor, Doctor of Technical Sciences, Professor of the Department of Mining, North Caucasian Institute of Mining and Metallurgy (State Technological University), Vladikavkaz, 362021, Russia.

e-mail:iugi@mail.ru

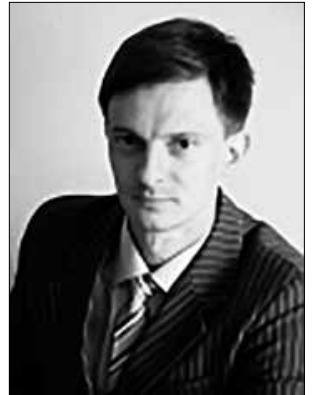

ПЫТАЛЕВ Иван Алексеевич доктор технических наук; директор Института горного дела и транспорта; ФГБОУ ВО «Магнитогорский государственный технический университет им. Г.И. Носова»; 455000, г. Магнитогорск, Россия.

Ivan A. PYTALEV - Doctor of Technical Sciences, Director of the Institute of

Mining and Transport. Nosov Magnitogorsk State Technical University. 455000, Lenina Av. 38, Magnitogorsk, Russia. Ph.: +7(903) 090-66-24; e-mail:vehicle@list.ru

\section{PERSPECTIVES OF APPLYING WEBRTC FOR REMOTE-CONTROLLED MINING EQUIPMENT}

A. A. Kravtsov ${ }^{*}$,

V. I. Anischenko

V. A. Atrushkevich ${ }^{3}$,

I. A. Pytalev ${ }^{4}$

${ }^{1}$ «Infobip»Ltd, Saint-Petersburg, 191036,Russia,havok.08@mail.ru

${ }_{2}^{2}$ Spetsmodulproekt»Ltd, Moscow, 143007, Russia, anischenko-vas@yandex.ru

${ }^{3}$ North Caucasian Institute of Mining and Metallurgy (State Technological University), Vladikavkaz, 362021, Russia, iugi@mail.ru

${ }^{4}$ Institute of Mining and Transport, Nosov Magnitogorsk State Technical University, 455000, Magnitogorsk, Russia

DOI: $10.21177 / 1998-4502-2020-12-4-592-599$

Currently a lot of mining companies, such as Caterpillar, Sandvik, Atlas Copco and Komatsu are developing solutions for machines remote control and mining process automation. The purpose of these technologies is to increase labor efficiency and safety. Solutions for remote control should establish secure connection and transfer data with low latency - this could be implemented with WebRTC technology.

Several problems were revealed during open data analysis of Cisco, Sandvik, Moxa and Acksys remote control solutions - using of expensive IP-cameras, sophisticated network and security design. WebRTC could solve these and several other problems.

WebRTC operation principles reviewed further: initial information exchange via signaling server, use of ICE for discovering shortest path between peers and establishing peer-topeer connection. This could simplify network design and allow to use more cheap USB cameras instead of IP-cameras.

For security reasons WebRTC encrypts transmitted data with DTLS and SRTP algorithms. Encryption key fingerprints are exchanged over signaling server; after connection establishment, peers are exchanging keys itself over discovered route. But WebRTC specification does not define peer to signaling server communication, which may lead to breach in unsecure data channel, especially man-in-the-middle attack. To prevent this, software engineer should ensure that connection with signaling server is secure.

Mining machine model was developed to test data transmission latency. In this model, Raspberry Pi single-board computer is responsible for wireless connection, video encoding and commands processing. Received commands are passed to
Arduino controller, which operates electric engines controller. Three remote control scenarios were tested - model is near the operator and in direct line of sight; model is near operator, but not in direct line of sight; model and operator are far away from each other (over $1600 \mathrm{~km}$ ), model controlled over Internet. Test results shows that transmission latency does not exceed $300 \mathrm{~ms}$, which is suitable for real-time remote driving.

Keywords: WebRTC, mining automation, remote control, teleoperation, software.

\section{References:}

1. Johansson I., Dadhich S., Bodin U., Jonsson T. “Adaptive Video with SCReAM over LTE for Remote-Operated Working Machines", Wireless Communications and Mobile Computing, 2018, vol. 2018, no. 2, pp. 1-10. DOI: 10.1155/2018/3142496

2. Glover M. "Caterpillar's Autonomous Journey - The Argument for Autonomy”, SAE 2016 Commercial Vehicle Engineering Congress. Illinois, USA, 4-6 October, 2016. DOI: 10.4271/2016-01-8005

3. Oparin V. N., Rusin E. P., Taisiev A. P., Freidin A. M. et. al. International practice of mining automatization in underground mines, Novosibirsk, SO RAN, 2007, 99 p.

4. J.-G. Li, K. Zhan. "Intelligent Mining Technology for an Underground Metal Mine Based on Unmanned Equipment", Engineering, 2018, vol. 4, no. 3, pp. 381-391. DOI: 10.1016/j. eng.2018.05.013

5. Paraszczak J., Gustafson A., Schunnesson H. "Technical and operational aspects of autonomous LHD application in metal mines", International Journal of Mining, Reclamation and Environment, 2015, vol. 29, no. 5, pp. 391-403. DOI: $10.1080 / 17480930.2015 .1086553$ 
6. Markvardt R. V. "Relevance of using software remote control for roadheader", Proceedings of XI International Scientific Conference "Eurasia Science», Moscow, 31 October, 2017, Moscow, 2017, pp. 107-108.

7. Ha V. K. L., R. Chai, H. T. Nguyen. "A Telepresence Wheelchair with 360-Degree Vision Using WebRTC", Applied Sciences, 2020, vol. 10, no. 1:369, pp. 1-18. DOI: 10.3390/ app10010369

8. Melendez-Fernandez F., Galindo C., Gonzalez-Jimenez J. "A web-based solution for robotic telepresence", International Journal of Advanced Robotic Systems, 2017, vol. 14, no. 6, pp. 1-19. DOI: 10.1177/1729881417743738

9. P. Pierleoni et al. "An innovative WebRTC solution for e-Health services", IEEE 18th International Conference on eHealth Networking, Applications and Services (Healthcom). Munich, Germany, 14-16 September, 2016, pp. 1-6. DOI: 10.1109/HealthCom.2016.7749444

10. Jang-Jaccard J., Nepal S., Celler B., Yan B. "WebRTCbased video conferencing service for telehealth", Computing, 2014, vol. 98, pp. 169-193. DOI: 10.1007/s00607-014-0429-2

11. Wireless Networks enabling Autonomous Vehicles for Underground Mines. Available at: https:/www.cisco.com/c/ en/us/td/docs/solutions/Verticals/Industrial_Automation/IA Verticals/Mining/Mining1_5/IA-Mining-DG-_IA-Mining-DG. html (Accessed 27.09.2020).

12. Reliable Wireless for Monitoring Autonomous Mining Equipment. Available at: https:/www.moxa.com/en/articles/ reliable-wireless-for-monitoring-autonomous-mining-equipment (Accessed 27.09.2020).

13. Mining solutions. Available at: https://www.acksys.fr/ en/markets/mining (Accessed: 27.09.2020).

14. Web Real-Time Communications Working Group. Available at: https://www.w3.org/groups/wg/webrtc (Accessed: 29.09.2020).

15. El Hamzaoui A., Bensaid H., En-Nouaary A. "A Formal Model for WebRTC Signaling Using SDL", Lecture Notes in Computer Science, 2016, vol. 9944, pp. 202-208. DOI: 10.1007/978-4-319-46140-3_16

16. Sredojev B., Samardzija D., Posarac D. "WebRTC technology overview and signaling solution design and implementation", 38th International Convention on Information and Communication Technology, Electronics and Microelectronics (MIPRO), Opatija, Croatia, 25-29 May, 2015, pp. 1006-1009. DOI: 10.1007/978-4-319-46140-3 16

17. Conti M., Dragoni N., Lesyk V. "A Survey of Man in the Middle Attacks", IEEE Communications Surveys and Tutorials, 2016, vol. 18, no. 3, pp. 2027-2051. DOI: 10.1109/ COMST.2016.2548426

18. Levent-Levi T. WebRTC and Man in the Middle Attacks. Available at: https://webrtchacks.com/webrtc-and-manin-the-middle-attacks (Accessed: 01.10.2020).
19. Taymans W., Baker S., Wingo A., Bultje R. et al. GStreamer 1.10 Application Development Manual, Samurai Media Limited, 2017, 160 p.

20. https://github.com/alexey-kravtsov/robot-webrtc-pion (Accessed: 02.10.2020).

21. https://github.com/alexey-kravtsov/robot-signalingserver (Accessed: 02.10.2020).

22. Dadhich S., Bodin U., Sandin F., Andersson U. "From Tele-Remote Operation to Semi-Automated Wheel-Loader", International Journal of Electrical and Electronic Engineering and Telecommunications, 2018, vol. 7, no 4, pp. 178-182. DOI: 10.18178/ijeetc.7.4.178-182

23. Dadhich S., Bodin U., Andersson U. "Key challenges in automation of earth-moving machines", Automation in Construction, 2016, vol. 68, pp. 212-222. DOI: 10.1016/j.autcon.2016.05.009

24. Fernando C. L., Saraiji Y. S., Seishu Y., Kuriu N. "Effectiveness of Spatial Coherent Remote Drive Experience with a Telexistence Backhoe for Construction Sites", ICAT-EGVE 2015 - International Conference on Artificial Reality and Telexistence and Eurographics Symposium on Virtual Environments, Kyoto, Japan, 28-30 October, 2015, pp. 1-7. DOI: 10.2312/egve.20151312

25. Larsson J., Broxvall M., Saffiotti A. "An evaluation of local autonomy applied to teleoperated vehicles in underground mines", 2010 IEEE International Conference on Robotics and Automation, Anchorage, USA, 4-8 May, 2010, pp. 1745-1752. DOI: 10.1109/ROBOT.2010.5509276

26. Golik V. I., Gabaraev O. Z., Maslennikov S. A., Khasheva Z. M., Shulgaty L. P. "The provision of development conversion perspectives into undeground one for Russian iron ore deposits development", The Social Sciences (Pakistan), 2016, vol. 11, no. 18, pp. 4348-4351.

27. Dmitrak Yu. V., Golik V. I., Vernigor V. V. "Geomechanical prerequisites for maintaining the stability of workings in the development of water-rich deposits", Bulletin of the Tula State University. Earth Sciences, 2018, no. 1, pp. 218-229.

28. Klyuev R. V., Bosikov I. I., Mayer A. V., Gavrina O. A. "Comprehensive analysis of the effective technologies application to increase sustainable development of the naturaltechnical system", Sustainable Development of Mountain Territories, 2020, no.2, pp. 283-290. DOI: 10.21177/1998-45022020-12-2-283-290.

29. Klyuev R. V., Bosikov I. I., Egorova E. V., Gavrina O. A. "Assessment of mining-geological and mining technical conditions of the Severny pit with the use of mathematical models", Sustainable Development of Mountain Territories, 2020, no.3, pp. 418-427. DOI: 10.21177/1998-4502-2020-124-418-427.

Article received 13.07.2020. 
УДК: 621.71

DOI: 10.21177/1998-4502-202012-4-600-608

В исследовании описана технология текущего мониторинга динамического состояния автономных тяжелых платформ (АТП) на карьерных маршрутах, $в$ частности, представлена информация о формировании текущих траекторий (TT) АТП на их начальном и возвратном участках. Указаны причины возникновения и представлены аналитические описания девиаций TT от номинальных осевых траекторий (НОT). Начальный участок TT, автономно-спорадический, формируемый вследствие возникновения время от времени на маршруте случайных препятствий, и возвратный участок TT, принудительно-модальный, нейтрализующий ее девиацию от номинальной осевой траектории марирута, рассмотрены с позиций отображений одномерных сигналов динамики ТT в вейвлетсреде. В качестве рабочих вейвлет-фуннций используются вейвлеты Габора, а в качестве средств отображения квадратичные вейвлетраспределения класса Коэна. При этом рабочим расчетным распределением принято распределение Вигнера.

В заключение отмечены базовые положения, лежащие в основе представленных исследований. Сделан вывод о том, что эксплуатация автономного (беспилотного) горнотранспортного оборудования на горнодобывающих предприятиях,

расположенных в горных территориях, создает условия для устойчивого социально-экономического развития этих территорий.

\section{КЛЮЧЕВЫЕ СЛОВА:}

горные территории, автономные тяжелые платформы, текущие траектории АТП, вейвлеты Габора, алгоритм вейвлетпоиска соответствия, чирп-сигналы, распределения класса Коэна.

Статья поступила в редакцию 03.09.2020.

\section{МОНИТОРИНГ ДИНАМИЧЕСКОГО СОСТОЯНИЯ АВТОНОМНЫХ ТЯЖЕЛЫХ ПЛАТФОРМ НА КАРЬЕРНЫХ МАРШРУТАХ ГОРНОРУДНЫХ ПРЕДПРИЯТИЙ}

Костюк С. Г., 1

Чичерин И. В.,

Федосенков Б. А. ${ }^{1 *}$

Дубинкин Д. М. ${ }^{1}$

${ }^{1}$ Кузбасский государственный технический университет имени Т.Ф. Горбачева, 650000, Кемерово, Россия, rafwaveletsve@mail.ru

\section{Введение}

В ранее опубликованных исследованиях по автономным транспортным средствам (в том числе и по беспилотным карьерным самосвалам) были проанализированы вопросы: формирования маршрутных параметров и моделей перемещения карьерных автономных тяжелых платформ, сформулированные в рамках интегративной системы управления «умным карьером» [1]; мониторинга окружающей среды с помощью наземных колесных транспортных модулей [2]; современного состояния техники и технологий в области автономного управления движением транспортных средств на горнорудных карьерах [3; 4]; повышения технических характеристик карьерных самосвалов [5]; наблюдения за окружающей обстановкой при движении беспилотных транспортных средств (БТС) [6]; интеллектуализации БТС [7]; теории, алгоритмизации и реализации технологических процедур в программно-аппаратном комплексе интеллектуальных БТС [8]; систематизации и выработки терминологии относительно систем автоматизации для движущихся по дорогам общего пользования транспортных средств [9]; методологии, проектирования, разработки логических основ искусственного интеллекта для систем управления движением БТС $[10 ; 11]$ и исследования возможностей технического зрения для беспилотных автомобилей [12].

Вопросы, проанализированные в этих проектах, будучи приложенными к горнорудным предприятиям, расположенным в горных территориях, инициируют приток высококвалифицированной рабочей силы, способной внедрять и обслуживать инновационную технику, требующую знаний и умений нового уровня: информационных технологий и автоматизации на базе цифровой электроники и компьютерно-интегрированных систем, широкой цифровизации административно-хозяйственных комплексов. Такого рода технологии широко применяются, в том числе, и при разработке проектов, связанных с созданием беспилотной, автономной горнотранспортной техники, предназначенной для работы в системах безлюдной технологии.

В представленном исследовании, в частности, рассмотрены принципы управления передвижением АТП по прямым и искривленным технологическим маршрутам, заданным в так называемом формате сплайн-фреймов $(S$-фреймов).

На рис. 1 схематично изображены на прямом $S$-фрейме две девиационные текущие траектории с указанием прямых (отклоняющихся от номинальной осевой траектории - НОТ) и обратных (возвращающихся к НОТ) текущих траекторий (ТT). В программно-аппаратном комплексе, входящем в состав автоматизированной системы диспетчеризации, прямым и обратным переходным процессам ставятся в соответствие одномерные (скалярные) информационные чирп-сигналы $[13 ; 2]$ то есть сигналы $x(t)$ с времязависимой частотой.

Через $x(t)_{1}$ и $x(t)_{r}$ обозначим обобщенную координату движения АТП при девиации траектории соответственно влево и вправо от номинальной осевой траектории по ходу движения. 


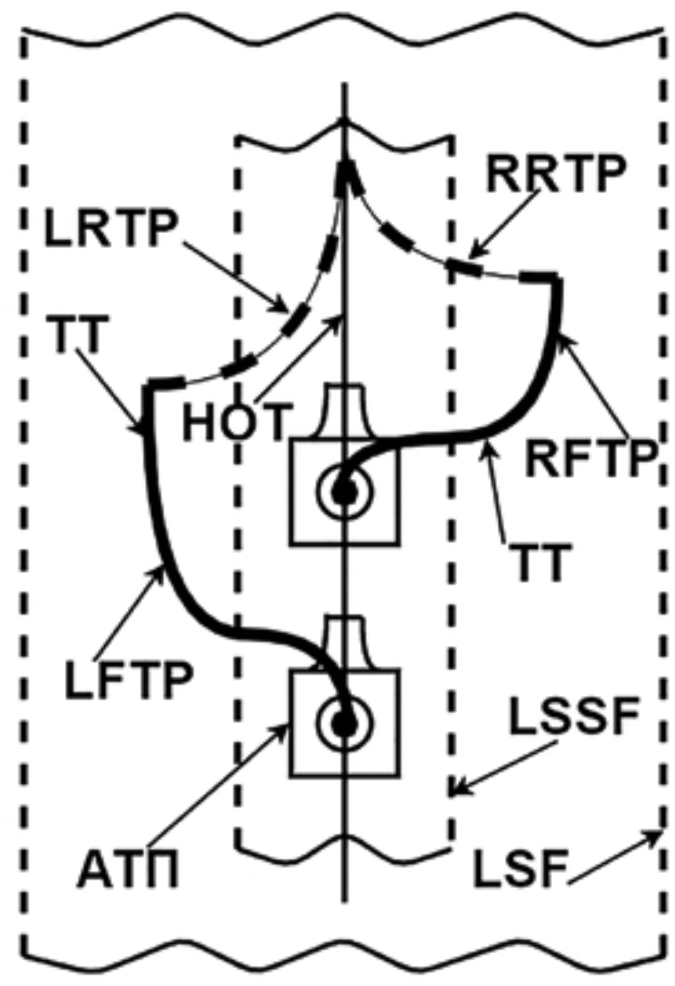

Puc. 1. Схема возникновения возмущенных прямых (девиационных) и формирования обратных восстанавливающих траекторий АТП на прямом участке $\mathrm{S}$-фрейма некоторого маршрута при уходе TT влево и вправо от НОТ

Fig. 1. Diagram of occurrence of disturbed forward (deviation) and formation of reverse recovery paths of AHP on the direct section of $S$-frame of some route when TT leave to the left and right of NAT.

Обозначения / Symbol

- LSF (Local Spline Frame) - локальный $S$-фрейм; - LSSF (Local Sub-Spline Frame) - локальный суб-S-фрейм; - HOT (Nominal axial paths of autonomous heavy platforms) номинальная осевая траектория движения АТП;

- LFTP / RFTP (Left Forward Transient Process / Right Forward Transient Process) - соответственно прямые переходные процессы девиации текущей траектории движения АТП влево / вправо от НОТ;

- LRTP / RRTP (Left Reverse Transient Process / Right Reverse Transient Process) - соответственно обратные переходные процессы восстановления НОТ при девиации текущей траектории (ТТ) движения АТП влево / вправо от НОТ

\section{Концепция текущего мониторинга траекторий ATI}

С целью информативно-полной и семантическипрозрачной обработки сигналов в программно-аппаратных комплексах подсистем автономного и внешнего управления [1] в программные комплексы последних введены фрагменты, обеспечивающие формирование так называемых вейвлет-функций [13; 14] и квадратичных вейвлет-распределений класса Коэна $[15 ; 16]$.

На рис. 2 представлен вид-реконструкция вейвлеткарты ( $W$-карты, карты Вигнера) $[17 ; 18]$, на которой в формате время-частотных распределений Вигнера изображен сигнал ухода ТТ АТП влево от НОТ, а на рис. 3 - сигнал отклонения ТТ АТП вправо. При этом девиации ТТ влево от НОТ соответствует задаваемое в программно-аппаратном комплексе АСД снижение частоты сигнала обобщенной переменной $x(t)$, а девиации ТТ вправо от НОТ - повышение частоты сигнала $x(t)_{r}$. На рис. 2 и 3 моменты $\tau_{l}$ и $\tau_{r}$ соответствуют началу девиации ТТ АТП влево/вправо от НОТ под действием автономно-спорадических возмущений, вызываемых возникновением на маршруте АТП каких-либо препятствий.

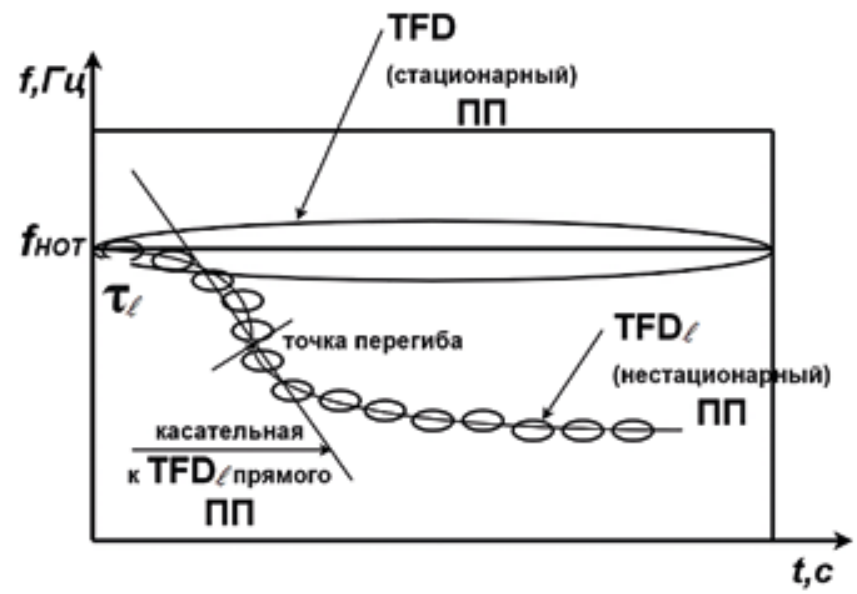

Puc. 2. Карта Вигнера, отображающая в вейвлет-среде стационарный сигнал и нестационарный с понижающейся частотой, соответствующий уходу ТТ АТП влево от НОТ

Fig. 2. Wigner map displaying stationary signal and non-stationary with a decreasing frequency, corresponding to the AHP CT moving to the left of NAT

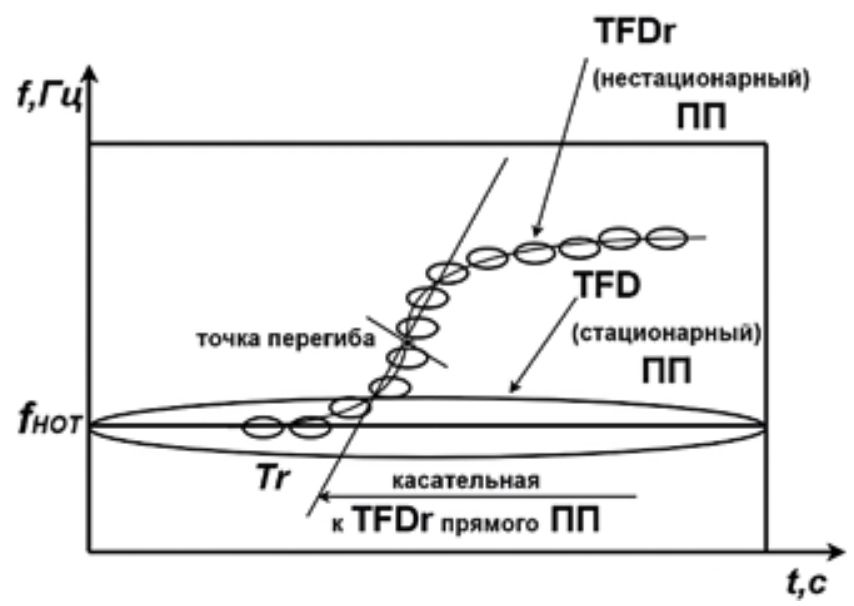

Puc. 3. Карта Вигнера, отображающая в вейвлет-среде стационарный сигнал и нестационарный с повышающейся частотой, соответствующий уходу ТТ АТП вправо от НОТ

Fig. 3. Wigner map displaying the stationary signal and nonstationary with an increasing frequency, corresponding to the AHP CT departure to the right of NAT

Распределение Вигнера, определяющее в нашем исследовании, является многомерно-квадратичным и имеет вид интегральной функции:

$$
\begin{aligned}
& W_{x}(t, \omega)=(2 \pi)^{-1} \int^{\infty} x(t+\tau / 2) \mathrm{x} \\
& \text { х } \psi(t-\tau / 2) \exp (-j \omega \tau) d \tau .
\end{aligned}
$$

Отсюда видно, что распределение Вигнера пред- 
ставляет собой взаимно-корреляционную функцию сигнала с время-частотным атомом (вейвлет-функцией) из определенной совокупности (вейвлет-тезауруса, или словаря) при его временном и частотном смещении относительно этих атомов. Таким образом, функция распределения Вигнера является двумерной или даже трехмерной функцией, поскольку интенсивность сигнала (значение взаимно-корреляционной функции) в двумерной время-частотной плоскости может быть охарактеризована как третья координата. Следовательно, функция распределения Вигнера характеризует распределение плотности энергии (интенсивности) сигнала.

Время-частотный атом-аппроксимант - вещественный вектор, имеющий вид:

$$
\psi_{I}^{\varphi}[n]=K_{j, \varphi} \cdot \psi_{j}[n-l] \cdot \cos \left(\frac{2 \pi \xi n}{N}+\varphi\right)
$$

где $K_{j, j}$ задает единичную норму вектора $\Psi_{\mathrm{I}}^{\varphi}[n]$, а начальная фаза $\varphi$ оптимизируется так, чтобы максимизировать скалярное произведение атома с остатком сигнала.

На рис. 4 слева показан переходный процесс, соответствующий девиации ТТ АТП влево от НОТ в 1D-формате; кроме того, здесь же представлены реконструированные по алгоритму вейвлет-поиска соответствия (ВПС) [13; 18; 19] сигнал, а также ошибка аппроксимации сигнала. Справа представлено многомерное отображение того же сигнала в виде распределения Вигнера.

Характер 1D-сигнала TT, девиирующей вправо от HOT (рис. 3), определяется апериодикой 2-го порядка и сформирован из отдельных время-частотных атомов (ВЧА) [20; 21] в соответствии с алгоритмом вейвлетпоиска соответствия.

По параметрам отображения такого нестационарного процесса определяются параметры предстоящего режима, режима динамического модального управления, возвращающего ТТ к НОТ. Кроме того, здесь же приведена форма вейвлет-отображения стационарно- го по частоте $f_{\text {нот }}$ сигнала. Подобная процедура реализуется и для сигнала, соответствующего уходу ТТ влево от НОТ (рис. 2).

\section{Процедуры обработки сигналов о текущих траекториях АТП}

Визуально-графическое отображение технологического сигнала, характеризующего динамику ТТ АТП на маршруте, формируется в многомерной вейвлетсреде, что позволяет информационно емко и семантически прозрачно представлять перемещение АТП в карьере.

Для того чтобы отслеживать движение АТП по текущим траекториям, предложен способ соответствия специфического 1D-информационного сигнала с время-зависимой мгновенной частотой - чирп-сигнала процессу формирования ТT.

Так, процессу отклонения ТТ от НОТ влево ставится в соответствие экспоненциальный чирп-сигнал с уменьшающейся частотой, а процессу отклонения ТT от НОТ вправо - экспоненциальный сигнал с возрастающей частотой. При этом начальный участок ТT, обусловленный ее девиацией от НОТ вследствие наличия (обнаружения радарно-лидарно-сонарной системой) какого-либо препятствия или встречной АТП на маршруте, описывается двухэкспоненциальной зависимостью вида (рис. 3):

$$
\begin{aligned}
x(t)= & k_{\mathrm{н}}\left[1-\left(T_{3} /\left(T_{3}-T_{4}\right)\right)\left(\exp \left(-t / T_{3}\right)+\right.\right. \\
& +\left(T_{4} /\left(T_{3}-T_{4}\right)\right)\left(\exp \left(-t / T_{4}\right)\right] .
\end{aligned}
$$

Этот участок ТТ именуется автономно-спорадическим, поскольку определяется случайными, возникающими время от времени, внешними возмущениями.

Конечный участок ТТ формируется принудительно, например, под действием динамического модального регулятора [22]. В этом случае его уместно именовать принудительно-модальным. Таким образом, принудительное техническое средство устраняет возникшую на начальном автономно-спорадическом участке ТT девиацию ее от НОТ, приводя ТТ к номинальной осе-

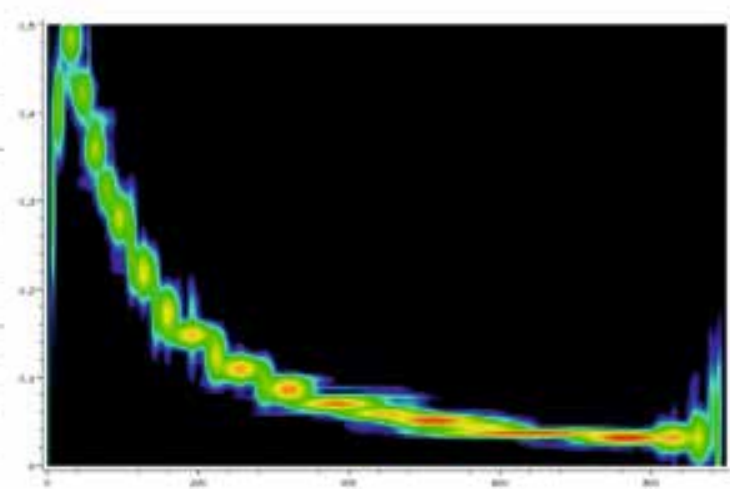

Puc. 4. Переходные процессы в одномерном формате и в виде отображения Вигнера, соответствующие отклонению ТТ АТП от НОТ влево

Fig. 4. Transient processes in one-dimensional format and in the form of Wigner representation, corresponding to the AHP CT deviation from NAT to the left 
вой траектории. Конечный участок ТТ может характеризоваться как двухэкспоненциальным сигналом, так и одноэкспоненциальным (рис. 2):

$$
x \cdot(t)=k_{\mathrm{K}}[1-(\exp (-t / T)],
$$

где Т3, T4, Т, $k_{\text {н }}, k_{\mathrm{r}}$ - соответственно постоянные времени сигнала начального участка ТТ и конечного; $k_{\text {н }}$ $k_{\text {к }}$ коэффициенты передачи для сигнала, соответствующего начальному и конечному участкам ТT.

При отображении чирп-сигналов в вейвлет-среде используются квадратичные вейвлет-распределения класса Коэна. В наших исследованиях в качестве рабочего инструмента применяется вейвлет-распределение Вигнера, в качестве вспомогательного (настроечного) - вейвлет-распределение Чуи-Уилльямса.

Для преобразования 1D-чирп-сигналов в вейвлет-распределения в работе используется адаптивная аппроксимация на базе алгоритма вейвлет-поиска соответствия.

В качестве базисных вейвлет-функций используются вейвлеты в составе избыточного словаря [13; 18], в котором, помимо вейвлетов Габора, содержатся вейвлеты из базисов Хевисайда, Гаусса, Дирака и Фурье.

При этом габоровская вейвлет-фукция, представляющая собой модулированную функцией Гаусса (c конечным носителем) гармоническую структуру:

$$
g(t)=\frac{1}{\sqrt{s}} g_{0}\left(\frac{t-\tau}{s}\right) \cos (\omega t+\psi),
$$

где $g_{0}(t)$ - модулирующая материнская вейвлет-функция Гаусса; $\omega$ и $\tau$ - текущие частота и смещение; $\psi-$ начальная фаза гармонического сигнала.

Использование вейвлет-функций Габора в качестве основных продиктовано их синусоидально-подобной формой. С учетом того, что вейвлеты Габора представляют собой модулированные функцией Гаусса синусоидальные сигналы, достижение критерия оптимального выбора из словаря соответствующего вейвлета (что соответствует оптимизации процедуры аппроксимации чирп-сигналов) является достаточно очевидным и комфортным.

Оптимизация процедуры аппроксимации определяется максимизацией скалярного произведения

$$
<x(t), g(t, \omega)>=x(t) \cdot g(t, \omega)^{T} \longrightarrow \max ,
$$

где $x(t)$ - аппроксимируемый фрагмент чирп-сигнала; $g(t, \omega)$ - выбираемая из словаря вейвлет-функция. При этом достижение указанного критерия обеспечивается варьированием четырех параметров вейвлета Габора:

- $\tau$ - смещение вейвлета по оси времени $t$;

- $s$ - масштаб вейвлета (величина поддержки вейвлета на оси $t)$;

- $\xi$ (здесь обозначено через $\omega$ ) - частота вписанной в функцию Гаусса синусоиды;

- $\psi$ - начальная фаза синусоиды.

Пятый параметр - мгновенная амплитуда вейвлета - исключается из списка варьируемых параме- тров, поскольку при проецировании анализируемого сигнала на вейвлет-словарь все отбираемые из него вейвлеты, так же как и анализируемые чирп-сигналы, нормализуются по квадратичной единичной норме:

$$
\begin{aligned}
\|x(t)\|_{2} & =\|g(t, \omega)\|_{2}=1 ; x(t) /\left[x(t) \cdot x(t)^{T}\right]^{0,5}= \\
& =g(t, \omega) /\left[g(t) \cdot g(t)^{T}\right]^{0,5}=1,
\end{aligned}
$$

где квадратичная норма сигнала есть расширенное понятие модуля на бесконечно мерное пространство.

При этом частота варьирования значений параметров вейвлетов Габора возрастает от $\tau$ к $\psi$. Отметим, что значения параметров $\tau, s, \xi$ содержатся в соответствующих разделах избыточного словаря Габора, а параметр $\psi$ варьируется вне словаря в диапазоне $[0,2 \pi]$.

В результате аппроксимации определенного чирпсигнала получаем его аппроксиманту в виде вейвлетряда:

$$
\sum_{i=1, m}<x(t)_{i}, g(t, \omega)_{I i}>g(t, \omega)_{I i},
$$

где $x(t)_{i}-i$-й анализируемый участок чирп-сигнала $x(t)$;

$g(t, \omega)_{I i}-$ вейвлет-функция Габора, выбранная на $i$-й итерации и обладающая индексом параметров $I_{i}=[\tau, s, \xi, \psi]$.

Для вейвлет-сигналов словаря Габора вида

$$
g(t)=\exp \left[-\alpha \frac{t^{2}}{2}+j\left(\frac{\beta t}{2}+\omega_{0} t\right)\right],
$$

т.е. сигналов, представляющих собой гармоники, модулированные функцией Гаусса, распределение Вигнера определяется как:

$$
W(t, \omega)=\exp \left[-\alpha t^{2}-\left(\omega-\beta t-\omega_{0}\right)^{2} / \alpha\right] .
$$

При использовании словаря с вейвлет-функциями Габора распределение Вигнера всегда положительно $[13 ; 18]$. Данное свойство позитивности распределения соответствует его семантической особенности способности отображать энергетическую плотность исследуемого сигнала.

Если коэффициент $\alpha$ - мал, то энергия сигнала концентрируется эллипсообразно вдоль линии с частотой $\omega=\omega_{0}+\beta t$, являющейся производной фазы $d\left[\left(\beta t / 2+\omega_{0)} t\right] / d t\right.$.

При $\alpha=0$ (при единичной модуляции) получаем частотно-время-зависимый сигнал

$$
x(t)_{\alpha=0}=\exp \left[\left(j \beta t / 2+\omega_{0}\right) t\right],
$$

распределение Вигнера которого вырождается в дельта-функцию с наклоном $\beta$ на время-частотной плоскости (рис. $5 a$ ):

$$
W(t, \omega)_{\alpha=0}=\delta\left[\left(\omega-\left(\beta t+\omega_{0}\right) .\right.\right.
$$

Отсюда видно, что вся энергия локализуется вдоль мгновенной частоты $\left(\beta t+\omega_{0}\right)$. При $\beta=0$ (и $\left.\alpha=0\right)$ энергия концентрируется вдоль горизонтальной линии на частоте $\omega_{0}=$ const (рис. 5 б):

$$
W(t, \omega)=\delta\left(\omega-\omega_{0}\right) .
$$


a)

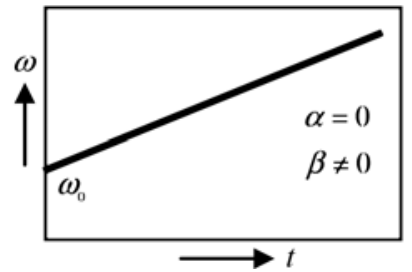

б)

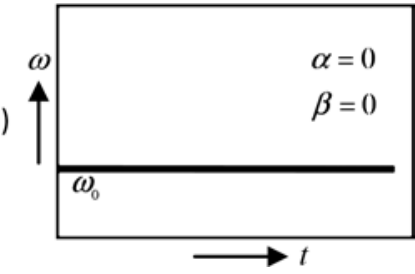

Puc. 5. Распределение Вигнера для: $\boldsymbol{a}$ - гармонического сигнала с время-зависимой частотой; $\sigma$ - гармонического сигнала с постоянной частотой

Fig. 5. Wigner distribution for: $a$ - a harmonic signal with a timedependent frequency; $b$ - a harmonic signal with a constant frequency
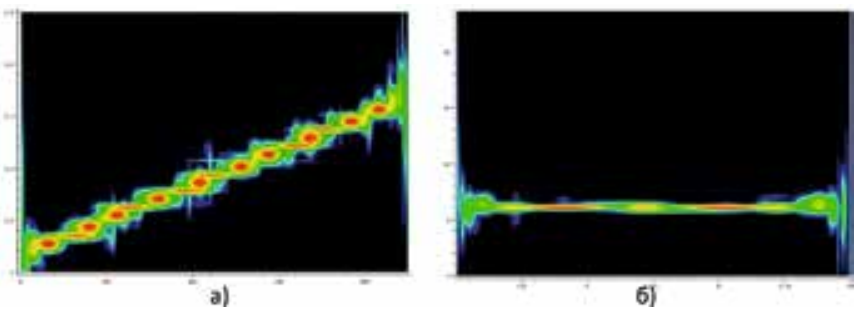

Puc. 6. Расчетные распределения Вигнера реальных сигналов для случаев:

$a$ - формула (1); $\sigma$ - формула (2)

Fig. 6. Estimated Wigner distributions of real signals for the cases: $a$-formula (1); $b$-formula (2)

Фактическая расчетная дискретность и частотновременной разброс отображения одномерного сигнала в виде его представления в $2 D$-пространстве (МСД-карты, то есть карты модифицированного сигнала динамики текущей траектории АТП) (рис. 6) объясняется спецификой алгоритма вейвлет-поиска соответствия, особенностями используемых вейвлетфункций и исходной дискретностью анализируемых сигналов [18].

Сигналу, представленному на рис. $6 a$, соответствует движение АТП по девиационной текущей траектории с ее отклонением вправо от НОТ, а сигналу на рис. $6 б-$ движение АТП по номинальной осевой траектории.

Заметим, что с целью адекватного выполнения процедур по проецированию текущих чирп-сигналов на словарь вейвлет-функций на предварительном этапе обработки чирп-сигналов последние подвергаются следующим операциям:

1) центрирования (исключения из сигналов постоянной составляющей);

2) дискретизации (преобразования центрированных сигналов посредством АЦП);

3) нормализации («выравнивания» мгновенных амплитуд дискретизированных сигналов о ТТ движения АТП, а также отбираемых вейвлет-функций из словаря).

\section{Заключение}

Описанные в исследовании способы мониторинга текущих траекторий движения АТП и процедуры обработки соответствующих сигналов основаны на следующих понятиях и результатах:

1) вейвлет-распределения класса Коэна;

2) избыточный словарь вейвлет-функций Габора;

3) алгоритм вейвлет-поиска соответствия;

4) отображения чирп-сигналов с линейно-возрастающей частотой и стационарного по частоте сигнала о текущих траекториях АТП, представленные в вейвлетсреде;

5) исполнение на предварительном этапе обработки сигналов процедур центрирования, дискретизации и нормализации анализируемых сигналов о текущих траекториях АТП, а также отбираемых из словаря вейвлетов на каждой итерации определенных вейвлетфункций.

Представленные процедуры реализации текущего мониторинга перемещения АТП по карьерным маршрутам и процесса обработки сигналов о динамическом изменении текущих траекторий, заложенные в программно-аппаратные комплексы подсистем автономного и внешнего управления системы «Умный карьер», обеспечивают адекватное выполнение требуемых функций.

Внедрение подобных структур автоматизации горнотранспортной техники в технологическое хозяйство горнорудных предприятий, расположенных в горных территориях, дает возможность привлекать квалифицированных специалистов для внедрения и эксплуатации нового высокотехнологичного оборудования, что, в свою очередь, способствует формированию условий для перспективного устойчивого социально-экономического развития горных территорий.

\section{БЛАГОДАРНОСТЬ / Acknowledgement:}

Работа выполнена при финансовой поддержке Министерства науки и высшего образования Российской Федерации в рамках соглашения № 075-11-20 19-034 от 22.11.2019 г. с ПАО КАМАЗ по комплексному проекту «Разработка и создание высокотехнологичного производства автономных тяжелых платформ для безлюдной добычи полезных ископаемых в системе "Умный карьер"» при участии ФГБОУ ВО «Кузбасский государственный технический университет им. Т.Ф. Горбачева» в части выполнения научно-исследовательских, опытно-конструкторских и технологических работ.

The work was carried out with the financial support of the Ministry of science and higher education of the Russian Federation within the framework of agreement no. 075-11-20 19-034 of 22.11.2019 with Kamaz PJSC on the complex project "Development and creation of high-tech production of autonomous heavy platforms for unmanned mining in the smart quarry system", with the participation of the Kuzbass state technical university named after T. F. Gorbachev" in terms of performing research, development and technological works. 
Авторы выражают благодарность сотрудникам института информационных технологий, машиностроения и автотранспорта ФГБОУ ВО «Кузбасский государственный технический университет имени Т.Ф. Горбачева» за содействие в размещении рукописи статьи в редакции журнала.

The authors express their gratitude to the staff of the Kuzbass State Technical University after Gorbachev T. F. (Institute of Information Technologies, Mechanical Engineering, and Motor Transport) in promoting to place the article manuscript in the periodical editorial office.

\section{КОНФЛИКТ ИНТЕРЕСОВ / Conflict of interest:}

Авторы заявляют об отсутствии конфликта интересов / The authors declare no conflict of interest.

\section{ДОЛЕВОЕ УЧАСТИЕ / Contribution:}

Авторы в написании статьи участвовали в равных долях / The authors participated in writing the article in equal parts.

\section{ЛИТЕРАТУРА:}

1. Концепция управления беспилотными транспортными средствами в условиях открытых горных работ / И.В. Чичерин, Б.А. Федосенков, И.С. Сыркин, В.Ю. Садовец, Д.М. Дубинкин // Известия вузов. Горный журнал, 2020. N8.

2. Алёшин Б.С., Черноморский А.И., Курис Э.Д. Наземные колесные транспортные модули для решения задач мониторинга окружающей среды горных территорий // Устойчивое развитие горных территорий. Т. 10. N 4 (38). 2018. C. $566-576$.

3. Дубинкин Д.М. Обоснование необходимости создания тяжелых платформ для открытых горных работ // Горное оборудование и электромеханика. 2020. N 4 (150). С. 59-64.

4. Дубинкин Д.М. Современное состояние техники и технологий в области автономного управления движением транспортных средств угольных карьеров // Горное оборудование и электромеханика. 2019. N 6. С. 8-15.

5. Voronov Yu., Voronov A., Grishin S., Bujankin A., Increasing the technical level of mining haul trucks // E3S Web of Conferences The Second International Innovative Mining Symposium. 2017.

6. Naranjo J. E. Anguita Autonomous vehicle for surveillance missions in off-road environment / J. E. Naranjo [et al.] // IEEE Intelligent Vehicles Symposium (IV), Gothenburg. 2016. P. 98-103.

7. Nonami K. Autonomous Control Systems and Vehicles. Intelligent Unmanned Systems / K. Nonami [et al.] // Springer Japan. 2013. 306 p.

8. Cheng H. Autonomous Intelligent Vehicles. Theory, Algorithms, and Implementation // Springer. 2011. 163 p.

9. SAE J3016. Taxonomy and Definitions for Terms Related to Driving Automation Systems for OnRoad Motor Vehicles. SAE. 2016. 30 p.

10. Shadrin S.S. Methodology of autonomous road vehicles, integrated in intellectual transport environment, driving control systems design. D. Sc. Thesis. 05.05.03. Bauman State Technical University. Moscow, 2017. 400 p.

11. Shadrin S.S. Experimental Autonomous Road Vehicle with Logical Artificial Intelligence / S.S. Shadrin, O.O. Varlamov, A.M. Ivanov // Journal of Advanced Transportation. 2017. Article ID 2492765. 10 p. DOI: $10.1155 / 2017 / 2492765$.
12. Saikin A.M. The Analysis of Technical Vision Problems Typical for Driverless Vehicles / A.M. Saikin, S.E. Buznikov, K.E. Karpukhin // Research Journal of Pharmaceutical, Biological and Chemical Sciences. 2016. V. 7. N 4. P. 2053-2059.

13. Малла С. Вейвлеты в обработке сигналов. М.: Мир, $2005.673 \mathrm{c}$.

14. Добеши И. Десять лекций по вейвлетам. М.Ижевск: Регулярная и хаотическая динамика, 2001.

15. Auger F., Chassande-Mottin E. Quadratic timefrequency analysis I: Cohen's class, Time-frequency analysis: concepts and methods // ISTE, 2008, January. P. 131-163.

16. Fedosenkov D.B. [et al.]. Cohen's class time-frequency distributions for measurement signals as a means of monitoring technological processes // Steel in Translation. 2019. Vol. 49. N 4. P. $252-256$.

17. Debnath L. Recent development in the Wigner-Ville distribution and time-frequency signal analysis // PINSA, 68A:1 - January 2002. P. 35-56.

18. Федосенков Б.А., Федосенков Д.В. Автоматизированное управление смесеприготовительными процессами в вейвлет-среде: монография. Кемерово: Кемеровский технологический институт пищевой промышленности, 2015. 189 с.

19. Mallat S., Zhang Z. Matching pursuit with time-frequency dictionaries // IEEE Transactions on Signal Processing. 1993. Vol. 41, N 12. P. 3397-3415.

20. Boashash B. Measures, performance assessment, and enhancement TFDs. - In Time-frequency signal analysis and processing: a comprehensive reference // Academic Press. 2016, January. P. 387-452.

21. Townsend S. Sparse Approximation and Atomic Decomposition: Considering Atom Interactions in Evaluating and Building Signal Representations / S. Townsend, B. Lee, Jr. // Dissertation ... PhD. March 2009. 260 p.

22. Федосенков Д.Б., Симикова А.А., Федосенков Б.А. Синтез системы модального управления блоком дозирующих устройств // Машиностроение: инновационные аспекты развития: Материалы международной научно-практической конференции. Санкт-Петербург: СПб. ФНИЦ МС, 2019. N2. C. 162-167. 


\title{
СВЕДЕНИЯ ОБ АВТОРАХ / Information about authors:
}

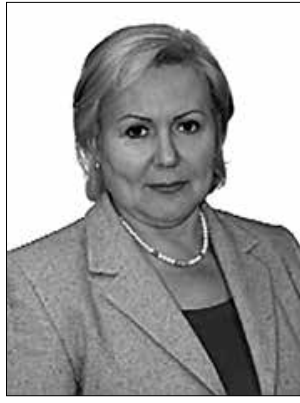

КОСТЮК Светлана Георгевна - кандидат технических наук, доцент, проректор по научной работе и международному сотрудничеству, ФГБОУ ВО «Кузбасский государственный технический университет имени Т.Ф. Горбачева».

650000, Кемерово, Россия.

Тел.: 8(384-2) 68-23-83.

ksg.adm@kuzstu.ru

Svetlana. G. KOSTYUK - Candidate of Technical Sciences, Associate Professor, Vice-Rector for Scientific Work and International Cooperation, T.F. Gorbachev Kuzbass State Technical University,

Kemerovo, 650000, Russia.

Ph.: + 7(384-2) 68-23-83;

ksg.adm@kuzstu.ru

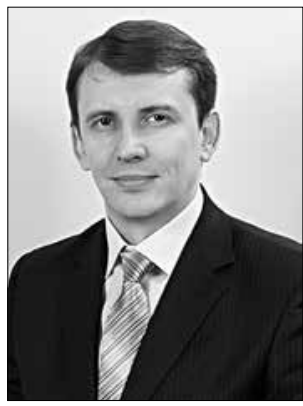

ЧИЧЕРИН Иван Владимирович - кандидат технических наук, доцент, заведующий кафедрой «Информационные и автоматизированные производственные системы», ФГБОУ ВО «Кузбасский государственный технический университет имени Т.Ф. Горбачева».

650000, Кемерово, Россия.

Тел.: 8-905-912-1187,

8(3842)-39-63-10;

chicivan@yandex.ru

Ivan V. CHICHERIN - Candidate of Technical Sciences, Associate Professor, Head of the Department "Information and Computeraided Manufacturing Systems", T.F. Gorbachev Kuzbass State Technical University.

Kemerovo, 650000, Russia.

Ph.: +7(905)912-1187, 8(3842)-39-63-10; chicivan@yandex.ru

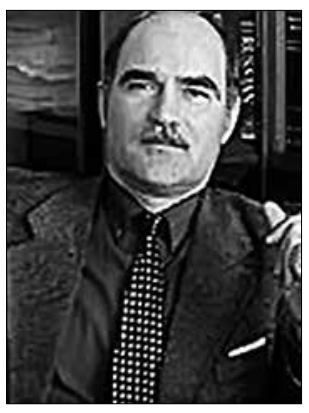

ФЕДОСЕНКОВ Борис Андреевич - доктор технических наук, профессор, профессор кафедры «Информационные и автоматизированные производственные системы», ФГБОУ ВО «Кузбасский государственный технический университет имени Т.Ф. Горбачева».

650000 , Кемерово, Россия.

Тел.: 8(3842)-39-63-10;

rafwaveletsve@mail.ru

Boris A. FEDOSENKOV - Professor, Doctor of Technical Sciences, Professor of the Department "Information and Computer-aided Manufacturing Systems", T.F. Gorbachev Kuzbass State Technical University.

650000, Kemerovo, Russia

Ph.:+7(3842)-39-63-10; rafwaveletsve@mail.ru

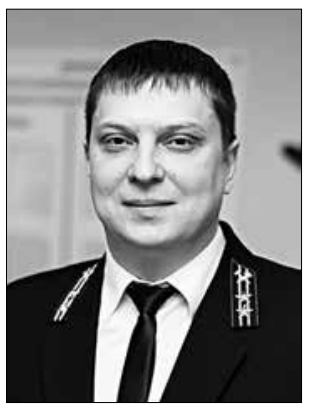

ДУБИНКИН Дмитрий Михайлович - кандидат технических наук, доцент, руководитель научного центра «Цифровые технологии», доцент кафедры металлорежущие станки и инструменты, ФГБОУ ВО «Кузбасский государственный технический университет имени Т.Ф. Горбачева».

650000 , Кемерово, Россия.

Тел.: 8 (913) 405-9411;

ddm.tm@kuzstu.ru

Dmitry M. DUBINKIN - Candidate of Technical Sciences, Associate Professor, Director Scientific Center "Digital Technologies", Associate Professor of The Metal Cutting Mashines and Tools Department T.F. Gorbachev Kuzbass State Technical University,

Kemerovo, 650000, Russia.

Ph.:+7(913)405-9411; ddm.tm@kuzstu.ru

\section{MONITORING OF THE DYNAMIC STATE OF AUTONOMOUS HEAVY PLATFORMS ON THE QUARRY ROUTES OF MINING ENTERPRISES}

\author{
S. G. Kostyuk ${ }^{1}$, \\ I. V. Chicherin ', \\ B. A. Fedosenkov ${ }^{1 *}$, \\ D. M. Dubinkin ${ }^{1}$ \\ ${ }^{1}$ T. F. Gorbachev Kuzbass State Technical University, Kemerovo, 650000, Russia, rafwaveletsve@mail.ru
}

DOI: $10.21177 / 1998-4502-2020-12-4-600-608$

Purpose of work. The article presents the results of theoretical research and developments obtained at the Kuzbass state technical university on the implementation of current monitoring and bringing about signal processing procedures for the dynamic state of autonomous heavy platforms (AHP) on open pit mine routes. In order to obtain information about the generated current trajectories (CT) of unmanned mining dump trucks, in the software and hardware complexes of the computer-aided dispatching system (in the external control subsystem - ECSS and the autonomous control subsystem -
ACSS) installed on-board of an AHP, one-dimensional (scalar) continuous signals (hereinafter converted into discrete digital ones) with a time-dependent instantaneous frequency, the so-called chirp signals, are put in accordance with the current trajectories of the AHP.

Research methods. This approach makes it possible to continuously monitor and manage the dynamics of current ATP trajectories with a high degree of efficiency. Note that for the purpose of information-rich and semantically transparent representation of information about the current state 
of the AHP CT, the chirp signals of the CT are converted into multidimensional Cohen's class time-frequency wavelet distributions. The Wigner-Ville distribution (hereinafter referred to as the Wigner distribution) is selected as a working tool for performing computational procedures in the hardware / software module. This distribution is based on the Gabor basis wavelet functions and the wavelet matching pursuit algorithm. The choice of Gabor wavelets as the main ones is explained by their sinusoidal-like shape, since they are sinusoidal signals modulated by the Gauss window. On the other hand, the analyzed 1D-signals indicating the current position of the AHP on the route are also sinusoidal-like. This makes it possible to approximate current signals with high accuracy based on their comparison with the wavelet functions selected from the redundant wavelet dictionary. This approximation is adaptive, since it is performed on separate local fragments of the signal analyzed depending on approximating wavelets. This is the essence of the wavelet matching pursuit algorithm. The resulting wavelet series is then transformed into the Wigner time-frequency distribution, which is used to form a corresponding CT.

Research results. As an example, reconstructions of time-frequency distributions (TFD) are given, corresponding to the deviation of a certain CT to the left (the trajectory signal decreases exponentially) and to the right (the CT-signal increases) from the nominal axial trajectory (NAT). The calculated scalar signal and its TFD for the AHP CT deviating to the left from NAT are also presented. In addition, on the basis of theoretical explanations the calculated linear-increasing TFD is demonstrated, corresponding to the CT-deviation to the right from NAT, and the time invariant stationary TFD characterizing the movement of AHP along the NAT line.

Conclusion. Based on the results obtained, it is concluded that the most appropriate ways to monitor the current trajectories of AHP movement and procedures for processing the corresponding signals are the operations implemented in computer-aided subsystems of external and autonomous control and based on such concepts as the Cohen's class wavelet distributions, Gabor redundant dictionary of wavelet functions, the wavelet matching pursuit algorithm, and the representation of technological chirp-signals, as well as frequency-stationary signals about the current AHP trajectories represented in the wavelet medium. In this connection, the authors concluded that the procedures realizing the current monitoring of AHP movement on open pit mine routes and implementing the process of analyzing a relevant dynamic change in current trajectories, described in the article and embedded in software and hardware autonomous and external control subsystems of "Smart opencast mine" are adequate for performing required functions.

The introduction of the principles of computer-aided controlling the unmanned mining vehicles allows you to optimize labor costs for the operation of mining equipment, reduce the cost of current work, and attract highly qualified specialists for the development and operation of innovative transport equipment. The implementation of such prospects in mountainous regions (of a country) makes it possible to diversify the range of labor resources and, in general, contribute to the sustainable social and economic development of mountain territories.
Keywords: mountain areas, autonomous heavy platforms, current AHP trajectories, Gabor wavelets, wavelet matching pursuit algorithm, chirp signals, Cohen's class distributions

\section{References:}

1. Chicherin I.V., Fedosenkov B.A., Syrkin I.S., Sadovets V.Yu., Dubinkin D.M., "Concept of unmanned vehicle control in open mining", Mining Magazine, 2020, no. 8.

2. Alyoshin B.S., Chernomorsky A.I., Kuris E.D., "Ground wheeled transport modules for solving the problems of monitoring the environment of mountain areas", Sustainable Development of Mountain Territories, 2018, vol. 10, no. 4 (38), pp. 566-576.

3. Dubinkin D.M., "Justification of the need to create heavy platforms for open-pit mining", Mining Equipment and Electromechanics, 2020, no.4 (150), pp. 59-64.

4. Dubinkin D.M. "Current state of engineering and technology in the field of autonomous traffic control of coalmine vehicles", Mining Equipment and Electromechanics, 2019, no. 6, pp. 8-15.

5. Voronov Yu., Voronov A., Grishin S., Bujankin A., "Increasing the technical level of mining haul trucks", E3S Web of Conferences the Second International Innovative Mining Symposium, 2017.

6. Naranjo J. E. "Anguita Autonomous vehicle for surveillance missions in off-road environment", IEEE Intelligent Vehicles Symposium (IV), Gothenburg, 2016, pp. 98103.

7. Nonami K. et al. Autonomous Control Systems and Vehicles. Intelligent Unmanned Systems, Springer Japan, 2013, $306 \mathrm{p}$.

8. Cheng H. Autonomous Intelligent Vehicles. Theory, Algorithms, and Implementation, Springer, 2011, 163 p.

9. SAE J3016. Taxonomy and Definitions for Terms Related to Driving Automation Systems for on Road Motor Vehicles, SAE, 2016, $30 \mathrm{p}$.

10. Shadrin S.S. Methodology of autonomous road vehicles, integrated in intellectual transport environment, driving control systems design: dissert. D. Sc. (Engineering) Thesis. 05.05.03. Bauman State Technical University, Moscow, 2017, 400 p.

11. Shadrin S.S., Varlamov O.O., Ivanov A.M. "Experimental Autonomous Road Vehicle with Logical Artificial Intelligence", Journal of Advanced Transportation, 2017, 10 p. Article ID 2492765. DOI: 10.1155/2017/2492765.

12. Saikin A.M., Buznikov S.E., Karpukhin K.E. "The Analysis of Technical Vision Problems Typical for Driverless Vehicles", Research Journal of Pharmaceutical, Biological and Chemical Sciences, 2016, v. 7, no 4, pp. 2053-2059.

13. Mallat S. A Wavelets in Signal Processing, Mir Publ., Moscow, 2005, 673 p.

14. Daubechies I. Ten Lectures on Wavelets, Regular and chaotic dynamics. 2001, 464 p.

15. Auger F., Chassande-Mottin E. "Quadratic timefrequency analysis I: Cohen's class, Time-frequency analysis: concepts and methods", ISTE, 2008 January, pp. 131-163.

16. Fedosenkov D.B. et al. "Cohen's class timefrequency distributions for measurement signals as a means of monitoring technological processes", Steel in Translation, 2019, vol. 49, No 4, pp. $252-256$.

17. Debnath L. "Recent development in the Wigner-Ville 
distribution and time-frequency signal analysis", PINSA, 68A:1 - January 2002, pp. 35-56.

18. Fedosenkov B.A., Fedosenkov D.B. Computeraided control of mixing processes in the wavelet medium, Kemerovsky Technological Institute of Food Science and Technology, Kemerovo, 2015, 189 p.

19. Mallat S. and Zhang Z. Matching pursuit with time-frequency dictionaries, IEEE Transactions on Signal Processing, 1993, vol. 41, no. 12, pp. 3397-3415.

20. Boashash B. Measures, performance assessment, and enhancement TFDs, In Time-frequency signal analysis and processing: a comprehensive reference, Academic Press, 2016, January, pp. 387-452.
21. Townsend S. Sparse Approximation and Atomic Decomposition: Considering Atom Interactions in Evaluating and Building Signal Representations / S. Townsend, B. Lee, Jr. PhD Thesis, March 2009, 260 p.

22. Fedosenkov D.B., Simikova A.A., Fedosenkov B.A. "Synthesis of the modal control system of the feeding unit", Engineering: Innovative Development Plans, Materials of the International Scientific and Practical Conference, St. Petersburg, 2019, no. 2.

Article received 03.09.2020. 


\section{НАУЧНОЕ МHЕНИЕ}

SCIENTIFIC OPINION

\section{МЕЖДИСЦИПЛИНАРНЫЕ АСПЕКТЫ УСТОЙЧИВОГО РАЗВИТИЯ ГОРНЫХ ТЕРРИТОРИЙ: РОЛЬ СОЦИАЛЬНО- КУЛЬТУРНЫХ ФАКТОРОВ}

\begin{abstract}
Гуня А. Н. ${ }^{1 *}$, Хадзарагова Е.А. ${ }^{2}$, Хетагуров В.Н. ${ }^{2}$, Караев Ю.И. ${ }^{2,3}$

${ }^{1}$ Институт географрии РАН, 119017, Москва, Россия gunyaa@yahoo.com

${ }^{2}$ Северо-Кавказский горно-металлургический институт (государственный технологический университет), 362021, Владикавказ, Россия ${ }^{3}$ Автономная некоммерческая организация "Международный инновационный научнотехнологический центр "Устойчивое развитие горных территорий» СевероКавказского горно-металлургического института (государственного технологического университета), 362021, Владикавказ, Россия
\end{abstract}

\section{Введение}

Анализу устойчивого развития горных территорий посвящено множество публикаций, а также регулярно выходящих изданий. Среди них выделяются пять журналов, представляющих проблематику комплексного и междисциплинарного исследования горных территорий [1]: Журнал альпийских исследований (Journal of Alpine Research, Франция), Горные исследования и развитие (Mountain Research and Development - MRD, Швейцария), Журнал горной науки (Journal of Mountain Science, Китай), Экомонт - журнал по исследованию и управлению охраняемыми горными территориями (eco.mont - Journal of Protected Mountain Areas Research and Management, Австрия) и журнал «Устойчивое развитие горных территорий» (Владикавказ, Россия). Самым старым является Журнал альпийских исследований, издающийся с 1913 года, самым молодым - Журнал «Устойчивое развитие горных территорий (УРГТ)», издающийся с 2009 года. На современном этапе с его возросшими потоками информации взаимодействие журналов представляется важным фактором, способствующим качеству работ и отражению острых методологических и практических проблем развития горных территорий во всем мире. Этому порой мешают языковые барьеры. Русскоязычные публикации о горах часто остаются неизвестными исследователям в мире.

В 2018 году между журналами УРГТ и MRD было достигнуто соглашение о подготовке совместного тематического номера о роли культуры в горах. Целью
УДК: 91:001.89; 910.21

DOI: 10.21177/1998-4502-202012-4-609-619

В основу статьи положень материалы обзора номеров двух ведущих журналов, посвященных горным территориям: Устойчивое развитие горных территорий (УРГТ) и Горные исследования и развитие (MRD). Соглашение о подготовке совместного тематического номера о роли культуры в горах было достигнуто в 2018 г. Целью соглашения стало отобразить вклад культурных факторов в устойчивое развитие горных территорий, а также расширение научного обмена между сообществами, говорящими на разных языках. Не в последнюю очередь было важным отразить разницу в подходах $и$ методах "визуализации» научной мысли на Заnаdе и в России, интеграции и контекстуализации знания, что имеет решающее значение для обеспечения устойчивого развития $в$ глобальном аспекте.

\section{КЛЮЧЕВЫЕ СЛОВА:}

культура, социальнокультурные фракторы, устойчивое развитие горных территорий, культурный ландшафт, институты.

Статья поступила в редакцию 28.08.2020. 
соглашения стало отобразить вклад культурных факторов в устойчивое развитие горных территорий, а также расширение научного обмена между научными сообществами, использующими разные языки и концепции. Не в последнюю очередь было важным отразить разницу в подходах и методах «визуализации» научной мысли на Западе и в России, интеграции и контекстуализации знания, что имеет решающее значение для обеспечения устойчивого развития в глобальном аспекте.

Горы во всем мире характеризуются богатым культурным разнообразием, выражающимся в самобытности горного населения, языках, искусстве, методах ведения сельского хозяйства, социально-экономическом устройстве, управлении и др. Большинство горных культурных ландшафтов сформировались на протяжении веков горными народами с различными мировоззрениями и знаниями об управлении природными ресурсами. С другой стороны, горы играют важную духовную и социальную роль, имея особое значение в формировании идентичности людей, становлении их религий и культур. В горных сообществах происходят глубокие и быстрые процессы социокультурных изменений, вызванные такими факторами, как эмиграция, урбанизация и растущая интеграция в рыночную экономику. Эти изменения, несомненно, угрожают богатому культурному наследию гор. Однако многие горные сообщества творчески реагируют на изменения и приспосабливаются к ним, опираясь на свое культурное наследие и интегрируя новые знания, чтобы формировать свои собственные инновационные пути развития на местном уровне.

Структура сравниваемых журналов и требования к оформлению статей существенно отличаются. Так MRD выделяет три типа знаний, которые представляют в журнале различные рубрики [2]. Трансформационные знания (mountain development) представляют опыт и исследовательские идеи в отношении развития. В контексте отражения роли культуры в горах такие знания отвечают на вопросы о том, как знания местных сообществ могут способствовать устойчивому развитию и природопользованию в горах, как горные культуры помогают адаптироваться в меняющемся мире, какие при этом новшества относительно безболезненно заимствуются местными сообществами и даже способствуют устойчивости, как культурное разнообразие форм жизнедеятельности помогает справиться с внешними процессами унификации, индивидуализации и др.

Системные знания (Mountain Research) отражают использование комплексного подхода при решении проблем, возникших в результате разного рода изменений, внешних и внутренних факторов. Этот род знаний позволяет ответить на вопросы о том, как горные культуры подвергаются влиянию таких социокультурных изменений, как миграция, урбанизация и рыноч- ная интеграция, конфликты, изменение культурных ландшафтов и др.

Целевые знания (mountain agenda) включают обобщение и синтез научных разработок в определенной области. Касательно темы культуры, такие обобщения направлены на характеристику состояния горных культур в контексте глобальных трендов, оценку современных представлений горных сообществ о благополучии и развитии, выработку предложений по программам поддержки устойчивости в области культуры, вклада горного культурного наследия в цели по устойчивому развитию.

Журнал УРГТ таких рубрик не имеет. Работы, публикуемые в нем, отражают широкое предметное поле исследований, тесно связанное с практическим использованием результатов работ. Это связано также с тем, что сам журнал был основан в университете с естественно-технической специализацией. И, несмотря на то, что журнал уже давно вышел из рамок этой специализации, публикуя и гуманитарные статьи, его идеология осталась. Ее в целом можно охарактеризовать как строго фокусированное исследование, дающее представления о новых достижениях в конкретной области с блоком рекомендаций для устойчивого развития. Это позволяет публиковать работы с разной глубиной методологических разработок, представляя некий уровень научной рефлексии о состоянии научных исследований в конкретной области устойчивого развития горных регионов. Чтобы расширить потенциальную аудиторию читателей за рубежом, УРГТ дает расширенные рефераты статей на английском.

Целью нашей работы был анализ роли культуры в устойчивом развитии горных территорий в разных регионах и с разными подходами отражения результатов научных исследований в публикациях.

\section{Методы и данные исследований}

В основу анализа положены два тематических выпуска журналов УРГT и MRD, которые посвящены роли культуры в горах. Всего проанализировано 13 статей. Из них пять подготовлены для публикации в УРГТ и 8 для MRD. В последствии одна статья из УРГТ была опубликована в MRD. Как видно из таблицы параметрами для анализа и сравнения стали: тематические фокусы статей, охватываемые регионы, набор ключевых слов, формулировка цели, концепции. Более подробно проанализированы основные выводы статей. 9 статей охватывают горы Азии (Кавказ - 3, Гималаи -2 , Тибет и его восточное горное обрамление - 2, Горы Сибири - 2), по две статьи посвящено Альпам и Андам.

\section{Результаты исследований}

Отражение в публикациях проблематики, касающейся культурного компонента в горах, демонстрирует разную концептуальную глубину и использование терминологического аппарата. Такие 
ключевые слова, как культура (в сочетании - культурное наследие, культурный ландшафт, культурные ценности и др.), устойчивость и устойчивое развитие, общины - встречаются наиболее часто (более чем в двух работах). Туризм, пастбище, традиции, горы, коренные народы - эти слова и термины используются реже. Большинство ключевых слов не повторяется, что характеризует достаточно узкую специфику статей.

Российский номер журнала, посвященного роли культуры в горах, предваряло выступление Р. Г. Абдулатипова, крупного российского ученого в области культурологии и национальных отношений, политика, возглавлявшего горный регион Дагестан и непосредственно занимавшегося решением проблем устойчивого развития горных территорий. В его кратком выступлении было, в частности, подчеркнуто, что горным сообществам не просто отвечать на современные вызовы. Хотя некоторые горные сообщества находят эффективные механизмы адаптации, в чем большая заслуга культурных кодов горских народов. В статье Е. Ю. Колбовского с соавторами [3] поднимаются вопросы исследования и сохранности культурных ландшафтов. На примере изучения напашных террас на Северном Кавказа продемонстрированы некоторые методы их изучения с помощью ГИС. Приводятся сравнения с Альпами, опыт применения напашных террас которых может быть полезен и для Северного Кавказа. В статье Баденкова Ю.П. [4] рассматривается опыт жизнедеятельности и ареалы распространения старообрядцев. Подчеркивается, что культурный компонент жизни, в частности, вера, позволила выработать этой группе населения механизмы адаптации к меняющимся условиям. В статье Косовцевой Т. И. [5] рассмотрены культурные ландшафты баварских Альп, опыт их встраивания в общеевропейский контекст. Подчеркнуто, что такие элементы культуры населения, как диалекты, одежда, традиции могут не только дополнять культурные ландшафты, но и сохранить аутентичность, сделать привлекательными для туристов. В статье Гильфеновой В. И. [6] сделана попытка оценить эффективность институциональной среды, регулирующей природопользование эвенков - малочисленного народа Сибири. Отмечено, что быстрая смена институтов привела к росту значения неформальных институтов, в рамках которых эвенкам легче было гарантировать доступ к традиционным ресурсам, обеспечивающих их жизнедеятельность.

B MRD в разделе «Развитие горных районов» три статьи исследуют подходы, которые используют горные сообщества для адаптации к социально-экономическим и политическим изменениям. Сэйнтеной Т. и соавторы (Saintenoy et al - [7]) анализируют реализацию проекта «Культурный путь», направленного на возрождение горных троп, использовавшихся коренными народами Анд в своей повседневной жизни. Авторы критически подходят к механизмам реализации этой идеи, подчеркивая необходимость вовлечения местных сообществ в этот процесс. Культурное наследие - не должно быть лишь объектом охраны, оно должно активно использоваться местным населением. Чжэ Я. и др. (Zhe et al - [8]) анализируют адаптивные стратегии пастухов яков на Тибетском нагорье в условиях деколлективизации пастбищных угодий и внедрения рыночных механизмов, в частности, введения договорных контрактов на пастбища, что привело к разрушению традиционных способов пастбищного яководства. Наилучшим выходом из создавшегося положения считается сохранение коллективных начал в рамках местного самоуправления. Грамм В. и коллеги (Gramm et al - [9]) раскрывают социальные возможности сельского хозяйства, которые способствуют решению социально-экономических проблем и предотвращают разрушение культурной самобытности и традиций горного населения. На примере фермерских хозяйств в Южном Тироле продемонстрированы возможности получения навыков ведения сельского хозяйства для детей и женщин, что важно не только для сохранения традиций, но и дает им возможность заработать.

Раздел «горные исследования» содержит пять статей. В статье Лопес-Сандовал М. и Мальдонадо П. (López-Sandoval, Maldonado - [10]) анализируется использование пастбищ в высокогорье Эквадора. Авторы пришли к выводу, что освоение пастбищ, сопровождаемое перевыпасом, - результат отсутствия эффективных местных институтов. Местные сообщества должны приложить усилия по развитию новых институтов, используя местное институциональное и культурное разнообразие. В статье Гугушвили Т. и его коллег (Gugushvili et al - [11]) исследуется влияние развития туризма на традиционное гостеприимство в горах Грузии. На материалах этой работы показано, что в отношениях гостя и хозяина возникают новые отношения, не укладывающиеся в чисто коммерческие. Дополнительные бесплатные услуги, распределение ролей, в которых гости получают некоторые функции, позволяет говорить о гостеприимстве как о культурном феномене.

В статье Гуни А. и соавторов (Gunya et al - [12]) исследуются различные пути трансформации отгонно-пастбищного животноводства в четырех регионах Северного Кавказа в результате социально-политических изменений. Авторы анализируют и сравнивают факторы, способствующие или препятствующие практике отгонного животноводства, актеры и институты отгонного животноводства в дореволюционный, советский и постсоветский периоды.

Две статьи в разделе «горные исследования» по- 
священы культурным ценностям и представлениям. В своем исследовании Пош Е. и соавторы (Posch et al - [13]) исследуют роль ценностей и мировоззрения в поведении владельцев гостиниц перед лицом стихийных бедствий в Непале. Основываясь на результатах опроса, они утверждают, что различные восприятия стихийно-разрушительных процессов связаны не только с социально-демографическими или социально-экономическими особенностями, но и с разными культурно-ценностными представлениями. Исследование Баду М. и соавторов (Badu et al - [14]) также проводилось в Непале. В своей статье они анализируют восприятие сообществом взаимосвязи между лесом и водой. Большинство населения уверено, что чем больше леса, тем больше воды. Хотя исследования опровергают эти устоявшиеся мнения. Подчеркнута необходимость более эффективного обмена информацией и обсуждения результатов исследований для разработки планов устойчивого управления водосборными бассейнами.

Статья И-Да Ан и др. (Yi-Da An et al - [15]) представляет количественный анализ костюмов чанской этнической группы в Китае, раскрывая их пространственную дифференциацию и корреляцию с природными факторами. Горные народы имеют одежду, максимально адаптированную как к природным условиям, так и к социально-культурному контексту, традициям.

\section{Дискуссия}

Краткий обзор статей показал, что значимость социально-культурных факторов по-разному проявляется в тех или иных регионах мира. К тому же глубина исследования, применяемые методы оценок и интерпретация социально-культурных процессов для горных территорий сильно различается в разных научных школах и странах с тем или иным опытом развития науки. Часть работ слабо связана или вообще не связана с конкретной научной концепцией, в рамках которой происходило исследование. Вместо этого приводится связь со смежными научными концепциями, такими, как, концепция социально-экологической системы [16], институциональный подход [17] и др.

Таким образом, единой концепции «горной культуры» в статьях не представлено. Нет и ссылок на глубокие теоретические построения по культуре со стороны социологов или культурологов. Работы дают скорее представление о границах области, которая очерчивает проявление культурного фактора в развитии горных сообществ. Для этой, еще не совсем определившейся области, характерны:

- локальность и своеобразие рассматриваемых проблем развития;

- культурно кодированная иррациональность, основанная на приоритете традиционных ценностей над экономическими;

- горное традиционное природопользование стремится к балансу с природоохранными задачами;
- набор методов отличается пестротой и междисциплинарностью, попытки инструментализации культурной компоненты выглядят весьма новаторскими;

- важной особенностью статей, анализирующих культурную компоненту, является их практическая направленность, связь с решением насущных проблем горных территорий.

В зарубежных статьях отмечено, что горная культура - это не только объект охраны, это важный фактор развития [18], который проявляется в конкретных ситуациях: сельские фермеры в процессе своей работы передают знания молодежи [9], культурное наследие используется местным населением в туризме [7], традиционные институты помогают преодолеть резкие социально-политические изменения [5;8].

Имеются некоторые схожести сюжетов статей из MRD и УРГТ. Так, статьи Гильфановой В.И. [5] и Чжэ Я. и др. [8] посвящены способам адаптации местного населения к социально-политическим изменениям последних десятилетий. И в том и другом случае упор на самоорганизацию и местные (часто, неформальные) институты предоставляется как наиболее эффективный путь выживания горного населения.

Статьи, представленные в УРГТ и MRD, различаются формами подачи материалов и глубиной концептуальной проработки. В российских статьях (за исключением статьи Е. Ю. Колбовского и соавторов [6]), анализ концептуальных основ не представлен или представлен слабо. Стиль почти всех российских статей близок к научно-публицистическому, что видно по отсутствию методологического контекста и ссылок на научные статьи.

\section{Заключение}

Сравнение анализа статей о роли культуры в горах, представленных в российском и швейцарском журналах, показало как схожесть в оценках роли культуры в устойчивом развитии, так и различия в подходах и глубине анализа эмпирических данных. В статьях признается фундаментальная важность культуры для устойчивого развития в горных районах и предотвращения разрушения горных сообществ с уникальными системами природопользования. Инициатива по совместной подготовке статей по такой важной теме, как роль культуры в горах способствует глобальным усилиям по генерированию знаний, демонстрации путей интеграции культурной компоненты в практику и политику развития. Это совпадает с целями и задачами ЮНЕСКО, в частности с усилиями по разработке показателей культурной компоненты развития [19].

В российских статьях упор сделан на результаты эмпирических наблюдений, в то время как концептуальной составляющей уделено меньше внимания. В зарубежных статьях описанию эмпирических данных предшествует анализ методологического контекста, хотя единый теоретико-методологический контекст 
Название статей, ключевые слова, цели и концептуальная привязка

Article title, keywords, goals and conceptual anchor

\begin{tabular}{|c|c|c|c|c|c|}
\hline $\begin{array}{c}\text { Название статьи } \\
\text { Article title }\end{array}$ & $\begin{array}{l}\text { Регион ис- } \\
\text { следования } \\
\text { Study region }\end{array}$ & $\begin{array}{c}\text { Ключевые слова } \\
\text { Keywords }\end{array}$ & $\begin{array}{c}\text { Основная цель/ } \\
\text { задача } \\
\text { Main goal }\end{array}$ & \begin{tabular}{|c|} 
Концепции, \\
использо- \\
ванные в \\
работе \\
Objective \\
Concepts used \\
in the work
\end{tabular} & $\begin{array}{l}\text { Основной вклад } \\
\text { в концепцию } \\
\text { Major contribution } \\
\text { to the concept }\end{array}$ \\
\hline 1 & 2 & 3 & 4 & \begin{tabular}{|l|}
5 \\
\end{tabular} & 6 \\
\hline \multicolumn{6}{|c|}{ Mountain Research and Development } \\
\hline $\begin{array}{l}\text { Трудности на пути к созда- } \\
\text { нию наследия для раз- } \\
\text { вития сельских районов в } \\
\text { высокогорье Арики } \\
\text { Challenges to building } \\
\text { heritage for rural } \\
\text { development in the Arica } \\
\text { Highlands }\end{array}$ & $\begin{array}{l}\text { Анды, Чили, } \\
\text { Боливия } \\
\text { Andes, Chile, } \\
\text { Bolivia }\end{array}$ & \begin{tabular}{|l|} 
культурное наследие, \\
территория коренных на- \\
родов, развитие сельских \\
территорий, туризм, наце- \\
ленный на использование \\
культурного наследия, \\
ландшафт, Анды, Чили, \\
Боливия \\
Cultural heritage, \\
indigenous territories, \\
rural development, cultural \\
heritage tourism, landscape, \\
Andes, Chile, Bolivia
\end{tabular} & $\begin{array}{l}\text { Анализ потенци- } \\
\text { ала культурного } \\
\text { наследия как } \\
\text { инструмента } \\
\text { местного раз- } \\
\text { вития в текущем } \\
\text { социально-поли- } \\
\text { тическом контек- } \\
\text { сте Анд } \\
\text { Analysis of the } \\
\text { potential of } \\
\text { cultural heritage } \\
\text { as a tool for local } \\
\text { development in } \\
\text { the current socio- } \\
\text { political context of } \\
\text { the Andes }\end{array}$ & $\begin{array}{l}\text { культурное } \\
\text { наследие } \\
\text { cultural } \\
\text { heritage } \\
\\
\end{array}$ & \begin{tabular}{|l|} 
Культурное на- \\
следие, представ- \\
ленное маршру- \\
тами на месте \\
древних троп, \\
является важным \\
полем взаимо- \\
действия разных \\
актеров \\
The cultural \\
heritage \\
represented by \\
routes on the site of \\
ancient trails is an \\
important field of \\
interaction between \\
different actors \\
\end{tabular} \\
\hline $\begin{array}{l}\text { Адаптивные стратегии, } \\
\text { принятые пастухами про- } \\
\text { тив деколлективизации } \\
\text { пастбищ на Тибетском } \\
\text { нагорье в Китае } \\
\text { A daptive strategies adopted } \\
\text { by shepherds against the } \\
\text { decollectivization of pastures } \\
\text { in the Tibetan Highlands in } \\
\text { China }\end{array}$ & $\begin{array}{l}\text { Тибет, Китай } \\
\text { Tibet, China }\end{array}$ & $\begin{array}{l}\text { Адаптивные стратегии, } \\
\text { деколлективизация паст- } \\
\text { бищных угодий, выпас, } \\
\text { политика контрактов на } \\
\text { пастбищные угодья, про- } \\
\text { ект кочевых поселений, } \\
\text { Тибет } \\
\text { Adaptive strategies, } \\
\text { rangeland } \\
\text { decollectivization, grazing, } \\
\text { rangeland contract policy, } \\
\text { nomad settlement project, } \\
\text { Tibet }\end{array}$ & $\begin{array}{l}\text { Анализ адап- } \\
\text { тивных страте- } \\
\text { гий яководов в } \\
\text { условиях де- } \\
\text { коллективизации } \\
\text { пастбищ на } \\
\text { Тибете } \\
\text { Analysis of } \\
\text { adaptive strategies } \\
\text { of yak farmers in } \\
\text { conditions of de- } \\
\text { collectivization of } \\
\text { pastures in Tibet }\end{array}$ & \begin{tabular}{|l} 
Социаль- \\
но-поли- \\
тические \\
изменения, \\
политика \\
контрактов, \\
адаптация \\
Socio- \\
political \\
changes, \\
contract \\
policy, \\
adaptation
\end{tabular} & $\begin{array}{l}\text { Местное само- } \\
\text { управление } \\
\text { - лучший путь } \\
\text { адаптации в райо- } \\
\text { нах пастбищного } \\
\text { использования } \\
\text { Local government } \\
\text { is the best way to } \\
\text { adapt in rangeland } \\
\text { areas }\end{array}$ \\
\hline $\begin{array}{l}\text { Передача и трансформа- } \\
\text { ция (агро) культурных } \\
\text { ценностей горного земле- } \\
\text { делия: образовательные } \\
\text { услуги на базе фермерских } \\
\text { хозяйств в Южном Тироле } \\
\text { Transmission and } \\
\text { Transformation of (Agro) } \\
\text { Cultural Values in Mountain } \\
\text { Agriculture: Farm-Based } \\
\text { Education Services in South } \\
\text { Tyrol }\end{array}$ & $\begin{array}{l}\text { Альпы, } \\
\text { Италия } \\
\text { Alps, Italy }\end{array}$ & $\begin{array}{l}\text { Социально ориентирован- } \\
\text { ное сельское хозяйство, } \\
\text { семейные фермы, Южный } \\
\text { Тироль, сельскохозяй- } \\
\text { ственные ценности, куль- } \\
\text { турные ценности, тради- } \\
\text { ции, образовательные ус- } \\
\text { луги, женщины-фермеры } \\
\text { Socially oriented } \\
\text { agriculture, family farms, } \\
\text { South Tyrol, agricultural } \\
\text { values, cultural values, } \\
\text { traditions, educational } \\
\text { services, women farmers }\end{array}$ & $\begin{array}{l}\text { Анализ потен- } \\
\text { циала социаль- } \\
\text { ного фермерства } \\
\text { для передачи и } \\
\text { преобразования } \\
\text { (агро) культур- } \\
\text { ных ценностей } \\
\text { Analysis of the } \\
\text { potential of social } \\
\text { farming for the } \\
\text { transfer and } \\
\text { transformation } \\
\text { of (agro) cultural } \\
\text { values }\end{array}$ & $\begin{array}{l}\text { Социально- } \\
\text { ориенти- } \\
\text { рованное } \\
\text { сельское } \\
\text { хозяйство, } \\
\text { передача } \\
\text { знаний } \\
\text { Socially- } \\
\text { oriented } \\
\text { agriculture, } \\
\text { knowledge } \\
\text { transfer }\end{array}$ & $\begin{array}{l}\text { Социальное } \\
\text { сельское хо- } \\
\text { зяйство через } \\
\text { образовательные } \\
\text { услуги способ- } \\
\text { ствует передаче } \\
\text { агрокультурных } \\
\text { ценностей } \\
\text { Social agriculture } \\
\text { through } \\
\text { educational } \\
\text { services contributes } \\
\text { to the transfer of } \\
\text { agricultural values }\end{array}$ \\
\hline
\end{tabular}


Продолжение таблиць

\begin{tabular}{|c|c|c|c|c|c|}
\hline 1 & 2 & 3 & 4 & 5 & 6 \\
\hline $\begin{array}{l}\text { Изменения, коллективные } \\
\text { действия и культурная } \\
\text { устойчивость в управле- } \\
\text { нии (природопользовани- } \\
\text { ем) на Парамо в Эквадоре } \\
\text { Change, collective action } \\
\text { and cultural sustainability in } \\
\text { management (environmental } \\
\text { management) at Paramo in } \\
\text { Ecuador }\end{array}$ & $\begin{array}{l}\text { Анды, } \\
\text { Эквадор } \\
\text { Andes, } \\
\text { Ecuador }\end{array}$ & $\begin{array}{l}\text { Парамос, культурная } \\
\text { устойчивость, социально- } \\
\text { экологические системы, } \\
\text { коллективное управление } \\
\text { ресурсами, общинное } \\
\text { управление, Эквадор, } \\
\text { Анды } \\
\text { Paramos, cultural sustain- } \\
\text { ability, socio-ecological } \\
\text { systems, collective resource } \\
\text { management, commu- } \\
\text { nity management, Ecuador, } \\
\text { Andes }\end{array}$ & $\begin{array}{l}\text { Каким образом } \\
\text { менялась практи- } \\
\text { ка выпаса и роль } \\
\text { в этом институ- } \\
\text { тов общинного } \\
\text { управления? } \\
\text { How have grazing } \\
\text { practices and the } \\
\text { role of community } \\
\text { governance institu- } \\
\text { tions changed? }\end{array}$ & \begin{tabular}{|l|} 
Социально- \\
экологиче- \\
ские систе- \\
мы \\
Socio-ecolog- \\
ical systems
\end{tabular} & \begin{tabular}{|l|} 
Горные со- \\
общества должны \\
развивать соб- \\
ственные инсти- \\
туциональные \\
механизмы для \\
коллективного \\
управления при- \\
родопользова- \\
нием \\
Mountain com- \\
munities should \\
develop their own \\
institutional mech- \\
anisms for collec- \\
tive environmental \\
management
\end{tabular} \\
\hline $\begin{array}{l}\text { Что делать? Как ценности } \\
\text { и мировоззрение влияют } \\
\text { на устойчивость к стихий- } \\
\text { ным бедствиям: пример из } \\
\text { региона Мустанг, Непал } \\
\text { What to do? How Values and } \\
\text { Attitudes Affect Resilience to } \\
\text { Disasters: An Example from } \\
\text { the Mustang Region, Nepal }\end{array}$ & $\begin{array}{l}\text { Гималаи, } \\
\text { Непал } \\
\text { Himalayas, } \\
\text { Nepal } \\
\end{array}$ & $\begin{array}{l}\text { готовность, предотвраще- } \\
\text { ние, сегментация, устой- } \\
\text { чивость, ценностные } \\
\text { ориентации, стихийные } \\
\text { бедствия, туристические } \\
\text { предприниматели, Непал } \\
\text { Preparedness, prevention, } \\
\text { segmentation, resilience, } \\
\text { value orientations, natural } \\
\text { disasters, tourism entrepre- } \\
\text { neurs, Nepal }\end{array}$ & \begin{tabular}{|l|} 
Какие имеются \\
типы поведения \\
по профилактике \\
стихийных бед- \\
ствий и как они \\
коррелируют с \\
социально-эконо- \\
мическими и дру- \\
гими факторами \\
и ценностями? \\
What are the types \\
of disaster preven- \\
tion behaviors \\
and how do they \\
correlate with \\
socio-economic \\
and other factors \\
and values?
\end{tabular} & \begin{tabular}{|l|} 
Устой- \\
чивость \\
(resilience) \\
к стихийно- \\
разрушаю- \\
щим процес- \\
сам \\
Resilience to \\
spontaneously \\
destructive \\
processes \\
\end{tabular} & \begin{tabular}{|l|} 
Различная \\
устойчивость к \\
стихийно-разру- \\
шающим про- \\
цессам связана с \\
разными культур- \\
но-ценностными \\
представлениями \\
Different resistance \\
to spontaneously \\
destructive pro- \\
cesses is associ- \\
ated with different \\
cultural and value \\
ideas
\end{tabular} \\
\hline $\begin{array}{l}\text { Сохраняется ли традици- } \\
\text { онное грузинское госте- } \\
\text { приимство при развитии } \\
\text { туризма? примеры из } \\
\text { высокогорных районов } \\
\text { Грузии } \\
\text { Is the traditional Georgian } \\
\text { hospitality preserved in the } \\
\text { development of tourism? } \\
\text { examples from the highlands } \\
\text { of Georgia }\end{array}$ & $\begin{array}{l}\text { Кавказ, } \\
\text { Грузия } \\
\text { Caucasus, } \\
\text { Georgia }\end{array}$ & $\begin{array}{l}\text { Гостеприимство, приба- } \\
\text { вочный продукт, туризм, } \\
\text { горы, традиция, коммер- } \\
\text { циализация, цифровые } \\
\text { данные о путешестви- } \\
\text { ях, гибридный подход, } \\
\text { Грузия } \\
\text { Hospitality, value } \\
\text { added product, tourism, } \\
\text { mountains, tradition, } \\
\text { commercialization, } \\
\text { digital travel data, hybrid } \\
\text { approach, Georgia }\end{array}$ & $\begin{array}{l}\text { Сохранилось } \\
\text { ли самобытное } \\
\text { грузинское госте- } \\
\text { приимство или } \\
\text { превратилась в } \\
\text { товар в условиях } \\
\text { ускоренного раз- } \\
\text { вития туризма? } \\
\text { Has the original } \\
\text { Georgian hospital- } \\
\text { ity been preserved } \\
\text { or has it turned } \\
\text { into a commodity } \\
\text { in the context of } \\
\text { the accelerated } \\
\text { development of } \\
\text { tourism? }\end{array}$ & \begin{tabular}{|l|} 
Обосно- \\
ванная на \\
эмпириче- \\
ских данных \\
теория \\
(grounded \\
theory) \\
Grounded \\
theory
\end{tabular} & \begin{tabular}{|l|} 
Дополнительные \\
бесплатные услу- \\
ги, распределение \\
ролей, в которых \\
гости получают \\
некоторые функ- \\
ции, и др. позво- \\
ляет говорить о \\
гостеприимстве \\
как культурном \\
феномене \\
Additional free ser- \\
vices, distribution \\
of roles in which \\
guests receive \\
some functions, \\
etc. allows us to \\
talk about hospital- \\
ity as a cultural \\
phenomenon
\end{tabular} \\
\hline
\end{tabular}


Продолжение таблищь

\begin{tabular}{|c|c|c|c|c|c|}
\hline 1 & 2 & 3 & 4 & 5 & 6 \\
\hline $\begin{array}{l}\text { Управление лесными } \\
\text { водосборами в среднего- } \\
\text { рьях Непала в условиях } \\
\text { противоречащих представ- } \\
\text { лений о взаимоотношени- } \\
\text { ях между лесом и водой: } \\
\text { проблемы и возможности } \\
\text { Management of forest wa- } \\
\text { tersheds in the midlands of } \\
\text { Nepal in the face of con- } \\
\text { flicting perceptions of the } \\
\text { relationship between forest } \\
\text { and water: challenges and } \\
\text { opportunities }\end{array}$ & $\begin{array}{l}\text { Гималаи, } \\
\text { Непал } \\
\text { Himalayas, } \\
\text { Nepal } \\
\end{array}$ & $\begin{array}{l}\text { Лес, вода, восприятие } \\
\text { сообщества, среднегорье } \\
\text { Непала, общинное лесное } \\
\text { хозяйство } \\
\text { Forest, water, community } \\
\text { perception, Nepal's } \\
\text { midlands, community } \\
\text { forestry }\end{array}$ & \begin{tabular}{|l|} 
Обоснование \\
устойчивого \\
управления \\
лесными водо- \\
сборами средних \\
холмов Непала \\
Rationale for \\
Sustainable \\
Management of \\
Nepal's Mid-Hills \\
Forest Watersheds
\end{tabular} & $\begin{array}{l}\text { Единого } \\
\text { концепта } \\
\text { нет } \\
\text { There is no } \\
\text { single concept }\end{array}$ & \begin{tabular}{|l|} 
Вклад в меж- \\
дисциплинарное \\
понимание управ- \\
ления лесными \\
водосборами, \\
роль культуры \\
Contributions to \\
interdisciplinary \\
understanding of \\
forest watershed \\
management, the \\
role of culture
\end{tabular} \\
\hline $\begin{array}{l}\text { Исследование ценности } \\
\text { костюмов народности цзян } \\
\text { в Китае: пример из прак- } \\
\text { тики Западной провинции } \\
\text { Сычуань } \\
\text { Exploring the Value of Jiang } \\
\text { Costumes in China: A Case } \\
\text { Study in Western Sichuan }\end{array}$ & \begin{tabular}{|l|} 
Сино-Тибет- \\
ские горы, \\
Китай \\
Sino-Tibetan \\
mountains, \\
China \\
\end{tabular} & \begin{tabular}{|l|} 
Цзян национальность, \\
география костюма, \\
культурное наследие, \\
культурный символ, про- \\
странственная дифферен- \\
циация, геодетектор \\
Jiang nationality, costume \\
geography, cultural \\
heritage, cultural symbol, \\
spatial differentiation, \\
geodetector
\end{tabular} & \begin{tabular}{|l|} 
Количественный \\
анализ костю- \\
мов чанской на- \\
циональности \\
в Китае, про- \\
странственная \\
дифференциация \\
и корреляция с \\
природными фак- \\
торами \\
Quantitative analy- \\
sis of the costumes \\
of Ch'an nationali- \\
ty in China, spatial \\
differentiation and \\
correlation with \\
natural factors
\end{tabular} & $\begin{array}{l}\text { Единого } \\
\text { концепта } \\
\text { нет } \\
\text { There is no } \\
\text { single } \\
\text { concept }\end{array}$ & $\begin{array}{l}\text { Метод иссле- } \\
\text { дования может } \\
\text { быть применен } \\
\text { к исследованиям } \\
\text { других этниче- } \\
\text { ских культур } \\
\text { The research } \\
\text { method can be } \\
\text { applied to the } \\
\text { research of other } \\
\text { ethnic cultures }\end{array}$ \\
\hline $\begin{array}{l}\text { Постсоветские транс- } \\
\text { формации пасторальных } \\
\text { систем на Северном Кав- } \\
\text { казе: развитие гибридных } \\
\text { институтов } \\
\text { Post-Soviet Transformations } \\
\text { of Pastoral Systems in the } \\
\text { North Caucasus: Develop- } \\
\text { ment of Hybrid Institutions }\end{array}$ & $\begin{array}{l}\text { Кавказ, } \\
\text { Россия } \\
\text { Caucasus, } \\
\text { Russia }\end{array}$ & $\begin{array}{l}\text { Отгонно-пастбищное } \\
\text { животноводство, пастора- } \\
\text { лизм, горы, скотоводство, } \\
\text { пастбище, традиционные } \\
\text { институты, институцио- } \\
\text { нальные гибриды, Север- } \\
\text { ный Кавказ } \\
\text { Shelter-pasture animal } \\
\text { husbandry, pastoralism, } \\
\text { mountains, cattle breeding, } \\
\text { pasture, traditional institu- } \\
\text { tions, institutional hybrids, } \\
\text { North Caucasus }\end{array}$ & \begin{tabular}{|l|} 
Определить фак- \\
торы, лежащие \\
в основе транс- \\
формации пасто- \\
ральных систем \\
на Северном \\
Кавказе \\
Identify the factors \\
underlying the \\
transformation of \\
pastoral systems in \\
the North Caucasus
\end{tabular} & $\mid$\begin{tabular}{|} 
Пасторализм \\
Pastoralism \\
\\
\end{tabular} & $\begin{array}{l}\text { Гибридные } \\
\text { (формальные и } \\
\text { неформальные) } \\
\text { институты лежат } \\
\text { в основе горного } \\
\text { пасторализма на } \\
\text { Северном Кавказе } \\
\text { Hybrid (formal and } \\
\text { informal) institu- } \\
\text { tions underlie } \\
\text { mountain pastoral- } \\
\text { ism in the North } \\
\text { Caucasus }\end{array}$ \\
\hline \multicolumn{6}{|c|}{ Устойчивое развитие горных территорий / Sustainable Development of Mountain Territories } \\
\hline $\begin{array}{l}\text { Роль формальных и не- } \\
\text { формальных институтов в } \\
\text { развитии традиционного } \\
\text { природопользования в } \\
\text { горно-таежной зоне Сиби- } \\
\text { ри (на примере эвенков } \\
\text { Забайкальского края) } \\
\text { The role of formal and } \\
\text { informal institutions in the } \\
\text { development of traditional } \\
\text { nature management in the } \\
\text { mountain-taiga zone }\end{array}$ & $\begin{array}{l}\text { Горы Юга } \\
\text { Сибири, } \\
\text { Россия } \\
\text { Mountains of } \\
\text { South Siberia, } \\
\text { Russia }\end{array}$ & $\begin{array}{l}\text { Устойчивое развитие, } \\
\text { институты, коренные } \\
\text { народы, Забайкальский } \\
\text { край, эвенки, оленевод- } \\
\text { ство, охота } \\
\text { Sustainable development, } \\
\text { institutions indigenous } \\
\text { peoples, Trans-Baikal } \\
\text { Territory, Evenki, reindeer } \\
\text { husbandry, hunting }\end{array}$ & \begin{tabular}{l|l} 
Оценка роли & $\mathrm{I}$ \\
формальных и & с \\
неформальных & $\mathrm{I}$ \\
институтов в & $I$ \\
природопользо- & с \\
вании эвенков & \\
Assessing the & \\
role of formal \\
ny and informal \\
institutions in the \\
environmental \\
management of the \\
Evenks
\end{tabular} & $\begin{array}{l}\text { Институци- } \\
\text { ональный } \\
\text { подход } \\
\text { Institutional } \\
\text { approach }\end{array}$ & $\begin{array}{l}\text { Новые институты } \\
\text { создают трудно- } \\
\text { сти для традици- } \\
\text { онного природо- } \\
\text { пользования, что } \\
\text { компенсируется } \\
\text { неформальными } \\
\text { институтами } \\
\text { New institutions } \\
\text { create difficulties } \\
\text { for traditional } \\
\text { nature } \\
\text { management, }\end{array}$ \\
\hline
\end{tabular}


Продолюение таблиць

\begin{tabular}{|c|c|c|c|c|c|}
\hline 1 & 2 & 3 & 4 & 5 & 6 \\
\hline $\begin{array}{l}\text { of Siberia (on the example } \\
\text { of the Evenks of the Trans- } \\
\text { Baikal Territory) }\end{array}$ & & & & & $\begin{array}{l}\text { which is } \\
\text { compensated } \\
\text { by informal } \\
\text { institutions }\end{array}$ \\
\hline $\begin{array}{l}\text { Факторы сохранения } \\
\text { культурного ландшафта в } \\
\text { Баварских Альпах } \\
\text { Cultural landscape } \\
\text { conservation factors in the } \\
\text { Bavarian Alps }\end{array}$ & $\begin{array}{l}\text { Альпы, Гер- } \\
\text { мания } \\
\text { Alps, } \\
\text { Germany }\end{array}$ & $\begin{array}{l}\text { Альпийский регион, Ба- } \\
\text { варские Альпы, культур- } \\
\text { ный ландшафт, тради- } \\
\text { ции землепользования, } \\
\text { общины } \\
\text { Alpine region, Bavarian } \\
\text { Alps, cultural landscape, } \\
\text { traditions land use, } \\
\text { communities }\end{array}$ & $\begin{array}{l}\text { Региональные } \\
\text { особенности } \\
\text { развития горного } \\
\text { хозяйства и изме- } \\
\text { нение и состоя- } \\
\text { ние культурных } \\
\text { ландшафтов } \\
\text { Regional features } \\
\text { of development } \\
\text { mining and } \\
\text { change and } \\
\text { state of cultural } \\
\text { landscapes }\end{array}$ & $\begin{array}{l}\text { Отсутствует } \\
\text { Is absent }\end{array}$ & $\begin{array}{l}\text { Отсутствует } \\
\text { Is absent }\end{array}$ \\
\hline $\begin{array}{l}\text { Культура и развитие } \\
\text { горных территорий: уни- } \\
\text { кальная модель русских } \\
\text { староверов «Беловодье» } \\
\text { Culture and development of } \\
\text { mountain areas: a unique } \\
\text { model of Russian Old } \\
\text { Believers "Belovodye" }\end{array}$ & $\begin{array}{l}\text { Алтай и со- } \\
\text { пряженные } \\
\text { регионы, } \\
\text { Россия, } \\
\text { Китай } \\
\text { Altai and } \\
\text { adjacent } \\
\text { regions, } \\
\text { Russia, China }\end{array}$ & $\begin{array}{l}\text { Устойчивое развитие, гор- } \\
\text { ные территории, культура, } \\
\text { староверы, Беловодье, } \\
\text { Алтай, Дальний Восток } \\
\text { Sustainable development, } \\
\text { mountain territories, } \\
\text { culture, Old Believers, } \\
\text { Belovodye, Altai, Far East }\end{array}$ & $\begin{array}{l}\text { Описание жизни } \\
\text { русских старове- } \\
\text { ров в горах } \\
\text { Description of the } \\
\text { life of Russian Old } \\
\text { Believers in the } \\
\text { mountains }\end{array}$ & $\begin{array}{l}\text { Устойчивое } \\
\text { развитие } \\
\text { Sustainable } \\
\text { development }\end{array}$ & $\begin{array}{l}\text { Роли культурного } \\
\text { фактора в устой- } \\
\text { чивом развитии } \\
\text { The role of the } \\
\text { cultural factor } \\
\text { in sustainable } \\
\text { development }\end{array}$ \\
\hline $\begin{array}{l}\text { Культурные ландшафты } \\
\text { гор Северного Кавказа: } \\
\text { подходы к исследованию, } \\
\text { реконструкции и сохра- } \\
\text { нению } \\
\text { Cultural landscapes } \\
\text { of the North Caucasus } \\
\text { mountains: approaches to } \\
\text { research, reconstruction and } \\
\text { conservation }\end{array}$ & $\begin{array}{l}\text { Кавказ, } \\
\text { Россия } \\
\text { Caucasus, } \\
\text { Russia } \\
\\
\\
\end{array}$ & $\begin{array}{l}\text { Культурные ландшафты } \\
\text { гор, Чеченская Респу- } \\
\text { блика, ландшафтно- } \\
\text { хозяйственный ареал, } \\
\text { нагорные террасы, ГИС- } \\
\text { моделирование, управле- } \\
\text { ние ландшафтами } \\
\text { Cultural landscapes } \\
\text { mountains, Chechen } \\
\text { Republic, landscape- } \\
\text { economic area, mountain } \\
\text { terraces, GIS modeling, } \\
\text { landscape management }\end{array}$ & $\begin{array}{l}\text { Выявить особен- } \\
\text { ности культур- } \\
\text { ных ландшафтов } \\
\text { гор Северного } \\
\text { Кавказа, оценить } \\
\text { их сохранность и } \\
\text { перспективы ре- } \\
\text { витализации } \\
\text { To reveal the } \\
\text { features of } \\
\text { the cultural } \\
\text { landscapes of the } \\
\text { North Caucasus } \\
\text { mountains, to } \\
\text { assess their } \\
\text { preservation and } \\
\text { prospects for } \\
\text { revitalization }\end{array}$ & $\begin{array}{l}\text { Культурный } \\
\text { ландшафт } \\
\text { Cultural } \\
\text { landscape }\end{array}$ & $\begin{array}{l}\text { Вклад в методику } \\
\text { картографирова- } \\
\text { ния культурных } \\
\text { ландшафтов } \\
\text { Contribution to the } \\
\text { methodology of } \\
\text { mapping cultural } \\
\text { landscapes }\end{array}$ \\
\hline
\end{tabular}

культуры не представлен. Русскоязычный сектор информации, отражающий проблематику устойчивого развития горных территорий в России и на пространстве бывшего СССР, имеет большой потенциал, кото- рый, однако, слабо доступен для европейской и мировой аудитории. Намечающийся альянс двух журналов может облегчить трансфер знаний как в концептуально-теоретической, так и в эмпирической областях. 


\section{ЛИТЕРАТУРА:}

1. Zimmermann A., Wymann S. von D., Mathez-Stiefel S-L., Molden D. \& Breu Th. A brief history of peer-reviewed mountain journals: how platforms for knowledge relevant to sustainable mountain development emerged // Eco.mont. July 2018. Vol. 10. Number 2. http://epub.oeaw.ac.at/eco.mont. https:// dx.doi.org/10.1553/eco.mont-10-2s84.

2. Mathez-Stiefel S-L., Wymann S. von D., Zimmermann A., Breu Th, Molden D. Focus Issue: The Role of Culture in Transformation Towards Sustainable Development in Mountains // Mountain Research and Development. 15 November 2019. 39(4). 1-2. https://doi.org/10.1659/mrd.3904.

3. Колбовский Е.Ю., Петрушина М.Н., Петров Л.А., Гагаева 3.Ш. Культурные ландшафты гор Северного Кавказа: подходы к исследованию, реконструкции и сохранению // Устойчивое развитие горных территорий. 2019. Т. 11, N 3(41). С. 397-412.

4. Баденков Ю.П. Культура и развитие горных территорий: уникальная модель русских староверов «Беловодье» // Устойчивое развитие горных территорий. 2019. Т. 11, N 3(41). C. 380-396.

5. Косовцова Т. И. Факторы сохранения культурного ландшафта в Баварских Альпах // Устойчивое развитие горных территорий. 2019. Т. 11, N 3(41). С. 371-380.

6. Гильфанова В.И. Роль формальных и неформальных институтов в развитии традиционного природопользования в горно-таежной зоне Сибири (на примере эвенков Забайкальского края) // Устойчивое развитие горных территорий. T.11, N 3(41). C. 363-370.

7. Saintenoy T., Estefane F. G., Jofré D., Masaguer M. Walking and Stumbling on the Paths of Heritage-making for Rural Development in the Arica Highlands // Mountain Research and Development. 39(4). D1-D10. https://doi.org/10.1659/MRDJOURNAL-D-19-00015.1.

8. Zhe Ya., Cili J., Mace R.H., Juan D., Pengpeng B., Guozhen D. Adaptive Strategies Adopted by Herders Against the Decollectivization of Rangeland in the Qinghai-Tibetan Plateau in China // Mountain Research and Development. 39(4). D11-D20, (15 November 2019) https://doi.org/10.1659/MRD-JOURNAL-D-19-00034.1.

9. Gramm V., Hoffmann Ch., Cattivelli V. Transmitting and Transforming (Agri)-Cultural Values of Mountain Farming: Farm-Based Educational Services in South Tyrol // Mountain Research and Development. 39(4). D21-D28. https://doi. org/10.1659/MRD-JOURNAL-D-19-00009.1.

10. López-Sandoval M., Maldonado P. Change, Collective Action, and Cultural Resilience in Páramo Management in Ec- uador // Mountain Research and Development. 15 November 2019. 39(4). R1-R9, https://doi.org/10.1659/MRD-JOURNALD-19-00007.1

11. Posch E., Höferl K.M., Steiger R., Bell R., Gurung L. Ke garne? How Values and Worldviews Influence Resilience to Natural Hazards: A Case Study From Mustang, Nepal // Mountain Research and Development. 15 November 2019. 39(4). R10R19. https://doi.org/10.1659/MRD-JOURNAL-D-19-00005.1

12. Gugushvili T., Salukvadze G., Salukvadze J. Has Traditional Georgian Hospitality Been Sustained Under Tourism Development? Evidence from the High-Mountain Regions of Georgia // Mountain Research and Development. 15 November 2019. 39(4). R20-R26, https://doi.org/10.1659/MRD-JOURNAL-D-19-00011.1

13. Badu M., Nuberg I., Cedamon E., Sharma S. Management of the Forested Catchments of Nepal's Mid-hills Amid Mismatched Perceptions of Forest-Water Relationships: Challenges and Opportunities // Mountain Research and Development. 15 November 2019. 39(4). R27-R36, https://doi.org/10.1659/ MRD-JOURNAL-D-18-00023.1

14. An Yi-Da, Yi X., Wang Q., Yan W.-P., Guo Y.-L. Research on the Heritage Value of Chiang Nationality Costumes in China: A Case Study in Western Sichuan Province // Mountain Research and Development. 15 November 2019. 39(4). R37R48. https://doi.org/10.1659/MRD-JOURNAL-D-19-00043.1

15. Gunya A,, Gairabekov U., Karaev Yu., Lysenko A., Elmurzaev R., Janibekova H. Post-Soviet Transformations in Pastoral Systems in the North Caucasus: The Development of Hybrid Institutions // Mountain Research and Development. 15 December 2019. 39(4). R49-R59, https://doi.org/10.1659/ MRD-JOURNAL-D-20-00047.1

16. McGinnis M, Ostrom E. 2014. Social-ecological system framework: Initial changes and continuing challenges. Ecology and Society 19(2):30. http://dx.doi.org/10.5751/ES-06387190230.

17. Гуня А.Н. Социально-ориентированные концепции и подходы в исследовании горных территорий Кавказа и обеспечении устойчивого развития // Устойчивое развитие горных территорий. 2015. N3 (25). С. 15-22.

18. Harvey D. 2008. The history of heritage. In: Graham B, Howard P, editors. The Ashgate Research Companion to Heritage and Identity. Aldershot, United Kingdom: Ashgate, pp, 1936.18 .

19. Culture 2030 Indicators: Thematic Indicators for Culture in the 2030 Agenda. Paris, France: UNESCO. https://whc. unesco.org/en/culture2030indicators.

\section{КРИТЕРИИ АВТОРСТВА / Contribution:}

Гуня А.Н. в значительной степени участвовал в написании работы, в её концепции, в анализе и интерпретации материала; Хадзарагова Е.А. принимала участие в написании работы и в обсуждении её концепции; Хетагуров В.Н. корректировал рукопись до её подачи в редакцию; Караев Ю.И. участвовал в написании работы, анализе и интерпретации материала.

Gunya A.N. to a large extent participated in the writing of the work, in its concept, in the analysis and interpretation of the material; Khadzaragova E.A. took part in writing the work and in discussing its concept; $\boldsymbol{V}$. N. Khetagurov corrected the manuscript before submitting it to the editor; Yu.I. Karaev participated in writing the work, analyzing and interpreting the material.

КОНФЛИКТ ИНТЕРЕСОВ / Conflict of interest:

Авторы заявляют об отсутствии конфликта интересов / The authors declare no conflict of interest. 


\section{СВЕДЕНИЯ ОБ АВТОРАХ / Information about authors:}

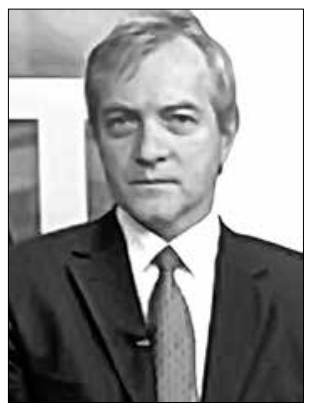

ГУНЯ Алексей Николаевич доктор географических наук, профессор, руководитель горной группы МАВ-6 программы ЮНЕСКО «Человек и биосфера» в Институте географии Российской Академии наук, старший научный сотрудник ИГ РАН, 119017, Москва, Россия.

A. N. GUNYA-Doctor of Geographical Sciences, Professor, Head of the Mountain Group MAV-6 of the UNESCO program "Man and the Biosphere" at the Institute of Geography of the Russian Academy of Sciences, Senior Researcher of the IG RAS, Moscow, Russia.

gunyaa@yahoo.com

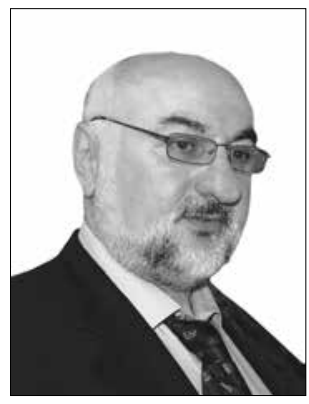

КАРАЕВ Юрий Исаевич - директор Центра разработки программ устойчивого развития горных территорий (Центр «Горы»), директор Автономной некоммерческой организации "Международный инновационный научно-технологический центр «Устойчивое развитие горных территорий» (АНО МИНТЦ «Горы») Северо-Кавказского горнометаллургического института (государственного технологического университета), Владикавказ, Россия.

Yu. I. KARAEV-Director of the Center for Development of Programs for Sustainable Development of Mountain Territories (Center "Mountains"), Director of the Autonomous Non-profit Organization "International Innovative Scientific and Technological Center" Sustainable Development of Mountain Territories "(ANO MINTC " Mountains») North Caucasian Institute of Mining and Metallurgy (State Technological University), Vladikavkaz, 362021, Russia.

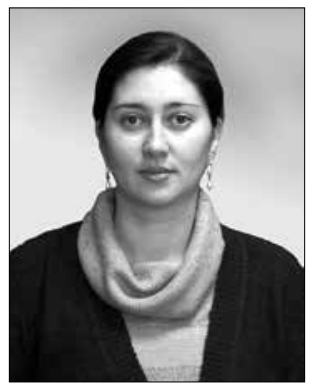

ХАДЗАРАГОВА Елена Александровна - доктор технических наук, профессор, проректор по научной работе и инновационной деятельности, заведующий кафедрой металлургии цветных металлов и автоматизации металлургических процессов Северо-Кавказского горно-металлургического института (государственного технологического университета), 362021, Владикавказ, Россия.

E. A. KHADZARAGOVA-Doctor of Technical Sciences, Professor, Vice-rector for Research and Innovation, Head of the Department of Metallurgy of Non-ferrous Metals and Automation of Metallurgical Processes of the North Caucasus on Mining and Metallurgy Institute (State Technological University), Vladikavkaz, 362021, Russia.

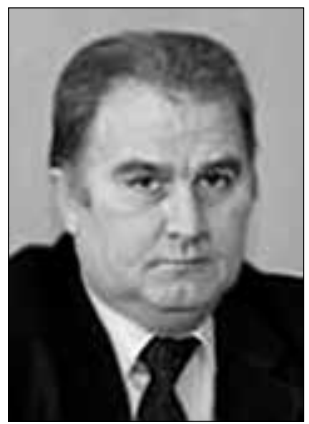

ХЕТАГУРОВ Валерий Николаевич - доктор технических наук, профессор, профессор кафедры технологических машин и оборудования Северо-Кавказского горно-металлургического института (государственного технологического университета), 362021, Владикавказ, Россия.

V. N. KHETAGUROV- Doctor of Technical Sciences, Professor, Professor of the Department of Technological Machines and Equipment. North Caucasian Institute on Mining and Metallurgy, Vladikavkaz, 362021, Russia.

\section{INTERDISCIPLINARY ASPECTS OF SUSTAINABLE DEVELOPMENT OF MOUNTAIN TERRITORIES: THE ROLE OF SOCIO-CULTURAL FACTORS}

A. N. Gunya ${ }^{1^{*}}$,

E. A. Khadzaragova ${ }^{2}$,

V. N. Khetagurov' ${ }^{2}$,

Yu. I. Karaev ${ }^{3}$

IInstitute of Geography of the Russian Academy of Sciences, Moscow, 119017, Russia, gunyaa@yahoo.com

${ }^{2}$ North Caucasian Institute of Mining and Metallurgy (State Technological University), Vladikavkaz, 362021, Russia

${ }^{3}$ Center for Development of Programs for Sustainable Development of Mountain Territories (Center "Mountains"); Autonomous Non-profit Organization "International Innovative Scientific and Technological Center" Sustainable Development of Mountain Territories" (ANO MINTC "Mountains") of North Caucasian Institute of Mining and Metallurgy (State Technological University), Vladikavkaz, 362021 Russia

\section{DOI: $10.21177 / 1998-4502-2020-12-4-609-619$}

The purpose of this work is to analyze the role of culture in the sustainable development of mountain areas in different regions and with different approaches to reflecting this topic of research in scientific publications. The analysis is based on two thematic issues of the journals Sustainable Development of Mountain Territories (SDMT) and Mountain Research and Development (MRD), which focus on the role of culture in mountains. The joint thematic issue was based on the task to reflect the contribution of cultural factors to the sustainable development of mountain areas, as well as the expansion of scientific exchange between communities speaking different languages. Last but not least, it was important to reflect the difference in approaches and methods of "visualization" of scientific thought in the West and in Russia, integration and contextualization of knowledge, which is crucial for ensuring sustainable development in the global aspect. 
In total, 13 articles were analyzed (4 in the SDMT and 9 in the MRD). The parameters for analysis and comparison were: thematic focuses of articles, regions covered, a set of keywords, goal formulation, concepts. 9 articles cover the mountains of Asia (Caucasus - 3, Himalayas - 2, Tibet and its eastern mountain frame - 2, Mountains of Siberia -2), two articles each are devoted to the Alps and Andes. Comparison of the analysis of articles on the role of culture in the mountains, presented in the Russian and Swiss journals, showed both similarities in assessments of the role of culture in sustainable development and differences in approaches and depth of analysis of empirical data.

The articles recognize the fundamental importance of culture for sustainable development in mountainous regions and preventing the destruction of mountain communities with unique environmental management systems. The initiative to jointly produce articles on such an important topic as the role of culture in the mountains contributes to global efforts to generate knowledge, demonstrating how to integrate the cultural component into development practice and policy. This is in line with the goals and objectives of UNESCO, in particular with efforts to develop indicators for the cultural dimension of development.

Keywords: Culture, socio-cultural factors, sustainable development of mountainous areas, cultural landscape, institutions.

\section{References:}

1. Zimmermann A., Wymann S. von D., Mathez-Stiefel S-L., Molden D. \& Breu Th. "A brief history of peer-reviewed mountain journals: how platforms for knowledge relevant to sustainable mountain development emerged", Eco.mont, vol.10, no.2, July 2018. http://epub.oeaw.ac.at/eco.mont. https://dx.doi.org/10.1553/eco.mont-10-2s84.

2. Mathez-Stiefel S-L., Wymann S. von D., Zimmermann A., Breu Th, Molden D. "Focus Issue: The Role of Culture in Transformation Towards Sustainable Development in Mountains", Mountain Research and Development, 39(4), 1-2, 15 November 2019. https://doi.org/10.1659/mrd.3904.

3. Kolbovsky E. Yu., Petrushina M. N., Petrov L. A., Gagaeva Z.Sh. "Cultural landscapes of the mountains of the North Caucasus: approaches to research, reconstruction and preservations", Sustainable Development of Mountain Territories, v. 11, no 3(41), pp. 397-412, (in Russian).

4. Badenkov Yu.P. "Culture and development of mountain territories: unique model of Russian old believers "Belovodye", Sustainable Development of Mountain Territories, 2019, v. 11, no 3(41), pp, 380-396, (in Russian).

5. Kosovtsova T. I. "Factors of conservation of cultural landscapes of the Bavarian Alps", Sustainable Development of Mountain Territories, 2019, v. 11, no.3(41), pp. 371-380 (in Russian).

6. Gilfanova V. I. "The role of formal and informal institutions in the development of traditional natural use in the mountain-taiga zone of Siberia (on the example of Evenk Zabaikalsky region)", Sustainable Development of Mountain Territories, V. 11, no 3(41), pp. 363-370, (in Russian).

7. Saintenoy T., Estefane F. G., Jofré D., Masaguer M. "Walking and Stumbling on the Paths of Heritage-making for Rural Development in the Arica Highlands", Mountain Research and Development, 39(4), D1-D10. https://doi. org/10.1659/MRD-JOURNAL-D-19-00015.1.

8. Zhe Ya., Cili J., Mace R.H., Juan D., Pengpeng B.,
Guozhen D. Adaptive Strategies Adopted by Herders Against the Decollectivization of Rangeland in the Qinghai-Tibetan Plateau in China. Mountain Research and Development. 39(4), D11-D20, (15 November 2019) https://doi.org/10.1659/ MRD-JOURNAL-D-19-00034.1.

9. Gramm V., Hoffmann Ch., Cattivelli V. Transmitting and Transforming (Agri)-Cultural Values of Mountain Farming: Farm-Based Educational Services in South Tyrol. Mountain Research and Development. 39(4), D21-D28. https://doi. org/10.1659/MRD-JOURNAL-D-19-00009.1.

10. López-Sandoval M., Maldonado P. Change, Collective Action, and Cultural Resilience in Páramo Management in Ecuador. Mountain Research and Development. 39(4), R1-R9, (15 November 2019) https://doi.org/10.1659/MRD-JOURNAL-D-19-00007.1

11. Posch E., Höferl K.M., Steiger R., Bell R., Gurung L. Ke garne? How Values and Worldviews Influence Resilience to Natural Hazards: A Case Study From Mustang, Nepal. Mountain Research and Development. 39(4), R10-R19. https://doi. org/10.1659/MRD-JOURNAL-D-19-00005.1

12. Gugushvili T., Salukvadze G., Salukvadze J. Has Traditional Georgian Hospitality Been Sustained Under Tourism Development? Evidence from the High-Mountain Regions of Georgia. Mountain Research and Development. 39(4), R20R26, (15 November 2019) https://doi.org/10.1659/MRDJOURNAL-D-19-00011.1

13. Badu M., Nuberg I., Cedamon E., Sharma S. Management of the Forested Catchments of Nepal's Mid-hills Amid Mismatched Perceptions of Forest-Water Relationships: Challenges and Opportunities. Mountain Research and Development. 39(4), R27-R36, (15 November 2019) https://doi. org/10.1659/MRD-JOURNAL-D-18-00023.1

14. An Yi-Da, Yi X., Wang Q., Yan W.-P., Guo Y.-L. Research on the Heritage Value of Chiang Nationality Costumes in China: A Case Study in Western Sichuan Province. Mountain Research and Development. 39(4), R37-R48, (15 November 2019) https://doi.org/10.1659/MRD-JOURNALD-19-00043.1

15. Gunya A, Gairabekov U., Karaev Yu., Lysenko A., Elmurzaev R., Janibekova H. Post-Soviet Transformations in Pastoral Systems in the North Caucasus: The Development of Hybrid Institutions. Mountain Research and Development. 39(4), R49-R59, (15 December 2019) https://doi.org/10.1659/ MRD-JOURNAL-D-20-00047.1

16. McGinnis M, Ostrom E. 2014. Social-ecological system framework: Initial changes and continuing challenges. Ecology and Society 19(2):30. http://dx.doi. org/10.5751/ES06387-190230.

17. Gunya A.N. Socially-oriented concepts and approaches in the Caucasus mountain research and sustainable development. Sustainable development of mountain territories. No 3 (25), 2015, pp. 15-22, (in Russian).

18. Harvey D. 2008. The history of heritage. In : Graham B, Howard P, editors. The Ashgate Research Companion to Heritage and Identity. Aldershot, United Kingdom: Ashgate, pp 19-36.18.

19. Culture 2030 Indicators: Thematic Indicators for Culture in the 2030 Agenda. Paris, France: UNESCO. https://whc. unesco.org/en/culture2030indicators.

Article received 28.08.2020. 


\section{ГЛУБОКОУВАЖАЕМЫЕ КОЛЛЕГИ!}

В соответствии с заключением Президиума ВАК Минобрнауки РФ от 26.03.2019 г. статьи для публикации в журнале «Устойчивое развитие горных территорий» принимаются по следующим отраслям и группам наук:

05.05.06 - Горные машины (технические науки);

25.00.13 - Обогащение полезных ископаемых (технические науки);

25.00.20 - Геомеханика, разрушение горных пород, рудничная аэрогазодинамика и горная теплофизика (технические науки);

25.00.22 - Геотехнология (подземная, открытая и строительная) (технические науки);

25.00 .23 - Физическая география и биогеография, география почв и геохимия ландшафтов (географические науки);

25.00.24 - Экономическая, социальная, политическая и рекреационная география (географические науки).

Помимо этого, в рамках международной базы цитирования Scopus тематика Журнала ориентирована на следующие отрасли и группы наук:

1. Технические науки (Enginering);

2. Науки о Земле и планетарные науки (Earth and Planetary Sciences);

3. Наука об окружающей среде (Environmental Science).

В журнале «Устойчивое развитие горных территорий» печатаются:

- статьи с изложением новых научных результатов, объемом не более 10 машинописных страниц, включая иллюстрации и таблицы;

- краткие сообщения, содержащие информацию о важных результатах предварительных исследований, объемом 3 -5 страниц (эти материалы впоследствии могут использоваться в тексте полной статьи);

- обзоры печатных работ по актуальным проблемам устойчивого развития горных территорий, объемом $20-25$ страниц по заказу редакции.

К опубликованию также принимаются платные рекламные сообщения о новых материалах, технологиях, приборах и аппаратуре, соответствующие тематике журнала.

Все работы должны соответствовать тематике журнала. Предоставленные рукописи проходят этапы предварительного и итогового рецензирования, и в случае необходимости, направляются авторам на исправление и доработку. Рукописи в журнале публикуются на русском либо английском языках, аннотации на русском и английском языках.

Журнал публикует исключительно оригинальные статьи. Автор несет полную ответственность за соблюдение этого требования. Рукописи, не принятые к опубликованию, авторам не возвращаются. Редакция также не возвращает присылаемые материалы.

Редакция оставляет за собой право производить сокращение и редакторскую правку текста статьи. Исправления в тексте и иллюстрациях авторы могут вносить только на стадии подготовки статьи к набору. Корректура авторам для просмотра не высылается.

Несоблюдение правил оформления рукописи приведет к отклонению статьи.

Публикация бесплатна для авторов статей, написанных по заказу редакции, и для аспирантов.

За сведения в рекламных материалах редакция ответственности не несет.

Перепечатка допускается только с разрешения редакции и с обязательной ссылкой на журнал «Устойчивое развитие горных территорий».

С инструкцией для авторов и правилами оформления статьи Вы можете ознакомиться на сайте журнала:

http://www.naukagor.ru

Адрес редакции:

Россия, РСО-Алания, 362021, Владикавказ, ул. Николаева, 44. Северо-Кавказский горно-металлургический институт (государственный технологический университет).

Редакция журнала «Устойчивое развитие горных территорий».

Тел.: +7(918)707-39-25 (моб.), 8(8672) 40-73-60; 8(8672) 40-72-28 (служ.)

E-mail:editor@naukagor.ru. 


\section{DEAR COLLEAGUES!}

In accordance with the conclusion of the Presidium of the HAC of the Ministry of Education and Science of the Russian Federation from 26.03.2019 the articles for publication in the journal «Sustainable Development of the Mountain Territories» are accepted in the following branches and groups of sciences:

05.05.06 - Mining machines (Technical Sciences);

25.00.13 - Mineral processing (Technical Sciences);

25.00.20 - Geo-mechanics, destruction of rocks, miner aero-gas-dynamics and mining thermal physics (Engineering science);

25.00.22 - Geo-technology (underground, open and construction) (Technical Sciences);

25.00.23 - Physical geography and biogeography, soil geography and landscape geo-chemistry (Geographical Sciences);

25.00.24 - Economic, social, political and recreational geography (Geographical Sciences).

According to the gradation of Sciences accepted in international citation systems Scopus and Web of Science articles for publication in the journal «Sustainable Development of the Mountain Territories» are accepted by the following branches and groups of Sciences:

1. Engineering;

2. Earth and Planetary Sciences;

3. Environmental Science.

The journal «Sustainable Development of the Mountain Territories» publishes:

- articles interpreting the new scientific- research results of volume not more than 10 type written pages including illustrations and tables;

- brief messages containing information on the important results of the preliminary research of volume 3-5 pages (these materials can be used in the full article text);

- reviews of the typewritten articles on the actual problems of the sustainable development of the mountain territories, volume 20-25 pages by the editor's order, also the paid advertisements concerning new materials, devices and equipment in terms of the journal theme are accepted to the publication.

All papers must correspond to the journal theme.

The presented manuscripts pass the preliminary and total reading stages and if necessary are sent back to the authors for the correction and finishing.

The manuscripts are published in Russian and in English, the abstracts in Russian and in English as well.

The journal publishes only the original articles. The author is fully responsible for the requirement.

The manuscripts are not returned to the authors in case of being rejected in publication. The editor has a right to make reductions and corrections of the article text. All corrections in the text and Fig.s can be done by the authors only at the stage of the typesetting preparations. The correction isn't sent to the authors for revision.

The infringement of the manuscript lay-out rules will lead to the publication delay or the article rejection.

The publication is free of charge for the authors, the fees aren't paid.

The authors (or the author) of each article having been published in the regular number of the journal have the right to get the authors' copies or their articles from the editorship.

The editorship isn't responsible for the advertisement information.

Reprinting is allowed only with the editorship permission with the obligatory references to the journal «Sustainable Development of the Mountain Territories».

You can find instructions for authors and rules for article design on the magazine's website:

http://www.naukagor.ru

The editorial office address: 44 Nikolaev Str., Vladikavkaz, North Ossetia-Alania, Russia, 362021, The North Caucasian Institute of Mining and Metallurgy (The State Technological University), the Editorials of the journal «Sustainable Development of Mountain Territories»».

Phone: +7(918)707-39-25 (mob.), +7(8672) 40-73-60.

E-mail:editor@naukagor.ru. 

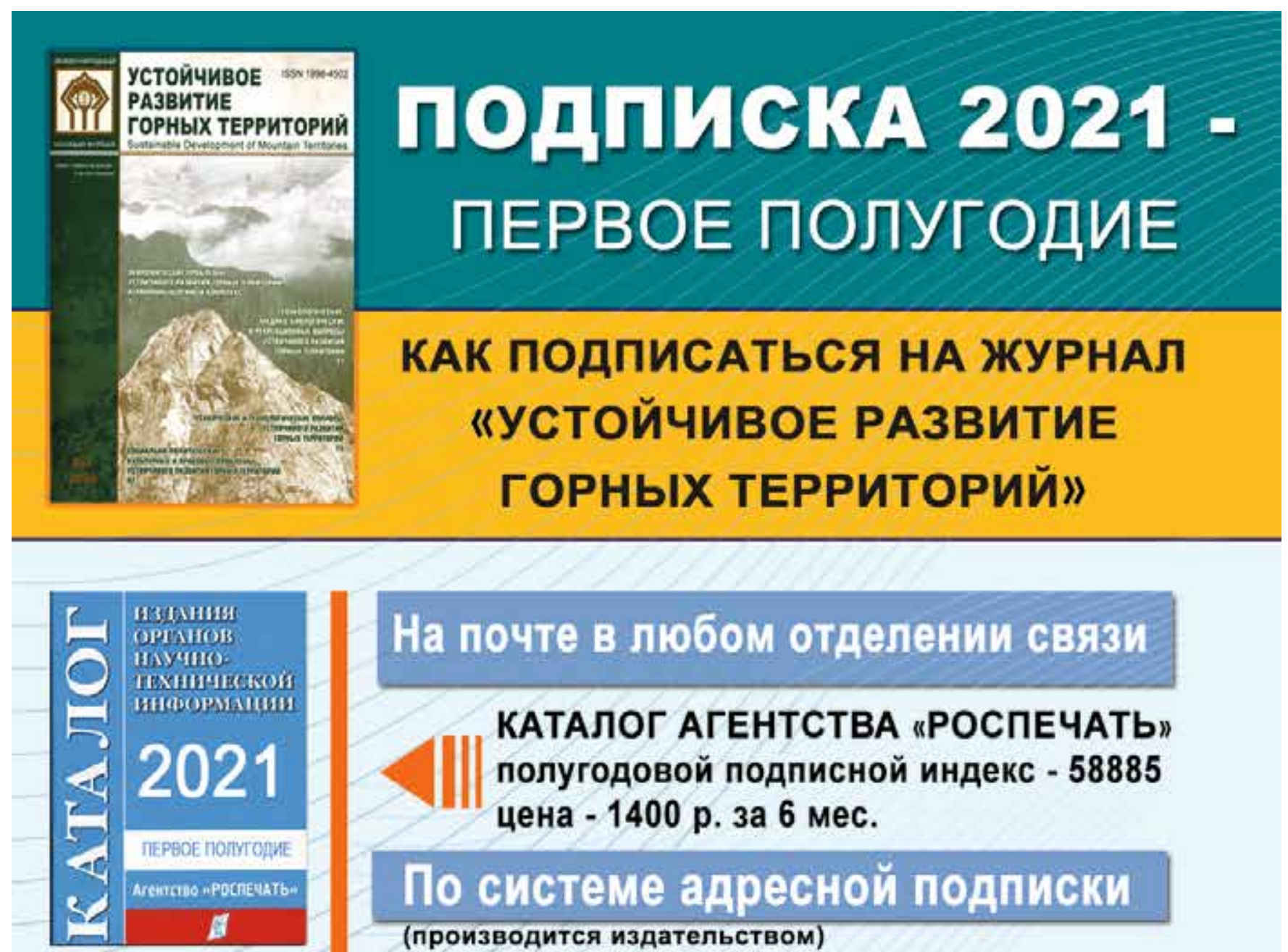

\section{На почте в любом отделении связи}

КАТАЛОГ АГЕНТСТВА „РОСПЕЧАТЬ" полугодовой подписной индекс - 58885 цена - 1400 р. 3 а 6 мес.

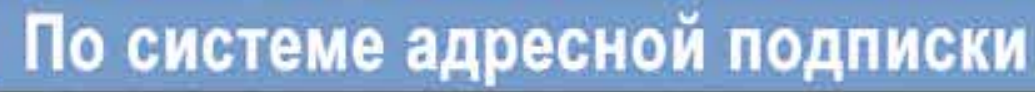 (производится издательством) \\ цена - 1200 р. 3 а 6 мес. \\ A.}

Удобно! Бухгалтерия заполняет платежное поручение, сдает его в банк - и все! (укажите свой адрес в платежном поручении) Выгодно! Никаких почтовых надбавок, а значит - дешевле! Быстро! Отправка журнала ценной бандеролью по адресу подписчика сразу из типографии.

Надежно! Если вы не получили журнал, издательство гарантированно досылает Вам пропавший номер.
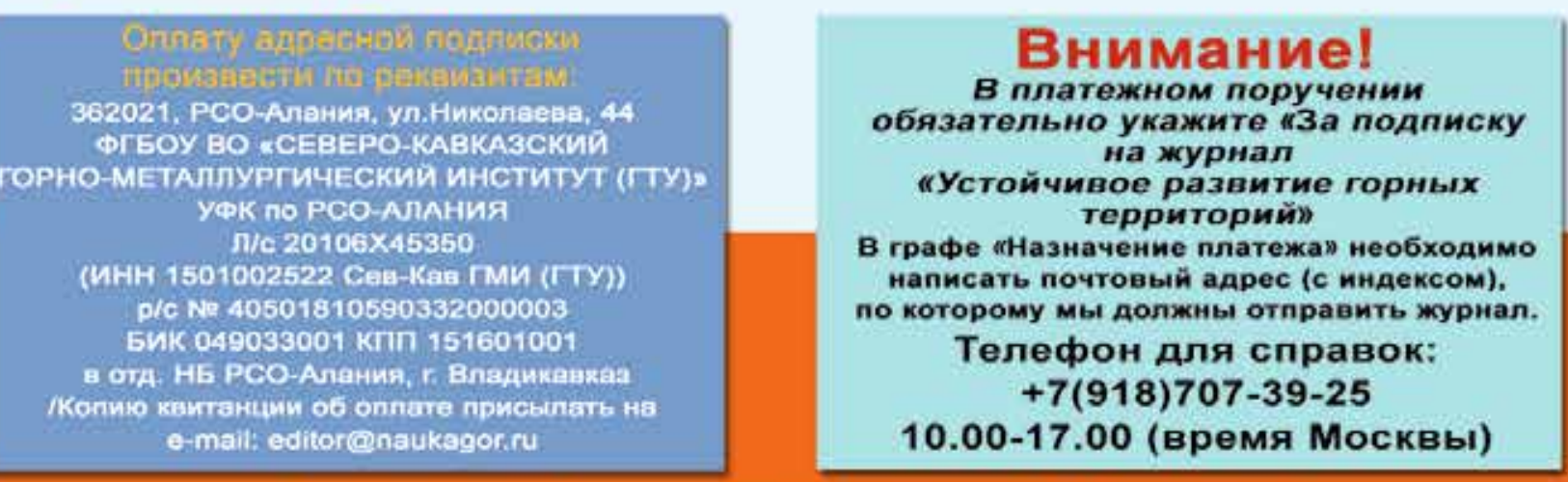

Стоимость адресной подписки для любого региона РФ НДС не облагается Стоимость доставки включена. 

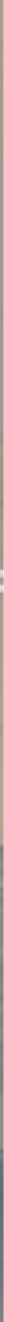